\title{
SUPPORTING INFORMATION \\ Synthesis of Enantioenriched Fluorinated Enol \\ Silanes Enabled by Asymmetric Reductive Coupling \\ of Fluoroalkylacylsilanes and 1,3-Enynes and Brook \\ Rearrangement
}

Xiaowu Fang, ${ }^{\dagger}$ Songwei Wen, ${ }^{\dagger}$ Peishen Jin, Wenjing Bao, Shanshan Liu, Hengjiang Cong and Xiao Shen*

Institute for Advanced Studies, Engineering Research Center of Organosilicon Compounds \& Materials, Ministry of Education, College of Chemistry and Molecular Sciences, Wuhan University, 299 Bayi Road, Wuhan, Hubei 430072, China

xiaoshen@whu.edu.cn

\section{Table of Contents}

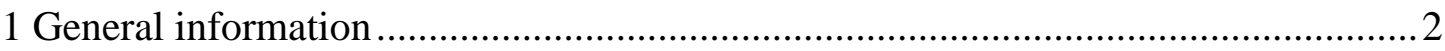

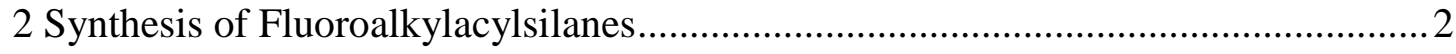

3 Synthesis of $\alpha$-Trifluoromethyl Alcohols 3a-3q and 3ad....................................... 3

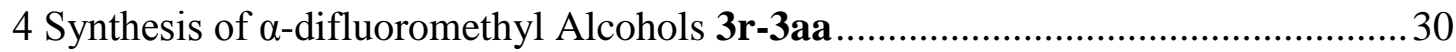

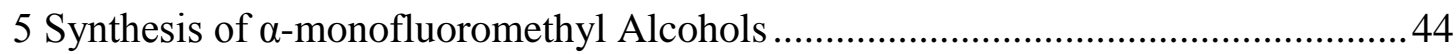

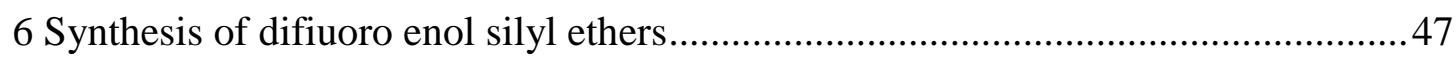

7 Downstream transformations of chiral $\beta$, $\beta$-difluoro enol silanes 7 ........................68

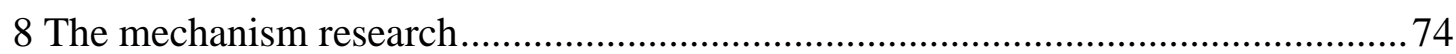

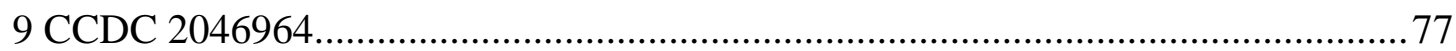

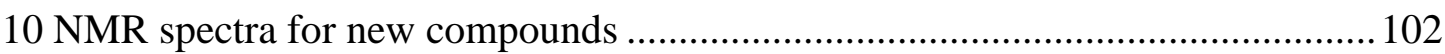

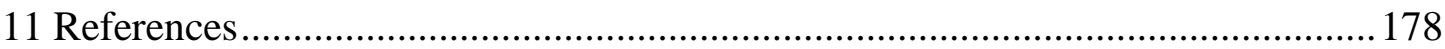




\section{General information}

All reactions were performed in the argon-filled glovebox or under nitrogen using standard Schlenk techniques, unless otherwise noted. Solvents were dried with standard procedures. Column chromatography was performed using 300 400 mesh silica gel. Thin layer chromatography (TLC) was performed on EM reagents $0.25 \mathrm{~mm}$ silica $60-\mathrm{F}$ plates. ${ }^{1} \mathrm{H},{ }^{13} \mathrm{C},{ }^{19} \mathrm{~F}$ were recorded on Bruker 600 and JNM ECZ 400 using $\mathrm{CDCl}_{3}$ as solvent and tetramethylsilane (TMS) as the internal standard. Chemical shifts were reported in ppm, upfield to TMS (0.00 ppm) for and relative to $\mathrm{CDCl}_{3}(7.26 \mathrm{ppm}, 77.16 \mathrm{ppm})$ for ${ }^{1} \mathrm{H}$ NMR and ${ }^{13} \mathrm{C}$ NMR. Data are reported as: multiplicity $(\mathrm{s}=$ singlet, $\mathrm{d}=$ doublet, $\mathrm{dd}=$ double of doublet $\mathrm{t}=$ triplet, $\mathrm{dt}=$ double of triplet, $\mathrm{q}=$ quartet, $\mathrm{m}=$ multiplet $)$, coupling constant in hertz $(\mathrm{Hz})$ and signal area integration in natural numbers. ${ }^{13} \mathrm{C}$ NMR analyses were run with decoupling. HPLC analysis was conducted on a Thermo Fisher Ultimate 3000 series instrument. High resolution mass spectrum was obtained on Thermo LTQ XL Orbitrap. Infrared spectra were recorded on an Agilent Technologies Cary 630 FTIR and wavelengths are reported in $\mathrm{cm}^{-1}$. Melting point was measured by INESA SGW X 4. All reagents were used as received and solvents were dried according to standard procedure. Unless otherwise noted, all reagents and solvents were purchased from commercial suppliers $\left(\mathrm{Cu}(\mathrm{OAc})_{2}\right.$ was purchased from Alfa. Josiphos SL-J011-1 was purchased from Sinocompound. DMMS was purchased from TCI. $t$ - $\mathrm{BuOH}$ was purchased from Adamas.) and used without further purification. 1,3-Enynes ${ }^{1}$ and Fluoroalkylacylsilanes ${ }^{2}$ were synthesized according to reported procedures.

Enantiomeric excess (ee) values were determined by high performance liquid chromatography (HPLC) analysis using a chiral stationary phase. Racemic samples were prepared using racemic ligand (E.g. racemic BINAP or prepared by mixing a 1:1 ratio of $(R, S)$ - Josiphos SL-J011-1 and $(S, R)$ - Josiphos SL-J011-2). Optical rotations were measured on an INESA SGW-533 polarimeter with $[\alpha]_{\mathrm{D}}$ values reported in degrees; concentration (c) is in $\mathrm{mg} / \mathrm{mL}$. Melting points (m.p.) were obtained on a Mel-Temp capillary melting point apparatus. The absolute configuration of product was determined by comparison of analytical data with $\mathbf{3 w}$ (optical rotation). The absolute configuration of product $\mathbf{3 w}$ was determined by single-crystal X-ray structure analysis.

\section{Synthesis of Fluoroalkylacylsilanes}

\section{1-(Dimethyl(phenyl)silyl)-2,2,2-trifluoroethan-1-one (2a)}

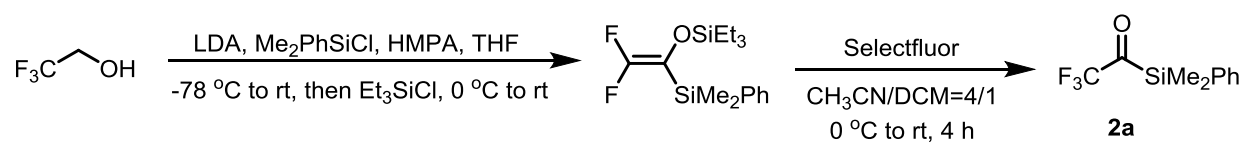

Under nitrogen, to a stirring solution of 2,2,2-trifluoroethanol (10 g, 100 mmol. 1.0 equiv.) and phenyldimethylchlorosilane (17 g, $100 \mathrm{mmol}, 1.0$ equiv.) and HMPA $(10 \mathrm{~mL})$ in dry THF $(100 \mathrm{~mL})$ was added LDA (prepared by diisopropylamine with $n$-BuLi in THF, 3.5 equiv.) dropwise with syringe at -78 ${ }^{\circ} \mathrm{C}$. The mixture was stirred at $-78{ }^{\circ} \mathrm{C}$ for four hours and then allowed to rise to room temperature for another 12 hours. And then triethylchlorosilane ( $25 \mathrm{~mL}, 150 \mathrm{mmol}, 1.5$ equiv.) was added to the mixture at $0{ }^{\circ} \mathrm{C}$. The mixture was stirred at room temperature for 4 hours before quenching reaction by filtration. Product (2,2-difluoro-1-((triethylsilyl)oxy)vinyl)dimethyl(phenyl)silane was purified by silica gel column chromatography (silica gel: 200 300 mesh). Yellow oil; $\mathrm{R}_{\mathrm{f}}=0.8(\mathrm{PE}) ; 25 \mathrm{~g}, 76 \%$ yield.

Under nitrogen, to a solution of selectfluor ( $40 \mathrm{~g}, 114 \mathrm{mmol}, 1.5$ equiv.) in $400 \mathrm{~mL}$ of $\mathrm{MeCN}$ was added a solution of (2,2-difluoro-1-((triethylsilyl)oxy)vinyl)dimethyl(phenyl)silane ( $25 \mathrm{~g}, 76 \mathrm{mmol}$. 1.0 equiv.) in $100 \mathrm{~mL}$ of DCM at $0{ }^{\circ} \mathrm{C}$. The resulting mixture was stirred at room temperature for $12 \mathrm{~h}$ and quenched 
by the addition of $200 \mathrm{~mL}$ water, then extracted with DCM $(3 \times 300 \mathrm{~mL})$. The organic layer was dried over $\mathrm{Na}_{2} \mathrm{SO}_{4}$, filtered and concentrated. Distillation of the residue $\left(65-68{ }^{\circ} \mathrm{C} / 20 \mathrm{mbar}\right)$ gave the 1(dimethyl(phenyl)silyl)-2,2,2-trifluoroethan-1-one 2a as slight yellow oil (10.6 g, 61\%). It is a known compound and spectral data match the reported literature values ${ }^{2 \mathrm{c}}$.

\section{1-(Dimethyl(phenyl)silyl)-2,2-difluoroethan-1-one (2b)}

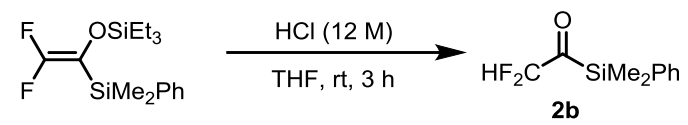

To a stirring solution of (2,2-difluoro-1-((triethylsilyl)oxy)vinyl)dimethyl(phenyl)silane (15.7g, $48 \mathrm{mmol}$, 1.0 equiv. ) in dry THF $(10 \mathrm{~mL})$ at $0{ }^{\circ} \mathrm{C}$ was added con. $\mathrm{HCl}(20 \mathrm{~mL})$, the reaction medium was brought to room temperature and stirred for $3.0 \mathrm{~h}$, then extracted with EA $(3 \times 500 \mathrm{~mL})$. The combined organic phase was washed with brine, dried over $\mathrm{Na}_{2} \mathrm{SO}_{4}$, filtered, and concentrated. Product $\mathbf{2 b}$ was purified by silica gel column chromatography (siliga: 200 300 mesh) using PE as eluent (light yellow oil, 8.1 g, 37.9 mmol, 79\% yield). It is a known compound and spectral data match the reported literature values ${ }^{2 \mathrm{c}}$.

\section{1-(Dimethyl(phenyl)silyl)-2-fluoroethan-1-one (2c)}

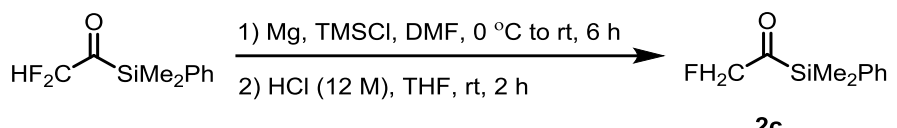

Under nitrogen, to a mixture of magnesium ( $0.97 \mathrm{~g}, 40 \mathrm{mmol}, 4.0$ equiv.), TMSCl ( $3.26 \mathrm{~g}, 30 \mathrm{mmol}, 3.0$ equiv.) and DMF ( $80 \mathrm{~mL})$, 1-(dimethyl(phenyl)silyl)-2,2-difluoroethan-1-one (2.14 g, $10 \mathrm{mmol}, 1.0$ equiv.) was added under $0{ }^{\circ} \mathrm{C}$ and allowed to rt, the mixture was stirred for $6 \mathrm{~h}$, and then quenched by 20 $\mathrm{mL} \mathrm{H}_{2} \mathrm{O}$. After filtration. The mixture was washed by water $(3 \times 40 \mathrm{~mL})$ and then extracted with EtOAc $(3 \times 40 \mathrm{~mL})$. The organic layer was dried over anhydrous $\mathrm{Na}_{2} \mathrm{SO}_{4}$, filtered, concentrated, and then filtered through a short plug of silica gel (200 300 mesh) eluting with PE, The crude product was dissolved in THF $(20 \mathrm{~mL})$ and then concentrated hydrochloric $(12 \mathrm{M}, 5 \mathrm{~mL})$ was added. The mixture was stirred at room temperature for $2 \mathrm{~h}$ and quenched by the addition of a saturated solution of $\mathrm{NaHCO}_{3}$ $(20 \mathrm{~mL})$, then extracted with ethyl acetate $(3 \times 40 \mathrm{~mL})$. The organic layer was dried over anhydrous $\mathrm{Na}_{2} \mathrm{SO}_{4}$, filtered, and concentrated. Product $2 \mathbf{c}$ was purified by silica gel column chromatography (silica gel: 200 300 mesh). Yellow oil; $\mathrm{R}_{\mathrm{f}}=0.46(\mathrm{PE} / \mathrm{EA}=20 / 1) ; 1.27 \mathrm{~g}, 65 \%$ yield; NMR spectroscopy: ${ }^{1} \mathrm{H}$ NMR $\left(400 \mathrm{MHz}, \mathrm{CDCl}_{3}, 25^{\circ} \mathrm{C}\right) \delta 7.59-7.55(\mathrm{~m}, 2 \mathrm{H}), 7.45-7.38(\mathrm{~m}, 3 \mathrm{H}), 4.77(\mathrm{~d}, J=48.2 \mathrm{~Hz}, 2 \mathrm{H}), 0.57$ (s, 3H), 0.56 (s, 3H); ${ }^{13} \mathbf{C}$ NMR (101 MHz, $\left.\mathrm{CDCl}_{3}, 25^{\circ} \mathrm{C}\right) \delta 242.3$ (d, $\left.J=27.0 \mathrm{~Hz}\right), 134.3,133.2,130.3$, 128.4, $91.2(\mathrm{~d}, J=181.3 \mathrm{~Hz}),-4.8 ;{ }^{19} \mathbf{F}$ NMR $\left(376 \mathrm{MHz}, \mathrm{CDCl}_{3}, 25^{\circ} \mathrm{C}\right) \delta-229.5(\mathrm{t}, J=48.2 \mathrm{~Hz}, 1 \mathrm{~F})$; HRMS (ESI, m/z): calcd for $\mathrm{C}_{10} \mathrm{H}_{13} \mathrm{FOSiNa}^{+}(\mathrm{M}+\mathrm{Na})^{+}: 219.0612$; Found: 219.0615 .

3 Synthesis of $\alpha$-Trifluoromethyl Alcohols 3a-3q and 3ad

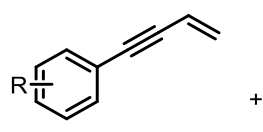

$1,2.0$ equiv

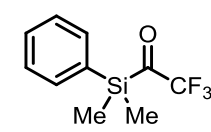

1.0 equiv.

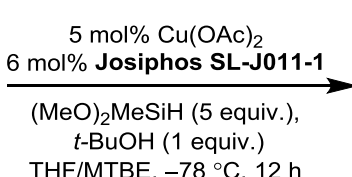

THF/MTBE, $-78^{\circ} \mathrm{C}, 12 \mathrm{~h}$

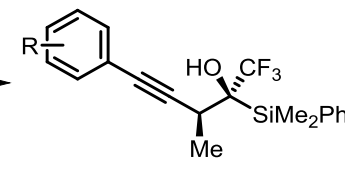

3

In a glovebox, to an oven-dried $10 \mathrm{~mL}$ Schlenk tube equipped with a magnetic stir bar was added $\mathrm{Cu}(\mathrm{OAc})_{2}$ (2.3 mg, $0.0125 \mathrm{mmol}, 5 \mathrm{~mol} \%$ ), Josiphos SL-J011-1 (10.2 mg, $\left.0.015 \mathrm{mmol}, 6 \mathrm{~mol} \%\right)$, and 
dry solvent $(1 \mathrm{~mL})$ sequentially. The mixture was stirred at room temperature for 30 min before the addition of DMMS (153.5 $\mu \mathrm{L}, 1.25 \mathrm{mmol}, 5$ equiv.), $t$-BuOH $(24 \mu \mathrm{L}, 0.25 \mathrm{mmol}, 1$ equiv.) and 1 (2 equiv.). The tube was then sealed, removed from the glove box and allowed to stir at $-78{ }^{\circ} \mathrm{C}$ for $5 \mathrm{~min}$, after which the mixture was added 1-(dimethyl(phenyl)silyl)-2,2,2-trifluoroethanone (58 mg, $0.25 \mathrm{mmol}$, 1 equiv.,) in $5 \mathrm{~mL}$ using a syringe driven by an injection pump at a constant flow rate (within $6 \mathrm{~h}$ ). After stirring for another $6 \mathrm{~h}$, a saturated solution of $\mathrm{NH}_{4} \mathrm{~F}$ in $\mathrm{MeOH}$ (ca. $6 \mathrm{~mL}$ ) was carefully added to quench the reaction (Caution: gas evolution was observed). The reaction mixture was allowed to stir for $20 \mathrm{~min}$ at room temperature, diluted with EtOAc (ca. $10 \mathrm{~mL}$ ), stirred for an additional $10 \mathrm{~min}$ at room temperature and then filtered through a short plug of celite $(1-2 \mathrm{~cm})$ eluting with EtOAc $(\mathrm{ca} .50 \mathrm{~mL})$. The solvent was removed in vacuo with the aid of a rotary evaporator. At this point, the crude yield and the diastereomeric ratio ( $\mathrm{dr}$ ) were determined by ${ }^{19} \mathrm{~F}$ NMR spectroscopic analysis using $\mathrm{PhCF}_{3}$ as the internal standard. The crude product was purified with column chromatography on silica gel (300 400 mesh) to afford the title compound 3 .

\section{(2R, 3S)-2-(Dimethyl(phenyl)silyl)-1,1,1-trifluoro-3-methyl-5-phenylpent-4-yn-2-ol (3a)}

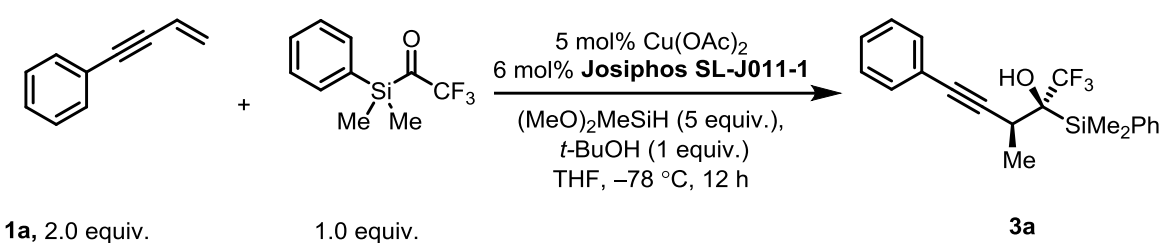

In a glovebox, to an oven-dried $10 \mathrm{~mL}$ Schlenk tube equipped with a magnetic stir bar was added $\mathrm{Cu}(\mathrm{OAc})_{2}$ (5 mol\%), Josiphos SL-J011-1 (6 mol\%), and dry THF (1 mL) sequentially. The mixture was stirred at room temperature for $30 \mathrm{~min}$ before the addition of DMMS ( 5 equiv.), $t$ - $\mathrm{BuOH}$ ( 1 equiv.) and 1 a (2 equiv.). The tube was then sealed, removed from the glove box and allowed to stir at $-78^{\circ} \mathrm{C}$ for 5 min, after which the mixture was added 1-(dimethyl(phenyl)silyl)-2,2,2-trifluoroethanone (1 equiv., 0.25 $\mathrm{mmol}$ ) in $5 \mathrm{~mL}$ using a syringe driven by an injection pump at a constant flow rate (within $6 \mathrm{~h}$ ). After stirring for another $6 \mathrm{~h}$, a saturated solution of $\mathrm{NH}_{4} \mathrm{~F}$ in $\mathrm{MeOH}$ (ca. $6 \mathrm{~mL}$ ) was carefully added to quench the reaction (Caution: gas evolution was observed). The reaction mixture was allowed to stir for $20 \mathrm{~min}$ at room temperature, diluted with EtOAc (ca. $10 \mathrm{~mL}$ ), stirred for an additional $10 \mathrm{~min}$ at room temperature and then filtered through a short plug of celite $(1-2 \mathrm{~cm})$ eluting with EtOAc (ca. $50 \mathrm{~mL})$. The solvent was removed in vacuo with the aid of a rotary evaporator. At this point, the crude yield and the diastereomeric ratio ( $\mathrm{dr}$ ) were determined by ${ }^{19} \mathrm{~F}$ NMR spectroscopic analysis using $\mathrm{PhCF}_{3}$ as the internal standard. The crude product was purified with column chromatography on silica gel (300 400 mesh) to afford the title compound 3a. Colorless oil; $\mathbf{R}_{\mathbf{f}}=0.53(\mathrm{PE} / \mathrm{EA}=10 / 1) ; 74.2 \mathrm{mg}, 82 \%$ yield, 99\% ee, 99:1 dr; $[\boldsymbol{\alpha}]^{\mathbf{2 5}} \mathbf{D}=-86.6\left(c=1.55, \mathrm{CHCl}_{3}\right)$; NMR spectroscopy: ${ }^{1} \mathbf{H} \mathbf{~ N M R}\left(400 \mathrm{MHz}, \mathrm{CDCl}_{3}, 25^{\circ} \mathrm{C}\right) \delta$ 7.65 (d, $J=8.0 \mathrm{~Hz}, 2 \mathrm{H}), 7.47-7.33(\mathrm{~m}, 5 \mathrm{H}), 7.29$ (d, $J=5.3 \mathrm{~Hz}, 3 \mathrm{H}), 3.09$ (q, $J=7.4 \mathrm{~Hz}, 1 \mathrm{H}), 2.69$ (s, $1 \mathrm{H}), 1.27(\mathrm{dd}, J=7.4,1.8 \mathrm{~Hz}, 3 \mathrm{H}), 0.60(\mathrm{~s}, 3 \mathrm{H}), 0.56(\mathrm{~s}, 3 \mathrm{H}) ;{ }^{13} \mathbf{C ~ N M R}\left(101 \mathrm{MHz}, \mathrm{CDCl}_{3}, 25^{\circ} \mathrm{C}\right) \delta$ 135.0, 134.6, 131.8, 130.2, 128.4, 128.1, 127.9 (q, $J=286.7 \mathrm{~Hz}), 122.9,88.0,85.1,71.4(\mathrm{q}, J=27.9 \mathrm{~Hz})$, 33.2, 16.5, -3.2, -3.5; ${ }^{19} \mathbf{F}$ NMR $\left(376 \mathrm{MHz} \mathrm{CDCl}_{3}, 25^{\circ} \mathrm{C}\right) \delta-67.5$ (s, 3F); IR (ATR): 3649, 3496, 3459, 3213, 3189, 3049, 2885, 1718, 1457, 1327, 1238, 1156, 816, 757, $708 \mathrm{~cm}^{-1}$; HRMS (ESI, m/z): calcd for $\mathrm{C}_{20} \mathrm{H}_{21} \mathrm{~F}_{3} \mathrm{OSiNa}^{+}(\mathrm{M}+\mathrm{Na})^{+}$: 385.1206; Found: 385.1238; HPLC analysis (AD-H column, 3\% $i$ $\mathrm{PrOH} /$ hexane, $0.80 \mathrm{~mL} / \mathrm{min}, 20{ }^{\circ} \mathrm{C}, 254 \mathrm{~nm}$ ) indicated $99 \%$ ee: $t_{\mathrm{R}}($ major $)=5.42 \mathrm{~min}, t_{\mathrm{R}}($ minor $)=5.64$ $\min$. 
Racemic 3a:

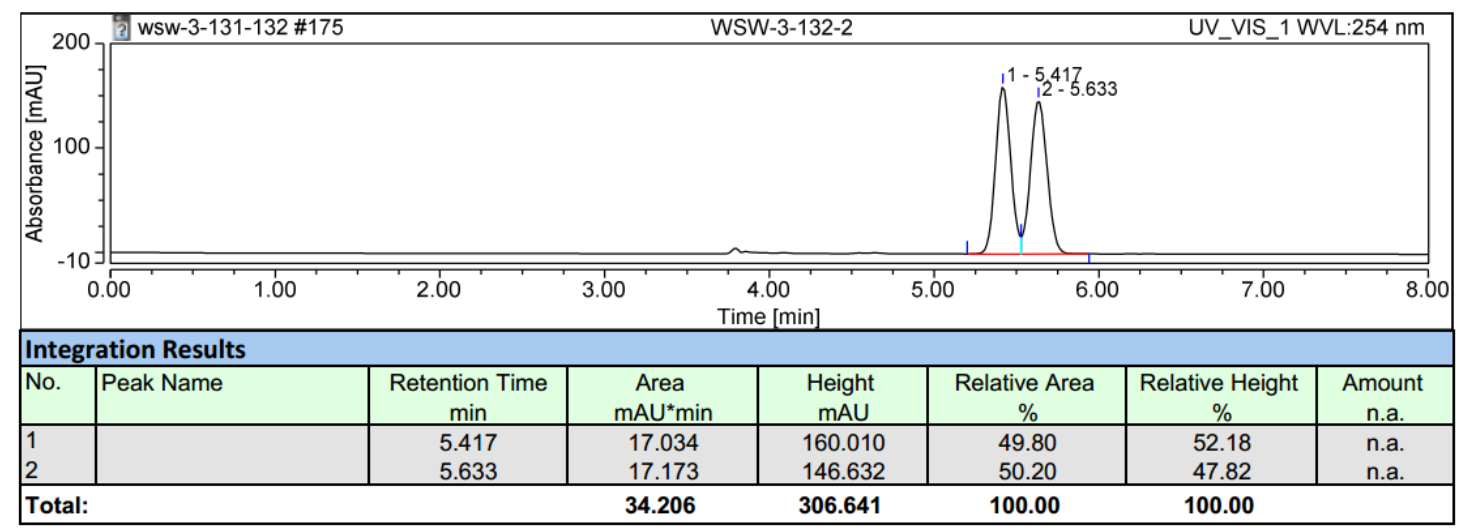

\section{Enantioenriched 3a:}

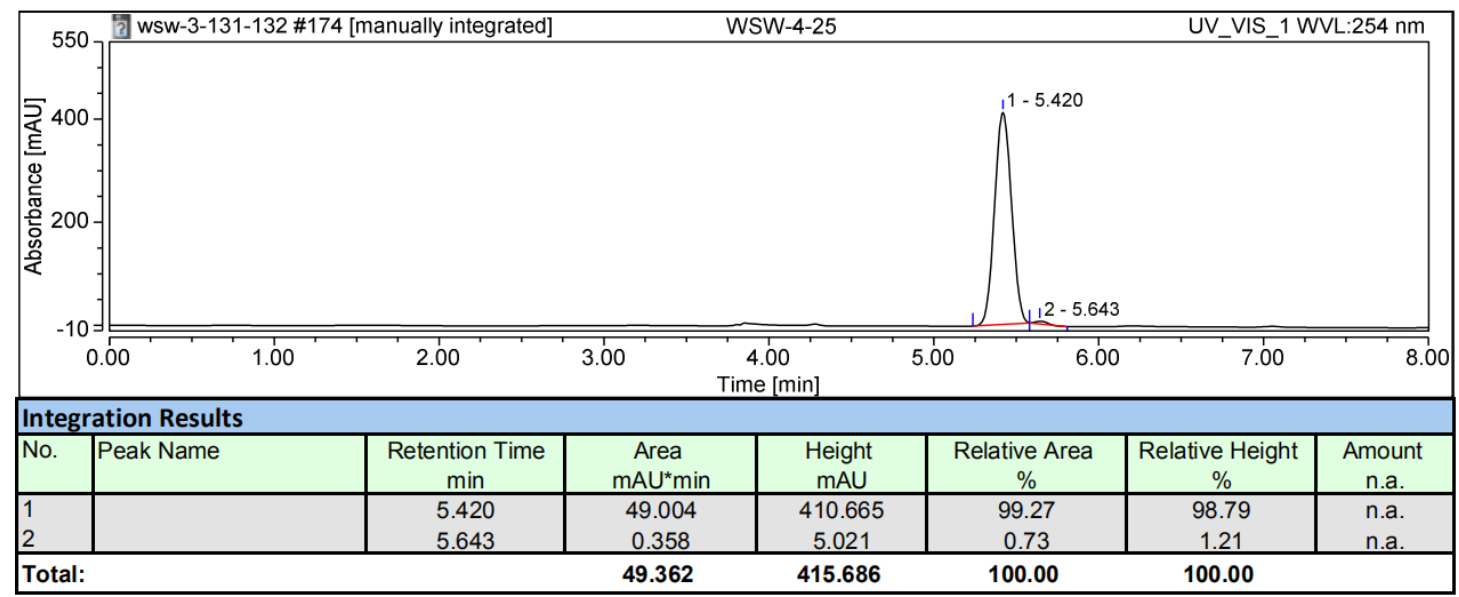

(2R, 3S)-2-(Dimethyl(phenyl)silyl)-1,1,1-trifluoro-5-(2-fluorophenyl)-3-methylpent-4-yn-2-ol (3b)<smiles>C=CC#Cc1ccccc1F</smiles>

1b, 2.0 equiv.

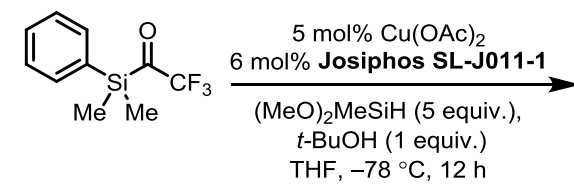

1.0 equiv.

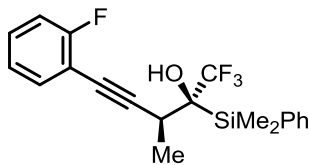

3b

In a glovebox, to an oven-dried $10 \mathrm{~mL}$ Schlenk tube equipped with a magnetic stir bar was added $\mathrm{Cu}(\mathrm{OAc})_{2}$ (5 mol\%), Josiphos SL-J011-1 (6 mol\%), and dry THF (1 mL) sequentially. The mixture was stirred at room temperature for $30 \mathrm{~min}$ before the addition of DMMS (5 equiv.), $t$-BuOH ( 1 equiv.) and 1b ( 2 equiv.). The tube was then sealed, removed from the glove box and allowed to stir at $-78^{\circ} \mathrm{C}$ for 5 min, after which the mixture was added 1-(dimethyl(phenyl)silyl)-2,2,2-trifluoroethanone (1 equiv., 0.25 mmol) in $5 \mathrm{~mL}$ THF using a syringe driven by an injection pump at a constant flow rate (within $6 \mathrm{~h}$ ). After stirring for another $6 \mathrm{~h}$, a saturated solution of $\mathrm{NH}_{4} \mathrm{~F}$ in $\mathrm{MeOH}$ (ca. $6 \mathrm{~mL}$ ) was carefully added to quench the reaction (Caution: gas evolution was observed). The reaction mixture was allowed to stir for $20 \mathrm{~min}$ at room temperature, diluted with EtOAc (ca. $10 \mathrm{~mL})$, stirred for an additional $10 \mathrm{~min}$ at room temperature and then filtered through a short plug of celite $(1-2 \mathrm{~cm})$ eluting with EtOAc (ca. $50 \mathrm{~mL})$. The solvent was removed in vacuo with the aid of a rotary evaporator. At this point, the crude yield and the diastereomeric ratio $(\mathrm{dr})$ were determined by ${ }^{19} \mathrm{~F}$ NMR spectroscopic analysis using $\mathrm{PhCF}_{3}$ as the internal standard. The crude product was purified with column chromatography on silica gel (300 400 
mesh) to afford the title compound 3b. Colorless oil; $\mathbf{R}_{\mathbf{f}}=0.53(\mathrm{PE} / \mathrm{EA}=10 / 1) ; 77.9 \mathrm{mg}, 82 \%$ yield, > 99\% ee, > 99:1 dr; $[\boldsymbol{\alpha}]^{\mathbf{2 5}} \mathbf{\mathbf { D }}=-77.8\left(c=2.55, \mathrm{CHCl}_{3}\right)$; NMR spectroscopy: ${ }^{\mathbf{1}} \mathbf{H} \mathbf{~ N M R}\left(400 \mathrm{MHz}, \mathrm{CDCl}_{3}\right.$, $\left.25^{\circ} \mathrm{C}\right) \delta 7.66(\mathrm{dd}, J=7.8,1.7 \mathrm{~Hz}, 2 \mathrm{H}), 7.48-7.24(\mathrm{~m}, 5 \mathrm{H}), 7.10-7.02(\mathrm{~m}, 2 \mathrm{H}), 3.14(\mathrm{q}, J=7.4 \mathrm{~Hz}, 1 \mathrm{H})$, $2.74(\mathrm{~s}, 1 \mathrm{H}), 1.29$ (dq, $J=7.4,1.8 \mathrm{~Hz}, 3 \mathrm{H}), 0.61(\mathrm{~s}, 3 \mathrm{H}), 0.57(\mathrm{~s}, 3 \mathrm{H}) ;{ }^{13} \mathbf{C ~ N M R}\left(101 \mathrm{MHz}, \mathrm{CDCl}_{3}, 25\right.$ $\left.{ }^{\circ} \mathrm{C}\right) 163.0(\mathrm{~d}, J=251.1 \mathrm{~Hz}), 134.9,134.5,133.6,130.1(\mathrm{~d}, J=8.1 \mathrm{~Hz}) ., 130.0,128.2,127.9(\mathrm{q}, J=286.2$ Hz) $124.0(\mathrm{~d}, J=3.7 \mathrm{~Hz}), 115.6(\mathrm{~d}, J=21.1 \mathrm{~Hz}), 111.5(\mathrm{~d}, J=15.6 \mathrm{~Hz}), 93.5,78.4,71.4(\mathrm{q}, J=28.1 \mathrm{~Hz})$, $33.4,16.4,-3.3,-3.5 ;{ }^{19} \mathbf{F}$ NMR $\left(376 \mathrm{MHz}, \mathrm{CDCl}_{3}, 25{ }^{\circ} \mathrm{C}\right) \delta-67.6$ (s, 3F), -110.3 (dd, J= 15.1, 7.4 Hz); IR (ATR): 3496, 3298, 3071, 2926, 2855, 2359, 1614, 1491, 1383, 1238, 1156, 910, 816, 760, $708 \mathrm{~cm}^{-}$

1; HRMS (ESI, m/z): calcd for $\mathrm{C}_{20} \mathrm{H}_{20} \mathrm{~F}_{4} \mathrm{OSiNa}^{+}(\mathrm{M}+\mathrm{Na})^{+}$: 403.1112; Found: 403.1108; HPLC analysis (AD-H column, $3 \% i-\mathrm{PrOH} /$ hexane, $0.80 \mathrm{~mL} / \mathrm{min}, 20{ }^{\circ} \mathrm{C}, 254 \mathrm{~nm}$ ) indicated $>99 \%$ ee: $t_{\mathrm{R}}($ major $)=5.43$ $\min , t_{\mathrm{R}}($ minor $)=5.71 \mathrm{~min}$.

\section{Racemic 3b:}

\begin{tabular}{|l|l|c|c|c|c|c|c|}
\hline & \\
\hline
\end{tabular}

Enantioenriched 3b:

\begin{tabular}{|l|l|c|c|c|c|c|}
\hline & \multicolumn{3}{c}{ UV_VIS_1 WVL:254 nm } \\
\hline
\end{tabular}

(2R, 3S)-2-(Dimethyl(phenyl)silyl)-1,1,1-trifluoro-5-(3-fluorophenyl)-3-methylpent-4-yn-2-ol (3c)

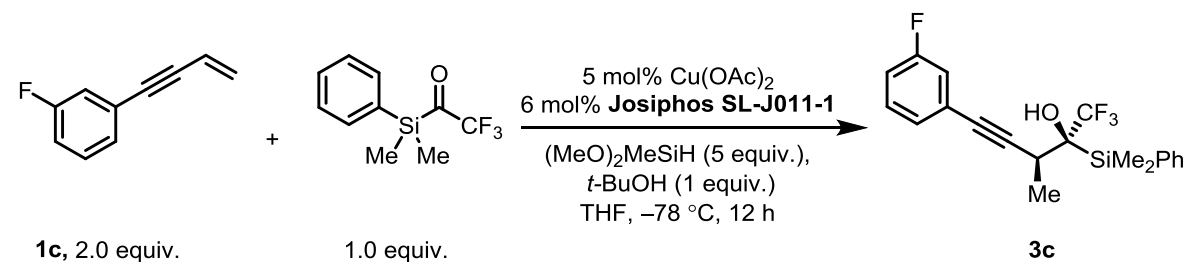

In a glovebox, to an oven-dried $10 \mathrm{~mL}$ Schlenk tube equipped with a magnetic stir bar was added $\mathrm{Cu}(\mathrm{OAc})_{2}$ (5 mol\%), Josiphos SL-J011-1 (6 mol\%), and dry THF (1 mL) sequentially. The mixture was 
stirred at room temperature for $30 \mathrm{~min}$ before the addition of DMMS (5 equiv.), $t$-BuOH (1 equiv.) and 1c ( 2 equiv.). The tube was then sealed, removed from the glove box and allowed to stir at $-78^{\circ} \mathrm{C}$ for 5 min, after which the mixture was added 1-(dimethyl(phenyl)silyl)-2,2,2-trifluoroethanone (1 equiv., 0.25 $\mathrm{mmol}$ ) in $5 \mathrm{~mL}$ using a syringe driven by an injection pump at a constant flow rate (within $6 \mathrm{~h}$ ). After stirring for another $6 \mathrm{~h}$, a saturated solution of $\mathrm{NH}_{4} \mathrm{~F}$ in $\mathrm{MeOH}$ (ca. $6 \mathrm{~mL}$ ) was carefully added to quench the reaction (Caution: gas evolution was observed). The reaction mixture was allowed to stir for $20 \mathrm{~min}$ at room temperature, diluted with EtOAc (ca. $10 \mathrm{~mL}$ ), stirred for an additional $10 \mathrm{~min}$ at room temperature and then filtered through a short plug of celite $(1-2 \mathrm{~cm})$ eluting with EtOAc (ca. $50 \mathrm{~mL})$. The solvent was removed in vacuo with the aid of a rotary evaporator. At this point, the crude yield and the diastereomeric ratio (dr) were determined by ${ }^{19} \mathrm{~F}$ NMR spectroscopic analysis using $\mathrm{PhCF}_{3}$ as the internal standard. The crude product was purified with column chromatography on silica gel (300 400 mesh) to afford the title compound $3 \mathbf{c}$. colorless oil; $\mathbf{R}_{\mathbf{f}}=0.51$ (PE/EA $\left.=10 / 1\right) ; 74.1 \mathrm{mg}, 78 \%$ yield, $93 \%$ ee, 98:2 dr; $[\boldsymbol{\alpha}]^{25} \mathbf{D}=-67.8\left(c=2.95, \mathrm{CHCl}_{3}\right)$ NMR spectroscopy: ${ }^{1} \mathbf{H} \mathbf{N M R}\left(400 \mathrm{MHz}, \mathrm{CDCl}_{3}, 25^{\circ} \mathrm{C}\right) \delta$ 7.68-7.63 (m, 2H), 7.47-7.37 (m, 3H), 7.25 (td, $J=7.6,5.8 \mathrm{~Hz}, 1 \mathrm{H}), 7.15(\mathrm{dt}, J=7.7,1.3 \mathrm{~Hz}, 1 \mathrm{H})$, 7.09-6.98 (m, 2H), 3.08 (q, $J=7.4 \mathrm{~Hz}, 1 \mathrm{H}), 2.61(\mathrm{~s}, 1 \mathrm{H}), 1.27$ (dq, $J=7.4,1.7 \mathrm{~Hz}, 3 \mathrm{H}), 0.61(\mathrm{~s}, 3 \mathrm{H})$, 0.57 (s, 3H); ${ }^{13} \mathrm{C}$ NMR $\left(101 \mathrm{MHz}, \mathrm{CDCl}_{3}, 25^{\circ} \mathrm{C}\right) \delta 162.5$ (d, $\left.J=246.6 \mathrm{~Hz}\right) .135 .0,134.5,130.3,130.0$ (d, $J=8.7 \mathrm{~Hz}), 127.9$ (q, $J=286.3 \mathrm{~Hz}), 127.7(\mathrm{~d}, J=3.1 \mathrm{~Hz}), 128.2,124.8(\mathrm{~d}, J=9.5 \mathrm{~Hz}), 118.6$ (d, $J=$ $22.7 \mathrm{~Hz}), 115.8(\mathrm{~d}, J=21.2 \mathrm{~Hz}), 89.3,83.8,71.5$ (q, $J=28.0 \mathrm{~Hz}), 33.1,16.5,-3.2,-3.4 ;{ }^{19} \mathbf{F}$ NMR $(375$ $\mathrm{MHz}, \mathrm{CDCl}_{3}, 25^{\circ} \mathrm{C}$ ) $\delta-67.7$ (s, 3F), $-112.8-112.9$ (m, 1F); IR (ATR): 3496, 3302, 3075, 2952, 2926, $2855,1610,1580,1487,1152,872,842,783,738,705 \mathrm{~cm}^{-1}$; HRMS (ESI, m/z): calcd for $\mathrm{C}_{20} \mathrm{H}_{21} \mathrm{~F}_{4} \mathrm{OSi}^{+}$ $(\mathrm{M}+\mathrm{H})^{+}$: 381.1292; Found: 381.1285; HPLC analysis (OD-H column, $2 \% i-\mathrm{PrOH} / \mathrm{hexane}, 0.50$ $\mathrm{mL} / \mathrm{min}, 20^{\circ} \mathrm{C}, 254 \mathrm{~nm}$ ) indicated $93 \%$ ee: $t_{\mathrm{R}}($ major $)=11.20 \mathrm{~min}, t_{\mathrm{R}}(\operatorname{minor})=10.77 \mathrm{~min}$. 
Racemic 3c:

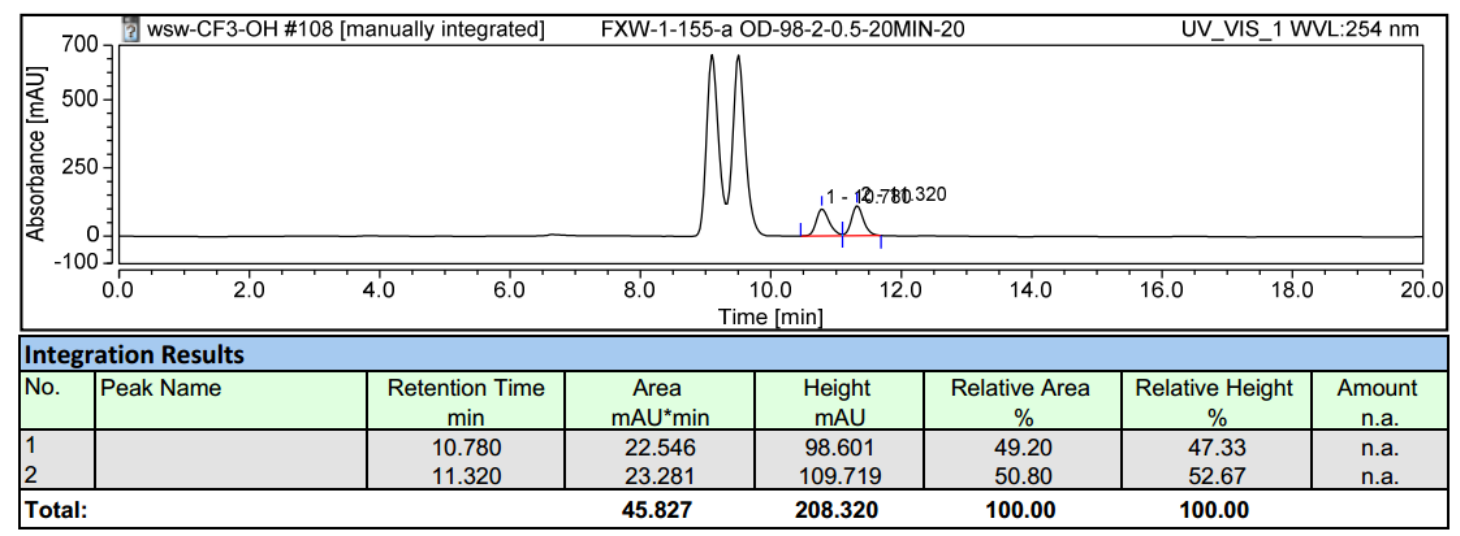

\section{Enantioenriched 3c:}

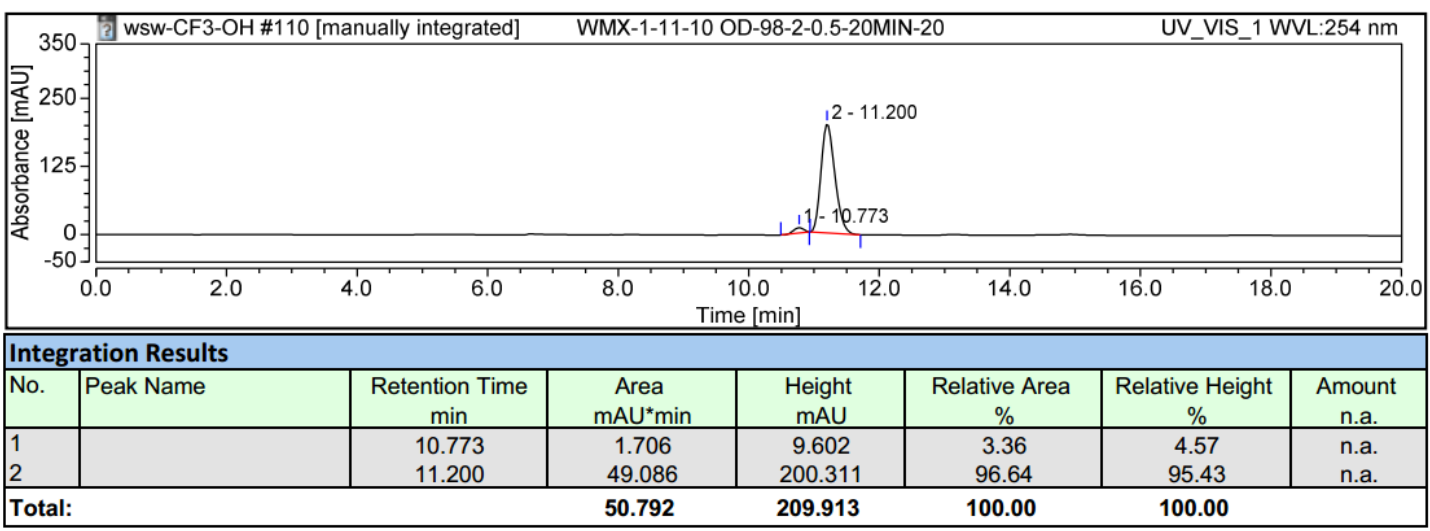

(2R, 3S)-2-(Dimethyl(phenyl)silyl)-1,1,1-trifluoro-5-(4-fluorophenyl)-3-methylpent-4-yn-2-ol (3d)<smiles>C=CC#Cc1ccc(F)cc1</smiles>

1d, 2.0 equiv

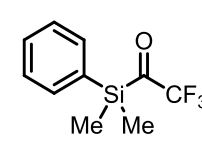

1.0 equiv.

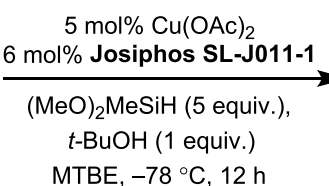

MTBE, $-78^{\circ} \mathrm{C}, 12 \mathrm{~h}$

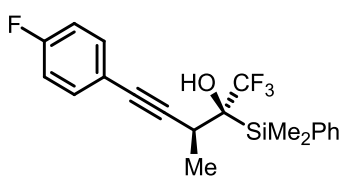

$3 d$

In a glovebox, to an oven-dried $10 \mathrm{~mL}$ Schlenk tube equipped with a magnetic stir bar was added $\mathrm{Cu}(\mathrm{OAc})_{2}$ (5 mol\%), Josiphos SL-J011-1 (6 mol\%), and dry MTBE (1 mL) sequentially. The mixture was stirred at room temperature for $30 \mathrm{~min}$ before the addition of DMMS ( 5 equiv.), $t$ - $\mathrm{BuOH}$ ( 1 equiv.) and $1 \mathbf{d}$ ( 2 equiv.). The tube was then sealed, removed from the glove box and allowed to stir at $-78{ }^{\circ} \mathrm{C}$ for $5 \mathrm{~min}$, after which the mixture was added 1-(dimethyl(phenyl)silyl)-2,2,2-trifluoroethanone (1 equiv., $0.25 \mathrm{mmol}$ ) in $5 \mathrm{~mL}$ MTBE using a syringe driven by an injection pump at a constant flow rate (within $6 \mathrm{~h}$ ). After stirring for another $6 \mathrm{~h}$, then a saturated solution of $\mathrm{NH}_{4} \mathrm{~F}$ in $\mathrm{MeOH}$ (ca. $6 \mathrm{~mL}$ ) was carefully added to quench the reaction (Caution: gas evolution was observed). The reaction mixture was allowed to stir for $20 \mathrm{~min}$ at room temperature, diluted with EtOAc (ca. $10 \mathrm{~mL}$ ), stirred for an additional $10 \mathrm{~min}$ at room temperature and then filtered through a short plug of celite $(1-2 \mathrm{~cm})$ eluting with EtOAc (ca. 50 $\mathrm{mL}$ ). The solvent was removed in vacuo with the aid of a rotary evaporator. At this point, the crude yield and the diastereomeric ratio (dr) were determined by ${ }^{19} \mathrm{~F}$ NMR spectroscopic analysis using $\mathrm{PhCF}_{3}$ as the internal standard. The crude product was purified with column chromatography on silica gel (300 400 mesh) with PE as eluent to afford the title compound 3d. Colorless oil; $\mathbf{R}_{\mathbf{f}}=0.71(\mathrm{PE} / \mathrm{EA}=$ 
10/1); $75.1 \mathrm{mg}, 79 \%$ yield, $>99 \%$ ee, $99: 1 \mathrm{dr} ;[\boldsymbol{\alpha}]^{25} \mathbf{D}=-32.9\left(c=6.60, \mathrm{CHCl}_{3}\right) \mathrm{NMR}$ spectroscopy: ${ }^{1} \mathbf{H}$ NMR $\left(400 \mathrm{MHz}, \mathrm{CDCl}_{3}, 25^{\circ} \mathrm{C}\right) \delta 7.67-7.62(\mathrm{~m}, 2 \mathrm{H}), 7.47-7.31(\mathrm{~m}, 5 \mathrm{H}), 6.98(\mathrm{t}, J=8.7 \mathrm{~Hz}, 2 \mathrm{H}), 3.06$ $(\mathrm{q}, J=7.4 \mathrm{~Hz}, 1 \mathrm{H}), 2.65(\mathrm{~s}, 1 \mathrm{H}), 1.26(\mathrm{dd}, J=7.4,1.8 \mathrm{~Hz}, 3 \mathrm{H}), 0.60(\mathrm{~s}, 3 \mathrm{H}), 0.56(\mathrm{~s}, 3 \mathrm{H}) ;{ }^{13} \mathbf{C} \mathbf{N M R}$ $\left(101 \mathrm{MHz}, \mathrm{CDCl}_{3}, 25^{\circ} \mathrm{C}\right) 162.6(\mathrm{~d}, J=250.6 \mathrm{~Hz}), 134.9,134.6,133.7(\mathrm{~d}, J=8.4 \mathrm{~Hz}), 130.2,128.2$, $127.9(\mathrm{q}, J=286.6 \mathrm{~Hz}), 119.0,115.7(\mathrm{~d}, J=22.1 \mathrm{~Hz}), 87.7,84.0,71.4$ (q, $J=27.9 \mathrm{~Hz}), 33.1,16.5,-3.2$, $-3.5 ;{ }^{19} \mathbf{F}$ NMR $\left(376 \mathrm{MHz}, \mathrm{CDCl}_{3}, 25^{\circ} \mathrm{C}\right) \delta-67.6(\mathrm{~s}, 3 \mathrm{~F}),-110.8--110.9$ (m, 1F); IR (ATR): 3675, 3552 , 3496, 3299, 3071, 2982, 2952, 1722., 1670, 1506, 1152, 835, 783, 738, $705 \mathrm{~cm}^{-1}$; HRMS (ESI, m/z): calcd for $\mathrm{C}_{20} \mathrm{H}_{21} \mathrm{~F}_{4} \mathrm{OSi}^{+}(\mathrm{M}+\mathrm{H})^{+}$: 381.1292; Found: 381.1286; HPLC analysis (AD-H column, 3\% $i-\mathrm{PrOH} /$ hexane, $0.80 \mathrm{~mL} / \mathrm{min}, 20^{\circ} \mathrm{C}, 254 \mathrm{~nm}$ ) indicated $>99 \%$ ee: $t_{\mathrm{R}}$ (major) $=5.69 \mathrm{~min}$.

Racemic 3d:

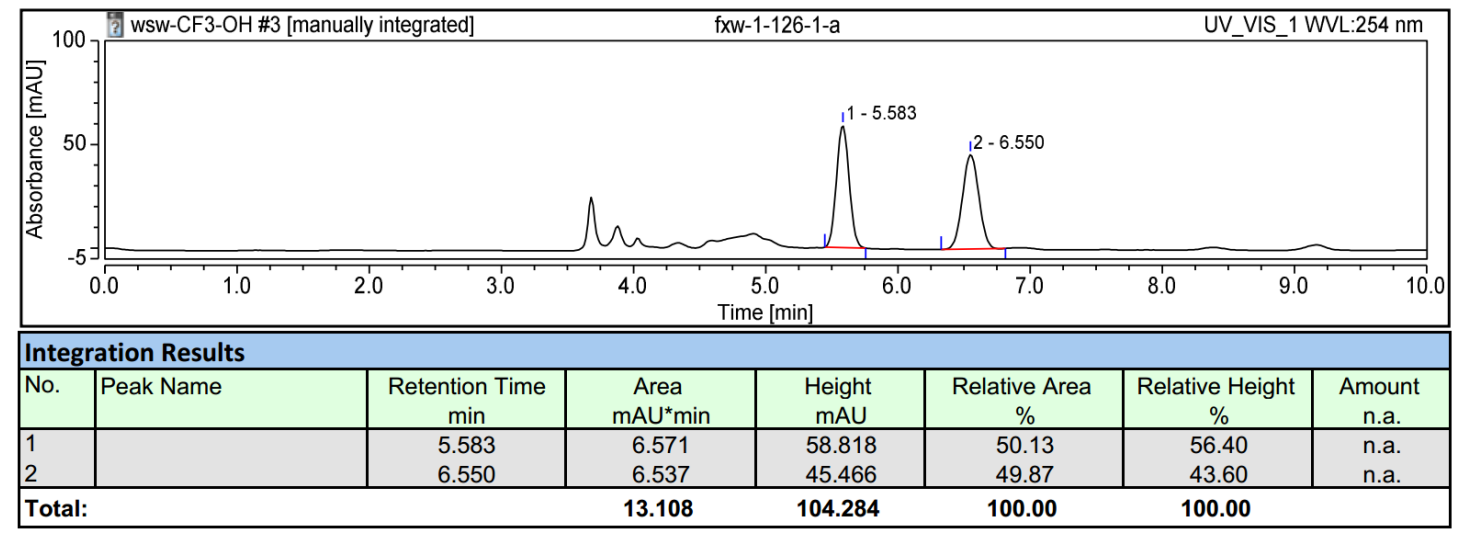

\section{Enantioenriched 3d:}

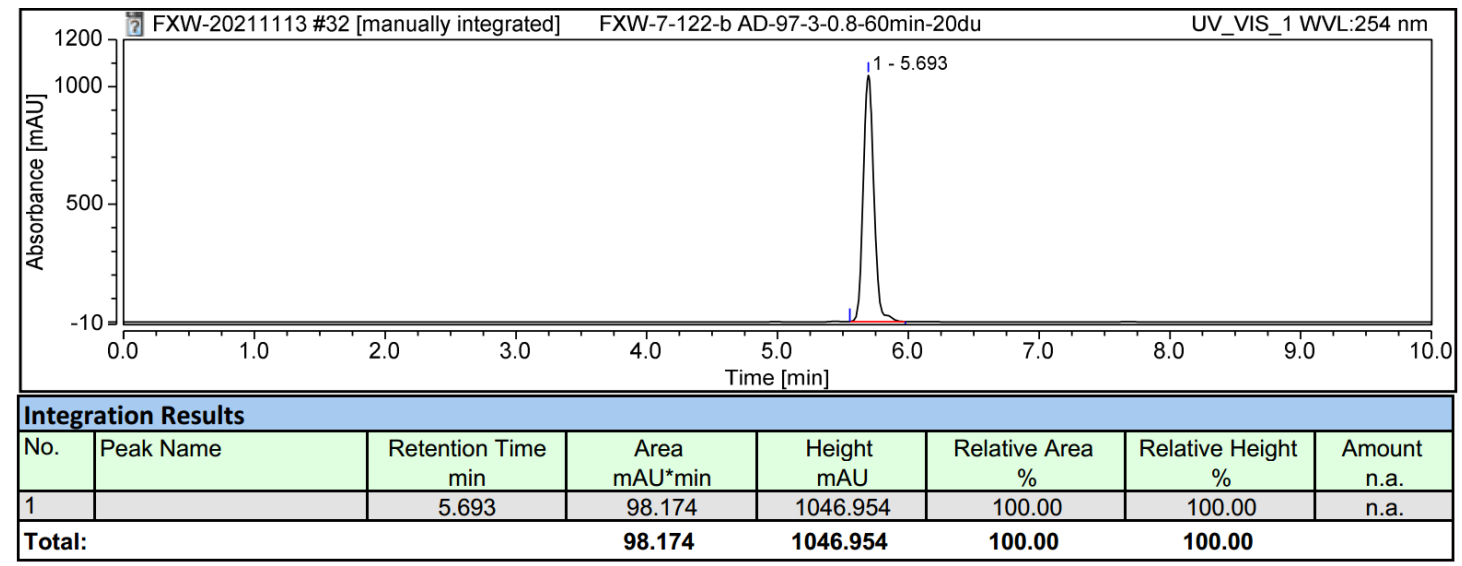

(2R, 3S)-5-(4-Chlorophenyl)-2-(dimethyl(phenyl)silyl)-1,1,1-trifluoro-3-methylpent-4-yn-2-ol (3e)

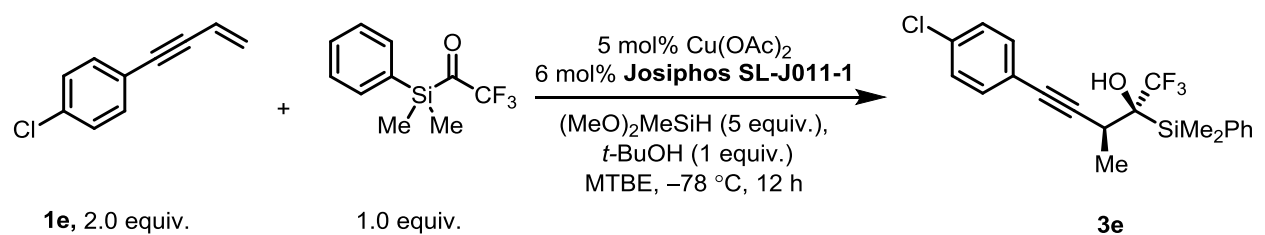

In a glovebox, to an oven-dried $10 \mathrm{~mL}$ Schlenk tube equipped with a magnetic stir bar was added $\mathrm{Cu}(\mathrm{OAc})_{2}$ (5 mol\%), Josiphos SL-J011-1 (6 mol\%), and dry MTBE (1 mL) sequentially. The mixture was stirred at room temperature for $30 \mathrm{~min}$ before the addition of DMMS (5 equiv.), $t$-BuOH ( 1 equiv.) and $1 \mathrm{e}$ ( 2 equiv.). The tube was then sealed, removed from the glove box and allowed to stir at $-78^{\circ} \mathrm{C}$ 
for 5 min, after which the mixture was added 1-(dimethyl(phenyl)silyl)-2,2,2-trifluoroethanone (1 equiv., $0.25 \mathrm{mmol}$ ) in $5 \mathrm{~mL}$ MTBE using a syringe driven by an injection pump at a constant flow rate (within $6 \mathrm{~h}$ ). After stirring for another $6 \mathrm{~h}$, a saturated solution of $\mathrm{NH}_{4} \mathrm{~F}$ in $\mathrm{MeOH}$ (ca. $6 \mathrm{~mL}$ ) was carefully added to quench the reaction (Caution: gas evolution was observed). The reaction mixture was allowed to stir for $20 \mathrm{~min}$ at room temperature, diluted with EtOAc (ca. $10 \mathrm{~mL}$ ), stirred for an additional $10 \mathrm{~min}$ at room temperature and then filtered through a short plug of celite $(1-2 \mathrm{~cm})$ eluting with EtOAc (ca. $50 \mathrm{~mL})$. The solvent was removed in vacuo with the aid of a rotary evaporator. At this point, the crude yield and the diastereomeric ratio ( $\mathrm{dr}$ ) were determined by ${ }^{19} \mathrm{~F}$ NMR spectroscopic analysis using $\mathrm{PhCF}_{3}$ as the internal standard. The crude product was purified with column chromatography on silica gel (300 400 mesh) to afford the title compound 3e; Colorless oil. $\mathbf{R}_{\mathbf{f}}=0.69(\mathrm{PE} / \mathrm{EA}=10 / 1) ; 92.1 \mathrm{mg}, 93 \%$ yield, > 99\% ee, 99:1 dr; $[\boldsymbol{\alpha}]^{\mathbf{2 5}} \mathbf{D}=-54.5\left(c=3.25, \mathrm{CHCl}_{3}\right)$ NMR spectroscopy: ${ }^{\mathbf{1}} \mathbf{H} \mathbf{~ N M R}\left(400 \mathrm{MHz}, \mathrm{CDCl}_{3}, 25\right.$ $\left.{ }^{\circ} \mathrm{C}\right) \delta 7.64(\mathrm{dd}, J=7.8,1.7 \mathrm{~Hz}, 2 \mathrm{H}), 7.46-7.36(\mathrm{~m}, 3 \mathrm{H}), 7.30-7.24(\mathrm{~m}, 4 \mathrm{H}), 3.06(\mathrm{q}, J=7.4 \mathrm{~Hz}, 1 \mathrm{H})$, $2.60(\mathrm{~s}, 1 \mathrm{H}), 1.26(\mathrm{dq}, J=7.4,1.7 \mathrm{~Hz}, 3 \mathrm{H}), 0.59(\mathrm{~s}, 3 \mathrm{H}), 0.55(\mathrm{~s}, 3 \mathrm{H}) ;{ }^{13} \mathbf{C} \mathbf{N M R}\left(101 \mathrm{MHz}, \mathrm{CDCl}_{3}, 25\right.$ $\left.{ }^{\circ} \mathrm{C}\right) \delta 134.9,134.5,134.4,133.0,130.3,128.8128 .2,127.9(\mathrm{q}, J=286.5 \mathrm{~Hz}) 121.4,89.2,83.9,71.4(\mathrm{dd}$, $J=55.9,27.9 \mathrm{~Hz}), 33.2,16.5,-3.2,-3.5 ;{ }^{19} \mathbf{F ~ N M R}\left(376 \mathrm{MHz}, \mathrm{CDCl}_{3}, 25{ }^{\circ} \mathrm{C}\right) \delta-67.6(\mathrm{~s}, 3 \mathrm{~F})$; IR (ATR): 3496, 3290, 3191, 3071, 2926, 1726, 1670, 1592, 1491, 1238, 1152, 951, 813, 738, $705 \mathrm{~cm}^{-1}$; HRMS (ESI, m/z): calcd for $\mathrm{C}_{20} \mathrm{H}_{24} \mathrm{ClF}_{3} \mathrm{OSiN}\left(\mathrm{M}+\mathrm{NH}_{4}\right)^{+}$: 414.1262; Found: 414.1249; HPLC analysis (AD-H column, $3 \% i-\mathrm{PrOH} /$ hexane, $0.80 \mathrm{~mL} / \mathrm{min}, 20^{\circ} \mathrm{C}, 254 \mathrm{~nm}$ ) indicated $>99 \%$ ee: $t_{\mathrm{R}}$ (major) $=5.89 \mathrm{~min}$.

\section{Racemic 3e:}

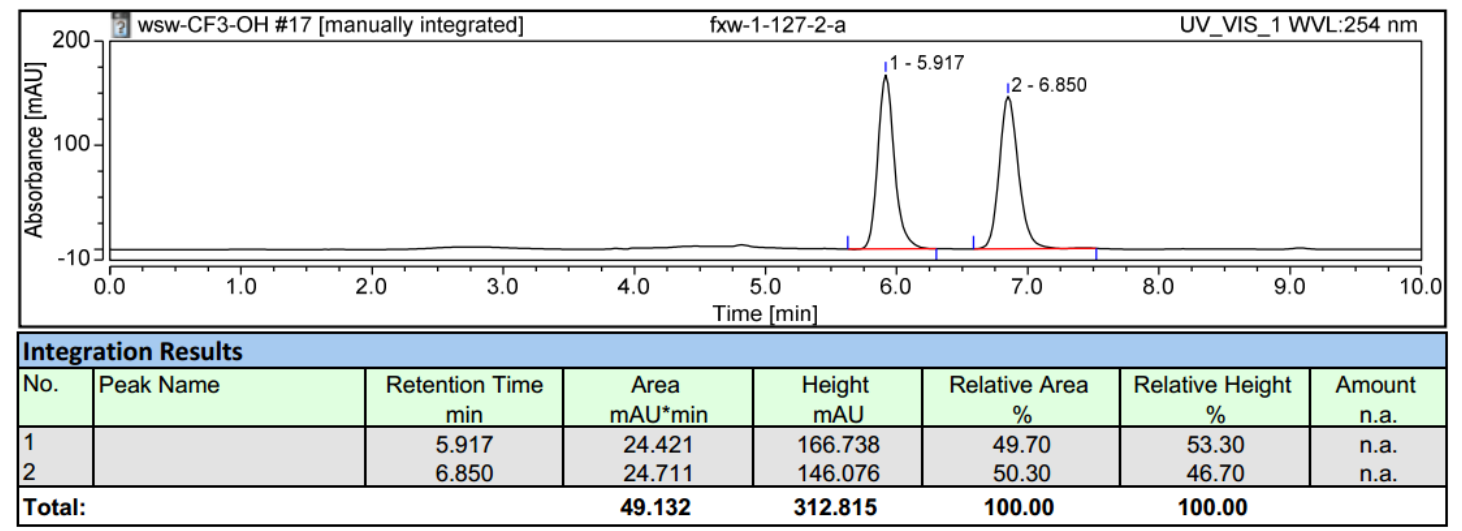

\section{Enantioenriched 3e:}

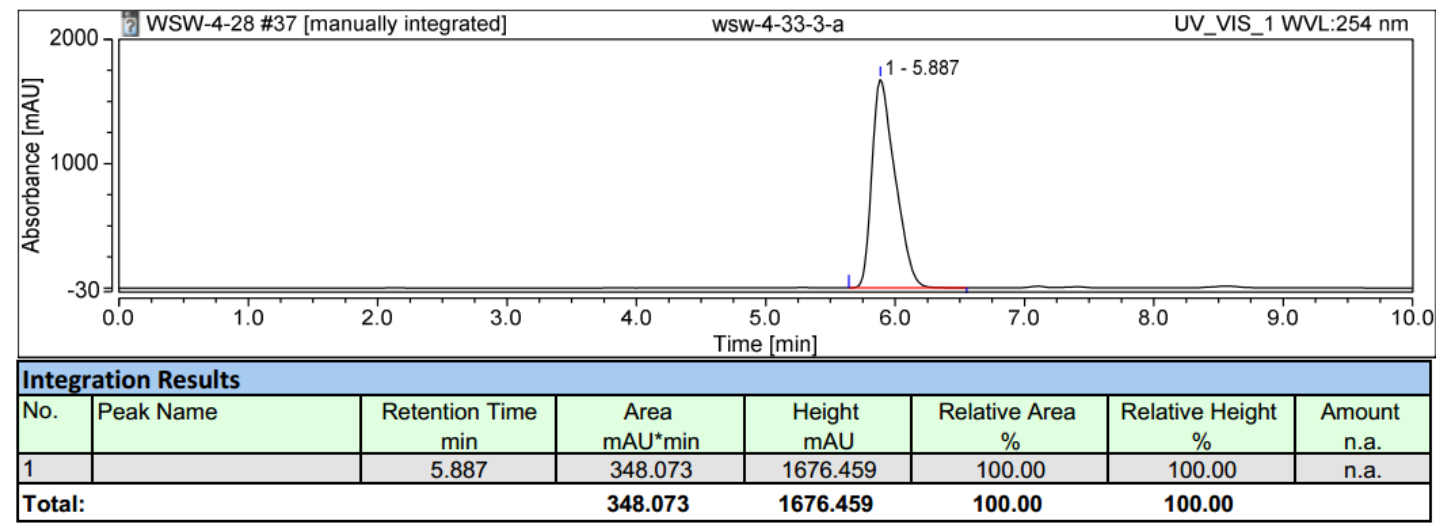


<smiles>C=CC#Cc1ccc(Br)cc1</smiles>

1f, 2.0 equiv.

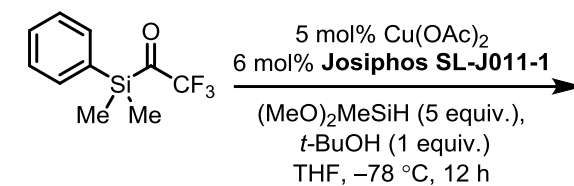

1.0 equiv.<smiles>CC(C#Cc1ccc(Br)cc1)[C@](O)(O[AsH2]c1ccccc1)C(F)(F)F</smiles>

$3 f$

In a glovebox, to an oven-dried $10 \mathrm{~mL}$ Schlenk tube equipped with a magnetic stir bar was added $\mathrm{Cu}(\mathrm{OAc})_{2}$ (5 mol\%), Josiphos SL-J011-1 (6 mol\%), and dry THF (1 mL) sequentially. The mixture was stirred at room temperature for $30 \mathrm{~min}$ before the addition of DMMS (5 equiv.), $t$-BuOH ( 1 equiv.) and 1f ( 2 equiv.). The tube was then sealed, removed from the glove box and allowed to stir at $-78^{\circ} \mathrm{C}$ for 5 min, after which the mixture was added 1-(dimethyl(phenyl)silyl)-2,2,2-trifluoroethanone (1 equiv., 0.25 mmol) in $5 \mathrm{~mL}$ THF using a syringe driven by an injection pump at a constant flow rate (within $6 \mathrm{~h}$ ). After stirring for another $6 \mathrm{~h}$, a saturated solution of $\mathrm{NH}_{4} \mathrm{~F}$ in $\mathrm{MeOH}$ (ca. $6 \mathrm{~mL}$ ) was carefully added to quench the reaction (Caution: gas evolution was observed). The reaction mixture was allowed to stir for $20 \mathrm{~min}$ at room temperature, diluted with EtOAc (ca. $10 \mathrm{~mL})$, stirred for an additional $10 \mathrm{~min}$ at room temperature and then filtered through a short plug of celite $(1-2 \mathrm{~cm})$ eluting with EtOAc $(\mathrm{ca} .50 \mathrm{~mL})$. The solvent was removed in vacuo with the aid of a rotary evaporator. At this point, the crude yield and the diastereomeric ratio (dr) were determined by ${ }^{19} \mathrm{~F}$ NMR spectroscopic analysis using $\mathrm{PhCF}_{3}$ as the internal standard. The crude product was purified with column chromatography on silica gel (300 400 mesh) to afford the title compound 3f. Colorless oil; $\mathbf{R}_{\mathbf{f}}=0.56(\mathrm{PE} / \mathrm{EA}=10 / 1) ; 102.5 \mathrm{mg}, 93 \%$ yield, > 99\% ee, 99:1 dr; $[\boldsymbol{\alpha}]^{25} \mathbf{D}=-74.2\left(c=5.28, \mathrm{CHCl}_{3}\right)$ NMR spectroscopy: ${ }^{1} \mathbf{H}$ NMR (400 MHz, $\mathrm{CDCl}_{3}, 25$ $\left.{ }^{\circ} \mathrm{C}\right) \delta 7.65(\mathrm{dd}, J=7.9,1.7 \mathrm{~Hz}, 2 \mathrm{H}), 7.48-7.36(\mathrm{~m}, 5 \mathrm{H}), 7.25-7.20(\mathrm{~m}, 2 \mathrm{H}), 3.08(\mathrm{q}, J=7.4 \mathrm{~Hz}, 1 \mathrm{H})$, $2.62(\mathrm{~s}, 1 \mathrm{H}), 1.27(\mathrm{dd}, J=7.4,1.8 \mathrm{~Hz}, 3 \mathrm{H}), 0.61(\mathrm{~s}, 3 \mathrm{H}), 0.57(\mathrm{~s}, 3 \mathrm{H}) ;{ }^{13} \mathbf{C ~ N M R}\left(101 \mathrm{MHz}, \mathrm{CDCl}_{3}, 25\right.$ $\left.{ }^{\circ} \mathrm{C}\right) \delta 134.9,134.5,133.2,130.3,128.2,127.9(\mathrm{q}, J=286.5 \mathrm{~Hz}), 126.5,122.6,121.9,89.4,83.9,71.43$ $(\mathrm{q}, J=28.0 \mathrm{~Hz}), 33.2,16.5,-3.2,-3.4 ;{ }^{19} \mathbf{F}$ NMR $\left(376 \mathrm{MHz}, \mathrm{CDCl}_{3}, 25{ }^{\circ} \mathrm{C}\right) \delta-67.6$ (s, 3F); IR (ATR): 3496, 3347, 3250, 3071, 2948, 2907, 1487, 1427, 1323, 1238, 1152, 1014, 817, 738, $705 \mathrm{~cm}^{-1}$; HRMS (ESI, m/z): calcd for $\mathrm{C}_{20} \mathrm{H}_{21} \mathrm{BrF}_{3} \mathrm{OSi}(\mathrm{M}+\mathrm{H})^{+}$: 441.0492; Found: 441.0498; HPLC analysis (AD-H column, $3 \% i-\mathrm{PrOH} /$ hexane, $0.80 \mathrm{~mL} / \mathrm{min}, 20^{\circ} \mathrm{C}, 254 \mathrm{~nm}$ ) indicated $>99 \%$ ee: $t_{\mathrm{R}}$ (major) $=5.99 \mathrm{~min}$.

\section{Racemic 3f:}

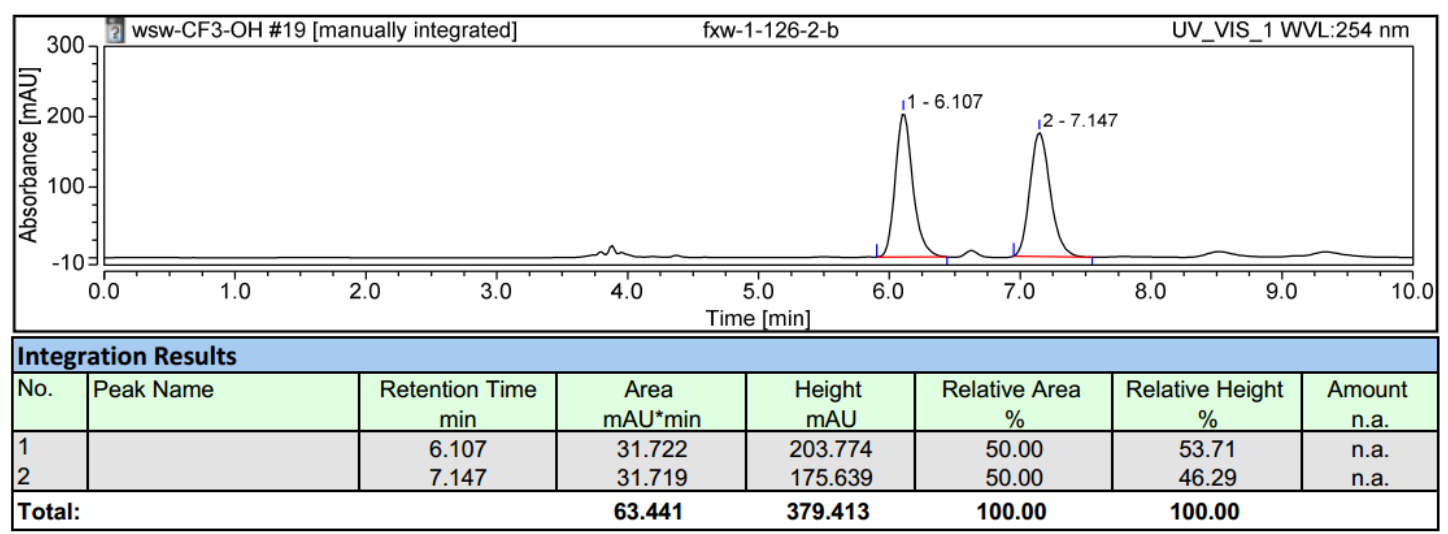


Enantioenriched 3f:

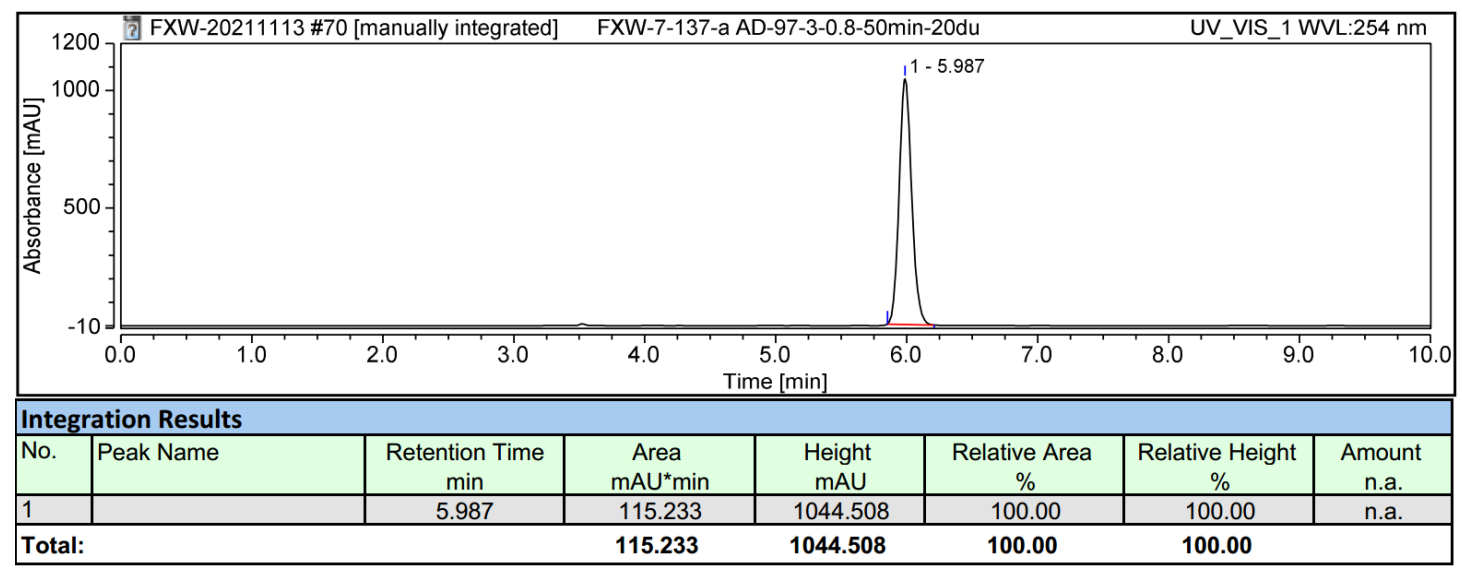

2R, 3S)-2-(Dimethyl(phenyl)silyl)-1,1,1-trifluoro-3-methyl-5-(4-nitrophenyl)pent-4-yn-2-ol (3g)

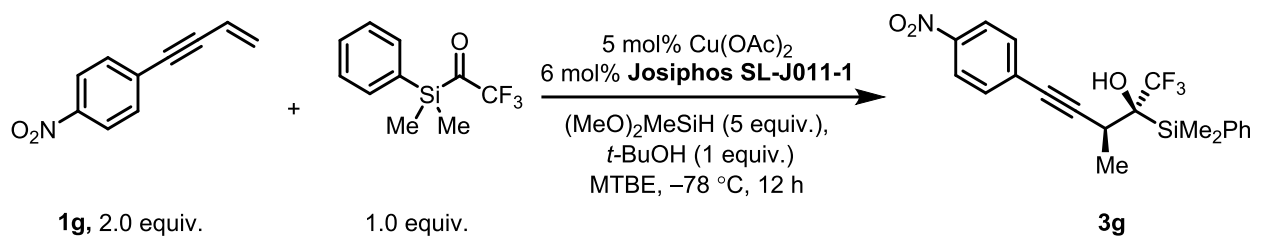

In a glovebox, to an oven-dried $10 \mathrm{~mL}$ Schlenk tube equipped with a magnetic stir bar was added $\mathrm{Cu}(\mathrm{OAc})_{2}(5 \mathrm{~mol} \%)$, Josiphos SL-J011-1 (6 mol\%), and dry MTBE $(1 \mathrm{~mL})$ sequentially. The mixture was stirred at room temperature for $30 \mathrm{~min}$ before the addition of DMMS ( 5 equiv.), $t$-BuOH (1 equiv.) and $1 \mathrm{~g}$ ( 2 equiv.). The tube was then sealed, removed from the glove box and allowed to stir at $-78^{\circ} \mathrm{C}$ for $5 \mathrm{~min}$, after which the mixture was added 1-(dimethyl(phenyl)silyl)-2,2,2-trifluoroethanone (1 equiv., $0.25 \mathrm{mmol}$ ) in $5 \mathrm{~mL}$ MTBE using a syringe driven by an injection pump at a constant flow rate (within $6 \mathrm{~h}$ ) After stirring for another $6 \mathrm{~h}$, a saturated solution of $\mathrm{NH}_{4} \mathrm{~F}$ in $\mathrm{MeOH}$ (ca. $6 \mathrm{~mL}$ ) was carefully added to quench the reaction (Caution: gas evolution was observed). The reaction mixture was allowed to stir for $20 \mathrm{~min}$ at room temperature, diluted with EtOAc (ca. $10 \mathrm{~mL}$ ), stirred for an additional $10 \mathrm{~min}$ at room temperature and then filtered through a short plug of celite $(1-2 \mathrm{~cm})$ eluting with EtOAc (ca. $50 \mathrm{~mL}$ ). The solvent was removed in vacuo with the aid of a rotary evaporator. At this point, the crude yield and the diastereomeric ratio (dr) were determined by ${ }^{19} \mathrm{~F}$ NMR spectroscopic analysis using $\mathrm{PhCF}_{3}$ as the internal standard. The crude product was purified with column chromatography on silica gel (300 400 mesh) to afford the title compound 3g. Yellow solid; mp: 90.8-91.9 ${ }^{\circ} \mathrm{C} ; \mathbf{R}_{\mathbf{f}}=0.44(\mathrm{PE} / \mathrm{EA}=10 / 1) ; 82$ $\mathrm{mg}, 81 \%$ yield, $91 \%$ ee, $98: 2 \mathrm{dr} ;[\boldsymbol{\alpha}]^{25} \mathbf{D}=-39.5\left(c=8.5, \mathrm{CHCl}_{3}\right)$ NMR spectroscopy: ${ }^{1} \mathbf{H}$ NMR $(600$ $\left.\mathrm{MHz}, \mathrm{CDCl}_{3}, 25^{\circ} \mathrm{C}\right) \delta 8.18-8.13(\mathrm{~m}, 2 \mathrm{H}), 7.64(\mathrm{dd}, J=8.0,1.5 \mathrm{~Hz}, 2 \mathrm{H}), 7.56-7.38(\mathrm{~m}, 5 \mathrm{H}), 3.11(\mathrm{q}, J$ $=7.4 \mathrm{~Hz}, 1 \mathrm{H}), 2.51(\mathrm{~s}, 1 \mathrm{H}), 1.29(\mathrm{dd}, J=7.4,1.7 \mathrm{~Hz}, 3 \mathrm{H}), 0.61(\mathrm{~s}, 1 \mathrm{H}), 0.56(\mathrm{~s}, 1 \mathrm{H}) ;{ }^{13} \mathbf{C}$ NMR $(151$ $\left.\mathrm{MHz}, \mathrm{CDCl}_{3}, 25^{\circ} \mathrm{C}\right) \delta 147.2,134.9,134.2,132.6,130.4,129.9,128.2,127.8(\mathrm{q}, J=285.9 \mathrm{~Hz}) 123.7$, 94.2, 83.1, 71.7 (q, $J=28.0 \mathrm{~Hz}), 33.3,16.4,-3.2,-3.4 ;{ }^{19} \mathbf{F}$ NMR $\left(565 \mathrm{MHz}, \mathrm{CDCl}_{3}, 25{ }^{\circ} \mathrm{C}\right) \delta-67.9(\mathrm{~s}$, 3F); IR (ATR): 3672, 3497, 3191, 3075, 2926, 2805, 2233, 1595, 1342, 1260, 1152, 859, 813, 753, 705 $\mathrm{cm}^{-1}$; HRMS (ESI, m/z): calcd for $\mathrm{C}_{20} \mathrm{H}_{20} \mathrm{~F}_{3} \mathrm{O}_{3} \mathrm{NClSi}^{-}(\mathrm{M}+\mathrm{Cl})^{-}$: 442.0859; Found: 442.0856; HPLC analysis (IA column, $3 \% i-\mathrm{PrOH} /$ hexane, $1.0 \mathrm{~mL} / \mathrm{min}, 20^{\circ} \mathrm{C}, 230 \mathrm{~nm}$ ) indicated $91 \%$ ee: $t_{\mathrm{R}}$ (major) $=$ $10.84 \mathrm{~min}, t_{\mathrm{R}}($ minor $)=10.10 \mathrm{~min}$. 
Racemic 3g:

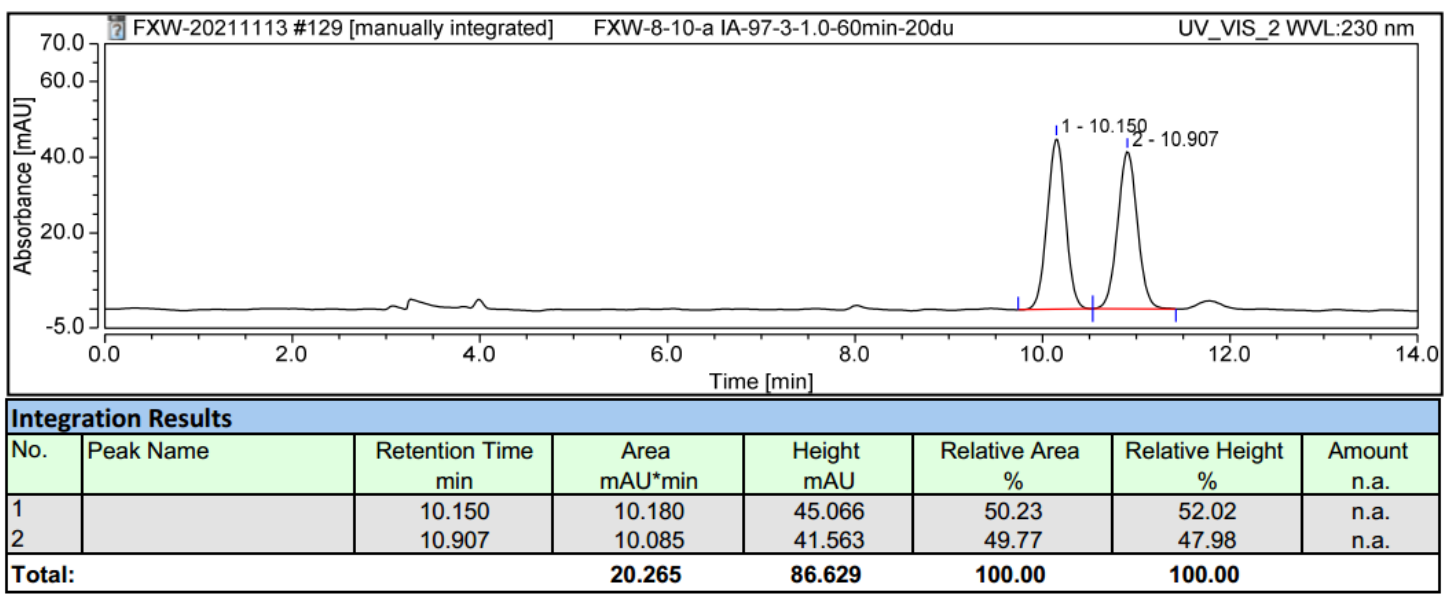

Enantioenriched 3g:

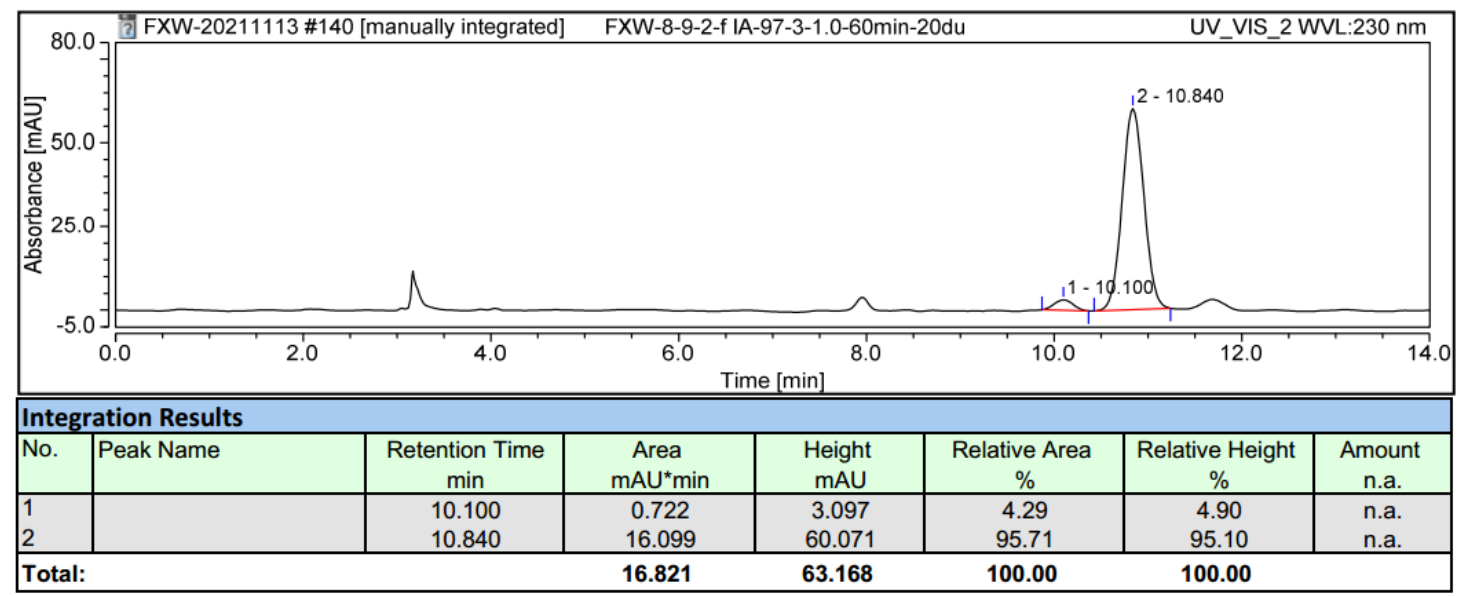

(2R, 3S)-2-(Dimethyl(phenyl)silyl)-1,1,1-trifluoro-5-(4-methoxyphenyl)-3-methylpent-4-yn-2- ol

(3h)

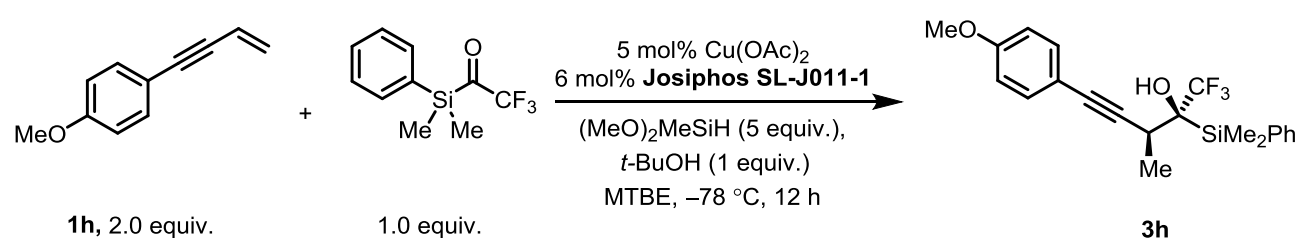

In a glovebox, to an oven-dried $10 \mathrm{~mL}$ Schlenk tube equipped with a magnetic stir bar was added $\mathrm{Cu}(\mathrm{OAc})_{2}$ (5 mol\%), Josiphos SL-J011-1 (6 mol\%), and dry MTBE $(1 \mathrm{~mL})$ sequentially. The mixture was stirred at room temperature for $30 \mathrm{~min}$ before the addition of DMMS (5 equiv.), $t$-BuOH (1 equiv.) and $\mathbf{1 h}$ ( 2 equiv.). The tube was then sealed, removed from the glove box and allowed to stir at $-78{ }^{\circ} \mathrm{C}$ for 5 min, after which the mixture was added 1-(dimethyl(phenyl)silyl)-2,2,2-trifluoroethanone (1 equiv., $0.25 \mathrm{mmol}$ ) in $5 \mathrm{~mL}$ MTBE using a syringe driven by an injection pump at a constant flow rate (within $6 \mathrm{~h}$ ). After stirring for another $6 \mathrm{~h}$, a saturated solution of $\mathrm{NH}_{4} \mathrm{~F}$ in $\mathrm{MeOH}$ (ca. $6 \mathrm{~mL}$ ) was carefully added to quench the reaction (Caution: gas evolution was observed). The reaction mixture was allowed to stir for $20 \mathrm{~min}$ at room temperature, diluted with EtOAc (ca. $10 \mathrm{~mL}$ ), stirred for an additional $10 \mathrm{~min}$ at room temperature and then filtered through a short plug of celite $(1-2 \mathrm{~cm})$ eluting with EtOAc $(\mathrm{ca} .50 \mathrm{~mL})$. 
The solvent was removed in vacuo with the aid of a rotary evaporator. At this point, the crude yield and the diastereomeric ratio ( $\mathrm{dr}$ ) were determined by ${ }^{19} \mathrm{~F}$ NMR spectroscopic analysis using $\mathrm{PhCF}_{3}$ as the internal standard. The crude product was purified with column chromatography on silica gel (300 400 mesh) to afford the title compound 3h. Colorless oil; $\mathbf{R}_{\mathbf{f}}=0.58(\mathrm{PE} / \mathrm{EA}=10 / 1) ; 78.4 \mathrm{mg}, 80 \%$ yield, > 99\% ee, $>$ 99:1 dr; $[\boldsymbol{\alpha}]^{25} \mathbf{D}=-61.8\left(c=16.5, \mathrm{CHCl}_{3}\right)$; NMR spectroscopy: ${ }^{1} \mathbf{H}$ NMR (400 MHz, $\mathrm{CDCl}_{3}$, $\left.25^{\circ} \mathrm{C}\right) \delta 7.67-7.63(\mathrm{~m}, 2 \mathrm{H}), 7.47-7.36(\mathrm{~m}, 3 \mathrm{H}), 7.33-7.28(\mathrm{~m}, 2 \mathrm{H}), 6.83-6.79(\mathrm{~m}, 2 \mathrm{H}), 3.80(\mathrm{~s}, 3 \mathrm{H})$, 3.07 (q, $J=7.4 \mathrm{~Hz}, 1 \mathrm{H}), 2.73(\mathrm{~s}, 1 \mathrm{H}), 1.25(\mathrm{dq}, J=7.4,1.8 \mathrm{~Hz}, 3 \mathrm{H}), 0.59$ (s, 3H), $0.55(\mathrm{~s}, 3 \mathrm{H}) ;{ }^{13}$ C NMR $\left(100 \mathrm{MHz}, \mathrm{CDCl}_{3}, 25^{\circ} \mathrm{C}\right) \delta 159.7,134.9,134.7,133.2,130.2,128.1,128.0$ (q, $\left.J=286.5 \mathrm{~Hz}\right), 115.0$, $114.0,86.4,85.0,71.3$ (q, $J=27.9 \mathrm{~Hz}), 55.4,33.2,16.6,-3.2,-3.5 ;{ }^{19} \mathbf{F} \mathbf{N M R}\left(375 \mathrm{MHz}, \mathrm{CDCl}_{3}, 25^{\circ} \mathrm{C}\right)$ $\delta-67.5$ (s, 3F); IR (ATR): 3612, 3481, 3370, 3049, 2922, 2856, 1607, 1560, 1290, 1249, 1152, 1033, 813, 738, $705 \mathrm{~cm}^{-1}$; HRMS (ESI, m/z): calcd for $\mathrm{C}_{21} \mathrm{H}_{24} \mathrm{~F}_{3} \mathrm{O}_{2} \mathrm{Si}(\mathrm{M}+\mathrm{H})^{+}:$393.1492; Found: 393.1478 ; HPLC analysis (AD-H column, $1 \% i-\mathrm{PrOH} / \mathrm{h}$ exane, $0.50 \mathrm{~mL} / \mathrm{min}, 20^{\circ} \mathrm{C}, 254 \mathrm{~nm}$ ) indicated $>99 \%$ ee: $t_{\mathrm{R}}($ major $)=14.21 \mathrm{~min}$.

Racemic 3h:

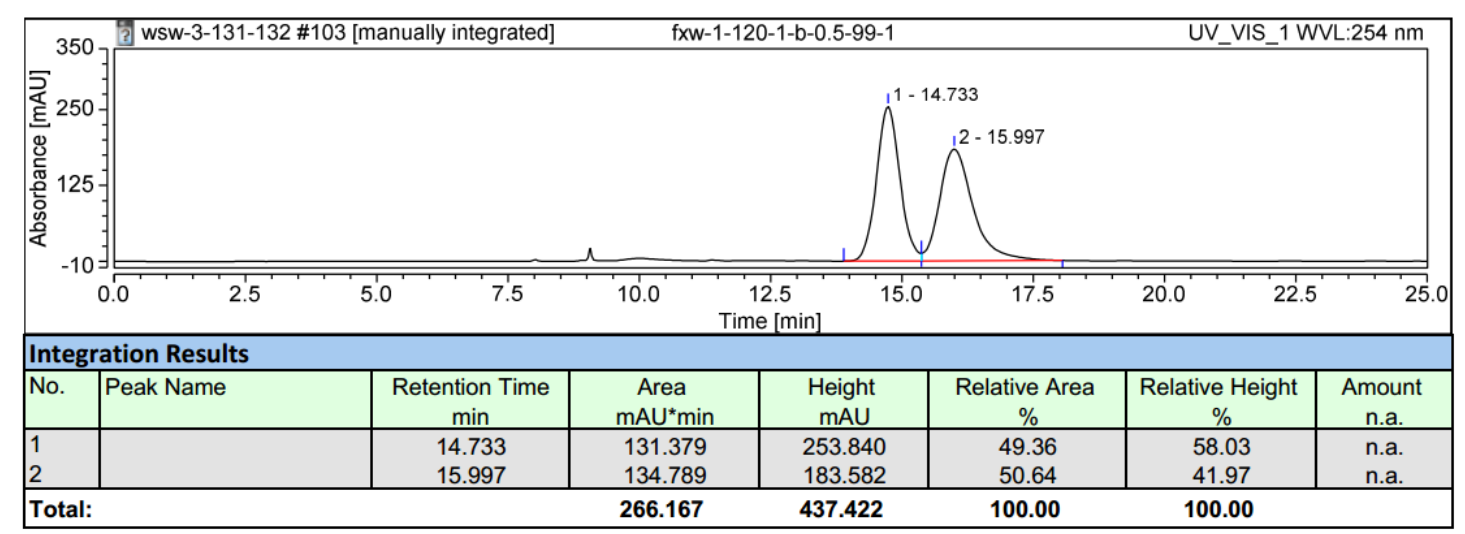

\section{Enantioenriched 3h:}

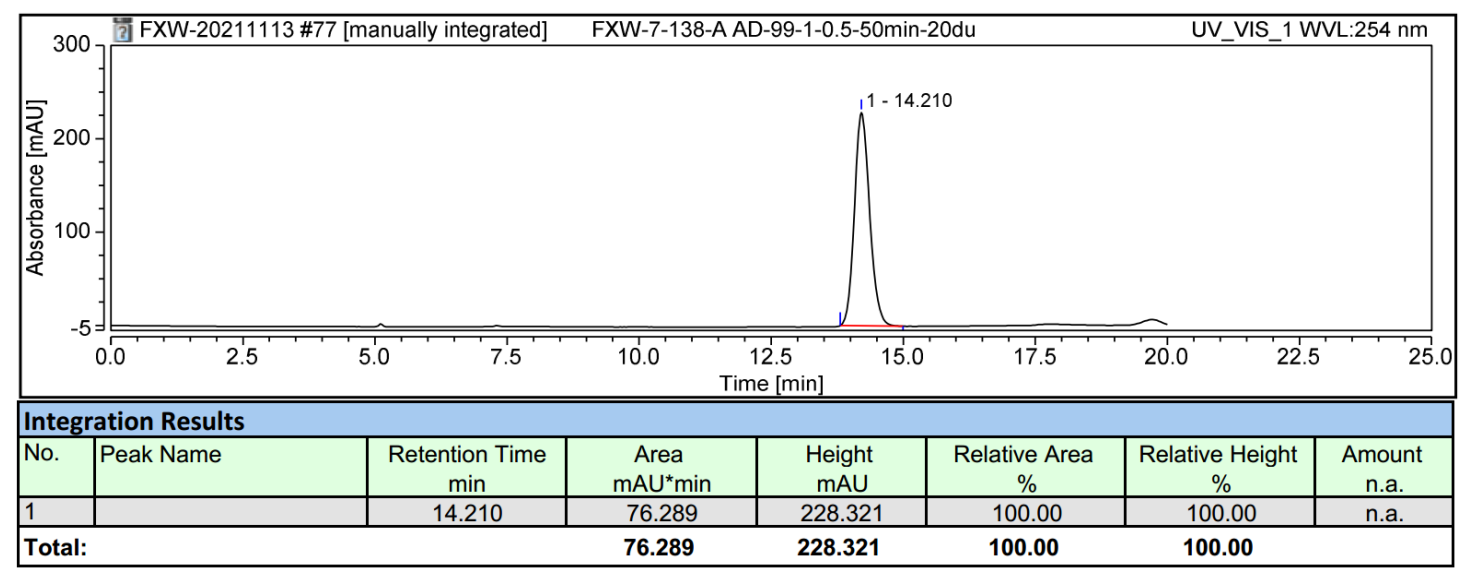

(2R,3S)-2-(dimethyl(phenyl)silyl)-1,1,1-trifluoro-5-(3-methoxyphenyl)-3-methylpent-4-yn-2-ol(3i)

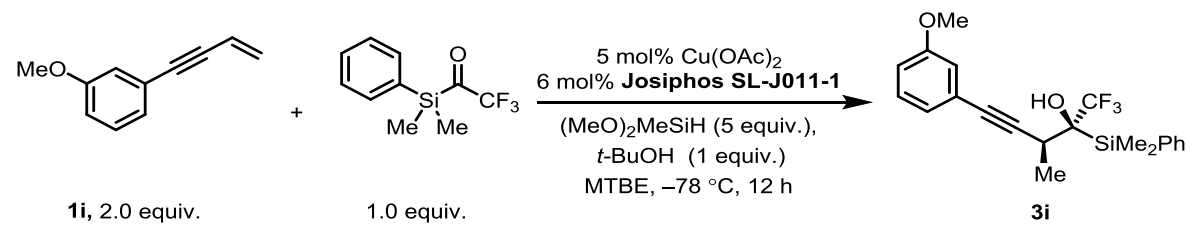

In a glovebox, to an oven-dried $10 \mathrm{~mL}$ Schlenk tube equipped with a magnetic stir bar was added 
$\mathrm{Cu}(\mathrm{OAc})_{2}$ (5 mol\%), Josiphos SL-J011-1 (6 mol\%), and dry MTBE $(1 \mathrm{~mL})$ sequentially. The mixture was stirred at room temperature for $30 \mathrm{~min}$ before the addition of DMMS ( 5 equiv.), $t$-BuOH (1 equiv.) and $1 \mathbf{i}$ ( 2 equiv.). The tube was then sealed, removed from the glove box and allowed to stir at $-78{ }^{\circ} \mathrm{C}$ for $5 \mathrm{~min}$, after which the mixture was added 1-(dimethyl(phenyl)silyl)-2,2,2-trifluoroethanone (1 equiv., $0.25 \mathrm{mmol}$ ) in $5 \mathrm{~mL}$ MTBE using a syringe driven by an injection pump at a constant flow rate (within $6 \mathrm{~h}$ ). After stirring for another $6 \mathrm{~h}$, a saturated solution of $\mathrm{NH}_{4} \mathrm{~F}$ in $\mathrm{MeOH}$ (ca. $6 \mathrm{~mL}$ ) was carefully added to quench the reaction (Caution: gas evolution was observed). The reaction mixture was allowed to stir for $20 \mathrm{~min}$ at room temperature, diluted with EtOAc (ca. $10 \mathrm{~mL}$ ), stirred for an additional $10 \mathrm{~min}$ at room temperature and then filtered through a short plug of celite $(1-2 \mathrm{~cm})$ eluting with EtOAc (ca. $50 \mathrm{~mL}$ ). The solvent was removed in vacuo with the aid of a rotary evaporator. At this point, the crude yield and the diastereomeric ratio (dr) were determined by ${ }^{19} \mathrm{~F}$ NMR spectroscopic analysis using $\mathrm{PhCF}_{3}$ as the internal standard. The crude product was purified with column chromatography on silica gel (300 400 mesh) to afford the title compound 3i. Colorless oil; $\mathbf{R}_{\mathbf{f}}=0.6(\mathrm{PE} / \mathrm{EA}=10 / 1) ; 78 \mathrm{mg}, 80 \%$ yield, $96 \%$ ee, $97: 3 \mathrm{dr} ;[\boldsymbol{\alpha}]^{25} \mathbf{D}=-53.1\left(c=3.25, \mathrm{CHCl}_{3}\right)$ NMR spectroscopy: ${ }^{1} \mathbf{H} \mathbf{~ N M R}\left(400 \mathrm{MHz}, \mathrm{CDCl}_{3}, 25^{\circ} \mathrm{C}\right) \delta$ 7.65 (dd, $J=7.8,1.6 \mathrm{~Hz}, 2 \mathrm{H}), 7.47-7.37$ (m, 3H), 7.19 (t, $J=7.9 \mathrm{~Hz}, 1 \mathrm{H}), 6.97$ (d, $J=7.6 \mathrm{~Hz}, 1 \mathrm{H})$, 6.91-6.83 (m, 2H), 3.78 (s, 3H), 3.08 (q, $J=7.4 \mathrm{~Hz}, 1 \mathrm{H}), 2.69$ (s, $1 \mathrm{H}), 1.27$ (dq, $J=7.4,1.8 \mathrm{~Hz}, 3 \mathrm{H})$, 0.60 (s, 3H), 0.56 (s, 3H); ${ }^{13} \mathbf{C}$ NMR $\left(151 \mathrm{MHz}, \mathrm{CDCl}_{3}, 25^{\circ} \mathrm{C}\right) \delta 159.4,134.9,134.6,130.2,129.5,128.1$, 127.9 (d, $J=286.3 \mathrm{~Hz}), 124.3,123.9,116.6,115.0,87.8,85.0,71.4$ (d, $J=27.9 \mathrm{~Hz}), 55.4,33.2,16.5$, $-3.2,-3.5 ;{ }^{19} \mathbf{F}$ NMR $\left(376 \mathrm{MHz}, \mathrm{CDCl}_{3}, 25^{\circ} \mathrm{C}\right) \delta-67.5$ (s, 3F); IR (ATR): 3489, 3000, 2952, 1603, 1487 , 1428, 1319, 1286, 1241, 1156, 1088, 1043, 909, 816, $708 \mathrm{~cm}^{-1}$; HRMS (ESI, m/z): calcd for $\mathrm{C}_{21} \mathrm{H}_{24} \mathrm{~F}_{3} \mathrm{O}_{2} \mathrm{Si} \quad(\mathrm{M}+\mathrm{H})^{+}:$393.1492; Found: 393.1493; HPLC analysis (AD-H column, 3\% $i-\mathrm{PrOH} /$ hexane, $0.8 \mathrm{~mL} / \mathrm{min}, 20^{\circ} \mathrm{C}, 254 \mathrm{~nm}$ ) indicated $96 \%$ ee: $t_{\mathrm{R}}($ major $)=7.35 \mathrm{~min}, t_{\mathrm{R}}($ minor $)=8.77$ $\min$.

\section{Racemic 3i:}

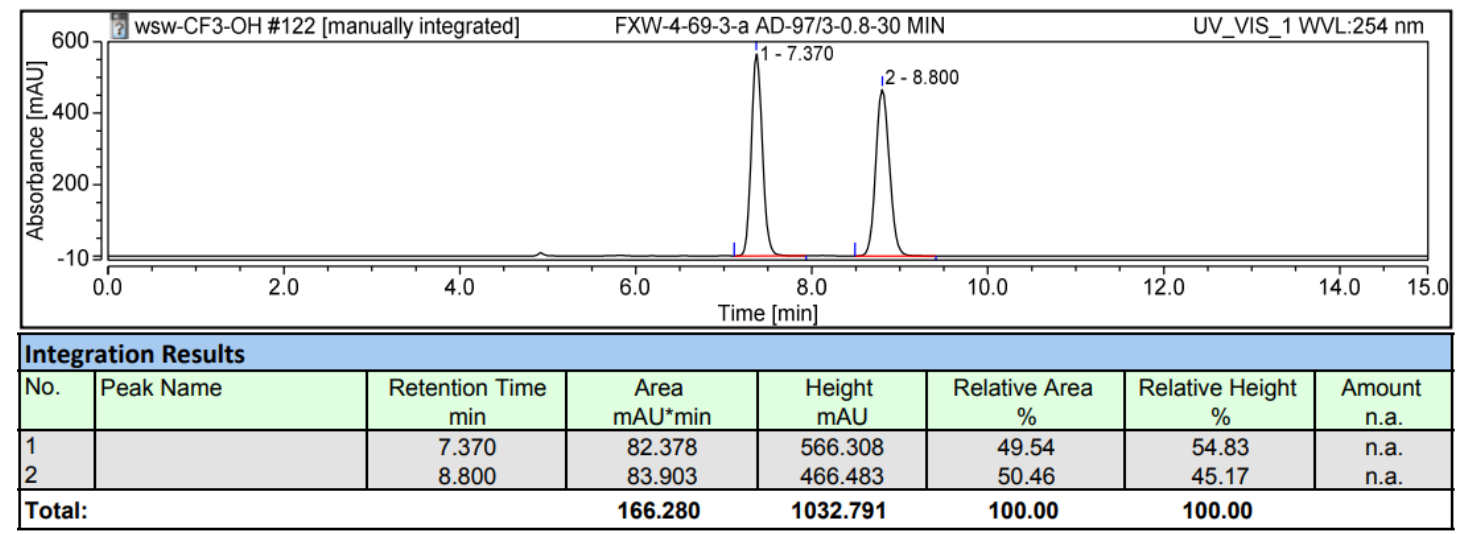


Enantioenriched 3i:

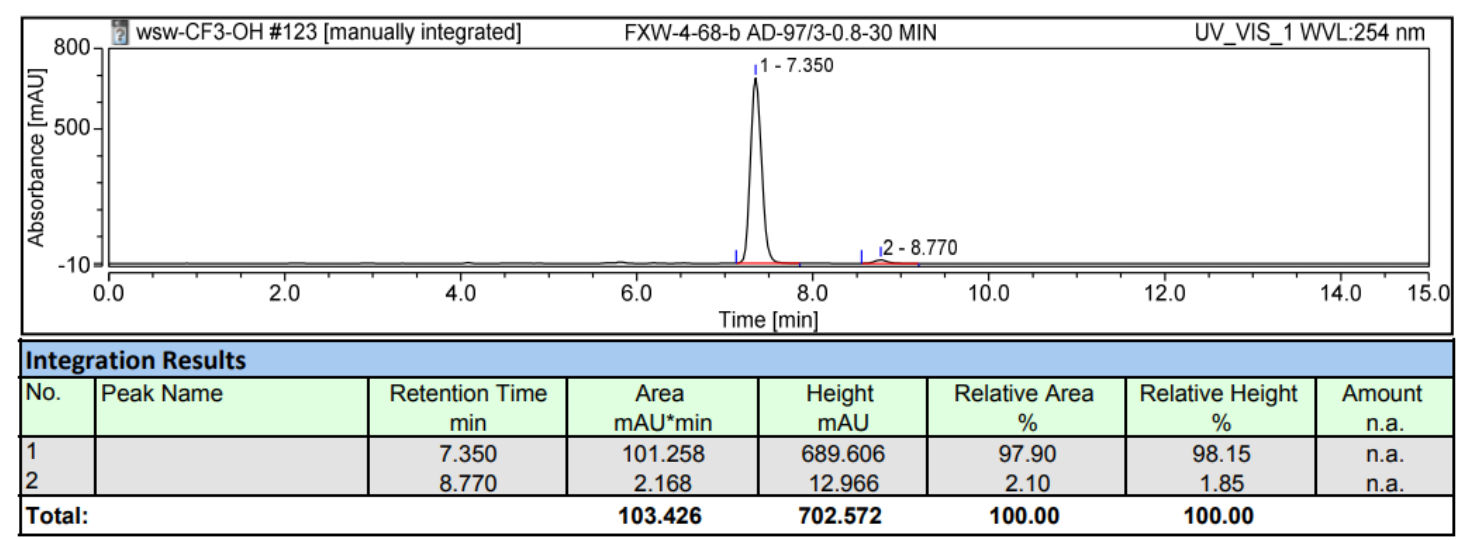

(2R, 3S)-2-(Dimethyl(phenyl)silyl)-1,1,1-trifluoro-3-methyl-5-(p-tolyl)pent-4-yn-2-ol (3j)<smiles>C=CC#Cc1ccc(C)cc1</smiles>

1j, 2.0 equiv<smiles>[Y9][Si]([14CH3])(C([13CH3])=O)c1ccccc1</smiles>

1.0 equiv.

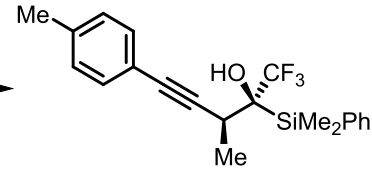

3j

In a glovebox, to an oven-dried $10 \mathrm{~mL}$ Schlenk tube equipped with a magnetic stir bar was added $\mathrm{Cu}(\mathrm{OAc})_{2}$ (5 mol\%), Josiphos SL-J011-1 (6 mol\%), and dry MTBE $(1 \mathrm{~mL})$ sequentially. The mixture was stirred at room temperature for $30 \mathrm{~min}$ before the addition of DMMS ( 5 equiv.), $t$-BuOH (1 equiv.) and $1 \mathbf{j}$ ( 2 equiv.). The tube was then sealed, removed from the glove box and allowed to stir at $-78{ }^{\circ} \mathrm{C}$ for $5 \mathrm{~min}$, after which the mixture was added 1-(dimethyl(phenyl)silyl)-2,2,2-trifluoroethanone (1 equiv., $0.25 \mathrm{mmol}$ ) in $5 \mathrm{~mL}$ MTBE using a syringe driven by an injection pump at a constant flow rate (within $6 \mathrm{~h}$ ). After stirring for another $6 \mathrm{~h}$, a saturated solution of $\mathrm{NH}_{4} \mathrm{~F}$ in $\mathrm{MeOH}$ (ca. $6 \mathrm{~mL}$ ) was carefully added to quench the reaction (Caution: gas evolution was observed). The reaction mixture was allowed to stir for $20 \mathrm{~min}$ at room temperature, diluted with EtOAc (ca. $10 \mathrm{~mL}$ ), stirred for an additional $10 \mathrm{~min}$ at room temperature and then filtered through a short plug of celite $(1-2 \mathrm{~cm})$ eluting with EtOAc (ca. $50 \mathrm{~mL}$ ). The solvent was removed in vacuo with the aid of a rotary evaporator. At this point, the crude yield and the diastereomeric ratio (dr) were determined by ${ }^{19} \mathrm{~F}$ NMR spectroscopic analysis using $\mathrm{PhCF}_{3}$ as the internal standard. The crude product was purified with column chromatography on silica gel (300 400 mesh) to afford the title compound $\mathbf{3 j}$. Colorless oil; $\mathbf{R}_{\mathbf{f}}=0.56(\mathrm{PE} / \mathrm{EA}=10 / 1) ; 77.1 \mathrm{mg}, 82 \%$ yield, $>$ 99\% ee, 97:3 dr; $[\boldsymbol{\alpha}]^{25} \mathbf{D}=-86.4\left(c=3.80, \mathrm{CHCl}_{3}\right)$ NMR spectroscopy: ${ }^{1} \mathbf{H}$ NMR $\left(400 \mathrm{MHz}, \mathrm{CDCl}_{3}, 25\right.$ $\left.{ }^{\circ} \mathrm{C}\right) \delta 7.67-7.62(\mathrm{~m}, 2 \mathrm{H}), 7.47-7.36(\mathrm{~m}, 3 \mathrm{H}), 7.27(\mathrm{~d}, J=1.8 \mathrm{~Hz}, 1 \mathrm{H}), 7.25(\mathrm{~d}, J=1.9 \mathrm{~Hz}, 1 \mathrm{H}), 7.09(\mathrm{~d}$, $J=7.8 \mathrm{~Hz}, 2 \mathrm{H}), 3.07$ (q, $J=7.4 \mathrm{~Hz}, 1 \mathrm{H}), 2.71(\mathrm{~s}, 1 \mathrm{H}), 2.33(\mathrm{~s}, 3 \mathrm{H}), 1.25(\mathrm{dt}, J=7.5,1.8 \mathrm{~Hz}, 3 \mathrm{H}), 0.59$ (s, 3H), 0.55 (s, 3H); ${ }^{13} \mathbf{C}$ NMR $\left(101 \mathrm{MHz}, \mathrm{CDCl}_{3}, 25{ }^{\circ} \mathrm{C}\right) \delta 138.5,134.9,134.7,131.7,130.2,129.2$, $128.1,127.9$ (q, $J=286.2 \mathrm{~Hz}$ ), 119.8, 87.2, 85.2, 71.3 (q, $J=28.0 \mathrm{~Hz}), 33.2,21.6,16.6,-3.2,-3.5 ;{ }^{19} \mathbf{F}$ NMR (376 MHz, $\left.\mathrm{CDCl}_{3}, 25^{\circ} \mathrm{C}\right) \delta-67.5$ (s, 3F); IR (ATR): 3880, 3489, 3206, 3071, 2967, 1771, 1666 , 1588, 1431, 1238, 1118, 951, 816, 738, $708 \mathrm{~cm}^{-1}$; HRMS (ESI, m/z): calcd for $\mathrm{C}_{21} \mathrm{H}_{24} \mathrm{~F}_{3} \mathrm{OSi}^{+}(\mathrm{M}+\mathrm{H})^{+}$: 377.1543; Found: 377.1533 ; HPLC analysis (AD-H column, $3 \% i-\mathrm{PrOH} / \mathrm{hexane}, 0.80 \mathrm{~mL} / \mathrm{min}, 20^{\circ} \mathrm{C}$, $254 \mathrm{~nm}$ ) indicated $>99 \%$ ee: $t_{\mathrm{R}}$ (major) $=4.85 \mathrm{~min}$. 
Racemic 3j:

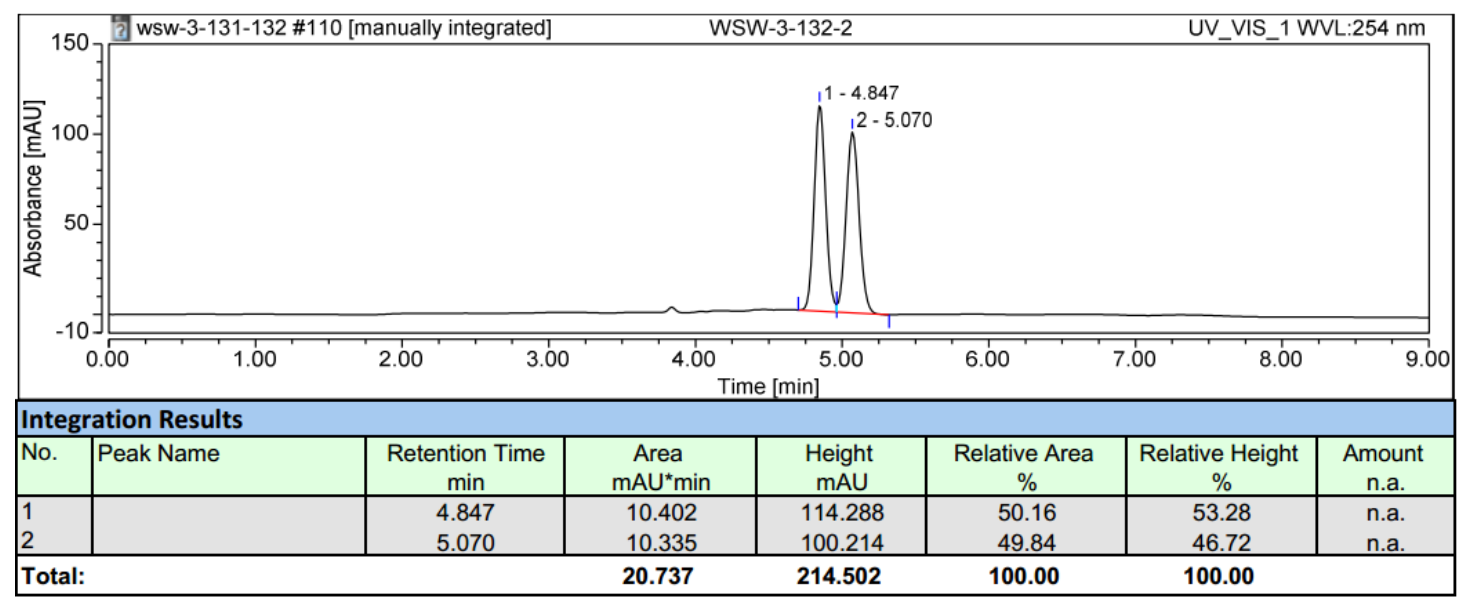

Enantioenriched 3j:

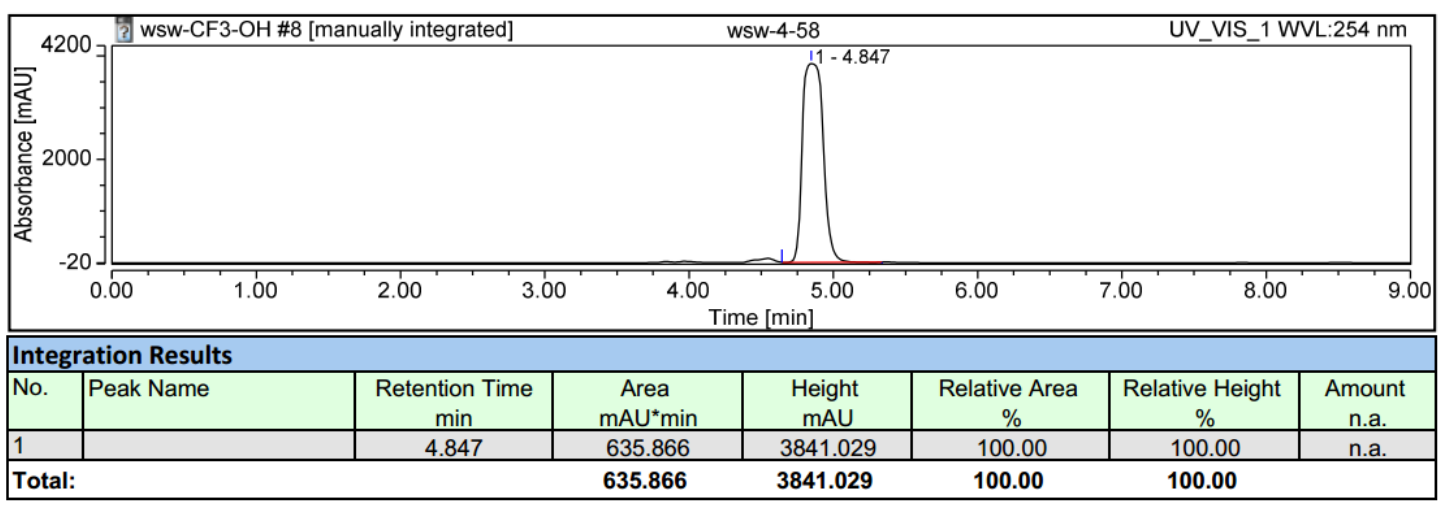

(2R,3S)-2-(dimethyl(phenyl)silyl)-5-(2,4-dimethylphenyl)-1,1,1-trifluoro-3-methylpent-4-yn-2-ol

(3k)

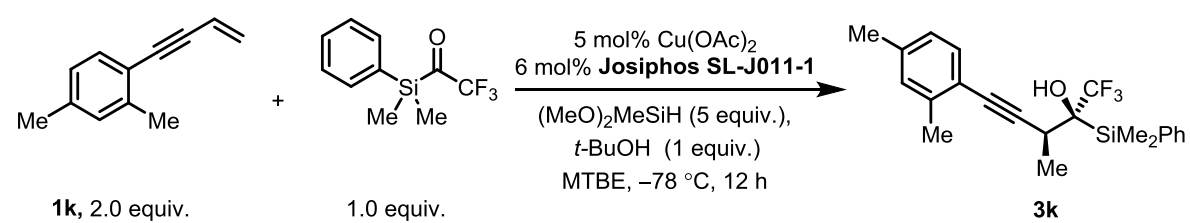

In a glovebox, to an oven-dried $10 \mathrm{~mL}$ Schlenk tube equipped with a magnetic stir bar was added $\mathrm{Cu}(\mathrm{OAc})_{2}$ (5 mol\%), Josiphos SL-J011-1 (6 mol\%), and dry MTBE (1 mL) sequentially. The mixture was stirred at room temperature for $30 \mathrm{~min}$ before the addition of DMMS ( 5 equiv.), $t$-BuOH (1 equiv.) and $1 \mathbf{k}$ ( 2 equiv.). The tube was then sealed, removed from the glove box and allowed to stir at $-78^{\circ} \mathrm{C}$ for $5 \mathrm{~min}$, after which the mixture was added 1-(dimethyl(phenyl)silyl)-2,2,2-trifluoroethanone (1 equiv., $0.25 \mathrm{mmol}$ ) in $5 \mathrm{~mL}$ MTBE using a syringe driven by an injection pump at a constant flow rate (within $6 \mathrm{~h}$ ). After stirring for another $6 \mathrm{~h}$, a saturated solution of $\mathrm{NH}_{4} \mathrm{~F}$ in $\mathrm{MeOH}(\mathrm{ca} .6 \mathrm{~mL}$ ) was carefully added to quench the reaction (Caution: gas evolution was observed). The reaction mixture was allowed to stir for $20 \mathrm{~min}$ at room temperature, diluted with EtOAc (ca. $10 \mathrm{~mL}$ ), stirred for an additional $10 \mathrm{~min}$ at room temperature and then filtered through a short plug of celite $(1-2 \mathrm{~cm})$ eluting with EtOAc (ca. $50 \mathrm{~mL}$ ). The solvent was removed in vacuo with the aid of a rotary evaporator. At this point, the crude yield and 
the diastereomeric ratio (dr) were determined by ${ }^{19} \mathrm{~F}$ NMR spectroscopic analysis using $\mathrm{PhCF}_{3}$ as the internal standard. The crude product was purified with column chromatography on silica gel (300 400 mesh) to afford the title compound $3 \mathbf{k}$; Colorless oil; $\mathbf{R}_{\mathbf{f}}=0.62(\mathrm{PE} / \mathrm{EA}=10 / 1) ; 72 \mathrm{mg}, 74 \%$ yield, 95\% ee, 90:10 dr; $[\boldsymbol{\alpha}]^{25} \mathbf{D}=-60.36\left(c=9.75, \mathrm{CHCl}_{3}\right)$ NMR spectroscopy: ${ }^{1} \mathbf{H} \mathbf{~ N M R}\left(400 \mathrm{MHz}, \mathrm{CDCl}_{3}, 25{ }^{\circ} \mathrm{C}\right)$ $\delta 7.68-7.63(\mathrm{~m}, 2 \mathrm{H}), 7.47-7.38(\mathrm{~m}, 3 \mathrm{H}), 7.23(\mathrm{~d}, J=7.8 \mathrm{~Hz}, 1 \mathrm{H}), 7.00(\mathrm{~s}, 1 \mathrm{H}), 6.92(\mathrm{~d}, J=7.8 \mathrm{~Hz}, 1 \mathrm{H})$, $3.13(\mathrm{q}, J=7.4 \mathrm{~Hz}, 1 \mathrm{H}), 2.77(\mathrm{~s}, 1 \mathrm{H}), 2.34(\mathrm{~s}, 3 \mathrm{H}), 2.30(\mathrm{~s}, 3 \mathrm{H}), 1.28(\mathrm{dq}, J=7.4,1.8 \mathrm{~Hz}, 3 \mathrm{H}), 0.60(\mathrm{~s}$, $3 \mathrm{H}), 0.56(\mathrm{~s}, 3 \mathrm{H}) ;{ }^{13} \mathbf{C} \mathbf{N M R}\left(151 \mathrm{MHz}, \mathrm{CDCl}_{3}, 25{ }^{\circ} \mathrm{C}\right) \delta 140.2,138.5,134.9,134.7,132.1,130.4,130.2$, $128.1,127.9$ (q, $J=286.8 \mathrm{~Hz}) 126.4,119.6,90.8,84.3,71.2(\mathrm{q}, J=28.0 \mathrm{~Hz}), 33.5,21.5,20.7,16.8,-3.3$, -3.5; ${ }^{19}$ F NMR $\left(376 \mathrm{MHz}, \mathrm{CDCl}_{3}, 25{ }^{\circ} \mathrm{C}\right) \delta-67.2$ (s, 3F); IR (ATR): 3489, 2986, 2919, 1614, 1498 , 1431, 1327, 1238, 1156, 1089, 1025, 909, 816, 738, $704 \mathrm{~cm}^{-1}$; HRMS (ESI, m/z): calcd for $\mathrm{C}_{22} \mathrm{H}_{26} \mathrm{~F}_{3} \mathrm{OSi}$ $(\mathrm{M}+\mathrm{H})^{+}:$391.1700; Found: 391.1694; HPLC analysis (AD-H column, $3 \% i-\mathrm{PrOH} / \mathrm{hexane}, 0.8 \mathrm{~mL} / \mathrm{min}$, $20^{\circ} \mathrm{C}, 254 \mathrm{~nm}$ ) indicated $95 \%$ ee: $t_{\mathrm{R}}$ (major) $=4.98 \mathrm{~min}, t_{\mathrm{R}}($ minor $)=5.37 \mathrm{~min}$.

\section{Racemic 3k:}

\begin{tabular}{|l||l|c|c|c|c|c|}
\hline & \\
\hline
\end{tabular}

\section{Enantioenriched 3k:}

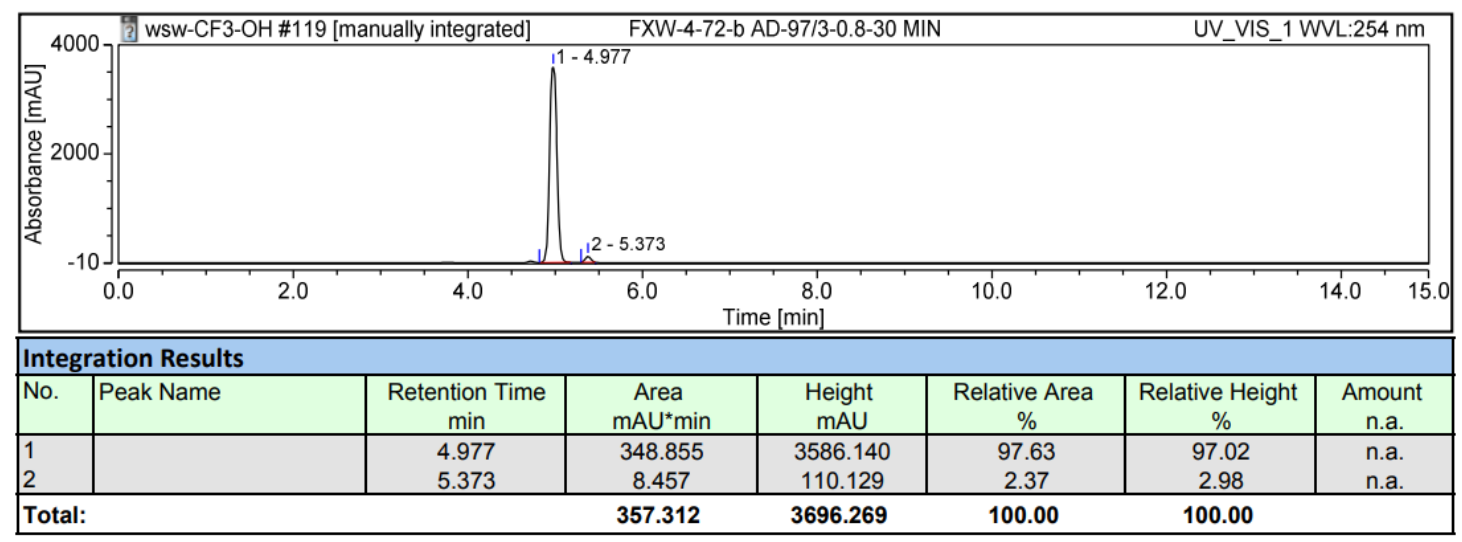

(2R, 3S)-2-(Dimethyl(phenyl)silyl)-1,1,1-trifluoro-3-methyl-5-(4-pentylphenyl)pent-4-yn-2-ol (3I)

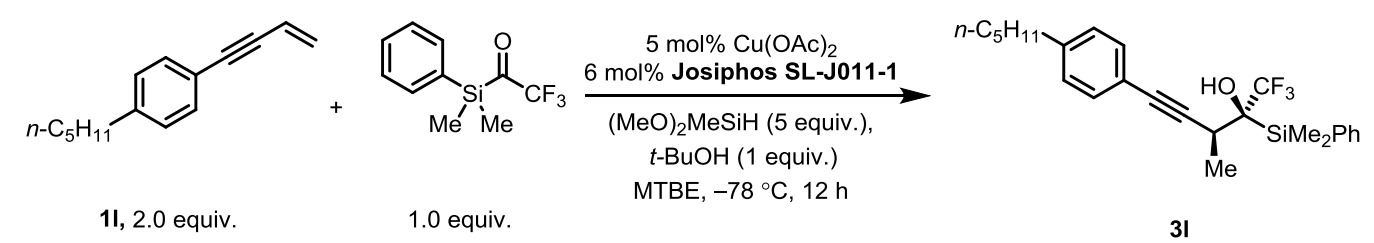

In a glovebox, to an oven-dried $10 \mathrm{~mL}$ Schlenk tube equipped with a magnetic stir bar was added 
$\mathrm{Cu}(\mathrm{OAc})_{2}$ (5 mol\%), Josiphos SL-J011-1 (6 mol\%), and dry MTBE $(1 \mathrm{~mL})$ sequentially. The mixture was stirred at room temperature for $30 \mathrm{~min}$ before the addition of DMMS ( 5 equiv.), $t$-BuOH (1 equiv.) and 11 ( 2 equiv.). The tube was then sealed, removed from the glove box and allowed to stir at $-78^{\circ} \mathrm{C}$ for $5 \mathrm{~min}$, after which the mixture was added 1-(dimethyl(phenyl)silyl)-2,2,2-trifluoroethanone (1 equiv., $0.25 \mathrm{mmol}$ ) in $5 \mathrm{~mL}$ MTBE using a syringe driven by an injection pump at a constant flow rate (within $6 \mathrm{~h}$ ). After stirring for another $6 \mathrm{~h}$, a saturated solution of $\mathrm{NH}_{4} \mathrm{~F}$ in $\mathrm{MeOH}$ (ca. $6 \mathrm{~mL}$ ) was carefully added to quench the reaction (Caution: gas evolution was observed). The reaction mixture was allowed to stir for $20 \mathrm{~min}$ at room temperature, diluted with EtOAc (ca. $10 \mathrm{~mL}$ ), stirred for an additional $10 \mathrm{~min}$ at room temperature and then filtered through a short plug of celite $(1-2 \mathrm{~cm})$ eluting with EtOAc (ca. $50 \mathrm{~mL}$ ). The solvent was removed in vacuo with the aid of a rotary evaporator. At this point, the crude yield and the diastereomeric ratio (dr) were determined by ${ }^{19} \mathrm{~F}$ NMR spectroscopic analysis using $\mathrm{PhCF}_{3}$ as the internal standard. The crude product was purified with column chromatography on silica gel (300 400 mesh) to afford the title compound 31. Colorless oil; $\mathbf{R}_{\mathbf{f}}=0.60$ (PE/EA $\left.=10 / 1\right) ; 70.2 \mathrm{mg}, 65 \%$ yield, $>$ 99\% ee, 97:3 dr; $[\boldsymbol{\alpha}]^{25} \mathbf{D}=-75.7\left(c=3.95 ; \mathrm{CHCl}_{3}\right)$ NMR spectroscopy: ${ }^{1} \mathbf{H} \mathbf{~ N M R}\left(400 \mathrm{MHz}, \mathrm{CDCl}_{3}, 25\right.$ $\left.{ }^{\circ} \mathrm{C}\right) 7.66-7.63(\mathrm{~m}, 2 \mathrm{H}), 7.46-7.36(\mathrm{~m}, 3 \mathrm{H}), 7.30-7.26(\mathrm{~m}, 2 \mathrm{H}), 7.09(\mathrm{~d}, J=8.2 \mathrm{~Hz}, 2 \mathrm{H}), 3.07$ (q, $J=7.4$ $\mathrm{Hz}, 1 \mathrm{H}), 2.71(\mathrm{~s}, 1 \mathrm{H}), 2.62-2.54(\mathrm{~m}, 2 \mathrm{H}), 1.32-1.23(\mathrm{~m}, 9 \mathrm{H}), 0.90-0.85(\mathrm{~m}, 3 \mathrm{H}), 0.59(\mathrm{~s}, 3 \mathrm{H}), 0.55(\mathrm{~s}$, $3 \mathrm{H}) ;{ }^{13} \mathrm{C}$ NMR $\left(151 \mathrm{MHz}, \mathrm{CDCl}_{3}, 2{ }^{\circ} \mathrm{C}\right) \delta 143.6,134.9,134.7,131.7,130.2,128.5,128.1,127.9$ (q, $J$ $=286.3 \mathrm{~Hz}$ ), 120.0, 87.2, 85.2, 71.3 (q, $J=28.0 \mathrm{~Hz}), 36.0,33.2,31.6,31.1,22.7,16.6,14.2,-3.2,-3.5$; ${ }^{19} \mathbf{F}$ NMR (376 MHz, $\left.\mathrm{CDCl}_{3}, 25{ }^{\circ} \mathrm{C}\right) \delta-67.5(\mathrm{~s}, 3 \mathrm{~F})$; IR (ATR): 3701, 3493, 3295, 3071, 2930, 2835, 1510, 1461, 1238, 1152, 951, 910, 839, 738, $705 \mathrm{~cm}^{-1}$; HRMS (ESI, m/z): calcd for $\mathrm{C}_{25} \mathrm{H}_{32} \mathrm{~F}_{3} \mathrm{OSi}^{+}$ $(\mathrm{M}+\mathrm{H})^{+}$: 433.2169; Found: 433.2156; HPLC analysis (AD-H column, $0.5 \% i-\mathrm{PrOH} /$ hexane, 0.50 $\mathrm{mL} / \mathrm{min}, 20^{\circ} \mathrm{C}, 254 \mathrm{~nm}$ ) indicated $99.5 \%$ ee: $t_{\mathrm{R}}($ major $)=15.58 \mathrm{~min}, t_{\mathrm{R}}($ minor $)=19.33 \mathrm{~min}$

\section{Racemic 31:}

\begin{tabular}{|l|l|l|l|l|l|l|l|}
\hline & \\
\hline
\end{tabular}


Enantioenriched 31:

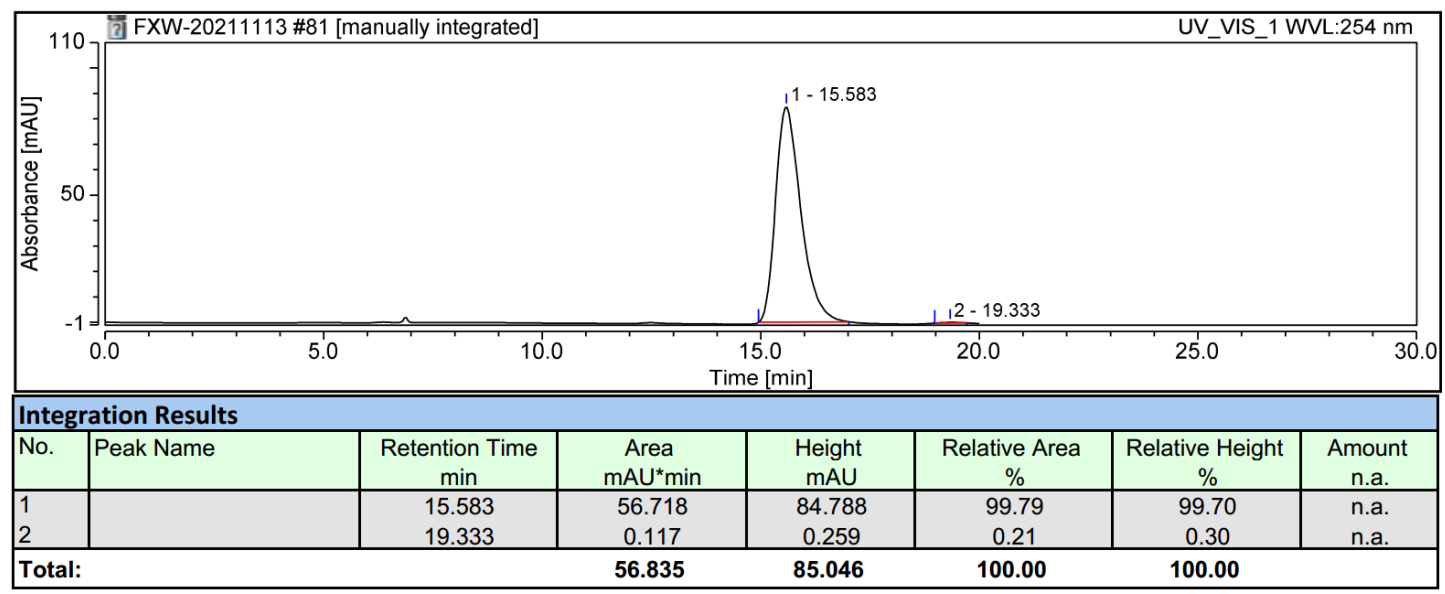

(2R,3S)-5-(4-(tert-Butyl)phenyl)-2-(dimethyl(phenyl)silyl)-1,1,1-trifluoro-3-methylpent-4-yn-2-ol

(3m)

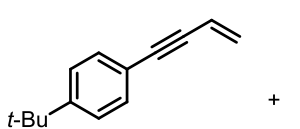

$1 \mathrm{~m}, 2.0$ equiv

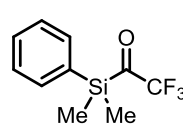

1.0 equiv.

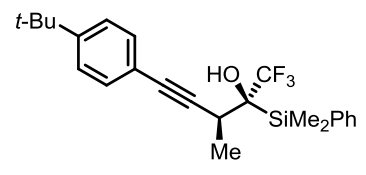

$3 m$

In a glovebox, to an oven-dried $10 \mathrm{~mL}$ Schlenk tube equipped with a magnetic stir bar was added $\mathrm{Cu}(\mathrm{OAc})_{2}$ (5 mol\%), Josiphos SL-J011-1 (6 mol\%), and dry MTBE (1 mL) sequentially. The mixture was stirred at room temperature for $30 \mathrm{~min}$ before the addition of DMMS ( 5 equiv.), $t$ - $\mathrm{BuOH}$ ( 1 equiv.) and $1 \mathbf{m}$ ( 2 equiv.). The tube was then sealed, removed from the glove box and allowed to stir at $-78{ }^{\circ} \mathrm{C}$ for $5 \mathrm{~min}$, after which the mixture was added 1-(dimethyl(phenyl)silyl)-2,2,2-trifluoroethanone (1 equiv., $0.25 \mathrm{mmol}$ ) in $5 \mathrm{~mL}$ MTBE using a syringe driven by an injection pump at a constant flow rate (within $6 \mathrm{~h}$ ). After stirring for another $6 \mathrm{~h}$, a saturated solution of $\mathrm{NH}_{4} \mathrm{~F}$ in $\mathrm{MeOH}$ (ca. $6 \mathrm{~mL}$ ) was carefully added to quench the reaction (Caution: gas evolution was observed). The reaction mixture was allowed to stir for $20 \mathrm{~min}$ at room temperature, diluted with EtOAc (ca. $10 \mathrm{~mL}$ ), stirred for an additional $10 \mathrm{~min}$ at room temperature and then filtered through a short plug of celite $(1-2 \mathrm{~cm})$ eluting with EtOAc (ca. $50 \mathrm{~mL})$. The solvent was removed in vacuo with the aid of a rotary evaporator. At this point, the crude yield and the diastereomeric ratio (dr) were determined by ${ }^{19} \mathrm{~F}$ NMR spectroscopic analysis using $\mathrm{PhCF}_{3}$ as the internal standard. The crude product was purified with column chromatography on silica gel (300 400 mesh) to afford the title compound $\mathbf{3 m}$. Colorless oil; $\mathbf{R}_{\mathbf{f}}=0.58(\mathrm{PE} / \mathrm{EA}=10 / 1) ; 71.1 \mathrm{mg}, 68 \%$ yield, 96\% ee, 97:3 dr; $[\alpha]^{25} \mathbf{D}=-74.6\left(c=2.65, \mathrm{CHCl}_{3}\right)$ NMR spectroscopy: ${ }^{1} \mathbf{H}$ NMR $\left(400 \mathrm{MHz}, \mathrm{CDCl}_{3}, 25\right.$ $\left.{ }^{\circ} \mathrm{C}\right) \delta 7.68-7.63(\mathrm{~m}, 2 \mathrm{H}), 7.45-7.37(\mathrm{~m}, 3 \mathrm{H}), 7.31(\mathrm{~s}, 4 \mathrm{H}), 3.08(\mathrm{q}, J=7.4 \mathrm{~Hz}, 1 \mathrm{H}), 2.72(\mathrm{~s}, 1 \mathrm{H}), 1.30$ (s, 9H), $1.26(\mathrm{dd}, J=7.3,1.9 \mathrm{~Hz}, 3 \mathrm{H}), 0.60(\mathrm{~s}, 3 \mathrm{H}), 0.56(\mathrm{~s}, 3 \mathrm{H}) ;{ }^{13} \mathbf{C} \mathbf{N M R}\left(151 \mathrm{MHz}, \mathrm{CDCl}_{3}, 25{ }^{\circ} \mathrm{C}\right) 151.7$, 134.9, 134.7, 131.5, 130.2, 128.1, 127.9 (q, $J=286.5 \mathrm{~Hz}), 125.4,119.8,87.2,85.2,71.3$ (q, $J=27.9 \mathrm{~Hz})$, 34.9, 33.2, 31.3, 16.6, -3.2, -3.5; ${ }^{19} \mathbf{F}$ NMR $\left(375 \mathrm{MHz}, \mathrm{CDCl}_{3}, 25{ }^{\circ} \mathrm{C}\right) \delta-67.5$ (s, 3F); IR (ATR): 3649 , 3489, 3314, 3179, 2963, 1715, 1670, 1506, 1461, 1323, 1238, 1156, 835, 738, $705 \mathrm{~cm}^{-1}$; HRMS (ESI, $\mathrm{m} / \mathrm{z}$ ): calcd for $\mathrm{C}_{24} \mathrm{H}_{30} \mathrm{~F}_{3} \mathrm{OSi}^{+}(\mathrm{M}+\mathrm{H})^{+}: 419.2013$; Found: 419.1997; HPLC analysis (AD-H column, $1 \%$ $i-\mathrm{PrOH} /$ hexane, $0.80 \mathrm{~mL} / \mathrm{min}, 20^{\circ} \mathrm{C}, 254 \mathrm{~nm}$ ) indicated $96 \%$ ee: $t_{\mathrm{R}}($ major $)=7.87 \mathrm{~min}, \mathrm{t}_{\mathrm{R}}($ minor $)=8.13$ $\min$ 
Racemic 3m:

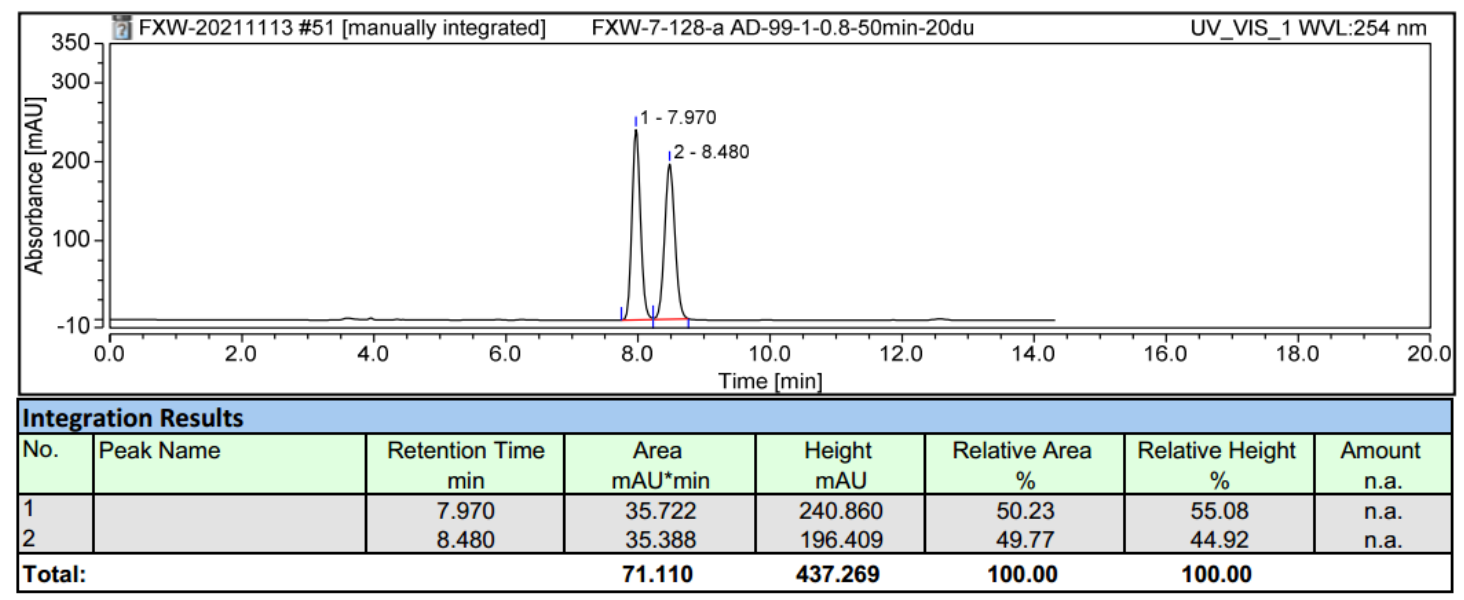

Enantioenriched 3m:

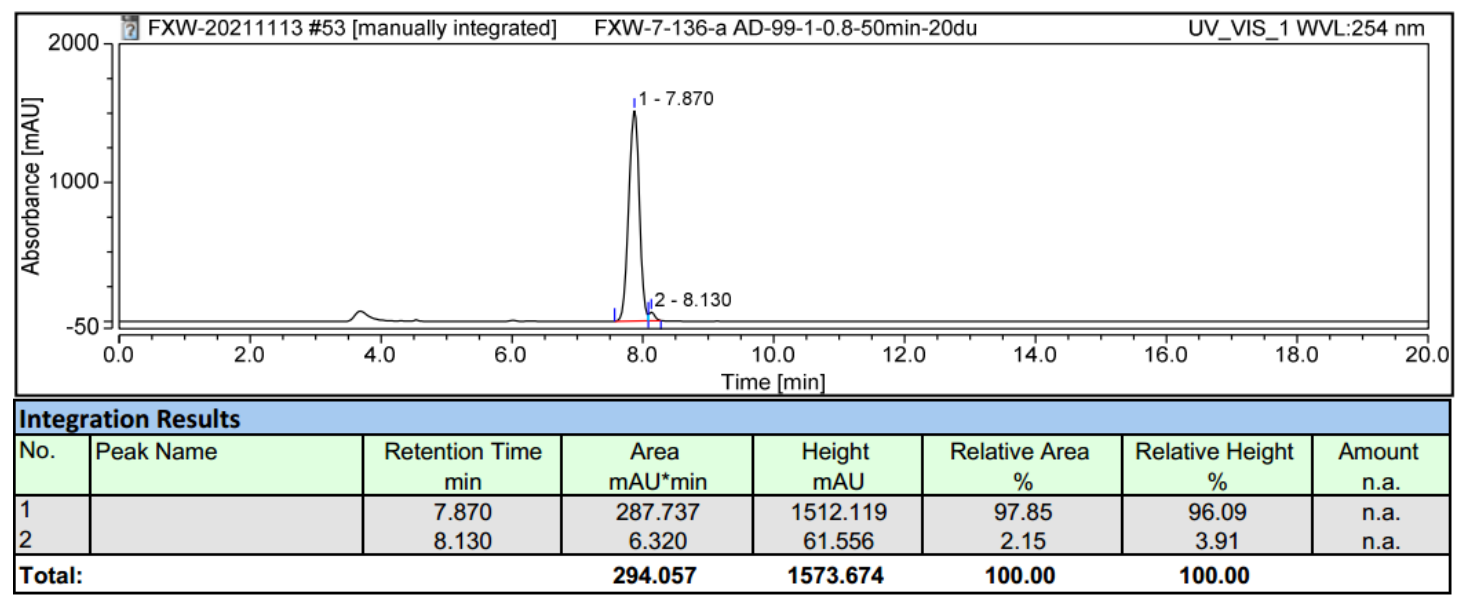

(2R, 3S)-2-(Dimethyl(phenyl)silyl)-1,1,1-trifluoro-3-methyl-5-(thiophen-2-yl)pent-4-yn-2-ol (3n)

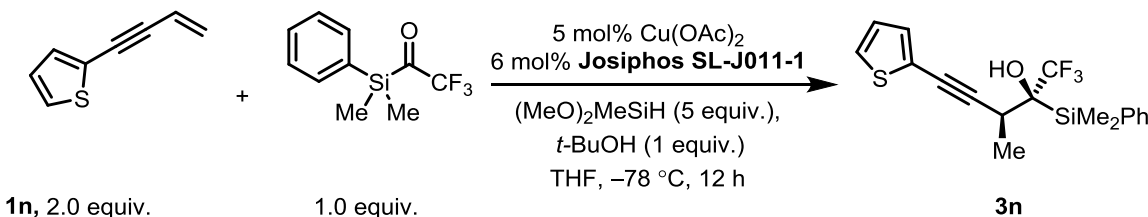

In a glovebox, to an oven-dried $10 \mathrm{~mL}$ Schlenk tube equipped with a magnetic stir bar was added $\mathrm{Cu}(\mathrm{OAc})_{2}$ (5 mol\%), Josiphos SL-J011-1 (6 mol\%), and dry THF (1 mL) sequentially. The mixture was stirred at room temperature for $30 \mathrm{~min}$ before the addition of DMMS ( 5 equiv.), $t$-BuOH ( 1 equiv.) and 1n ( 2 equiv.). The tube was then sealed, removed from the glove box and allowed to stir at $-78^{\circ} \mathrm{C}$ for 5 min, after which the mixture was added 1-(dimethyl(phenyl)silyl)-2,2,2-trifluoroethanone (1 equiv., 0.25 $\mathrm{mmol}$ ) in $5 \mathrm{~mL}$ using a syringe driven by an injection pump at a constant flow rate (within $6 \mathrm{~h}$ ). After stirring for another $6 \mathrm{~h}$, a saturated solution of $\mathrm{NH}_{4} \mathrm{~F}$ in $\mathrm{MeOH}$ (ca. $6 \mathrm{~mL}$ ) was carefully added to quench the reaction (Caution: gas evolution was observed). The reaction mixture was allowed to stir for $20 \mathrm{~min}$ at room temperature, diluted with EtOAc (ca. $10 \mathrm{~mL}$ ), stirred for an additional 10 min at room temperature and then filtered through a short plug of celite $(1-2 \mathrm{~cm})$ eluting with EtOAc $(\mathrm{ca} .50 \mathrm{~mL})$. The solvent was removed in vacuo with the aid of a rotary evaporator. At this point, the crude yield and 
the diastereomeric ratio (dr) were determined by ${ }^{19} \mathrm{~F}$ NMR spectroscopic analysis using $\mathrm{PhCF}_{3}$ as the internal standard. The crude product was purified with column chromatography on silica gel (300 400 mesh) to afford the title compound 3n; Colorless oil; $\mathbf{R}_{\mathbf{f}}=0.52(\mathrm{PE} / \mathrm{EA}=10 / 1) ; 83.7 \mathrm{mg}, 91 \%$ yield, $98 \%$ ee, 96:4 dr; $[\boldsymbol{\alpha}]^{\mathbf{2 5}} \mathbf{D}=-75.1\left(c=2.88, \mathrm{CHCl}_{3}\right)$ NMR spectroscopy: ${ }^{1} \mathbf{H}$ NMR $\left(400 \mathrm{MHz}, \mathrm{CDCl}_{3}, 25{ }^{\circ} \mathrm{C}\right)$ 7.67-7.62 (m, 2H), 7.47-7.36 (m, 3H), $7.22(\mathrm{dd}, J=5.2,1.1 \mathrm{~Hz}, 1 \mathrm{H}), 7.14(\mathrm{dd}, J=3.6,1.2 \mathrm{~Hz}, 1 \mathrm{H})$, $6.94(\mathrm{dd}, J=5.2,3.7 \mathrm{~Hz}, 1 \mathrm{H}), 3.10$ (q, $J=7.4 \mathrm{~Hz}, 1 \mathrm{H}), 2.58$ (s, 1H), 1.25 (dq, $J=7.4,1.7 \mathrm{~Hz}, 3 \mathrm{H}), 0.60$ $(\mathrm{s}, 3 \mathrm{H}), 0.56(\mathrm{~s}, 3 \mathrm{H}) ;{ }^{13} \mathbf{C} \mathbf{N M R}\left(101 \mathrm{MHz}, \mathrm{CDCl}_{3}, 25{ }^{\circ} \mathrm{C}\right) \delta 135.0,134.5,132.1,130.2,128.2,127.9$ (q, $J=286.3 \mathrm{~Hz}), 127.1,127.0,122.9,92.2,78.2,71.5(\mathrm{q}, J=28.0 \mathrm{~Hz}), 33.4,16.40,-3.2,-3.4 ;{ }^{19}$ F NMR $\left(376 \mathrm{MHz} \mathrm{CDCl}_{3}, 25^{\circ} \mathrm{C}\right) \delta-67.8(\mathrm{~s}, 3 \mathrm{~F})$; IR (ATR): 3489, 3295, 3206, 3071, 2963, 1722, 1592, 1457 , 1323, 1238, 1152, 1021, 947, 839, 738, $705 \mathrm{~cm}^{-1}$; HRMS (ESI, m/z): calcd for $\mathrm{C}_{18} \mathrm{H}_{20} \mathrm{~F}_{3} \mathrm{OSSi}^{+}(\mathrm{M}+\mathrm{H})^{+}$: 369.0951; Found: 369.0937; HPLC analysis (AD-H column, 3\% i-PrOH/hexane, $0.80 \mathrm{~mL} / \mathrm{min}, 20^{\circ} \mathrm{C}$, $254 \mathrm{~nm}$ ) indicated $98 \%$ ee: $t_{\mathrm{R}}$ (major $)=5.63 \mathrm{~min}, t_{\mathrm{R}}($ minor $)=5.90 \mathrm{~min}$.

\section{Racemic 3n:}

\begin{tabular}{|l|l|l|l|l|c|c|c|}
\hline & \\
\hline
\end{tabular}

\section{Enantioenriched 3n:}

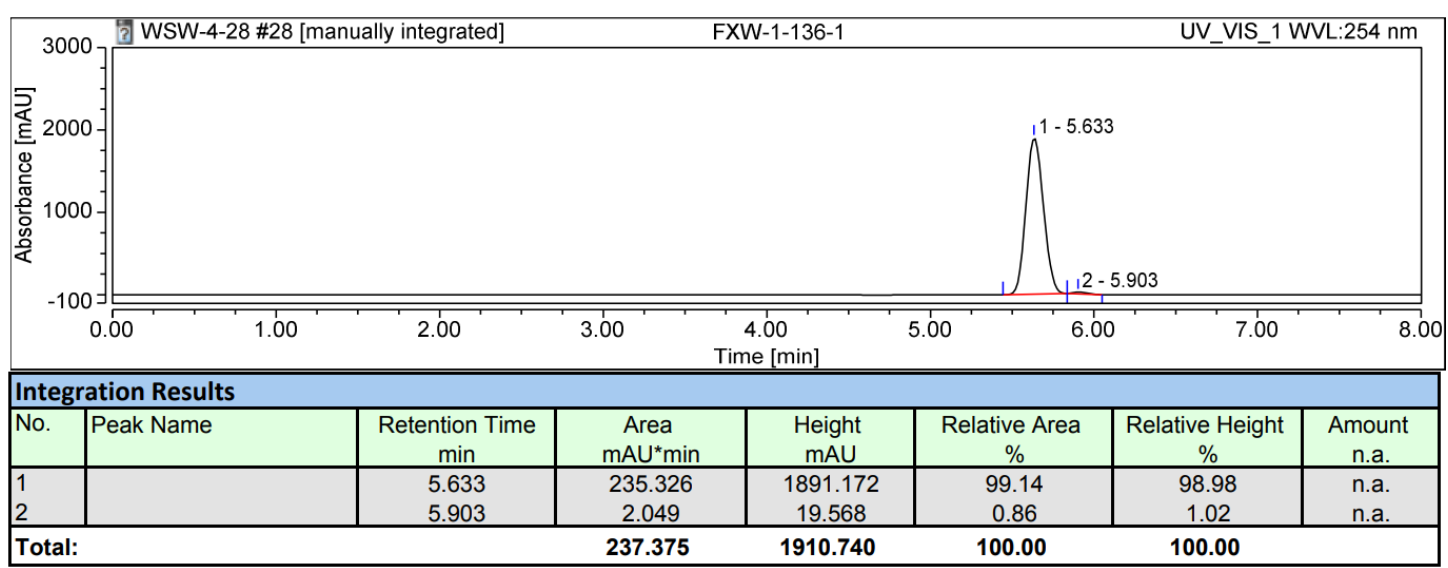

(2R, 3S)-2-(Dimethyl(phenyl)silyl)-1,1,1-trifluoro-3-methyl-5-(thiophen-3-yl)pent-4-yn-2-ol (3o)

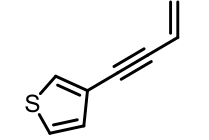

10, 2.0 equiv.

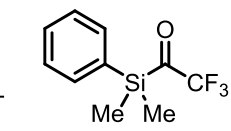

1.0 equiv

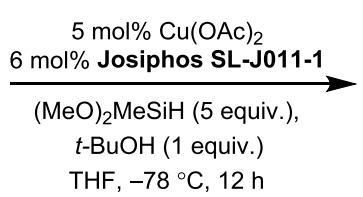

$\mathrm{THF},-78^{\circ} \mathrm{C}, 12 \mathrm{~h}$

In a glovebox, to an oven-dried $10 \mathrm{~mL}$ Schlenk tube equipped with a magnetic stir bar was added $\mathrm{Cu}(\mathrm{OAc})_{2}(5 \mathrm{~mol} \%)$, Josiphos SL-J011-1 (6 mol\%), and dry THF (1 mL) sequentially. The mixture was 
stirred at room temperature for $30 \mathrm{~min}$ before the addition of DMMS (5 equiv.), $t$-BuOH ( 1 equiv.) and 10 ( 2 equiv.). The tube was then sealed, removed from the glove box and allowed to stir at $-78^{\circ} \mathrm{C}$ for 5 min, after which the mixture was added 1-(dimethyl(phenyl)silyl)-2,2,2-trifluoroethanone (1 equiv., 0.25 mmol) in $5 \mathrm{~mL}$ THF using a syringe driven by an injection pump at a constant flow rate (within $6 \mathrm{~h}$ ). After stirring for another $6 \mathrm{~h}$, a saturated solution of $\mathrm{NH}_{4} \mathrm{~F}$ in $\mathrm{MeOH}$ (ca. $6 \mathrm{~mL}$ ) was carefully added to quench the reaction (Caution: gas evolution was observed). The reaction mixture was allowed to stir for $20 \mathrm{~min}$ at room temperature, diluted with EtOAc (ca. $10 \mathrm{~mL})$, stirred for an additional $10 \mathrm{~min}$ at room temperature and then filtered through a short plug of celite $(1-2 \mathrm{~cm})$ eluting with EtOAc (ca. $50 \mathrm{~mL})$. The solvent was removed in vacuo with the aid of a rotary evaporator. At this point, the crude yield and the diastereomeric ratio $(\mathrm{dr})$ were determined by ${ }^{19} \mathrm{~F}$ NMR spectroscopic analysis using $\mathrm{PhCF}_{3}$ as the internal standard. The crude product was purified with column chromatography on silica gel (300 400 mesh) to afford the title compound 3o. Colorless oil; $\mathbf{R}_{\mathbf{f}}=0.67(\mathrm{PE} / \mathrm{EA}=10 / 1) ; 71.8 \mathrm{mg}, 78 \%$ yield, 99\% ee, 98:2 dr; $[\alpha]^{25} \mathbf{D}=-64.9\left(c=5.00, \mathrm{CHCl}_{3}\right) \mathrm{NMR}$ spectroscopy: ${ }^{1} \mathbf{H} \mathbf{~ N M R}\left(400 \mathrm{MHz}, \mathrm{CDCl}_{3,} 25^{\circ} \mathrm{C}\right) \delta$ 7.67-7.62 (m, 2H), 7.46-7.35 (m, 4H), $7.24(\mathrm{dd}, J=5.0,3.0 \mathrm{~Hz}, 1 \mathrm{H}), 7.04(\mathrm{dd}, J=5.0,1.2 \mathrm{~Hz}, 1 \mathrm{H})$, 3.07 (q, $J=7.4 \mathrm{~Hz}, 1 \mathrm{H}), 2.66(\mathrm{~s}, 1 \mathrm{H}), 1.25(\mathrm{dq}, J=7.5,1.8 \mathrm{~Hz}, 3 \mathrm{H}), 0.59$ (s, 3H), $0.55(\mathrm{~s}, 3 \mathrm{H}) ;{ }^{13} \mathbf{C} \mathbf{N M R}$ $\left(101 \mathrm{MHz}, \mathrm{CDCl}_{3}, 25^{\circ} \mathrm{C}\right) \delta 134.9,134.6,130.2,130.0,128.9,128.1,127.9$ (q, $\left.J=286.5 \mathrm{~Hz}\right), 125.4$, $121.9,87.6,80.2,71.3(\mathrm{q}, J=28.1 \mathrm{~Hz}), 33.2,16.5,-3.2,-3.5 ;{ }^{19} \mathbf{F} \mathbf{N M R}\left(376 \mathrm{MHz}, \mathrm{CDCl}_{3}, 25{ }^{\circ} \mathrm{C}\right) \delta$ -67.6 (s, 3F); IR (ATR): 3675, 3489, 3109, 2986, 2851, 1614, 1502, 1439, 1357, 1241, 1152, 842, 816, 738, $705 \mathrm{~cm}^{-1}$; HRMS (ESI, m/z): calcd for $\mathrm{C}_{18} \mathrm{H}_{20} \mathrm{~F}_{3} \mathrm{OSSi}^{+}(\mathrm{M}+\mathrm{H})^{+}: 369.0951$; Found: 369.0942; HPLC analysis (AD-H column, 3\% $i-\mathrm{PrOH} /$ hexane, $0.80 \mathrm{~mL} / \mathrm{min}, 20{ }^{\circ} \mathrm{C}, 254 \mathrm{~nm}$ ) indicated $99 \%$ ee: $t_{\mathrm{R}}$ (major) $=5.76 \mathrm{~min}, t_{\mathrm{R}}($ minor $)=5.97 \mathrm{~min}$.

\section{Racemic 30:}

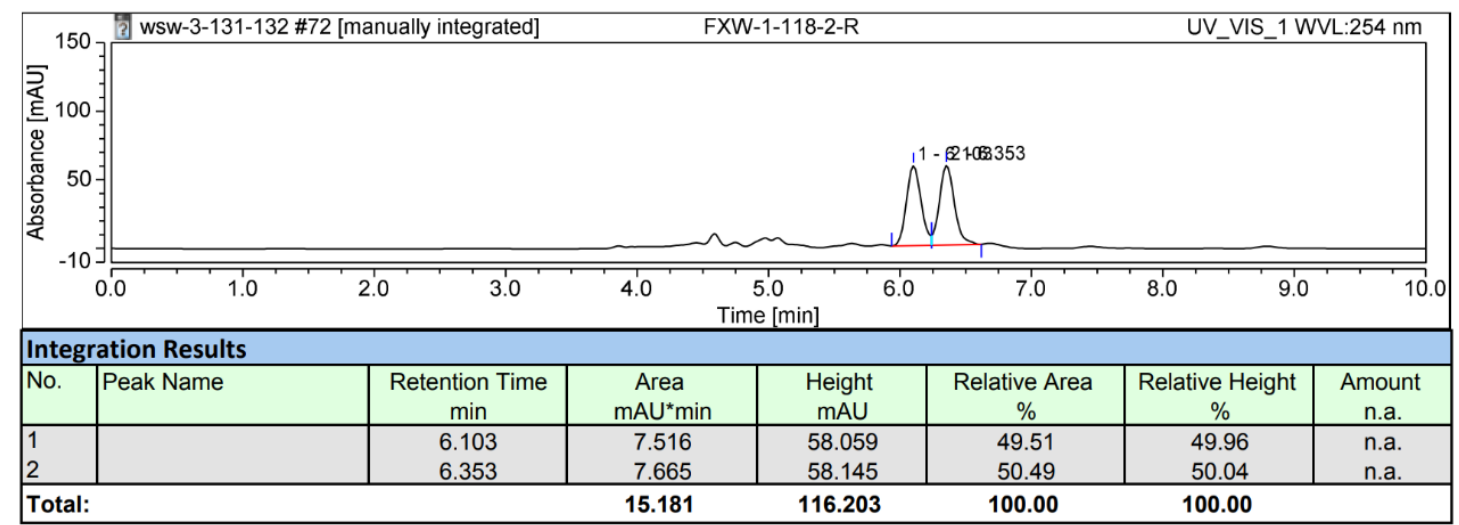


Enantioenriched 3o:

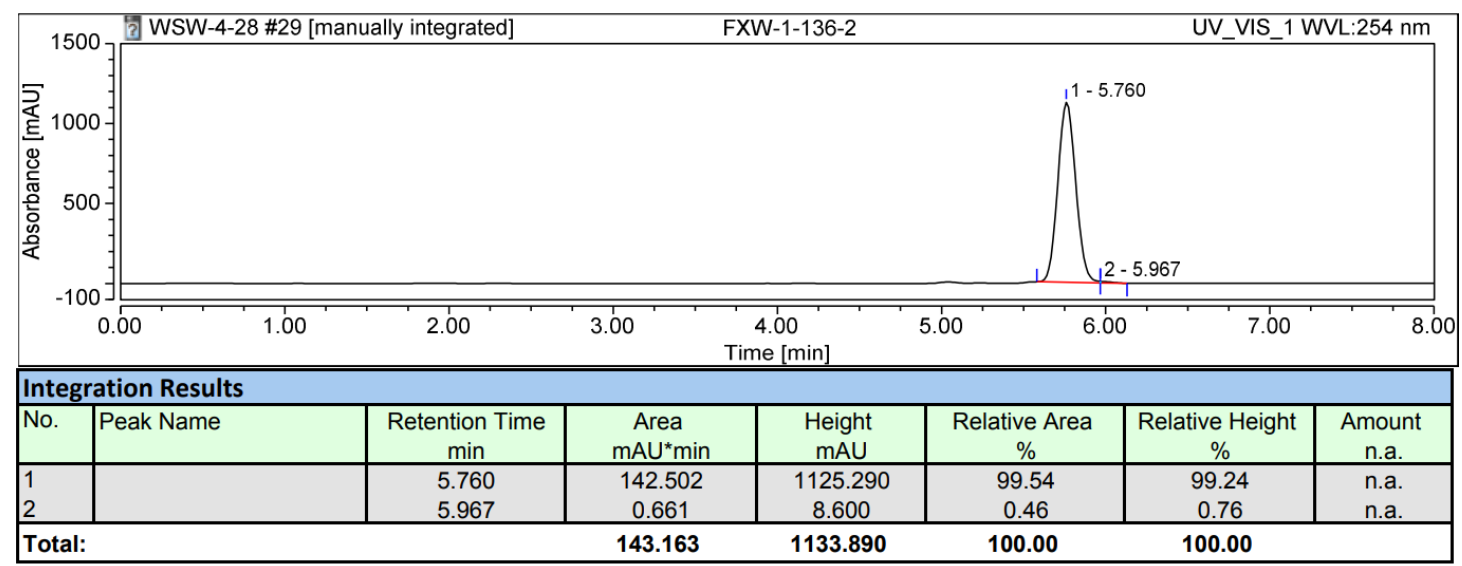

(2R, 3S)-2-(Dimethyl(phenyl)silyl)-1,1,1-trifluoro-3-methyl-5-(pyridin-3-yl)pent-4-yn-2-ol (3p)

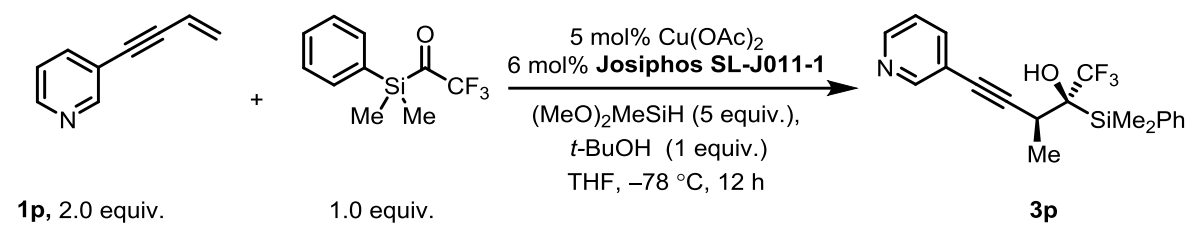

In a glovebox, to an oven-dried $10 \mathrm{~mL}$ Schlenk tube equipped with a magnetic stir bar was added $\mathrm{Cu}(\mathrm{OAc})_{2}$ (5 mol\%), Josiphos SL-J011-1 (6 mol\%), and dry THF (1 mL) sequentially. The mixture was stirred at room temperature for $30 \mathrm{~min}$ before the addition of DMMS (5 equiv.), $t$-BuOH ( 1 equiv.) and 1p ( 2 equiv.). The tube was then sealed, removed from the glove box and allowed to stir at $-78^{\circ} \mathrm{C}$ for 5 min, after which the mixture was added 1-(dimethyl(phenyl)silyl)-2,2,2-trifluoroethanone (1 equiv., 0.25 mmol) in $5 \mathrm{~mL}$ THF using a syringe driven by an injection pump at a constant flow rate (within $6 \mathrm{~h}$ ). After stirring for another $6 \mathrm{~h}$, a saturated solution of $\mathrm{NH}_{4} \mathrm{~F}$ in $\mathrm{MeOH}$ (ca. $6 \mathrm{~mL}$ ) was carefully added to quench the reaction (Caution: gas evolution was observed). The reaction mixture was allowed to stir for $20 \mathrm{~min}$ at room temperature, diluted with EtOAc (ca. $10 \mathrm{~mL})$, stirred for an additional $10 \mathrm{~min}$ at room temperature and then filtered through a short plug of celite $(1-2 \mathrm{~cm})$ eluting with EtOAc $(\mathrm{ca} .50 \mathrm{~mL})$. The solvent was removed in vacuo with the aid of a rotary evaporator. At this point, the crude yield and the diastereomeric ratio ( $\mathrm{dr}$ ) were determined by ${ }^{19} \mathrm{~F}$ NMR spectroscopic analysis using $\mathrm{PhCF}_{3}$ as the internal standard. The crude product was purified with column chromatography on silica gel (300 400 mesh) to afford the title compound 3p. Colorless oil; $\mathbf{R}_{\mathbf{f}}=0.2(\mathrm{PE} / \mathrm{EA}=10 / 1) ; 70.8 \mathrm{mg}, 79 \%$ yield, 94\% ee, 97:3 dr; $[\boldsymbol{\alpha}]^{25} \mathbf{D}=-41.7\left(c=4.00, \mathrm{CHCl}_{3}\right)$ NMR spectroscopy: ${ }^{1} \mathbf{H} \mathbf{N M R}\left(400 \mathrm{MHz}, \mathrm{CDCl}_{3}, 25{ }^{\circ} \mathrm{C}\right) \delta$ 8.62-8.48 (m, 2H), 7.69-7.61 (m, 3H), 7.49-7.35 (m, 3H), 7.25-7.20 (m, 1H), 3.10 (q, J=7.4 Hz, 1H), $2.63(\mathrm{~s}, 1 \mathrm{H}), 1.28(\mathrm{dq}, J=7.4,1.7 \mathrm{~Hz}, 3 \mathrm{H}), 0.60$ (s, 3H), $0.56(\mathrm{~s}, 3 \mathrm{H}) ;{ }^{13} \mathbf{C} \mathbf{N M R}\left(101 \mathrm{MHz}, \mathrm{CDCl}_{3}, 25\right.$ $\left.{ }^{\circ} \mathrm{C}\right) \delta 152.2,147.8,139.0,134.9,134.4,130.3,128.2,127.9(\mathrm{q}, J=287.2 \mathrm{~Hz}), 123.2,120.3,92.2,81.4$, $71.62(\mathrm{q}, J=27.9 \mathrm{~Hz}), 33.2,16.5,-3.2,-3.4 ;{ }^{19} \mathbf{F} \mathbf{~ N M R}\left(376 \mathrm{MHz}, \mathrm{CDCl}_{3}, 25{ }^{\circ} \mathrm{C}\right) \delta-67.7(\mathrm{~s}, 3 \mathrm{~F}) ; \mathbf{I R}$ (ATR): 3791, 3612, 3463, 3381, 3168, 3056, 2878, 2799, 1670, 1592, 1409, 1152, 813, 738, $705 \mathrm{~cm}^{-1}$; HRMS (ESI, m/z): calcd for $\mathrm{C}_{19} \mathrm{H}_{21} \mathrm{~F}_{3} \mathrm{NOSi}^{+}(\mathrm{M}+\mathrm{H})^{+}$: 364.1339; Found: 364.1325; HPLC analysis (AS-H column, $2 \% i-\mathrm{PrOH} /$ hexane, $1.0 \mathrm{~mL} / \mathrm{min}, 20^{\circ} \mathrm{C}, 240 \mathrm{~nm}$ ) indicated $94 \%$ ee: $t_{\mathrm{R}}$ (major) $=10.70$ $\min , t_{\mathrm{R}}($ minor $)=13.06 \mathrm{~min}$

\section{Racemic 3p:}




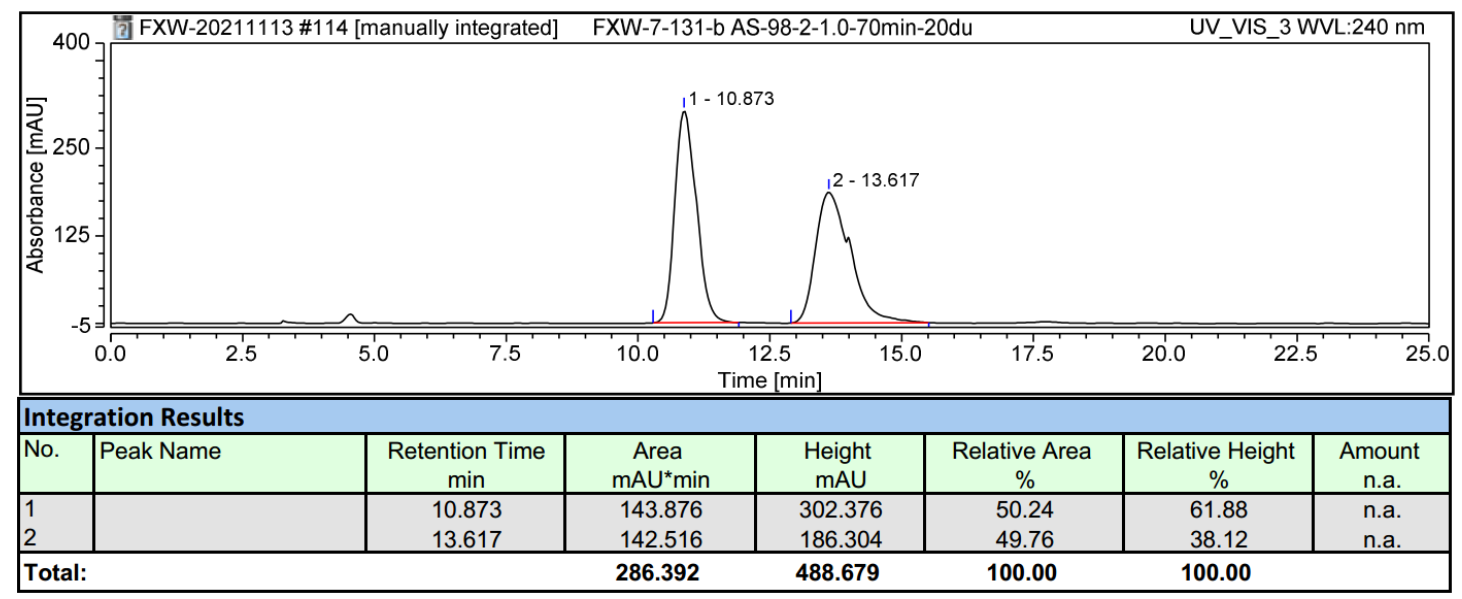

Enantioenriched 3p:

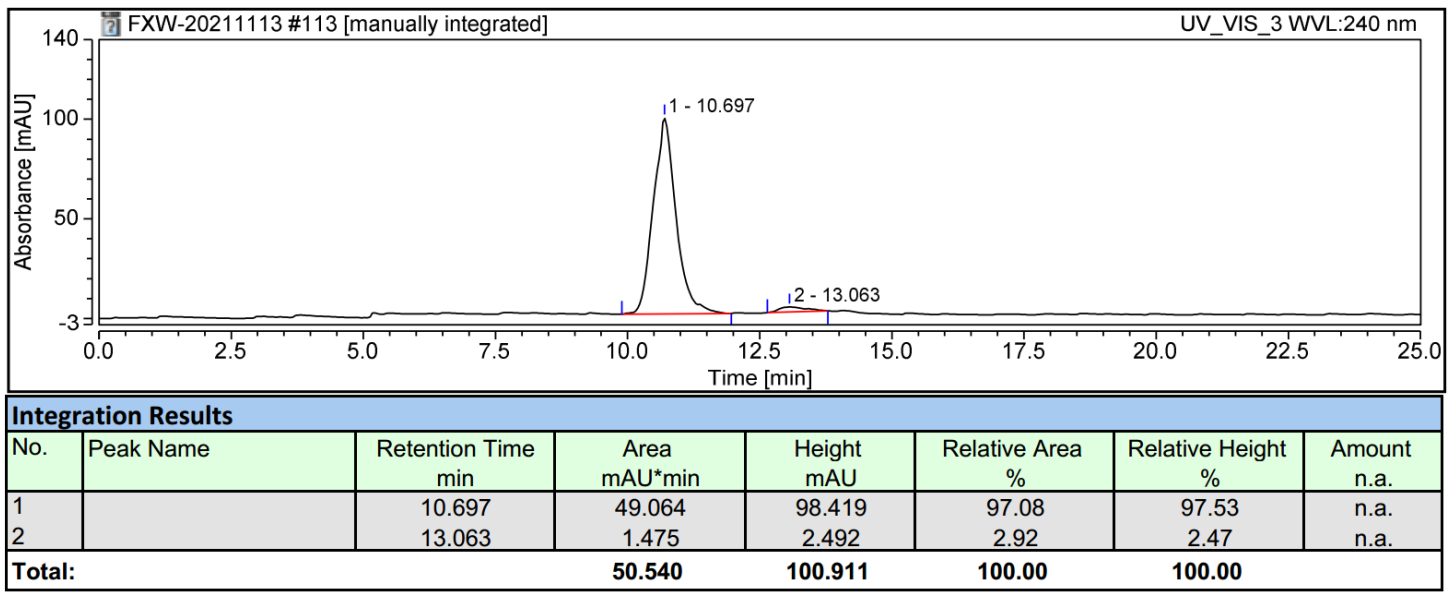

(5S,6R)-6-(Dimethyl(phenyl)silyl)-7,7,7-trifluoro-6-hydroxy-5-methylhept-3-yn-1-yl-4-

methylbenzenesulfonate (3q)
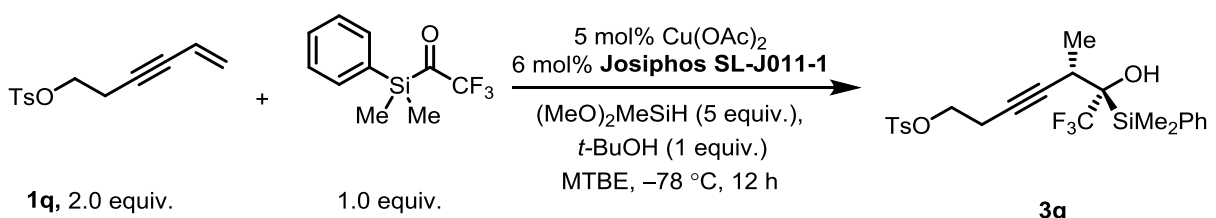

$3 q$

In a glovebox, to an oven-dried $10 \mathrm{~mL}$ Schlenk tube equipped with a magnetic stir bar was added $\mathrm{Cu}(\mathrm{OAc})_{2}$ (5 mol\%), Josiphos SL-J011-1 (6 mol\%), and dry MTBE $(1 \mathrm{~mL})$ sequentially. The mixture was stirred at room temperature for $30 \mathrm{~min}$ before the addition of DMMS (5 equiv.), $t$-BuOH (1 equiv.) and $1 \mathbf{q}$ ( 2 equiv.). The tube was then sealed, removed from the glove box and allowed to stir at $-78^{\circ} \mathrm{C}$ for $5 \mathrm{~min}$, after which the mixture was added 1-(dimethyl(phenyl)silyl)-2,2,2-trifluoroethanone (1 equiv., $0.25 \mathrm{mmol}$ ) in $5 \mathrm{~mL}$ MTBE using a syringe driven by an injection pump at a constant flow rate (within $6 \mathrm{~h}$ ). After stirring for another $6 \mathrm{~h}$, a saturated solution of $\mathrm{NH}_{4} \mathrm{~F}$ in $\mathrm{MeOH}$ (ca. $6 \mathrm{~mL}$ ) was carefully added to quench the reaction (Caution: gas evolution was observed). The reaction mixture was allowed to stir for $20 \mathrm{~min}$ at room temperature, diluted with EtOAc (ca. $10 \mathrm{~mL}$ ), stirred for an additional $10 \mathrm{~min}$ at room temperature and then filtered through a short plug of celite $(1-2 \mathrm{~cm})$ eluting with EtOAc $(\mathrm{ca} .50 \mathrm{~mL})$. The solvent was removed in vacuo with the aid of a rotary evaporator. At this point, the crude yield and the diastereomeric ratio (dr) were determined by ${ }^{19} \mathrm{~F}$ NMR spectroscopic analysis using $\mathrm{PhCF}_{3}$ as the 
internal standard. The crude product was purified with column chromatography on silica gel (300 400 mesh) to afford the title compound 3q. Colorless oil; $\mathbf{R}_{\mathbf{f}}=0.32(\mathrm{PE} / \mathrm{EA}=10 / 1) ; 84.7 \mathrm{mg}, 70 \%$ yield, > 99\% ee, 93:7 dr; $[\boldsymbol{\alpha}]^{\mathbf{2 5}} \mathbf{D}=-29.7\left(c=6.00, \mathrm{CHCl}_{3}\right)$ NMR spectroscopy: ${ }^{1} \mathbf{H}$ NMR $\left(400 \mathrm{MHz}, \mathrm{CDCl}_{3}, 25\right.$ $\left.{ }^{\circ} \mathrm{C}\right) 7.78(\mathrm{~d}, J=8.3 \mathrm{~Hz}, 2 \mathrm{H}), 7.63-7.56(\mathrm{~m}, 2 \mathrm{H}), 7.43-7.32(\mathrm{~m}, 5 \mathrm{H}), 4.03(\mathrm{t}, J=6.9 \mathrm{~Hz}, 2 \mathrm{H}), 2.78(\mathrm{q}, J$ $=7.4 \mathrm{~Hz}, 1 \mathrm{H}), 2.58(\mathrm{~s}, 1 \mathrm{H}), 2.51(\mathrm{td}, J=6.9,2.3 \mathrm{~Hz}, 2 \mathrm{H}), 2.45(\mathrm{~s}, 3 \mathrm{H}), 1.10(\mathrm{dq}, J=7.4,1.8 \mathrm{~Hz}, 3 \mathrm{H})$, $0.53(\mathrm{~s}, 3 \mathrm{H}), 0.50(\mathrm{~s}, 3 \mathrm{H}) ;{ }^{13} \mathbf{C} \mathbf{N M R}\left(101 \mathrm{MHz}, \mathrm{CDCl}_{3}, 25^{\circ} \mathrm{C}\right) \delta 145.1,134.9,134.6,133.0,130.2,130.0$, $128.1,128.1,127.8$ (q, $J=286.5 \mathrm{~Hz}), 81.2,79.3,71.0$ (q, $J=56.1,28.2 \mathrm{~Hz}), 67.7,32.6,21.8,19.9,16.5$, $-3.4,-3.5 ;{ }^{19} \mathbf{F ~ N M R}\left(376 \mathrm{MHz}, \mathrm{CDCl}_{3}, 25^{\circ} \mathrm{C}\right) \delta-67.3$ (s, 3F); IR (ATR): 3735, 3671, 3481, 3172, 2960 , 2851, 1599, 1428, 1241, 1174, 902, 839, 742, 705, $664 \mathrm{~cm}^{-1}$; HRMS (ESI, m/z): calcd for $\mathrm{C}_{23} \mathrm{H}_{31} \mathrm{~F}_{3} \mathrm{O}_{4} \mathrm{SSiN}^{+}\left(\mathrm{M}+\mathrm{NH}_{4}\right)^{+}:$502.1690; Found: 502.1669; HPLC analysis (AD-H column, 5\% $i-\mathrm{PrOH} /$ hexane, $1.0 \mathrm{~mL} / \mathrm{min}, 20^{\circ} \mathrm{C}, 254 \mathrm{~nm}$ ) indicated $>99 \%$ ee: $t_{\mathrm{R}}($ major $)=5.51 \mathrm{~min}$.

Racemic 3q:

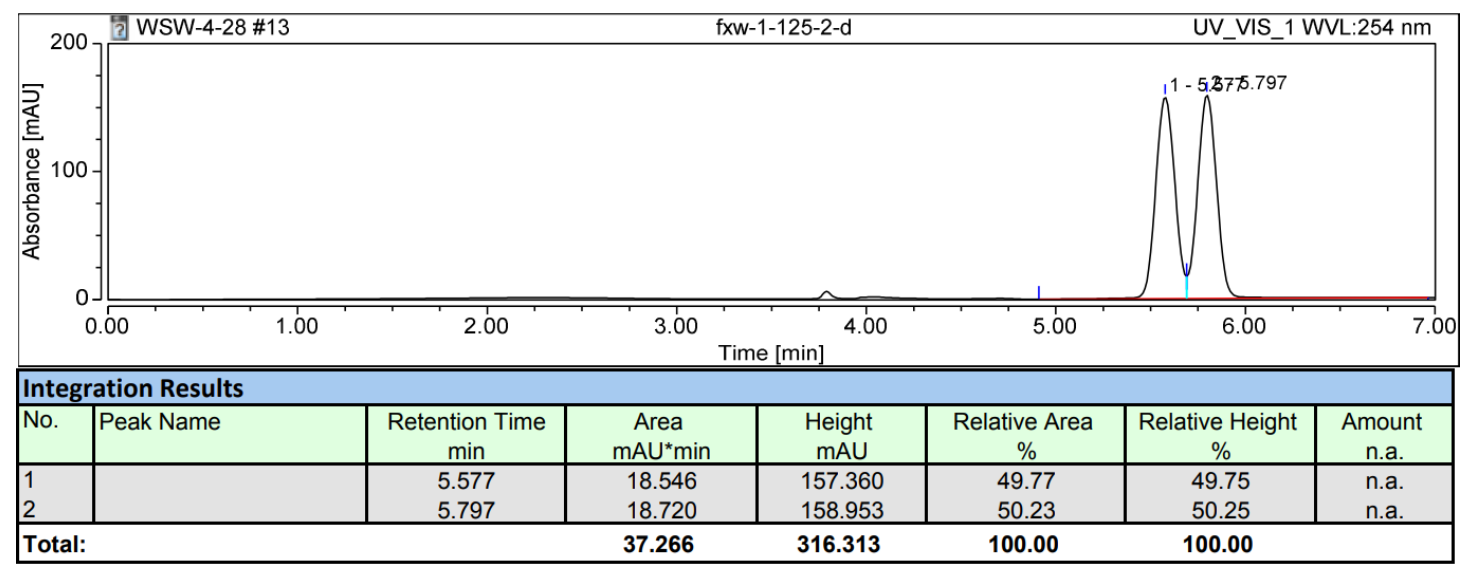

\section{Enantioenriched 3q:}

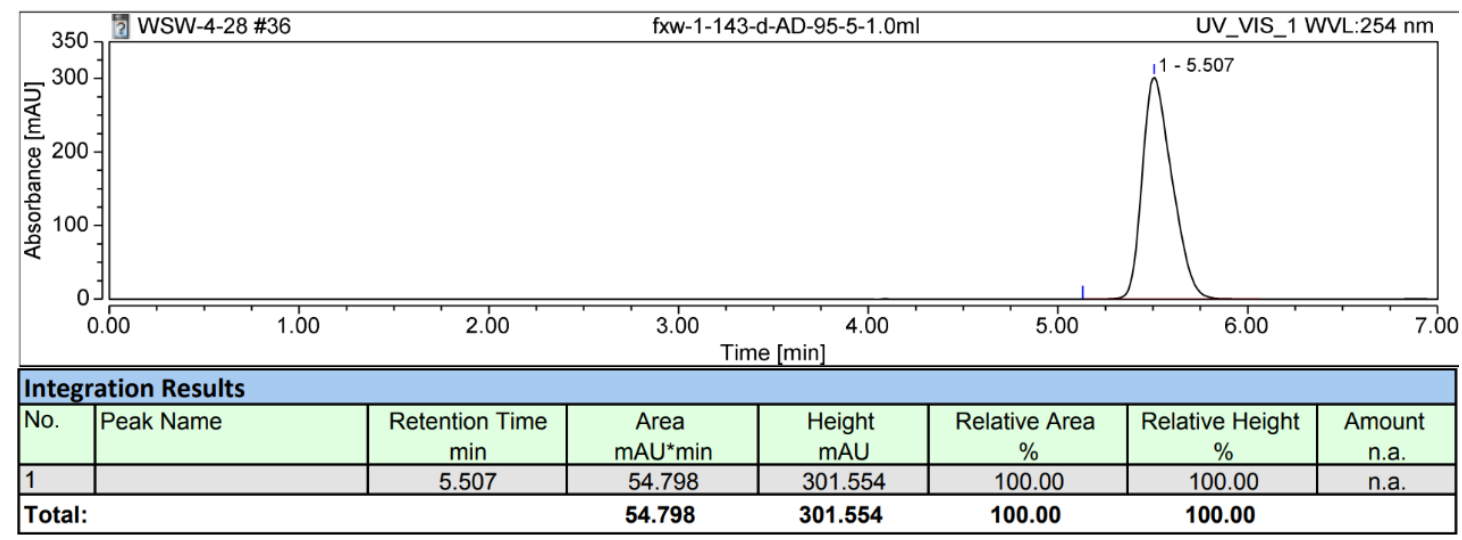

(2R,3S)-2-(dimethyl(phenyl)silyl)-3-ethyl-1,1,1-trifluoro-5-phenylpent-4-yn-2-ol (3ad)

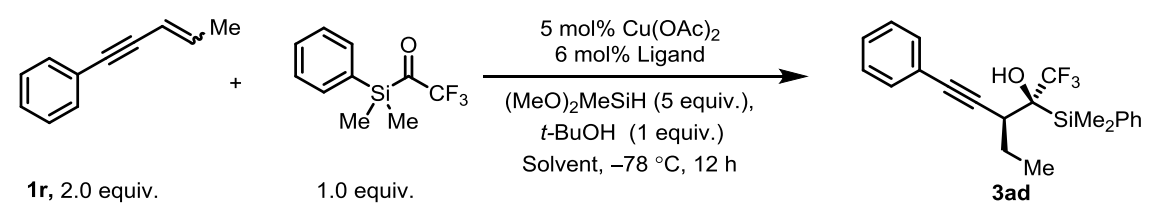

Procedure 1: In a glovebox, to an oven-dried $10 \mathrm{~mL}$ Schlenk tube equipped with a magnetic stir bar was added $\mathrm{Cu}(\mathrm{OAc})_{2}$ (5 mol\%), Josiphos SL-J011-1 (6 mol\%), and dry MTBE (1 mL) sequentially. The mixture was stirred at room temperature for $30 \mathrm{~min}$ before the addition of DMMS ( 5 equiv.), $t$ - $\mathrm{BuOH}$ ( 1 
equiv.) and 1r ( 2 equiv.). The tube was then sealed, removed from the glove box and allowed to stir at $-78^{\circ} \mathrm{C}$ for $5 \mathrm{~min}$, after which the mixture was added 1-(dimethyl(phenyl)silyl)-2,2,2-trifluoroethanone (1 equiv., $0.25 \mathrm{mmol}$ ) in $5 \mathrm{~mL}$ MTBE using a syringe driven by an injection pump at a constant flow rate (within $6 \mathrm{~h}$ ). After stirring for another $6 \mathrm{~h}$, a saturated solution of $\mathrm{NH}_{4} \mathrm{~F}$ in $\mathrm{MeOH}$ (ca. $6 \mathrm{~mL}$ ) was carefully added to quench the reaction (Caution: gas evolution was observed). The reaction mixture was allowed to stir for $20 \mathrm{~min}$ at room temperature, diluted with EtOAc (ca. $10 \mathrm{~mL}$ ), stirred for an additional $10 \mathrm{~min}$ at room temperature and then filtered through a short plug of celite $(1-2 \mathrm{~cm})$ eluting with EtOAc $(\mathrm{ca} .50$ $\mathrm{mL}$ ). The solvent was removed in vacuo with the aid of a rotary evaporator. At this point, the crude yield and the diastereomeric ratio (dr) were determined by ${ }^{19} \mathrm{~F}$ NMR spectroscopic analysis using $\mathrm{PhCF}_{3}$ as the internal standard. The crude product was purified with column chromatography on silica gel (300 400 mesh) to afford the title compound 3ad. Colorless oil; $\mathbf{R}_{\mathbf{f}}=0.55$ (PE/EA=20/1); $15.7 \mathrm{mg}, 17 \%$ yield, $90 \%$ ee, $97: 3 \mathrm{dr} ;[\boldsymbol{\alpha}]^{25} \mathbf{D}=-49.9\left(c=0.5, \mathrm{CHCl}_{3}\right)$ NMR spectroscopy: ${ }^{1} \mathbf{H} \mathbf{N M R}\left(400 \mathrm{MHz}, \mathrm{CDCl}_{3}\right.$, $\left.25^{\circ} \mathrm{C}\right) \delta$ 7.66-7.61 (m, 2H), 7.47-7.36 (m, 5H), 7.31-7.26 (m, 3H), $2.77(\mathrm{~s}, 1 \mathrm{H}), 2.77-2.73(\mathrm{~m}, 1 \mathrm{H})$, $1.61-1.55(\mathrm{~m}, 2 \mathrm{H}), 0.89$ (t, $J=7.3 \mathrm{~Hz}, 3 \mathrm{H}), 0.59(\mathrm{~s}, 3 \mathrm{H}), 0.56(\mathrm{~s}, 3 \mathrm{H}) ;{ }^{13} \mathbf{C} \mathbf{N M R}\left(151 \mathrm{MHz}, \mathrm{CDCl}_{3}, 25\right.$ $\left.{ }^{\circ} \mathrm{C}\right) \delta 134.8,134.6,131.8,130.2,128.4,128.4,128.2,127.9(\mathrm{q}, J=286.3 \mathrm{~Hz}), 123.0,86.7,86.1,71.2(\mathrm{q}$, $J=28.3 \mathrm{~Hz}), 41.9,23.7,13.5,-3.2,-3.6 . ;{ }^{19} \mathbf{F}$ NMR $\left(376 \mathrm{MHz}, \mathrm{CDCl}_{3}, 25^{\circ} \mathrm{C}\right) \delta-67.7$ (s, 3F); IR (ATR): 3493, 2971, 2930, 1670, 1491, 1431, 1312, 1256, 1156, 1107, 917, 839, 783, 757, $708 \mathrm{~cm}^{-1}$; HRMS (ESI, $\mathrm{m} / \mathrm{z}$ ): calcd for $\mathrm{C}_{21} \mathrm{H}_{24} \mathrm{~F}_{3} \mathrm{OSi}(\mathrm{M}+\mathrm{H})^{+}: 377.1543$; Found: 377.1552 ; HPLC analysis (AD-H column, $3 \%$ $i-\mathrm{PrOH} / \mathrm{hexane}, 0.8 \mathrm{~mL} / \mathrm{min}, 20^{\circ} \mathrm{C}, 254 \mathrm{~nm}$ ) indicated $90 \%$ ee $: t_{\mathrm{R}}$ (major) $=5.12 \mathrm{~min}, t_{\mathrm{R}}($ minor $)=5.86$ $\min$

Procedure 2: In a glovebox, to an oven-dried $10 \mathrm{~mL}$ Schlenk tube equipped with a magnetic stir bar was added $\mathrm{Cu}(\mathrm{OAc})_{2}(5 \mathrm{~mol} \%),(S, S)$-Ph-BPE (6 mol\%), and dry THF $(1 \mathrm{~mL})$ sequentially. The mixture was stirred at room temperature for $30 \mathrm{~min}$ before the addition of DMMS ( 5 equiv.), $t$-BuOH (1 equiv.) and $\operatorname{1r}\left(2\right.$ equiv.). The tube was then sealed, removed from the glove box and allowed to stir at $-78^{\circ} \mathrm{C}$ for 5 min, after which the mixture was added 1-(dimethyl(phenyl)silyl)-2,2,2-trifluoroethanone (1 equiv., 0.25 $\mathrm{mmol}$ ) in $5 \mathrm{~mL}$ THF using a syringe driven by an injection pump at a constant flow rate (within $6 \mathrm{~h}$ ). After stirring for another $6 \mathrm{~h}$, a saturated solution of $\mathrm{NH}_{4} \mathrm{~F}$ in $\mathrm{MeOH}$ (ca. $6 \mathrm{~mL}$ ) was carefully added to quench the reaction (Caution: gas evolution was observed). The reaction mixture was allowed to stir for $20 \mathrm{~min}$ at room temperature, diluted with EtOAc (ca. $10 \mathrm{~mL}$ ), stirred for an additional $10 \mathrm{~min}$ at room temperature and then filtered through a short plug of celite $(1-2 \mathrm{~cm})$ eluting with EtOAc (ca. $50 \mathrm{~mL})$. The solvent was removed in vacuo with the aid of a rotary evaporator. At this point, the crude yield and the diastereomeric ratio (dr) were determined by ${ }^{19} \mathrm{~F}$ NMR spectroscopic analysis using $\mathrm{PhCF}_{3}$ as the internal standard. The crude product was purified with column chromatography on silica gel (300 400 mesh) to afford the title compound 3ad. $37.3 \mathrm{mg}, 40 \%$ yield, $93 \%$ ee, $97: 3 \mathrm{dr}$; $[\boldsymbol{\alpha}]^{25} \mathbf{D}=-63.2(c=2.25$, $\mathrm{CHCl}_{3}$ ); HPLC analysis (AD-H column, $3 \% i-\mathrm{PrOH} /$ hexane, $0.8 \mathrm{~mL} / \mathrm{min}, 20^{\circ} \mathrm{C}, 254 \mathrm{~nm}$ ) indicated $93 \%$ ee $: t_{\mathrm{R}}($ major $)=4.92 \mathrm{~min}, t_{\mathrm{R}}($ minor $)=5.70 \mathrm{~min}$ 
racemic 3ad:

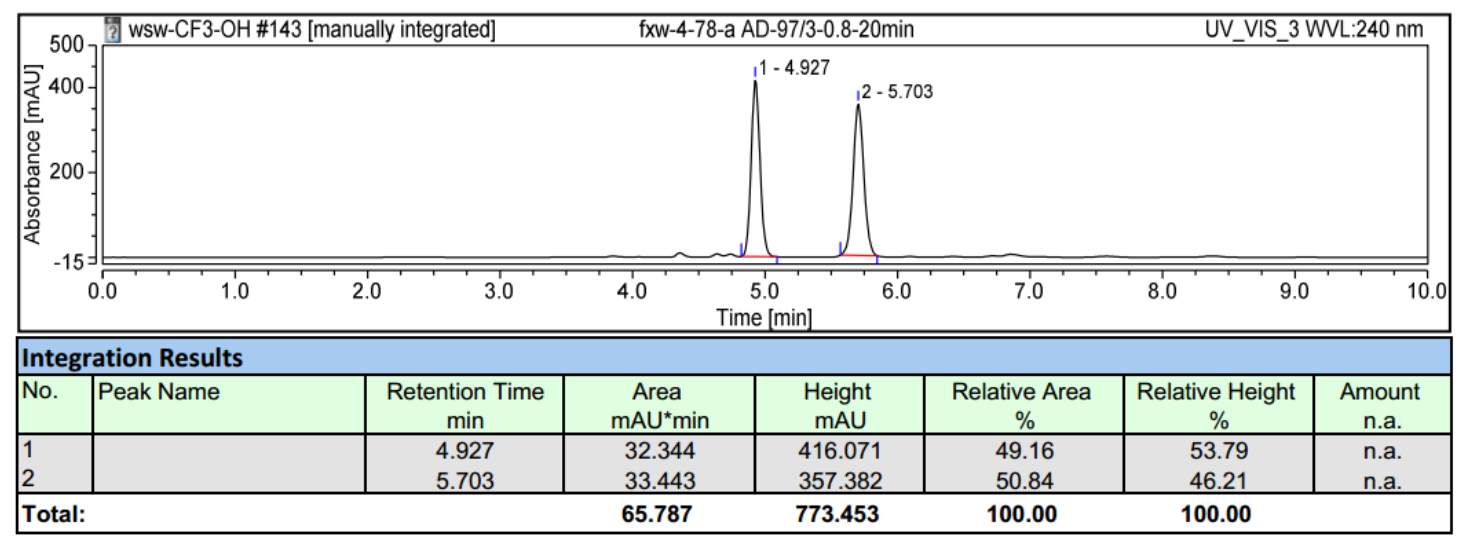

Enantioenriched 3ad (Procedure 1):

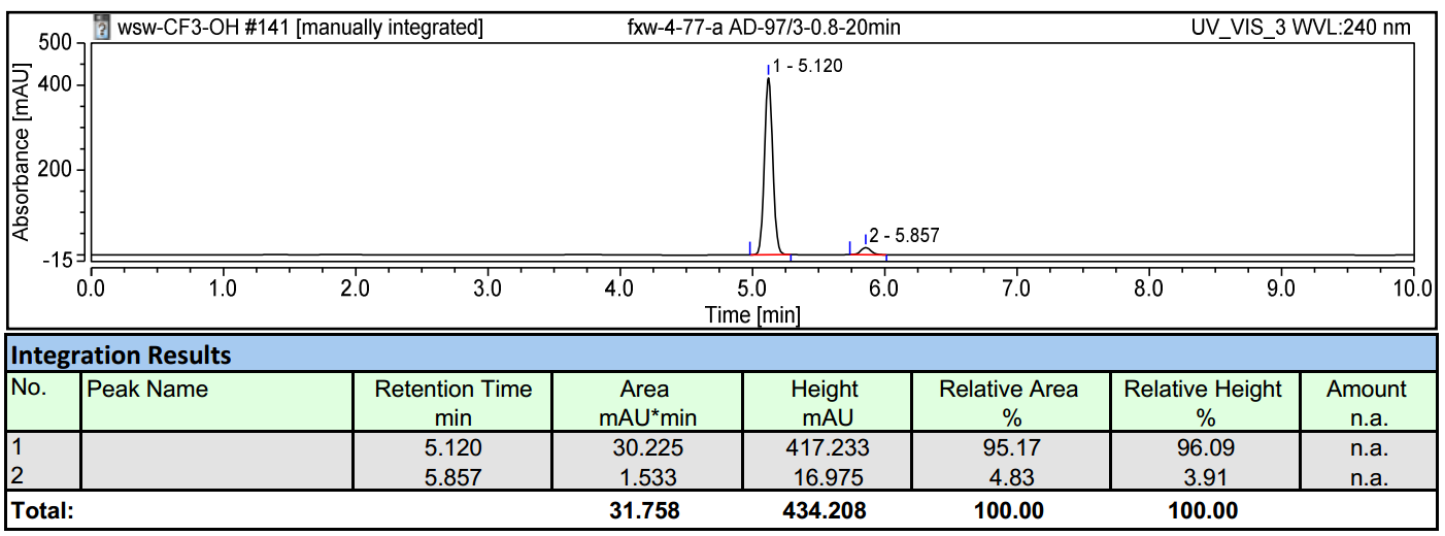

\section{Enantioenriched 3ad (Procedure 2):}

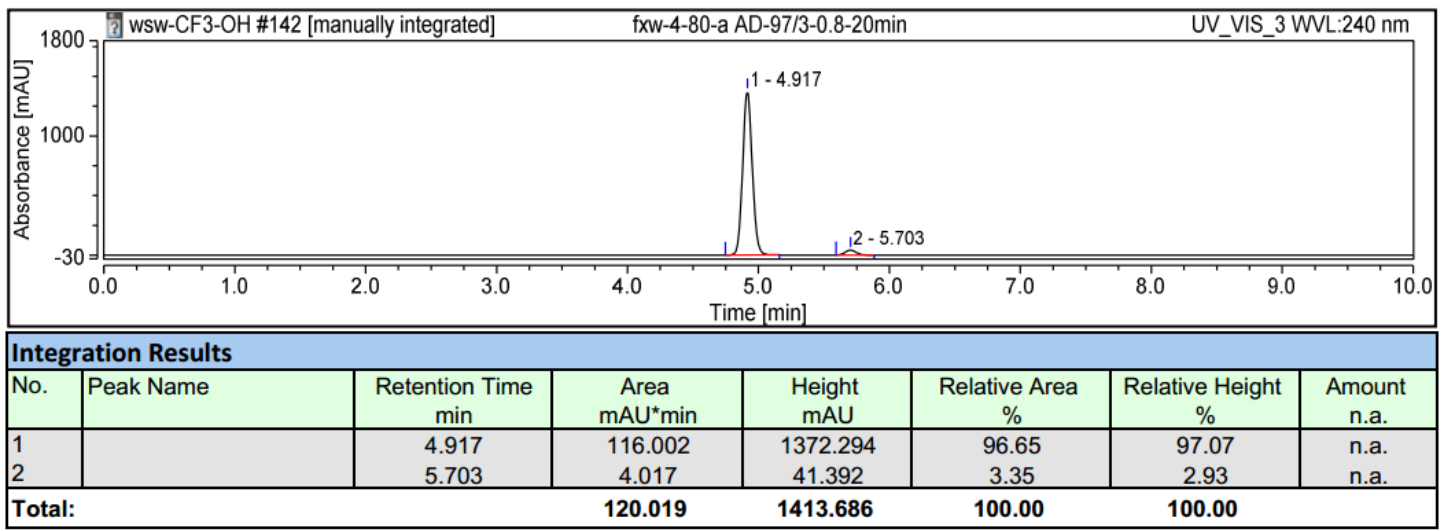

\section{Failed examples}

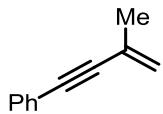

2.0 equiv.<smiles>C[Si](C)(C(=O)F)c1ccccc1</smiles>

$5 \mathrm{~mol} \% \mathrm{Cu}(\mathrm{OAc})_{2}$ 6 mol\% Josiphos SL-J011-1

$\mathrm{MeO})_{2} \mathrm{MeSiH}$ (5 equiv.)

$t$-BuOH ( 1 equiv.)

THF, $-78^{\circ} \mathrm{C}, 12 \mathrm{~h}$

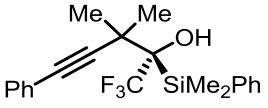

$3 a e$

In a glovebox, to an oven-dried $10 \mathrm{~mL}$ Schlenk tube equipped with a magnetic stir bar was added $\mathrm{Cu}(\mathrm{OAc})_{2}$ (5 mol\%), Josiphos SL-J011-1 (6 mol\%), and dry THF (1 mL) sequentially. The mixture was stirred at room temperature for $30 \mathrm{~min}$ before the addition of DMMS (5 equiv.), $t$-BuOH (1 equiv.) and 
(3-methylbut-3-en-1-yn-1-yl)benzene (2 equiv.). The tube was then sealed, removed from the glove box and allowed to stir at $-78{ }^{\circ} \mathrm{C}$ for $5 \mathrm{~min}$, after which the mixture was added 1-(dimethyl(phenyl)silyl)2,2,2-trifluoroethanone (1 equiv., $0.25 \mathrm{mmol}$ ) in $5 \mathrm{~mL}$ THF using a syringe driven by an injection pump at a constant flow rate (within $6 \mathrm{~h}$ ). After stirring for another $6 \mathrm{~h}$, a saturated solution of $\mathrm{NH}_{4} \mathrm{~F}$ in $\mathrm{MeOH}$ (ca. $6 \mathrm{~mL}$ ) was carefully added to quench the reaction (Caution: gas evolution was observed). The reaction mixture was allowed to stir for $20 \mathrm{~min}$ at room temperature, diluted with EtOAc (ca. $10 \mathrm{~mL}$ ), stirred for an additional $10 \mathrm{~min}$ at room temperature and then filtered through a short plug of celite (1-2 $\mathrm{cm}$ ) eluting with EtOAc (ca. $50 \mathrm{~mL}$ ). The solvent was removed in vacuo with the aid of a rotary evaporator. At this point, the crude yield was determined by ${ }^{19} \mathrm{~F}$ NMR spectroscopic analysis using $\mathrm{PhCF}_{3}$ as the internal standard. $100 \%$ conv., $0 \%$ yield of ${ }^{19} \mathrm{~F}$ NMR.

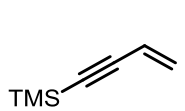

2.0 equiv.

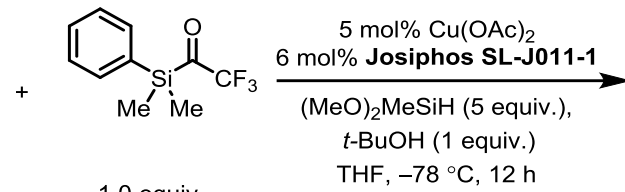

1.0 equiv.

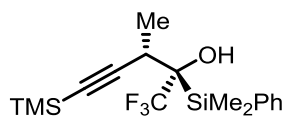

3 af

In a glovebox, to an oven-dried $10 \mathrm{~mL}$ Schlenk tube equipped with a magnetic stir bar was added $\mathrm{Cu}(\mathrm{OAc})_{2}$ (5 mol\%), Josiphos SL-J011-1 (6 mol\%), and dry THF (1 mL) sequentially. The mixture was stirred at room temperature for $30 \mathrm{~min}$ before the addition of DMMS (5 equiv.), $t$-BuOH ( 1 equiv.) and but-3-en-1-yn-1-yltrimethylsilane (2 equiv.). The tube was then sealed, removed from the glove box and allowed to stir at $-78{ }^{\circ} \mathrm{C}$ for $5 \mathrm{~min}$, after which the mixture was added 1-(dimethyl(phenyl)silyl)-2,2,2trifluoroethanone ( 1 equiv., $0.25 \mathrm{mmol}$ ) in $5 \mathrm{~mL}$ THF using a syringe driven by an injection pump at a constant flow rate (within $6 \mathrm{~h}$ ). After stirring for another $6 \mathrm{~h}$, a saturated solution of $\mathrm{NH}_{4} \mathrm{~F}$ in $\mathrm{MeOH}$ (ca. $6 \mathrm{~mL}$ ) was carefully added to quench the reaction (Caution: gas evolution was observed). The reaction mixture was allowed to stir for $20 \mathrm{~min}$ at room temperature, diluted with EtOAc (ca. $10 \mathrm{~mL}$ ), stirred for an additional $10 \mathrm{~min}$ at room temperature and then filtered through a short plug of celite $(1-2 \mathrm{~cm})$ eluting with EtOAc (ca. $50 \mathrm{~mL}$ ). The solvent was removed in vacuo with the aid of a rotary evaporator. At this point, the crude yield was determined by ${ }^{19} \mathrm{~F}$ NMR spectroscopic analysis using $\mathrm{PhCF}_{3}$ as the internal standard.100\% conv., $8 \%$ yield of ${ }^{19} \mathrm{~F}$ NMR. Real yield less than $5 \%$ (a mixture containing a small amount of product is isolated by column chromatography on silica gel).

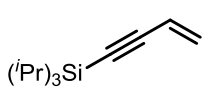

2.0 equiv

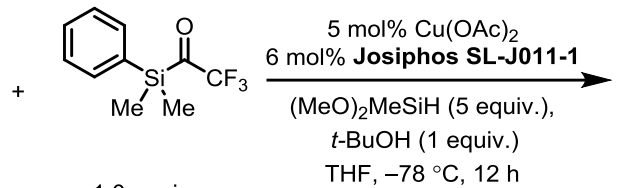

1.0 equiv.

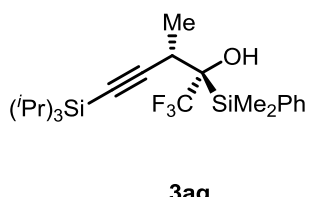

3ag

In a glovebox, to an oven-dried $10 \mathrm{~mL}$ Schlenk tube equipped with a magnetic stir bar was added $\mathrm{Cu}(\mathrm{OAc})_{2}$ (5 mol\%), Josiphos SL-J011-1 (6 mol\%), and dry THF (1 mL) sequentially. The mixture was stirred at room temperature for $30 \mathrm{~min}$ before the addition of DMMS (5 equiv.), $t$-BuOH ( 1 equiv.) and but-3-en-1-yn-1-yltriisopropylsilane (2 equiv.). The tube was then sealed, removed from the glove box and allowed to stir at $-78{ }^{\circ} \mathrm{C}$ for $5 \mathrm{~min}$, after which the mixture was added 1-(dimethyl(phenyl)silyl)2,2,2-trifluoroethanone ( 1 equiv., $0.25 \mathrm{mmol}$ ) in $5 \mathrm{~mL}$ THF using a syringe driven by an injection pump at a constant flow rate (within $6 \mathrm{~h}$ ). After stirring for another $6 \mathrm{~h}$, a saturated solution of $\mathrm{NH}_{4} \mathrm{~F}$ in $\mathrm{MeOH}$ (ca. $6 \mathrm{~mL}$ ) was carefully added to quench the reaction (Caution: gas evolution was observed). The reaction mixture was allowed to stir for $20 \mathrm{~min}$ at room temperature, diluted with EtOAc (ca. $10 \mathrm{~mL}$ ), stirred for an additional $10 \mathrm{~min}$ at room temperature and then filtered through a short plug of celite (1-2 
$\mathrm{cm}$ ) eluting with EtOAc (ca. $50 \mathrm{~mL}$ ). The solvent was removed in vacuo with the aid of a rotary evaporator. At this point, the crude yield was determined by ${ }^{19} \mathrm{~F} \mathrm{NMR}$ spectroscopic analysis using $\mathrm{PhCF}_{3}$ as the internal standard. $100 \%$ conv., $1 \%$ yield of ${ }^{19} \mathrm{~F}$ NMR.

4 Synthesis of $\alpha$-difluoromethyl Alcohols 3r-3aa

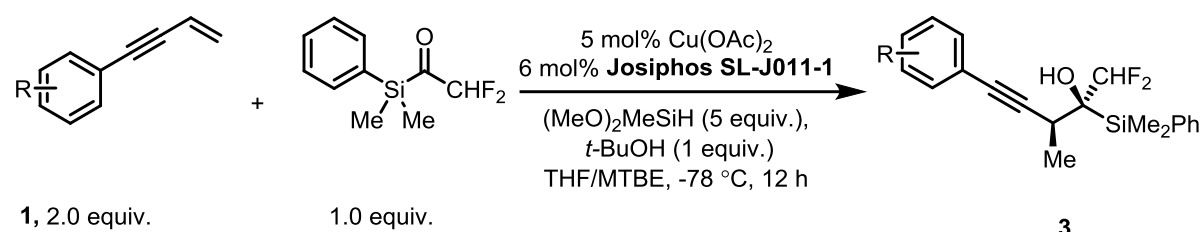

In a glovebox, to an oven-dried $10 \mathrm{~mL}$ Schlenk tube equipped with a magnetic stir bar was added $\mathrm{Cu}(\mathrm{OAc})_{2}$ (2.3 mg, $0.0125 \mathrm{mmol}, 5 \mathrm{~mol} \%$ ), Josiphos SL-J011-1 (10.2 mg, $0.015 \mathrm{mmol}, 6 \mathrm{~mol} \%$ ), and dry solvent $(1 \mathrm{~mL})$ sequentially. The mixture was stirred at room temperature for 30 min before the addition of DMMS (153.5 $\mu \mathrm{L}, 1.25 \mathrm{mmol}, 5$ equiv.), $t$-BuOH $(24 \mu \mathrm{L}, 0.25 \mathrm{mmol}, 1$ equiv.) and 1 (2 equiv.). The tube was then sealed, removed from the glove box and allowed to stir at $-78^{\circ} \mathrm{C}$ for $5 \mathrm{~min}$, after which the mixture was added 1-(dimethyl(phenyl)silyl)-2,2-difluoroethan-1-one (54 mg, $0.25 \mathrm{mmol}$, 1 equiv.) in $5 \mathrm{~mL}$ using a syringe driven by an injection pump at a constant flow rate (within $6 \mathrm{~h}$ ). After stirring for another $6 \mathrm{~h}$, a saturated solution of $\mathrm{NH}_{4} \mathrm{~F}$ in $\mathrm{MeOH}$ (ca. $6 \mathrm{~mL}$ ) was carefully added to quench the reaction (Caution: gas evolution was observed). The reaction mixture was allowed to stir for $20 \mathrm{~min}$ at room temperature, diluted with EtOAc (ca. $10 \mathrm{~mL}$ ), stirred for an additional 10 min at room temperature and then filtered through a short plug of celite $(1-2 \mathrm{~cm})$ eluting with EtOAc (ca. $50 \mathrm{~mL})$. The solvent was removed in vacuo with the aid of a rotary evaporator. At this point, the crude yield and the diastereomeric ratio ( $\mathrm{dr}$ ) were determined by ${ }^{19} \mathrm{~F}$ NMR spectroscopic analysis using $\mathrm{PhCF}_{3}$ as the internal standard. The crude product was purified with column chromatography on silica gel (300 400 mesh) to afford the title compound $\mathbf{3}$.

\section{(2R,3S)-2-(dimethyl(phenyl)silyl)-1,1-difluoro-3-methyl-5-phenylpent-4-yn-2-ol (3r)}

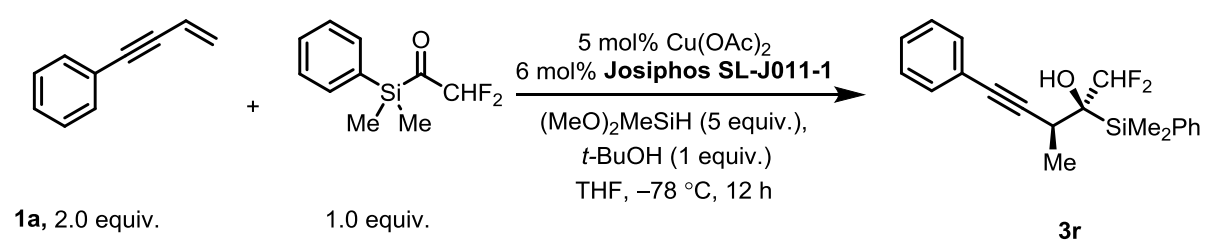

In a glovebox, to an oven-dried $10 \mathrm{~mL}$ Schlenk tube equipped with a magnetic stir bar was added $\mathrm{Cu}(\mathrm{OAc})_{2}$ (5 mol\%), Josiphos SL-J011-1 (6 mol\%), and dry THF (1 mL) sequentially. The mixture was stirred at room temperature for $30 \mathrm{~min}$ before the addition of DMMS ( 5 equiv.), $t$-BuOH ( 1 equiv.) and 1 a (2 equiv.). The tube was then sealed, removed from the glove box and allowed to stir at $-78{ }^{\circ} \mathrm{C}$ for 5 min, after which the mixture was added 1-(dimethyl(phenyl)silyl)-2,2-difluoroethan-1-one (1 equiv., $0.25 \mathrm{mmol}$ ) in $5 \mathrm{~mL}$ THF using a syringe driven by an injection pump at a constant flow rate (within 6 h). After stirring for another $6 \mathrm{~h}$, a saturated solution of $\mathrm{NH}_{4} \mathrm{~F}$ in $\mathrm{MeOH}$ (ca. $6 \mathrm{~mL}$ ) was carefully added to quench the reaction (Caution: gas evolution was observed). The reaction mixture was allowed to stir for $20 \mathrm{~min}$ at room temperature, diluted with EtOAc (ca. $10 \mathrm{~mL}$ ), stirred for an additional $10 \mathrm{~min}$ at room temperature and then filtered through a short plug of celite $(1-2 \mathrm{~cm})$ eluting with EtOAc (ca. $50 \mathrm{~mL})$. The solvent was removed in vacuo with the aid of a rotary evaporator. At this point, the crude yield and the diastereomeric ratio (dr) were determined by ${ }^{19} \mathrm{~F}$ NMR spectroscopic analysis using $\mathrm{PhCF}_{3}$ as the internal standard. The crude product was purified with column chromatography on silica gel (300 400 
mesh) with afford the title compound $3 \mathbf{r}$. Colorless oil; $\mathbf{R}_{\mathbf{f}}=0.52(\mathrm{PE} / \mathrm{EA}=10 / 1) ; 77.4 \mathrm{mg}, 90 \%$ yield, $>$ 99\% ee, 92:8 dr; $[\boldsymbol{\alpha}]^{\mathbf{2 5}} \mathbf{D}=-110.0\left(c=5.55, \mathrm{CHCl}_{3}\right)$ NMR spectroscopy: ${ }^{1} \mathbf{H} \mathbf{~ N M R}\left(400 \mathrm{MHz}, \mathrm{CDCl}_{3}, 25\right.$ $\left.{ }^{\circ} \mathrm{C}\right) \delta 7.71-7.66(\mathrm{~m}, 2 \mathrm{H}), 7.43-7.37(\mathrm{~m}, 5 \mathrm{H}), 7.35-7.30(\mathrm{~m}, 3 \mathrm{H}), 6.13(\mathrm{dd}, J=56.3,54.8 \mathrm{~Hz}, 1 \mathrm{H}), 2.96$ $(\mathrm{q}, J=7.2 \mathrm{~Hz}, 1 \mathrm{H}), 2.02(\mathrm{~s}, 1 \mathrm{H}), 1.30(\mathrm{dd}, J=7.2,2.7 \mathrm{~Hz}, 3 \mathrm{H}), 0.62(\mathrm{~s}, 3 \mathrm{H}), 0.59(\mathrm{~s}, 3 \mathrm{H}) ;{ }^{13} \mathbf{C} \mathbf{N M R}$ $\left(151 \mathrm{MHz}, \mathrm{CDCl}_{3}, 25^{\circ} \mathrm{C}\right) \delta 135.2,135.1,131.7,129.93,128.5,128.3,128.0,123.2,118.8(\mathrm{dd}, J=247.6$, $240.9 \mathrm{~Hz}), 90.0,84.7,71.0(\mathrm{dd}, J=25.5,18.3 \mathrm{~Hz}), 31.6,15.3,-3.4,-3.5 ;{ }^{19} \mathbf{F} \mathbf{N M R}\left(376 \mathrm{MHz}, \mathrm{CDCl}_{3}\right.$, $\left.25^{\circ} \mathrm{C}\right) \delta-120.0-125.5$ (m, 2F); IR (ATR): 3705, 3675, 3571, 3194, 2978, 2885, 1957, 1670, 1491, 1252, 1141, 954, 876, 757, $705 \mathrm{~cm}^{-1}$; HRMS (ESI, m/z): calcd for $\mathrm{C}_{20} \mathrm{H}_{23} \mathrm{~F}_{2} \mathrm{OSi}^{+}(\mathrm{M}+\mathrm{H})^{+}: 345.1481$; Found: 345.1484; HPLC analysis (AD-H column, $1 \% i-\mathrm{PrOH} /$ hexane, $0.50 \mathrm{~mL} / \mathrm{min}, 20{ }^{\circ} \mathrm{C}, 254 \mathrm{~nm}$ ) indicated $>99 \%$ ee: $t_{\mathrm{R}}$ (major) $=16.92 \mathrm{~min}$.

Racemic 3r:

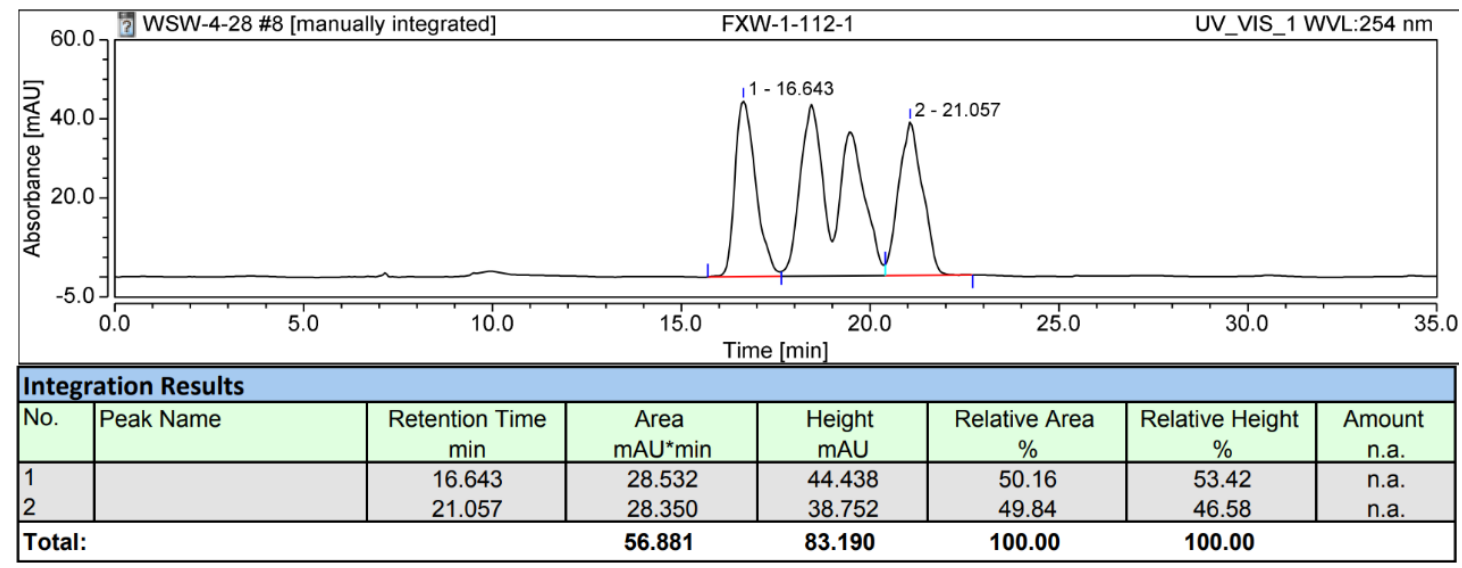

\section{Enantioenriched 3r:}

\begin{tabular}{|l|l|l|l|l|l|l|}
\hline Chromatogram & UV_VIS_1 WVL:254 nm \\
\hline
\end{tabular}

(2R,3S)-2-(dimethyl(phenyl)silyl)-1,1-difluoro-5-(2-fluorophenyl)-3-methylpent-4-yn-2-ol (3s)

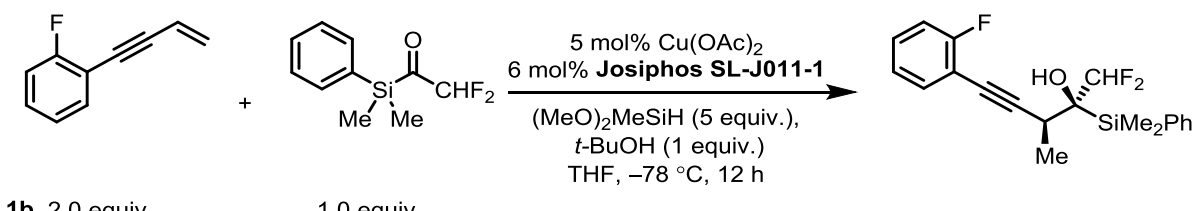

In a glovebox, to an oven-dried $10 \mathrm{~mL}$ Schlenk tube equipped with a magnetic stir bar was added $\mathrm{Cu}(\mathrm{OAc})_{2}$ (5 mol\%), Josiphos SL-J011-1 (6 mol\%), and dry THF (1 mL) sequentially. The mixture was 
stirred at room temperature for $30 \mathrm{~min}$ before the addition of DMMS (5 equiv.), $t$-BuOH ( 1 equiv.) and $\mathbf{1 b}$ ( 2 equiv.). The tube was then sealed, removed from the glove box and allowed to stir at $-78^{\circ} \mathrm{C}$ for 5 min, after which the mixture was added 1-(dimethyl(phenyl)silyl)-2,2-difluoroethan-1-one (1 equiv., $0.25 \mathrm{mmol}$ ) in $5 \mathrm{~mL}$ using a syringe driven by an injection pump at a constant flow rate (within $6 \mathrm{~h}$ ). After stirring for another $6 \mathrm{~h}$, a saturated solution of $\mathrm{NH}_{4} \mathrm{~F}$ in $\mathrm{MeOH}$ (ca. $6 \mathrm{~mL}$ ) was carefully added to quench the reaction (Caution: gas evolution was observed). The reaction mixture was allowed to stir for $20 \mathrm{~min}$ at room temperature, diluted with EtOAc (ca. $10 \mathrm{~mL})$, stirred for an additional $10 \mathrm{~min}$ at room temperature and then filtered through a short plug of celite $(1-2 \mathrm{~cm})$ eluting with EtOAc (ca. $50 \mathrm{~mL})$. The solvent was removed in vacuo with the aid of a rotary evaporator. At this point, the crude yield and the diastereomeric ratio ( $\mathrm{dr}$ ) were determined by ${ }^{19} \mathrm{~F}$ NMR spectroscopic analysis using $\mathrm{PhCF}_{3}$ as the internal standard. The crude product was purified with column chromatography on silica gel (300 400 mesh) to afford the title compound 3s; Colorless oil; $\mathbf{R}_{\mathbf{f}}=0.68(\mathrm{PE} / \mathrm{EA}=10 / 1) ; 55.2 \mathrm{mg}, 61 \%$ yield, > 99\% ee, 96:4 dr; $[\boldsymbol{\alpha}]^{\mathbf{2 5}} \mathbf{D}=-81.3\left(c=3.45, \mathrm{CHCl}_{3}\right)$; NMR spectroscopy: ${ }^{1} \mathbf{H} \mathbf{~ N M R}\left(400 \mathrm{MHz}, \mathrm{CDCl}_{3}, 25\right.$ $\left.{ }^{\circ} \mathrm{C}\right) \delta 7.68-7.65(\mathrm{~m}, 2 \mathrm{H}), 7.43-7.36(\mathrm{~m}, 3 \mathrm{H}), 7.31-7.24(\mathrm{~m}, 1 \mathrm{H}), 7.14(\mathrm{dt}, J=7.6,1.3 \mathrm{~Hz}, 1 \mathrm{H}), 7.06-7.01$ (m, 2H), 6.09 (dd, $J=56.3,54.8 \mathrm{~Hz}, 1 \mathrm{H}), 2.95$ (q, $J=7.1 \mathrm{~Hz}, 1 \mathrm{H}), 2.00$ (s, 1H), 1.30 (dd, $J=7.2,2.5$ $\mathrm{Hz}, 3 \mathrm{H}), 0.60(\mathrm{~s}, 3 \mathrm{H}), 0.57$ (s, 3H); ${ }^{13} \mathbf{C} \mathbf{N M R}\left(151 \mathrm{MHz}, \mathrm{CDCl}_{3}, 25^{\circ} \mathrm{C}\right) \delta 162.5(\mathrm{~d}, J=246.4 \mathrm{~Hz}), 135.1$, 135.0, 130.1, 130.0, 128.1, 127.5 (d, $J=3.2 \mathrm{~Hz}), 125.0$ (d, $J=9.3 \mathrm{~Hz}), 118.7$ (dd, $J=247.5,241.7 \mathrm{~Hz})$, $118.5(\mathrm{~d}, J=22.8 \mathrm{~Hz}), 115.7(\mathrm{~d}, J=21.2 \mathrm{~Hz}), 99.1,83.4,71.0(\mathrm{dd}, J=25.5,19.1 \mathrm{~Hz}), 31.5,15.2,-3.5$, $-3.6 ;{ }^{19} \mathbf{F}$ NMR $\left(376 \mathrm{MHz}, \mathrm{CDCl}_{3}, 25^{\circ} \mathrm{C}\right) \delta-112.7--112.9(\mathrm{~m}, 1 \mathrm{~F}),-120.0--125.4$ (m, 2F); IR (ATR): 3679, 3567, 3243, 2982, 1670, 1487, 1375, 1264, 1174, 1107, 928, 839, 783, 738, $705 \mathrm{~cm}^{-1}$; HRMS (ESI, $\mathrm{m} / \mathrm{z}$ ): calcd for $\mathrm{C}_{20} \mathrm{H}_{22} \mathrm{~F}_{3} \mathrm{OSi}^{+}(\mathrm{M}+\mathrm{H})^{+}: 363.1387$; Found: 363.1386; HPLC analysis (AD-H column, $1 \%$ $i-\mathrm{PrOH} /$ hexane, $0.50 \mathrm{~mL} / \mathrm{min}, 20{ }^{\circ} \mathrm{C}, 254 \mathrm{~nm}$ ) indicated $>99 \%$ ee: $t_{\mathrm{R}}$ (major) $=14.51 \mathrm{~min}$.

\section{Racemic 3s:}

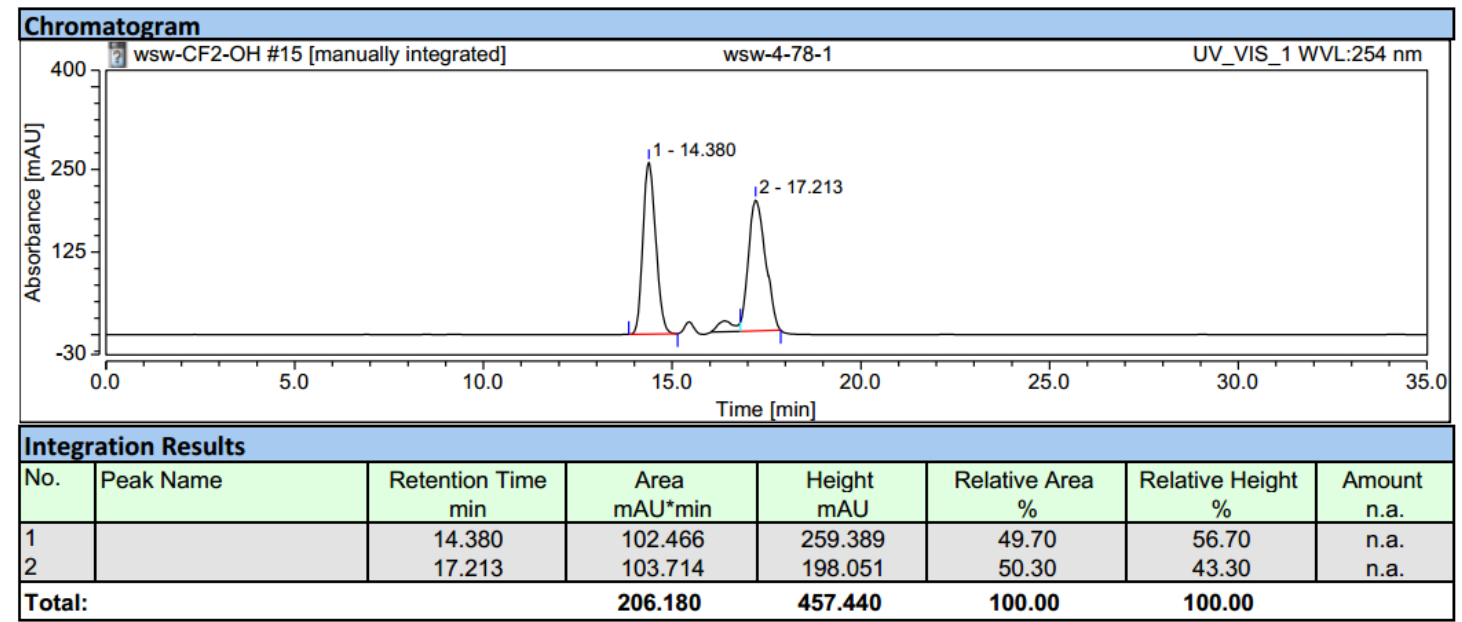


Enantioenriched 3s:

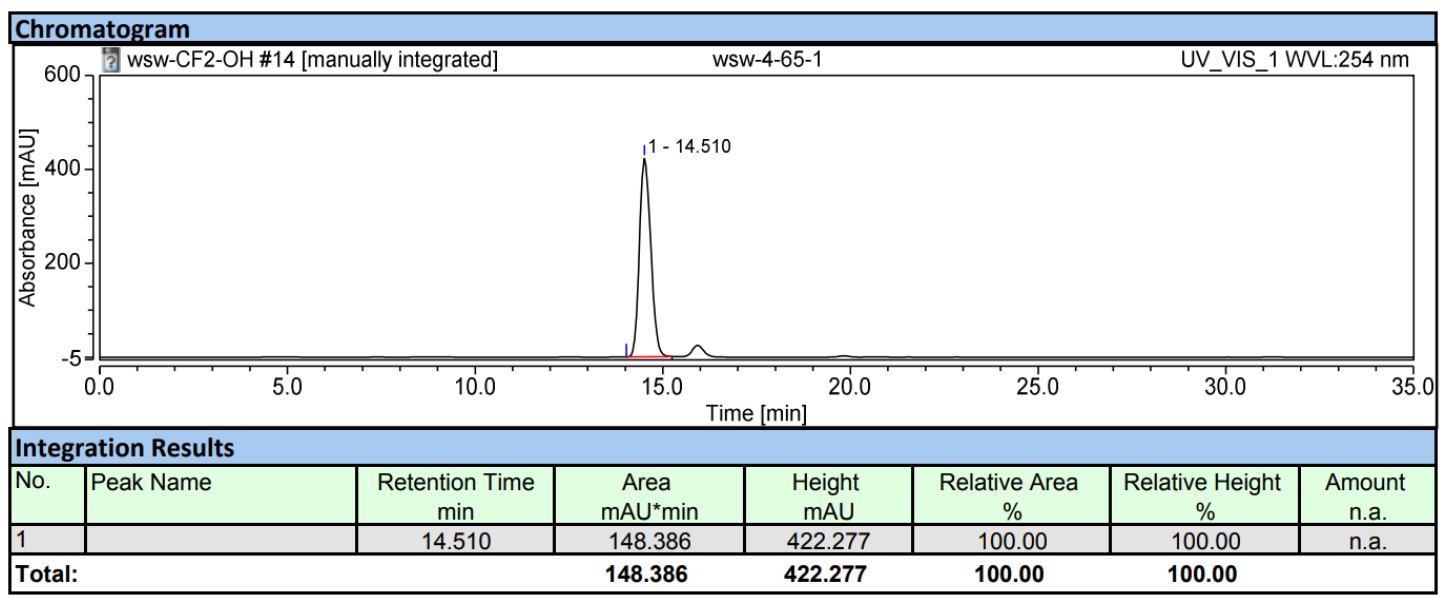

(2R,3S)-2-(dimethyl(phenyl)silyl)-1,1-difluoro-5-(3-fluorophenyl)-3-methylpent-4-yn-2-ol (3t)

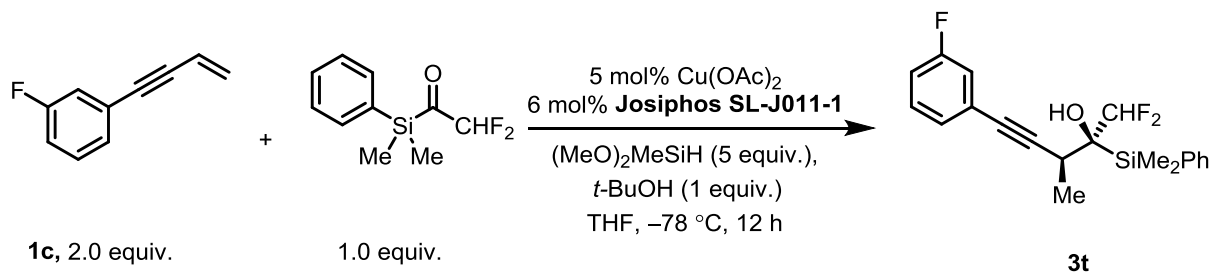

In a glovebox, to an oven-dried $10 \mathrm{~mL}$ Schlenk tube equipped with a magnetic stir bar was added $\mathrm{Cu}(\mathrm{OAc})_{2}$ (5 mol\%), Josiphos SL-J011-1 (6 mol\%), and dry THF (1 mL) sequentially. The mixture was stirred at room temperature for $30 \mathrm{~min}$ before the addition of DMMS (5 equiv.), $t$-BuOH ( 1 equiv.) and 1c ( 2 equiv.). The tube was then sealed, removed from the glove box and allowed to stir at $-78^{\circ} \mathrm{C}$ for 5 min, after which the mixture was added 1-(dimethyl(phenyl)silyl)-2,2-difluoroethan-1-one (1 equiv., $0.25 \mathrm{mmol}$ ) in $5 \mathrm{~mL}$ THF using a syringe driven by an injection pump at a constant flow rate (within 6 h).. After stirring for another $6 \mathrm{~h}$, a saturated solution of $\mathrm{NH}_{4} \mathrm{~F}$ in $\mathrm{MeOH}$ (ca. $6 \mathrm{~mL}$ ) was carefully added to quench the reaction (Caution: gas evolution was observed). The reaction mixture was allowed to stir for $20 \mathrm{~min}$ at room temperature, diluted with EtOAc (ca. $10 \mathrm{~mL}$ ), stirred for an additional $10 \mathrm{~min}$ at room temperature and then filtered through a short plug of celite $(1-2 \mathrm{~cm})$ eluting with EtOAc (ca. $50 \mathrm{~mL})$. The solvent was removed in vacuo with the aid of a rotary evaporator. At this point, the crude yield and the diastereomeric ratio (dr) were determined by ${ }^{19} \mathrm{~F}$ NMR spectroscopic analysis using $\mathrm{PhCF}_{3}$ as the internal standard. The crude product was purified with column chromatography on silica gel (300 400 mesh) to afford the title compound 3t. Colorless oil; $\mathbf{R}_{\mathbf{f}}=0.58(\mathrm{PE} / \mathrm{EA}=10 / 1) ; 59.7 \mathrm{mg}, 66 \%$ yield, > 99\% ee, 96:4 dr; $[\boldsymbol{\alpha}]^{25} \mathbf{D}=-74.8\left(c=3.25, \mathrm{CHCl}_{3}\right)$; NMR spectroscopy: ${ }^{1} \mathbf{H} \mathbf{~ N M R}\left(400 \mathrm{MHz}, \mathrm{CDCl}_{3}, 25\right.$ $\left.{ }^{\circ} \mathrm{C}\right) \delta$ 7.69-7.64 (m, 2H), 7.41-7.27 (m, 5H), 7.12-7.05 (m, 2H), $6.15(\mathrm{dd}, J=56.2,54.6 \mathrm{~Hz}, 1 \mathrm{H}), 2.97$ $(\mathrm{q}, J=7.9,7.0 \mathrm{~Hz}, 1 \mathrm{H}), 2.00(\mathrm{~s}, 1 \mathrm{H}), 1.30(\mathrm{dd}, J=7.2,2.6 \mathrm{~Hz}, 3 \mathrm{H}), 0.60(\mathrm{~s}, 3 \mathrm{H}), 0.57$ (s, 3H); ${ }^{13} \mathbf{C} \mathbf{N M R}$ $\left(151 \mathrm{MHz}, \mathrm{CDCl}_{3}, 25^{\circ} \mathrm{C}\right) \delta 163.1(\mathrm{~d}, J=250.8 \mathrm{~Hz}), 135.1,135.1,133.5,130.0(\mathrm{~d}, J=7.8 \mathrm{~Hz}), 129.9$, 128.0, $124.1(\mathrm{~d}, J=3.7 \mathrm{~Hz}), 118.8(\mathrm{dd}, J=247.8,240.6 \mathrm{~Hz}), 115.7(\mathrm{~d}, J=21.0 \mathrm{~Hz}), 111.7(\mathrm{~d}, J=15.5$ $\mathrm{Hz}), 95.3,78.3,71.0(\mathrm{dd}, J=25.7,18.4 \mathrm{~Hz}), 31.7,15.3,-3.5,-3.6 ;{ }^{19} \mathbf{F} \mathbf{N M R}\left(376 \mathrm{MHz}, \mathrm{CDCl}_{3}, 25{ }^{\circ} \mathrm{C}\right)$ $\delta-110.1-110.2$ (m, 1F), -120.1--125.4 (m, 2F); IR (ATR): 3806, 3675, 3563, 3071, 2982, 2236, 1730 , 15730, 1379, 1252, 1111, 1033, 820, 757, $705 \mathrm{~cm}^{-1}$; HRMS (ESI, m/z): calcd for $\mathrm{C}_{20} \mathrm{H}_{22} \mathrm{~F}_{3} \mathrm{OSi}^{+}(\mathrm{M}+\mathrm{H})^{+}$: 363.1387; Found: 363.1384; HPLC analysis (AD-H column, $1 \% i-\mathrm{PrOH} / \mathrm{hexane}, 0.50 \mathrm{~mL} / \mathrm{min}, 20^{\circ} \mathrm{C}$, 
$254 \mathrm{~nm}$ ) indicated $>99 \%$ ee: $t_{\mathrm{R}}$ (major) $=14.31 \mathrm{~min}$.

\section{Racemic 3t:}

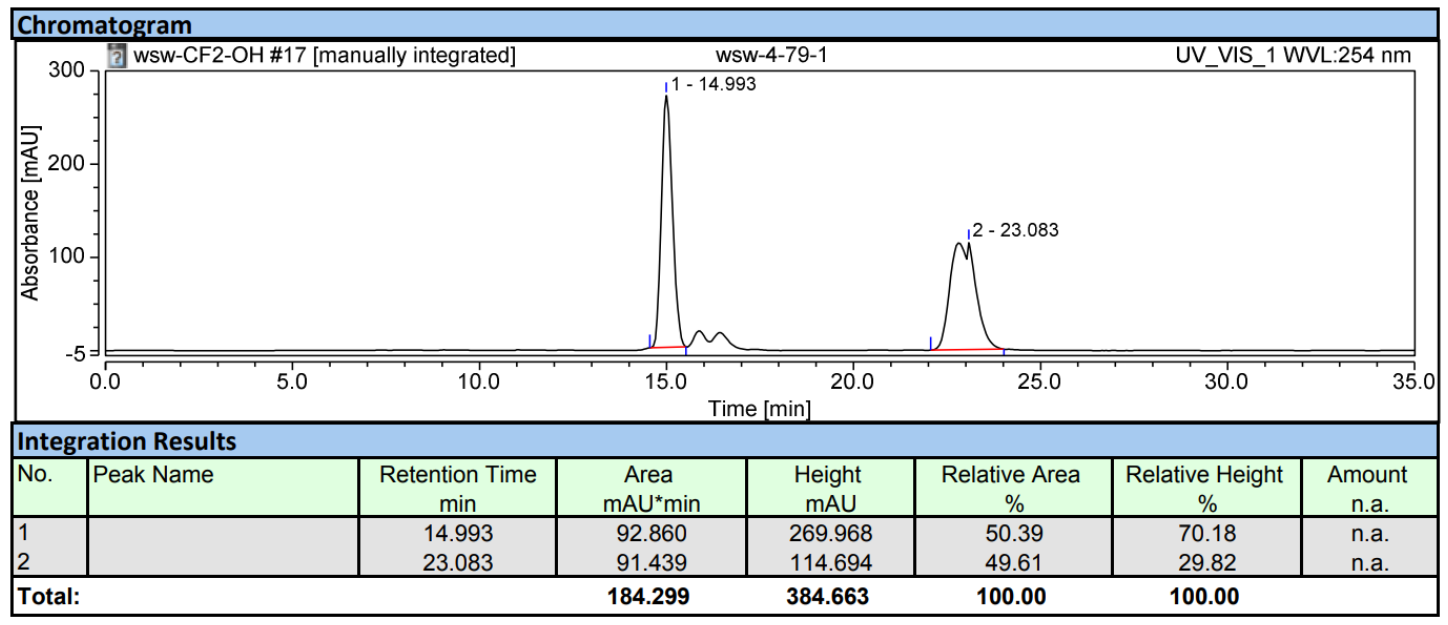

\section{Enantioenriched 3t:}

\begin{tabular}{|l|l|l|l|l|l|l|}
\hline Chromatogram & UV_VIS_1 WVL:254 nm \\
\hline
\end{tabular}

(2R,3S)-2-(dimethyl(phenyl)silyl)-1,1-difluoro-5-(4-fluorophenyl)-3-methylpent-4-yn-2-ol (3u)

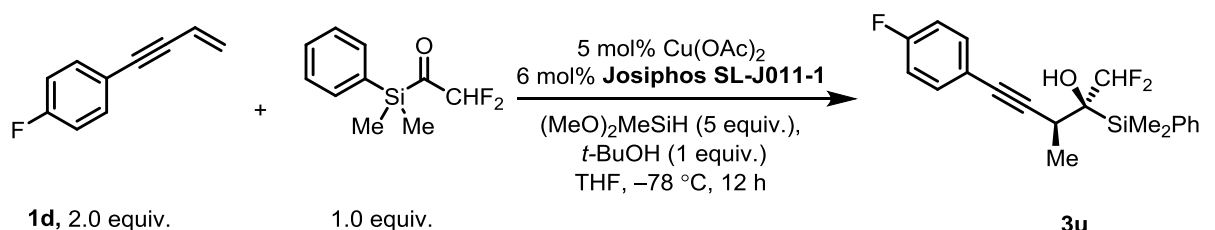

In a glovebox, to an oven-dried $10 \mathrm{~mL}$ Schlenk tube equipped with a magnetic stir bar was added $\mathrm{Cu}(\mathrm{OAc})_{2}$ (5 mol\%), Josiphos SL-J011-1 (6 mol\%), and dry THF (1 mL) sequentially. The mixture was stirred at room temperature for $30 \mathrm{~min}$ before the addition of DMMS (5 equiv.), $t$-BuOH ( 1 equiv.) and 1d ( 2 equiv.). The tube was then sealed, removed from the glove box and allowed to stir at $-78^{\circ} \mathrm{C}$ for 5 min, after which the mixture was added 1-(dimethyl(phenyl)silyl)-2,2-difluoroethan-1-one (1 equiv., $0.25 \mathrm{mmol}$ ) in $5 \mathrm{~mL}$ THF using a syringe driven by an injection pump at a constant flow rate (within 6 h).. After stirring for another $6 \mathrm{~h}$, a saturated solution of $\mathrm{NH}_{4} \mathrm{~F}$ in $\mathrm{MeOH}$ (ca. $6 \mathrm{~mL}$ ) was carefully added to quench the reaction (Caution: gas evolution was observed). The reaction mixture was allowed to stir for $20 \mathrm{~min}$ at room temperature, diluted with EtOAc (ca. $10 \mathrm{~mL}$ ), stirred for an additional $10 \mathrm{~min}$ at room temperature and then filtered through a short plug of celite $(1-2 \mathrm{~cm})$ eluting with EtOAc $(\mathrm{ca} .50 \mathrm{~mL})$. 
The solvent was removed in vacuo with the aid of a rotary evaporator. At this point, the crude yield and the diastereomeric ratio ( $\mathrm{dr}$ ) were determined by ${ }^{19} \mathrm{~F}$ NMR spectroscopic analysis using $\mathrm{PhCF}_{3}$ as the internal standard. The crude product was purified with column chromatography on silica gel (300 400 mesh) to afford the title compound 3u. Colorless oil; $\mathbf{R}_{\mathbf{f}}=0.56(\mathrm{PE} / \mathrm{EA}=10 / 1) ; 56.1 \mathrm{mg}, 62 \%$ yield, > 99\% ee, 96:4 dr; $[\boldsymbol{\alpha}]^{25} \mathbf{D}=-112.0\left(c=3.05, \mathrm{CHCl}_{3}\right)$; NMR spectroscopy: ${ }^{\mathbf{1}} \mathbf{H} \mathbf{~ N M R}\left(400 \mathrm{MHz}, \mathrm{CDCl}_{3}, 25\right.$ $\left.{ }^{\circ} \mathrm{C}\right) \delta 7.65(\mathrm{dd}, J=7.8,1.7 \mathrm{~Hz}, 2 \mathrm{H}), 7.42-7.30(\mathrm{~m}, 5 \mathrm{H}), 7.03-6.96(\mathrm{~m}, 2 \mathrm{H}), 6.08(\mathrm{dd}, J=56.3,54.8 \mathrm{~Hz}$, $1 \mathrm{H}), 2.93$ (q, $J=7.2 \mathrm{~Hz}, 1 \mathrm{H}), 1.97(\mathrm{~s}, 1 \mathrm{H}), 1.28(\mathrm{dd}, J=7.1,2.5 \mathrm{~Hz}, 3 \mathrm{H}), 0.59(\mathrm{~s}, 3 \mathrm{H}), 0.56(\mathrm{~s}, 3 \mathrm{H}) ;{ }^{13} \mathbf{C}$ NMR $\left(151 \mathrm{MHz}, \mathrm{CDCl}_{3}, 25^{\circ} \mathrm{C}\right) \delta 162.6(\mathrm{~d}, J=249.1 \mathrm{~Hz}), 135.2,135.1,133.5(\mathrm{~d}, J=8.2 \mathrm{~Hz}), 123.0$, 128.0, $119.2(\mathrm{~d}, J=3.6 \mathrm{~Hz}), 118.8(\mathrm{dd}, J=247.5,241.4 \mathrm{~Hz}), 115.7$ (d, $J=22.2 \mathrm{~Hz}), 89.7,83.6,71.0$ (dd, $J=25.5,18.8 \mathrm{~Hz}), 31.5,15.3,-3.4,-3.5 ;{ }^{19} \mathbf{F}$ NMR $\left(376 \mathrm{MHz}, \mathrm{CDCl}_{3}, 25{ }^{\circ} \mathrm{C}\right) \delta-111.0(\mathrm{ddd}, J=13.3$, 8.8, 4.6 Hz, 1F), -120.0 --124.4 (m, 2F); IR (ATR): 3686, 3563, 3347, 3317, 3071, 2982, 1767, 1602 , 1506, 1428, 1111, 958, 835, 738, $705 \mathrm{~cm}^{-1}$; HRMS (ESI, m/z): calcd for $\mathrm{C}_{20} \mathrm{H}_{22} \mathrm{~F}_{3} \mathrm{OSi}^{+}(\mathrm{M}+\mathrm{H})^{+}: 363.1387$; Found: 363.1385 ; HPLC analysis (AD-H column, $1 \% i-\mathrm{PrOH} /$ hexane, $0.50 \mathrm{~mL} / \mathrm{min}, 20{ }^{\circ} \mathrm{C}, 254 \mathrm{~nm}$ ) indicated $>99 \%$ ee: $t_{\mathrm{R}}$ (major) $=18.35 \mathrm{~min}$.

\section{Racemic 3u:}

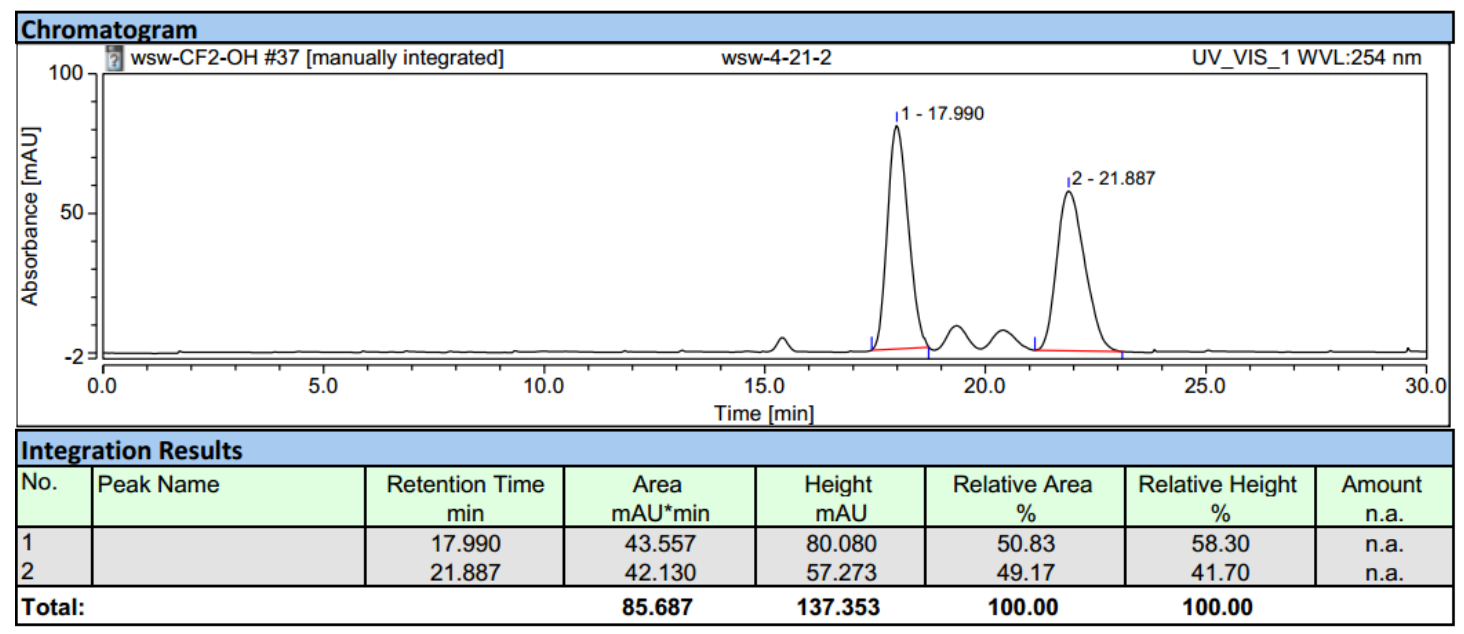

\section{Enantioenriched 3u:}

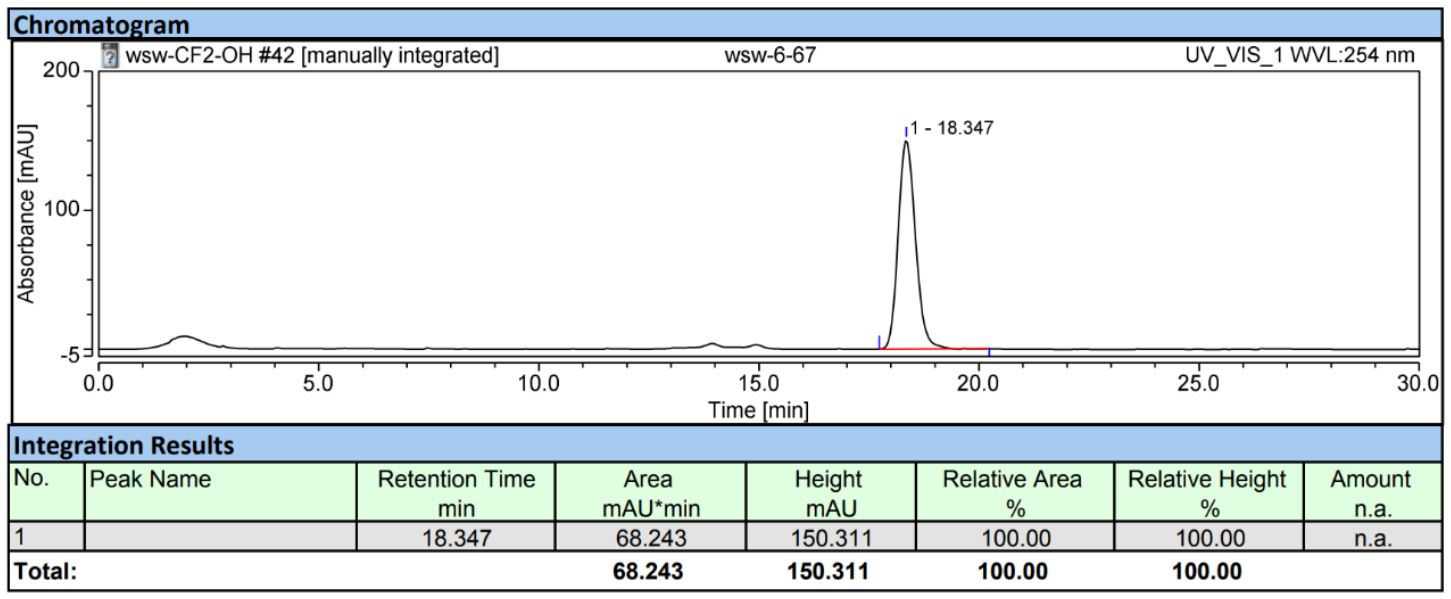


<smiles>C=CC#Cc1ccc(Br)cc1</smiles>

1f, 2.0 equiv.

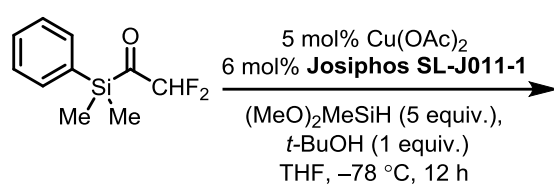

1.0 equiv.<smiles>CC(C#Cc1ccc(Br)cc1)C(O)(C(C)(F)F)C(F)(F)O[14C](=O)c1ccccc1</smiles>

$3 v$

In a glovebox, to an oven-dried $10 \mathrm{~mL}$ Schlenk tube equipped with a magnetic stir bar was added $\mathrm{Cu}(\mathrm{OAc})_{2}$ (5 mol\%), Josiphos SL-J011-1 (6 mol\%), and dry THF (1 mL) sequentially. The mixture was stirred at room temperature for $30 \mathrm{~min}$ before the addition of DMMS (5 equiv.), $t$-BuOH ( 1 equiv.) and 1f ( 2 equiv.). The tube was then sealed, removed from the glove box and allowed to stir at $-78^{\circ} \mathrm{C}$ for 5 min, after which the mixture was added 1-(dimethyl(phenyl)silyl)-2,2-difluoroethan-1-one (1 equiv., $0.25 \mathrm{mmol}$ ) in $5 \mathrm{~mL}$ THF using a syringe driven by an injection pump at a constant flow rate (within 6 h). After stirring for another $6 \mathrm{~h}$, a saturated solution of $\mathrm{NH}_{4} \mathrm{~F}$ in $\mathrm{MeOH}$ (ca. $6 \mathrm{~mL}$ ) was carefully added to quench the reaction (Caution: gas evolution was observed). The reaction mixture was allowed to stir for $20 \mathrm{~min}$ at room temperature, diluted with EtOAc (ca. $10 \mathrm{~mL})$, stirred for an additional 10 min at room temperature and then filtered through a short plug of celite $(1-2 \mathrm{~cm})$ eluting with EtOAc (ca. $50 \mathrm{~mL})$. The solvent was removed in vacuo with the aid of a rotary evaporator. At this point, the crude yield and the diastereomeric ratio ( $\mathrm{dr}$ ) were determined by ${ }^{19} \mathrm{~F}$ NMR spectroscopic analysis using $\mathrm{PhCF}_{3}$ as the internal standard. The crude product was purified with column chromatography on silica gel (300 400 mesh) to afford the title compound 3v. Colorless oil; $\mathbf{R}_{\mathbf{f}}=0.60(\mathrm{PE} / \mathrm{EA}=10 / 1) ; 80.2 \mathrm{mg}, 76 \%$ yield, 95\% ee, $94: 6 \mathrm{dr} ;[\boldsymbol{\alpha}]^{25} \mathbf{D}=-101.2\left(c=2.55, \mathrm{CHCl}_{3}\right)$; NMR spectroscopy: ${ }^{1} \mathbf{H}$ NMR $\left(400 \mathrm{MHz}, \mathrm{CDCl}_{3}, 25{ }^{\circ} \mathrm{C}\right)$ $\delta 7.65(\mathrm{dd}, J=7.8,1.7 \mathrm{~Hz}, 2 \mathrm{H}), 7.45-7.34(\mathrm{~m}, 5 \mathrm{H}), 7.22-7.18(\mathrm{~m}, 2 \mathrm{H}), 6.07(\mathrm{dd}, J=56.3,54.8 \mathrm{~Hz}, 1 \mathrm{H})$, $2.93(\mathrm{q}, J=7.1 \mathrm{~Hz}, 1 \mathrm{H}), 1.97(\mathrm{~s}, 1 \mathrm{H}), 1.28(\mathrm{dd}, J=7.2,2.5 \mathrm{~Hz}, 3 \mathrm{H}), 0.58(\mathrm{~s}, 3 \mathrm{H}), 0.55(\mathrm{~s}, 3 \mathrm{H}) ;{ }^{13} \mathbf{C} \mathbf{N M R}$ $\left(151 \mathrm{MHz}, \mathrm{CDCl}_{3}, 25^{\circ} \mathrm{C}\right) \delta 135.1,135.0,133.1,131.7,123.0,128.0,122.5,122.1,118.8(\mathrm{dd}, J=247.3$, 241.6 Hz), 91.3, 83.6. $71.0(\mathrm{dd}, J=25.5,18.7 \mathrm{~Hz}), 31.6,15.2,-3.5,-3.6 ;{ }^{19} \mathbf{F ~ N M R}\left(376 \mathrm{MHz}, \mathrm{CDCl}_{3}\right.$, $\left.25^{\circ} \mathrm{C}\right) \delta-120.1--124.4$ (m, 2F); IR (ATR): 3835, 3645, 3567, 3411, 3310, 3280, 3967, 1901, 1767, 1588, 1487, 1252, 1111, 913, $738 \mathrm{~cm}^{-1}$; HRMS (ESI, m/z): calcd for $\mathrm{C}_{20} \mathrm{H}_{22} \mathrm{BrF}_{2} \mathrm{OSi}^{+}(\mathrm{M}+\mathrm{H})^{+}: 423.0586$; Found: 423.0580; HPLC analysis (AD-H column, $\left.1 \% i-\mathrm{PrOH} / \mathrm{hexane}, 0.50 \mathrm{~mL} / \mathrm{min}, 20{ }^{\circ} \mathrm{C}, 254 \mathrm{~nm}\right)$ indicated $95 \%$ ee: $t_{\mathrm{R}}($ major $)=15.32 \mathrm{~min}, t_{\mathrm{R}}($ minor $)=18.10 \mathrm{~min}$.

\section{Racemic 3v:}

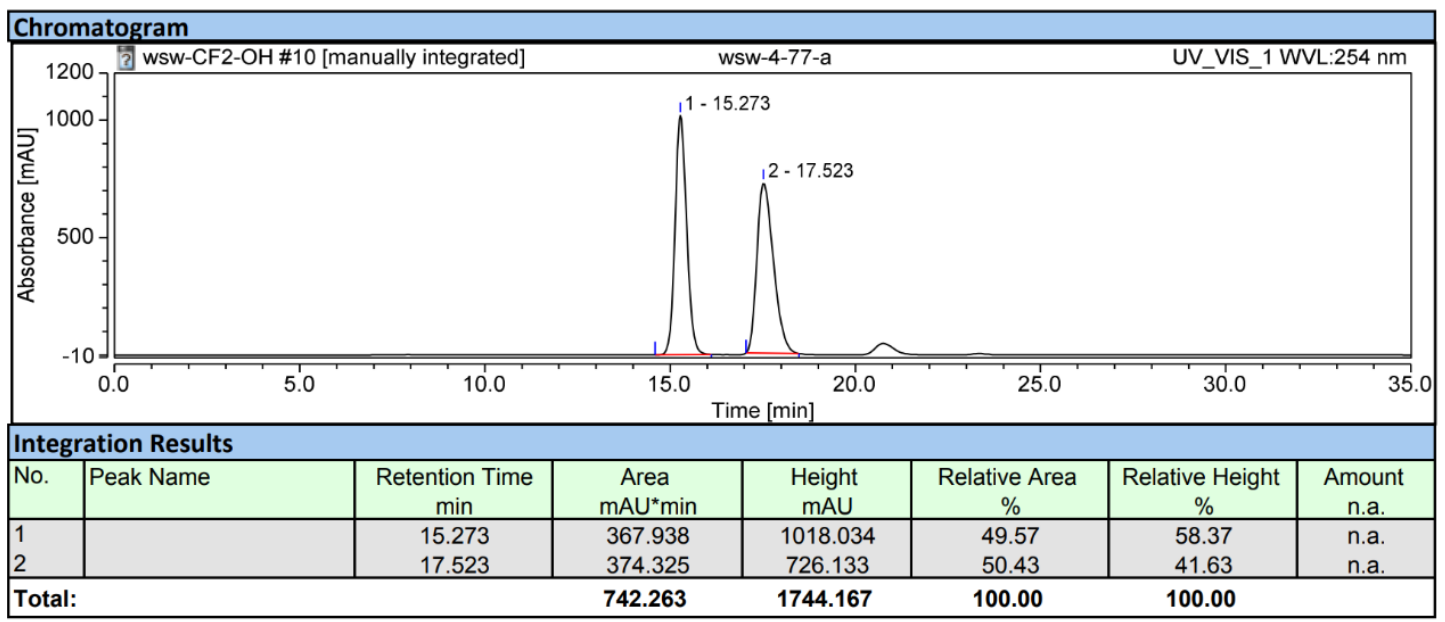


Enantioenriched 3v:

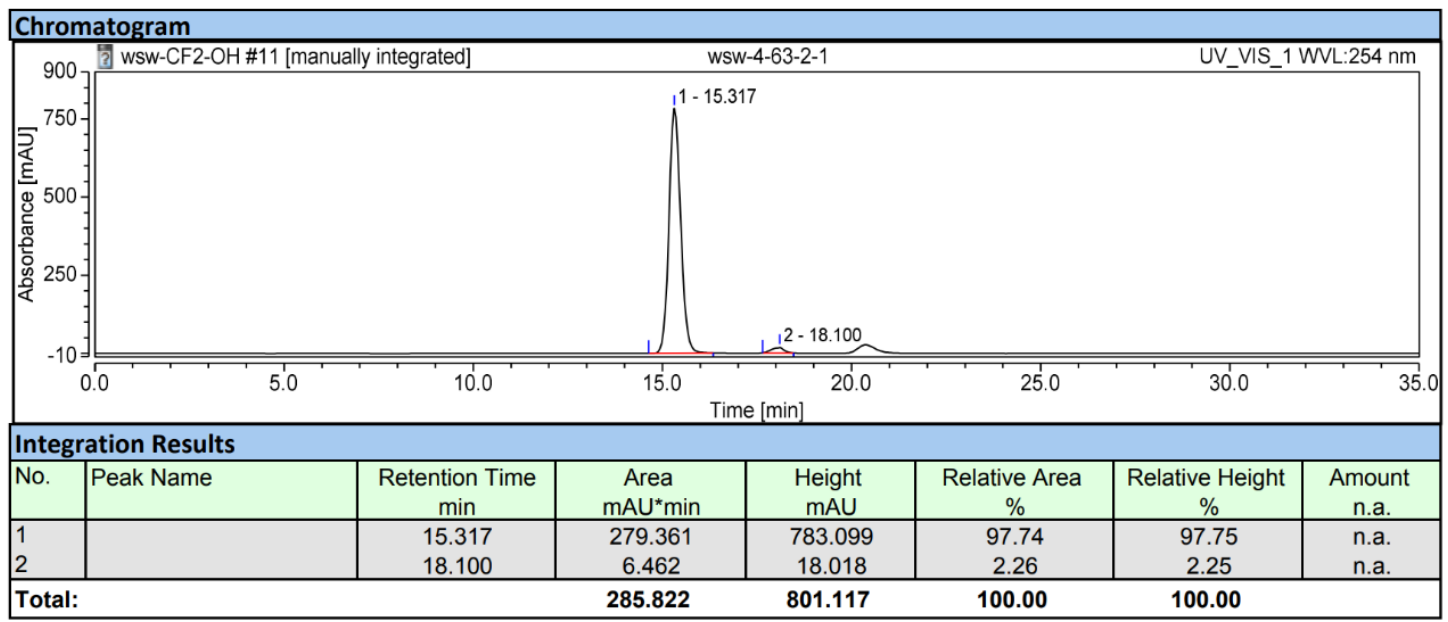

(2R, 3S)-2-(dimethyl(phenyl)silyl)-1,1-difluoro-3-methyl-5-(4-nitrophenyl)pent-4-yn-2-ol (3w)<smiles>C=CC#Cc1ccc([N+](=O)[O-])cc1</smiles>

$1 \mathrm{~g}, 2.0$ equiv.<smiles>C[Si](C)(C(=O)CF)c1ccccc1</smiles>

1.0 equiv.

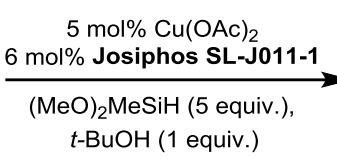

$5 \mathrm{~mol} \% \mathrm{Cu}(\mathrm{OAc})_{2}$ 6 mol\% Josiphos SL-J011-1 $(\mathrm{MeO})_{2} \mathrm{MeSiH}$ (5 equiv.) $t$-BuOH (1 equiv.) MTBE, $-78^{\circ} \mathrm{C}, 12 \mathrm{~h}$<smiles>CC(C#Cc1ccc([N+](=O)[O-])cc1)[C@@](O)(Oc1ccccc1)C(F)F</smiles>

$3 w$

In a glovebox, to an oven-dried $10 \mathrm{~mL}$ Schlenk tube equipped with a magnetic stir bar was added $\mathrm{Cu}(\mathrm{OAc})_{2}$ (5 mol\%), Josiphos SL-J011-1 (6 mol\%), and dry MTBE (1 mL) sequentially. The mixture was stirred at room temperature for $30 \mathrm{~min}$ before the addition of DMMS (5 equiv.), $t$-BuOH ( 1 equiv.) and $1 \mathrm{~g}$ ( 2 equiv.). The tube was then sealed, removed from the glove box and allowed to stir at $-78{ }^{\circ} \mathrm{C}$ for $5 \mathrm{~min}$, after which the mixture was added 1-(dimethyl(phenyl)silyl)-2,2-difluoroethan-1-one (1 equiv., $0.25 \mathrm{mmol}$ ) in $5 \mathrm{~mL}$ MTBE using a syringe driven by an injection pump at a constant flow rate (within $6 \mathrm{~h}$ ). After stirring for another $6 \mathrm{~h}$, a saturated solution of $\mathrm{NH}_{4} \mathrm{~F}$ in $\mathrm{MeOH}$ (ca. $6 \mathrm{~mL}$ ) was carefully added to quench the reaction (Caution: gas evolution was observed). The reaction mixture was allowed to stir for $20 \mathrm{~min}$ at room temperature, diluted with EtOAc (ca. $10 \mathrm{~mL}$ ), stirred for an additional $10 \mathrm{~min}$ at room temperature and then filtered through a short plug of celite $(1-2 \mathrm{~cm})$ eluting with EtOAc $(\mathrm{ca} .50 \mathrm{~mL})$. The solvent was removed in vacuo with the aid of a rotary evaporator. At this point, the crude yield and the diastereomeric ratio $(\mathrm{dr})$ were determined by ${ }^{19} \mathrm{~F}$ NMR spectroscopic analysis using $\mathrm{PhCF}_{3}$ as the internal standard. The crude product was purified with column chromatography on silica gel (300 400 mesh) to afford the title compound $3 \mathbf{w}$; Yellow solid; mp: $61.0-65.0^{\circ} \mathrm{C} ; \mathbf{R}_{\mathbf{f}}=0.56(\mathrm{PE} / \mathrm{EA}=10 / 1) ; 41.8$ mg, 43\% yield, $>99 \%$ ee, $93: 7 \mathrm{dr} ;[\boldsymbol{\alpha}]^{25} \mathbf{D}=-21.2\left(c=1.73, \mathrm{CHCl}_{3}\right)$; NMR spectroscopy: ${ }^{1} \mathbf{H} \mathbf{N M R}(600$ $\left.\mathrm{MHz}, \mathrm{CDCl}_{3}, 25^{\circ} \mathrm{C}\right) \delta 7.67(\mathrm{~d}, J=6.4 \mathrm{~Hz}, 2 \mathrm{H}), 7.44-7.35(\mathrm{~m}, 4 \mathrm{H}), 7.35-7.29(\mathrm{~m}, 3 \mathrm{H}), 6.12(\mathrm{t}, J=55.0$ $\mathrm{Hz}, 1 \mathrm{H}), 2.94$ (q, $J=7.0 \mathrm{~Hz}, 1 \mathrm{H}), 1.99$ (s, 1H), 1.29 (dd, $J=7.2,2.5 \mathrm{~Hz}, 3 \mathrm{H}), 0.61(\mathrm{~s}, 3 \mathrm{H}), 0.58(\mathrm{~s}, 3 \mathrm{H})$; ${ }^{13} \mathrm{C}$ NMR (151 MHz, $\left.\mathrm{CDCl}_{3}, 25{ }^{\circ} \mathrm{C}\right) \delta 147.2,135.0,134.9,132.5,132.4,130.1,128.1,123.7,118.7$ (dd, $J=246.7,242.7 \mathrm{~Hz}), 96.0,82.9,70.9(\mathrm{dd}, J=25.6,20.1 \mathrm{~Hz}), 31.6,15.2,-3.6 ;{ }^{19} \mathbf{F}$ NMR $(565 \mathrm{MHz}$, $\left.\mathrm{CDCl}_{3}, 25^{\circ} \mathrm{C}\right) \delta-120.3-124.3$ (m, 2F); IR (ATR): 3888, 3720, 3563, 3433, 3232, 3071, 2982, 2232 , 1681, 1521, 1111, 854, 783, 728, $705 \mathrm{~cm}^{-1}$; HRMS (ESI, m/z): calcd for $\mathrm{C}_{20} \mathrm{H}_{21} \mathrm{O}_{3} \mathrm{~F}_{2} \mathrm{NClSi}^{-}(\mathrm{M}+\mathrm{Cl})^{-}$: 424.0953; Found: 442.0953; HPLC analysis (AD-H column, $1 \% i-\mathrm{PrOH} / \mathrm{hexane}, 0.50 \mathrm{~mL} / \mathrm{min}, 20^{\circ} \mathrm{C}$, $254 \mathrm{~nm}$ ) indicated $>99 \%$ ee: $t_{\mathrm{R}}$ (major) $=18.21 \mathrm{~min}$. 
Racemic 3w:

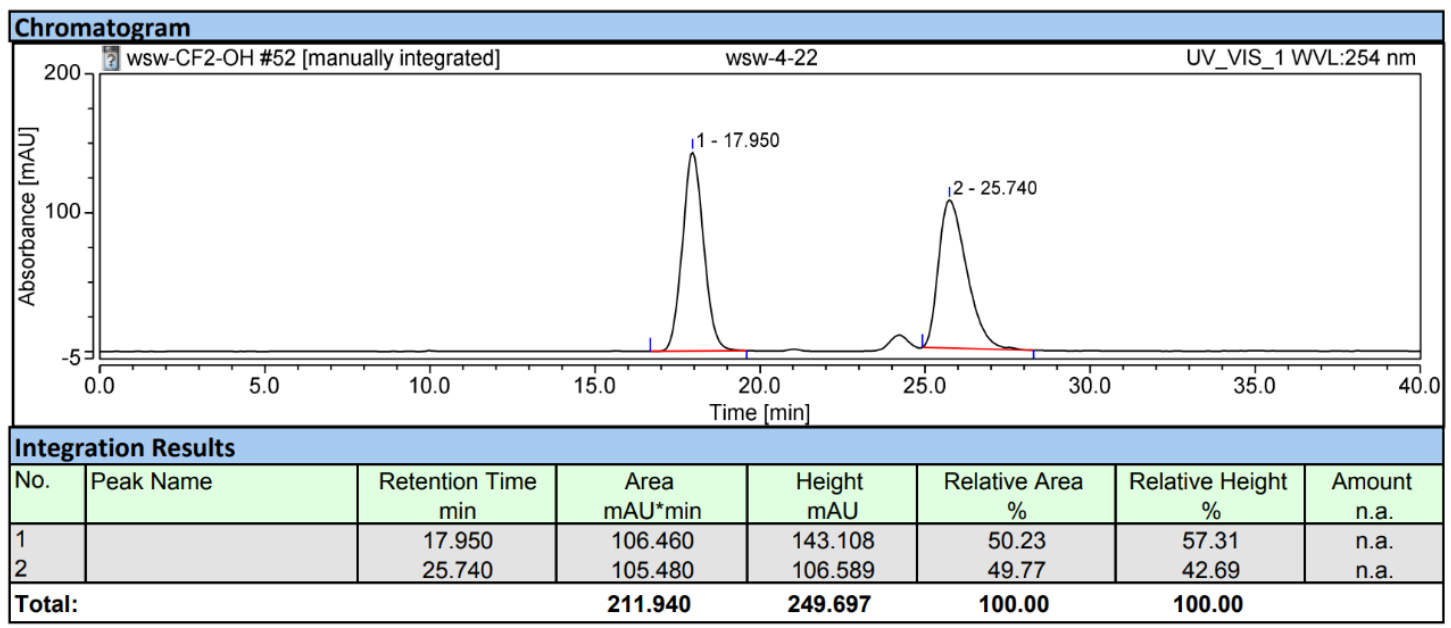

\section{Enantioenriched 3w:}

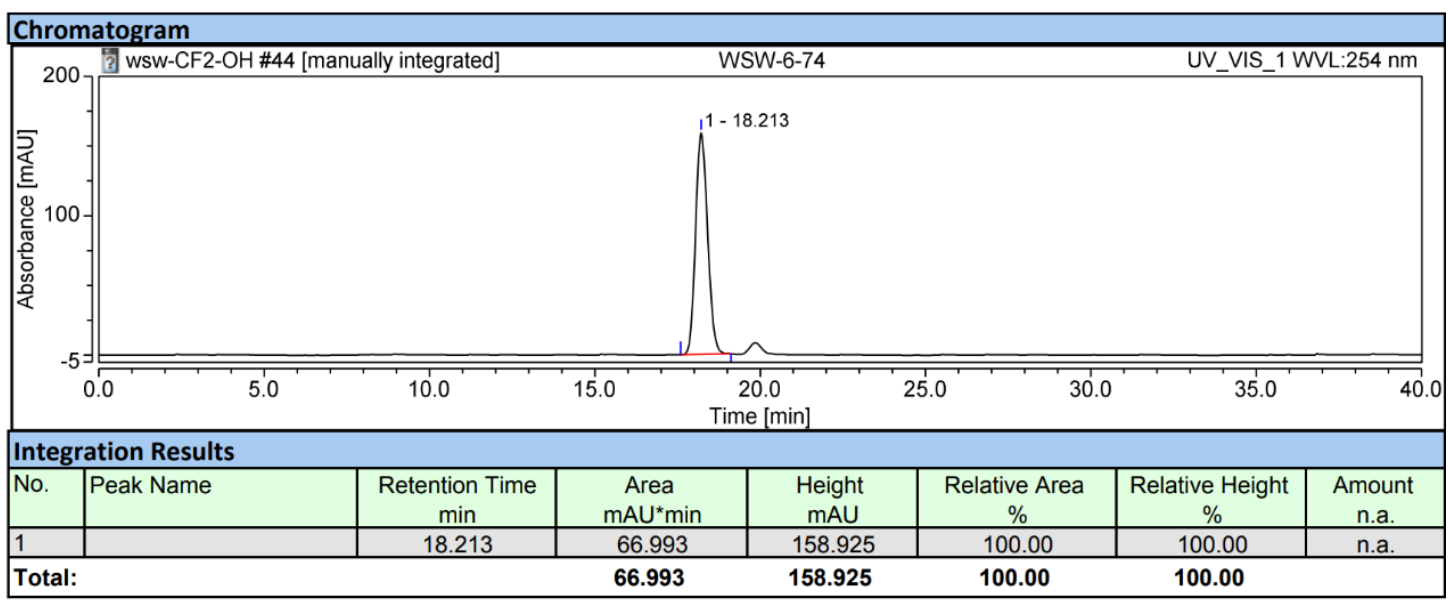

(2R,3S)-2-(dimethyl(phenyl)silyl)-1,1-difluoro-5-(4-methoxyphenyl)-3-methylpent-4-yn-2-ol (3x)

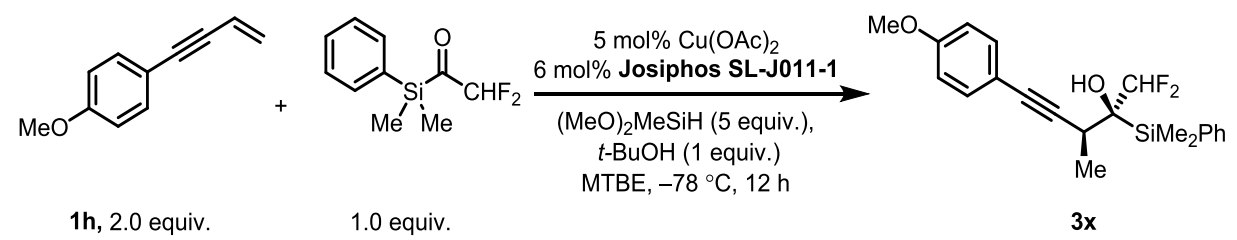

In a glovebox, to an oven-dried $10 \mathrm{~mL}$ Schlenk tube equipped with a magnetic stir bar was added $\mathrm{Cu}(\mathrm{OAc})_{2}(5 \mathrm{~mol} \%)$, Josiphos SL-J011-1 (6 mol\%), and dry MTBE (1 mL) sequentially. The mixture was stirred at room temperature for $30 \mathrm{~min}$ before the addition of DMMS (5 equiv.), $t$-BuOH ( 1 equiv.) and $\mathbf{1 h}$ ( 2 equiv.). The tube was then sealed, removed from the glove box and allowed to stir at $-78{ }^{\circ} \mathrm{C}$ for $5 \mathrm{~min}$, after which the mixture was added 1-(dimethyl(phenyl)silyl)-2,2-difluoroethan-1-one (1 equiv., $0.25 \mathrm{mmol}$ ) in $5 \mathrm{~mL} \mathrm{MTBE}$ using a syringe driven by an injection pump at a constant flow rate (within $6 \mathrm{~h}$ ). After stirring for another $6 \mathrm{~h}$, a saturated solution of $\mathrm{NH}_{4} \mathrm{~F}$ in $\mathrm{MeOH}$ (ca. $6 \mathrm{~mL}$ ) was carefully added to quench the reaction (Caution: gas evolution was observed). The reaction mixture was allowed to stir for $20 \mathrm{~min}$ at room temperature, diluted with EtOAc (ca. $10 \mathrm{~mL}$ ), stirred for an additional $10 \mathrm{~min}$ at room temperature and then filtered through a short plug of celite $(1-2 \mathrm{~cm})$ eluting with EtOAc $(\mathrm{ca} .50 \mathrm{~mL})$. The solvent was removed in vacuo with the aid of a rotary evaporator. At this point, the crude yield and 
the diastereomeric ratio (dr) were determined by ${ }^{19} \mathrm{~F}$ NMR spectroscopic analysis using $\mathrm{PhCF}_{3}$ as the internal standard. The crude product was purified with column chromatography on silica gel (300 400 mesh) to afford the title compound 3x. Colorless oil. $\mathbf{R}_{\mathbf{f}}=0.61(\mathrm{PE} / \mathrm{EA}=10 / 1) ; 84.2 \mathrm{mg}, 90 \%$ yield, $>$ 99\% ee, 96:4 dr; $[\boldsymbol{\alpha}]^{25} \mathbf{D}=-111.6\left(c=1.40, \mathrm{CHCl}_{3}\right)$; NMR spectroscopy: ${ }^{1} \mathbf{H}$ NMR (400 MHz, $\mathrm{CDCl}_{3}, 25$ $\left.{ }^{\circ} \mathrm{C}\right) 7.67(\mathrm{dd}, J=7.8,1.8 \mathrm{~Hz}, 2 \mathrm{H}), 7.44-7.34(\mathrm{~m}, 3 \mathrm{H}), 7.32-7.28(\mathrm{~m}, 2 \mathrm{H}), 6.87-6.82(\mathrm{~m}, 2 \mathrm{H}), 6.12(\mathrm{dd}$, $J=56.2,54.8 \mathrm{~Hz}, 1 \mathrm{H}), 3.82(\mathrm{~s}, 3 \mathrm{H}), 2.92(\mathrm{q}, J=7.0 \mathrm{~Hz}, 1 \mathrm{H}), 1.98(\mathrm{~s}, 1 \mathrm{H}), 1.27(\mathrm{dd}, J=7.1,2.6 \mathrm{~Hz}, 3 \mathrm{H})$, $0.60(\mathrm{~s}, 3 \mathrm{H}), 0.56(\mathrm{~s}, 3 \mathrm{H}) ;{ }^{13} \mathbf{C} \mathbf{N M R}\left(151 \mathrm{MHz}, \mathrm{CDCl}_{3}, 25^{\circ} \mathrm{C}\right) \delta 159.6,135.3,135.1,133.0,129.9,128.0$, $118.8(\mathrm{dd}, J=247.9,240.6 \mathrm{~Hz}), 115.3,114.1,88.5,84.6,71.1(\mathrm{dd}, J=25.5,18.2 \mathrm{~Hz}), 55.4,31.6,15.4$, $-3.4,-3.5 ;{ }^{19} \mathbf{F}$ NMR $\left(376 \mathrm{MHz}, \mathrm{CDCl}_{3}, 25^{\circ} \mathrm{C}\right) \delta-120.0-124.4$ (m, 2F); IR (ATR): 3567, 3194, 3071, 3963, 2907, 2542, 1670, 1580, 1510, 1461, 1290, 1107, 917, 835, $738 \mathrm{~cm}^{-1}$; HRMS (ESI, m/z): calcd for $\mathrm{C}_{21} \mathrm{H}_{25} \mathrm{~F}_{2} \mathrm{O}_{2} \mathrm{Si}^{+}(\mathrm{M}+\mathrm{H})^{+}$: 375.1586; Found: 375.1584; HPLC analysis (AD-H column, $1 \%$ $i-\mathrm{PrOH} /$ hexane, $0.50 \mathrm{~mL} / \mathrm{min}, 20{ }^{\circ} \mathrm{C}, 254 \mathrm{~nm}$ ) indicated $>99 \%$ ee: $t_{\mathrm{R}}$ (major) $=25.74 \mathrm{~min}, t_{\mathrm{R}}($ minor $)=$ $30.13 \mathrm{~min}$

\section{Racemic 3x:}

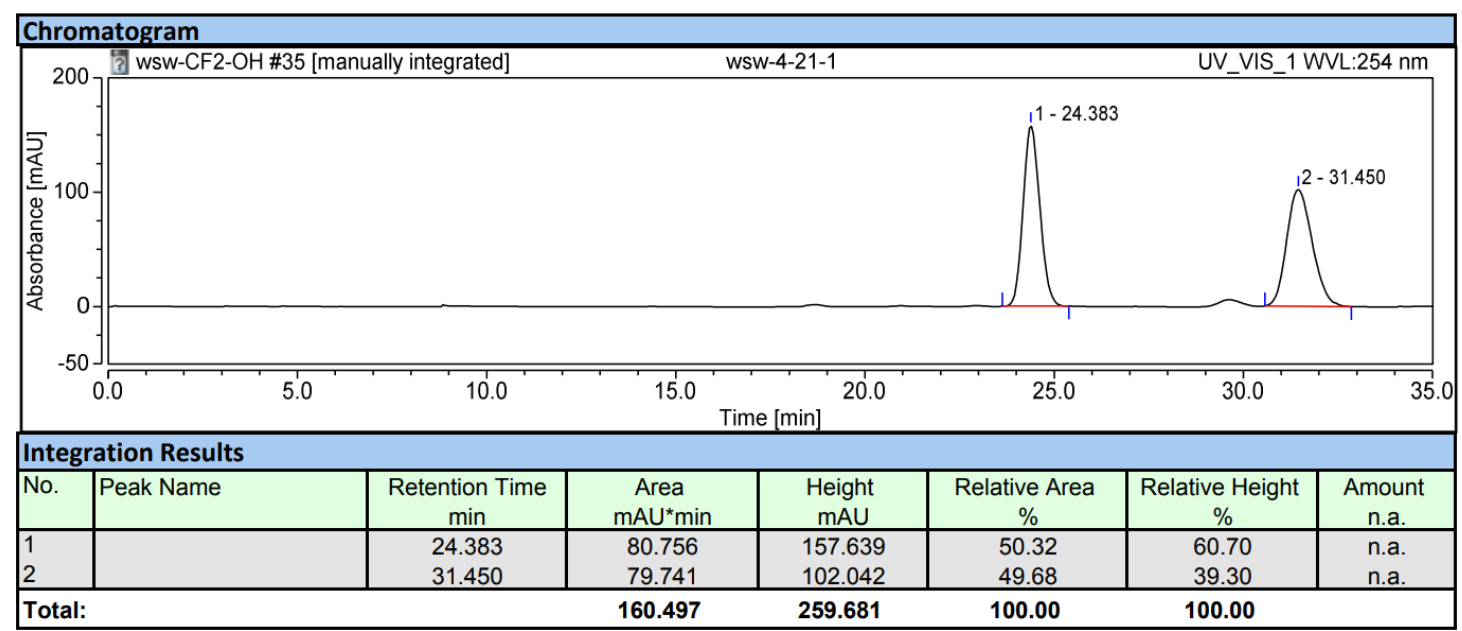

\section{Enantioenriched 3x:}

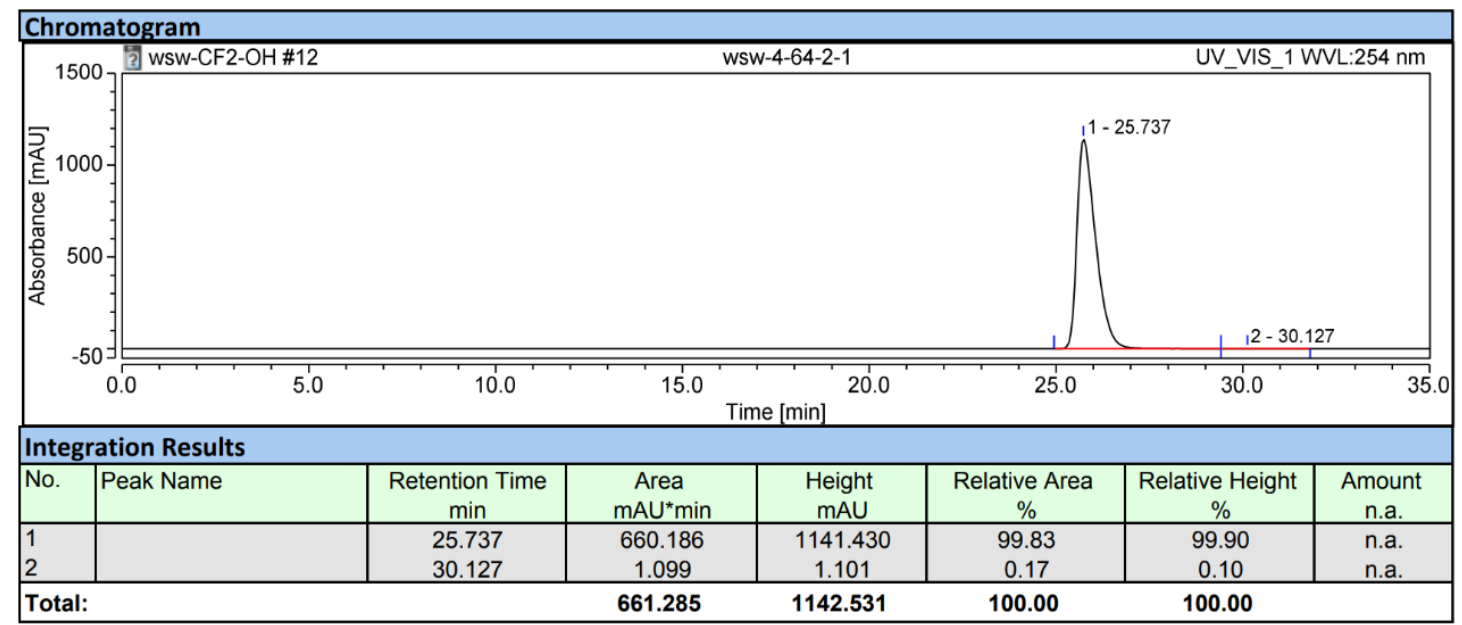


(2R,3S)-2-(dimethyl(phenyl)silyl)-1,1-difluoro-3-methyl-5-(thiophen-2-yl)pent-4-yn-2-ol (3y)

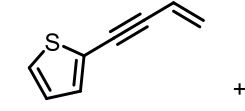

1n, 2.0 equiv.<smiles>CC(=O)[Si](C)(C)c1ccccc1</smiles>

1.0 equiv.

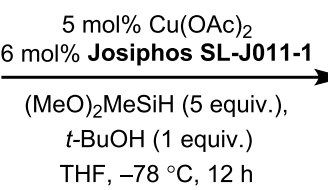

$5 \mathrm{~mol} \% \mathrm{Cu}(\mathrm{OAc})_{2}$ 6 mol\% Josiphos SL-J011-1 $t$ - $\mathrm{BuOH}$ ( 1 equiv.) $\mathrm{THF},-78^{\circ} \mathrm{C}, 12 \mathrm{~h}$

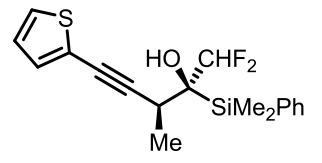

$3 y$

In a glovebox, to an oven-dried $10 \mathrm{~mL}$ Schlenk tube equipped with a magnetic stir bar was added $\mathrm{Cu}(\mathrm{OAc})_{2}$ (5 mol\%), Josiphos SL-J011-1 (6 mol\%), and dry THF ( $\left.1 \mathrm{~mL}\right)$ sequentially. The mixture was stirred at room temperature for $30 \mathrm{~min}$ before the addition of DMMS ( 5 equiv.), $t$-BuOH (1 equiv.) and 1n ( 2 equiv.). The tube was then sealed, removed from the glove box and allowed to stir at $-78^{\circ} \mathrm{C}$ for 5 min, after which the mixture was added 1-(dimethyl(phenyl)silyl)-2,2-difluoroethan-1-one (1 equiv., $0.25 \mathrm{mmol}$ ) in $5 \mathrm{~mL}$ THF using a syringe driven by an injection pump at a constant flow rate (within 6 h). After stirring for another $6 \mathrm{~h}$, then a saturated solution of $\mathrm{NH}_{4} \mathrm{~F}$ in $\mathrm{MeOH}$ (ca. $6 \mathrm{~mL}$ ) was carefully added to quench the reaction (Caution: gas evolution was observed). The reaction mixture was allowed to stir for $20 \mathrm{~min}$ at room temperature, diluted with EtOAc (ca. $10 \mathrm{~mL}$ ), stirred for an additional $10 \mathrm{~min}$ at room temperature and then filtered through a short plug of celite $(1-2 \mathrm{~cm})$ eluting with EtOAc (ca. 50 $\mathrm{mL}$ ). The solvent was removed in vacuo with the aid of a rotary evaporator. At this point, the crude yield and the diastereomeric ratio (dr) were determined by ${ }^{19} \mathrm{~F}$ NMR spectroscopic analysis using $\mathrm{PhCF}_{3}$ as the internal standard. The crude product was purified with column chromatography on silica gel (300 400 mesh) to afford the title compound 3y. Colorless oil; $\mathbf{R}_{\mathbf{f}}=0.53$ (PE/EA=10/1); $74.4 \mathrm{mg}, 85 \%$ yield, $96 \%$ ee, $95: 5 \mathrm{dr} ;[\boldsymbol{\alpha}]^{25} \mathbf{D}=-121.0\left(c=4.93, \mathrm{CHCl}_{3}\right)$ NMR spectroscopy: ${ }^{1} \mathbf{H}$ NMR $(400 \mathrm{MHz}$, $\left.\mathrm{CDCl}_{3}, 25^{\circ} \mathrm{C}\right) \delta 7.67(\mathrm{dd}, J=7.7,1.8 \mathrm{~Hz}, 2 \mathrm{H}), 7.45-7.34(\mathrm{~m}, 3 \mathrm{H}), 7.24(\mathrm{dd}, J=5.2,1.2 \mathrm{~Hz}, 1 \mathrm{H}), 7.14$ (dd, $J=3.6,1.2 \mathrm{~Hz}, 1 \mathrm{H}), 6.97(\mathrm{dd}, J=5.2,3.6 \mathrm{~Hz}, 1 \mathrm{H}), 6.08(\mathrm{dd}, J=56.2,54.7 \mathrm{~Hz}, 1 \mathrm{H}), 3.00-2.84(\mathrm{~m}$, 1H), $1.98(\mathrm{~s}, 1 \mathrm{H}), 1.27(\mathrm{dd}, J=7.2,2.7 \mathrm{~Hz}, 3 \mathrm{H}), 0.60(\mathrm{~s}, 3 \mathrm{H}), 0.57(\mathrm{~s}, 3 \mathrm{H}) ;{ }^{13} \mathbf{C} \mathbf{N M R}\left(151 \mathrm{MHz}, \mathrm{CDCl}_{3}\right.$, $\left.25^{\circ} \mathrm{C}\right) \delta 135.1,131.8,130.0128 .0,127.1,127.0,123.2,118.7$ (dd, $\left.J=247.7,241.0 \mathrm{~Hz}\right), 94.0,78.0,71.1$ $(\mathrm{dd}, J=25.5,18.5 \mathrm{~Hz}), 32.0,15.1,-3.4,-3.6 ;{ }^{19} \mathbf{F} \mathbf{~ N M R}\left(376 \mathrm{MHz}, \mathrm{CDCl}_{3,}, 2{ }^{\circ} \mathrm{C}\right) \delta-120.0-124.4(\mathrm{~m}$, 2F); IR (ATR): 3563, 3336, 3213, 3161, 3071, 2982, 1730, 1588, 1429, 1252, 1141, 910, 835, 738.0, $701 \mathrm{~cm}^{-1}$; HRMS (ESI, m/z): calcd for $\mathrm{C}_{18} \mathrm{H}_{21} \mathrm{~F}_{2} \mathrm{OSSi}^{+}(\mathrm{M}+\mathrm{H})^{+}: 351.1045$; Found: 351.1042; HPLC analysis (AD-H column, $1 \% i-\mathrm{PrOH} / \mathrm{hexane}, 0.50 \mathrm{~mL} / \mathrm{min}, 20^{\circ} \mathrm{C}, 254 \mathrm{~nm}$ ) indicated $96 \%$ ee: $t_{\mathrm{R}}$ (major) $=16.05 \mathrm{~min}, t_{\mathrm{R}}($ minor $)=18.58 \mathrm{~min}$.

\section{Racemic 3y:}

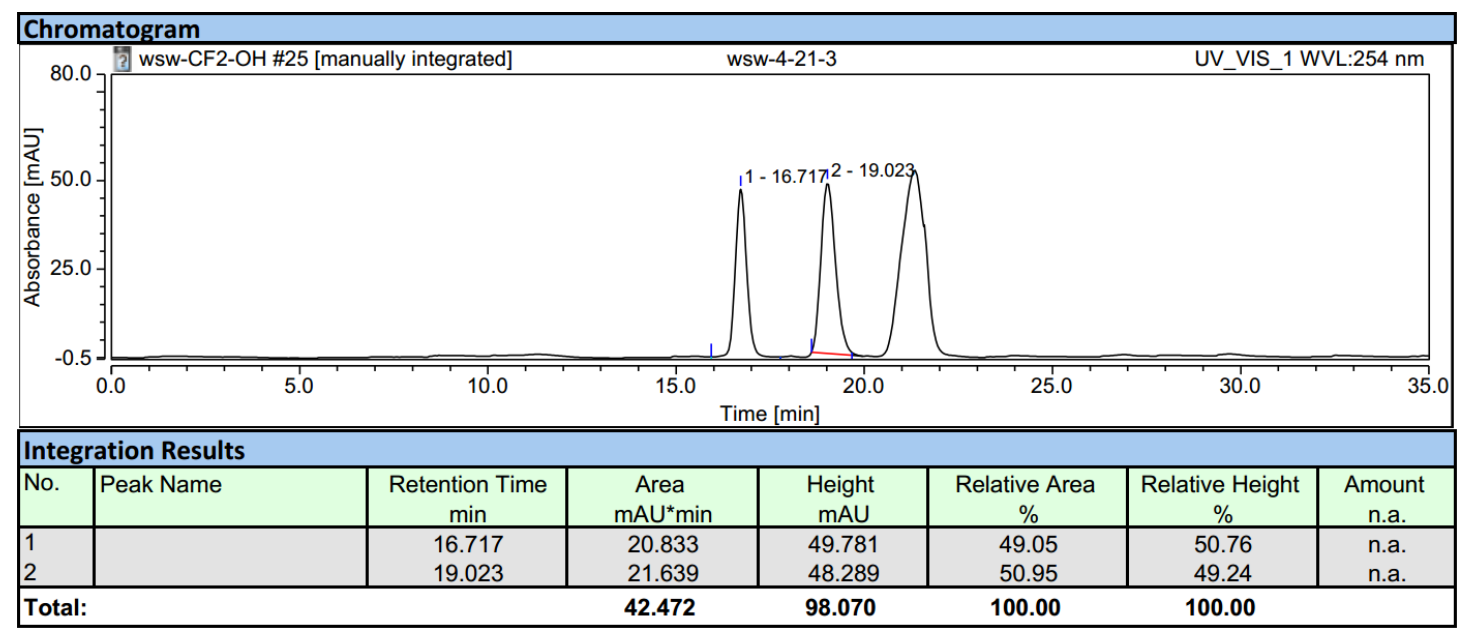


Enantioenriched 3y:

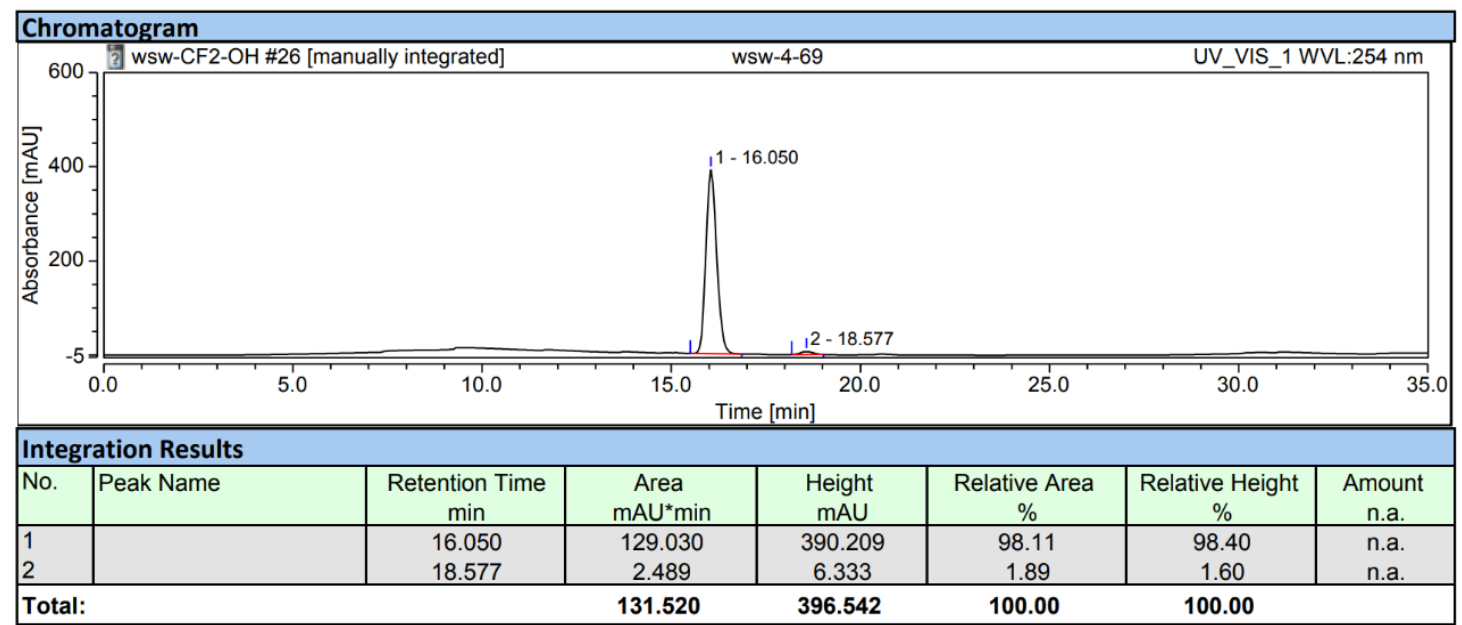

(2R,3S)-2-(dimethyl(phenyl)silyl)-1,1-difluoro-3-methyl-5-(thiophen-3-yl)pent-4-yn-2-ol (3z)

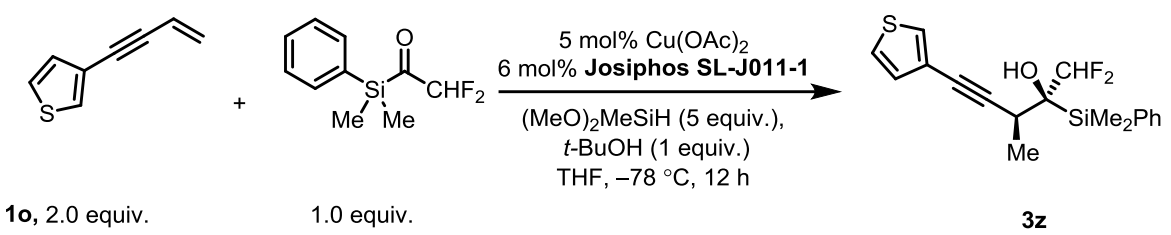

In a glovebox, to an oven-dried $10 \mathrm{~mL}$ Schlenk tube equipped with a magnetic stir bar was added $\mathrm{Cu}(\mathrm{OAc})_{2}$ (5 mol\%), Josiphos SL-J011-1 (6 mol\%), and dry THF ( $\left.1 \mathrm{~mL}\right)$ sequentially. The mixture was stirred at room temperature for $30 \mathrm{~min}$ before the addition of DMMS (5 equiv.), $t$-BuOH (1 equiv.) and 10 (2 equiv.). The tube was then sealed, removed from the glove box and allowed to stir at $-78{ }^{\circ} \mathrm{C}$ for 5 min, after which the mixture was added 1-(dimethyl(phenyl)silyl)-2,2-difluoroethan-1-one (1 equiv., $0.25 \mathrm{mmol}$ ) in $5 \mathrm{~mL}$ THF using a syringe driven by an injection pump at a constant flow rate (within 6 h). After stirring for another $6 \mathrm{~h}$, a saturated solution of $\mathrm{NH}_{4} \mathrm{~F}$ in $\mathrm{MeOH}$ (ca. $6 \mathrm{~mL}$ ) was carefully added to quench the reaction (Caution: gas evolution was observed). The reaction mixture was allowed to stir for $20 \mathrm{~min}$ at room temperature, diluted with EtOAc (ca. $10 \mathrm{~mL}$ ), stirred for an additional $10 \mathrm{~min}$ at room temperature and then filtered through a short plug of celite $(1-2 \mathrm{~cm})$ eluting with EtOAc $(\mathrm{ca} .50 \mathrm{~mL})$. The solvent was removed in vacuo with the aid of a rotary evaporator. At this point, the crude yield and the diastereomeric ratio (dr) were determined by ${ }^{19} \mathrm{~F}$ NMR spectroscopic analysis using $\mathrm{PhCF}_{3}$ as the internal standard. The crude product was purified with column chromatography on silica gel (300 400 mesh) to afford the title compound $\mathbf{3 z}$; Colorless oil; $\mathbf{R}_{\mathbf{f}}=0.53$ (PE/EA = 10/1); $55.1 \mathrm{mg}, 63 \%$ yield, $92 \%$ ee, $95: 5 \mathrm{dr} ;[\boldsymbol{\alpha}]^{25} \mathbf{D}=-114.1\left(c=2.53, \mathrm{CHCl}_{3}\right)$; NMR spectroscopy: ${ }^{1} \mathbf{H} \mathbf{~ N M R}\left(400 \mathrm{MHz}, \mathrm{CDCl}_{3}, 2{ }^{\circ} \mathrm{C}\right)$ $\delta 7.66(\mathrm{dd}, J=7.8,1.8 \mathrm{~Hz}, 2 \mathrm{H}), 7.44-7.33(\mathrm{~m}, 4 \mathrm{H}), 7.28-7.26(\mathrm{~m}, 1 \mathrm{H}), 7.05(\mathrm{dd}, J=5.0,1.2 \mathrm{~Hz}, 1 \mathrm{H})$, $6.10(\mathrm{dd}, J=56.2,54.7 \mathrm{~Hz}, 1 \mathrm{H}), 2.92(\mathrm{q}, J=7.2 \mathrm{~Hz}, 1 \mathrm{H}), 1.98(\mathrm{~s}, 1 \mathrm{H}), 1.27$ (dd, $J=7.2,2.7 \mathrm{~Hz}, 3 \mathrm{H})$, 0.60 (s, 3H), 0.56 (s, 3H); ${ }^{13} \mathbf{C}$ NMR $\left(151 \mathrm{MHz}, \mathrm{CDCl}_{3}, 25^{\circ} \mathrm{C}\right) 135.2,135.1,129.9,129.9,128.5,128.0$, $125.5,122.2,118.8(\mathrm{dd}, J=247.9,240.9 \mathrm{~Hz}), 89.5,79.9,71.1(\mathrm{dd}, J=25.4,18.4 \mathrm{~Hz}), 31.6,15.3,-3.4$, $-3.5 ;{ }^{19} \mathbf{F}$ NMR ( $376 \mathrm{MHz}, \mathrm{CDCl}_{3}, 25^{\circ} \mathrm{C}$ ) $\delta-120.0-124.4$ (m, 2F); IR (ATR): 3667, 3556, 3326, 3455, 3109, 2987, 1771, 1607, 1510, 1252, 1111, 910, 839, 783, $738 \mathrm{~cm}^{-1}$; HRMS (ESI, m/z): calcd for $\mathrm{C}_{18} \mathrm{H}_{21} \mathrm{~F}_{2} \mathrm{OSSi}^{+}(\mathrm{M}+\mathrm{H})^{+}:$351.1045; Found: 351.1043; HPLC analysis (AD-H column, $1 \%$ $i-\mathrm{PrOH} /$ hexane, $\left.0.50 \mathrm{~mL} / \mathrm{min}, 20^{\circ} \mathrm{C}, 254 \mathrm{~nm}\right)$ indicated $92 \%$ ee: $t_{\mathrm{R}}($ major $)=15.60 \mathrm{~min}, t_{\mathrm{R}}($ minor $)=$ $19.60 \mathrm{~min}$. 
Racemic 3z:

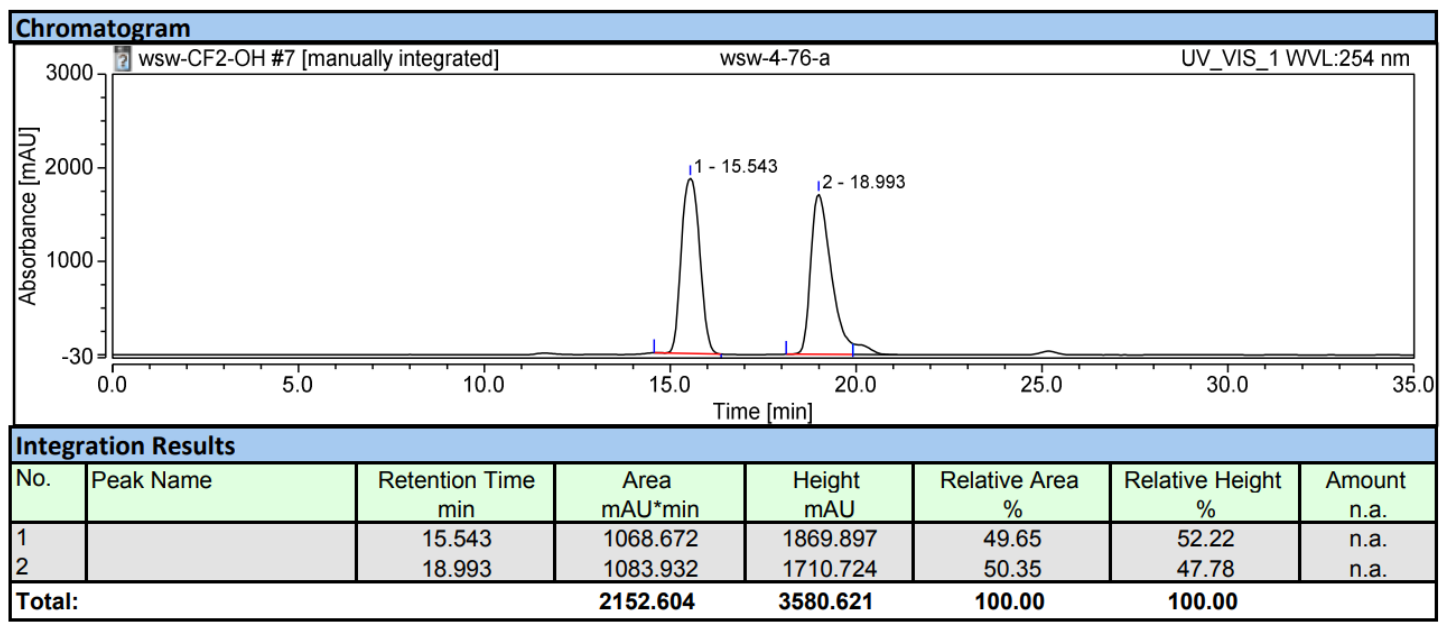

\section{Enantioenriched 3z:}

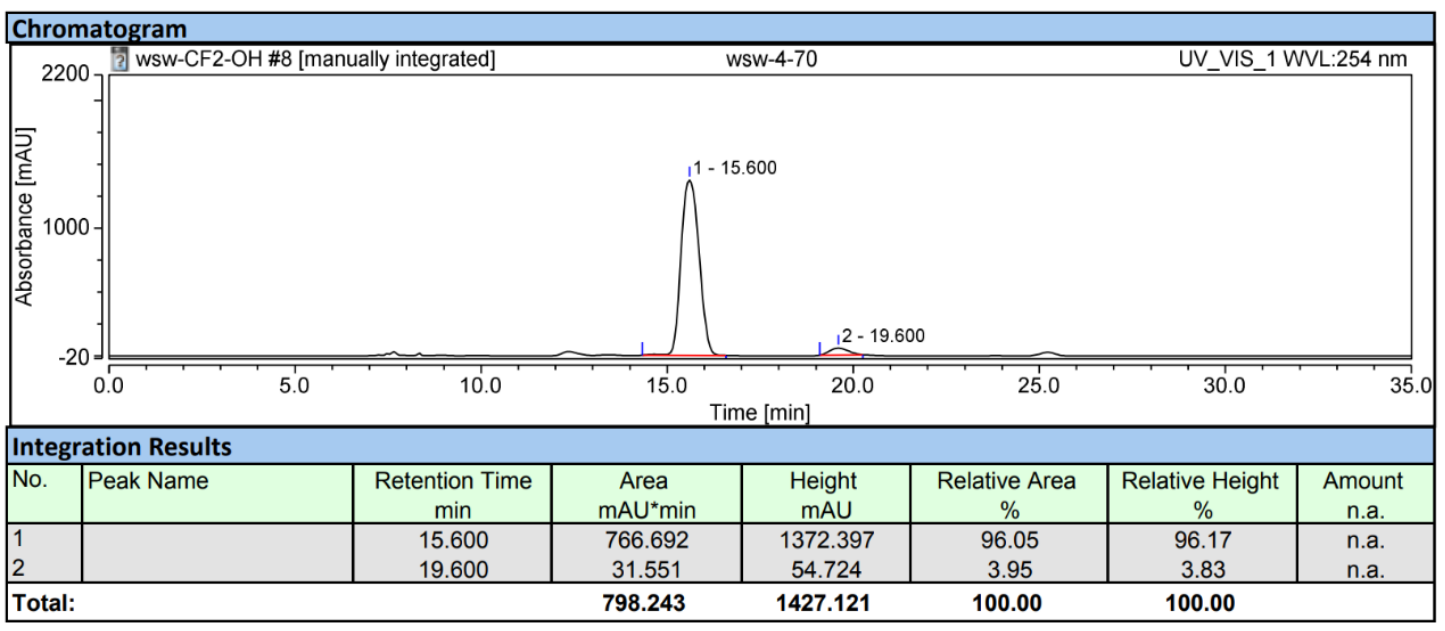

(2R,3S)-2-(dimethyl(phenyl)silyl)-1,1-difluoro-3-methyl-5-(pyridin-3-yl)pent-4-yn-2-ol (3aa)

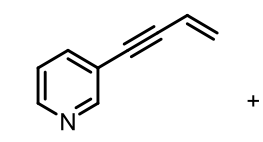

1p, 2.0 equiv.<smiles>C[Si](C)(C(=O)CF)c1ccccc1</smiles>

$5 \mathrm{~mol} \% \mathrm{Cu}(\mathrm{OAc})_{2}$ $6 \mathrm{~mol} \%$ Josiphos SL-J011-1 $(\mathrm{MeO})_{2} \mathrm{MeSiH}$ (5 equiv.), $t$-BuOH (1 equiv.) MTBE, $-78^{\circ} \mathrm{C}, 12 \mathrm{~h}$

In a glovebox, to an oven-dried $10 \mathrm{~mL}$ Schlenk tube equipped with a magnetic stir bar was added $\mathrm{Cu}(\mathrm{OAc})_{2}$ (5 mol\%), Josiphos SL-J011-1 (6 mol\%), and dry MTBE (1 mL) sequentially. The mixture was stirred at room temperature for $30 \mathrm{~min}$ before the addition of DMMS (5 equiv.), $t$ - $\mathrm{BuOH}$ ( 1 equiv.) and $1 p$ ( 2 equiv.). The tube was then sealed, removed from the glove box and allowed to stir at $-78{ }^{\circ} \mathrm{C}$ for $5 \mathrm{~min}$, after which the mixture was added 1-(dimethyl(phenyl)silyl)-2,2-difluoroethan-1-one (1 equiv., $0.25 \mathrm{mmol}$ ) in $5 \mathrm{~mL}$ MTBE using a syringe driven by an injection pump at a constant flow rate (within $6 \mathrm{~h}$ ).. After stirring for another $6 \mathrm{~h}$, a saturated solution of $\mathrm{NH}_{4} \mathrm{~F}$ in $\mathrm{MeOH}$ (ca. $6 \mathrm{~mL}$ ) was carefully added to quench the reaction (Caution: gas evolution was observed). The reaction mixture was allowed to stir for $20 \mathrm{~min}$ at room temperature, diluted with EtOAc (ca. $10 \mathrm{~mL}$ ), stirred for an additional $10 \mathrm{~min}$ at room temperature and then filtered through a short plug of celite $(1-2 \mathrm{~cm})$ eluting with EtOAc $(\mathrm{ca} .50 \mathrm{~mL})$. 
The solvent was removed in vacuo with the aid of a rotary evaporator. At this point, the crude yield and the diastereomeric ratio ( $\mathrm{dr}$ ) were determined by ${ }^{19} \mathrm{~F}$ NMR spectroscopic analysis using $\mathrm{PhCF}_{3}$ as the internal standard. The crude product was purified with column chromatography on silica gel (300 400 mesh) to afford the title compound 3aa. Yellow solid; mp: 70.0-71.0 ${ }^{\circ} \mathrm{C} ; \mathbf{R}_{\mathbf{f}}=0.2(\mathrm{PE} / \mathrm{EA}=10 / 1) ; 40.5$ mg, 47\% yield, 99\% ee, 96:4 dr; $[\boldsymbol{\alpha}]^{25} \mathbf{D}=-57.3\left(c=2.03, \mathrm{CHCl}_{3}\right)$; NMR spectroscopy: ${ }^{1} \mathbf{H}$ NMR (400 $\left.\mathrm{MHz}, \mathrm{CDCl}_{3}, 25{ }^{\circ} \mathrm{C}\right) \delta 8.60-8.49(\mathrm{~m}, 2 \mathrm{H}), 7.69-7.58(\mathrm{~m}, 3 \mathrm{H}), 7.44-7.33(\mathrm{~m}, 3 \mathrm{H}), 7.25-7.22(\mathrm{~m}, 1 \mathrm{H})$, $6.07(\mathrm{dd}, J=56.3,54.8 \mathrm{~Hz}, 1 \mathrm{H}), 2.98$ (q, $J=7.2 \mathrm{~Hz}, 1 \mathrm{H}), 2.02(\mathrm{~s}, 1 \mathrm{H}), 1.31(\mathrm{dd}, J=7.1,2.4 \mathrm{~Hz}, 3 \mathrm{H})$, 0.59 (s, 3H), 0.56 (s, 3H); $\left.{ }^{13} \mathbf{C ~ N M R ~ ( 1 5 1 ~ M H z , ~} \mathrm{CDCl}_{3}, 25^{\circ} \mathrm{C}\right) \delta 152.3,148.7,138.6,135.0,130.0,128.1$, 123.1, 118.7 (dd, $J=247.6,241.6 \mathrm{~Hz}), 93.7,81.3,70.9$ (dd, $J=25.6,19.4 \mathrm{~Hz}), 31.6,15.2,-3.5,-3.5$; ${ }^{19}$ F NMR (376 MHz, $\left.\mathrm{CDCl}_{3,}, 25^{\circ} \mathrm{C}\right) \delta-120.1-124.3$ (m, 2F); IR (ATR): 3910, 3593, 3280, 2982, 2907 , 2837, 2106, 1730, 1588, 1379, 1183, 913, 824, 738, $705 \mathrm{~cm}^{-1}$; HRMS (ESI, m/z): calcd for $\mathrm{C}_{19} \mathrm{H}_{22} \mathrm{~F}_{2} \mathrm{NOSi}^{+}(\mathrm{M}+\mathrm{H})^{+}:$346.1433; Found: 346.1429; HPLC analysis (IA column, $3 \% i-\mathrm{PrOH} /$ hexane, $0.80 \mathrm{~mL} / \mathrm{min}, 20{ }^{\circ} \mathrm{C}, 230 \mathrm{~nm}$ ) indicated $>99 \%$ ee: $t_{\mathrm{R}}$ (major) $=29.50 \mathrm{~min}$.

\section{Racemic 3aa:}

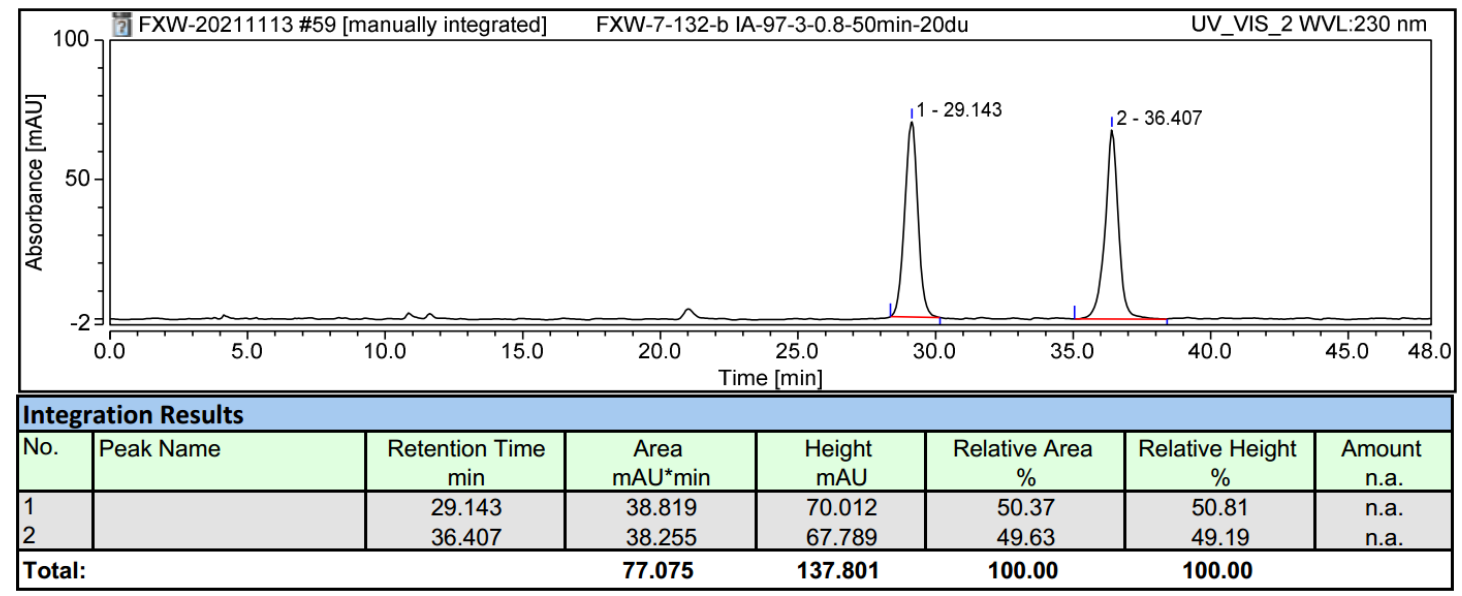

\section{Enantioenriched 3aa:}

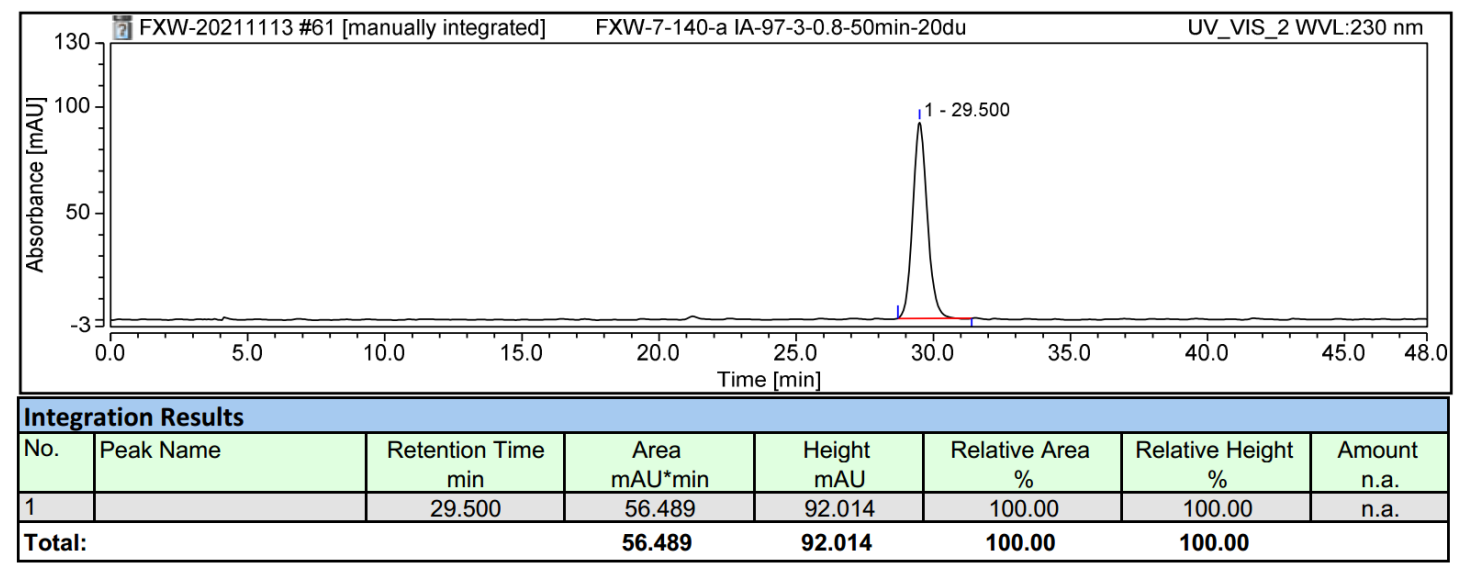


5 Synthesis of $\alpha$-monofluoromethyl Alcohols

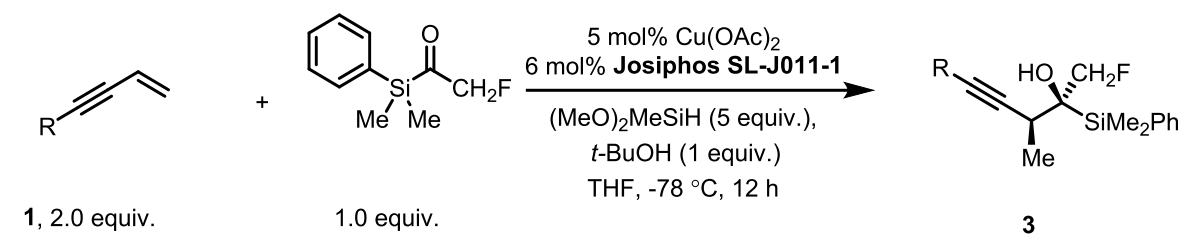

In a glovebox, to an oven-dried $10 \mathrm{~mL}$ Schlenk tube equipped with a magnetic stir bar was added $\mathrm{Cu}(\mathrm{OAc})_{2}(2.3 \mathrm{mg}, 0.0125 \mathrm{mmol}, 5 \mathrm{~mol} \%)$, Josiphos SL-J011-1 (10.2 mg, $\left.0.015 \mathrm{mml}, 6 \mathrm{~mol} \%\right)$, and dry THF $(1 \mathrm{~mL})$ sequentially. The mixture was stirred at room temperature for $30 \mathrm{~min}$ before the addition of DMMS (153.5 $\mu \mathrm{L}, 1.25$ mmol, 5 equiv.), $t$ - $\mathrm{BuOH}$ ( $24 \mu \mathrm{L}, 0.25$ mmol, 1 equiv.) and 1 (2 equiv.). The tube was then sealed, removed from the glove box and allowed to stir at $-78{ }^{\circ} \mathrm{C}$ for $5 \mathrm{~min}$, after which the mixture was added 1-(dimethyl(phenyl)silyl)-2-fluoroethanone ( $49 \mathrm{mg}, 0.25 \mathrm{mmol}, 1$ equiv.) in $5 \mathrm{~mL}$ THF using a syringe driven by an injection pump at a constant flow rate (within $6 \mathrm{~h}$ ). After stirring for another $6 \mathrm{~h}$, a saturated solution of $\mathrm{NH}_{4} \mathrm{~F}$ in $\mathrm{MeOH}$ (ca. $6 \mathrm{~mL}$ ) was carefully added to quench the reaction (Caution: gas evolution was observed). The reaction mixture was allowed to stir for $20 \mathrm{~min}$ at room temperature, diluted with EtOAc (ca. $10 \mathrm{~mL}$ ), stirred for an additional $10 \mathrm{~min}$ at room temperature and then filtered through a short plug of celite $(1-2 \mathrm{~cm})$ eluting with EtOAc (ca. $50 \mathrm{~mL})$. The solvent was removed in vacuo with the aid of a rotary evaporator. At this point, the crude yield and the diastereomeric ratio (dr) were determined by ${ }^{19} \mathrm{~F}$ NMR spectroscopic analysis using $\mathrm{PhCF}_{3}$ as the internal standard. The crude product was purified fast with column chromatography on silica gel (200 300 mesh) to afford the title compound 3 .

\section{(2R, 3S)-2-(Dimethyl(phenyl)silyl)-1-fluoro-3-methyl-5-phenylpent-4-yn-2-ol (3ab)}

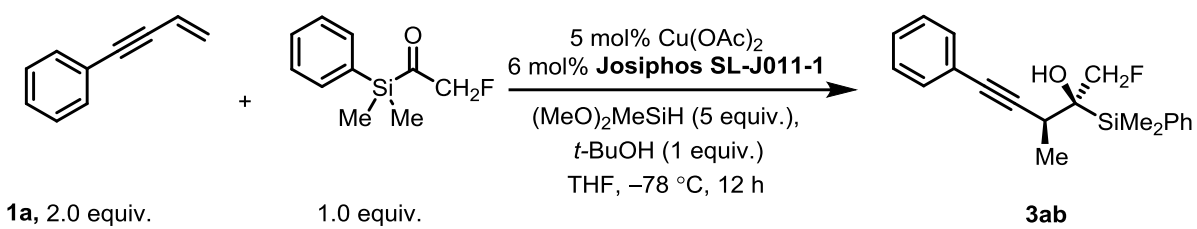

In a glovebox, to an oven-dried $10 \mathrm{~mL}$ Schlenk tube equipped with a magnetic stir bar was added $\mathrm{Cu}(\mathrm{OAc})_{2}(5 \mathrm{~mol} \%)$, Josiphos SL-J011-1 (6 mol\%), and dry THF $(1 \mathrm{~mL})$ sequentially. The mixture was stirred at room temperature for $30 \mathrm{~min}$ before the addition of DMMS (5 equiv.), $t$-BuOH (1 equiv.) and 1a (2 equiv.). The tube was then sealed, removed from the glove box and allowed to stir at $-78{ }^{\circ} \mathrm{C}$ for 5 min, after which the mixture was added 1-(dimethyl(phenyl)silyl)-2,2,2-trifluoroethanone (1 equiv., 0.25 $\mathrm{mmol}$ ) in $5 \mathrm{~mL}$ THF using a syringe driven by an injection pump at a constant flow rate (within $6 \mathrm{~h}$ ). After stirring for another $6 \mathrm{~h}$, a saturated solution of $\mathrm{NH}_{4} \mathrm{~F}$ in $\mathrm{MeOH}$ (ca. $6 \mathrm{~mL}$ ) was carefully added to quench the reaction (Caution: gas evolution was observed). The reaction mixture was allowed to stir for $20 \mathrm{~min}$ at room temperature, diluted with EtOAc (ca. $10 \mathrm{~mL}$ ), stirred for an additional $10 \mathrm{~min}$ at room temperature and then filtered through a short plug of celite $(1-2 \mathrm{~cm})$ eluting with EtOAc (ca. $50 \mathrm{~mL})$. The solvent was removed in vacuo with the aid of a rotary evaporator. At this point, the crude yield and the diastereomeric ratio (dr) were determined by ${ }^{19} \mathrm{~F}$ NMR spectroscopic analysis using $\mathrm{PhCF}_{3}$ as the internal standard. The crude product was purified fast with column chromatography on silica gel (200 300 mesh) to afford the title compound 3ab; Colorless oil; $\mathbf{R}_{\mathbf{f}}=0.44$ (PE/EA=20/1); $70.1 \mathrm{mg}, 86 \%$ yield, $>99 \%$ ee, $98: 2 \mathrm{dr} ;[\boldsymbol{\alpha}]^{25} \mathbf{D}=-64.1\left(c=3.50, \mathrm{CHCl}_{3}\right)$; NMR spectroscopy: ${ }^{1} \mathbf{H}$ NMR $(400 \mathrm{MHz}$, $\left.\mathrm{CDCl}_{3}, 25^{\circ} \mathrm{C}\right) \delta 7.66(\mathrm{dd}, J=7.6,1.9 \mathrm{~Hz}, 2 \mathrm{H}), 7.40-7.33(\mathrm{~m}, 5 \mathrm{H}), 7.31$ (q, $\left.J=3.7 \mathrm{~Hz}, 3 \mathrm{H}\right), 4.96-4.52$ 
$(\mathrm{m}, 2 \mathrm{H}), 2.96(\mathrm{qd}, J=7.2,2.4 \mathrm{~Hz}, 1 \mathrm{H}), 1.92(\mathrm{~s}, 1 \mathrm{H}), 1.27(\mathrm{dd}, J=7.2,0.7 \mathrm{~Hz}, 3 \mathrm{H}), 0.55(\mathrm{~s}, 3 \mathrm{H}), 0.54(\mathrm{~s}$, $3 \mathrm{H}) ;{ }^{13} \mathrm{C}$ NMR $\left(101 \mathrm{MHz}, \mathrm{CDCl}_{3}, 25{ }^{\circ} \mathrm{C}\right) 135.9,135.0,131.7,131.7,129.7,128.5,128.2,128.0,90.8$, $88.5(\mathrm{~d}, J=167.0 \mathrm{~Hz}), 84.2,70.5(\mathrm{~d}, J=22.3 \mathrm{~Hz}), 32.3,15.5,-3.5,-3.8 ;{ }^{19} \mathbf{F ~ N M R}\left(376 \mathrm{MHz}, \mathrm{CDCl}_{3}\right.$, $\left.25^{\circ} \mathrm{C}\right) \delta-227.1(\mathrm{t}, J=48.4 \mathrm{~Hz}, 1 \mathrm{~F})$; IR (ATR): 3597, 3407, 3273, 3071, 2926, 2240, 1670, 1651, 1491, 1375, 1252, 1111, 895, 705, $667 \mathrm{~cm}^{-1}$; HRMS (ESI, m/z): calcd for $\mathrm{C}_{20} \mathrm{H}_{24} \mathrm{FOSi}^{+}(\mathrm{M}+\mathrm{H})^{+}: 327.1575$; Found: 327.1577 ; HPLC analysis (AS-H column, $0.8 \% i-\mathrm{PrOH} / \mathrm{hexane}, 0.50 \mathrm{~mL} / \mathrm{min}, 12{ }^{\circ} \mathrm{C}, 254 \mathrm{~nm}$ ) indicated $>99 \%$ ee: $t_{\mathrm{R}}$ (major) $=16.62 \mathrm{~min}$.

\section{Racemic 3ab:}

\begin{tabular}{|l|l|c|c|c|c|c|c|}
\hline & \multicolumn{1}{|c|}{ UV_VIS_1 WVL:254 nm } \\
\hline
\end{tabular}

\section{Enantioenriched 3ab:}

\begin{tabular}{|l|l|l|l|l|l|l|}
\hline & \\
\hline
\end{tabular}

(2R, 3S)-2-(Dimethyl(phenyl)silyl)-1-fluoro-3-methyl-5-(thiophen-2-yl)pent-4-yn-2-ol (3ac)

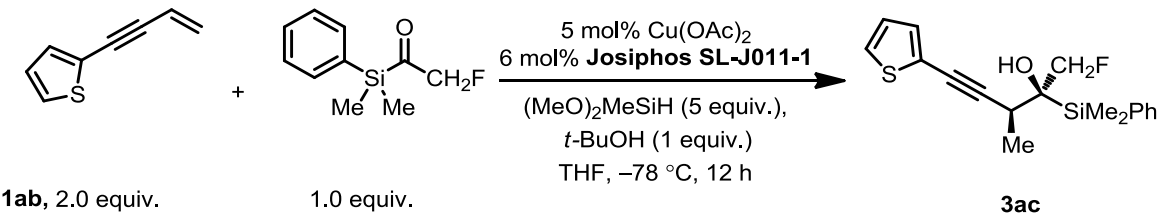

In a glovebox, to an oven-dried $10 \mathrm{~mL}$ Schlenk tube equipped with a magnetic stir bar was added $\mathrm{Cu}(\mathrm{OAc})_{2}$ (5 mol\%), Josiphos SL-J011-1 (6 mol\%), and dry THF (1 mL) sequentially. The mixture was stirred at room temperature for $30 \mathrm{~min}$ before the addition of DMMS ( 5 equiv.), $t$-BuOH ( 1 equiv.) and 1n ( 2 equiv.). The tube was then sealed, removed from the glove box and allowed to stir at $-78^{\circ} \mathrm{C}$ for 5 min, after which the mixture was added 1-(dimethyl(phenyl)silyl)-2,2,2-trifluoroethanone (1 equiv., 0.25 mmol) in $5 \mathrm{~mL}$ THF using a syringe driven by an injection pump at a constant flow rate (within $6 \mathrm{~h}$ ). After stirring for another $6 \mathrm{~h}$, a saturated solution of $\mathrm{NH}_{4} \mathrm{~F}$ in $\mathrm{MeOH}$ (ca. $6 \mathrm{~mL}$ ) was carefully added to 
quench the reaction (Caution: gas evolution was observed). The reaction mixture was allowed to stir for $20 \mathrm{~min}$ at room temperature, diluted with EtOAc (ca. $10 \mathrm{~mL}$ ), stirred for an additional $10 \mathrm{~min}$ at room temperature and then filtered through a short plug of celite $(1-2 \mathrm{~cm})$ eluting with EtOAc $(\mathrm{ca} .50 \mathrm{~mL})$. The solvent was removed in vacuo with the aid of a rotary evaporator. At this point, the crude yield and the diastereomeric ratio $(\mathrm{dr})$ were determined by ${ }^{19} \mathrm{~F}$ NMR spectroscopic analysis using $\mathrm{PhCF}_{3}$ as the internal standard. The crude product was purified fast with column chromatography on silica gel (200 300 mesh) to afford the title compound 4ac; Colorless oil. $\mathbf{R}_{\mathbf{f}}=0.35$ (PE/EA=20/1); $67.2 \mathrm{mg}, 81 \%$ yield, $>99 \%$ ee, $>99: 1 \mathrm{dr} ;[\boldsymbol{\alpha}]^{25} \mathbf{D}=-54.1\left(c=0.75, \mathrm{CHCl}_{3}\right)$; NMR spectroscopy: ${ }^{1} \mathbf{H} \mathbf{N M R}(600 \mathrm{MHz}$, $\left.\mathrm{CDCl}_{3}, 25^{\circ} \mathrm{C}\right) 7.67-7.63(\mathrm{~m}, 2 \mathrm{H}), 7.42-7.34(\mathrm{~m}, 3 \mathrm{H}), 7.22(\mathrm{dd}, J=5.2,1.2 \mathrm{~Hz}, 1 \mathrm{H}), 7.12(\mathrm{dd}, J=3.6$, $1.2 \mathrm{~Hz}, 1 \mathrm{H}), 6.96(\mathrm{dd}, J=5.2,3.6 \mathrm{~Hz}, 1 \mathrm{H}), 4.86-4.60(\mathrm{~m}, 2 \mathrm{H}), 2.95(\mathrm{qd}, J=7.1,2.3 \mathrm{~Hz}, 1 \mathrm{H}), 1.95(\mathrm{~s}$, $1 \mathrm{H}), 1.25(\mathrm{~d}, J=7.9 \mathrm{~Hz}, 3 \mathrm{H}), 0.55(\mathrm{~s}, 3 \mathrm{H}), 0.53(\mathrm{~s}, 3 \mathrm{H}) ;{ }^{13} \mathbf{C ~ N M R}\left(151 \mathrm{MHz}, \mathrm{CDCl}_{3}, 25{ }^{\circ} \mathrm{C}\right) \delta 135.8$, 135.0, 131.6, 129.7, 128.0, 127.0, 126.7, 123.4, 94.9, 88.5 (d, $J=167.4 \mathrm{~Hz}), 70.6$ (d, $J=22.3 \mathrm{~Hz}), 32.5$, 15.3, -3.5, -3.8; ${ }^{19} \mathbf{F}$ NMR $\left(376 \mathrm{MHz}, \mathrm{CDCl}_{3}, 25{ }^{\circ} \mathrm{C}\right) \delta-227.2(\mathrm{t}, J=48.3 \mathrm{~Hz}, 1 \mathrm{~F})$; IR (ATR): 3876 , 3756, 3612, 3355, 3068, 2956, 1726, 1506, 1457, 1379, 1111, 939, 887, 816, 701 $\mathrm{cm}^{-1}$; HRMS (ESI, m/z): calcd for $\mathrm{C}_{18} \mathrm{H}_{22} \mathrm{FOSSi}^{+}(\mathrm{M}+\mathrm{H})^{+}: 333.1139$; Found: 333.1137; HPLC analysis (OD-H column, $0.7 \%$ $i-\mathrm{PrOH} /$ hexane, $0.60 \mathrm{~mL} / \mathrm{min}, 12{ }^{\circ} \mathrm{C}, 254 \mathrm{~nm}$ ) indicated $>99 \%$ ee: $t_{\mathrm{R}}$ (major) $=17.97 \mathrm{~min}$.

\section{Racemic 3ac:}

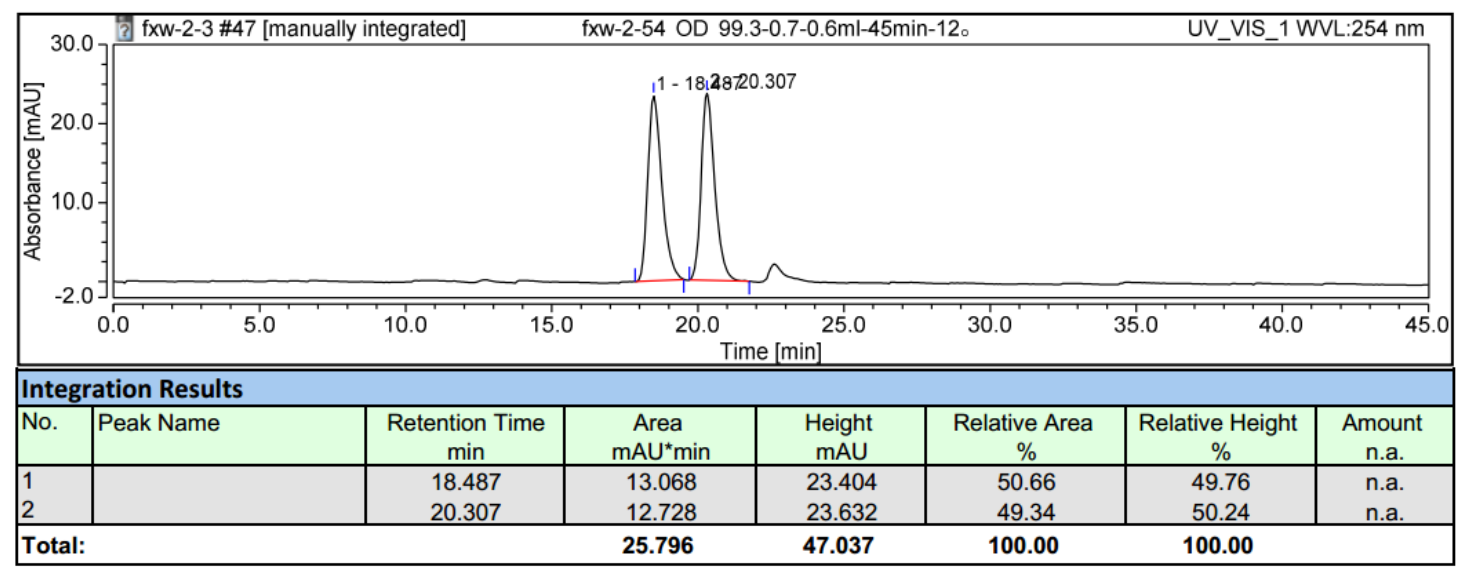

Enantioenriched 3ac:

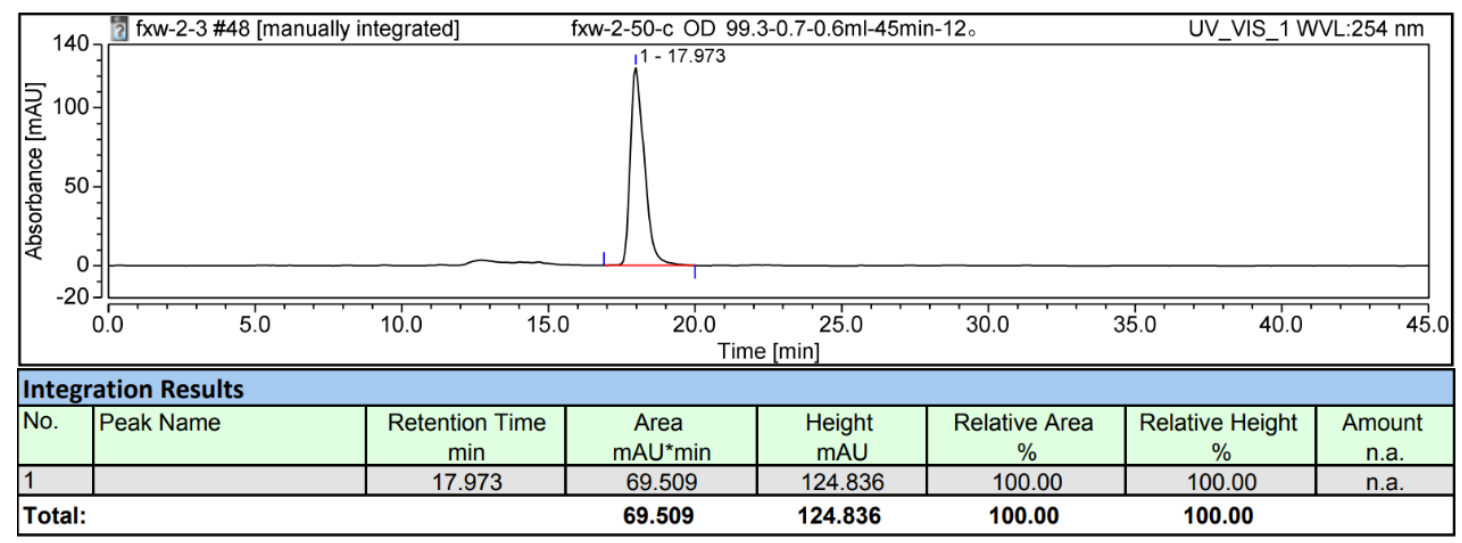


6 Synthesis of difiuoro enol silyl ethers

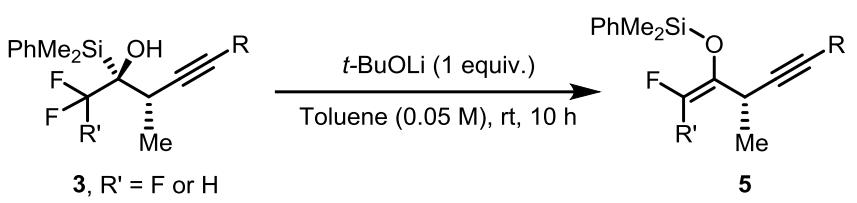

In a glovebox, to an oven-dried $5 \mathrm{~mL}$ screw-cap reaction tube equipped with a magnetic stir bar was added $3(0.1 \mathrm{mmol}), t$-BuOLi ( $8 \mathrm{mg}, 0.1 \mathrm{mmol}, 1$ equiv.), and dry toluene $(2 \mathrm{~mL})$ sequentially. The mixture was stirred at room temperature for $5 \mathrm{~min}$. The tube was then sealed, removed from the glove box and allowed to stir at room temperature for $10 \mathrm{~h}$. And then filtered through a short plug of silica gel (100 200 mesh) eluting with hexane (ca. $10 \mathrm{~mL}$ ). The solvent was removed in vacuo with the aid of a rotary evaporator to afford the title compound $\mathbf{5}$.

(S)-((1,1-difluoro-3-methyl-5-phenylpent-1-en-4-yn-2-yl)oxy)dimethyl(phenyl)silane (5a)

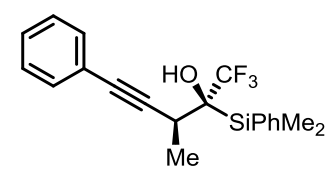

$3 a$

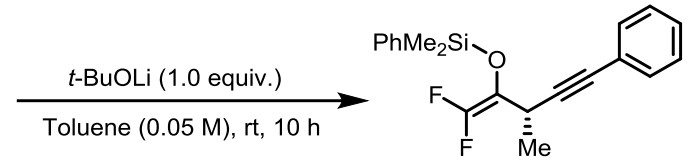

$5 \mathbf{a}$

In a glovebox, to an oven-dried $5 \mathrm{~mL}$ screw-cap reaction tube equipped with a magnetic stir bar was added 3a $(0.1 \mathrm{mmol}), t$-BuOLi (1 equiv., $0.1 \mathrm{mmol})$, and dry toluene $(2 \mathrm{~mL})$ sequentially. The mixture was stirred at room temperature for $5 \mathrm{~min}$. The tube was then sealed, removed from the glove box and allowed to stir at room temperature for $10 \mathrm{~h}$. And then filtered through a short plug of silica gel (100 200 mesh) eluting with hexane (ca. $10 \mathrm{~mL}$ ). The solvent was removed in vacuo with the aid of a rotary evaporator to afford the title compound 5a. Colorless oil; $\mathbf{R}_{\mathbf{f}}=0.79$ (PE/EA $\left.=10 / 1\right) ; 33.9 \mathrm{mg}, 99 \%$ yield, $>$ $99 \%$ ee; $[\boldsymbol{\alpha}]^{25} \mathbf{D}=-23.2\left(c=4.28, \mathrm{CHCl}_{3}\right)$; NMR spectroscopy: ${ }^{1} \mathbf{H} \mathbf{~ N M R}\left(600 \mathrm{MHz}, \mathrm{CDCl}_{3}, 25{ }^{\circ} \mathrm{C}\right) \delta$ 7.68-7.65 (m, 2H), 7.42-7.38 (m, 1H), 7.37-7.31 (m, 4H), 7.29-7.26 (m, 3H), 3.64-3.58 (m, 1H), 1.42 $(\mathrm{d}, J=7.1 \mathrm{~Hz}, 3 \mathrm{H}), 0.52(\mathrm{~s}, 3 \mathrm{H}), 0.51(\mathrm{~s}, 3 \mathrm{H}) ;{ }^{13} \mathbf{C} \mathbf{N M R}\left(151 \mathrm{MHz}, \mathrm{CDCl}_{3}, 25^{\circ} \mathrm{C}\right) \delta 153.6(\mathrm{dd}, J=283.2$, $278.6 \mathrm{~Hz}), 138.2$, 134.6, 132.7, 131.0, 129.4, 129.1, 128.9, 124.4, 115.2 (dd, $J=39.6,15.0 \mathrm{~Hz}), 82.8$, $78.2,27.6,19.8,0.1,-0.2 ;{ }^{19} \mathbf{F}$ NMR $\left(376 \mathrm{MHz}, \mathrm{CDCl}_{3}, 25^{\circ} \mathrm{C}\right) \delta-105.4(\mathrm{~d}, J=83.4 \mathrm{~Hz}, 1 \mathrm{~F}),-118.6(\mathrm{dd}$, $J=83.2,3.3 \mathrm{~Hz}, 1 \mathrm{~F})$; IR (ATR): 3295, 3217, 2922, 2855, 1759, 1599, 1491, 1450, 1260, 1178, 1118 , 835, 794, 757, $693.3 \mathrm{~cm}^{-1}$; HRMS (ESI, m/z): calcd for $\mathrm{C}_{20} \mathrm{H}_{21} \mathrm{~F}_{2} \mathrm{OSi}^{+}(\mathrm{M}+\mathrm{H})^{+}$: 343.1324; Found: 343.1315; HPLC analysis (IB N-5 column, hexane, $1.0 \mathrm{~mL} / \mathrm{min}, 20^{\circ} \mathrm{C}, 254 \mathrm{~nm}$ ) indicated $>99 \%$ ee: $t_{\mathrm{R}}$ $($ major $)=6.46 \mathrm{~min}$. 
Racemic 5a:

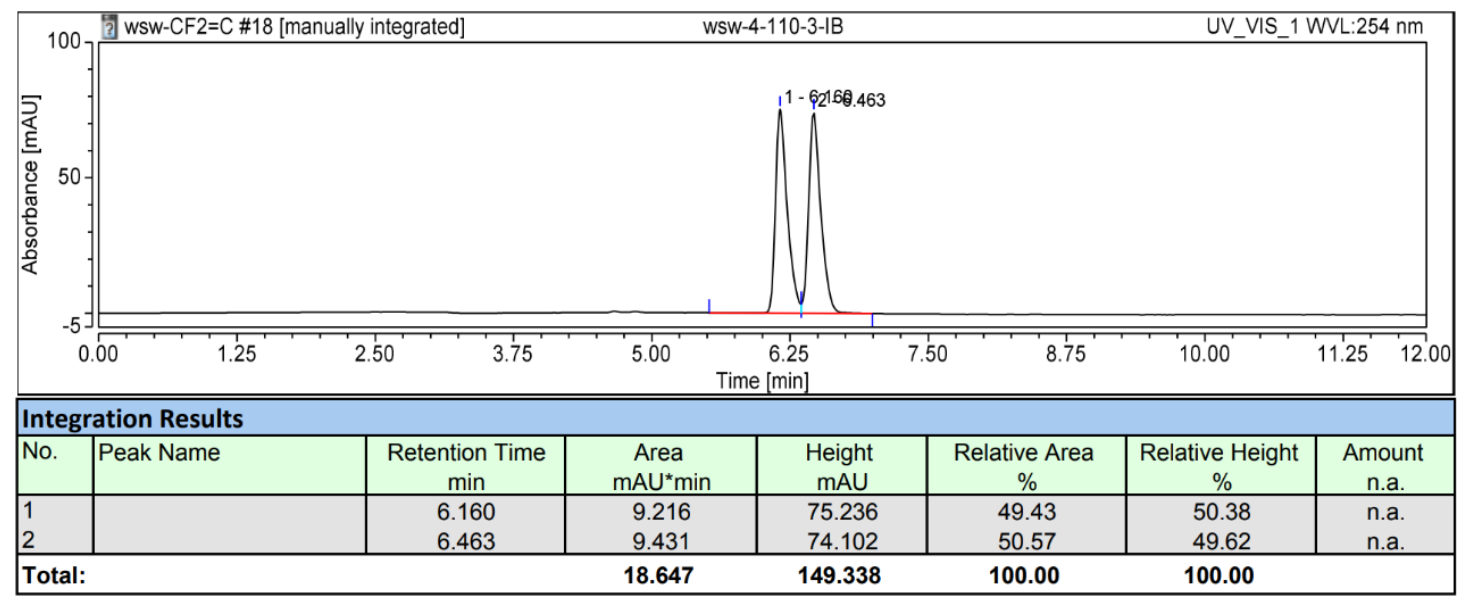

Enantioenriched 5a:

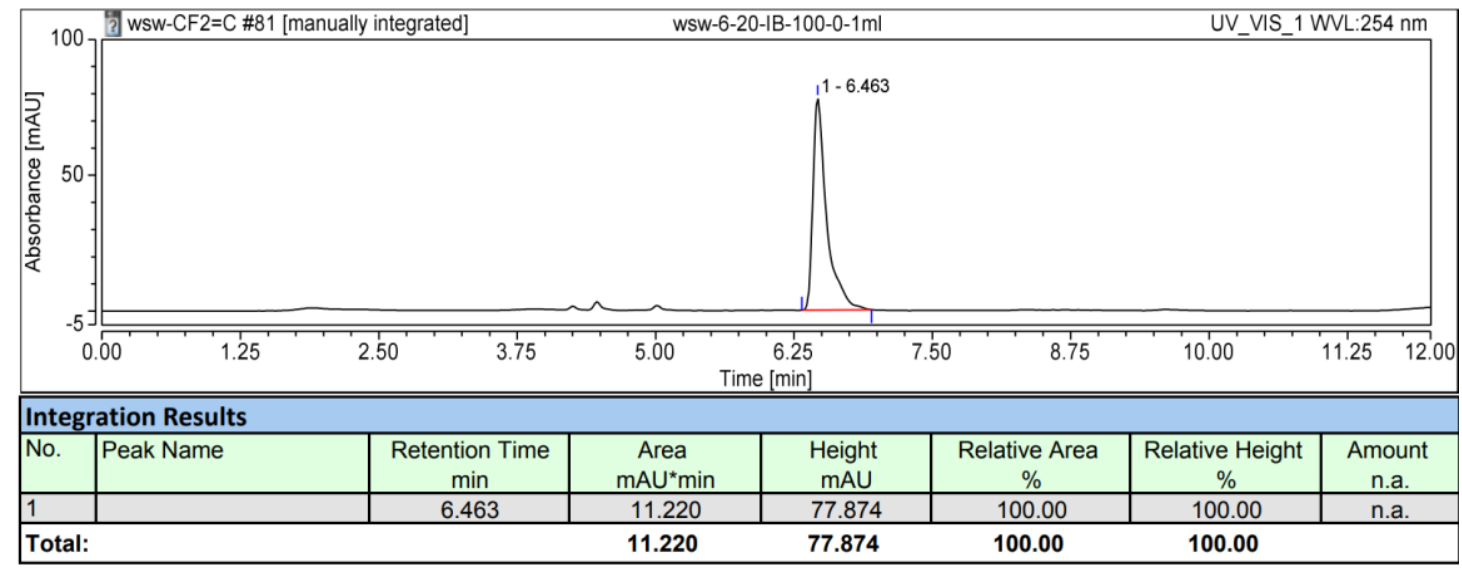

(S)-((1,1-difluoro-5-(2-fluorophenyl)-3-methylpent-1-en-4-yn-2-yl)oxy)dimethyl(phenyl)silane (5b)

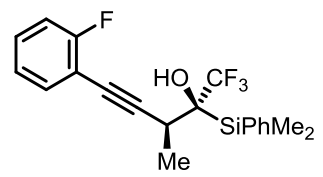

3b

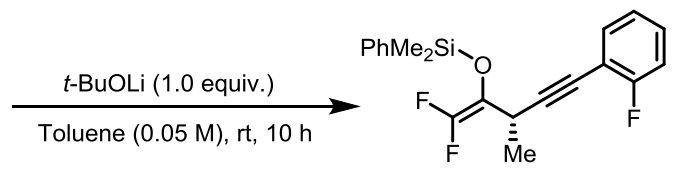

$5 b$

In a glovebox, to an oven-dried $5 \mathrm{~mL}$ screw-cap reaction tube equipped with a magnetic stir bar was added $\mathbf{3 b}(0.1 \mathrm{mmol}), t$-BuOLi (1 equiv., $0.1 \mathrm{mmol})$, and dry toluene $(2 \mathrm{~mL})$ sequentially. The mixture was stirred at room temperature for $5 \mathrm{~min}$. The tube was then sealed, removed from the glove box and allowed to stir at room temperature for $10 \mathrm{~h}$. And then filtered through a short plug of silica gel (100 200 mesh) eluting with hexane (ca. $10 \mathrm{~mL}$ ). The solvent was removed in vacuo with the aid of a rotary evaporator to afford the title compound $\mathbf{5 b}$. Colorless oil; $\mathbf{R}_{\mathbf{f}}=0.80(\mathrm{PE} / \mathrm{EA}=10 / 1) ; 35.3 \mathrm{mg}, 98 \%$ yield, $>$ 99\% ee; $[\boldsymbol{\alpha}]^{25} \mathbf{D}=-26.9\left(c=2.78, \mathrm{CHCl}_{3}\right)$; NMR spectroscopy: ${ }^{\mathbf{1}} \mathbf{H} \mathbf{N M R}\left(400 \mathrm{MHz}, \mathrm{CDCl}_{3}, 25{ }^{\circ} \mathrm{C}\right) \delta$ $7.66(\mathrm{dt}, J=7.8,1.5 \mathrm{~Hz}, 2 \mathrm{H}), 7.42-7.27(\mathrm{~m}, 5 \mathrm{H}), 7.09-7.00(\mathrm{~m}, 2 \mathrm{H}), 3.65(\mathrm{q}, J=7.0 \mathrm{~Hz}, 1 \mathrm{H}), 1.43(\mathrm{~d}$, $J=7.1 \mathrm{~Hz}, 3 \mathrm{H}), 0.51(\mathrm{~s}, 3 \mathrm{H}), 0.51(\mathrm{~s}, 3 \mathrm{H}) ;{ }^{13} \mathbf{C} \mathbf{N M R}\left(151 \mathrm{MHz}, \mathrm{CDCl}_{3}, 25{ }^{\circ} \mathrm{C}\right) \delta 163.0(\mathrm{~d}, J=250.9 \mathrm{~Hz})$, $152.6(\mathrm{dd}, J=283.1,278.6 \mathrm{~Hz}), 137.1,133.7,133.6,130.0,129.8(\mathrm{~d}, J=8.0 \mathrm{~Hz}), 127.9,124.0(\mathrm{~d}, J=3.8$ $\mathrm{Hz}), 115.6(\mathrm{~d}, J=21.1 \mathrm{~Hz}), 114.0(\mathrm{dd}, J=39.7,15.3 \mathrm{~Hz}), 111.9$ (d, $J=15.8 \mathrm{~Hz}), 95.2,75.2,26.8,18.7$, $-1.0,-1.3 ;{ }^{19} \mathbf{F}$ NMR $\left(376 \mathrm{MHz}, \mathrm{CDCl}_{3}, 25{ }^{\circ} \mathrm{C}\right)-105.2(\mathrm{~d}, J=83.2 \mathrm{~Hz}, 1 \mathrm{~F}),-110.2(\mathrm{dd}, J=15.5,6.8 \mathrm{~Hz}$, 
1F), -118.5 (dd, $J=82.0,3.0 \mathrm{~Hz}, 1 \mathrm{~F})$; IR (ATR): 3306, 3265, 3075, 2960, 1759, 1610, 1491, 1454, 1290, 1260, 1118, 838, 798, 760, $701 \mathrm{~cm}^{-1}$; HRMS (ESI, m/z): calcd for $\mathrm{C}_{20} \mathrm{H}_{20} \mathrm{~F}_{3} \mathrm{OSi}^{+}(\mathrm{M}+\mathrm{H})^{+}:$361.1230; Found: 361.1228; HPLC analysis (IB N-5 column, hexane, $1.0 \mathrm{~mL} / \mathrm{min}, 20^{\circ} \mathrm{C}, 254 \mathrm{~nm}$ ) indicated $>99 \%$ ee: $t_{\mathrm{R}}($ major $)=5.84 \mathrm{~min}$.

\section{Racemic 5b:}

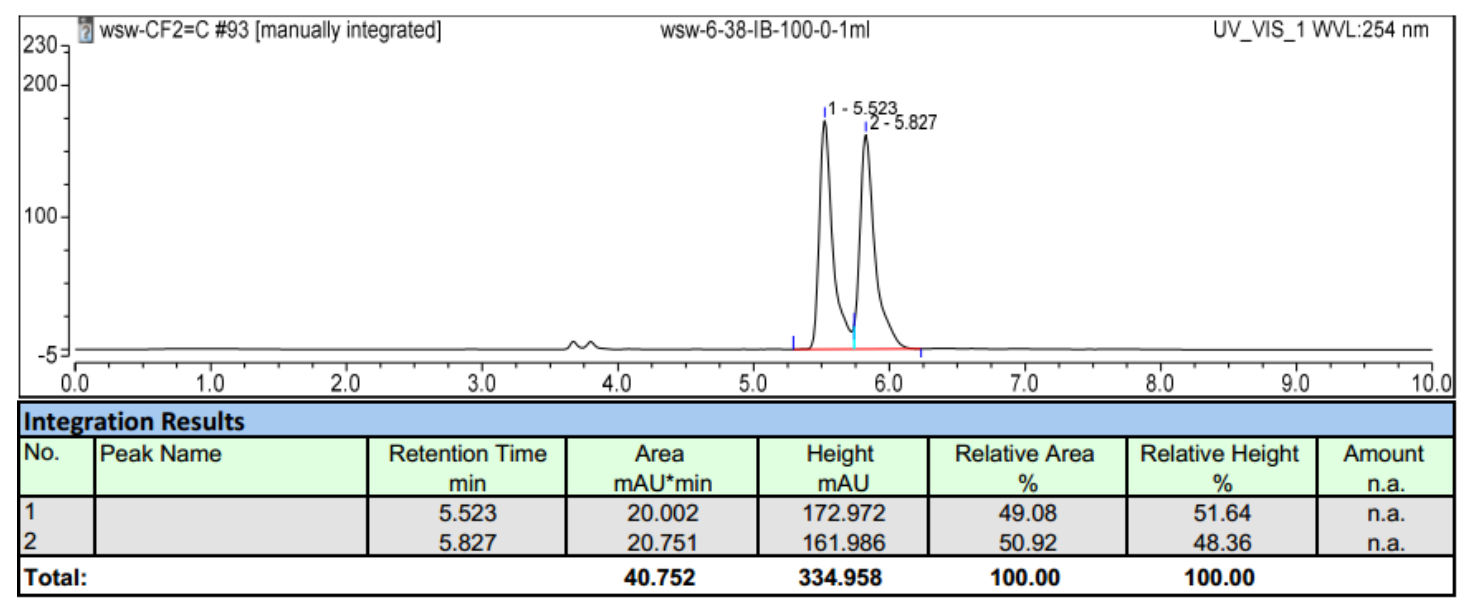

\section{Enantioenriched 5b:}

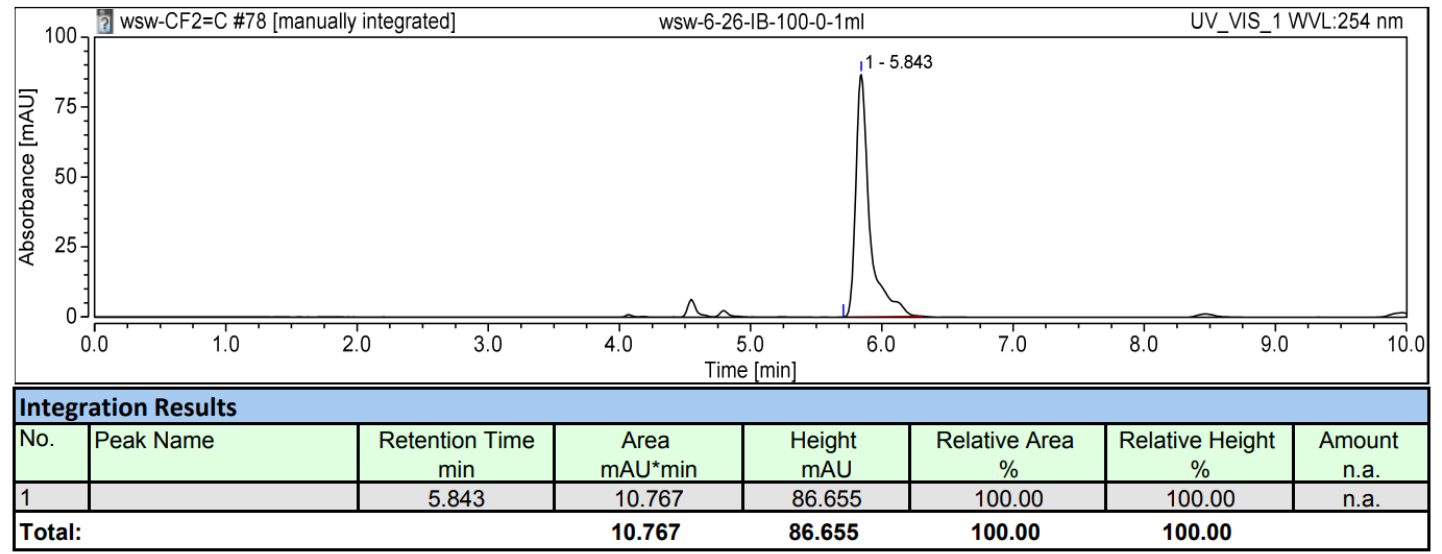

(S)-((1,1-difluoro-5-(3-fluorophenyl)-3-methylpent-1-en-4-yn-2-yl)oxy)dimethyl(phenyl)silane (5c)

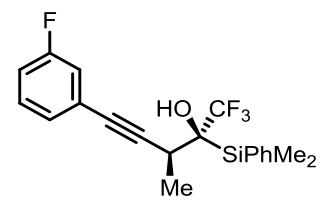

$3 c$

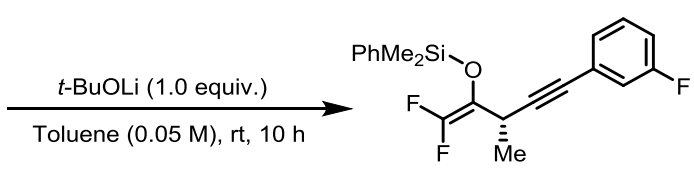

5c

In a glovebox, to an oven-dried $5 \mathrm{~mL}$ screw-cap reaction tube equipped with a magnetic stir bar was added $3 \mathbf{c}(0.1 \mathrm{mmol}), t$-BuOLi (1 equiv., $0.1 \mathrm{mmol})$, and dry toluene $(2 \mathrm{~mL})$ sequentially. The mixture was stirred at room temperature for $5 \mathrm{~min}$. The tube was then sealed, removed from the glove box and allowed to stir at room temperature for $10 \mathrm{~h}$. And then filtered through a short plug of silica gel (100 200 mesh) eluting with hexane (ca. $10 \mathrm{~mL}$ ). The solvent was removed in vacuo with the aid of a rotary evaporator to afford the title compound 5c. Colorless oil; $\mathbf{R}_{\mathbf{f}}=0.80(\mathrm{PE} / \mathrm{EA}=10 / 1) ; 35.6 \mathrm{mg}, 99 \%$ yield, 93\% ee; $[\boldsymbol{\alpha}]^{25} \mathbf{D}=-23.3\left(c=2.10, \mathrm{CHCl}_{3}\right)$; NMR spectroscopy: ${ }^{\mathbf{1}} \mathbf{H} \mathbf{N M R}\left(400 \mathrm{MHz}, \mathrm{CDCl}_{3}, 25^{\circ} \mathrm{C}\right) \delta$ $7.66(\mathrm{dd}, J=7.9,1.6 \mathrm{~Hz}, 2 \mathrm{H}), 7.41-7.26(\mathrm{~m}, 5 \mathrm{H}), 7.09-6.99(\mathrm{~m}, 2 \mathrm{H}), 3.73-3.56(\mathrm{~m}, 1 \mathrm{H}), 1.43(\mathrm{~d}, J=$ 
$7.1 \mathrm{~Hz}, 3 \mathrm{H}), 0.51(\mathrm{~s}, 3 \mathrm{H}), 0.50(\mathrm{~s}, 3 \mathrm{H}) ;{ }^{13} \mathbf{C} \mathbf{N M R}\left(151 \mathrm{MHz}, \mathrm{CDCl}_{3}, 25{ }^{\circ} \mathrm{C}\right) \delta 163.0(\mathrm{~d}, J=251.1 \mathrm{~Hz})$, $152.6(\mathrm{dd}, J=283.1,279.0 \mathrm{~Hz}), 137.1,133.7,133.6,130.0,129.8(\mathrm{~d}, J=8.0 \mathrm{~Hz}), 127.9,124.0(\mathrm{~d}, J=$ $3.7 \mathrm{~Hz}), 115.6(\mathrm{~d}, J=21.0 \mathrm{~Hz}) ., 114.0(\mathrm{dd}, J=39.5,15.2 \mathrm{~Hz}), 111.9$ (d, $J=15.8 \mathrm{~Hz}), 95.2,75.2,26.8$, $18.7,-1.0,-1.3 ;{ }^{19} \mathbf{F}$ NMR $\left(376 \mathrm{MHz}, \mathrm{CDCl}_{3}, 25{ }^{\circ} \mathrm{C}\right) \delta-106.2(\mathrm{~d}, J=82.4 \mathrm{~Hz}, 1 \mathrm{~F}),-111.1(\mathrm{~d}, J=6.4$ Hz, 1F), -119.5 (dd, $J=81.8,2.9$ Hz, 1F); IR (ATR): 3306, 3172, 3071, 2926, 2855, 1759, 1610, 1491 , 1454, 1259, 1118, 835, 794, 757, $701 \mathrm{~cm}^{-1}$; HRMS (ESI, m/z): calcd for $\mathrm{C}_{20} \mathrm{H}_{20} \mathrm{~F}_{3} \mathrm{OSi}^{+}(\mathrm{M}+\mathrm{H})^{+}: 361.1230$; Found: 361.1231; HPLC analysis (IB N-5 column, hexane, $1.0 \mathrm{~mL} / \mathrm{min}, 20^{\circ} \mathrm{C}, 254 \mathrm{~nm}$ ) indicated 93\% ee: $t_{\mathrm{R}}($ major $)=6.23 \mathrm{~min}, t_{\mathrm{R}}($ minor $)=6.50 \mathrm{~min}$.

\section{Racemic 5c:}

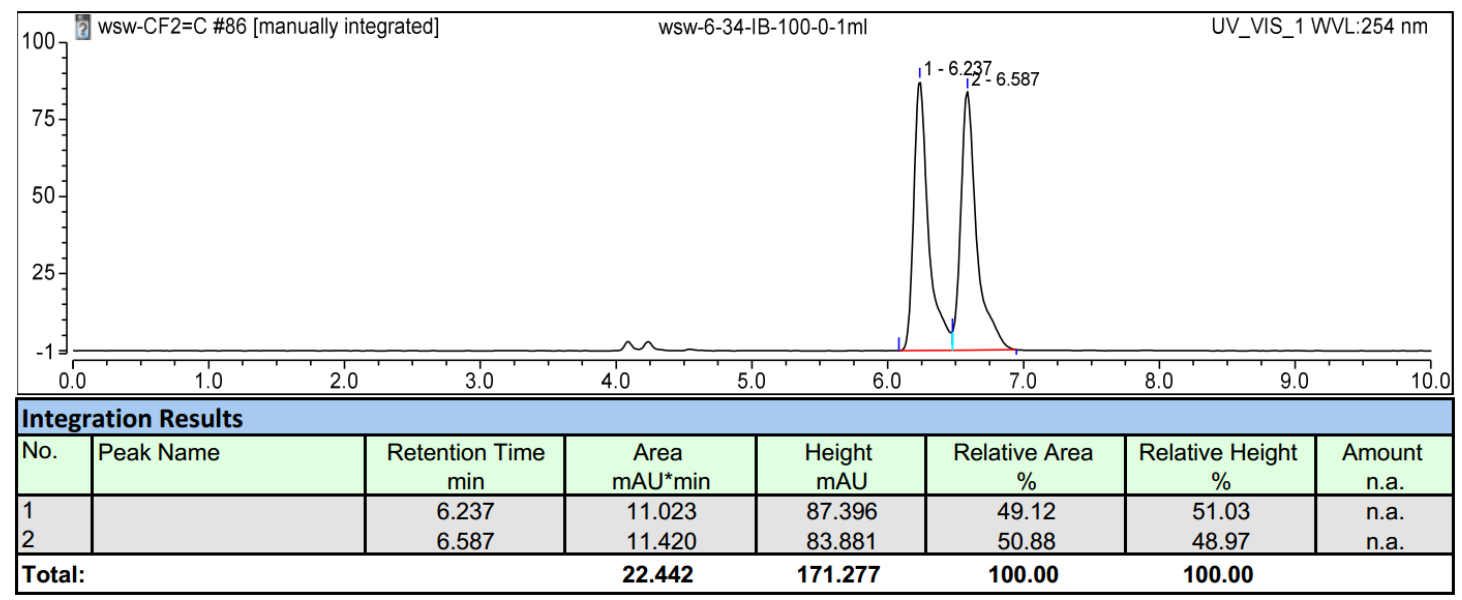

\section{Enantioenriched 5c:}

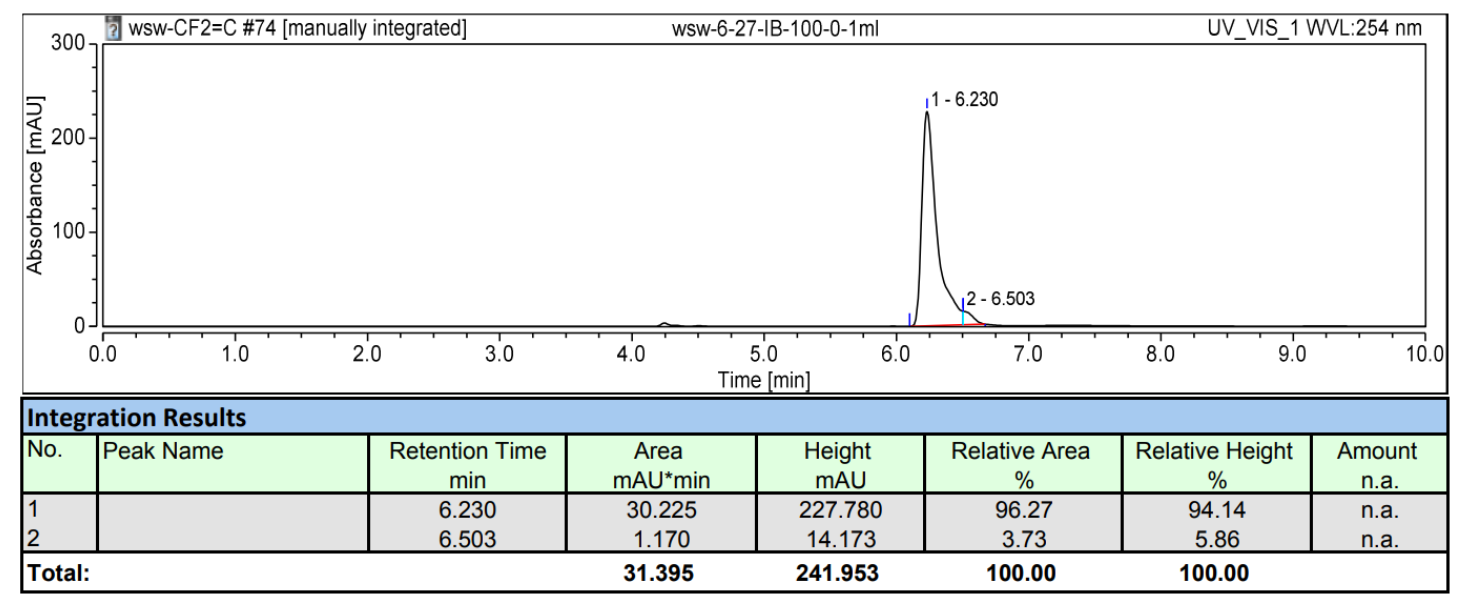

(S)-((1,1-difluoro-5-(4-fluorophenyl)-3-methylpent-1-en-4-yn-2-yl)oxy)dimethyl(phenyl)silane (5d)

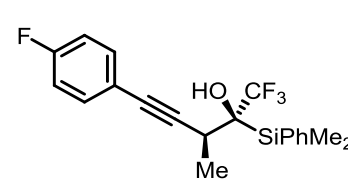

$3 \mathbf{d}$

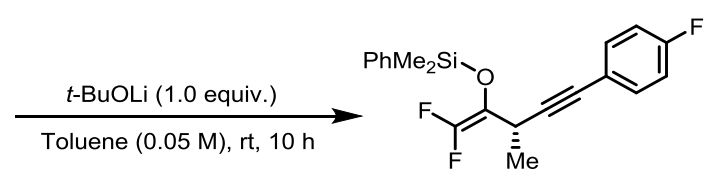

5d

In a glovebox, to an oven-dried $5 \mathrm{~mL}$ screw-cap reaction tube equipped with a magnetic stir bar was added 3d $(0.1 \mathrm{mmol}), t$-BuOLi (1 equiv., $0.1 \mathrm{mmol})$, and dry toluene $(2 \mathrm{~mL})$ sequentially. The mixture was stirred at room temperature for $5 \mathrm{~min}$. The tube was then sealed, removed from the glove box and 
allowed to stir at room temperature for $10 \mathrm{~h}$. And then filtered through a short plug of silica gel (100 200 mesh) eluting with hexane (ca. $10 \mathrm{~mL}$ ). The solvent was removed in vacuo with the aid of a rotary evaporator to afford the title compound 5d.Colorless oil; $\mathbf{R}_{\mathbf{f}}=0.75(\mathrm{PE} / \mathrm{EA}=10 / 1) ; 35.6 \mathrm{mg}, 99 \%$ yield, > 99\% ee; $[\boldsymbol{\alpha}]^{25} \mathbf{D}=-10.8\left(c=2.65, \mathrm{CHCl}_{3}\right)$; NMR spectroscopy: ${ }^{\mathbf{1}} \mathbf{H} \mathbf{N M R}\left(600 \mathrm{MHz}, \mathrm{CDCl}_{3}, 25^{\circ} \mathrm{C}\right) \delta$ 7.67-7.63 (m, 2H), 7.42-7.33 (m, 3H), 7.28-7.25 (m, 2H), 6.98-6.93 (m, 2H), 3.61-3.55 (m, 1H), 1.41 $(\mathrm{d}, J=7.1 \mathrm{~Hz}, 3 \mathrm{H}), 0.50(\mathrm{~s}, 3 \mathrm{H}), 0.50(\mathrm{~s}, 3 \mathrm{H}) ;{ }^{13} \mathbf{C ~ N M R}\left(151 \mathrm{MHz}, \mathrm{CDCl}_{3}, 25{ }^{\circ} \mathrm{C}\right) \delta 162.4(\mathrm{~d}, J=249.0$ $\mathrm{Hz}), 152.6(\mathrm{dd}, J=283.4,278.8 \mathrm{~Hz}) .137 .1,133.6,133.5,130.0,128.0,119.5$ (d, $J=3.7 \mathrm{~Hz}), 115.6$ (d, $J=21.9 \mathrm{~Hz}), 114.2(\mathrm{dd}, J=39.7,15.2 \mathrm{~Hz}), 89.6,80.7,26.6,18.8,0.1,-1.1 ;{ }^{19} \mathbf{F ~ N M R}\left(376 \mathrm{MHz}, \mathrm{CDCl}_{3}\right.$, $\left.25^{\circ} \mathrm{C}\right) \delta-105.4(\mathrm{~d}, J=83.4 \mathrm{~Hz}, 1 \mathrm{~F}),-111.4-111.5(\mathrm{~m}, 1 \mathrm{~F}),-118.6(\mathrm{dd}, J=83.4,4.2 \mathrm{~Hz}, 1 \mathrm{~F})$; IR (ATR): 3142.1, 3071.3, 2959.5, 2922.2, 1759.3, 1602.8, 1505.8, 1453.7, 1259.8, 1118.2, 1039.9, 834.9, 793.9, 734.3, 700.7 $\mathrm{cm}^{-1}$; HRMS (APCI, m/z): calcd for $\mathrm{C}_{20} \mathrm{H}_{20} \mathrm{~F}_{3} \mathrm{OSi}^{+}(\mathrm{M}+\mathrm{H})^{+}$: 361.1230; Found: 361.1236; HPLC analysis (IB N-5 column, hexane, $1.0 \mathrm{~mL} / \mathrm{min}, 20^{\circ} \mathrm{C}, 254 \mathrm{~nm}$ ) indicated $>99 \%$ ee: $t_{\mathrm{R}}$ $($ major $)=5.37 \mathrm{~min}$.

\section{Racemic 5d:}

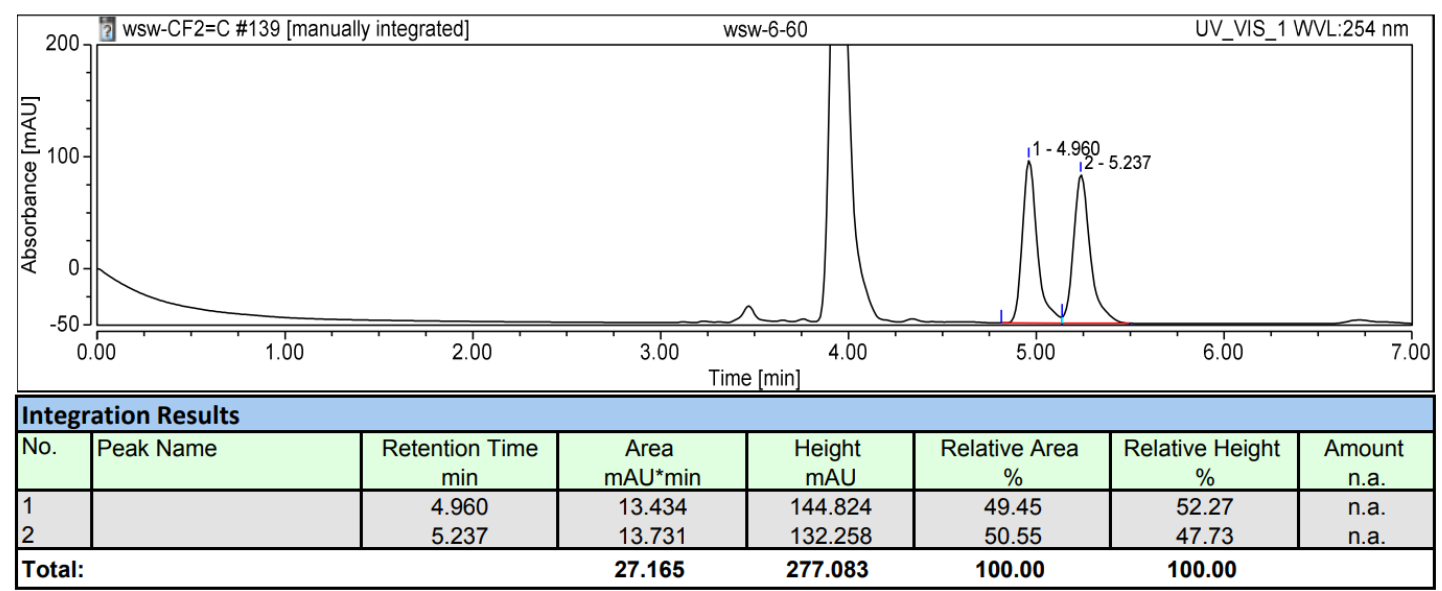

Enantioenriched 5d:

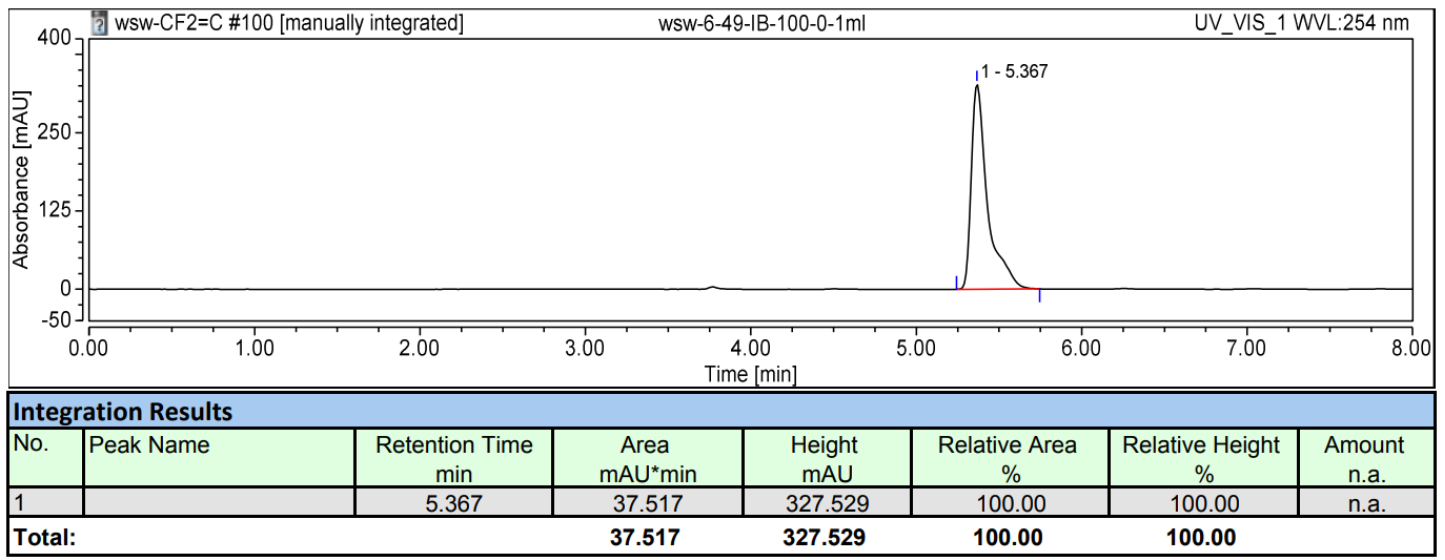


(S)-((5-(4-chlorophenyl)-1,1-difluoro-3-methylpent-1-en-4-yn-2-yl)oxy)dimethyl(phenyl)silane (5e)

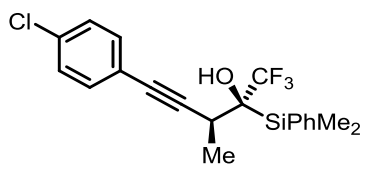

$3 e$

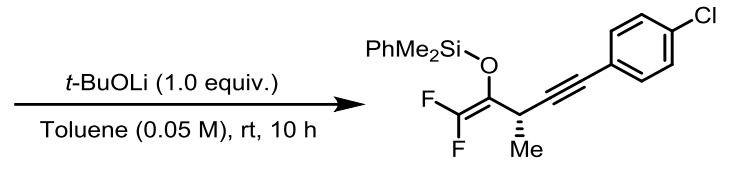

$5 e$

In a glovebox, to an oven-dried $5 \mathrm{~mL}$ screw-cap reaction tube equipped with a magnetic stir bar was added $3 \mathbf{e}(0.1 \mathrm{mmol}), t$-BuOLi ( 1 equiv., $0.1 \mathrm{mmol})$, and dry toluene $(2 \mathrm{~mL})$ sequentially. The mixture was stirred at room temperature for $5 \mathrm{~min}$. The tube was then sealed, removed from the glove box and allowed to stir at room temperature for $10 \mathrm{~h}$. And then filtered through a short plug of silica gel (100 200 mesh) eluting with hexane (ca. $10 \mathrm{~mL}$ ). The solvent was removed in vacuo with the aid of a rotary evaporator to afford the title compound 5e. Colorless oil; $\mathbf{R}_{\mathbf{f}}=0.80(\mathrm{PE} / \mathrm{EA}=10 / 1) ; 37.2 \mathrm{mg}, 99 \%$ yield, > 99\% ee; $[\boldsymbol{\alpha}]^{25} \mathbf{D}=-20.4\left(c=5.08, \mathrm{CHCl}_{3}\right)$; NMR spectroscopy: ${ }^{1} \mathbf{H} \mathbf{~ N M R}\left(400 \mathrm{MHz}, \mathrm{CDCl}_{3}, 25{ }^{\circ} \mathrm{C}\right) \delta$ $7.67-7.62(\mathrm{~m}, 2 \mathrm{H}), 7.43-7.31(\mathrm{~m}, 3 \mathrm{H}), 7.26-7.19(\mathrm{~m}, 4 \mathrm{H}), 3.65-3.51(\mathrm{~m}, 1 \mathrm{H}), 1.41(\mathrm{~d}, J=7.1 \mathrm{~Hz}$, $3 \mathrm{H}), 0.50(\mathrm{~s}, 6 \mathrm{H}) ;{ }^{13} \mathbf{C}$ NMR $\left(151 \mathrm{MHz}, \mathrm{CDCl}_{3}, 25{ }^{\circ} \mathrm{C}\right) \delta 152.6(\mathrm{dd}, J=283.2,278.9 \mathrm{~Hz}), 137.1,134.1$, 133.6, 133.0, 130.0, 128.7, 128.0, 121.9, 114.1 (dd, $J=39.7,15.2 \mathrm{~Hz}), 91.0,80.7,26.6,18.7,-1.02$, $-1.04 ;{ }^{19} \mathbf{F}$ NMR $\left(376 \mathrm{MHz}, \mathrm{CDCl}_{3}, 25^{\circ} \mathrm{C}\right) \delta-105.25(\mathrm{~d}, J=82.7 \mathrm{~Hz}, 1 \mathrm{~F}),-118.52(\mathrm{dd}, J=81.9,2.9 \mathrm{~Hz}$, 1F); IR (ATR): 3325, 3071, 2922, 2719, 1759, 1696, 1507, 1499, 1260, 1118, 1092, 831, 794, 734, 701 $\mathrm{cm}^{-1}$. HRMS (ESI, m/z): calcd for $\mathrm{C}_{20} \mathrm{H}_{20} \mathrm{~F}_{2} \mathrm{OClSi}^{+}(\mathrm{M}+\mathrm{H})^{+}: 377.0935$; Found: 377.0920 ; HPLC analysis (IB N-5 column, hexane, $1.0 \mathrm{~mL} / \mathrm{min}, 2{ }^{\circ} \mathrm{C}, 254 \mathrm{~nm}$ ) indicated $>99 \%$ ee: $t_{\mathrm{R}}$ (major) $=5.67 \mathrm{~min}$.

\section{Racemic 5e:}

\begin{tabular}{|l|l|c|c|c|c|c|}
\hline & \\
\hline
\end{tabular}




\section{Enantioenriched 5e:}

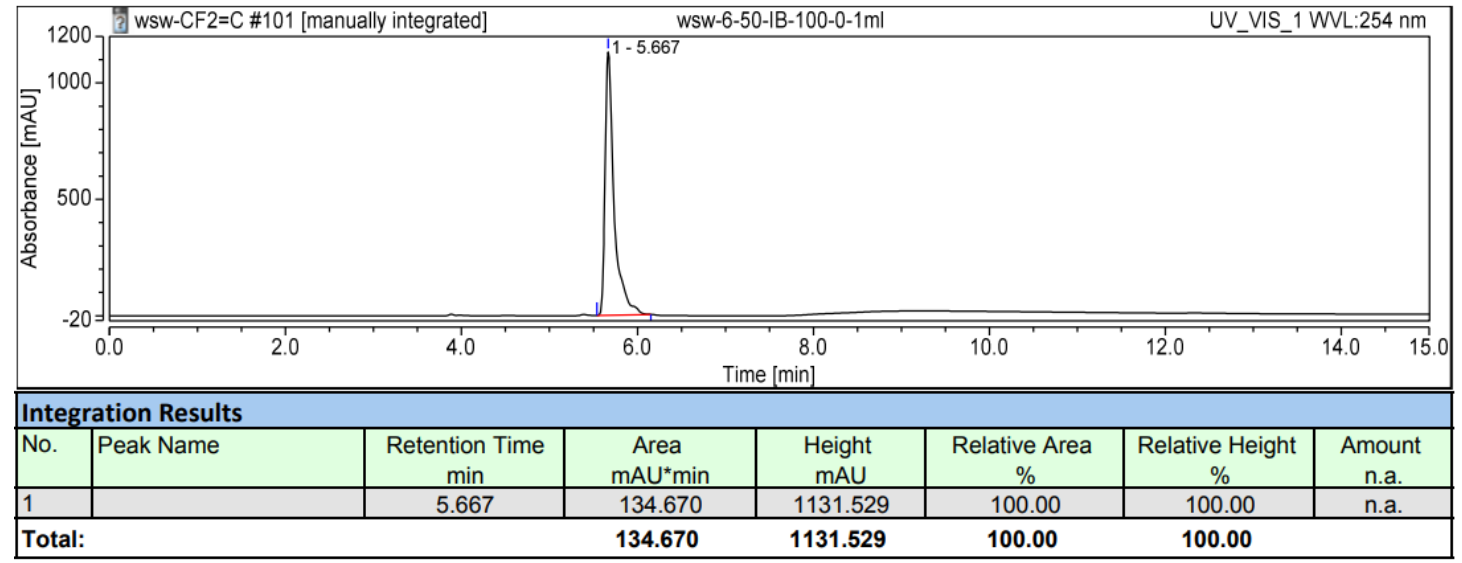

(S)-((5-(4-bromophenyl)-1,1-difluoro-3-methylpent-1-en-4-yn-2-yl)oxy)dimethyl(phenyl)silane (5f)

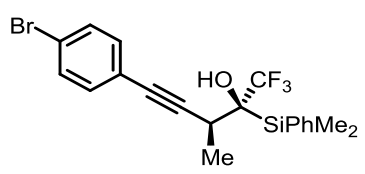

$3 f$

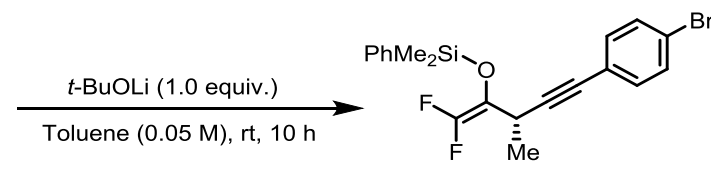

5 f

In a glovebox, to an oven-dried $5 \mathrm{~mL}$ screw-cap reaction tube equipped with a magnetic stir bar was added $\mathbf{3 f}(0.1 \mathrm{mmol}), t$-BuOLi ( 1 equiv., $0.1 \mathrm{mmol})$, and dry toluene $(2 \mathrm{~mL})$ sequentially. The mixture was stirred at room temperature for $5 \mathrm{~min}$. The tube was then sealed, removed from the glove box and allowed to stir at room temperature for $10 \mathrm{~h}$. And then filtered through a short plug of silica gel (100 200 mesh) eluting with hexane (ca. $10 \mathrm{~mL}$ ). The solvent was removed in vacuo with the aid of a rotary evaporator to afford the title compound $\mathbf{5 f}$. Colorless oil; $\mathbf{R}_{\mathbf{f}}=0.90$ (PE/EA $\left.=10 / 1\right) ; 41.2 \mathrm{mg}, 98 \%$ yield, $99 \%$ ee; $[\boldsymbol{\alpha}]^{25} \mathbf{D}=-27.6\left(c=2.93, \mathrm{CHCl}_{3}\right) ; \mathrm{NMR}$ spectroscopy: ${ }^{1} \mathbf{H} \mathbf{~ N M R}\left(600 \mathrm{MHz}, \mathrm{CDCl}_{3}, 25{ }^{\circ} \mathrm{C}\right) \delta$ 7.66-7.63 (m, 2H), 7.43-7.33 (m, 5H), 7.16-7.13 (m, 2H), $1.41(\mathrm{~d}, J=7.1 \mathrm{~Hz}, 3 \mathrm{H}), 0.50(\mathrm{~s}, 6 \mathrm{H}) ;{ }^{13} \mathbf{C}$ NMR $\left(151 \mathrm{MHz}, \mathrm{CDCl}_{3}, 25^{\circ} \mathrm{C}\right) \delta 152.6(\mathrm{dd}, J=283.1,279.0 \mathrm{~Hz}), 137.1,134.1,133.6,133.0,130.0$, $128.7,128.0,121.9,114.1(\mathrm{dd}, J=39.7,15.2 \mathrm{~Hz}), 91.0,80.7,26.6,18.7,-1.0,-1.0 ;{ }^{19} \mathbf{F}$ NMR $(376 \mathrm{MHz}$, $\left.\mathrm{CDCl}_{3}, 25^{\circ} \mathrm{C}\right) \delta-105.3(\mathrm{~d}, J=83.1 \mathrm{~Hz}, 1 \mathrm{~F}),-118.5(\mathrm{dd}, J=82.6,3.6 \mathrm{~Hz}, 1 \mathrm{~F}) ;$ IR (ATR): 3217,3181 , 2922, 2855, 1763, 1696, 1588, 1487, 1260, 1118, 1070, 869, 794, 734, $701 \mathrm{~cm}^{-1}$; HRMS (ESI, m/z): calcd for $\mathrm{C}_{20} \mathrm{H}_{19} \mathrm{BrF}_{2} \mathrm{OSiNa}^{+}(\mathrm{M}+\mathrm{Na})^{+}$: 443.0249; Found: 443.0275; HPLC analysis (IB N-5 column, hexane, $1.0 \mathrm{~mL} / \mathrm{min}, 20^{\circ} \mathrm{C}, 254 \mathrm{~nm}$ ) indicated $99 \%$ ee: $t_{\mathrm{R}}($ major $)=6.05 \mathrm{~min}, t_{\mathrm{R}}($ minor $)=6.39 \mathrm{~min}$. 


\section{Racemic 5f:}

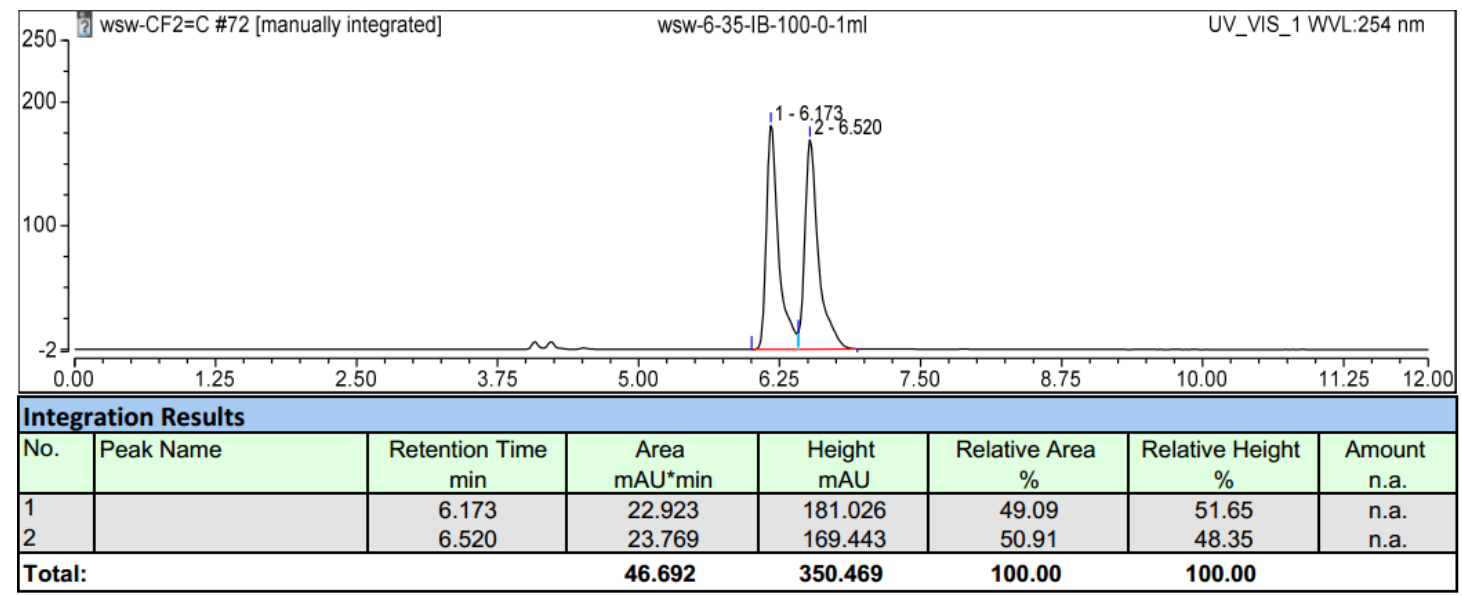

Enantioenriched 5f:

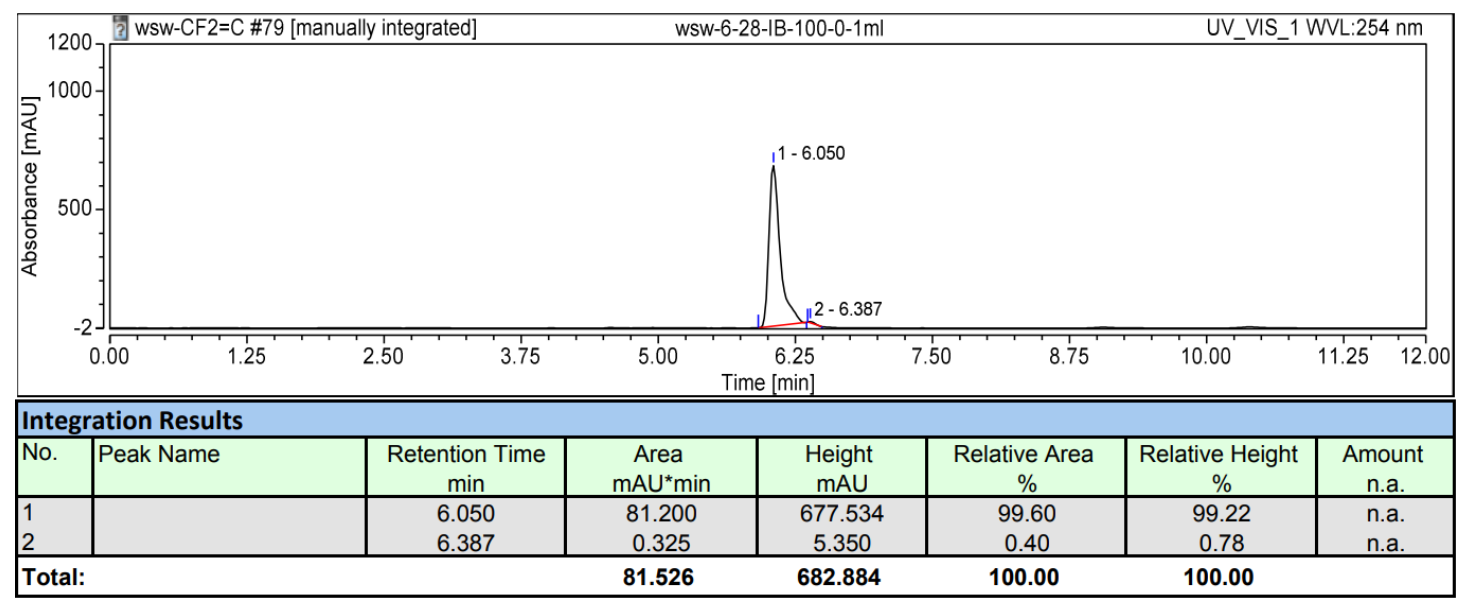

\section{(S)-((1,1-difluoro-5-(4-methoxyphenyl)-3-methylpent-1-en-4-yn-2-yl)oxy)dimethyl(phenyl)silane}

\section{(5g)}

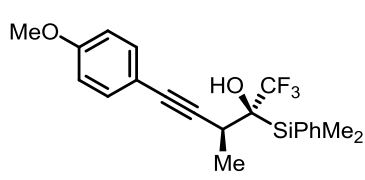

$3 \mathrm{~h}$

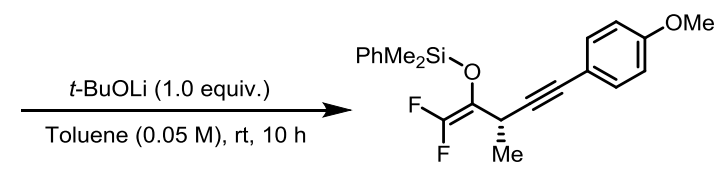

$5 g$

In a glovebox, to an oven-dried $5 \mathrm{~mL}$ screw-cap reaction tube equipped with a magnetic stir bar was added $\mathbf{3 h}(0.1 \mathrm{mmol}), t$-BuOLi (1 equiv., $0.1 \mathrm{mmol})$, and dry toluene $(2 \mathrm{~mL})$ sequentially. The mixture was stirred at room temperature for $5 \mathrm{~min}$. The tube was then sealed, removed from the glove box and allowed to stir at room temperature for $10 \mathrm{~h}$. And then filtered through a short plug of silica gel (100 200 mesh) eluting with hexane (ca. $10 \mathrm{~mL}$ ). The solvent was removed in vacuo with the aid of a rotary evaporator to afford the title compound 5g. Colorless oil; $\mathbf{R}_{\mathbf{f}}=0.40(\mathrm{PE} / \mathrm{EA}=10 / 1) ; 36.8 \mathrm{mg}, 99 \%$ yield, 98\% ee; $[\boldsymbol{\alpha}]^{25} \mathbf{D}=-25.4\left(c=3.93, \mathrm{CHCl}_{3}\right)$; NMR spectroscopy: ${ }^{1} \mathbf{H} \mathbf{N M R}\left(600 \mathrm{MHz}, \mathrm{CDCl}_{3}, 25{ }^{\circ} \mathrm{C}\right) \delta$ 7.69-7.64 (m, 2H), 7.42-7.33 (m, 3H), 7.28-7.23 (m, 2H), 6.82-6.78 (m, 2H), 3.80 (s, 3H), 3.64-3.54 $(\mathrm{m}, 1 \mathrm{H}), 1.40(\mathrm{~d}, J=7.1 \mathrm{~Hz}, 3 \mathrm{H}), 0.51(\mathrm{~s}, 3 \mathrm{H}), 0.50(\mathrm{~s}, 3 \mathrm{H}) ;{ }^{13} \mathbf{C} \mathbf{N M R}\left(151 \mathrm{MHz}, \mathrm{CDCl}_{3}, 25{ }^{\circ} \mathrm{C}\right) \delta 159.5$, $152.6(\mathrm{dd}, J=283.1,278.6 \mathrm{~Hz}), 137.2,133.6,133.1,129.9,127.9,115.6,114.4$ (dd, $J=39.7,14.8 \mathrm{~Hz}$ ), 
114.0, 88.4, 81.5, 55.4, 26.6, 18.9, $-0.9,-1.2 ;{ }^{19} \mathbf{F}$ NMR $\left(376 \mathrm{MHz}, \mathrm{CDCl}_{3}, 25{ }^{\circ} \mathrm{C}\right) \delta-105.6(\mathrm{~d}, J=83.8$ Hz, 1F), -118.8 (dd, $J=78.9,5.4$ Hz, 1F); IR (ATR): 3306, 3071, 2960, 2840, 1759, 1607, 1510, 1286, 1252, 1174, 910, 872, 790, 731, $701 \mathrm{~cm}^{-1}$; HRMS (ESI, m/z): calcd for $\mathrm{C}_{21} \mathrm{H}_{23} \mathrm{~F}_{2} \mathrm{O}_{2} \mathrm{Si}^{+}(\mathrm{M}+\mathrm{H})^{+}: 373.1430$; Found: 373.1431 ; HPLC analysis (IB N-5 column, hexane, $1.0 \mathrm{~mL} / \mathrm{min}, 20{ }^{\circ} \mathrm{C}, 254 \mathrm{~nm}$ ) indicated $98 \%$ ee: $t_{\mathrm{R}}($ major $)=14.32 \mathrm{~min}, t_{\mathrm{R}}($ minor $)=17.77 \mathrm{~min}$.

\section{Racemic 5g:}

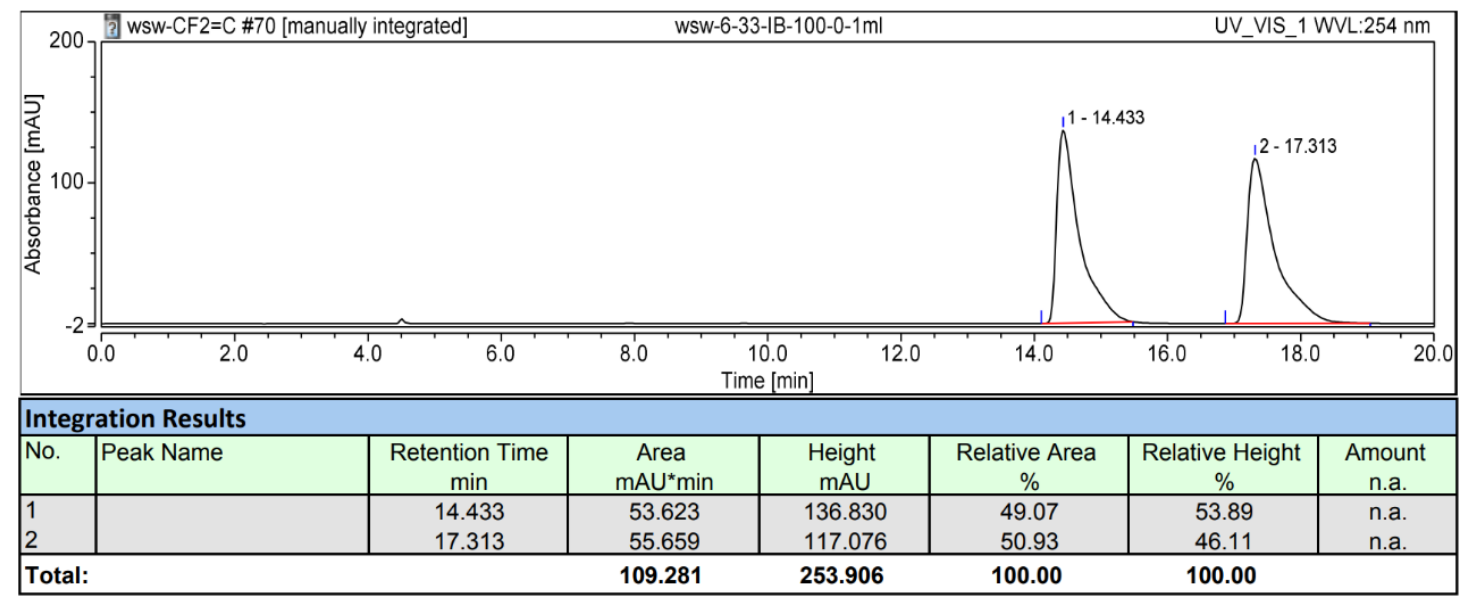

Enantioenriched 5g:

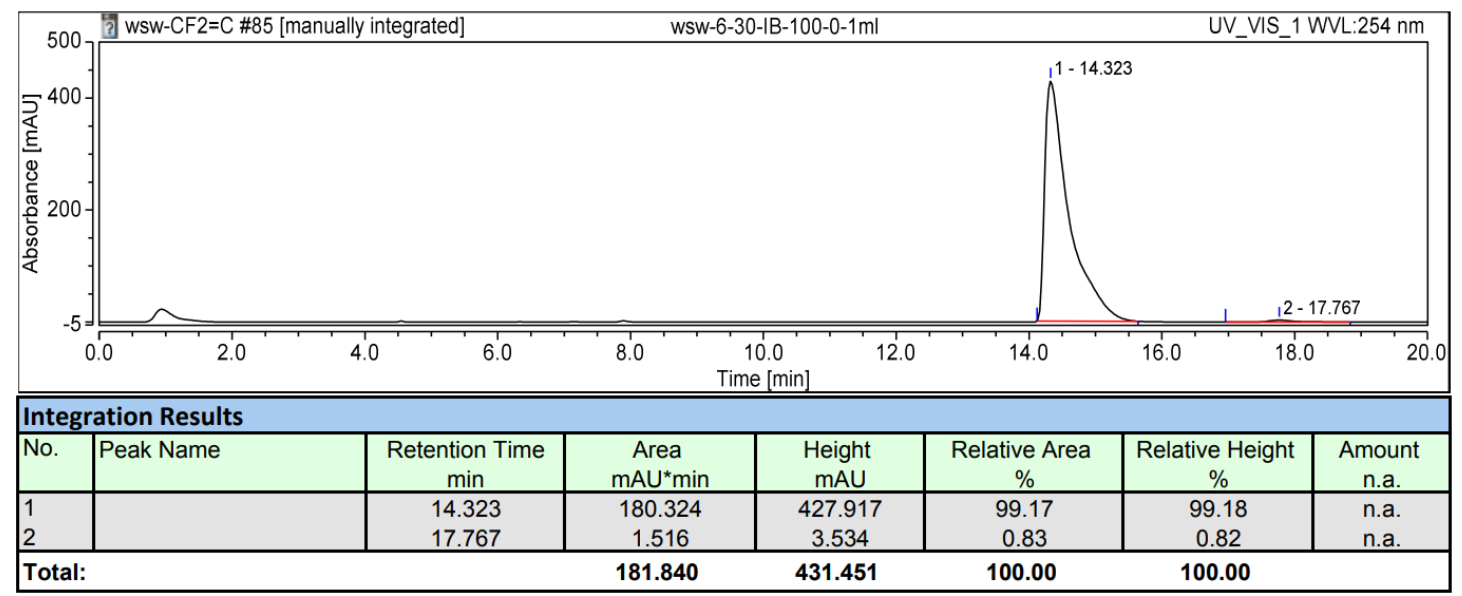

(S)-((1,1-difluoro-3-methyl-5-(p-tolyl)pent-1-en-4-yn-2-yl)oxy)dimethyl(phenyl)silane (5h)

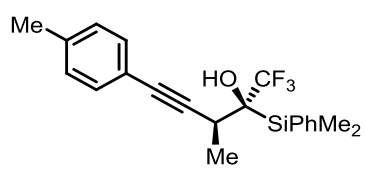

3j

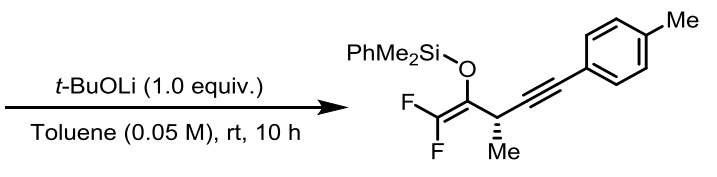

$5 \mathrm{~h}$

In a glovebox, to an oven-dried $5 \mathrm{~mL}$ screw-cap reaction tube equipped with a magnetic stir bar was added $3 \mathbf{j}$ ( $0.1 \mathrm{mmol}), t$-BuOLi ( 1 equiv., $0.1 \mathrm{mmol})$, and dry toluene $(2 \mathrm{~mL})$ sequentially. The mixture was stirred at room temperature for $5 \mathrm{~min}$. The tube was then sealed, removed from the glove box and allowed to stir at room temperature for $10 \mathrm{~h}$. And then filtered through a short plug of silica gel (100 200 mesh) eluting with hexane (ca. $10 \mathrm{~mL}$ ). The solvent was removed in vacuo with the aid of a rotary evaporator to afford the title compound $\mathbf{5 h}$. Colorless oil; $\mathbf{R}_{\mathbf{f}}=0.83(\mathrm{PE} / \mathrm{EA}=10 / 1) ; 35.2 \mathrm{mg}, 99 \%$ yield, 99\% ee; $[\boldsymbol{\alpha}]^{\mathbf{2 5}} \mathbf{D}=-31.8\left(c=1.73, \mathrm{CHCl}_{3}\right)$; NMR spectroscopy: ${ }^{1} \mathbf{H} \mathbf{N M R}\left(400 \mathrm{MHz}, \mathrm{CDCl}_{3}, 25{ }^{\circ} \mathrm{C}\right) \delta$ 
$7.63(\mathrm{~m}, 2 \mathrm{H}), 7.42-7.31(\mathrm{~m}, 3 \mathrm{H}), 7.24-7.19(\mathrm{~m}, 2 \mathrm{H}), 7.07$ (d, J=7.9 Hz, 2H), 3.64-3.54 (m, 1H), 2.32 $(\mathrm{s}, 3 \mathrm{H}), 1.40(\mathrm{~d}, J=7.1 \mathrm{~Hz}, 3 \mathrm{H}), 0.51(\mathrm{~s}, 3 \mathrm{H}), 0.50(\mathrm{~s}, 3 \mathrm{H}) ;{ }^{13} \mathbf{C} \mathbf{N M R}\left(151 \mathrm{MHz}, \mathrm{CDCl}_{3}, 25^{\circ} \mathrm{C}\right) \delta 152.6$ $(\mathrm{dd}, J=283.0,278.6 \mathrm{~Hz}), 138.1,137.2,133.6,131.6,130.0,129.1,127.9,120.4,114.3(\mathrm{dd}, J=39.7$, $14.8 \mathrm{~Hz}), 89.2,81.8,26.6,21.6,18.8,-0.9,-1.2 ;{ }^{19} \mathbf{F} \mathbf{N M R}\left(376 \mathrm{MHz}, \mathrm{CDCl}_{3}, 25{ }^{\circ} \mathrm{C}\right) \delta-105.6(\mathrm{~d}, J=$ 83.0 Hz, 1F), -118.7 (dd, $J=83.4,2.7 \mathrm{~Hz}, 1 \mathrm{~F}$ ); IR (ATR): 3071, 2926, 2855, 1759, 1692, 1510, 1454, 1260, 1182, 1118, 1040, 872, 794, 731, $701 \mathrm{~cm}^{-1}$; HRMS (ESI, m/z): calcd for $\mathrm{C}_{21} \mathrm{H}_{23} \mathrm{~F}_{2} \mathrm{OSi}^{+}(\mathrm{M}+\mathrm{H})^{+}$: 357.1481; Found: 357.1482; HPLC analysis (IB N-5 column, hexane, $1.0 \mathrm{~mL} / \mathrm{min}, 20{ }^{\circ} \mathrm{C}, 254 \mathrm{~nm}$ ) indicated $99 \%$ ee: $t_{\mathrm{R}}($ major $)=6.37 \mathrm{~min}, t_{\mathrm{R}}($ minor $)=7.90 \mathrm{~min}$.

\section{Racemic 5h:}

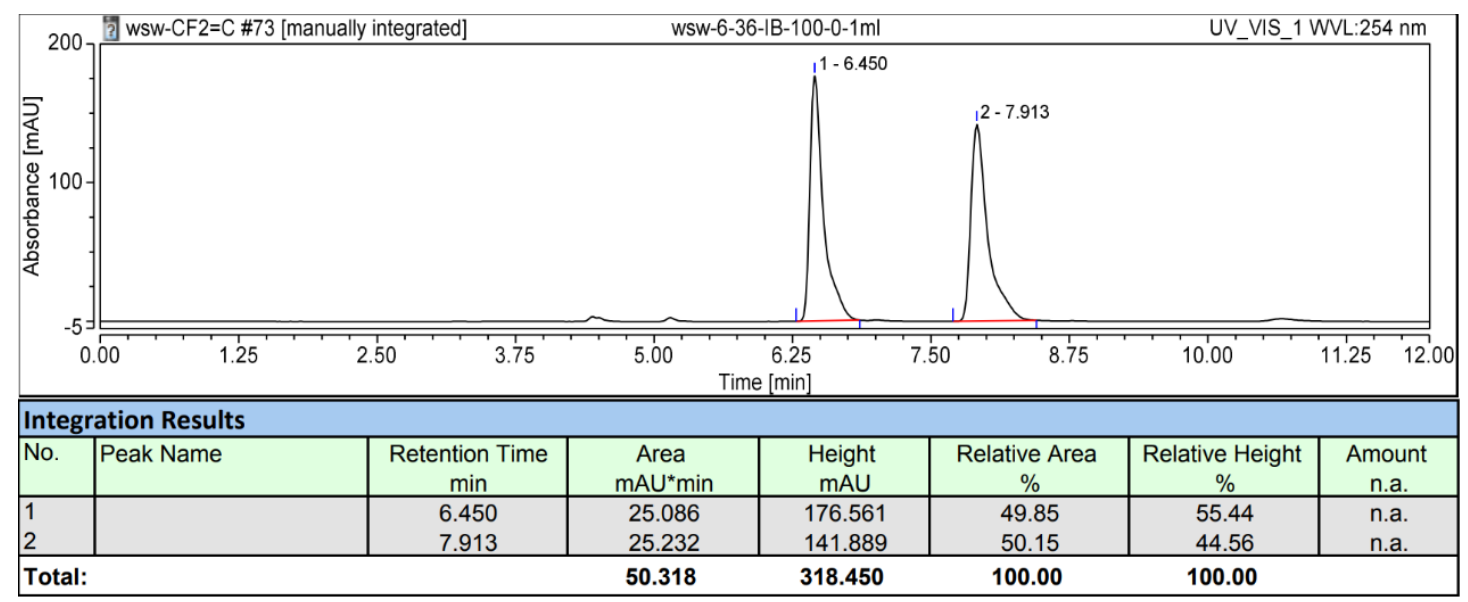

Enantioenriched 5h:

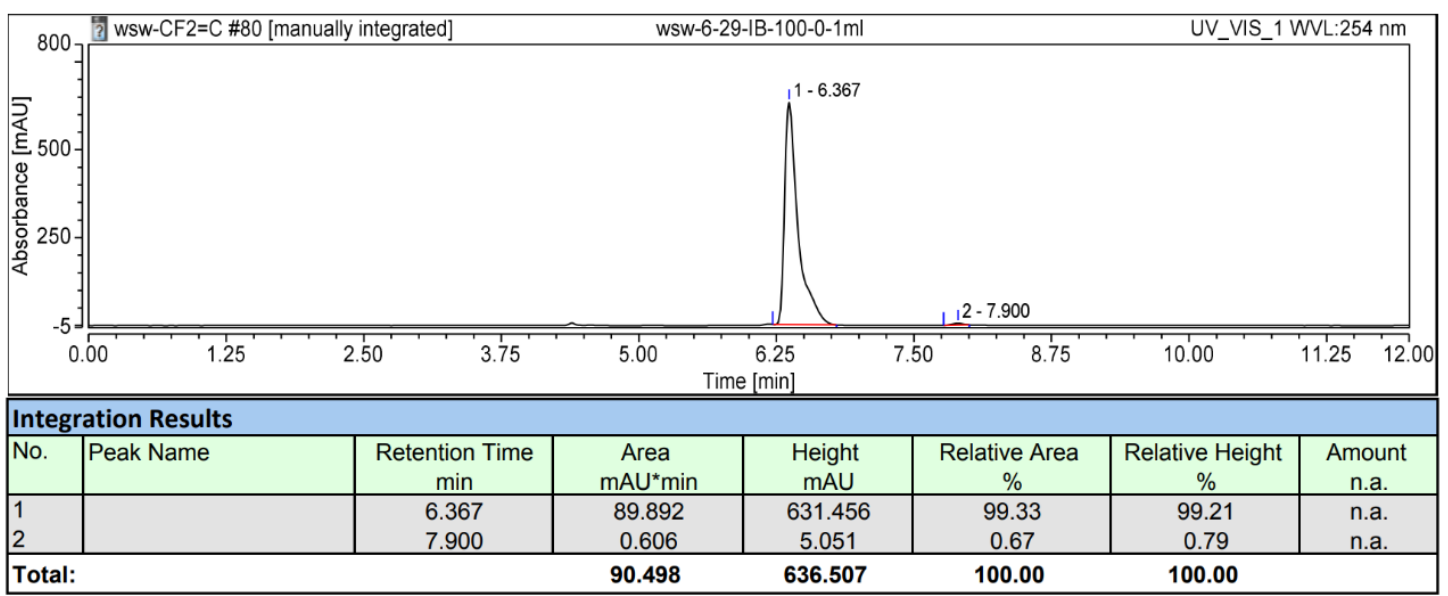

\section{(S)-((5-(4-ethylphenyl)-1,1-difluoro-3-methylpent-1-en-4-yn-2-yl)oxy)dimethyl(phenyl)silane (5i)}

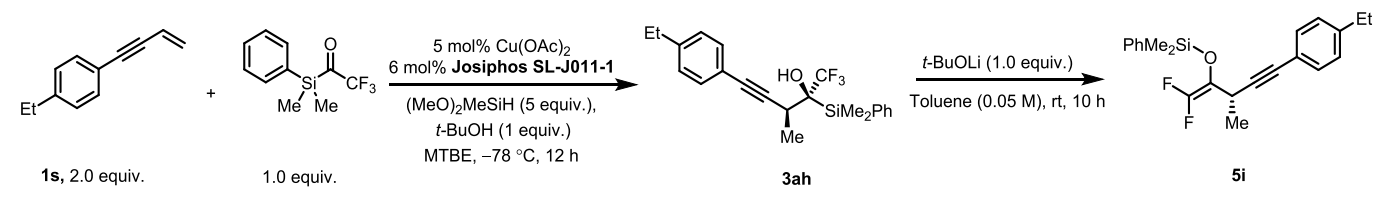

In a glovebox, to an oven-dried $10 \mathrm{~mL}$ Schlenk tube equipped with a magnetic stir bar was added $\mathrm{Cu}(\mathrm{OAc})_{2}$ (5 mol\%), Josiphos SL-J011-1 (6 mol\%), and dry MTBE (1 mL) sequentially. The mixture was stirred at room temperature for $30 \mathrm{~min}$ before the addition of DMMS ( 5 equiv.), $t$ - $\mathrm{BuOH}$ ( 1 equiv.) and $1 \mathrm{~s}$ ( 2 equiv.). The tube was then sealed, removed from the glove box and allowed to stir at $-78{ }^{\circ} \mathrm{C}$ for $5 \mathrm{~min}$, after which the mixture was added 1-(dimethyl(phenyl)silyl)-2,2,2-trifluoroethanone (1 equiv., 
$0.25 \mathrm{mmol}$ ) in $5 \mathrm{~mL}$ MTBE using a syringe driven by an injection pump at a constant flow rate (within $6 \mathrm{~h}$ ). After stirring for another $6 \mathrm{~h}$, a saturated solution of $\mathrm{NH}_{4} \mathrm{~F}$ in $\mathrm{MeOH}$ (ca. $6 \mathrm{~mL}$ ) was carefully added to quench the reaction (Caution: gas evolution was observed). The reaction mixture was allowed to stir for $20 \mathrm{~min}$ at room temperature, diluted with EtOAc (ca. $10 \mathrm{~mL}$ ), stirred for an additional $10 \mathrm{~min}$ at room temperature and then filtered through a short plug of celite $(1-2 \mathrm{~cm})$ eluting with EtOAc $(\mathrm{ca} .50 \mathrm{~mL})$. The solvent was removed in vacuo with the aid of a rotary evaporator. At this point, the crude yield and the diastereomeric ratio $(\mathrm{dr})$ were determined by ${ }^{19} \mathrm{~F}$ NMR spectroscopic analysis using $\mathrm{PhCF}_{3}$ as the internal standard. The crude product was purified with column chromatography on silica gel (300 400 mesh) to afford the title compound 3ah; Colorless oil; $\mathbf{R}_{\mathbf{f}}=0.56(\mathrm{PE} / \mathrm{EA}=10 / 1) ; 50.7 \mathrm{mg}, 52 \%$ yield, > 99\% ee, 97:3 dr; $[\boldsymbol{\alpha}]^{\mathbf{2 5}} \mathbf{D}=-105.9\left(c=1.50, \mathrm{CHCl}_{3}\right)$ NMR spectroscopy: ${ }^{1} \mathbf{H} \mathbf{~ N M R}\left(400 \mathrm{MHz}, \mathrm{CDCl}_{3}, 25\right.$ $\left.{ }^{\circ} \mathrm{C}\right) 7.67-7.62(\mathrm{~m}, 2 \mathrm{H}), 7.46-7.36(\mathrm{~m}, 3 \mathrm{H}), 7.31-7.27(\mathrm{~m}, 2 \mathrm{H}), 7.11(\mathrm{~d}, J=8.3 \mathrm{~Hz}, 2 \mathrm{H}), 3.08(\mathrm{q}, J=7.4$ $\mathrm{Hz}, 1 \mathrm{H}), 2.71(\mathrm{~s}, 1 \mathrm{H}), 2.63(\mathrm{q}, J=7.6 \mathrm{~Hz}, 2 \mathrm{H}), 1.25(\mathrm{dd}, J=7.4,1.8 \mathrm{~Hz}, 3 \mathrm{H}), 1.21(\mathrm{t}, J=7.6 \mathrm{~Hz}, 3 \mathrm{H})$, $0.59(\mathrm{~s}, 3 \mathrm{H}), 0.55(\mathrm{~s}, 3 \mathrm{H}) ;{ }^{13} \mathbf{C} \mathbf{N M R}\left(101 \mathrm{MHz}, \mathrm{CDCl}_{3}, 25^{\circ} \mathrm{C}\right) \delta 144.9,134.9,134.7,131.8,130.2,128.1$, 128.0, 127.9 (q, $J=286.3 \mathrm{~Hz}) 120.0,87.2,85.2,71.32$ (q, $J=27.9 \mathrm{~Hz}), 33.20,28.92,17.4,15.50,-3.20$, -3.46; ${ }^{19}$ F NMR $\left(376 \mathrm{MHz}, \mathrm{CDCl}_{3}, 25^{\circ} \mathrm{C}\right) \delta-67.5$ (s, 3F); IR (ATR): 3481, 3355, 3071, 2967, 1674 , 1513, 1461, 1327, 1260, 1152, 1025, 909, 835, 738, $705 \mathrm{~cm}^{-1}$; HRMS (ESI, m/z): calcd for $\mathrm{C}_{22} \mathrm{H}_{26} \mathrm{~F}_{3} \mathrm{OSi}^{+}$ $(\mathrm{M}+\mathrm{H})^{+}:$391.1700; Found: 391.1686; HPLC analysis (OD-H column, $2 \% i-\mathrm{PrOH} /$ hexane, 0.50 $\mathrm{mL} / \mathrm{min}, 20^{\circ} \mathrm{C}, 254 \mathrm{~nm}$ ) indicated $>99 \%$ ee: $t_{\mathrm{R}}$ (major) $=8.63 \mathrm{~min}$,

\section{Racemic 3ah:}

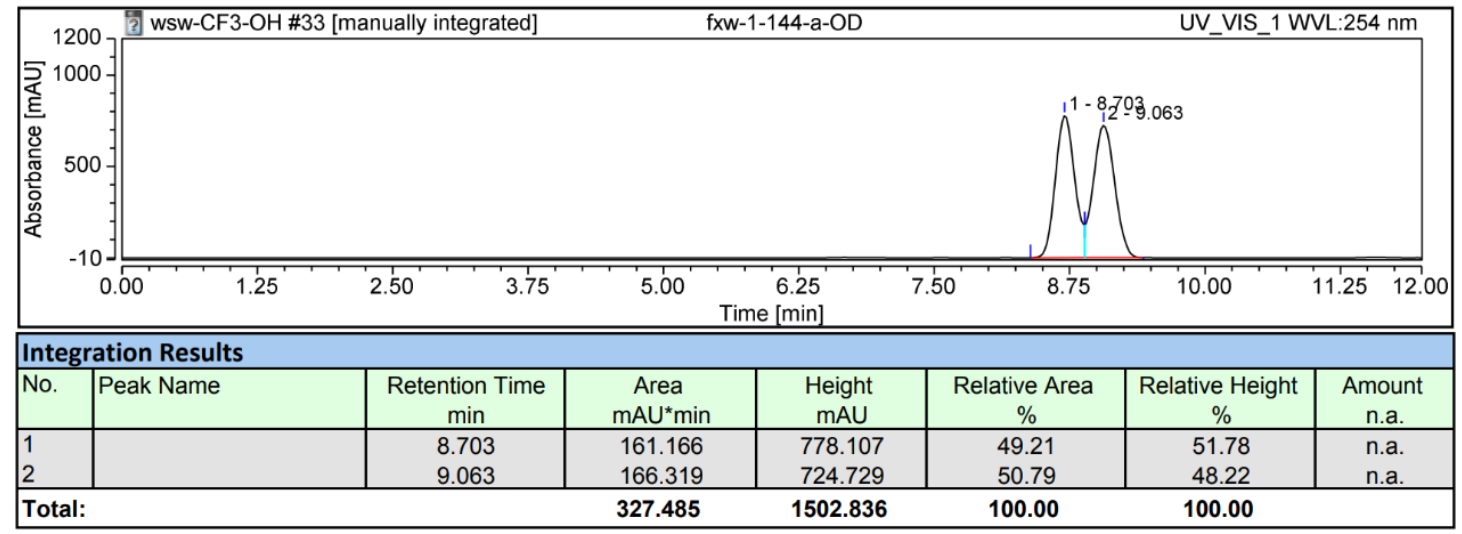

\section{Enantioenriched 3ah:}

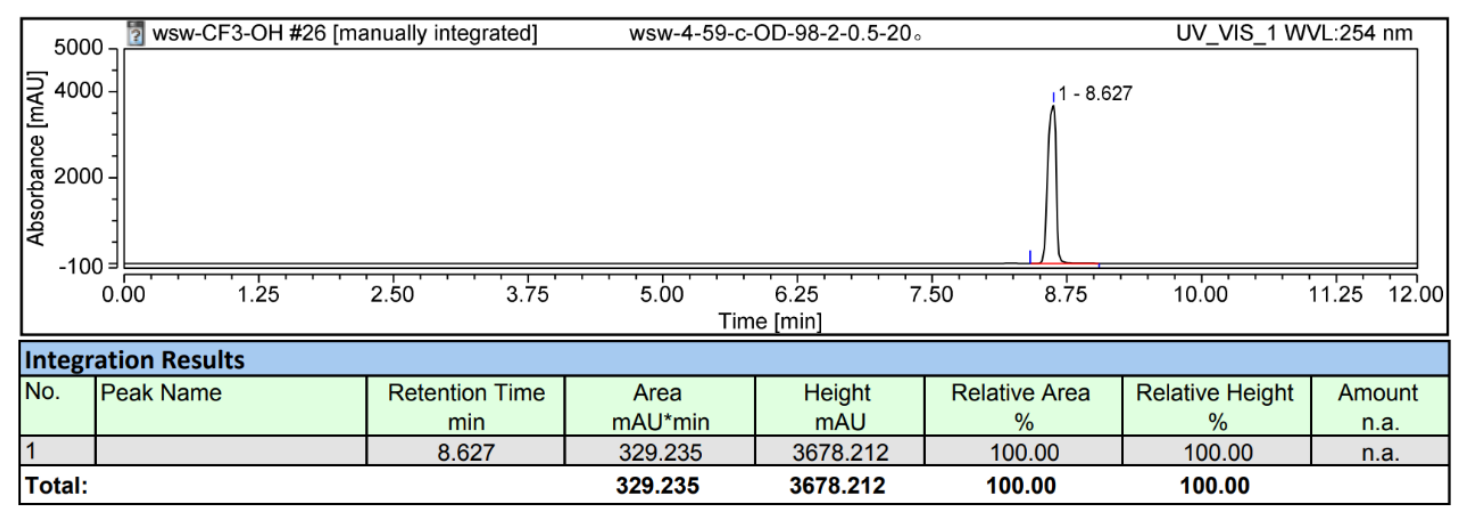

In a glovebox, to an oven-dried $5 \mathrm{~mL}$ screw-cap reaction tube equipped with a magnetic stir bar was added 3ah ( $0.1 \mathrm{mmol}), t$-BuOLi (1 equiv., $0.1 \mathrm{mmol})$, and dry toluene $(2 \mathrm{~mL})$ sequentially. The mixture was stirred at room temperature for $5 \mathrm{~min}$. The tube was then sealed, removed from the glove box and 
allowed to stir at room temperature for $10 \mathrm{~h}$. And then filtered through a short plug of silica gel (100 200 mesh) eluting with hexane (ca. $10 \mathrm{~mL}$ ). The solvent was removed in vacuo with the aid of a rotary evaporator to afford the title compound 5i. Colorless oil; $\mathbf{R}_{\mathbf{f}}=0.81(\mathrm{PE} / \mathrm{EA}=10 / 1) ; 36.6 \mathrm{mg}, 99 \%$ yield, 99\% ee; $[\boldsymbol{\alpha}]^{\mathbf{2 5}} \mathbf{D}=-49.3\left(c=1.08, \mathrm{CHCl}_{3}\right)$; NMR spectroscopy: ${ }^{\mathbf{1}} \mathbf{H} \mathbf{N M R}\left(600 \mathrm{MHz}, \mathrm{CDCl}_{3}, 25^{\circ} \mathrm{C}\right) \delta$ 7.69-7.61 (m, 2H), 7.43-7.30 (m, 3H), 7.26-7.22 (m, 2H), $7.10(\mathrm{~d}, J=8.2 \mathrm{~Hz}, 2 \mathrm{H}), 3.64-3.55(\mathrm{~m}, 1 \mathrm{H})$, $2.63(\mathrm{q}, J=7.6 \mathrm{~Hz}, 2 \mathrm{H}), 1.40(\mathrm{~d}, J=7.1 \mathrm{~Hz}, 3 \mathrm{H}), 1.22(\mathrm{t}, J=7.6 \mathrm{~Hz}, 3 \mathrm{H}), 0.51(\mathrm{~s}, 3 \mathrm{H}), 0.50(\mathrm{~s}, 3 \mathrm{H}) ;{ }^{13} \mathrm{C}$ NMR $\left(151 \mathrm{MHz}, \mathrm{CDCl}_{3}, 2{ }^{\circ} \mathrm{C}\right) \delta 152.6(\mathrm{dd}, J=282.8,278.7 \mathrm{~Hz}), 144.4,137.2,133.6,131.8,131.7$, 130.0, 127.9, 120.6, $114.3(\mathrm{dd}, J=39.6,14.9 \mathrm{~Hz}), 89.2,81.9,28.9,26.6,18.9,15.5,-0.9,-1.2 ;{ }^{19}$ F NMR $\left(565 \mathrm{MHz} \mathrm{CDCl}_{3}, 25^{\circ} \mathrm{C}\right)-105.7(\mathrm{~d}, J=83.6 \mathrm{~Hz}, 1 \mathrm{~F}),-118.8(\mathrm{dd}, J=83.5,3.8 \mathrm{~Hz}, 1 \mathrm{~F})$; IR (ATR): 3310 , 3071, 2959, 2926, 2855, 1763, 1510, 1457, 1375, 1260, 1118, 910, 872, 731, $701 \mathrm{~cm}^{-1}$; HRMS (ESI, $\mathrm{m} / \mathrm{z}$ ): calcd for $\mathrm{C}_{22} \mathrm{H}_{25} \mathrm{~F}_{2} \mathrm{OSi}^{+}(\mathrm{M}+\mathrm{H})^{+}$: 371.1637; Found: 371.1624 ; HPLC analysis (IB N-5 column, hexane, $1.0 \mathrm{~mL} / \min , 20^{\circ} \mathrm{C}, 254 \mathrm{~nm}$ ) indicated $99 \%$ ee: $t_{\mathrm{R}}($ major $)=5.94 \mathrm{~min}, t_{\mathrm{R}}($ minor $)=7.11 \mathrm{~min}$.

\section{Racemic 5i:}

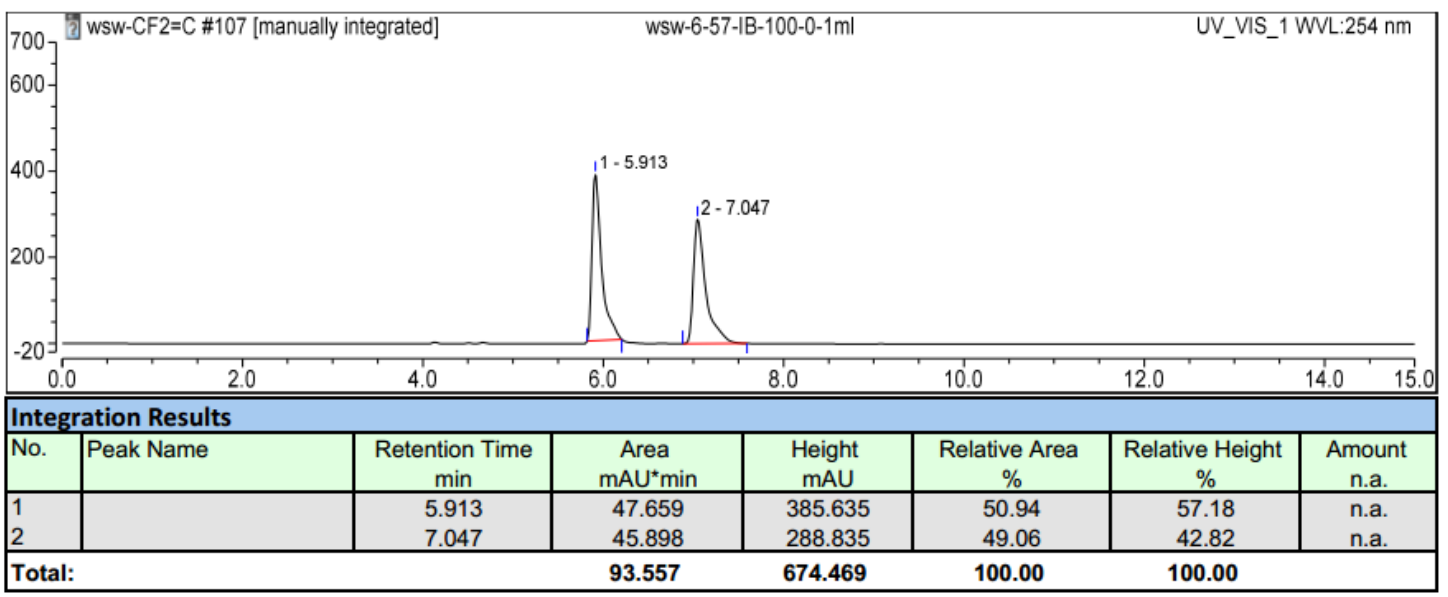

Enantioenriched 5i:

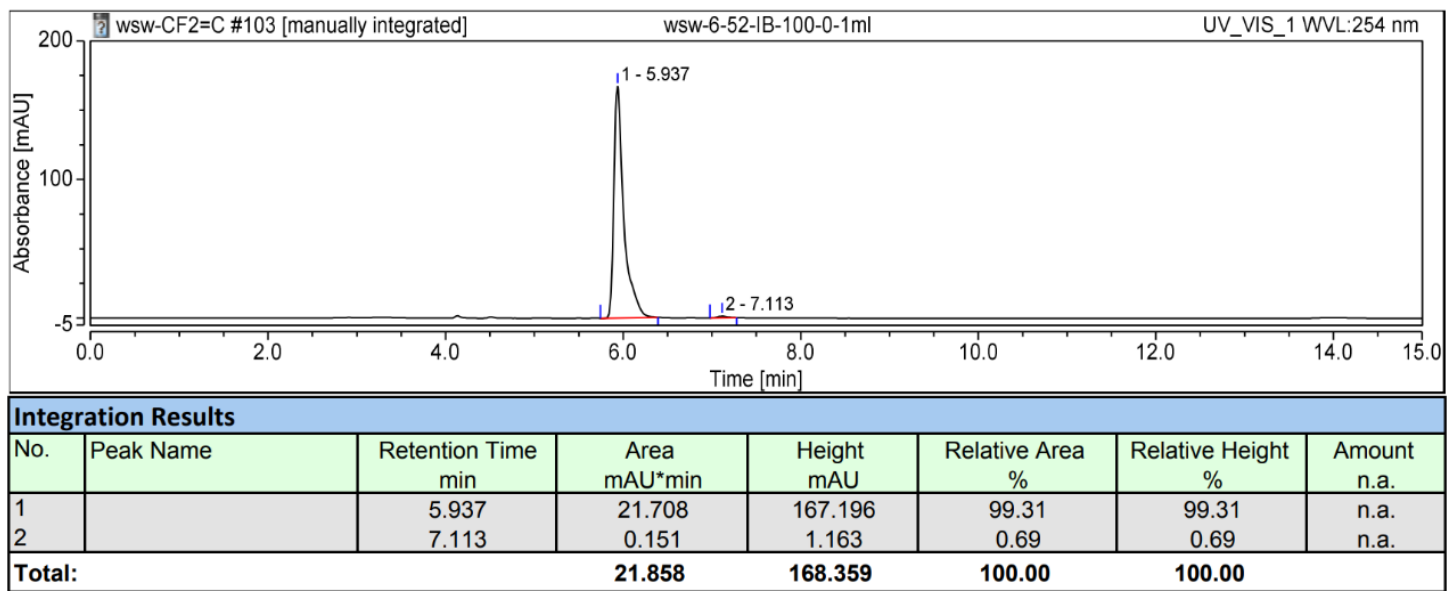


(S)-((5-(4-(tert-butyl)phenyl)-1,1-difluoro-3-methylpent-1-en-4-yn-2-

yl)oxy)dimethyl(phenyl)silane (5j)

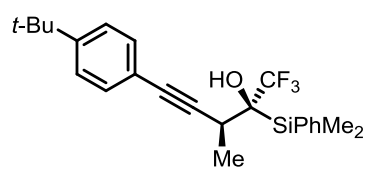

$3 \mathrm{~m}$

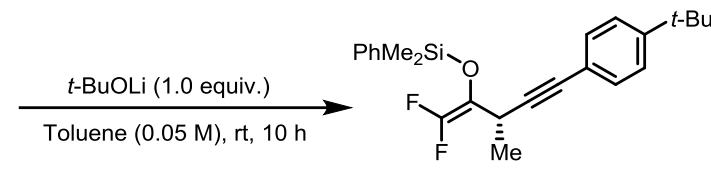

5j

In a glovebox, to an oven-dried $5 \mathrm{~mL}$ screw-cap reaction tube equipped with a magnetic stir bar was added $3 \mathrm{~m}(0.1 \mathrm{mmol}), t$-BuOLi ( 1 equiv., $0.1 \mathrm{mmol})$, and dry toluene $(2 \mathrm{~mL})$ sequentially. The mixture was stirred at room temperature for $5 \mathrm{~min}$. The tube was then sealed, removed from the glove box and allowed to stir at room temperature for $10 \mathrm{~h}$. And then filtered through a short plug of silica gel (100 200 mesh) eluting with hexane (ca. $10 \mathrm{~mL}$ ). The solvent was removed in vacuo with the aid of a rotary evaporator to afford the title compound $\mathbf{5 j}$. Colorless oil; $\mathbf{R}_{\mathbf{f}}=0.89$ (PE/EA $\left.=10 / 1\right) ; 39.4 \mathrm{mg}, 99 \%$ yield, 98\% ee; $[\alpha]^{25} \mathbf{D}=-9.49\left(c=5.43, \mathrm{CHCl}_{3}\right)$; NMR spectroscopy: ${ }^{1} \mathbf{H} \mathbf{~ N M R}\left(600 \mathrm{MHz}, \mathrm{CDCl}_{3}, 25{ }^{\circ} \mathrm{C}\right) \delta$ 7.68-7.65 (m, 2H), 7.41-7.32 (m, 3H), 7.31-7.23 (m, 4H), 3.63-3.56 (m, 1H), $1.40(\mathrm{~d}, J=7.1 \mathrm{~Hz}, 3 \mathrm{H})$, $1.30(\mathrm{~s}, 9 \mathrm{H}), 0.52(\mathrm{~s}, 3 \mathrm{H}), 0.51(\mathrm{~s}, 3 \mathrm{H}) ;{ }^{13} \mathbf{C}$ NMR $\left(151 \mathrm{MHz}, \mathrm{CDCl}_{3}, 25^{\circ} \mathrm{C}\right) \delta 152.6(\mathrm{dd}, J=283.0,278.6$ $\mathrm{Hz}), 151.2,137.2,133.6,131.4,130.0,127.9,125.3,120.4,114.3$ (dd, $J=39.7,14.8 \mathrm{~Hz}$ ), 89.2, 81.8, $34.8,31.3,26.6,18.9,-0.9,-1.2 ;{ }^{19} \mathbf{F}$ NMR $\left(376 \mathrm{MHz}, \mathrm{CDCl}_{3}, 25^{\circ} \mathrm{C}\right) \delta-105.6(\mathrm{~d}, J=83.3 \mathrm{~Hz}, 1 \mathrm{~F})$, -118.7 (dd, $J=83.4,3.0 \mathrm{~Hz}, 1 \mathrm{~F})$. IR (ATR): 3314, 3142, 3071, 2960, 2870, 1759, 1696, 1509, 1461, 1260, 1118, 872, 794, 731, $700.7 \mathrm{~cm}^{-1}$;HRMS (ESI, m/z): calcd for $\mathrm{C}_{24} \mathrm{H}_{29} \mathrm{~F}_{2} \mathrm{OSi}^{+}(\mathrm{M}+\mathrm{H})^{+}: 399.1950$; Found: 399.1937; HPLC analysis (IB N-5 column, hexane, $1.0 \mathrm{~mL} / \mathrm{min}, 20^{\circ} \mathrm{C}, 254 \mathrm{~nm}$ ) indicated $98 \%$ ee: $t_{\mathrm{R}}($ major $)=4.66 \mathrm{~min}, t_{\mathrm{R}}($ minor $)=5.03 \mathrm{~min}$.

\section{Racemic 5j:}

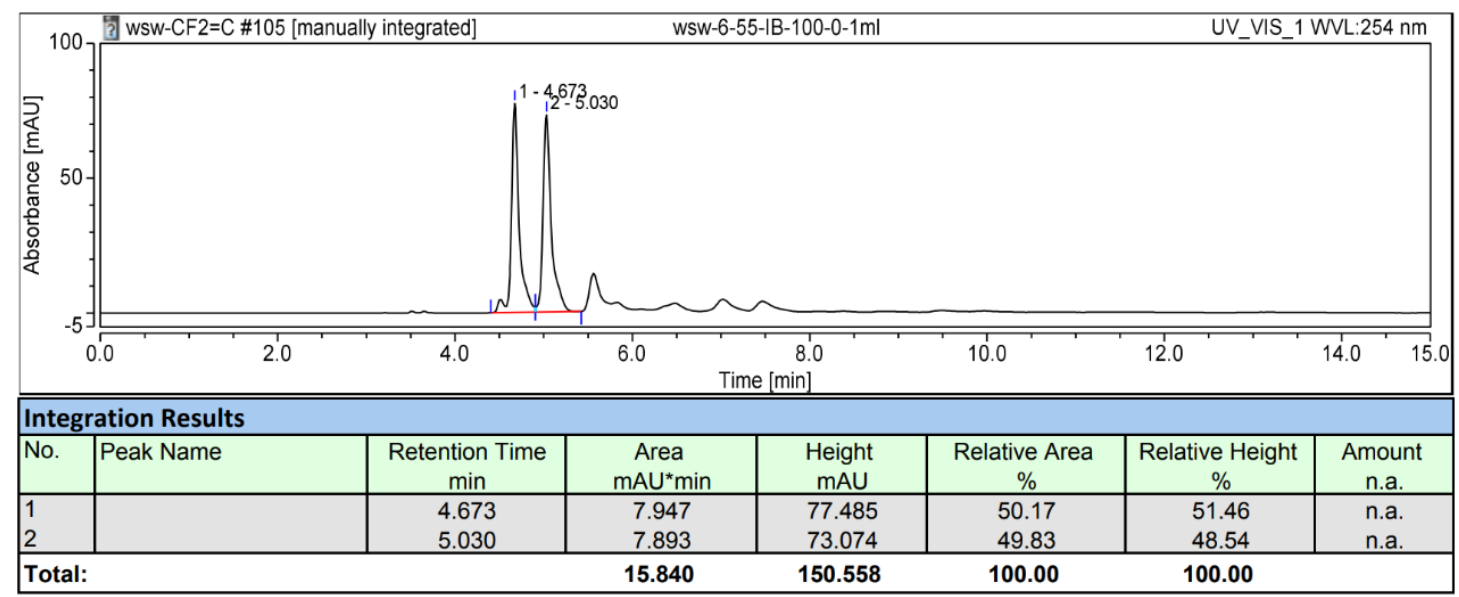




\section{Enantioenriched 5j:}

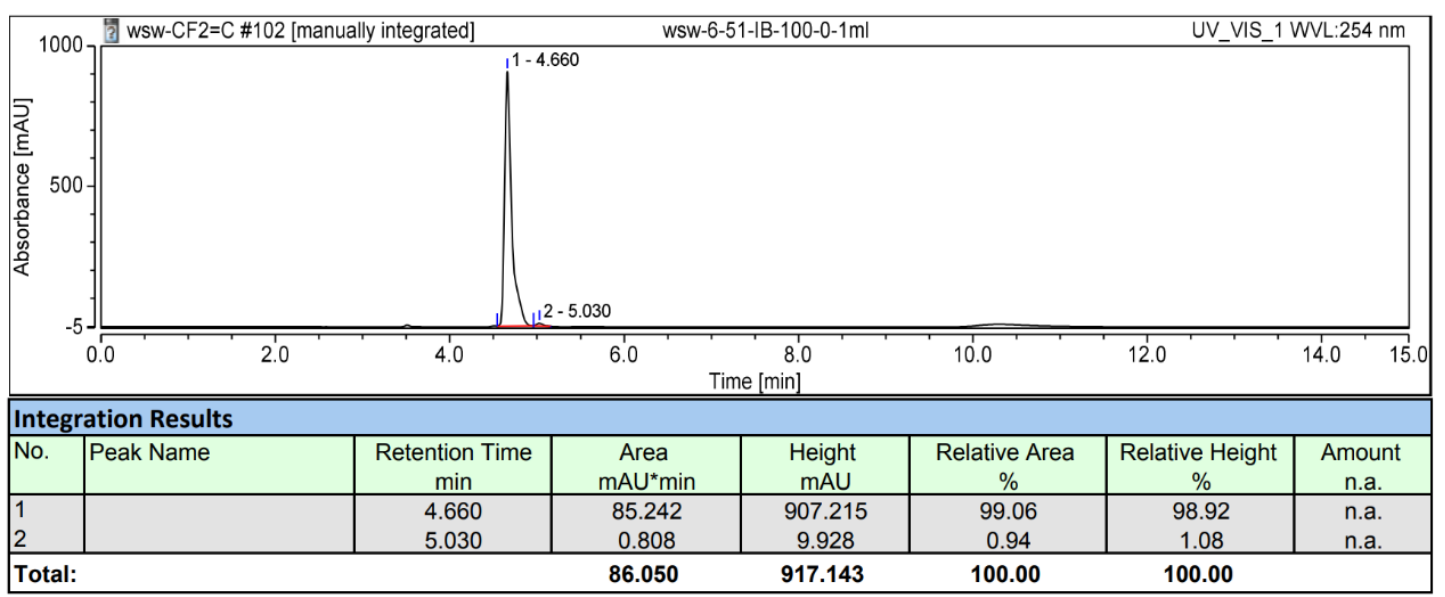

(S)-((1,1-difluoro-3-methyl-5-(thiophen-2-yl)pent-1-en-4-yn-2-yl)oxy)dimethyl(phenyl)silane (5k)

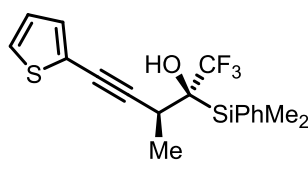

$3 n$

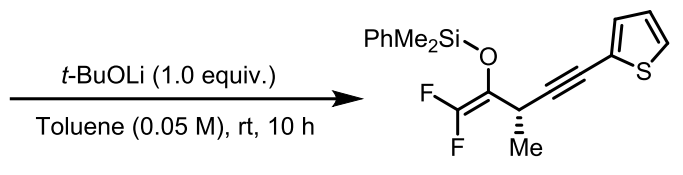

$5 \mathbf{k}$

In a glovebox, to an oven-dried $5 \mathrm{~mL}$ screw-cap reaction tube equipped with a magnetic stir bar was added $3 \mathbf{n}(0.1 \mathrm{mmol}), t$-BuOLi (1 equiv., $0.1 \mathrm{mmol})$, and dry toluene $(2 \mathrm{~mL})$ sequentially. The mixture was stirred at room temperature for $5 \mathrm{~min}$. The tube was then sealed, removed from the glove box and allowed to stir at room temperature for $10 \mathrm{~h}$. And then filtered through a short plug of silica gel (100 200 mesh) eluting with hexane (ca. $10 \mathrm{~mL}$ ). The solvent was removed in vacuo with the aid of a rotary evaporator to afford the title compound $\mathbf{5 k}$. Colorless oil; $\mathbf{R}_{\mathbf{f}}=0.80(\mathrm{PE} / \mathrm{EA}=10 / 1) ; 34.5 \mathrm{mg}, 99 \%$ yield, > $99 \%$ ee; $[\alpha]^{25} \mathbf{D}=-34.2\left(c=2.25, \mathrm{CHCl}_{3}\right)$; NMR spectroscopy: ${ }^{1} \mathbf{H}$ NMR $\left(600 \mathrm{MHz}, \mathrm{CDCl}_{3}, 25{ }^{\circ} \mathrm{C}\right) \delta$ $7.68-7.64(\mathrm{~m}, 2 \mathrm{H}), 7.43-7.34(\mathrm{~m}, 3 \mathrm{H}), 7.20(\mathrm{dd}, J=5.2,1.2 \mathrm{~Hz}, 1 \mathrm{H}), 7.08(\mathrm{dd}, J=3.6,1.1 \mathrm{~Hz}, 1 \mathrm{H})$, $6.94(\mathrm{dd}, J=5.2,3.6 \mathrm{~Hz}, 1 \mathrm{H}), 3.65-3.58(\mathrm{~m}, 1 \mathrm{H}), 1.41(\mathrm{~d}, J=7.1 \mathrm{~Hz}, 3 \mathrm{H}), 0.52(\mathrm{~s}, 3 \mathrm{H}), 0.51(\mathrm{~s}, 3 \mathrm{H})$; ${ }^{13} \mathrm{C}$ NMR $\left(151 \mathrm{MHz}, \mathrm{CDCl}_{3}, 25^{\circ} \mathrm{C}\right) \delta 152.6(\mathrm{dd}, J=283.4,278.9 \mathrm{~Hz}), 137.0,133.6,131.7,130.0,128.0$, $127.0,126.7,123.5,114.0(\mathrm{dd}, J=39.7,15.1 \mathrm{~Hz}), 93.9,75.1,26.9,18.6,-0.9,-1.2 ;{ }^{19} \mathbf{F}$ NMR $(376 \mathrm{MHz}$, $\left.\mathrm{CDCl}_{3}, 25^{\circ} \mathrm{C}\right) \delta-105.3(\mathrm{~d}, J=83.1 \mathrm{~Hz}, 1 \mathrm{~F}),-118.5(\mathrm{dd}, J=82.6,4.8 \mathrm{~Hz}, 1 \mathrm{~F})$; IR (ATR): 3321,3071 , 2926, 1763, 1592, 1428, 1260, 1193, 1103, 1036, 887, 835, 790, 731, $701 \mathrm{~cm}^{-1}$; HRMS (ESI, m/z): calcd for $\mathrm{C}_{18} \mathrm{H}_{19} \mathrm{~F}_{2} \mathrm{OSSi}^{+}(\mathrm{M}+\mathrm{H})^{+}: 349.0889$; Found: 349.0893; HPLC analysis (IB N-5 column, hexane, 1.0 $\mathrm{mL} / \mathrm{min}, 20^{\circ} \mathrm{C}, 254 \mathrm{~nm}$ ) indicated $98 \%$ ee: $t_{\mathrm{R}}($ major $)=7.27 \mathrm{~min}, t_{\mathrm{R}}($ minor $)=7.69 \mathrm{~min}$. 
Racemic 5k:

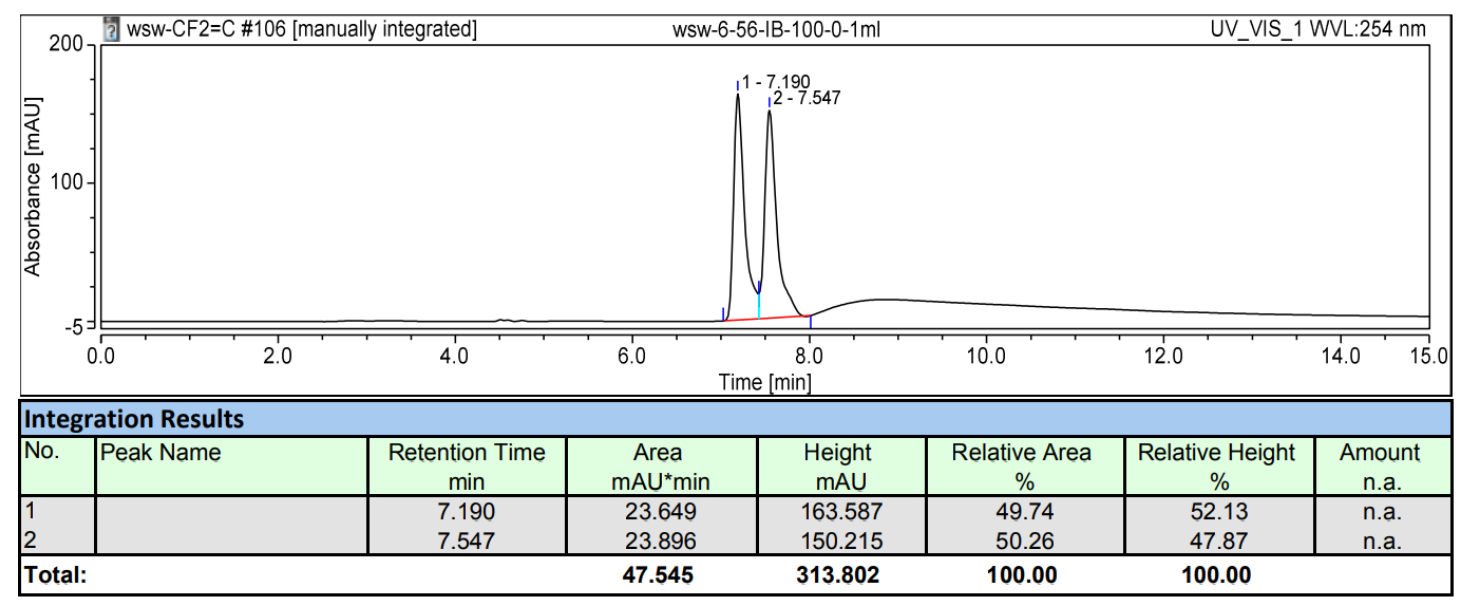

\section{Enantioenriched 5k:}

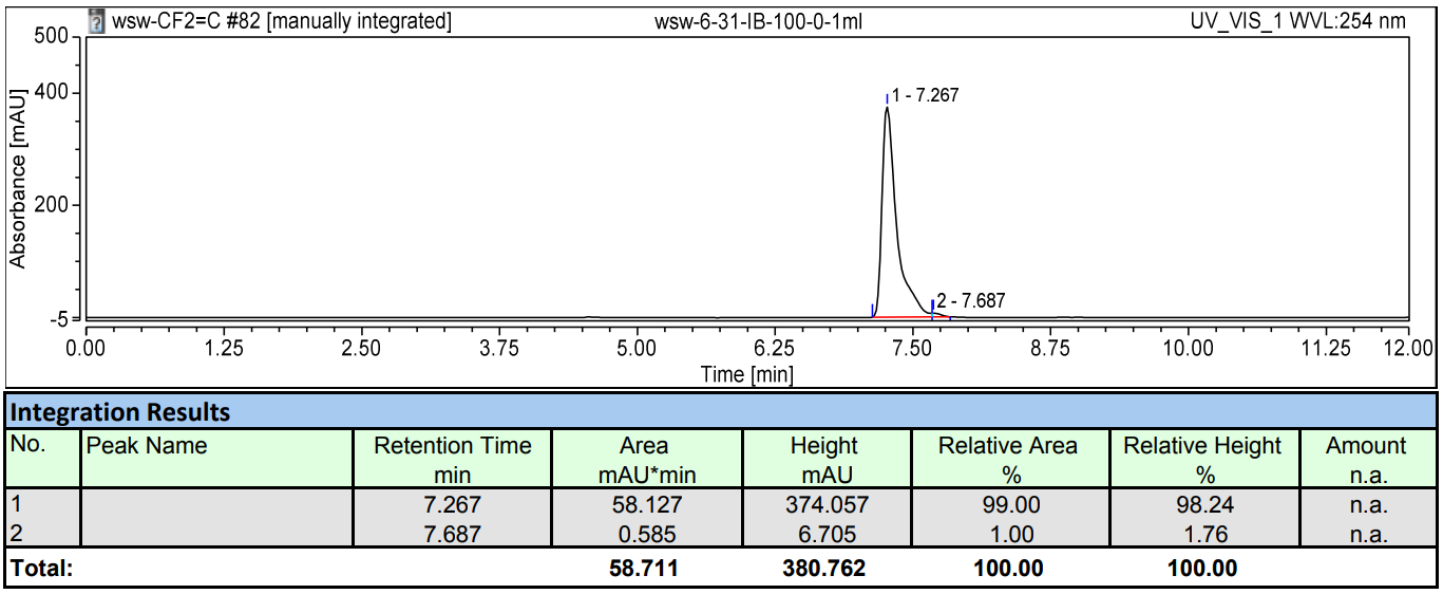

(S)-((1-fluoro-3-methyl-5-phenylpent-1-en-4-yn-2-yl)oxy)dimethyl(phenyl)silane (5l)

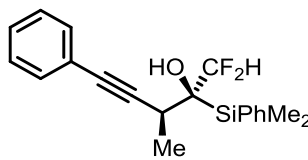

$3 r$

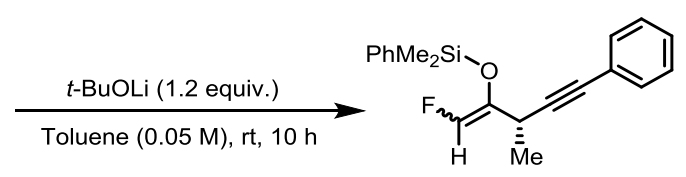

5

In a glovebox, to an oven-dried $5 \mathrm{~mL}$ screw-cap reaction tube equipped with a magnetic stir bar was added $3 \mathbf{r}(0.1 \mathrm{mmol}), t$-BuOLi (1 equiv., $0.1 \mathrm{mmol})$, and dry toluene $(2 \mathrm{~mL})$ sequentially. The mixture was stirred at room temperature for $5 \mathrm{~min}$. The tube was then sealed, removed from the glove box and allowed to stir at room temperature for $10 \mathrm{~h}$. And then filtered through a short plug of silica gel (100 200 mesh) eluting with hexane (ca. $10 \mathrm{~mL}$ ). The solvent was removed in vacuo with the aid of a rotary evaporator to afford the title compound 5l. Colorless oil; $\mathbf{R}_{\mathbf{f}}=0.75(\mathrm{PE} / \mathrm{EA}=10 / 1) ; 30.1 \mathrm{mg}, 93 \%$ yield, 99\% ee; 85:15 (Z/E); $[\alpha]^{25} \mathbf{D}=-12.5\left(c=3.50, \mathrm{CHCl}_{3}\right)$; NMR spectroscopy: ${ }^{1} \mathbf{H} \mathbf{~ N M R}\left(400 \mathrm{MHz}, \mathrm{CDCl}_{3}\right.$, $\left.25^{\circ} \mathrm{C}\right) \delta 7.69-7.62(\mathrm{~m}, 2 \mathrm{H}$, major + minor), 7.41-7.34 (m, 5H, major + minor), 7.29-7.26 (m, 3H, major + minor), 6.63 (d, $J=77.6 \mathrm{~Hz}, 0.85 \mathrm{H}$, major), 6.47 (d, $J=80.3 \mathrm{~Hz}, 0.15 \mathrm{H}$, minor), 3.99-3.93 (m, 0.15H, minor), 3.25-3.19 (m, 0.85H, major), 1.41 (d, $J=7.0 \mathrm{~Hz}, 3 \mathrm{H}$, major + minor), 0.52-0.50 (m, 6H, major + minor); ${ }^{13} \mathrm{C}$ NMR $\left(151 \mathrm{MHz}, \mathrm{CDCl}_{3}, 25{ }^{\circ} \mathrm{C}\right) \delta 143.0(\mathrm{~d}, J=27.3 \mathrm{~Hz}$, minor), $138.8(\mathrm{~d}, J=6.6 \mathrm{~Hz}$, 
major), 137.7 (major), 137.3 (minor), 136.8 (minor), 135.1 (major), 133.5 (major), 133.4 (minor), 131.8 (minor), 131.7 (major), 130.1 (minor), 129.9 (major), 128.4 (major), 128.3 (minor), 128.1 (minor), 128.1 (major), 127.9 (major), 127.9 (minor), 90.5 (minor), 89.7 (major), 82.5 (major), 81.1 (minor), 28.9 (major), 26.0 (minor), 19.4 (major), 18.8 (minor), -0.9 (major + minor), -1.4 (major + minor); ${ }^{19}$ F NMR $\left(376 \mathrm{MHz}, \mathrm{CDCl} 3,25^{\circ} \mathrm{C}\right) \delta-161.4(\mathrm{~d}, J=78.8 \mathrm{~Hz}, 0.85 \mathrm{~F}$, major), -171.1 (dd, $J=80.9,5.2 \mathrm{~Hz}, 0.15 \mathrm{~F}$, minor); IR (ATR): 3321, 3213, 3056, 2922, 2855, 2240, 1692, 1595, 1491, 1349, 1200, 1118, 820, 757, $693 \mathrm{~cm}^{-1}$; HRMS (ESI, m/z): calcd for $\mathrm{C}_{20} \mathrm{H}_{22} \mathrm{FOSi}^{+}(\mathrm{M}+\mathrm{H})^{+}:$325.1419; Found: 325.1421; HPLC analysis (IB N-5 column, hexane, $1.0 \mathrm{~mL} / \mathrm{min}, 20^{\circ} \mathrm{C}, 254 \mathrm{~nm}$ ) indicated $99 \%$ ee $(\mathrm{Z}): t_{\mathrm{R}}$ (major) $=14.10$ $\min , t_{\mathrm{R}}($ minor $)=12.30 \mathrm{~min}$; indicated $99 \%$ ee $(\mathrm{E}): t_{\mathrm{R}}($ major $)=9.00 \mathrm{~min}, t_{\mathrm{R}}($ minor $)=8.15 \mathrm{~min}$.

\section{NOESY of 5 I}

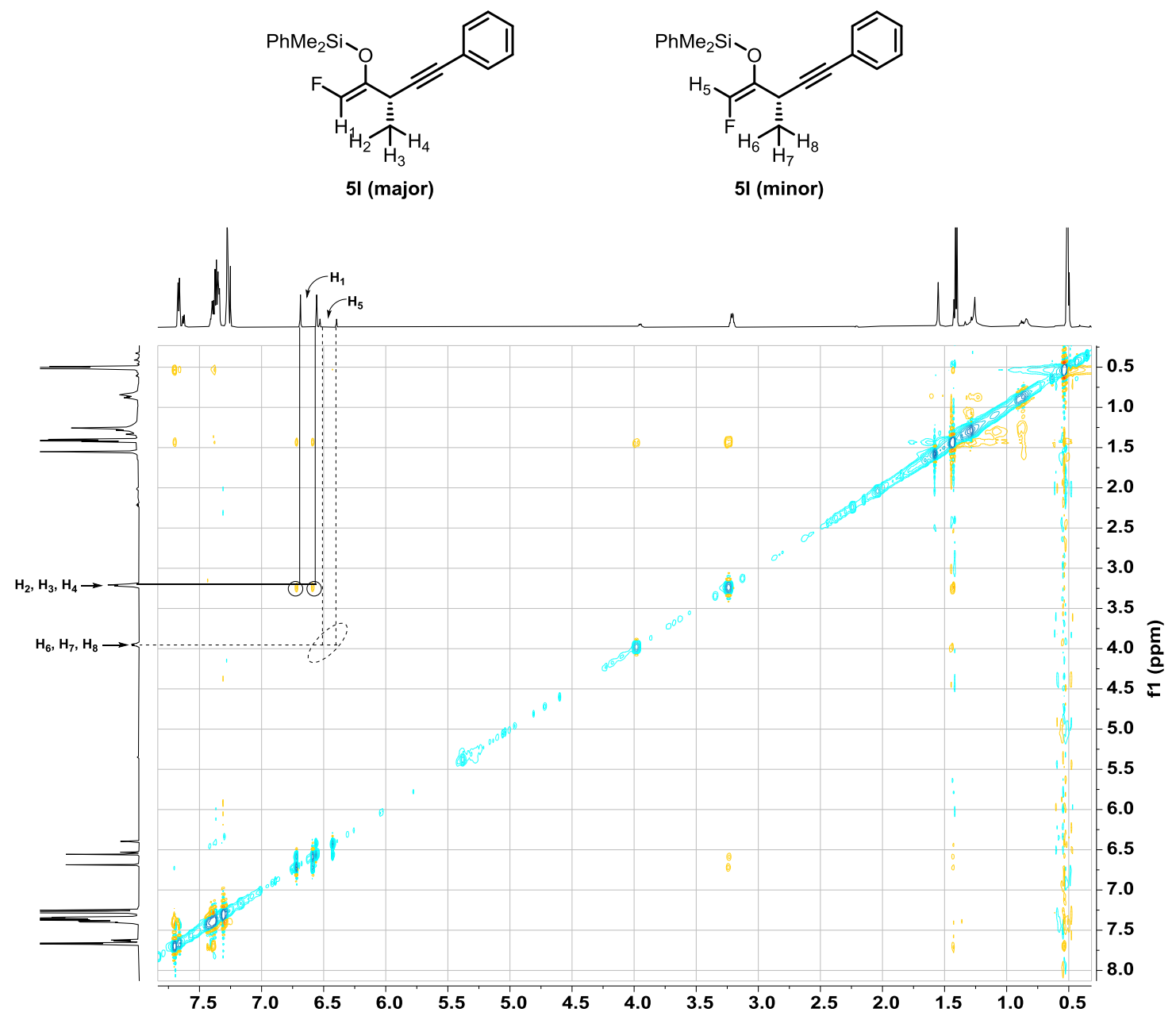

NOESY: $\mathrm{H}_{1}-\mathrm{H}_{2}, \mathrm{H}_{3}, \mathrm{H}_{4}$

$\mathrm{H}_{1}$ is correlated with $\mathrm{H}_{2}, \mathrm{H}_{3}, \mathrm{H}_{4}$ in NOESY spectroscopy. Therefore, 51 (major) was determined to be Z-type.

NOESY: $\mathrm{H}_{5}-\mathrm{H}_{6}, \mathrm{H}_{7}, \mathrm{H}_{8}$

$\mathrm{H}_{5}$ is not correlated with $\mathrm{H}_{6}, \mathrm{H}_{7}, \mathrm{H}_{8}$ in NOESY spectroscopy. Therefore, 51 (minor) was determined to be E-type. 
Racemic 51:

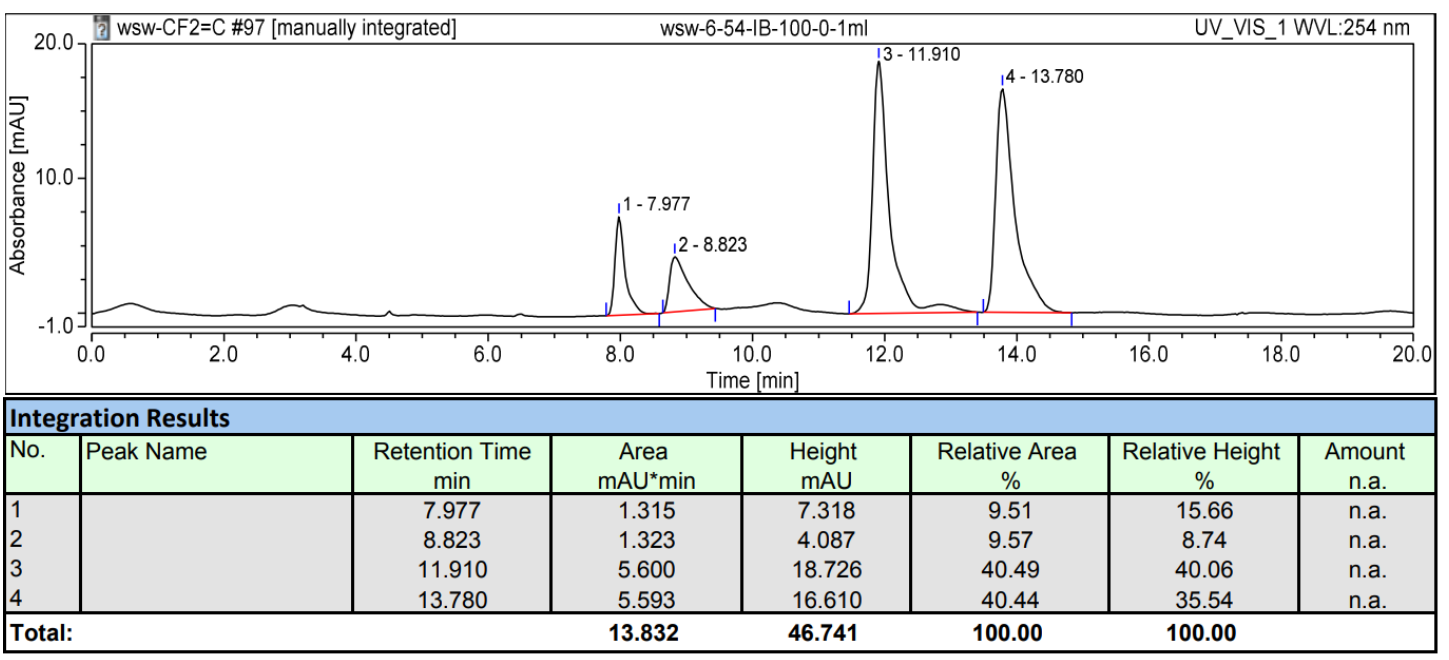

Enantioenriched 5l (Z):

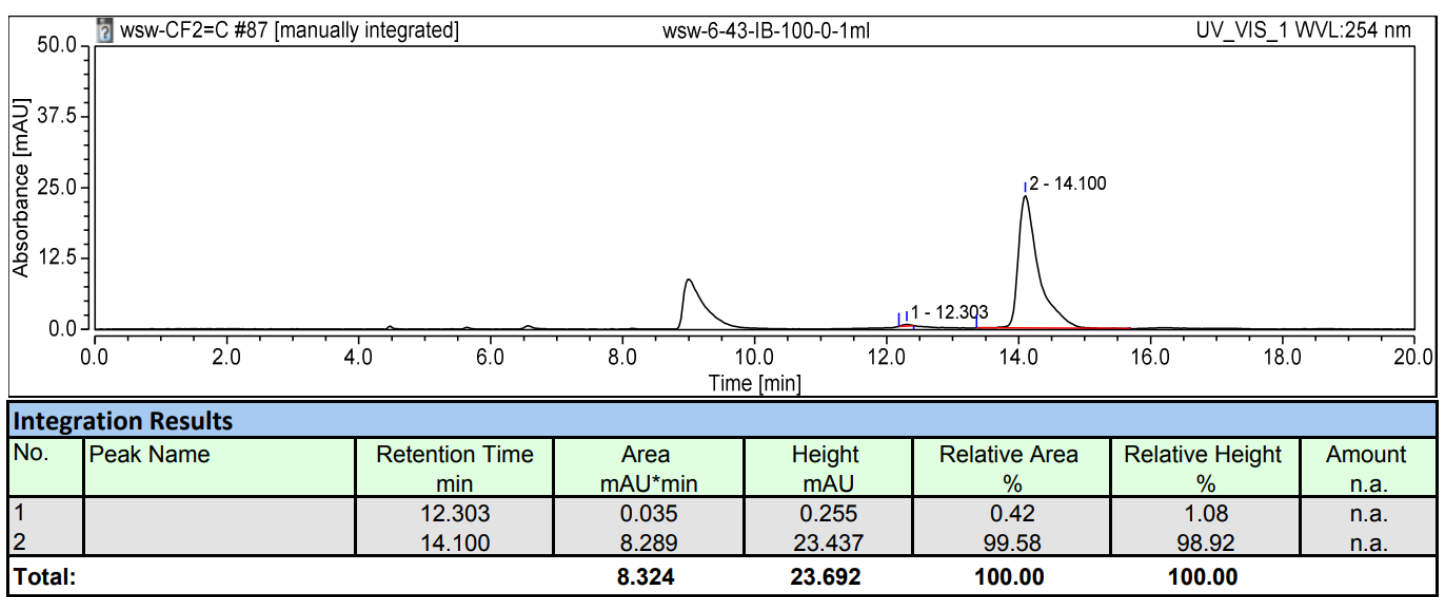

\section{Enantioenriched 5l (E):}

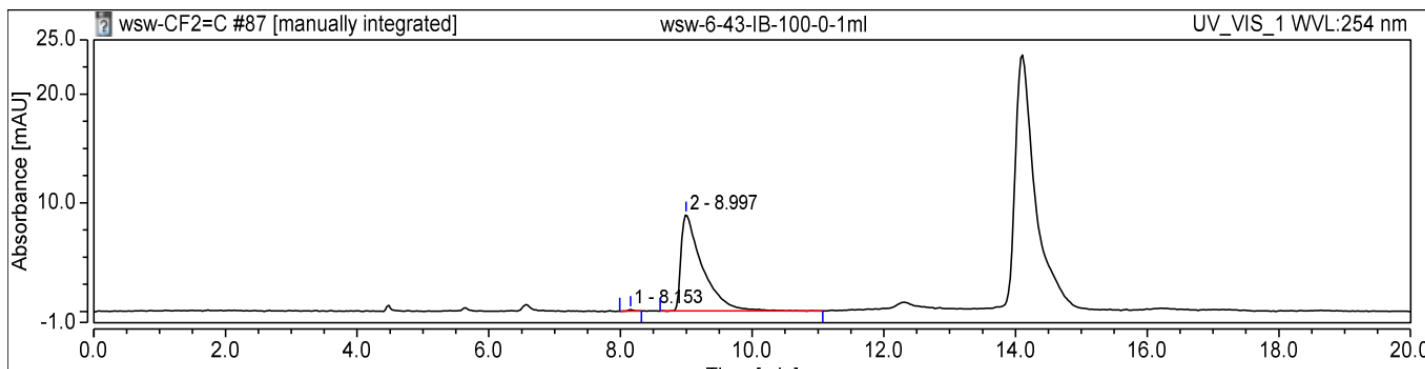

\begin{tabular}{|c|c|c|c|c|c|c|c|}
\hline \multicolumn{8}{|c|}{ Integration Results } \\
\hline No. & Peak Name & $\begin{array}{c}\text { Retention Time } \\
\text { min }\end{array}$ & $\begin{array}{c}\text { Area } \\
\mathrm{mAU* \operatorname {min }}\end{array}$ & $\begin{array}{c}\text { Height } \\
\text { mAU }\end{array}$ & $\begin{array}{c}\text { Relative Area } \\
\% \\
\end{array}$ & $\begin{array}{c}\text { Relative Height } \\
\% \\
\end{array}$ & $\begin{array}{c}\text { Amount } \\
\text { n.a. }\end{array}$ \\
\hline \begin{tabular}{|l}
1 \\
2 \\
\end{tabular} & & $\begin{array}{l}8.153 \\
8.997 \\
\end{array}$ & $\begin{array}{l}0.012 \\
3.326 \\
\end{array}$ & $\begin{array}{l}0.142 \\
8.861 \\
\end{array}$ & $\begin{array}{c}0.35 \\
99.65 \\
\end{array}$ & $\begin{array}{c}1.58 \\
98.42 \\
\end{array}$ & $\begin{array}{l}\text { n.a. } \\
\text { n.a. }\end{array}$ \\
\hline \multicolumn{3}{|c|}{ Total: } & 3.337 & 9.003 & 100.00 & 100.00 & \\
\hline
\end{tabular}


Multi-steps-one-isolation process for the synthesis of (S)-((1,1-difluoro-3-methyl-5- phenylpent-1en-4-yn-2-yl)oxy)dimethyl(phenyl)silane (5a)

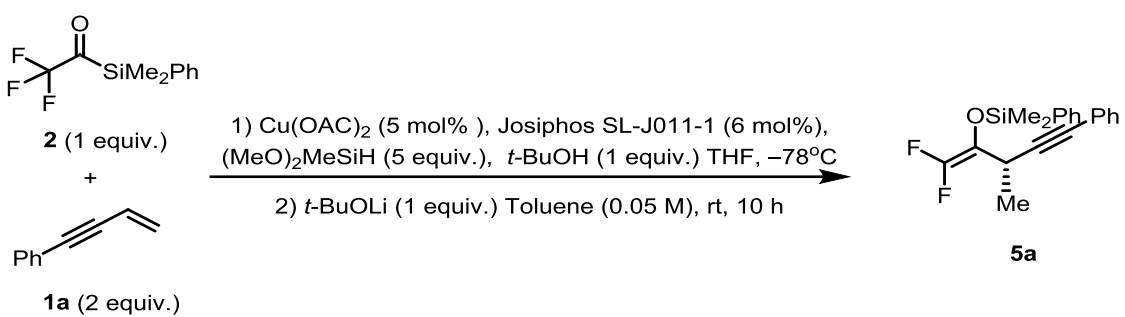

1) In a glovebox, to an oven-dried $10 \mathrm{~mL}$ Schlenk tube equipped with a magnetic stir bar was added $\mathrm{Cu}(\mathrm{OAC})_{2}$ (2.3 mg, $\left.0.0125 \mathrm{mmol}, 5 \mathrm{~mol} \%\right)$, Josiphos SL-J011-1 (10.2 mg, $\left.0.015 \mathrm{mmol}, 6 \mathrm{~mol} \%\right)$, and dry THF $(1 \mathrm{~mL})$ sequentially. The mixture was stirred at room temperature for $30 \mathrm{~min}$ before the addition of DMMS (153.5 $\mu \mathrm{L}, 1.25 \mathrm{mmol}, 5$ equiv.), $t$ - $\mathrm{BuOH}$ ( $24 \mu \mathrm{L}, 0.25 \mathrm{mmol}, 1$ equiv.) and $\mathbf{1 a}(67 \mu \mathrm{L}, 0.5$ mmol, 2 equiv.). The tube was then sealed, removed from the glove box and allowed to stir at $-78{ }^{\circ} \mathrm{C}$ for 5 min, after which the mixture was added slowly (within 6 h) 1-(dimethyl(phenyl)silyl)-2,2,2trifluoroethan-1-one 2 (58 mg, $0.25 \mathrm{mmol}, 1$ equiv.) in $5 \mathrm{~mL}$ THF. After stirring for another $6 \mathrm{~h}$, then a saturated solution of $\mathrm{NH}_{4} \mathrm{~F}$ in $\mathrm{MeOH}$ (ca. $6 \mathrm{~mL}$ ) was carefully added to quench the reaction (Caution: gas evolution was observed). The reaction mixture was allowed to stir for $20 \mathrm{~min}$ at room temperature, diluted with EtOAc (ca. $10 \mathrm{~mL}$ ), stirred for an additional $10 \mathrm{~min}$ at room temperature and then filtered through a short plug of silica gel (100 200 mesh) eluting with hexane (ca. $50 \mathrm{~mL})$. The solvent was removed in vacuo with the aid of a rotary evaporator to afford the crude compound.

2) In a glovebox, to an oven-dried $5 \mathrm{~mL}$ screw-cap reaction tube equipped with a magnetic stir bar was added the crude product, $t$ - $\mathrm{BuOLi}(20 \mathrm{mg}, 0.25 \mathrm{mmol} 1$ equiv.), and dry toluene $(5 \mathrm{~mL})$ sequentially. The mixture was stirred at room temperature for $5 \mathrm{~min}$. The tube was then sealed, removed from the glove box and allowed to stir at room temperature for $10 \mathrm{~h}$. And then filtered through a short plug of silica gel (100 200 mesh) eluting with hexane (ca. $25 \mathrm{~mL}$ ). The solvent was removed in vacuo with the aid of a rotary evaporator to afford the crude compound 5a. The crude product was purified with column chromatography on silica gel (100 200 mesh) to afford the title compound 5a. $65.0 \mathrm{mg}, 76 \%$ yield, $99 \%$ ee; HPLC analysis (IB N-5 column, hexane, $1.0 \mathrm{~mL} / \mathrm{min}, 20{ }^{\circ} \mathrm{C}, 254 \mathrm{~nm}$ ) indicated $99 \%$ ee: $t_{\mathrm{R}}$ (major) $=6.15 \mathrm{~min}$.

\section{Racemic 5a:}

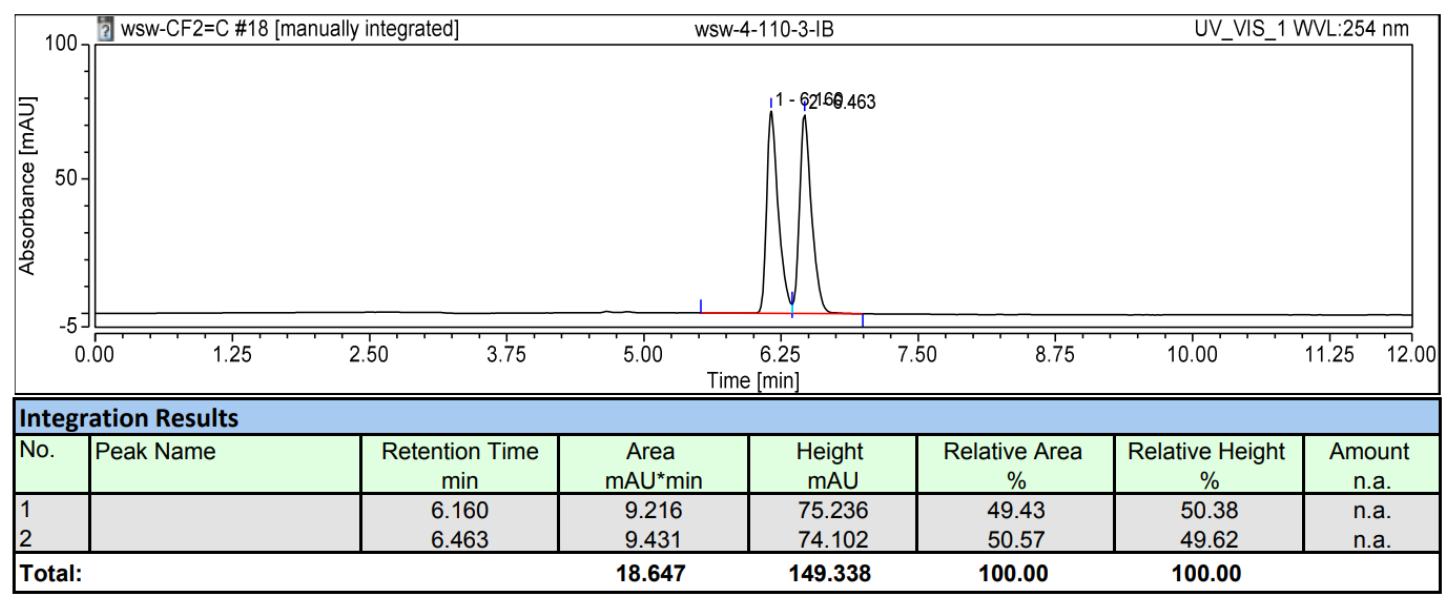


Enantioenriched 5a:

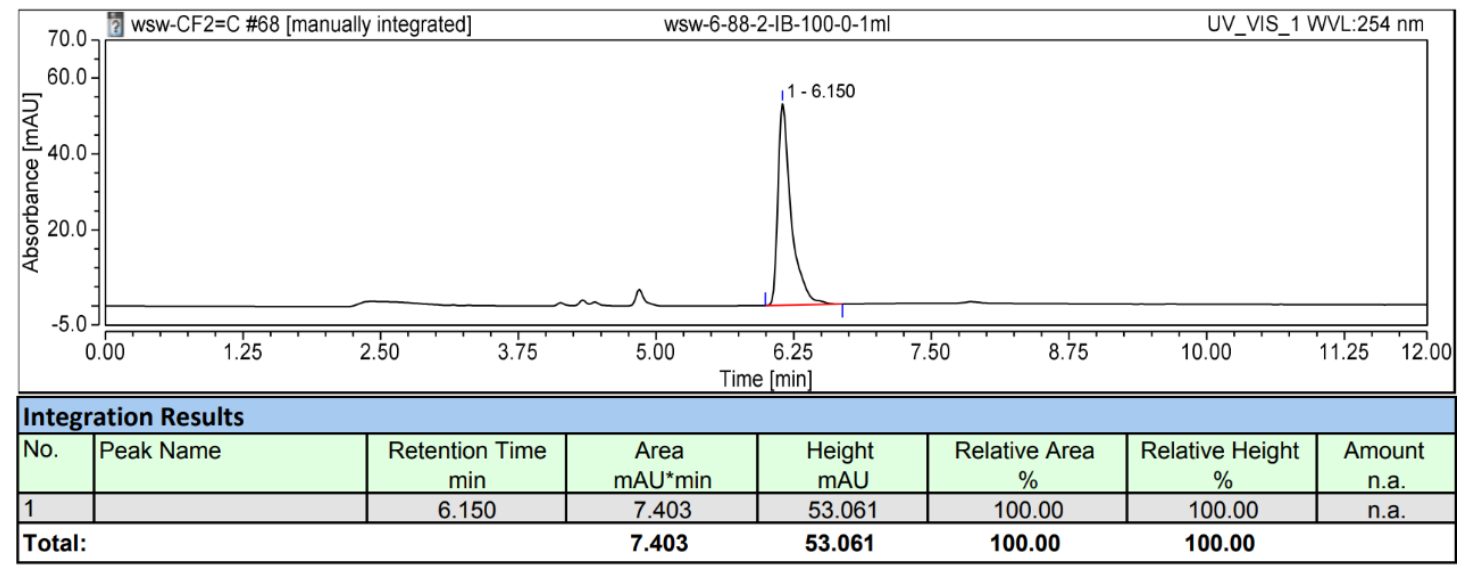

Multi-steps-one-isolation process for the synthesis of $(S, Z)-((1,1-$ difluoro-3-methyl-5- phenylpenta-

1,4-dien-2-yl)oxy)dimethyl(phenyl)silane (6)
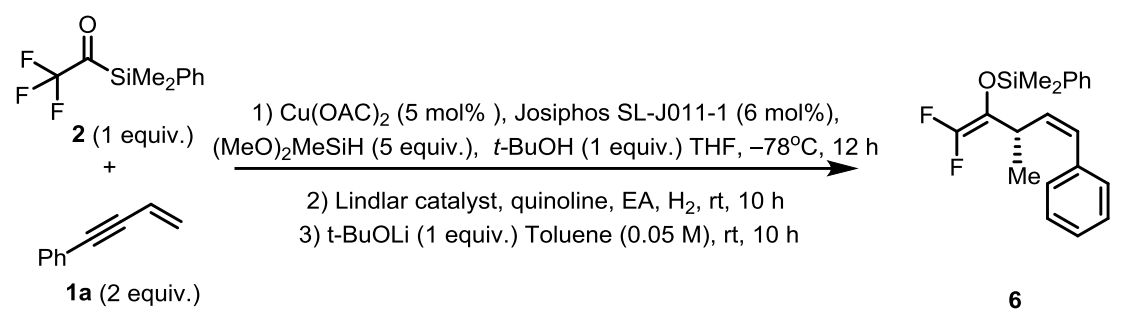

1) In a glovebox, to an oven-dried $10 \mathrm{~mL}$ Schlenk tube equipped with a magnetic stir bar was added $\mathrm{Cu}(\mathrm{OAC})_{2}$ (2.3 mg, $0.0125 \mathrm{mmol}, 5 \mathrm{~mol} \%$ ), Josiphos SL-J011-1 (10.2 mg, $0.015 \mathrm{mmol}, 6 \mathrm{~mol} \%$ ), and dry THF ( $1 \mathrm{~mL}$ ) sequentially. The mixture was stirred at room temperature for $30 \mathrm{~min}$ before the addition of DMMS (153.5 $\mu \mathrm{L}, 1.25$ mmol, 5 equiv.), $t$ - $\mathrm{BuOH}(24 \mu \mathrm{L}, 0.25 \mathrm{mmol}, 1$ equiv.) and $\mathbf{1 a}(67 \mu \mathrm{L}, 0.5$ mmol, 2 equiv.). The tube was then sealed, removed from the glove box and allowed to stir at $-78^{\circ} \mathrm{C}$ for 5 min, after which the mixture was added slowly (within 6 h) 1-(dimethyl(phenyl)silyl)-2,2,2trifluoroethan-1-one 2 (58 mg, $0.25 \mathrm{mmol}, 1$ equiv.) in $5 \mathrm{~mL}$ THF. After stirring for another $6 \mathrm{~h}$, then a saturated solution of $\mathrm{NH}_{4} \mathrm{~F}$ in $\mathrm{MeOH}$ (ca. $6 \mathrm{~mL}$ ) was carefully added to quench the reaction (Caution: gas evolution was observed). The reaction mixture was allowed to stir for $20 \mathrm{~min}$ at room temperature, diluted with EtOAc (ca. $10 \mathrm{~mL}$ ), stirred for an additional $10 \mathrm{~min}$ at room temperature and then filtered through a short plug of silica gel (100 200 mesh) eluting with hexane (ca. $50 \mathrm{~mL})$. The solvent was removed in vacuo with the aid of a rotary evaporator to afford the crude compound.

2) To a dry Schlenk tube were added Lindlar catalyst (palladium on calcium carbonate, $w / w(P d)=5 \%$, poisoned with lead acetate, $53 \mathrm{mg}, 0.025 \mathrm{mmol}, 10 \mathrm{~mol} \%)$, quinoline $(10.7 \mu \mathrm{L})$ and the crude compound $(0.25 \mathrm{mmol}) / \mathrm{EtOAc}(5 \mathrm{~mL})$ sequentially. The resulting mixture was frozen with a liquid nitrogen bath, degassed and refilled with $\mathrm{H}_{2}$ for three times. Then the reaction was allowed to stir at rt with a $\mathrm{H}_{2}$ balloon. After $12 \mathrm{~h}$, the mixture was filtrated through a short column of silica gel with EtOAc $(10 \mathrm{~mL})$. After evaporation, the new crude product is obtained.

3) In a glovebox, to an oven-dried $5 \mathrm{~mL}$ screw-cap reaction tube equipped with a magnetic stir bar was added the new crude product, $t$ - $\mathrm{BuOLi}(20 \mathrm{mg}, 0.25 \mathrm{mmol}, 1$ equiv.), and dry toluene $(5 \mathrm{~mL})$ sequentially. The mixture was stirred at room temperature for $5 \mathrm{~min}$. The tube was then sealed, removed from the glove box and allowed to stir at room temperature for $10 \mathrm{~h}$. And then filtered through a short plug of 
silica gel (100 200 mesh) eluting with hexane (ca. $25 \mathrm{~mL}$ ). The solvent was removed in vacuo with the aid of a rotary evaporator to afford the crude compound $\mathbf{6}$. The crude product was purified with column chromatography on silica gel (100 200 mesh) to afford the title compound 6. Colorless oil; $\mathbf{R}_{\mathbf{f}}=0.81$ $(\mathrm{PE} / \mathrm{EA}=10 / 1) ; 67.1 \mathrm{mg}, 78 \%$ yield, 97\% ee, $>$ 99:1 Z/E; $[\boldsymbol{\alpha}]^{25} \mathbf{D}=-132.0\left(c=7.5, \mathrm{CHCl}_{3}\right) ; \mathrm{NMR}^{2}$ spectroscopy: ${ }^{1} \mathbf{H}$ NMR (400 MHz, $\left.\mathrm{CDCl}_{3}, 25^{\circ} \mathrm{C}\right) \delta$ 7.64-7.58 (m, 2H), 7.45-7.28 (m, 5H), 7.24-7.17 $(\mathrm{m}, 3 \mathrm{H}), 6.43(\mathrm{~d}, J=11.6 \mathrm{~Hz}, 1 \mathrm{H}), 5.63(\mathrm{t}, J=10.3 \mathrm{~Hz}, 1 \mathrm{H}), 3.57(\mathrm{qd}, J=6.8,3.9 \mathrm{~Hz}, 1 \mathrm{H}), 1.14(\mathrm{~d}, J=$ $6.8 \mathrm{~Hz}, 3 \mathrm{H}), 0.47(\mathrm{~d}, J=1.4 \mathrm{~Hz}, 3 \mathrm{H}), 0.47(\mathrm{~d}, J=1.6 \mathrm{~Hz}, 3 \mathrm{H}) ;{ }^{13} \mathbf{C} \mathbf{N M R}\left(151 \mathrm{MHz}, \mathrm{CDCl}_{3}, 25{ }^{\circ} \mathrm{C}\right) \delta$ $152.6(\mathrm{dd}, J=282.7,277.5 \mathrm{~Hz}), 137.2,137.0,133.5,132.8,130.0,129.2,128.7,128.4,128.0,127.0$, $116.8(\mathrm{dd}, J=39.7,13.0 \mathrm{~Hz}), 32.0,19.0,-1.06,-1.17 ;{ }^{19} \mathbf{F}$ NMR $\left(376 \mathrm{MHz}, \mathrm{CDCl}_{3}, 25{ }^{\circ} \mathrm{C}\right) \delta-105.7(\mathrm{~d}$, $J=87.8 \mathrm{~Hz}, 1 \mathrm{~F}),-119.9$ (dd, $J=88.0,3.1 \mathrm{~Hz}, 1 \mathrm{~F})$; IR (ATR): 3056, 3023, 2960, 2926, 2646, 1886 , 1759, 1491, 1252, 1118, 880, 835, 790, 738, $701 \mathrm{~cm}^{-1}$; HRMS (ESI, m/z): calcd for $\mathrm{C}_{20} \mathrm{H}_{21} \mathrm{~F}_{2} \mathrm{OSi}^{+}$ $(\mathrm{M}+\mathrm{H})^{+}:$343.1335; Found: 343.1340; HPLC analysis (OD-H column, hexane, $1.0 \mathrm{~mL} / \mathrm{min}, 20{ }^{\circ} \mathrm{C}, 254$ $\mathrm{nm})$ indicated $97 \%$ ee: $t_{\mathrm{R}}($ major $)=6.10 \mathrm{~min}, t_{\mathrm{R}}($ minor $)=6.49 \mathrm{~min}$.

\section{Racemic 6:}

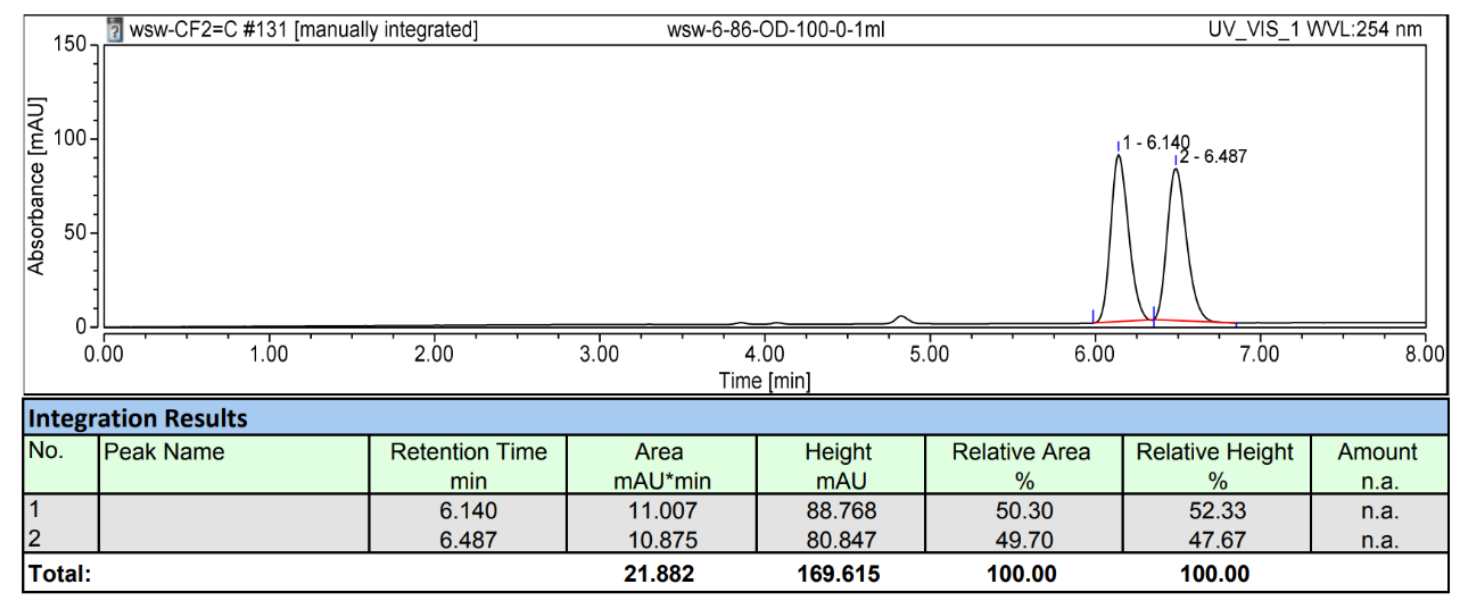

\section{Enantioenriched 6:}

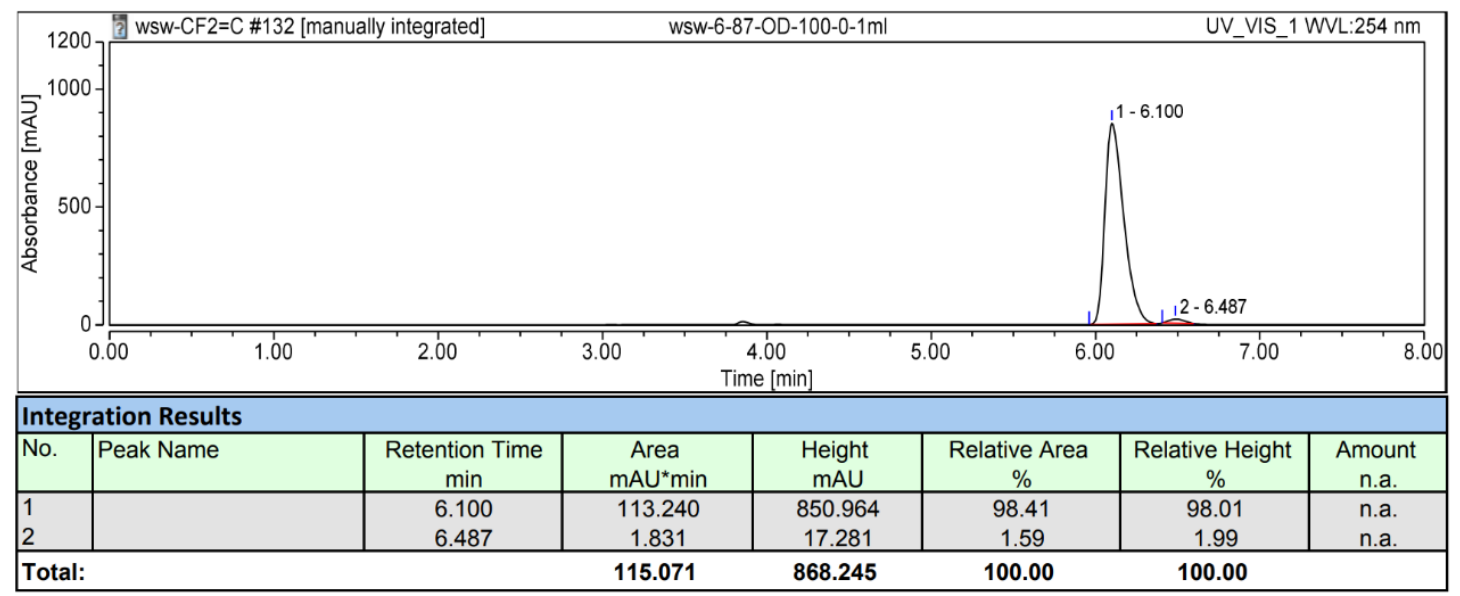


Multi-steps-one-isolation process for the synthesis of (S)-((1,1-difluoro-3-methyl-5- phenylpent-1en-2-yl)oxy)dimethyl(phenyl)silane (7)
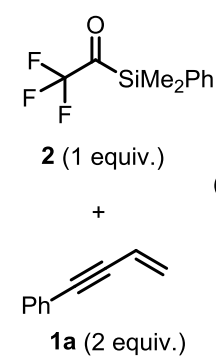

1) $\mathrm{Cu}(\mathrm{OAC})_{2}(5 \mathrm{~mol} \%)$, Josiphos SL-J011-1 (6 mol\%),
$(\mathrm{MeO})_{2} \mathrm{MeSiH}\left(5\right.$ equiv.), $t$ - $\mathrm{BuOH}\left(1\right.$ equiv.) THF, $-78^{\circ} \mathrm{C}, 12 \mathrm{~h}$

2) $\mathrm{Pd} / \mathrm{C}, \mathrm{EA}, \mathrm{H}_{2}, \mathrm{rt}, 12 \mathrm{~h}$

3) $t$-BuOLi (1 equiv.) Toluene $(0.05 \mathrm{M}), \mathrm{rt}, 10 \mathrm{~h}$

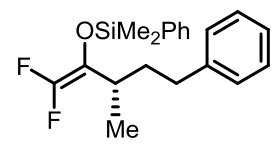

7

1) In a glovebox, to an oven-dried $10 \mathrm{~mL}$ Schlenk tube equipped with a magnetic stir bar was added $\mathrm{Cu}(\mathrm{OAC})_{2}$ (2.3 mg, $0.0125 \mathrm{mmol}, 5 \mathrm{~mol} \%$ ), Josiphos SL-J011-1 (10.2 mg, $0.015 \mathrm{mmol}, 6 \mathrm{~mol} \%$ ), and dry THF ( $1 \mathrm{~mL})$ sequentially. The mixture was stirred at room temperature for $30 \mathrm{~min}$ before the addition of DMMS (153.5 $\mu \mathrm{L}, 1.25 \mathrm{mmol}, 5$ equiv.), $t$-BuOH (24 $\mu \mathrm{L}, 0.25 \mathrm{mmol}, 1$ equiv.) and $\mathbf{1 a}(67 \mu \mathrm{L}, 0.5$ mmol, 2 equiv.). The tube was then sealed, removed from the glove box and allowed to stir at $-78^{\circ} \mathrm{C}$ for 5 min, after which the mixture was added slowly (within $6 \mathrm{~h}$ ) 1-(dimethyl(phenyl)silyl)-2,2,2trifluoroethan-1-one 2 (58 mg, $0.25 \mathrm{mmol}, 1$ equiv.) in $5 \mathrm{~mL}$ THF. After stirring for another $6 \mathrm{~h}$, then a saturated solution of $\mathrm{NH}_{4} \mathrm{~F}$ in $\mathrm{MeOH}(\mathrm{ca} .6 \mathrm{~mL}$ ) was carefully added to quench the reaction (Caution: gas evolution was observed). The reaction mixture was allowed to stir for $20 \mathrm{~min}$ at room temperature, diluted with EtOAc (ca. $10 \mathrm{~mL}$ ), stirred for an additional $10 \mathrm{~min}$ at room temperature and then filtered through a short plug of silica gel (100 200 mesh) eluting with hexane (ca. $50 \mathrm{~mL}$ ). The solvent was removed in vacuo with the aid of a rotary evaporator to afford the crude compound.

2) To a dry Schlenk tube were added Pd/C (dry, w/w (Pd) = 5\%, $79.5 \mathrm{mg}, 0.0375 \mathrm{mmol}, 15 \mathrm{~mol} \%$ ) and the crude compound $(0.25 \mathrm{mmol}) /$ EtOAc $(5 \mathrm{~mL})$ sequentially. The resulting mixture was frozen with a liquid nitrogen bath, degassed and refilled with $\mathrm{H}_{2}$ for three times. Then the reaction was allowed to stir at $\mathrm{rt}$ with a $\mathrm{H}_{2}$ balloon. After $12 \mathrm{~h}$, the mixture was filtrated through a short column of silica gel with EtOAc $(10 \mathrm{~mL})$. After evaporation, the new crude product is obtained.

3) In a glovebox, to an oven-dried $5 \mathrm{~mL}$ screw-cap reaction tube equipped with a magnetic stir bar was added the new crude product, $t$-BuOLi (20 mg, $0.25 \mathrm{mmol} 1$ equiv.), and dry toluene ( $5 \mathrm{~mL}$ ) sequentially. The mixture was stirred at room temperature for $5 \mathrm{~min}$. The tube was then sealed, removed from the glove box and allowed to stir at room temperature for $10 \mathrm{~h}$. And then filtered through a short plug of silica gel (100 200 mesh) eluting with hexane (ca. $25 \mathrm{~mL}$ ). The solvent was removed in vacuo with the aid of a rotary evaporator to afford the crude compound 7 . The crude product was purified with column chromatography on silica gel (100 200 mesh) to afford the title compound 7. Colorless oil; $\mathbf{R}_{\mathbf{f}}=0.82$ $(\mathrm{PE} / \mathrm{EA}=10 / 1) ; 64 \mathrm{mg}, 74 \%$ yield, 99\% ee; $[\boldsymbol{\alpha}]^{25} \mathbf{D}=-15.9\left(c=8.50, \mathrm{CHCl}_{3}\right) ; \mathrm{NMR}$ spectroscopy: ${ }^{1} \mathbf{H}$ NMR $\left(400 \mathrm{MHz}, \mathrm{CDCl}_{3}, 25^{\circ} \mathrm{C}\right) \delta$ 7.62-7.58 (m, 2H), 7.43-7.34 (m, 3H), 7.28-7.23 (m, 2H), 7.20-7.10 $(\mathrm{m}, 3 \mathrm{H}), 2.64-2.44(\mathrm{~m}, 2 \mathrm{H}), 2.42-2.30(\mathrm{~m}, 1 \mathrm{H}), 1.83-1.71(\mathrm{~m}, 1 \mathrm{H}), 1.63-1.52(\mathrm{~m}, 1 \mathrm{H}), 1.01(\mathrm{~d}, J=6.9$ $\mathrm{Hz}, 3 \mathrm{H}), 0.47$ (s, 3H), 0.47 (s, 3H); ${ }^{13} \mathbf{C ~ N M R}\left(151 \mathrm{MHz}, \mathrm{CDCl}_{3}, 25{ }^{\circ} \mathrm{C}\right) \delta 153.2$ (dd, $J=281.9,275.9$ Hz), 142.3, 137.3, 133.5, 130.0, 128.5, 128.4, 128.0, 125.9, 116.2 (dd, $J=40.2,12.2 \mathrm{~Hz}$ ), 35.2, 33.8, $32.4,18.1,-0.9,-1.0 ;{ }^{19} \mathbf{F}$ NMR $\left(376 \mathrm{MHz} \mathrm{CDCl}_{3}, 25{ }^{\circ} \mathrm{C}\right) \delta-105.4(\mathrm{~d}, J=89.6 \mathrm{~Hz}, 1 \mathrm{~F}),-120.9(\mathrm{dd}, J$ $=90.0,5.0 \mathrm{~Hz}, 1 \mathrm{~F}$ ); IR (ATR): 3068, 3027, 2930, 2855, 1759, 1602, 1498, 1454, 1290, 1118, 872, 835, 790, 742, $701 \mathrm{~cm}^{-1}$; HRMS (ESI, m/z): calcd for $\mathrm{C}_{20} \mathrm{H}_{23} \mathrm{~F}_{2} \mathrm{OSi}^{+}(\mathrm{M}+\mathrm{H})^{+}$: 345.1492; Found: 345.1496; HPLC analysis (AD-H column, hexane, $1.0 \mathrm{~mL} / \mathrm{min}, 20{ }^{\circ} \mathrm{C}, 254 \mathrm{~nm}$ ) indicated $99 \%$ ee: $t_{\mathrm{R}}($ major) $=$ $3.76 \mathrm{~min}$. 
Racemic 7:

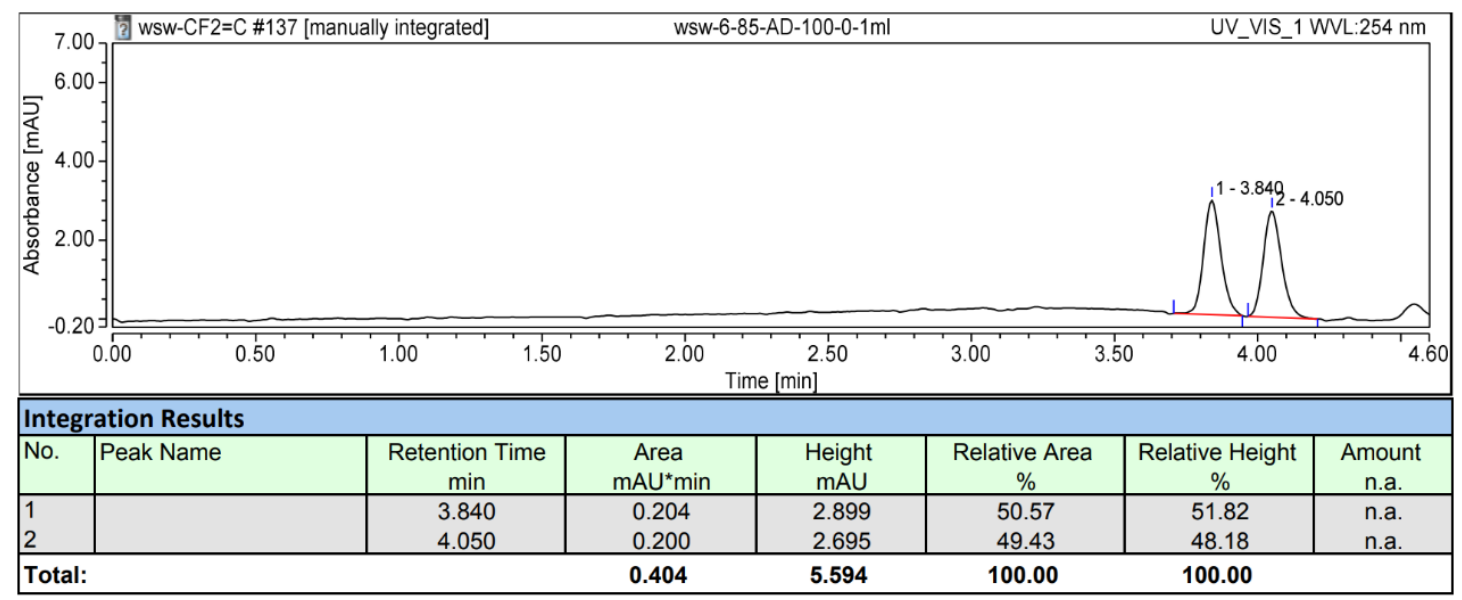

Enantioenriched 7:

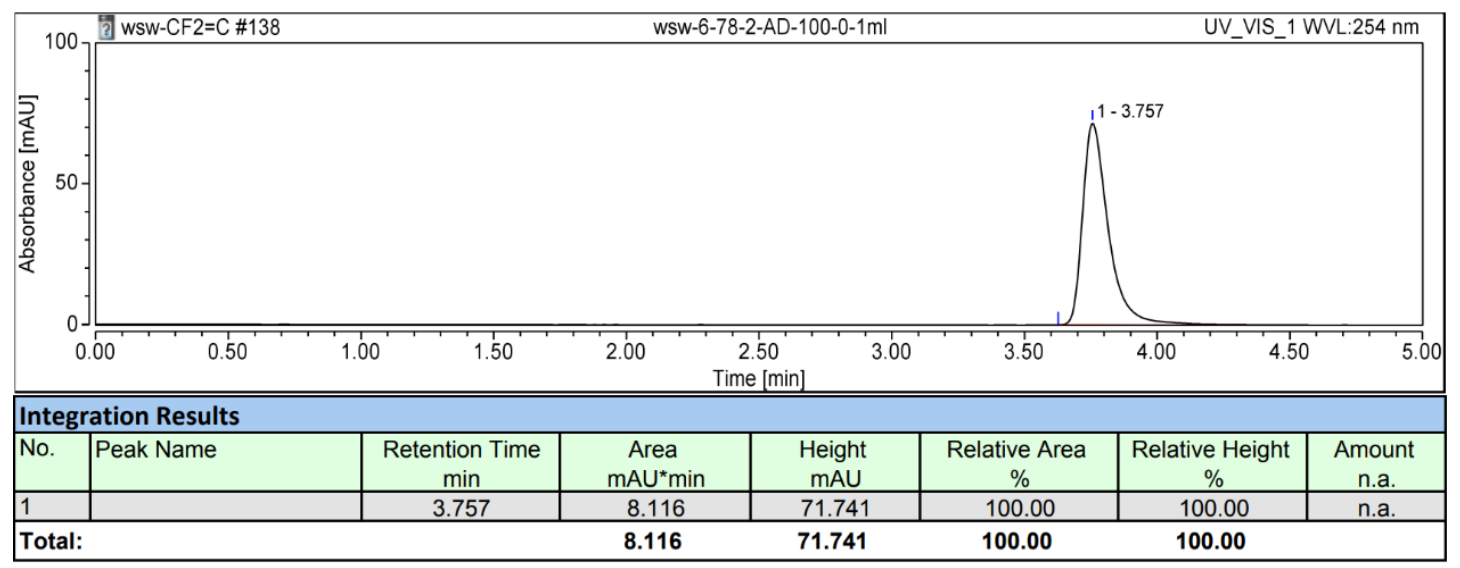

7 Downstream transformations of chiral $\beta, \beta$-difluoro enol silane 7

(S)-1,1-Difluoro-3-methyl-5-phenylpentan-2-one (8)<smiles>COC(=C(F)F)[C@@H](CCc1ccccc1)[C@H](C)OCc1ccccc1</smiles>

7

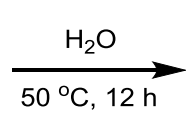

$\mathrm{HF}_{2} \mathrm{C}$

8

To a $5 \mathrm{~mL}$ screw-cap reaction tube equipped with a magnetic stir bar was added 7 ( $34.6 \mathrm{mg}, 0.1 \mathrm{mmol}$ ) and deionized water $(1 \mathrm{~mL})$. The mixture was stirred at $50^{\circ} \mathrm{C}$ for 12 hours, cooled to room temperature. The mixture was extracted with EtOAc ( $5 \mathrm{~mL}$ x 3), and the combined organic phases were dried over sodium sulfate, and concentrated. The residue was purified by column chromatography on silica gel (200 300 mesh) to afford the title compound 8. Colorless oil; $\mathbf{R}_{\mathbf{f}}=0.77(\mathrm{PE} / \mathrm{EA}=10 / 1) ; 20 \mathrm{mg}, 94 \%$ yield, 98\% ee; $[\boldsymbol{\alpha}]^{25} \mathbf{D}=-36.6\left(c=0.75, \mathrm{CHCl}_{3}\right) ;{ }^{1} \mathbf{H} \mathbf{N M R}\left(400 \mathrm{MHz}, \mathrm{CDCl}_{3}, 25{ }^{\circ} \mathrm{C}\right) \delta 7.34-7.27(\mathrm{~m}$, 2H), 7.24-7.14 (m, 3H), $5.71(\mathrm{t}, J=53.9 \mathrm{~Hz}, 1 \mathrm{H}), 3.37-2.87(\mathrm{~m}, 1 \mathrm{H}), 2.61$ (ddd, $J=9.2,6.7,2.5 \mathrm{~Hz}$, 2H), $2.12(\mathrm{ddt}, J=13.9,9.0,7.0 \mathrm{~Hz}, 1 \mathrm{H}), 1.72(\mathrm{ddt}, J=13.4,9.1,6.6 \mathrm{~Hz}, 1 \mathrm{H}), 1.22(\mathrm{~d}, J=7.0 \mathrm{~Hz}, 3 \mathrm{H})$; ${ }^{13} \mathbf{C}$ NMR $\left(151 \mathrm{MHz}, \mathrm{CDCl}_{3}, 25{ }^{\circ} \mathrm{C}\right) \delta 203.1(\mathrm{t}, J=24.9 \mathrm{~Hz}), 141.2,128.7,128.5,126.3,110.1(\mathrm{t}, J=$ $253.3 \mathrm{~Hz}), 40.2,33.9,33.3,16.1 ;{ }^{19} \mathbf{F}$ NMR $\left(376 \mathrm{MHz}, \mathrm{CDCl}_{3}, 25{ }^{\circ} \mathrm{C}\right) \delta-126.6(\mathrm{dd}, J=53.7,38.8 \mathrm{~Hz}$, 
2F); IR (ATR): 3023, 2926, 2855, 2751, 2482, 2356, 2102, 1961, 1894, 1730, 1599, 1454, 1264, 1033, $753 \mathrm{~cm}^{-1}$; HRMS (ESI, m/z): calcd for $\mathrm{C}_{12} \mathrm{H}_{13} \mathrm{~F}_{2} \mathrm{O}^{-}(\mathrm{M}-\mathrm{H})^{-}: 211.0940$; Found: 211.0939; HPLC analysis (IB N-5 column, $1 \% i-\mathrm{PrOH} /$ hexane, $0.80 \mathrm{~mL} / \mathrm{min}, 20{ }^{\circ} \mathrm{C}, 254 \mathrm{~nm}$ ) indicated $98 \%$ ee: $t_{\mathrm{R}}($ major$)=5.73$ $\min , t_{\mathrm{R}}($ minor $)=6.18 \mathrm{~min}$

\section{Racemic 8:}

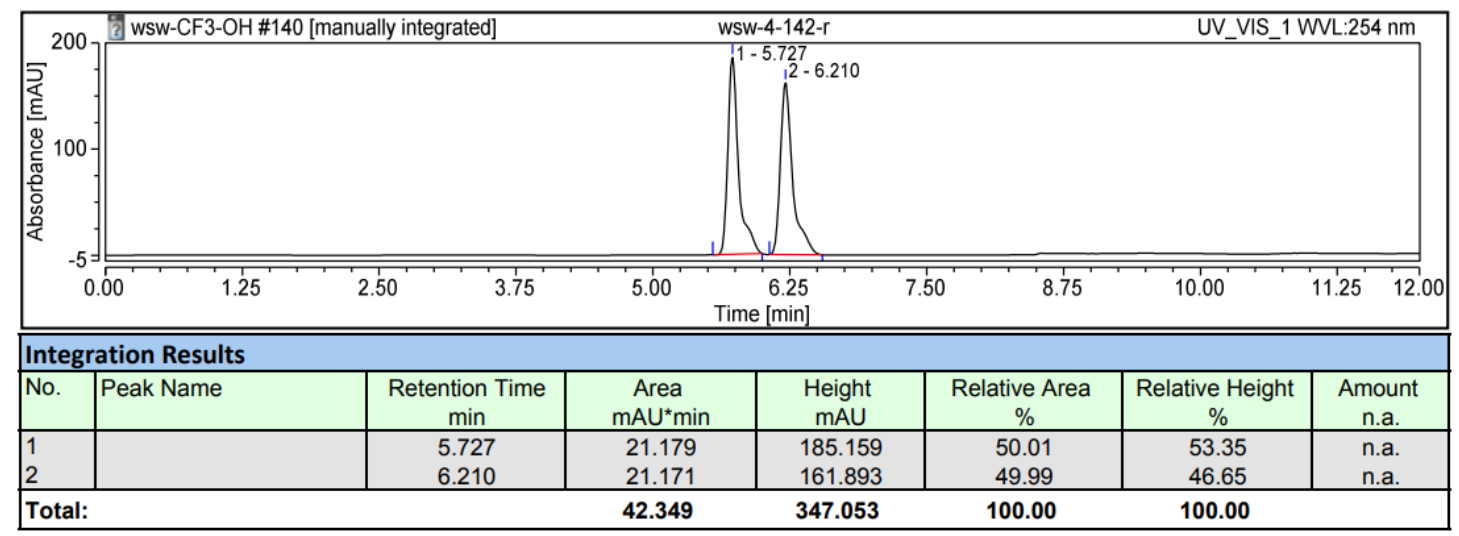

\section{Enantioenriched 8:}

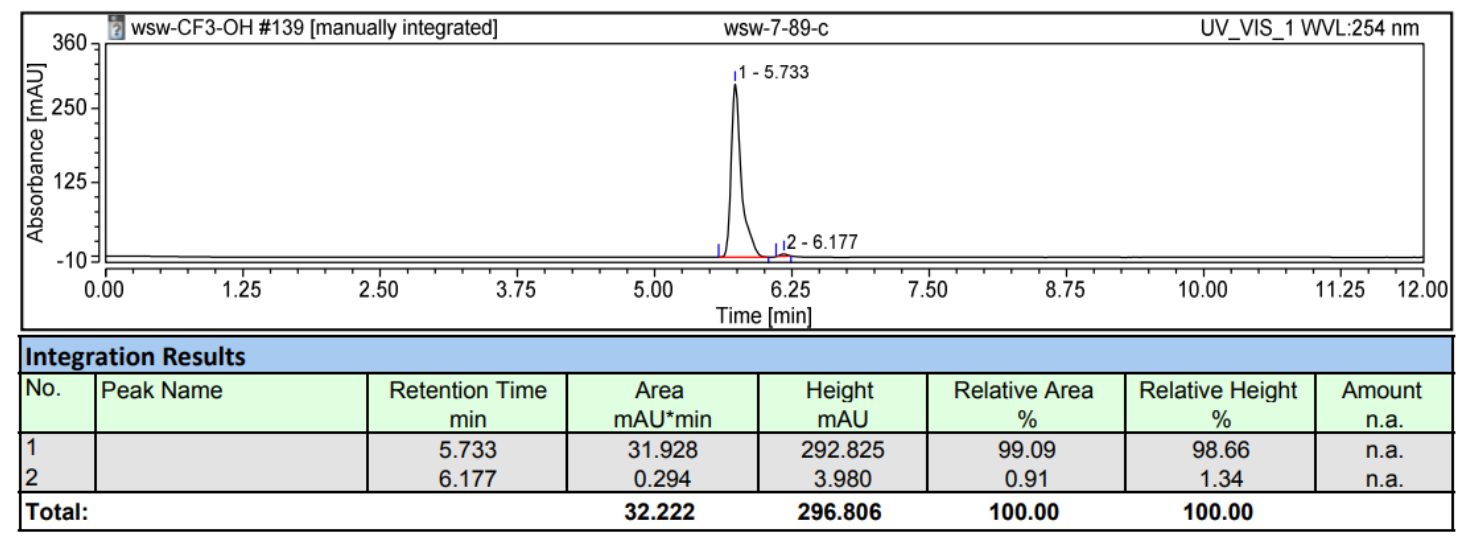

(S)-1,1,1-Trifluoro-3-methyl-5-phenylpentan-2-one (9)
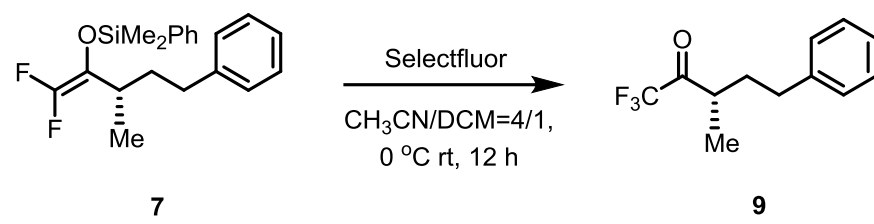

Under nitrogen, to a $5 \mathrm{~mL}$ screw-cap reaction tube equipped with a magnetic stir bar was added Selectfluor (53.1 mg, $0.15 \mathrm{mmol}, 1.5$ equiv.) and dry $\mathrm{CH}_{3} \mathrm{CN}(1.6 \mathrm{~mL})$. Then a solution of compound 7 (34.6 mg, $0.1 \mathrm{mmol}, 1.0$ equiv.) in dry DCM $(0.4 \mathrm{~mL})$ was added. The mixture was stirred at room temperature for 12 hours, The mixture was concentrated. And the residue was purified by column chromatography on silica gel (100 200 mesh) to afford the title compound $\mathbf{9}$. Colorless oil; $\mathbf{R}_{\mathbf{f}}=0.27$ $(\mathrm{PE} / \mathrm{EA}=50 / 1) ; 19 \mathrm{mg}, 83 \%$ yield, $98 \%$ ee; $[\boldsymbol{\alpha}]^{25} \mathbf{D}=+18.5\left(c=3.35, \mathrm{CHCl}_{3}\right) ;{ }^{1} \mathbf{H} \mathbf{N M R}(600 \mathrm{MHz}$, $\left.\mathrm{CDCl}_{3}, 25^{\circ} \mathrm{C}\right) \delta 7.30(\mathrm{t}, J=7.6 \mathrm{~Hz}, 2 \mathrm{H}), 7.21(\mathrm{t}, J=7.4 \mathrm{~Hz}, 1 \mathrm{H}), 7.16(\mathrm{~d}, J=6.6 \mathrm{~Hz}, 2 \mathrm{H}), 3.00(\mathrm{~h}, J=$ $6.9 \mathrm{~Hz}, 1 \mathrm{H}), 2.61(\mathrm{t}, J=7.2 \mathrm{~Hz}, 2 \mathrm{H}), 2.19-2.10(\mathrm{~m}, 1 \mathrm{H}), 1.81-1.70(\mathrm{~m}, 1 \mathrm{H}), 1.26(\mathrm{~d}, J=6.9 \mathrm{~Hz}, 3 \mathrm{H})$. ${ }^{13} \mathbf{C}$ NMR $\left(151 \mathrm{MHz}, \mathrm{CDCl}_{3}, 25{ }^{\circ} \mathrm{C}\right) \delta 195.3(\mathrm{q}, J=33.3 \mathrm{~Hz}), 140.8,128.7,128.4,126.4,115.9$ (q, $J=$ 293.0 Hz), 40.4, 33.9, 33.1, 16.2; ${ }^{19} \mathbf{F}$ NMR (376 MHz, $\left.\mathrm{CDCl}_{3}, 25^{\circ} \mathrm{C}\right) \delta-77.6$ (s, 1F); IR (ATR): 3064 , 
3030, 2978, 2937, 2863, 1759, 1607, 1498, 1457, 1383, 1290, 1208, 1148, 988, $746 \mathrm{~cm}^{-1}$; HRMS (ESI, $\mathrm{m} / \mathrm{z}$ ): calcd for $\mathrm{C}_{12} \mathrm{H}_{12} \mathrm{~F}_{3} \mathrm{O}^{-}(\mathrm{M}+\mathrm{H})^{+}$: 229.0846; Found: 229.0849; HPLC analysis (IB N-5 column, hexane, $0.60 \mathrm{~mL} / \mathrm{min}, 20^{\circ} \mathrm{C}, 210 \mathrm{~nm}$ ) indicated $98 \%$ ee: $t_{\mathrm{R}}($ major $)=13.72 \mathrm{~min}, t_{\mathrm{R}}($ minor $)=14.48 \mathrm{~min}$

\section{Racemic 9:}

\begin{tabular}{|l|l|l|l|l|l|l|}
\hline & \\
\hline
\end{tabular}

\section{Enantioenriched 9:}

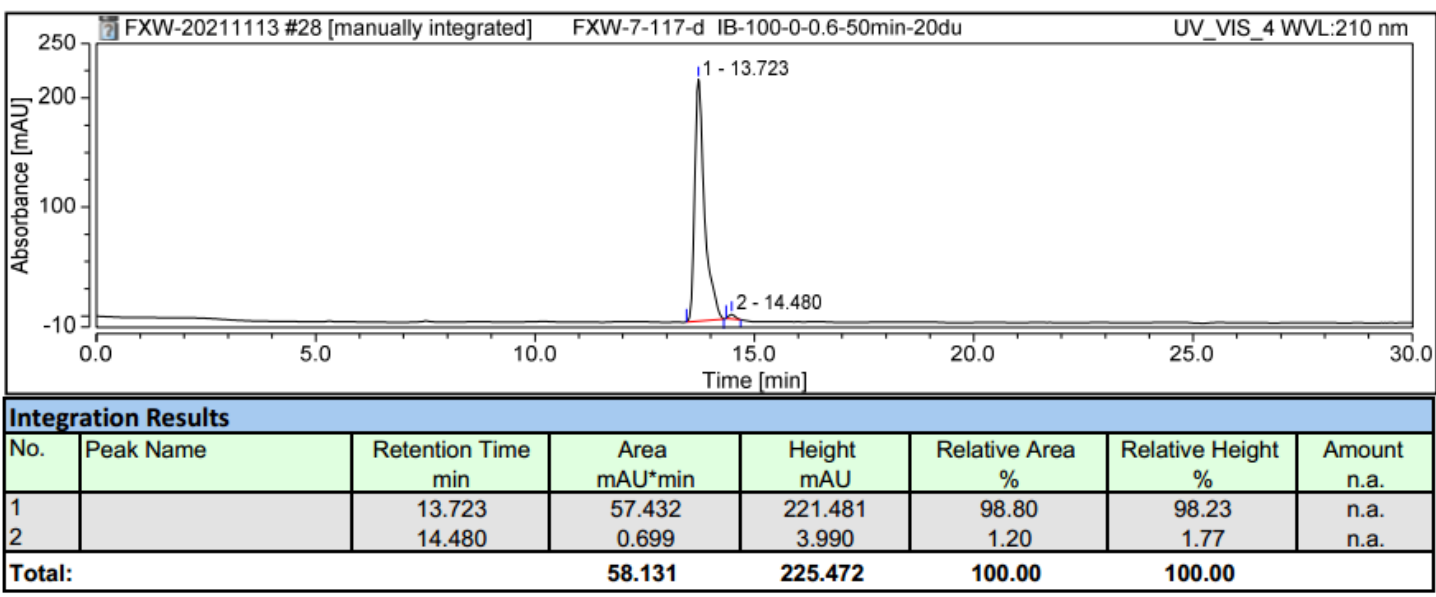

(S)-1-chloro-1,1-difluoro-3-methyl-5-phenylpentan-2-one (10)<smiles>COC(=C(F)F)[C@@H](C)OCc1ccccc1</smiles>

7

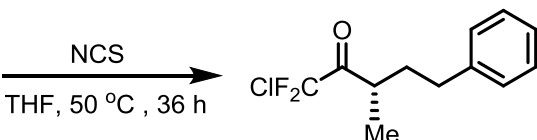

10

Under nitrogen, to a $5 \mathrm{~mL}$ screw-cap reaction tube equipped with a magnetic stir bar was added NCS (67 mg, $0.5 \mathrm{mmol}, 5.0$ equiv.) and dry THF (1 mL). Then a solution of compound 7 (34.6 mg, $0.1 \mathrm{mmol}, 1.0$ equiv.) in dry THF ( $1 \mathrm{~mL}$ ) was added at room temperature. The mixture was stirred at $50{ }^{\circ} \mathrm{C}$ for 36 hours, and then filtered through a short plug of silica gel (100 200 mesh) eluting with Ethyl acetate (ca. $10 \mathrm{~mL}$ ). The crude product was purified with column chromatography on silica gel (100 200 mesh) to afford the title compound 10. Colorless oil; $\mathbf{R}_{\mathbf{f}}=0.43(\mathrm{PE} / \mathrm{EA}=50 / 1) ; 21.4 \mathrm{mg}, 87 \%$ yield, 95\% ee; $[\boldsymbol{\alpha}]^{25} \mathbf{D}=+6.0$ $\left(c=1.25, \mathrm{CHCl}_{3}\right) ;{ }^{1} \mathbf{H}$ NMR $\left(400 \mathrm{MHz}, \mathrm{CDCl}_{3}, 25{ }^{\circ} \mathrm{C}\right) \delta 7.29(\mathrm{t}, J=7.4 \mathrm{~Hz}, 2 \mathrm{H}), 7.21(\mathrm{~d}, J=7.2 \mathrm{~Hz}$, $1 \mathrm{H}), 7.17(\mathrm{~d}, J=8.2 \mathrm{~Hz}, 2 \mathrm{H}), 3.10(\mathrm{~h}, J=6.9 \mathrm{~Hz}, 1 \mathrm{H}), 2.70-2.53(\mathrm{~m}, 2 \mathrm{H}), 2.13$ (ddd, $J=16.2,13.9,6.9$ $\mathrm{Hz}, 1 \mathrm{H}), 1.77$ (ddt, $J=13.1,9.4,6.4 \mathrm{~Hz}, 1 \mathrm{H}), 1.28$ (d, $J=6.9 \mathrm{~Hz}, 3 \mathrm{H}) .{ }^{13} \mathbf{C} \mathbf{N M R}\left(151 \mathrm{MHz}, \mathrm{CDCl}_{3}, 25\right.$ $\left.{ }^{\circ} \mathrm{C}\right) \delta 195.6(\mathrm{t}, J=28.3 \mathrm{~Hz}), 141.0,128.7,128.4,126.4,120.1(\mathrm{t}, J=306.9 \mathrm{~Hz}), 39.7,34.8,33.3,17.4$; 
${ }^{19}$ F NMR $\left(376 \mathrm{MHz}, \mathrm{CDCl}_{3}, 25^{\circ} \mathrm{C}\right) \delta-67.5(\mathrm{~d}, J=8.0 \mathrm{~Hz}, 2 \mathrm{~F})$; IR (ATR): 3064, 3027, 2926, 2859, 1752,1603, 1498, 1457, 1379, 1223, 1148, 1014, 993, 805, $745 \mathrm{~cm}^{-1}$; HRMS (APCI, m/z): calcd for $\mathrm{C}_{12} \mathrm{H}_{14} \mathrm{~F}_{2} \mathrm{OCl}^{+}(\mathrm{M}+\mathrm{H})^{+}$: 247.0696; Found: 247.0697; HPLC analysis (OD-H column, hexane, 1.0 $\mathrm{mL} / \mathrm{min}, 20^{\circ} \mathrm{C}, 210 \mathrm{~nm}$ ) indicated $95 \%$ ee: $t_{\mathrm{R}}($ major $)=10.45 \mathrm{~min}, t_{\mathrm{R}}($ minor $)=11.61 \mathrm{~min}$

\section{Racemic 10:}

\begin{tabular}{|l|l|l|l|l|l|l|}
\hline & \\
\hline
\end{tabular}

\section{Enantioenriched 10:}

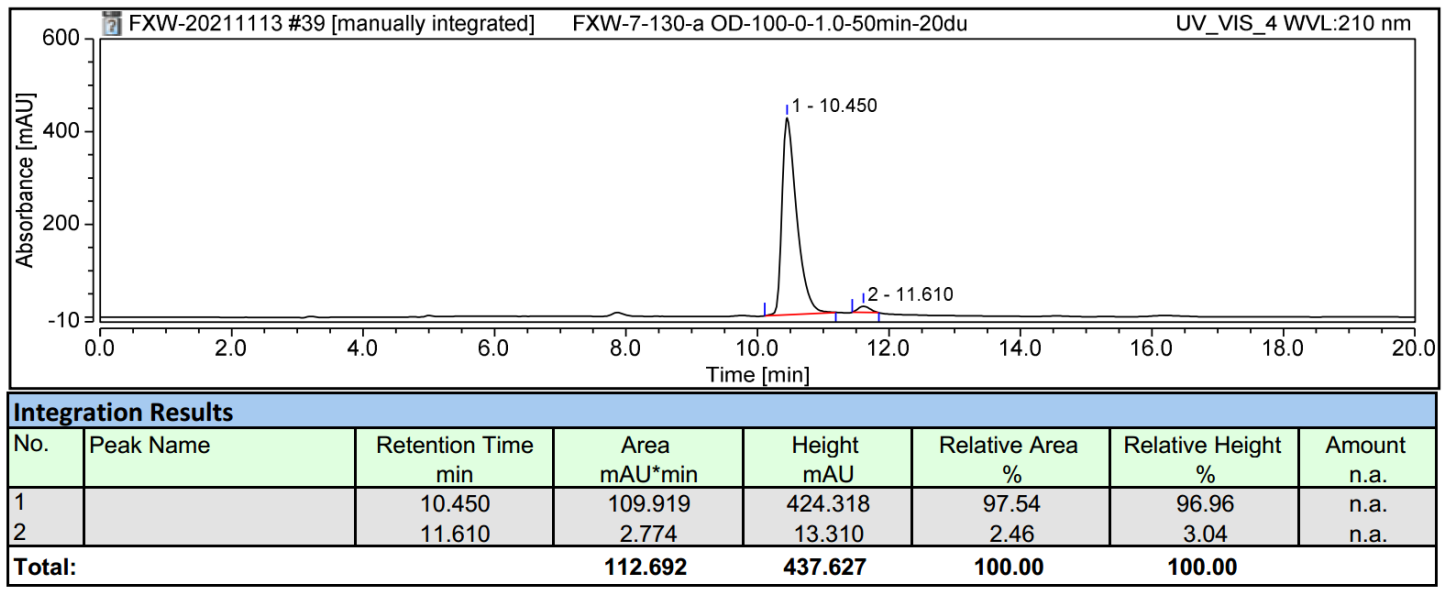

(S)-1-bromo-1,1-difluoro-3-methyl-5-phenylpentan-2-one (11)<smiles>COC(=C(F)F)[C@@H](CCc1ccccc1)Oc1ccccc1</smiles>

7

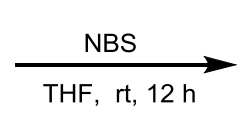<smiles>C[C@H](CCc1ccccc1)C(=O)C(F)(Br)Br</smiles>

11

Under nitrogen, to a $5 \mathrm{~mL}$ screw-cap reaction tube equipped with a magnetic stir bar was added NBS (27 $\mathrm{mg}, 0.15 \mathrm{mmol}, 1.5$ equiv.) and dry THF (1 mL). Then a solution of compound 7 (34.6 $\mathrm{mg}, 0.1 \mathrm{mmol}$, 1.0 equiv.) in dry THF $(1 \mathrm{~mL})$ was added at room temperature. The mixture was stirred at room temperature for 12 hours, and then filtered through a short plug of silica gel (100 200 mesh) eluting with Ethyl acetate (ca. $10 \mathrm{~mL}$ ). The crude product was purified with column chromatography on silica gel (100 200 mesh) to afford the title compound 11. Colorless oil; $\mathbf{R}_{\mathbf{f}}=0.54(\mathrm{PE} / \mathrm{EA}=50 / 1) ; 26.5 \mathrm{mg}, 91 \%$ yield, $97 \%$ ee; $[\boldsymbol{\alpha}]^{25} \mathbf{D}=+3.6\left(c=2.50, \mathrm{CHCl}_{3}\right) ;{ }^{1} \mathbf{H} \mathbf{N M R}\left(400 \mathrm{MHz}, \mathrm{CDCl}_{3}, 25^{\circ} \mathrm{C}\right) \delta 7.30(\mathrm{t}, J=7.4 \mathrm{~Hz}$, 2H), 7.22 (d, $J=7.1 \mathrm{~Hz}, 1 \mathrm{H}), 7.18$ (d, $J=7.7 \mathrm{~Hz}, 2 \mathrm{H}), 3.13$ (h, $J=6.9 \mathrm{~Hz}, 1 \mathrm{H}), 2.64$ (dt, $J=15.4,8.3$ $\mathrm{Hz}, 2 \mathrm{H}), 2.13$ (ddt, $J=13.7,11.3,5.7 \mathrm{~Hz}, 1 \mathrm{H}), 1.77$ (ddt, $J=13.0,9.6,6.2 \mathrm{~Hz}, 1 \mathrm{H}), 1.30$ (d, $J=6.9 \mathrm{~Hz}$, 
$3 \mathrm{H}) ;{ }^{13} \mathrm{C}$ NMR $\left(151 \mathrm{MHz}, \mathrm{CDCl}_{3}, 25^{\circ} \mathrm{C}\right) \delta 195.6(\mathrm{t}, J=25.1 \mathrm{~Hz}), 141.0,128.7,128.4,126.4,114.4(\mathrm{t}$, $J=321.3 \mathrm{~Hz}), 39.3,34.9,33.3,17.6 ;{ }^{19} \mathbf{F}$ NMR $\left(376 \mathrm{MHz}, \mathrm{CDCl}_{3}, 25{ }^{\circ} \mathrm{C}\right) \delta-63.7-64.9$ (m, 2F).; IR (ATR): 3064, 3030, 2982, 2941, 2859, 1946, 1752, 1603, 1495, 1454, 1219, 1144, 1006, 865, $697 \mathrm{~cm}^{-1}$; HRMS (APCI, m/z): calcd for $\mathrm{C}_{12} \mathrm{H}_{14} \mathrm{~F}_{2} \mathrm{OBr}^{+}(\mathrm{M}+\mathrm{H})^{+}$: 291.0191; Found: 291.0185; HPLC analysis $\left(\mathrm{OD}-\mathrm{H}\right.$ column, hexane, $1.0 \mathrm{~mL} / \mathrm{min}, 20^{\circ} \mathrm{C}, 210 \mathrm{~nm}$ ) indicated $97 \%$ ee: $t_{\mathrm{R}}$ (major) $=12.07 \mathrm{~min}, t_{\mathrm{R}}($ minor $)$ $=13.56 \mathrm{~min}$

\section{Racemic 11:}

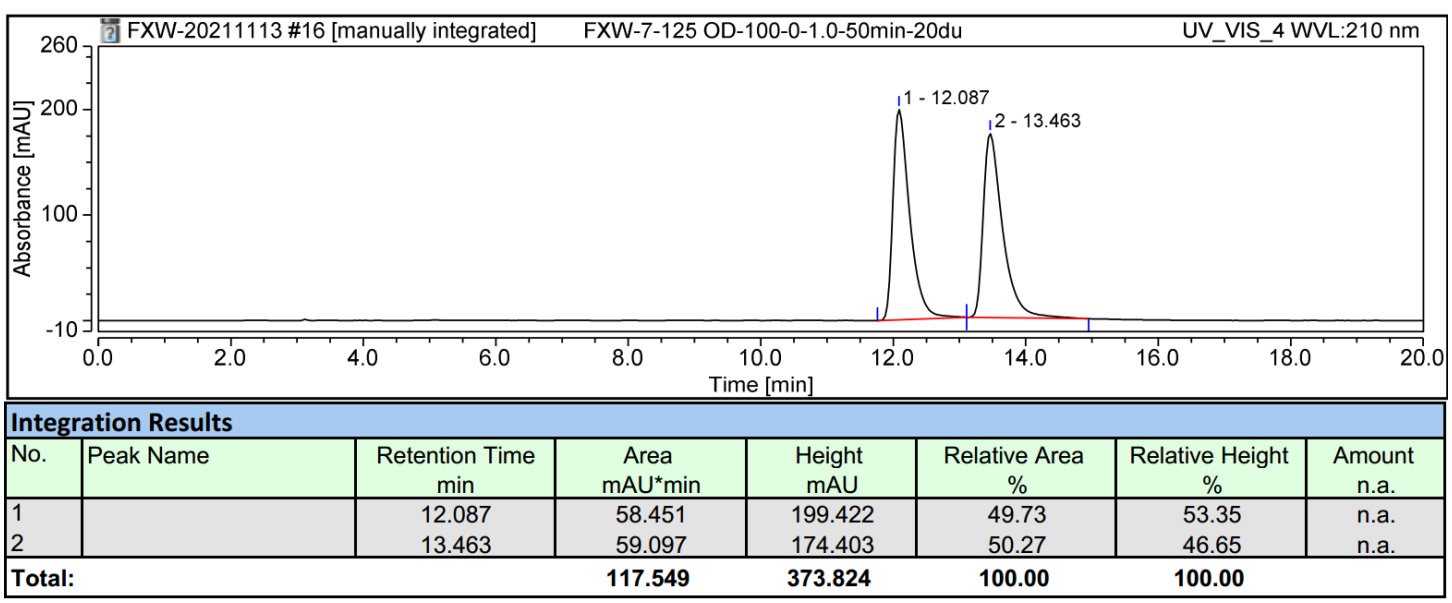

\section{Enantioenriched 11:}

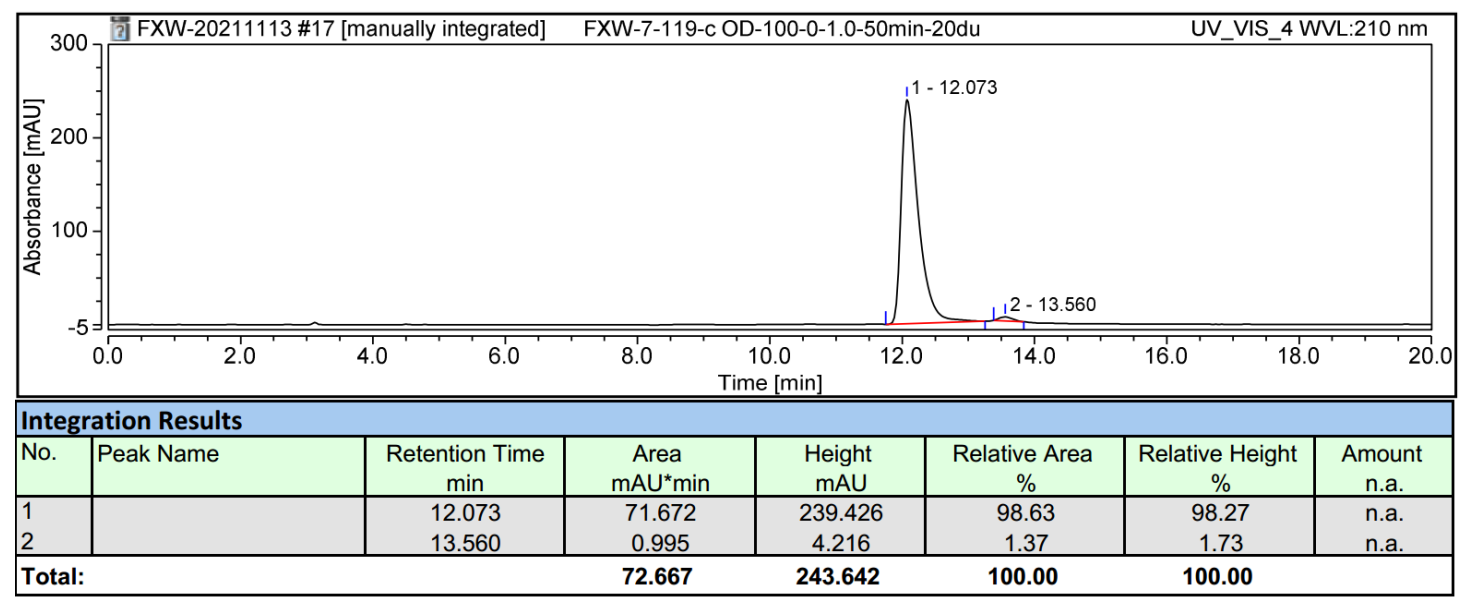

(4S)-2,2-difluoro-1-hydroxy-1-(4-methoxyphenyl)-4-methyl-6-phenylhexan-3-one (12)<smiles>COc1ccc(C(=O)NC(C)C(=O)c2ccc(OC)cc2)cc1</smiles>

To a $5 \mathrm{~mL}$ screw-cap reaction tube equipped with a magnetic stir bar were added 4-methoxybenzaldehyde (41 mg, $0.3 \mathrm{mmol}, 3.0$ equiv.), dry DCM (1.0 mL) and $\mathrm{BF}_{3} \bullet \mathrm{Et}_{2} \mathrm{O}$ (42.6 mg, $0.3 \mathrm{mmol}, 3.0$ equiv.) under argon sequentially. The mixture was allowed to stir at room temperature for $10 \mathrm{~min}$. A solution of 7 (34.6 $\mathrm{mg}, 0.1 \mathrm{mmol}, 1.0$ equiv.) in dry DCM $(1.0 \mathrm{~mL})$ was then added and the resulting mixture was stirred at room temperature for $10 \mathrm{~h}$. The mixture was filtered through a short plug of silica gel (100 200 mesh) eluting with Ethyl acetate (ca. $10 \mathrm{~mL}$ ). The crude product was purified with column chromatography on silica gel (100 200 mesh) to afford the title compound 12. The dr was determined by the analysis of unpurified mixture by ${ }^{19}$ F NMR. Colorless oil; $\mathbf{R}_{\mathbf{f}}=0.25(\mathrm{PE} / \mathrm{EA}=5 / 1) ; 30 \mathrm{mg}, 86 \%$ yield, $55: 45 \mathrm{dr}, 97 \%$ 
ee(major), $99 \%$ ee(minor); $[\boldsymbol{\alpha}]^{\mathbf{2 5}} \mathbf{\mathbf { D }}=+7.8\left(c=4.00, \mathrm{CHCl}_{3}\right) ;{ }^{\mathbf{1}} \mathbf{H} \mathbf{~ N M R}\left(400 \mathrm{MHz}, \mathrm{CDCl}_{3}, 25{ }^{\circ} \mathrm{C}\right) \delta 7.35$ (d, $J=8.2 \mathrm{~Hz}, 2 \mathrm{H}$, major+minor), 7.27 (q, $J=7.2 \mathrm{~Hz}, 2 \mathrm{H}$, major+minor), 7.17 (dd, $J=19.2,7.6 \mathrm{~Hz}, 2 \mathrm{H}$, major+minor), $7.08(\mathrm{~d}, J=7.5 \mathrm{~Hz}, 1 \mathrm{H}$, major+minor), $6.90(\mathrm{~d}, J=9.1 \mathrm{~Hz}, 2 \mathrm{H}$, major+minor), 5.14 (ddt, $J=17.2,8.9,4.8 \mathrm{~Hz}, 1 \mathrm{H}$, major+minor), 3.81 (s, 1.5H, major), 3.79 (s, 1.5H, minor), 2.99 (h, $J=6.8 \mathrm{~Hz}$, $1 \mathrm{H}$, major+minor), 2.65-2.52 (m, 2H, major+minor), $2.46(\mathrm{t}, J=8.1 \mathrm{~Hz}, 1 \mathrm{H}$, major+minor), 2.05 (td, $J$ $=15.8,15.0,6.9 \mathrm{~Hz}, 0.5 \mathrm{H}$, major), 1.95 (dq, $J=15.1,7.5 \mathrm{~Hz}, 0.5 \mathrm{H}$, minor), 1.60 (tq, $J=15.1,7.3 \mathrm{~Hz}$, $1 \mathrm{H}$, major+minor), $1.14\left(\mathrm{~d}, J=6.9 \mathrm{~Hz}, 1.5 \mathrm{H}\right.$, minor), $1.05\left(\mathrm{~d}, J=6.9 \mathrm{~Hz}, 1.5 \mathrm{H}\right.$, minor); ${ }^{13} \mathbf{C} \mathbf{N M R}(151$ $\mathrm{MHz}, \mathrm{CDCl}_{3}, 25^{\circ} \mathrm{C}$ ) $\delta 206.19$ (dd, $J=30.9,26.7 \mathrm{~Hz}$, major), 206.16 (dd, $J=31.2,25.8 \mathrm{~Hz}$, minor), 160.35 (major), 160.33 (minor), 141.6 (major), 141.4 (minor), 129.4 (minor), 129.3 (major), 128.54 (major), 128.53 (minor), 128.5 (major), 128.4 (minor), 126.9 (major+minor), 126.1 (major+minor), 115.1 (dd, $J=256.1,248.6 \mathrm{~Hz}$ ), 113.98 (minor), 113.96 (major), 72.9 (dd, $J=27.9,23.5 \mathrm{~Hz}$, major), 72.7 (dd, $J=28.0,23.6 \mathrm{~Hz}$, minor). 55.4 (major+minor), 41.0 (major), 40.9 (minor), 33.91 (major), 33.88 (minor), 33.3 (major), 33.2 (minor), 16.01 (major), 15.97 (minor).; ${ }^{19} \mathbf{F} \mathbf{N M R}\left(376 \mathrm{MHz}, \mathrm{CDCl}_{3}, 25{ }^{\circ} \mathrm{C}\right.$ ) $\delta-112.4$ (dd, $J=129.6,7.8 \mathrm{~Hz}, 0.46 \mathrm{~F}$, minor), -113.1 (dd, $J=130.9,8.2 \mathrm{~Hz}, 0.54 \mathrm{~F}$, major), -121.6 (dd, $J=81.4,16.5 \mathrm{~Hz}, 0.54 \mathrm{~F}$, major), -122.3 (dd, $J=80.3,16.5 \mathrm{~Hz}, 0.46 \mathrm{~F}$, minor); IR (ATR): 3481, 2930 , 2855, 1733, 1614, 1513, 1457, 1305, 1252, 1178, 1074, 1033, 962, 794, $701 \mathrm{~cm}^{-1}$; HRMS (APCI, m/z): calcd for $\mathrm{C}_{20} \mathrm{H}_{21} \mathrm{~F}_{2} \mathrm{O}_{2}{ }^{+}(\mathrm{M}-\mathrm{OH})^{+}:$331.1504; Found: 331.1502; HPLC analysis (AD-H column, 5\% $i$ $\mathrm{PrOH} /$ hexane, $1.0 \mathrm{~mL} / \mathrm{min}, 20{ }^{\circ} \mathrm{C}, 230 \mathrm{~nm}$ ) indicated 97\% ee (major diastereomer): $t_{\mathrm{R}}$ (major) $=33.66$ $\min , t_{\mathrm{R}}($ minor $)=25.12 \mathrm{~min} ; 99 \%$ ee $($ minor diastereomer $): t_{\mathrm{R}}($ major $)=27.94 \mathrm{~min}, t_{\mathrm{R}}($ minor $)=36.51$ $\min$;

\section{Racemic 12:}

\begin{tabular}{|l|l|l|l|l|l|l|}
\hline & \\
\hline
\end{tabular}


Enantioenriched 12 (major diastereomer):

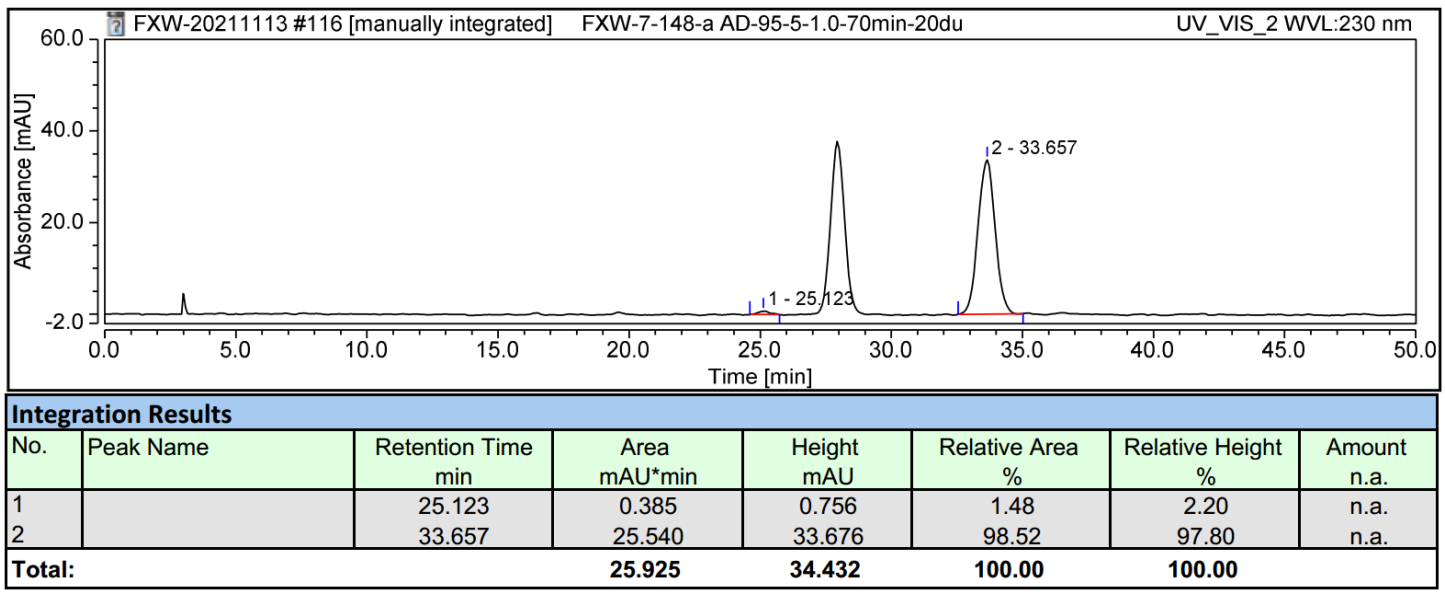

Enantioenriched 12 (minor diastereomer):

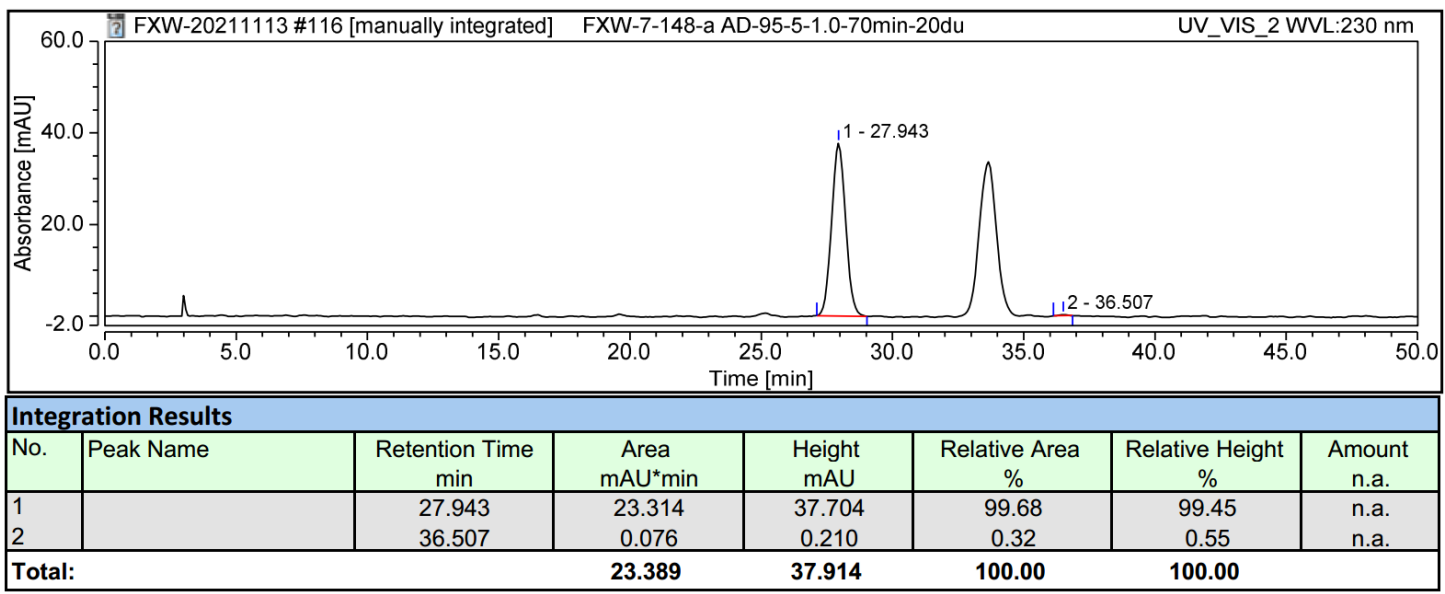

\section{The mechanism study}

a) Standard conditions

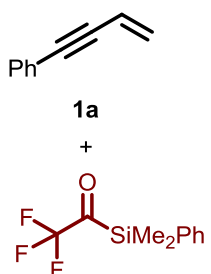

2a
$\mathrm{Cu}(\mathrm{OAC})_{2}(5 \mathrm{~mol} \%)$

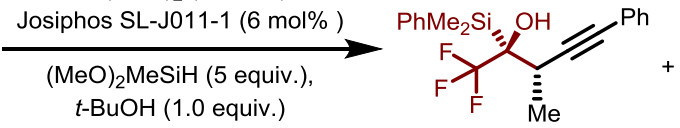
THF, $12 \mathrm{~h}$

3a, $81 \%$ yield, $97: 3 \mathrm{dr}$

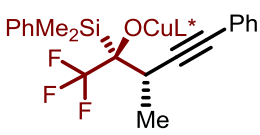

$3 a^{\prime}, 0 \%$ yield

b) Standard conditions without $t$ - $\mathrm{BuOH}$

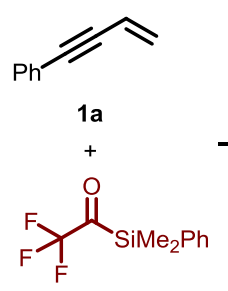

2a
$\mathrm{Cu}(\mathrm{OAC})_{2}(5 \mathrm{~mol} \%)$

Josiphos SL-J011-1 (6 mol\% ) $(\mathrm{MeO})_{2} \mathrm{MeSiH}$ ( 5 equiv.) THF, $12 \mathrm{~h}$

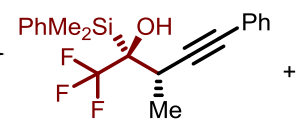

3a, $40 \%$ yield, $97: 3 \mathrm{dr}, 95 \%$ ee

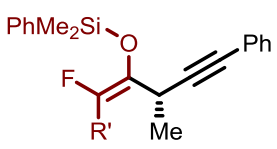

5a, $36 \%$ yield, $91 \%$ ee

Figure S1 
In order to probe the possible intermediates in the reaction, we monitored the above two reactions using ${ }^{19} \mathrm{~F} \mathrm{NMR}$ (without using saturated solution of $\mathrm{NH}_{4} \mathrm{~F}$ in $\mathrm{MeOH}$ to quench the reaction, adding 1 equivalent of $\mathrm{PhCF}_{3}$ as an internal standard under the protection of nitrogen). No signal of copper alkoxide intermediate $3 \mathbf{a}^{\prime}$ was detected regardless of the addition of tert-butanol or not (Figure S2). In reaction b, products 3a and 5a were found, but the enantioselectivities were lower. The loss of enantioselectivity for 5a may be due to the difference in the rate of the Brook rearrangement-fluoride elimination process of the different isomers of Intermediate 3a'.

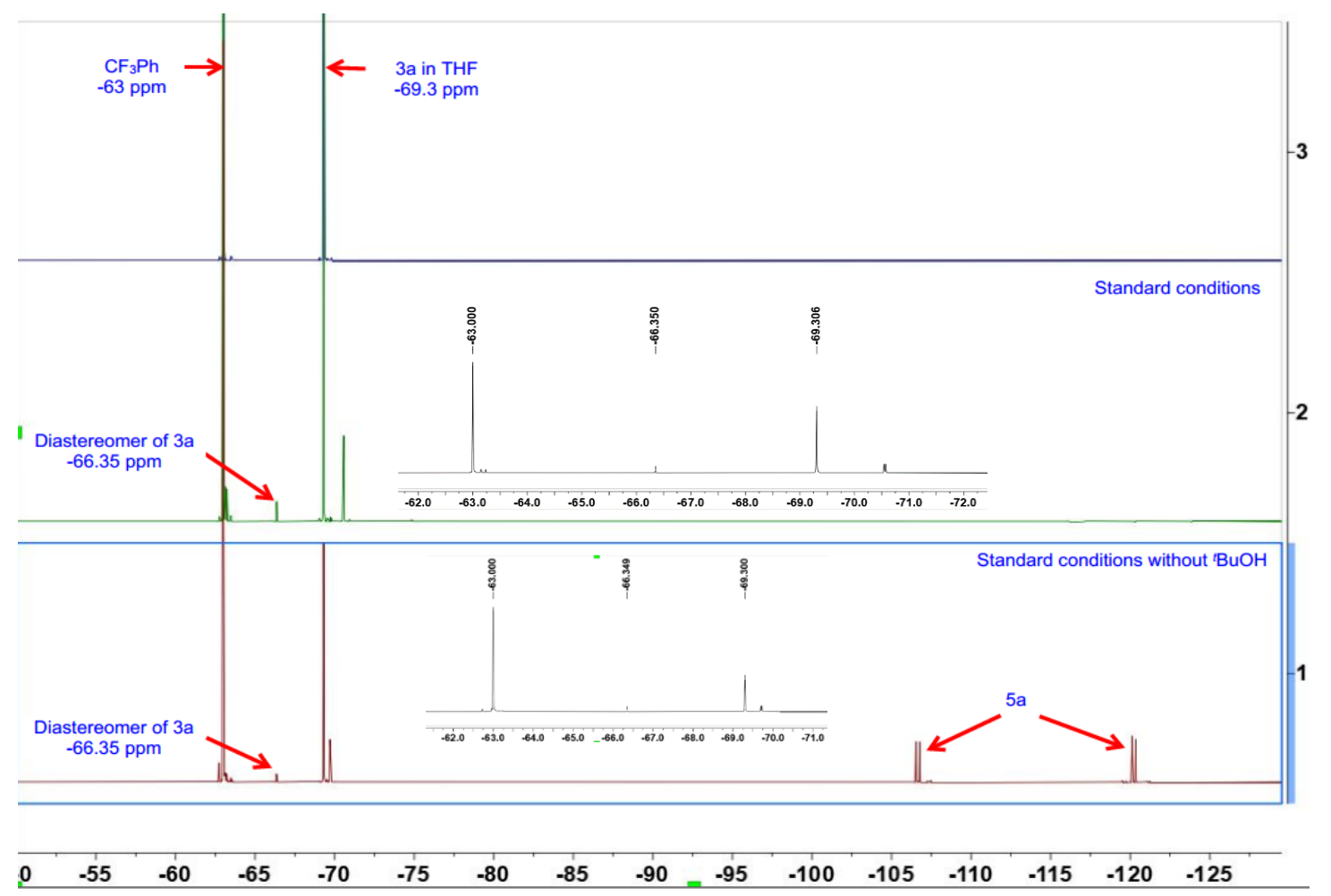

Figure S2 The ${ }^{19} \mathrm{~F}$ NMR analysis. Top: the ${ }^{19} \mathrm{~F}$ NMR of purified $\mathbf{3 a}$ in THF with $\mathrm{CF}_{3} \mathrm{Ph}$ as the internal standard; middle: the ${ }^{19} \mathrm{~F}$ NMR of reaction mixture under the standard conditions (without quench); bottom: the ${ }^{19} \mathrm{~F}$ NMR of reaction mixture without $t$ - $\mathrm{BuOH}$ under the standard conditions (without quench)

\section{Racemic 3a (Figure S1b):}

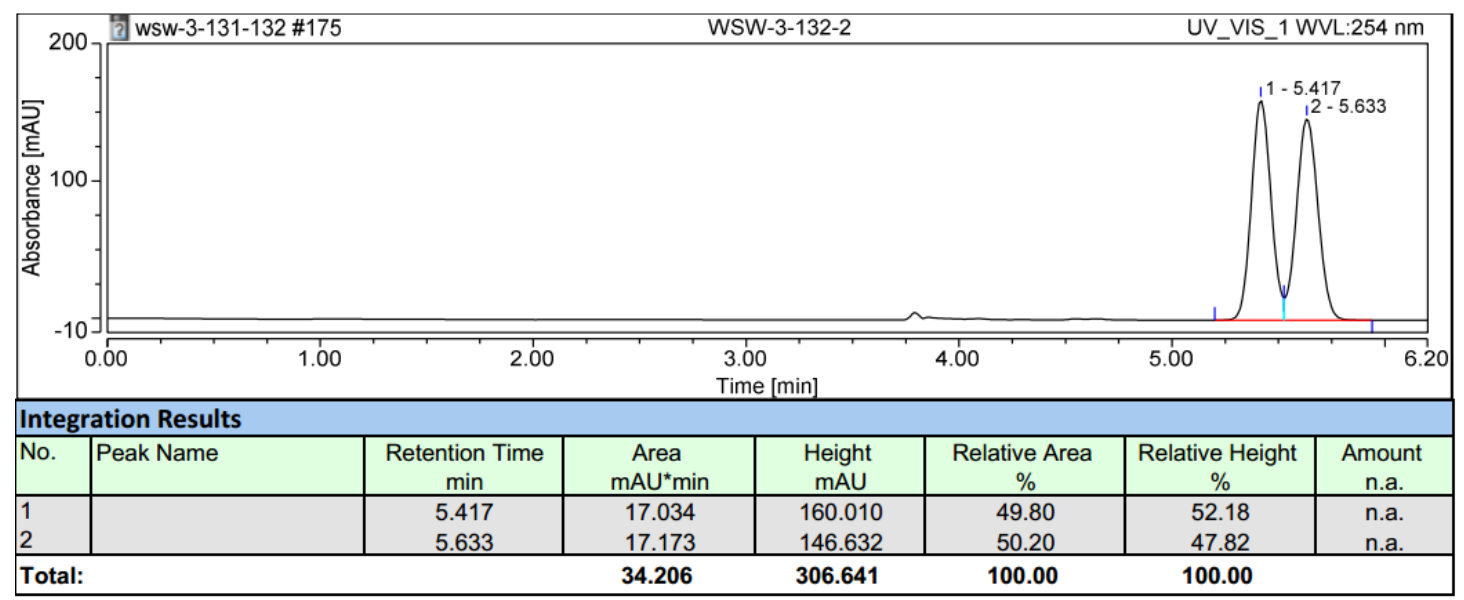


Enantioenriched 3a (Figure S1b):

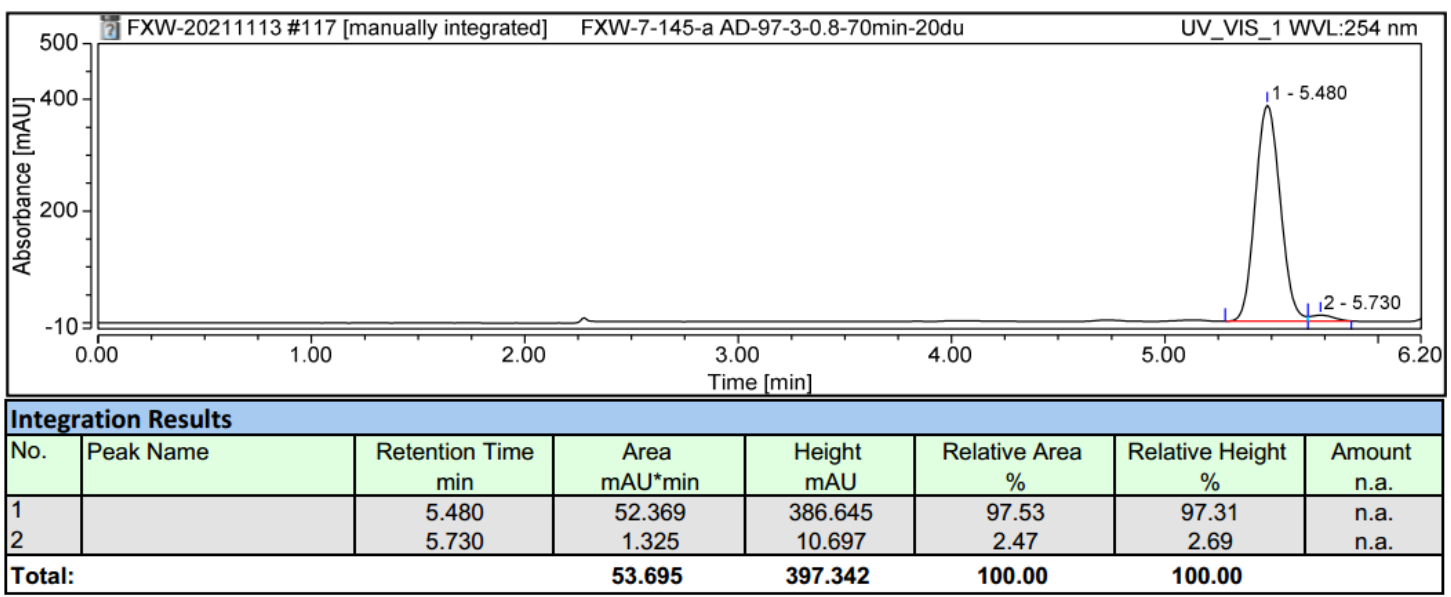

Racemic 5a (Figure S1b):

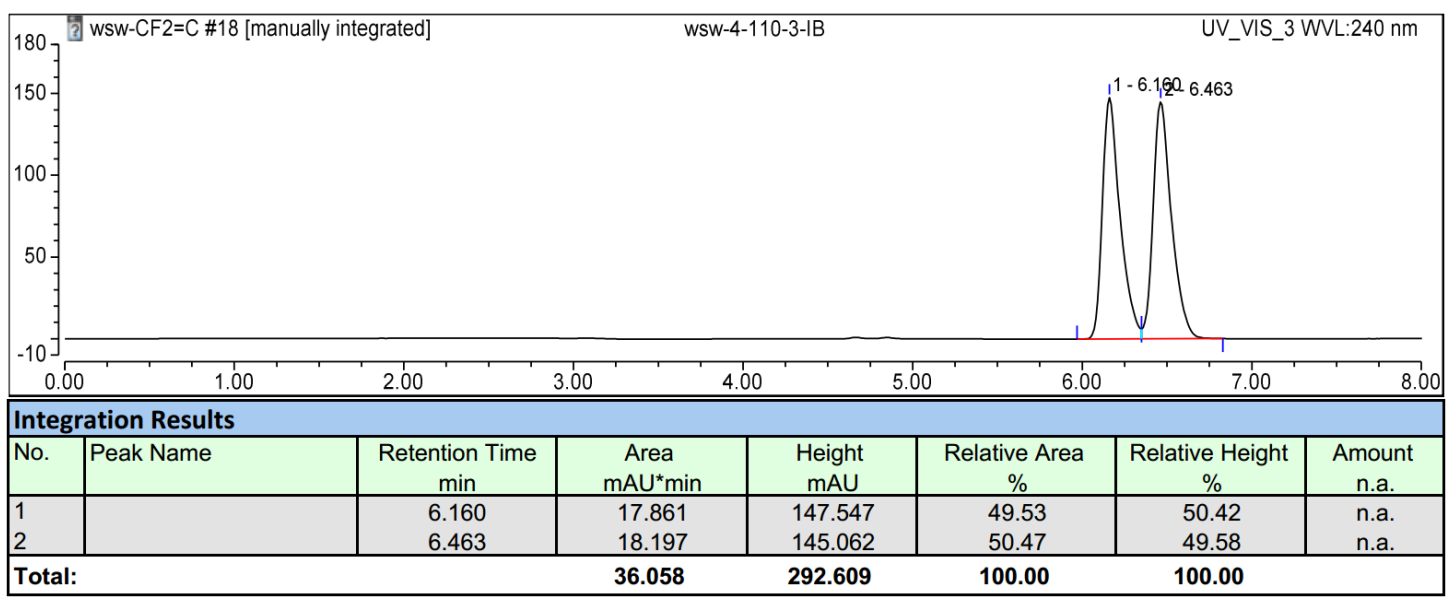

Enantioenriched 5a (sample from the reaction shown in Figure S1b):

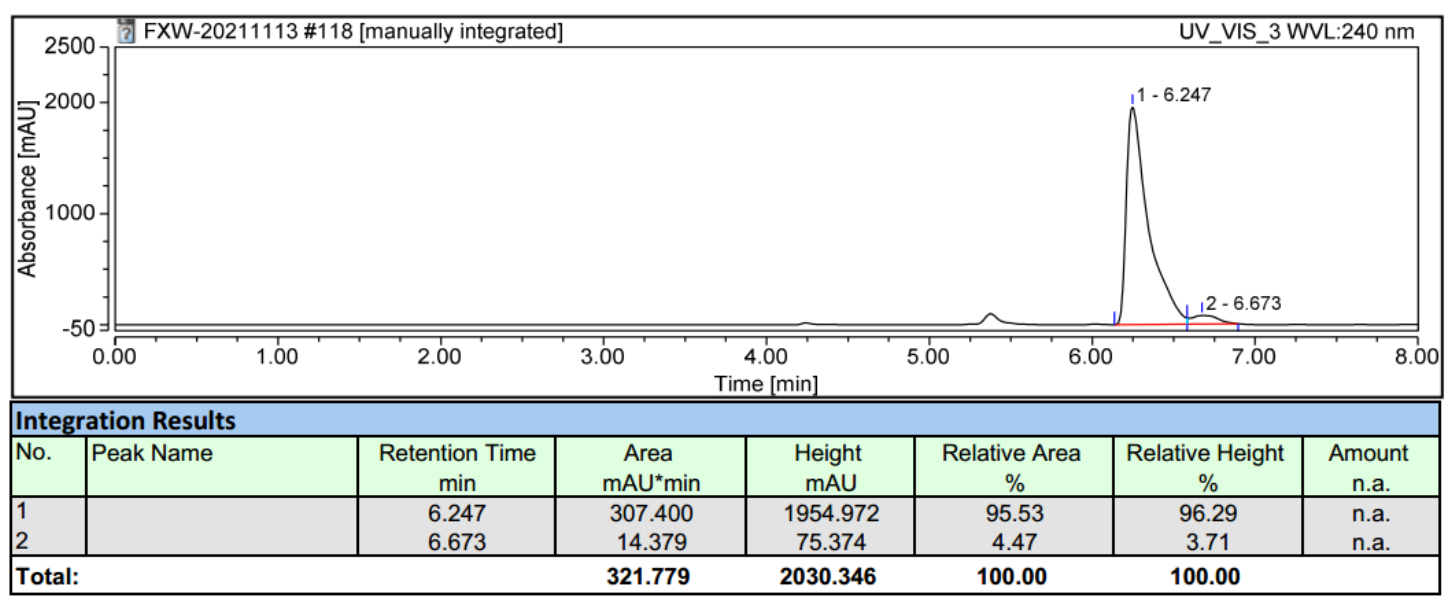




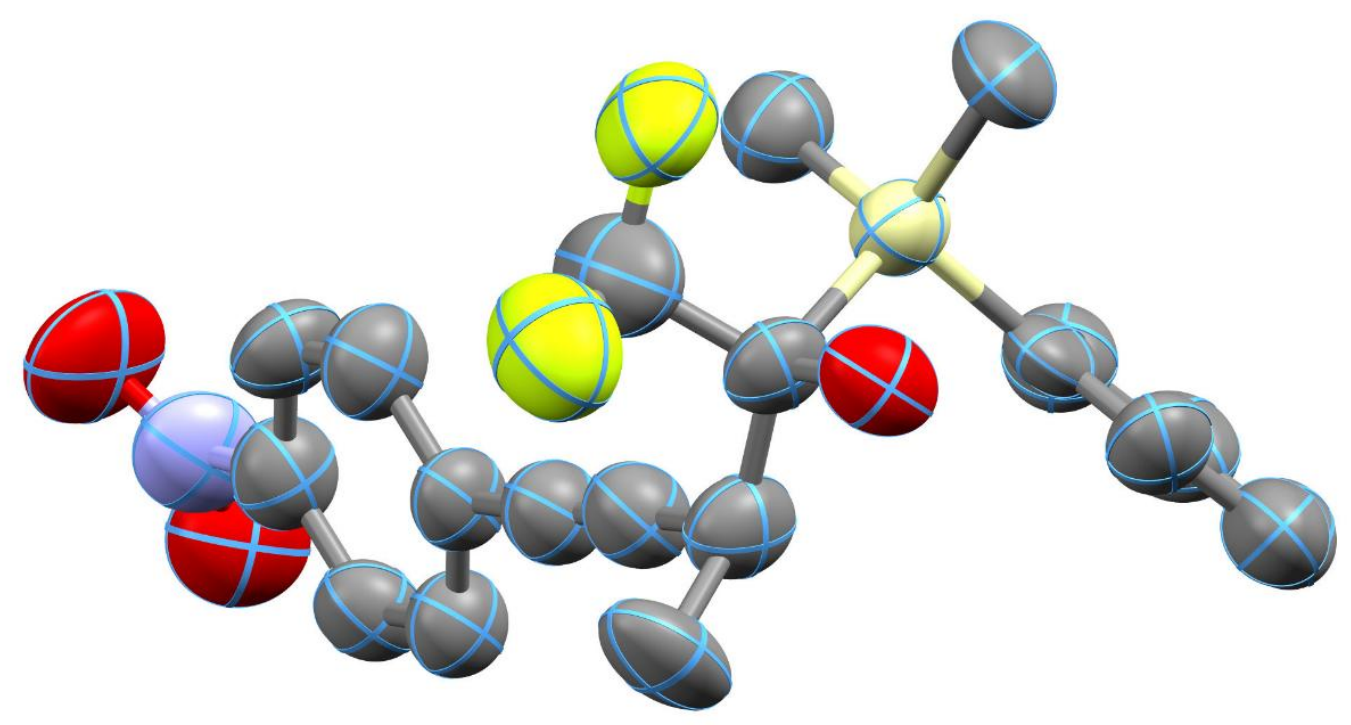

\section{ORTEP diagram of compound 3w-CCDC 2046964}

Table 1. Crystal data and structure refinement for final-wensongwei-wsw-4-74-250k-191223.

Identification code

Empirical formula

Formula weight

Temperature

Wavelength

Crystal system

Space group

Unit cell dimensions

Volume

Z

Density (calculated)

Absorption coefficient

$\mathrm{F}(000)$

Crystal size

Theta range for data collection

Index ranges wensongwei-wsw-4-74-250k-191223

C20 H21 F2 N O3 Si

389.47

274(30) K

$1.54184 \AA$

Triclinic

P1

$\mathrm{a}=9.1912(7) \AA$

$\alpha=97.232(4)^{\circ}$.

$\mathrm{b}=12.9247(8) \AA$

$\beta=97.041(5)^{\circ}$.

$\mathrm{c}=18.6126(5) \AA$

$\gamma=109.612(6)^{\circ}$.

2033.8(2) $\AA^{3}$

4

$1.272 \mathrm{Mg} / \mathrm{m}^{3}$

$1.350 \mathrm{~mm}^{-1}$

816

$0.04 \times 0.04 \times 0.02 \mathrm{~mm}^{3}$

2.431 to $64.998^{\circ}$.

$-10<=\mathrm{h}<=10,-15<=\mathrm{k}<=14,-21<=1<=21$ 
Reflections collected

Independent reflections

Completeness to theta $=64.998^{\circ}$

Absorption correction

Max. and min. transmission

Refinement method

Data / restraints / parameters

Goodness-of-fit on $\mathrm{F}^{2}$

Final R indices [I $>2 \operatorname{sigma}(\mathrm{I})]$

$\mathrm{R}$ indices (all data)

Absolute structure parameter

Extinction coefficient

Largest diff. peak and hole
54460

$13203[\mathrm{R}(\mathrm{int})=0.3016]$

$98.9 \%$

Semi-empirical from equivalents

1.00000 and 0.48643

Full-matrix least-squares on $\mathrm{F}^{2}$

13203 / 675 / 894

1.138

$\mathrm{R} 1=0.1285, \mathrm{wR} 2=0.3256$

$\mathrm{R} 1=0.2528, \mathrm{wR} 2=0.4322$

$-0.05(11)$

$\mathrm{n} / \mathrm{a}$

0.506 and -0.402 e. $\AA^{-3}$ 
Table 2. Atomic coordinates $\left(\mathrm{x} 10^{4}\right)$ and equivalent isotropic displacement parameters $\left(\AA^{2} \mathrm{x} 10^{3}\right)$ for final-wensongwei-wsw-4-74-250k-191223. U(eq) is defined as one third of the trace of the orthogonalized $\mathrm{U}^{\mathrm{ij}}$ tensor.

\begin{tabular}{|c|c|c|c|c|}
\hline & $\mathrm{x}$ & $\mathrm{y}$ & $\mathrm{z}$ & $\mathrm{U}(\mathrm{eq})$ \\
\hline $\operatorname{Si}(1)$ & $1232(7)$ & $4773(5)$ & $346(3)$ & $85(2)$ \\
\hline $\operatorname{Si}(4)$ & $6192(6)$ & $-547(5)$ & $9633(3)$ & $80(2)$ \\
\hline $\mathrm{Si}(3)$ & $2926(7)$ & 10582(5) & $6048(4)$ & $90(2)$ \\
\hline $\operatorname{Si}(2)$ & $6490(8)$ & $5599(6)$ & $3940(4)$ & $98(2)$ \\
\hline$F(6)$ & $4700(20)$ & $11253(15)$ & 7592(8) & $139(5)$ \\
\hline $\mathrm{O}(3)$ & $-1527(18)$ & $3797(12)$ & $738(10)$ & $102(4)$ \\
\hline$C(47)$ & $3680(30)$ & $7750(20)$ & $6023(12)$ & $81(5)$ \\
\hline $\mathrm{O}(6)$ & $6813(18)$ & $7686(15)$ & $3837(11)$ & $118(5)$ \\
\hline $\mathrm{O}(8)$ & $-300(20)$ & $2927(15)$ & $6459(13)$ & $134(7)$ \\
\hline $\mathrm{F}(2)$ & $1080(20)$ & $4524(13)$ & 1928(8) & $132(5)$ \\
\hline $\mathrm{N}(1)$ & $14570(30)$ & $4451(17)$ & $8519(15)$ & $107(6)$ \\
\hline $\mathrm{O}(11)$ & $15710(30)$ & $4907(15)$ & $9000(13)$ & $130(6)$ \\
\hline $\mathrm{N}(2)$ & $-580(30)$ & $3406(17)$ & $5968(16)$ & $110(6)$ \\
\hline $\mathrm{O}(9)$ & 5933(19) & $11778(13)$ & $6288(10)$ & $112(5)$ \\
\hline$C(41)$ & $567(16)$ & $4493(10)$ & $5988(8)$ & $87(6)$ \\
\hline$C(46)$ & $2030(18)$ & $4884(11)$ & $6439(8)$ & $105(7)$ \\
\hline$C(45)$ & $3069(14)$ & $5957(12)$ & $6452(8)$ & $96(7)$ \\
\hline$C(44)$ & $2644(16)$ & $6639(9)$ & $6013(8)$ & $82(5)$ \\
\hline$C(43)$ & 1181(18) & $6248(12)$ & $5561(8)$ & $109(7)$ \\
\hline$C(42)$ & $142(13)$ & $5175(13)$ & $5548(8)$ & $100(7)$ \\
\hline $\mathrm{C}(48)$ & $4480(30)$ & $8632(19)$ & $5958(11)$ & $75(5)$ \\
\hline $\mathrm{C}(49)$ & $5550(20)$ & $9835(18)$ & $5930(12)$ & $86(6)$ \\
\hline$C(68)$ & $9560(30)$ & $-507(19)$ & $9095(12)$ & $87(5)$ \\
\hline $\mathrm{F}(1)$ & $-910(20)$ & $4960(16)$ & 2118(9) & $151(6)$ \\
\hline $\mathrm{O}(12)$ & $5707(15)$ & $-2697(11)$ & $9224(9)$ & $89(4)$ \\
\hline$C(79)$ & $7750(20)$ & $-1001(14)$ & $11721(8)$ & $108(7)$ \\
\hline $\mathrm{C}(80)$ & 7021(17) & $-1184(10)$ & 10993(8) & $90(6)$ \\
\hline$C(75)$ & $7269(15)$ & $-298(12)$ & 10613(6) & $77(5)$ \\
\hline$C(76)$ & $8247(17)$ & $770(11)$ & 10961(9) & $93(6)$ \\
\hline$C(77)$ & $8976(17)$ & $953(12)$ & 11689(9) & $106(7)$ \\
\hline $\mathrm{C}(78)$ & $8728(19)$ & $67(17)$ & $12069(6)$ & $115(8)$ \\
\hline$C(11)$ & $-370(30)$ & $4880(20)$ & $908(13)$ & $102(7)$ \\
\hline
\end{tabular}




\begin{tabular}{|c|c|c|c|c|}
\hline$F(3)$ & $5890(20)$ & $6163(15)$ & $2450(8)$ & $144(6)$ \\
\hline $\mathrm{C}(69)$ & $8440(20)$ & $-1578(17)$ & $9248(13)$ & $88(6)$ \\
\hline $\mathrm{C}(4)$ & $2010(12)$ & $8980(8)$ & $1254(7)$ & $74(4)$ \\
\hline$C(3)$ & $3527(13)$ & $9224(9)$ & $1625(7)$ & $76(4)$ \\
\hline $\mathrm{C}(2)$ & $4615(11)$ & $10304(10)$ & 1733(7) & $80(4)$ \\
\hline $\mathrm{C}(1)$ & $4188(13)$ & $11140(8)$ & $1469(8)$ & $76(4)$ \\
\hline$C(6)$ & $2672(14)$ & $10896(9)$ & 1099(7) & $79(4)$ \\
\hline$C(5)$ & $1583(11)$ & $9816(10)$ & 991(7) & $79(4)$ \\
\hline$F(5)$ & 6873(19) & 10993(16) & $7506(8)$ & 141(5) \\
\hline $\mathrm{C}(21)$ & $-1363(18)$ & $1552(10)$ & 3929(9) & $93(6)$ \\
\hline $\mathrm{C}(22)$ & $60(20)$ & $1896(12)$ & $4408(8)$ & 118(8) \\
\hline $\mathrm{C}(23)$ & 1194(16) & 2934(13) & $4420(8)$ & 106(7) \\
\hline $\mathrm{C}(24)$ & $901(16)$ & $3627(10)$ & $3953(8)$ & $82(5)$ \\
\hline$C(25)$ & $-525(18)$ & $3283(12)$ & $3474(8)$ & $97(6)$ \\
\hline$C(26)$ & $-1657(15)$ & $2245(12)$ & $3462(8)$ & $99(7)$ \\
\hline $\mathrm{C}(73)$ & $4000(20)$ & $-1090(20)$ & $9616(13)$ & $102(7)$ \\
\hline $\mathrm{C}(31)$ & $5510(30)$ & $6670(20)$ & $3653(13)$ & 101(7) \\
\hline $\mathrm{C}(52)$ & $5330(30)$ & $10610(20)$ & $7196(14)$ & 109(7) \\
\hline$C(67)$ & $10470(20)$ & 293(18) & $8966(12)$ & $83(5)$ \\
\hline C(29) & $4230(30)$ & $6730(20)$ & $4104(12)$ & $96(7)$ \\
\hline $\mathrm{C}(30)$ & $3470(30)$ & $7590(20)$ & $3959(14)$ & 103(7) \\
\hline $\mathrm{C}(54)$ & $1430(30)$ & $9480(20)$ & $6418(15)$ & 118(8) \\
\hline$C(7)$ & $940(30)$ & $7840(20)$ & $1068(14)$ & $98(7)$ \\
\hline$C(35)$ & 6561(19) & $5657(15)$ & $4968(7)$ & $96(6)$ \\
\hline $\mathrm{C}(40)$ & 7333(18) & $6663(12)$ & $5451(9)$ & $98(6)$ \\
\hline C(39) & $7500(20)$ & $6687(14)$ & $6206(8)$ & 117(8) \\
\hline $\mathrm{C}(38)$ & $6900(20)$ & $5705(18)$ & $6478(7)$ & 115(8) \\
\hline $\mathrm{C}(37)$ & $6130(20)$ & $4699(14)$ & $5995(11)$ & 118(8) \\
\hline$C(36)$ & 5959(19) & $4675(12)$ & $5240(10)$ & $114(8)$ \\
\hline $\mathrm{F}(4)$ & $4560(20)$ & $7251(16)$ & $2589(9)$ & $158(6)$ \\
\hline$C(15)$ & $478(19)$ & $4802(13)$ & $-641(7)$ & $86(6)$ \\
\hline $\mathrm{C}(20)$ & $-933(19)$ & 4001(13) & $-1013(10)$ & 109(7) \\
\hline C(19) & $-1450(20)$ & $3992(17)$ & $-1748(10)$ & 139(9) \\
\hline $\mathrm{C}(18)$ & $-550(30)$ & $4780(20)$ & $-2112(7)$ & $146(10)$ \\
\hline $\mathrm{C}(17)$ & $860(30)$ & $5586(16)$ & $-1740(9)$ & 133(9) \\
\hline$C(16)$ & $1376(18)$ & $5595(12)$ & $-1004(9)$ & $105(7)$ \\
\hline $\mathrm{O}(7)$ & $-1710(30)$ & $3049(17)$ & $5471(15)$ & 147(8) \\
\hline $\mathrm{O}(10)$ & $14250(20)$ & $4815(17)$ & $7992(13)$ & $149(8)$ \\
\hline
\end{tabular}




\begin{tabular}{|c|c|c|c|c|}
\hline$C(66)$ & 11993(15) & $2937(10)$ & $8258(7)$ & $85(5)$ \\
\hline$C(65)$ & 10973(12) & $1918(10)$ & $8364(7)$ & $88(5)$ \\
\hline$C(64)$ & $11506(13)$ & 1309(9) & $8828(7)$ & $74(4)$ \\
\hline$C(63)$ & $13059(14)$ & $1718(10)$ & $9186(7)$ & $82(4)$ \\
\hline$C(62)$ & $14079(11)$ & $2737(10)$ & 9079(7) & $81(4)$ \\
\hline $\mathrm{C}(61)$ & $13546(14)$ & $3346(8)$ & $8615(8)$ & $87(5)$ \\
\hline$C(32)$ & $4850(30)$ & $6360(20)$ & $2843(13)$ & 112(8) \\
\hline $\mathrm{F}(7)$ & $6270(20)$ & $-2579(16)$ & 7808(9) & 151(6) \\
\hline$C(12)$ & $300(40)$ & $5180(20)$ & $1732(15)$ & 124(9) \\
\hline $\mathrm{C}(9)$ & $-1130(30)$ & $5742(19)$ & $659(14)$ & $95(6)$ \\
\hline $\mathrm{C}(33)$ & $8540(30)$ & $6130(30)$ & $3763(16)$ & 124(9) \\
\hline $\mathrm{C}(55)$ & $2586(19)$ & $10263(14)$ & $5006(7)$ & $91(6)$ \\
\hline$C(56)$ & 1243(19) & $9423(13)$ & $4604(11)$ & 117(8) \\
\hline $\mathrm{C}(57)$ & $960(20)$ & $9279(15)$ & $3841(11)$ & 134(9) \\
\hline $\mathrm{C}(58)$ & $2010(30)$ & $9970(20)$ & $3479(7)$ & $143(10)$ \\
\hline $\mathrm{C}(59)$ & $3360(20)$ & $10815(19)$ & 3881(9) & 143(10) \\
\hline$C(60)$ & $3643(17)$ & $10959(14)$ & $4645(9)$ & 111(8) \\
\hline $\mathrm{C}(51)$ & $5080(30)$ & $10660(20)$ & $6404(12)$ & 102(7) \\
\hline $\mathrm{C}(34)$ & $5380(30)$ & $4180(30)$ & $3384(17)$ & $140(10)$ \\
\hline $\mathrm{C}(8)$ & $20(30)$ & $6890(30)$ & $871(13)$ & $99(7)$ \\
\hline$C(10)$ & $-2670(30)$ & $5722(17)$ & $919(16)$ & 112(8) \\
\hline $\mathrm{C}(50)$ & $7270(20)$ & $9890(20)$ & $6136(15)$ & 109(8) \\
\hline$C(53)$ & $2750(30)$ & $11990(20)$ & $6382(16)$ & 123(9) \\
\hline$C(70)$ & $8920(30)$ & $-2557(19)$ & $8903(16)$ & 111(8) \\
\hline $\mathrm{C}(27)$ & $2010(30)$ & $4710(20)$ & $3980(13)$ & $91(6)$ \\
\hline $\mathrm{C}(14)$ & $3130(20)$ & $5950(20)$ & $682(14)$ & 113(8) \\
\hline$C(13)$ & $1440(30)$ & $3390(20)$ & $403(14)$ & 122(9) \\
\hline$C(28)$ & $3030(30)$ & $5570(30)$ & $4053(12)$ & $103(7)$ \\
\hline$C(74)$ & $6770(30)$ & $800(20)$ & $9296(12)$ & $99(7)$ \\
\hline $\mathrm{F}(8)$ & $4804(17)$ & $-1626(13)$ & $8073(7)$ & 121(4) \\
\hline $\mathrm{O}(1)$ & $6520(20)$ & $12497(15)$ & 1941(12) & 128(6) \\
\hline $\mathrm{O}(4)$ & $-3600(30)$ & 104(19) & $3445(14)$ & $165(10)$ \\
\hline $\mathrm{N}(3)$ & $-2530(30)$ & 501(18) & $3939(16)$ & 114(7) \\
\hline $\mathrm{N}(4)$ & $5300(20)$ & $12225(17)$ & $1528(13)$ & $100(6)$ \\
\hline $\mathrm{O}(5)$ & $-2330(30)$ & 41(17) & $4454(15)$ & 163(9) \\
\hline $\mathrm{O}(2)$ & $5080(20)$ & $12842(15)$ & $1155(13)$ & 151(9) \\
\hline $\mathrm{C}(71)$ & $6720(20)$ & $-1703(15)$ & $9043(10)$ & $74(5)$ \\
\hline $\mathrm{C}(72)$ & $6340(40)$ & $-1600(30)$ & $8221(15)$ & $123(7)$ \\
\hline
\end{tabular}


Table 3. Bond lengths $[\AA]$ and angles $\left[^{\circ}\right]$ for final-wensongwei-wsw-4-74-250k-191223.

\begin{tabular}{|c|c|}
\hline $\operatorname{Si}(1)-C(11)$ & $1.93(3)$ \\
\hline $\mathrm{Si}(1)-\mathrm{C}(15)$ & $1.891(13)$ \\
\hline $\mathrm{Si}(1)-\mathrm{C}(14)$ & $1.86(2)$ \\
\hline $\mathrm{Si}(1)-\mathrm{C}(13)$ & $1.88(3)$ \\
\hline $\mathrm{Si}(4)-\mathrm{C}(75)$ & $1.899(12)$ \\
\hline $\mathrm{Si}(4)-\mathrm{C}(73)$ & $1.89(2)$ \\
\hline $\operatorname{Si}(4)-C(74)$ & $1.85(2)$ \\
\hline $\operatorname{Si}(4)-C(71)$ & $1.97(2)$ \\
\hline $\mathrm{Si}(3)-\mathrm{C}(54)$ & $1.88(2)$ \\
\hline $\mathrm{Si}(3)-\mathrm{C}(55)$ & $1.894(14)$ \\
\hline $\mathrm{Si}(3)-\mathrm{C}(51)$ & $1.97(3)$ \\
\hline $\mathrm{Si}(3)-\mathrm{C}(53)$ & $1.92(2)$ \\
\hline $\operatorname{Si}(2)-C(31)$ & $1.98(3)$ \\
\hline $\mathrm{Si}(2)-\mathrm{C}(35)$ & $1.897(14)$ \\
\hline $\mathrm{Si}(2)-\mathrm{C}(33)$ & $1.86(3)$ \\
\hline $\mathrm{Si}(2)-\mathrm{C}(34)$ & $1.86(3)$ \\
\hline $\mathrm{F}(6)-\mathrm{C}(52)$ & $1.36(3)$ \\
\hline $\mathrm{O}(3)-\mathrm{H}(3)$ & 0.8200 \\
\hline $\mathrm{O}(3)-\mathrm{C}(11)$ & $1.41(3)$ \\
\hline $\mathrm{C}(47)-\mathrm{C}(44)$ & $1.43(3)$ \\
\hline $\mathrm{C}(47)-\mathrm{C}(48)$ & $1.16(3)$ \\
\hline $\mathrm{O}(6)-\mathrm{H}(6 \mathrm{~A})$ & 0.8200 \\
\hline $\mathrm{O}(6)-\mathrm{C}(31)$ & $1.41(3)$ \\
\hline $\mathrm{O}(8)-\mathrm{N}(2)$ & $1.21(3)$ \\
\hline $\mathrm{F}(2)-\mathrm{C}(12)$ & $1.34(3)$ \\
\hline $\mathrm{N}(1)-\mathrm{O}(11)$ & $1.21(3)$ \\
\hline $\mathrm{N}(1)-\mathrm{O}(10)$ & $1.19(3)$ \\
\hline $\mathrm{N}(1)-\mathrm{C}(61)$ & $1.47(2)$ \\
\hline $\mathrm{N}(2)-\mathrm{C}(41)$ & $1.44(2)$ \\
\hline $\mathrm{N}(2)-\mathrm{O}(7)$ & $1.22(3)$ \\
\hline $\mathrm{O}(9)-\mathrm{H}(9 \mathrm{~A})$ & 0.8200 \\
\hline $\mathrm{O}(9)-\mathrm{C}(51)$ & $1.46(3)$ \\
\hline $\mathrm{C}(41)-\mathrm{C}(46)$ & 1.3900 \\
\hline $\mathrm{C}(41)-\mathrm{C}(42)$ & 1.3900 \\
\hline $\mathrm{C}(46)-\mathrm{H}(46)$ & 0.9300 \\
\hline
\end{tabular}




\begin{tabular}{|c|c|}
\hline$C(46)-C(45)$ & 1.3900 \\
\hline $\mathrm{C}(45)-\mathrm{H}(45)$ & 0.9300 \\
\hline$C(45)-C(44)$ & 1.3900 \\
\hline $\mathrm{C}(44)-\mathrm{C}(43)$ & 1.3900 \\
\hline $\mathrm{C}(43)-\mathrm{H}(43)$ & 0.9300 \\
\hline $\mathrm{C}(43)-\mathrm{C}(42)$ & 1.3900 \\
\hline $\mathrm{C}(42)-\mathrm{H}(42)$ & 0.9300 \\
\hline C(48)-C(49) & $1.55(3)$ \\
\hline C(49)-H(49) & 0.9800 \\
\hline $\mathrm{C}(49)-\mathrm{C}(51)$ & $1.50(3)$ \\
\hline $\mathrm{C}(49)-\mathrm{C}(50)$ & $1.55(3)$ \\
\hline $\mathrm{C}(68)-\mathrm{C}(69)$ & $1.51(3)$ \\
\hline$C(68)-C(67)$ & $1.16(3)$ \\
\hline $\mathrm{F}(1)-\mathrm{C}(12)$ & $1.36(3)$ \\
\hline $\mathrm{O}(12)-\mathrm{H}(12 \mathrm{~A})$ & 0.8200 \\
\hline $\mathrm{O}(12)-\mathrm{C}(71)$ & $1.42(2)$ \\
\hline C(79)-H(79) & 0.9300 \\
\hline$C(79)-C(80)$ & 1.3900 \\
\hline $\mathrm{C}(79)-\mathrm{C}(78)$ & 1.3900 \\
\hline $\mathrm{C}(80)-\mathrm{H}(80)$ & 0.9300 \\
\hline $\mathrm{C}(80)-\mathrm{C}(75)$ & 1.3900 \\
\hline $\mathrm{C}(75)-\mathrm{C}(76)$ & 1.3900 \\
\hline $\mathrm{C}(76)-\mathrm{H}(76)$ & 0.9300 \\
\hline$C(76)-C(77)$ & 1.3900 \\
\hline $\mathrm{C}(77)-\mathrm{H}(77)$ & 0.9300 \\
\hline $\mathrm{C}(77)-\mathrm{C}(78)$ & 1.3900 \\
\hline $\mathrm{C}(78)-\mathrm{H}(78)$ & 0.9300 \\
\hline $\mathrm{C}(11)-\mathrm{C}(12)$ & $1.53(4)$ \\
\hline $\mathrm{C}(11)-\mathrm{C}(9)$ & $1.59(3)$ \\
\hline $\mathrm{F}(3)-\mathrm{C}(32)$ & $1.34(3)$ \\
\hline $\mathrm{C}(69)-\mathrm{H}(69)$ & 0.9800 \\
\hline $\mathrm{C}(69)-\mathrm{C}(70)$ & $1.56(3)$ \\
\hline $\mathrm{C}(69)-\mathrm{C}(71)$ & $1.53(3)$ \\
\hline $\mathrm{C}(4)-\mathrm{C}(3)$ & 1.3900 \\
\hline$C(4)-C(5)$ & 1.3900 \\
\hline$C(4)-C(7)$ & $1.44(3)$ \\
\hline $\mathrm{C}(3)-\mathrm{H}(3 \mathrm{~A})$ & 0.9300 \\
\hline $\mathrm{C}(3)-\mathrm{C}(2)$ & 1.3900 \\
\hline
\end{tabular}




\begin{tabular}{|c|c|}
\hline $\mathrm{C}(2)-\mathrm{H}(2)$ & 0.9300 \\
\hline$C(2)-C(1)$ & 1.3900 \\
\hline$C(1)-C(6)$ & 1.3900 \\
\hline $\mathrm{C}(1)-\mathrm{N}(4)$ & $1.41(2)$ \\
\hline $\mathrm{C}(6)-\mathrm{H}(6)$ & 0.9300 \\
\hline$C(6)-C(5)$ & 1.3900 \\
\hline $\mathrm{C}(5)-\mathrm{H}(5)$ & 0.9300 \\
\hline $\mathrm{F}(5)-\mathrm{C}(52)$ & $1.35(3)$ \\
\hline $\mathrm{C}(21)-\mathrm{C}(22)$ & 1.3900 \\
\hline $\mathrm{C}(21)-\mathrm{C}(26)$ & 1.3900 \\
\hline $\mathrm{C}(21)-\mathrm{N}(3)$ & $1.42(2)$ \\
\hline $\mathrm{C}(22)-\mathrm{H}(22)$ & 0.9300 \\
\hline$C(22)-C(23)$ & 1.3900 \\
\hline $\mathrm{C}(23)-\mathrm{H}(23)$ & 0.9300 \\
\hline$C(23)-C(24)$ & 1.3900 \\
\hline$C(24)-C(25)$ & 1.3900 \\
\hline$C(24)-C(27)$ & $1.42(3)$ \\
\hline $\mathrm{C}(25)-\mathrm{H}(25)$ & 0.9300 \\
\hline$C(25)-C(26)$ & 1.3900 \\
\hline $\mathrm{C}(26)-\mathrm{H}(26)$ & 0.9300 \\
\hline $\mathrm{C}(73)-\mathrm{H}(73 \mathrm{~A})$ & 0.9600 \\
\hline $\mathrm{C}(73)-\mathrm{H}(73 \mathrm{~B})$ & 0.9600 \\
\hline $\mathrm{C}(73)-\mathrm{H}(73 \mathrm{C})$ & 0.9600 \\
\hline$C(31)-C(29)$ & $1.55(3)$ \\
\hline $\mathrm{C}(31)-\mathrm{C}(32)$ & $1.50(3)$ \\
\hline $\mathrm{C}(52)-\mathrm{H}(52)$ & 0.9800 \\
\hline$C(52)-C(51)$ & $1.48(3)$ \\
\hline$C(67)-C(64)$ & $1.42(2)$ \\
\hline $\mathrm{C}(29)-\mathrm{H}(29)$ & 0.9800 \\
\hline$C(29)-C(30)$ & $1.53(3)$ \\
\hline $\mathrm{C}(29)-\mathrm{C}(28)$ & $1.52(4)$ \\
\hline $\mathrm{C}(30)-\mathrm{H}(30 \mathrm{~A})$ & 0.9600 \\
\hline $\mathrm{C}(30)-\mathrm{H}(30 \mathrm{~B})$ & 0.9600 \\
\hline $\mathrm{C}(30)-\mathrm{H}(30 \mathrm{C})$ & 0.9600 \\
\hline $\mathrm{C}(54)-\mathrm{H}(54 \mathrm{~A})$ & 0.9600 \\
\hline $\mathrm{C}(54)-\mathrm{H}(54 \mathrm{~B})$ & 0.9600 \\
\hline $\mathrm{C}(54)-\mathrm{H}(54 \mathrm{C})$ & 0.9600 \\
\hline$C(7)-C(8)$ & $1.21(3)$ \\
\hline
\end{tabular}




\begin{tabular}{|c|c|}
\hline $\mathrm{C}(35)-\mathrm{C}(40)$ & 1.3900 \\
\hline $\mathrm{C}(35)-\mathrm{C}(36)$ & 1.3900 \\
\hline $\mathrm{C}(40)-\mathrm{H}(40)$ & 0.9300 \\
\hline $\mathrm{C}(40)-\mathrm{C}(39)$ & 1.3900 \\
\hline C(39)-H(39) & 0.9300 \\
\hline C(39)-C(38) & 1.3900 \\
\hline $\mathrm{C}(38)-\mathrm{H}(38)$ & 0.9300 \\
\hline C(38)-C(37) & 1.3900 \\
\hline $\mathrm{C}(37)-\mathrm{H}(37)$ & 0.9300 \\
\hline$C(37)-C(36)$ & 1.3900 \\
\hline $\mathrm{C}(36)-\mathrm{H}(36)$ & 0.9300 \\
\hline $\mathrm{F}(4)-\mathrm{C}(32)$ & $1.39(3)$ \\
\hline$C(15)-C(20)$ & 1.3900 \\
\hline$C(15)-C(16)$ & 1.3900 \\
\hline $\mathrm{C}(20)-\mathrm{H}(20)$ & 0.9300 \\
\hline$C(20)-C(19)$ & 1.3900 \\
\hline C(19)-H(19) & 0.9300 \\
\hline$C(19)-C(18)$ & 1.3900 \\
\hline $\mathrm{C}(18)-\mathrm{H}(18)$ & 0.9300 \\
\hline $\mathrm{C}(18)-\mathrm{C}(17)$ & 1.3900 \\
\hline $\mathrm{C}(17)-\mathrm{H}(17)$ & 0.9300 \\
\hline$C(17)-C(16)$ & 1.3900 \\
\hline C(16)-H(16) & 0.9300 \\
\hline $\mathrm{C}(66)-\mathrm{H}(66)$ & 0.9300 \\
\hline$C(66)-C(65)$ & 1.3900 \\
\hline$C(66)-C(61)$ & 1.3900 \\
\hline $\mathrm{C}(65)-\mathrm{H}(65)$ & 0.9300 \\
\hline$C(65)-C(64)$ & 1.3900 \\
\hline C(64)-C(63) & 1.3900 \\
\hline $\mathrm{C}(63)-\mathrm{H}(63)$ & 0.9300 \\
\hline$C(63)-C(62)$ & 1.3900 \\
\hline $\mathrm{C}(62)-\mathrm{H}(62)$ & 0.9300 \\
\hline$C(62)-C(61)$ & 1.3900 \\
\hline C(32)-H(32) & 0.9800 \\
\hline $\mathrm{F}(7)-\mathrm{C}(72)$ & $1.37(3)$ \\
\hline $\mathrm{C}(12)-\mathrm{H}(12)$ & 0.9800 \\
\hline $\mathrm{C}(9)-\mathrm{H}(9)$ & 0.9800 \\
\hline $\mathrm{C}(9)-\mathrm{C}(8)$ & $1.47(4)$ \\
\hline
\end{tabular}




\begin{tabular}{|c|c|}
\hline $\mathrm{C}(9)-\mathrm{C}(10)$ & $1.55(3)$ \\
\hline $\mathrm{C}(33)-\mathrm{H}(33 \mathrm{~A})$ & 0.9600 \\
\hline $\mathrm{C}(33)-\mathrm{H}(33 \mathrm{~B})$ & 0.9600 \\
\hline $\mathrm{C}(33)-\mathrm{H}(33 \mathrm{C})$ & 0.9600 \\
\hline $\mathrm{C}(55)-\mathrm{C}(56)$ & 1.3900 \\
\hline$C(55)-C(60)$ & 1.3900 \\
\hline $\mathrm{C}(56)-\mathrm{H}(56)$ & 0.9300 \\
\hline$C(56)-C(57)$ & 1.3900 \\
\hline $\mathrm{C}(57)-\mathrm{H}(57)$ & 0.9300 \\
\hline $\mathrm{C}(57)-\mathrm{C}(58)$ & 1.3900 \\
\hline $\mathrm{C}(58)-\mathrm{H}(58)$ & 0.9300 \\
\hline $\mathrm{C}(58)-\mathrm{C}(59)$ & 1.3900 \\
\hline $\mathrm{C}(59)-\mathrm{H}(59)$ & 0.9300 \\
\hline$C(59)-C(60)$ & 1.3900 \\
\hline $\mathrm{C}(60)-\mathrm{H}(60)$ & 0.9300 \\
\hline $\mathrm{C}(34)-\mathrm{H}(34 \mathrm{~A})$ & 0.9600 \\
\hline $\mathrm{C}(34)-\mathrm{H}(34 \mathrm{~B})$ & 0.9600 \\
\hline $\mathrm{C}(34)-\mathrm{H}(34 \mathrm{C})$ & 0.9600 \\
\hline $\mathrm{C}(10)-\mathrm{H}(10 \mathrm{~A})$ & 0.9600 \\
\hline $\mathrm{C}(10)-\mathrm{H}(10 \mathrm{~B})$ & 0.9600 \\
\hline $\mathrm{C}(10)-\mathrm{H}(10 \mathrm{C})$ & 0.9600 \\
\hline $\mathrm{C}(50)-\mathrm{H}(50 \mathrm{~A})$ & 0.9600 \\
\hline $\mathrm{C}(50)-\mathrm{H}(50 \mathrm{~B})$ & 0.9600 \\
\hline $\mathrm{C}(50)-\mathrm{H}(50 \mathrm{C})$ & 0.9600 \\
\hline $\mathrm{C}(53)-\mathrm{H}(53 \mathrm{~A})$ & 0.9600 \\
\hline $\mathrm{C}(53)-\mathrm{H}(53 \mathrm{~B})$ & 0.9600 \\
\hline $\mathrm{C}(53)-\mathrm{H}(53 \mathrm{C})$ & 0.9600 \\
\hline $\mathrm{C}(70)-\mathrm{H}(70 \mathrm{~A})$ & 0.9600 \\
\hline $\mathrm{C}(70)-\mathrm{H}(70 \mathrm{~B})$ & 0.9600 \\
\hline $\mathrm{C}(70)-\mathrm{H}(70 \mathrm{C})$ & 0.9600 \\
\hline $\mathrm{C}(27)-\mathrm{C}(28)$ & $1.16(3)$ \\
\hline $\mathrm{C}(14)-\mathrm{H}(14 \mathrm{~A})$ & 0.9600 \\
\hline $\mathrm{C}(14)-\mathrm{H}(14 \mathrm{~B})$ & 0.9600 \\
\hline $\mathrm{C}(14)-\mathrm{H}(14 \mathrm{C})$ & 0.9600 \\
\hline $\mathrm{C}(13)-\mathrm{H}(13 \mathrm{~A})$ & 0.9600 \\
\hline $\mathrm{C}(13)-\mathrm{H}(13 \mathrm{~B})$ & 0.9600 \\
\hline $\mathrm{C}(13)-\mathrm{H}(13 \mathrm{C})$ & 0.9600 \\
\hline $\mathrm{C}(74)-\mathrm{H}(74 \mathrm{~A})$ & 0.9600 \\
\hline
\end{tabular}




\begin{tabular}{|c|c|}
\hline $\mathrm{C}(74)-\mathrm{H}(74 \mathrm{~B})$ & 0.9600 \\
\hline $\mathrm{C}(74)-\mathrm{H}(74 \mathrm{C})$ & 0.9600 \\
\hline $\mathrm{F}(8)-\mathrm{C}(72)$ & $1.39(3)$ \\
\hline $\mathrm{O}(1)-\mathrm{N}(4)$ & $1.20(2)$ \\
\hline $\mathrm{O}(4)-\mathrm{N}(3)$ & $1.18(3)$ \\
\hline $\mathrm{N}(3)-\mathrm{O}(5)$ & $1.22(3)$ \\
\hline $\mathrm{N}(4)-\mathrm{O}(2)$ & $1.17(2)$ \\
\hline $\mathrm{C}(71)-\mathrm{C}(72)$ & $1.56(3)$ \\
\hline $\mathrm{C}(72)-\mathrm{H}(72)$ & 0.9800 \\
\hline$C(15)-\operatorname{Si}(1)-C(11)$ & $106.9(9)$ \\
\hline $\mathrm{C}(14)-\mathrm{Si}(1)-\mathrm{C}(11)$ & $112.1(11)$ \\
\hline$C(14)-\operatorname{Si}(1)-C(15)$ & $109.5(10)$ \\
\hline $\mathrm{C}(14)-\mathrm{Si}(1)-\mathrm{C}(13)$ & $111.6(13)$ \\
\hline $\mathrm{C}(13)-\mathrm{Si}(1)-\mathrm{C}(11)$ & $107.2(11)$ \\
\hline $\mathrm{C}(13)-\mathrm{Si}(1)-\mathrm{C}(15)$ & $109.4(10)$ \\
\hline $\mathrm{C}(75)-\mathrm{Si}(4)-\mathrm{C}(71)$ & $107.8(7)$ \\
\hline $\mathrm{C}(73)-\mathrm{Si}(4)-\mathrm{C}(75)$ & $109.7(8)$ \\
\hline $\mathrm{C}(73)-\mathrm{Si}(4)-\mathrm{C}(71)$ & $108.0(10)$ \\
\hline $\mathrm{C}(74)-\mathrm{Si}(4)-\mathrm{C}(75)$ & $108.5(9)$ \\
\hline $\mathrm{C}(74)-\mathrm{Si}(4)-\mathrm{C}(73)$ & $109.6(11)$ \\
\hline $\mathrm{C}(74)-\mathrm{Si}(4)-\mathrm{C}(71)$ & $113.2(10)$ \\
\hline$C(54)-\operatorname{Si}(3)-C(55)$ & $110.9(10)$ \\
\hline $\mathrm{C}(54)-\mathrm{Si}(3)-\mathrm{C}(51)$ & $111.4(10)$ \\
\hline $\mathrm{C}(54)-\mathrm{Si}(3)-\mathrm{C}(53)$ & $107.7(13)$ \\
\hline $\mathrm{C}(55)-\mathrm{Si}(3)-\mathrm{C}(51)$ & 107.2(9) \\
\hline $\mathrm{C}(55)-\mathrm{Si}(3)-\mathrm{C}(53)$ & $110.6(10)$ \\
\hline$C(53)-\operatorname{Si}(3)-C(51)$ & $109.1(12)$ \\
\hline $\mathrm{C}(35)-\mathrm{Si}(2)-\mathrm{C}(31)$ & 107.0(9) \\
\hline $\mathrm{C}(33)-\mathrm{Si}(2)-\mathrm{C}(31)$ & $106.4(12)$ \\
\hline $\mathrm{C}(33)-\mathrm{Si}(2)-\mathrm{C}(35)$ & $108.5(11)$ \\
\hline $\mathrm{C}(33)-\mathrm{Si}(2)-\mathrm{C}(34)$ & $110.8(14)$ \\
\hline $\mathrm{C}(34)-\mathrm{Si}(2)-\mathrm{C}(31)$ & $110.1(12)$ \\
\hline $\mathrm{C}(34)-\mathrm{Si}(2)-\mathrm{C}(35)$ & $113.6(13)$ \\
\hline $\mathrm{C}(11)-\mathrm{O}(3)-\mathrm{H}(3)$ & 109.5 \\
\hline $\mathrm{C}(48)-\mathrm{C}(47)-\mathrm{C}(44)$ & $173(2)$ \\
\hline $\mathrm{C}(31)-\mathrm{O}(6)-\mathrm{H}(6 \mathrm{~A})$ & 109.5 \\
\hline $\mathrm{O}(11)-\mathrm{N}(1)-\mathrm{C}(61)$ & $115(2)$ \\
\hline
\end{tabular}




\begin{tabular}{|c|c|}
\hline $\mathrm{O}(10)-\mathrm{N}(1)-\mathrm{O}(11)$ & $126(2)$ \\
\hline $\mathrm{O}(10)-\mathrm{N}(1)-\mathrm{C}(61)$ & $119(2)$ \\
\hline $\mathrm{O}(8)-\mathrm{N}(2)-\mathrm{C}(41)$ & $115(3)$ \\
\hline $\mathrm{O}(8)-\mathrm{N}(2)-\mathrm{O}(7)$ & $126(2)$ \\
\hline $\mathrm{O}(7)-\mathrm{N}(2)-\mathrm{C}(41)$ & $118(2)$ \\
\hline $\mathrm{C}(51)-\mathrm{O}(9)-\mathrm{H}(9 \mathrm{~A})$ & 109.5 \\
\hline $\mathrm{C}(46)-\mathrm{C}(41)-\mathrm{N}(2)$ & $122.6(16)$ \\
\hline $\mathrm{C}(46)-\mathrm{C}(41)-\mathrm{C}(42)$ & 120.0 \\
\hline $\mathrm{C}(42)-\mathrm{C}(41)-\mathrm{N}(2)$ & $117.3(16)$ \\
\hline $\mathrm{C}(41)-\mathrm{C}(46)-\mathrm{H}(46)$ & 120.0 \\
\hline$C(45)-C(46)-C(41)$ & 120.0 \\
\hline $\mathrm{C}(45)-\mathrm{C}(46)-\mathrm{H}(46)$ & 120.0 \\
\hline $\mathrm{C}(46)-\mathrm{C}(45)-\mathrm{H}(45)$ & 120.0 \\
\hline $\mathrm{C}(46)-\mathrm{C}(45)-\mathrm{C}(44)$ & 120.0 \\
\hline $\mathrm{C}(44)-\mathrm{C}(45)-\mathrm{H}(45)$ & 120.0 \\
\hline$C(45)-C(44)-C(47)$ & $121.0(12)$ \\
\hline $\mathrm{C}(45)-\mathrm{C}(44)-\mathrm{C}(43)$ & 120.0 \\
\hline $\mathrm{C}(43)-\mathrm{C}(44)-\mathrm{C}(47)$ & $118.9(12)$ \\
\hline $\mathrm{C}(44)-\mathrm{C}(43)-\mathrm{H}(43)$ & 120.0 \\
\hline $\mathrm{C}(42)-\mathrm{C}(43)-\mathrm{C}(44)$ & 120.0 \\
\hline $\mathrm{C}(42)-\mathrm{C}(43)-\mathrm{H}(43)$ & 120.0 \\
\hline $\mathrm{C}(41)-\mathrm{C}(42)-\mathrm{H}(42)$ & 120.0 \\
\hline $\mathrm{C}(43)-\mathrm{C}(42)-\mathrm{C}(41)$ & 120.0 \\
\hline $\mathrm{C}(43)-\mathrm{C}(42)-\mathrm{H}(42)$ & 120.0 \\
\hline $\mathrm{C}(47)-\mathrm{C}(48)-\mathrm{C}(49)$ & $176(2)$ \\
\hline $\mathrm{C}(48)-\mathrm{C}(49)-\mathrm{H}(49)$ & 108.0 \\
\hline $\mathrm{C}(48)-\mathrm{C}(49)-\mathrm{C}(50)$ & $106.6(17)$ \\
\hline $\mathrm{C}(51)-\mathrm{C}(49)-\mathrm{C}(48)$ & $109.7(16)$ \\
\hline $\mathrm{C}(51)-\mathrm{C}(49)-\mathrm{H}(49)$ & 108.0 \\
\hline $\mathrm{C}(51)-\mathrm{C}(49)-\mathrm{C}(50)$ & $116(2)$ \\
\hline $\mathrm{C}(50)-\mathrm{C}(49)-\mathrm{H}(49)$ & 108.0 \\
\hline $\mathrm{C}(67)-\mathrm{C}(68)-\mathrm{C}(69)$ & $177(2)$ \\
\hline $\mathrm{C}(71)-\mathrm{O}(12)-\mathrm{H}(12 \mathrm{~A})$ & 109.5 \\
\hline $\mathrm{C}(80)-\mathrm{C}(79)-\mathrm{H}(79)$ & 120.0 \\
\hline $\mathrm{C}(80)-\mathrm{C}(79)-\mathrm{C}(78)$ & 120.0 \\
\hline $\mathrm{C}(78)-\mathrm{C}(79)-\mathrm{H}(79)$ & 120.0 \\
\hline $\mathrm{C}(79)-\mathrm{C}(80)-\mathrm{H}(80)$ & 120.0 \\
\hline $\mathrm{C}(79)-\mathrm{C}(80)-\mathrm{C}(75)$ & 120.0 \\
\hline
\end{tabular}




\begin{tabular}{|c|c|}
\hline $\mathrm{C}(75)-\mathrm{C}(80)-\mathrm{H}(80)$ & 120.0 \\
\hline $\mathrm{C}(80)-\mathrm{C}(75)-\mathrm{Si}(4)$ & $119.6(8)$ \\
\hline$C(76)-C(75)-S i(4)$ & $120.4(8)$ \\
\hline$C(76)-C(75)-C(80)$ & 120.0 \\
\hline $\mathrm{C}(75)-\mathrm{C}(76)-\mathrm{H}(76)$ & 120.0 \\
\hline$C(77)-C(76)-C(75)$ & 120.0 \\
\hline $\mathrm{C}(77)-\mathrm{C}(76)-\mathrm{H}(76)$ & 120.0 \\
\hline $\mathrm{C}(76)-\mathrm{C}(77)-\mathrm{H}(77)$ & 120.0 \\
\hline$C(78)-C(77)-C(76)$ & 120.0 \\
\hline $\mathrm{C}(78)-\mathrm{C}(77)-\mathrm{H}(77)$ & 120.0 \\
\hline $\mathrm{C}(79)-\mathrm{C}(78)-\mathrm{H}(78)$ & 120.0 \\
\hline $\mathrm{C}(77)-\mathrm{C}(78)-\mathrm{C}(79)$ & 120.0 \\
\hline $\mathrm{C}(77)-\mathrm{C}(78)-\mathrm{H}(78)$ & 120.0 \\
\hline $\mathrm{O}(3)-\mathrm{C}(11)-\mathrm{Si}(1)$ & $104.4(17)$ \\
\hline $\mathrm{O}(3)-\mathrm{C}(11)-\mathrm{C}(12)$ & $110.3(17)$ \\
\hline $\mathrm{O}(3)-\mathrm{C}(11)-\mathrm{C}(9)$ & $108.7(19)$ \\
\hline $\mathrm{C}(12)-\mathrm{C}(11)-\mathrm{Si}(1)$ & $110.7(19)$ \\
\hline $\mathrm{C}(12)-\mathrm{C}(11)-\mathrm{C}(9)$ & 111(2) \\
\hline $\mathrm{C}(9)-\mathrm{C}(11)-\mathrm{Si}(1)$ & $111.8(13)$ \\
\hline $\mathrm{C}(68)-\mathrm{C}(69)-\mathrm{H}(69)$ & 106.2 \\
\hline$C(68)-C(69)-C(70)$ & $107.8(19)$ \\
\hline $\mathrm{C}(68)-\mathrm{C}(69)-\mathrm{C}(71)$ & $113.0(16)$ \\
\hline $\mathrm{C}(70)-\mathrm{C}(69)-\mathrm{H}(69)$ & 106.2 \\
\hline $\mathrm{C}(71)-\mathrm{C}(69)-\mathrm{H}(69)$ & 106.2 \\
\hline$C(71)-C(69)-C(70)$ & $116.6(19)$ \\
\hline$C(3)-C(4)-C(5)$ & 120.0 \\
\hline$C(3)-C(4)-C(7)$ & $119.9(12)$ \\
\hline $\mathrm{C}(5)-\mathrm{C}(4)-\mathrm{C}(7)$ & $119.7(12)$ \\
\hline $\mathrm{C}(4)-\mathrm{C}(3)-\mathrm{H}(3 \mathrm{~A})$ & 120.0 \\
\hline $\mathrm{C}(4)-\mathrm{C}(3)-\mathrm{C}(2)$ & 120.0 \\
\hline $\mathrm{C}(2)-\mathrm{C}(3)-\mathrm{H}(3 \mathrm{~A})$ & 120.0 \\
\hline $\mathrm{C}(3)-\mathrm{C}(2)-\mathrm{H}(2)$ & 120.0 \\
\hline $\mathrm{C}(3)-\mathrm{C}(2)-\mathrm{C}(1)$ & 120.0 \\
\hline $\mathrm{C}(1)-\mathrm{C}(2)-\mathrm{H}(2)$ & 120.0 \\
\hline $\mathrm{C}(2)-\mathrm{C}(1)-\mathrm{N}(4)$ & $121.1(12)$ \\
\hline $\mathrm{C}(6)-\mathrm{C}(1)-\mathrm{C}(2)$ & 120.0 \\
\hline $\mathrm{C}(6)-\mathrm{C}(1)-\mathrm{N}(4)$ & $118.8(12)$ \\
\hline $\mathrm{C}(1)-\mathrm{C}(6)-\mathrm{H}(6)$ & 120.0 \\
\hline
\end{tabular}




\begin{tabular}{|c|c|}
\hline$C(1)-C(6)-C(5)$ & 120.0 \\
\hline $\mathrm{C}(5)-\mathrm{C}(6)-\mathrm{H}(6)$ & 120.0 \\
\hline $\mathrm{C}(4)-\mathrm{C}(5)-\mathrm{H}(5)$ & 120.0 \\
\hline$C(6)-C(5)-C(4)$ & 120.0 \\
\hline $\mathrm{C}(6)-\mathrm{C}(5)-\mathrm{H}(5)$ & 120.0 \\
\hline$C(22)-C(21)-C(26)$ & 120.0 \\
\hline $\mathrm{C}(22)-\mathrm{C}(21)-\mathrm{N}(3)$ & 119.3(17) \\
\hline $\mathrm{C}(26)-\mathrm{C}(21)-\mathrm{N}(3)$ & $120.7(17)$ \\
\hline $\mathrm{C}(21)-\mathrm{C}(22)-\mathrm{H}(22)$ & 120.0 \\
\hline$C(21)-C(22)-C(23)$ & 120.0 \\
\hline $\mathrm{C}(23)-\mathrm{C}(22)-\mathrm{H}(22)$ & 120.0 \\
\hline $\mathrm{C}(22)-\mathrm{C}(23)-\mathrm{H}(23)$ & 120.0 \\
\hline $\mathrm{C}(24)-\mathrm{C}(23)-\mathrm{C}(22)$ & 120.0 \\
\hline $\mathrm{C}(24)-\mathrm{C}(23)-\mathrm{H}(23)$ & 120.0 \\
\hline$C(23)-C(24)-C(25)$ & 120.0 \\
\hline$C(23)-C(24)-C(27)$ & $120.9(14)$ \\
\hline $\mathrm{C}(25)-\mathrm{C}(24)-\mathrm{C}(27)$ & $119.0(14)$ \\
\hline $\mathrm{C}(24)-\mathrm{C}(25)-\mathrm{H}(25)$ & 120.0 \\
\hline$C(26)-C(25)-C(24)$ & 120.0 \\
\hline $\mathrm{C}(26)-\mathrm{C}(25)-\mathrm{H}(25)$ & 120.0 \\
\hline $\mathrm{C}(21)-\mathrm{C}(26)-\mathrm{H}(26)$ & 120.0 \\
\hline$C(25)-C(26)-C(21)$ & 120.0 \\
\hline $\mathrm{C}(25)-\mathrm{C}(26)-\mathrm{H}(26)$ & 120.0 \\
\hline $\mathrm{Si}(4)-\mathrm{C}(73)-\mathrm{H}(73 \mathrm{~A})$ & 109.5 \\
\hline $\mathrm{Si}(4)-\mathrm{C}(73)-\mathrm{H}(73 \mathrm{~B})$ & 109.5 \\
\hline $\mathrm{Si}(4)-\mathrm{C}(73)-\mathrm{H}(73 \mathrm{C})$ & 109.5 \\
\hline $\mathrm{H}(73 \mathrm{~A})-\mathrm{C}(73)-\mathrm{H}(73 \mathrm{~B})$ & 109.5 \\
\hline $\mathrm{H}(73 \mathrm{~A})-\mathrm{C}(73)-\mathrm{H}(73 \mathrm{C})$ & 109.5 \\
\hline $\mathrm{H}(73 \mathrm{~B})-\mathrm{C}(73)-\mathrm{H}(73 \mathrm{C})$ & 109.5 \\
\hline $\mathrm{O}(6)-\mathrm{C}(31)-\mathrm{Si}(2)$ & $101.1(15)$ \\
\hline $\mathrm{O}(6)-\mathrm{C}(31)-\mathrm{C}(29)$ & $110(2)$ \\
\hline $\mathrm{O}(6)-\mathrm{C}(31)-\mathrm{C}(32)$ & $113(2)$ \\
\hline $\mathrm{C}(29)-\mathrm{C}(31)-\mathrm{Si}(2)$ & $112.4(17)$ \\
\hline $\mathrm{C}(32)-\mathrm{C}(31)-\mathrm{Si}(2)$ & 109.3(18) \\
\hline $\mathrm{C}(32)-\mathrm{C}(31)-\mathrm{C}(29)$ & $111(2)$ \\
\hline $\mathrm{F}(6)-\mathrm{C}(52)-\mathrm{H}(52)$ & 108.7 \\
\hline $\mathrm{F}(6)-\mathrm{C}(52)-\mathrm{C}(51)$ & $112(2)$ \\
\hline $\mathrm{F}(5)-\mathrm{C}(52)-\mathrm{F}(6)$ & $105(2)$ \\
\hline
\end{tabular}




\begin{tabular}{|c|c|}
\hline $\mathrm{F}(5)-\mathrm{C}(52)-\mathrm{H}(52)$ & 108.7 \\
\hline $\mathrm{F}(5)-\mathrm{C}(52)-\mathrm{C}(51)$ & $113(2)$ \\
\hline $\mathrm{C}(51)-\mathrm{C}(52)-\mathrm{H}(52)$ & 108.7 \\
\hline $\mathrm{C}(68)-\mathrm{C}(67)-\mathrm{C}(64)$ & $176(2)$ \\
\hline $\mathrm{C}(31)-\mathrm{C}(29)-\mathrm{H}(29)$ & 105.6 \\
\hline $\mathrm{C}(30)-\mathrm{C}(29)-\mathrm{C}(31)$ & $117(2)$ \\
\hline $\mathrm{C}(30)-\mathrm{C}(29)-\mathrm{H}(29)$ & 105.6 \\
\hline $\mathrm{C}(28)-\mathrm{C}(29)-\mathrm{C}(31)$ & $110(2)$ \\
\hline $\mathrm{C}(28)-\mathrm{C}(29)-\mathrm{H}(29)$ & 105.6 \\
\hline $\mathrm{C}(28)-\mathrm{C}(29)-\mathrm{C}(30)$ & 112.6(19) \\
\hline $\mathrm{C}(29)-\mathrm{C}(30)-\mathrm{H}(30 \mathrm{~A})$ & 109.5 \\
\hline $\mathrm{C}(29)-\mathrm{C}(30)-\mathrm{H}(30 \mathrm{~B})$ & 109.5 \\
\hline $\mathrm{C}(29)-\mathrm{C}(30)-\mathrm{H}(30 \mathrm{C})$ & 109.5 \\
\hline $\mathrm{H}(30 \mathrm{~A})-\mathrm{C}(30)-\mathrm{H}(30 \mathrm{~B})$ & 109.5 \\
\hline $\mathrm{H}(30 \mathrm{~A})-\mathrm{C}(30)-\mathrm{H}(30 \mathrm{C})$ & 109.5 \\
\hline $\mathrm{H}(30 \mathrm{~B})-\mathrm{C}(30)-\mathrm{H}(30 \mathrm{C})$ & 109.5 \\
\hline $\mathrm{Si}(3)-\mathrm{C}(54)-\mathrm{H}(54 \mathrm{~A})$ & 109.5 \\
\hline $\mathrm{Si}(3)-\mathrm{C}(54)-\mathrm{H}(54 \mathrm{~B})$ & 109.5 \\
\hline $\mathrm{Si}(3)-\mathrm{C}(54)-\mathrm{H}(54 \mathrm{C})$ & 109.5 \\
\hline $\mathrm{H}(54 \mathrm{~A})-\mathrm{C}(54)-\mathrm{H}(54 \mathrm{~B})$ & 109.5 \\
\hline $\mathrm{H}(54 \mathrm{~A})-\mathrm{C}(54)-\mathrm{H}(54 \mathrm{C})$ & 109.5 \\
\hline $\mathrm{H}(54 \mathrm{~B})-\mathrm{C}(54)-\mathrm{H}(54 \mathrm{C})$ & 109.5 \\
\hline $\mathrm{C}(8)-\mathrm{C}(7)-\mathrm{C}(4)$ & $176(2)$ \\
\hline $\mathrm{C}(40)-\mathrm{C}(35)-\mathrm{Si}(2)$ & $120.1(11)$ \\
\hline $\mathrm{C}(40)-\mathrm{C}(35)-\mathrm{C}(36)$ & 120.0 \\
\hline $\mathrm{C}(36)-\mathrm{C}(35)-\mathrm{Si}(2)$ & $119.7(11)$ \\
\hline $\mathrm{C}(35)-\mathrm{C}(40)-\mathrm{H}(40)$ & 120.0 \\
\hline $\mathrm{C}(35)-\mathrm{C}(40)-\mathrm{C}(39)$ & 120.0 \\
\hline $\mathrm{C}(39)-\mathrm{C}(40)-\mathrm{H}(40)$ & 120.0 \\
\hline $\mathrm{C}(40)-\mathrm{C}(39)-\mathrm{H}(39)$ & 120.0 \\
\hline $\mathrm{C}(38)-\mathrm{C}(39)-\mathrm{C}(40)$ & 120.0 \\
\hline $\mathrm{C}(38)-\mathrm{C}(39)-\mathrm{H}(39)$ & 120.0 \\
\hline $\mathrm{C}(39)-\mathrm{C}(38)-\mathrm{H}(38)$ & 120.0 \\
\hline $\mathrm{C}(37)-\mathrm{C}(38)-\mathrm{C}(39)$ & 120.0 \\
\hline $\mathrm{C}(37)-\mathrm{C}(38)-\mathrm{H}(38)$ & 120.0 \\
\hline $\mathrm{C}(38)-\mathrm{C}(37)-\mathrm{H}(37)$ & 120.0 \\
\hline$C(38)-C(37)-C(36)$ & 120.0 \\
\hline $\mathrm{C}(36)-\mathrm{C}(37)-\mathrm{H}(37)$ & 120.0 \\
\hline
\end{tabular}




\begin{tabular}{|c|c|}
\hline $\mathrm{C}(35)-\mathrm{C}(36)-\mathrm{H}(36)$ & 120.0 \\
\hline$C(37)-C(36)-C(35)$ & 120.0 \\
\hline $\mathrm{C}(37)-\mathrm{C}(36)-\mathrm{H}(36)$ & 120.0 \\
\hline$C(20)-C(15)-\operatorname{Si}(1)$ & 120.1(10) \\
\hline$C(20)-C(15)-C(16)$ & 120.0 \\
\hline $\mathrm{C}(16)-\mathrm{C}(15)-\mathrm{Si}(1)$ & $119.8(10)$ \\
\hline $\mathrm{C}(15)-\mathrm{C}(20)-\mathrm{H}(20)$ & 120.0 \\
\hline$C(19)-C(20)-C(15)$ & 120.0 \\
\hline $\mathrm{C}(19)-\mathrm{C}(20)-\mathrm{H}(20)$ & 120.0 \\
\hline $\mathrm{C}(20)-\mathrm{C}(19)-\mathrm{H}(19)$ & 120.0 \\
\hline$C(20)-C(19)-C(18)$ & 120.0 \\
\hline $\mathrm{C}(18)-\mathrm{C}(19)-\mathrm{H}(19)$ & 120.0 \\
\hline $\mathrm{C}(19)-\mathrm{C}(18)-\mathrm{H}(18)$ & 120.0 \\
\hline$C(19)-C(18)-C(17)$ & 120.0 \\
\hline $\mathrm{C}(17)-\mathrm{C}(18)-\mathrm{H}(18)$ & 120.0 \\
\hline $\mathrm{C}(18)-\mathrm{C}(17)-\mathrm{H}(17)$ & 120.0 \\
\hline$C(16)-C(17)-C(18)$ & 120.0 \\
\hline $\mathrm{C}(16)-\mathrm{C}(17)-\mathrm{H}(17)$ & 120.0 \\
\hline $\mathrm{C}(15)-\mathrm{C}(16)-\mathrm{H}(16)$ & 120.0 \\
\hline$C(17)-C(16)-C(15)$ & 120.0 \\
\hline $\mathrm{C}(17)-\mathrm{C}(16)-\mathrm{H}(16)$ & 120.0 \\
\hline $\mathrm{C}(65)-\mathrm{C}(66)-\mathrm{H}(66)$ & 120.0 \\
\hline$C(65)-C(66)-C(61)$ & 120.0 \\
\hline $\mathrm{C}(61)-\mathrm{C}(66)-\mathrm{H}(66)$ & 120.0 \\
\hline $\mathrm{C}(66)-\mathrm{C}(65)-\mathrm{H}(65)$ & 120.0 \\
\hline $\mathrm{C}(66)-\mathrm{C}(65)-\mathrm{C}(64)$ & 120.0 \\
\hline $\mathrm{C}(64)-\mathrm{C}(65)-\mathrm{H}(65)$ & 120.0 \\
\hline$C(65)-C(64)-C(67)$ & $120.8(11)$ \\
\hline $\mathrm{C}(63)-\mathrm{C}(64)-\mathrm{C}(67)$ & 119.1(11) \\
\hline$C(63)-C(64)-C(65)$ & 120.0 \\
\hline $\mathrm{C}(64)-\mathrm{C}(63)-\mathrm{H}(63)$ & 120.0 \\
\hline$C(64)-C(63)-C(62)$ & 120.0 \\
\hline $\mathrm{C}(62)-\mathrm{C}(63)-\mathrm{H}(63)$ & 120.0 \\
\hline $\mathrm{C}(63)-\mathrm{C}(62)-\mathrm{H}(62)$ & 120.0 \\
\hline$C(61)-C(62)-C(63)$ & 120.0 \\
\hline $\mathrm{C}(61)-\mathrm{C}(62)-\mathrm{H}(62)$ & 120.0 \\
\hline $\mathrm{C}(66)-\mathrm{C}(61)-\mathrm{N}(1)$ & $118.5(14)$ \\
\hline $\mathrm{C}(62)-\mathrm{C}(61)-\mathrm{N}(1)$ & $121.4(14)$ \\
\hline
\end{tabular}




\begin{tabular}{|c|c|}
\hline $\mathrm{C}(62)-\mathrm{C}(61)-\mathrm{C}(66)$ & 120.0 \\
\hline $\mathrm{F}(3)-\mathrm{C}(32)-\mathrm{C}(31)$ & $111(2)$ \\
\hline $\mathrm{F}(3)-\mathrm{C}(32)-\mathrm{F}(4)$ & $105(2)$ \\
\hline $\mathrm{F}(3)-\mathrm{C}(32)-\mathrm{H}(32)$ & 110.3 \\
\hline $\mathrm{C}(31)-\mathrm{C}(32)-\mathrm{H}(32)$ & 110.3 \\
\hline $\mathrm{F}(4)-\mathrm{C}(32)-\mathrm{C}(31)$ & $110(2)$ \\
\hline $\mathrm{F}(4)-\mathrm{C}(32)-\mathrm{H}(32)$ & 110.3 \\
\hline $\mathrm{F}(2)-\mathrm{C}(12)-\mathrm{F}(1)$ & $104.8(18)$ \\
\hline $\mathrm{F}(2)-\mathrm{C}(12)-\mathrm{C}(11)$ & $111(2)$ \\
\hline $\mathrm{F}(2)-\mathrm{C}(12)-\mathrm{H}(12)$ & 110.5 \\
\hline $\mathrm{F}(1)-\mathrm{C}(12)-\mathrm{C}(11)$ & $109(3)$ \\
\hline $\mathrm{F}(1)-\mathrm{C}(12)-\mathrm{H}(12)$ & 110.5 \\
\hline $\mathrm{C}(11)-\mathrm{C}(12)-\mathrm{H}(12)$ & 110.5 \\
\hline $\mathrm{C}(11)-\mathrm{C}(9)-\mathrm{H}(9)$ & 106.6 \\
\hline $\mathrm{C}(8)-\mathrm{C}(9)-\mathrm{C}(11)$ & $110.2(19)$ \\
\hline $\mathrm{C}(8)-\mathrm{C}(9)-\mathrm{H}(9)$ & 106.6 \\
\hline$C(8)-C(9)-C(10)$ & $108(2)$ \\
\hline $\mathrm{C}(10)-\mathrm{C}(9)-\mathrm{C}(11)$ & $118.0(17)$ \\
\hline $\mathrm{C}(10)-\mathrm{C}(9)-\mathrm{H}(9)$ & 106.6 \\
\hline $\mathrm{Si}(2)-\mathrm{C}(33)-\mathrm{H}(33 \mathrm{~A})$ & 109.5 \\
\hline $\mathrm{Si}(2)-\mathrm{C}(33)-\mathrm{H}(33 \mathrm{~B})$ & 109.5 \\
\hline $\mathrm{Si}(2)-\mathrm{C}(33)-\mathrm{H}(33 \mathrm{C})$ & 109.5 \\
\hline $\mathrm{H}(33 \mathrm{~A})-\mathrm{C}(33)-\mathrm{H}(33 \mathrm{~B})$ & 109.5 \\
\hline $\mathrm{H}(33 \mathrm{~A})-\mathrm{C}(33)-\mathrm{H}(33 \mathrm{C})$ & 109.5 \\
\hline $\mathrm{H}(33 \mathrm{~B})-\mathrm{C}(33)-\mathrm{H}(33 \mathrm{C})$ & 109.5 \\
\hline $\mathrm{C}(56)-\mathrm{C}(55)-\mathrm{Si}(3)$ & $121.4(10)$ \\
\hline$C(56)-C(55)-C(60)$ & 120.0 \\
\hline $\mathrm{C}(60)-\mathrm{C}(55)-\mathrm{Si}(3)$ & $118.3(10)$ \\
\hline $\mathrm{C}(55)-\mathrm{C}(56)-\mathrm{H}(56)$ & 120.0 \\
\hline $\mathrm{C}(55)-\mathrm{C}(56)-\mathrm{C}(57)$ & 120.0 \\
\hline $\mathrm{C}(57)-\mathrm{C}(56)-\mathrm{H}(56)$ & 120.0 \\
\hline $\mathrm{C}(56)-\mathrm{C}(57)-\mathrm{H}(57)$ & 120.0 \\
\hline$C(58)-C(57)-C(56)$ & 120.0 \\
\hline $\mathrm{C}(58)-\mathrm{C}(57)-\mathrm{H}(57)$ & 120.0 \\
\hline $\mathrm{C}(57)-\mathrm{C}(58)-\mathrm{H}(58)$ & 120.0 \\
\hline $\mathrm{C}(57)-\mathrm{C}(58)-\mathrm{C}(59)$ & 120.0 \\
\hline $\mathrm{C}(59)-\mathrm{C}(58)-\mathrm{H}(58)$ & 120.0 \\
\hline $\mathrm{C}(58)-\mathrm{C}(59)-\mathrm{H}(59)$ & 120.0 \\
\hline
\end{tabular}




\begin{tabular}{|c|c|}
\hline $\mathrm{C}(58)-\mathrm{C}(59)-\mathrm{C}(60)$ & 120.0 \\
\hline $\mathrm{C}(60)-\mathrm{C}(59)-\mathrm{H}(59)$ & 120.0 \\
\hline $\mathrm{C}(55)-\mathrm{C}(60)-\mathrm{H}(60)$ & 120.0 \\
\hline$C(59)-C(60)-C(55)$ & 120.0 \\
\hline $\mathrm{C}(59)-\mathrm{C}(60)-\mathrm{H}(60)$ & 120.0 \\
\hline $\mathrm{O}(9)-\mathrm{C}(51)-\mathrm{Si}(3)$ & $98.7(16)$ \\
\hline $\mathrm{O}(9)-\mathrm{C}(51)-\mathrm{C}(49)$ & $109.0(17)$ \\
\hline $\mathrm{O}(9)-\mathrm{C}(51)-\mathrm{C}(52)$ & $109.6(19)$ \\
\hline $\mathrm{C}(49)-\mathrm{C}(51)-\mathrm{Si}(3)$ & $112.6(15)$ \\
\hline $\mathrm{C}(52)-\mathrm{C}(51)-\mathrm{Si}(3)$ & $111.7(18)$ \\
\hline$C(52)-C(51)-C(49)$ & $114(2)$ \\
\hline $\mathrm{Si}(2)-\mathrm{C}(34)-\mathrm{H}(34 \mathrm{~A})$ & 109.5 \\
\hline $\mathrm{Si}(2)-\mathrm{C}(34)-\mathrm{H}(34 \mathrm{~B})$ & 109.5 \\
\hline $\mathrm{Si}(2)-\mathrm{C}(34)-\mathrm{H}(34 \mathrm{C})$ & 109.5 \\
\hline $\mathrm{H}(34 \mathrm{~A})-\mathrm{C}(34)-\mathrm{H}(34 \mathrm{~B})$ & 109.5 \\
\hline $\mathrm{H}(34 \mathrm{~A})-\mathrm{C}(34)-\mathrm{H}(34 \mathrm{C})$ & 109.5 \\
\hline $\mathrm{H}(34 \mathrm{~B})-\mathrm{C}(34)-\mathrm{H}(34 \mathrm{C})$ & 109.5 \\
\hline $\mathrm{C}(7)-\mathrm{C}(8)-\mathrm{C}(9)$ & 177(3) \\
\hline $\mathrm{C}(9)-\mathrm{C}(10)-\mathrm{H}(10 \mathrm{~A})$ & 109.5 \\
\hline $\mathrm{C}(9)-\mathrm{C}(10)-\mathrm{H}(10 \mathrm{~B})$ & 109.5 \\
\hline $\mathrm{C}(9)-\mathrm{C}(10)-\mathrm{H}(10 \mathrm{C})$ & 109.5 \\
\hline $\mathrm{H}(10 \mathrm{~A})-\mathrm{C}(10)-\mathrm{H}(10 \mathrm{~B})$ & 109.5 \\
\hline $\mathrm{H}(10 \mathrm{~A})-\mathrm{C}(10)-\mathrm{H}(10 \mathrm{C})$ & 109.5 \\
\hline $\mathrm{H}(10 \mathrm{~B})-\mathrm{C}(10)-\mathrm{H}(10 \mathrm{C})$ & 109.5 \\
\hline $\mathrm{C}(49)-\mathrm{C}(50)-\mathrm{H}(50 \mathrm{~A})$ & 109.5 \\
\hline $\mathrm{C}(49)-\mathrm{C}(50)-\mathrm{H}(50 \mathrm{~B})$ & 109.5 \\
\hline $\mathrm{C}(49)-\mathrm{C}(50)-\mathrm{H}(50 \mathrm{C})$ & 109.5 \\
\hline $\mathrm{H}(50 \mathrm{~A})-\mathrm{C}(50)-\mathrm{H}(50 \mathrm{~B})$ & 109.5 \\
\hline $\mathrm{H}(50 \mathrm{~A})-\mathrm{C}(50)-\mathrm{H}(50 \mathrm{C})$ & 109.5 \\
\hline $\mathrm{H}(50 \mathrm{~B})-\mathrm{C}(50)-\mathrm{H}(50 \mathrm{C})$ & 109.5 \\
\hline $\mathrm{Si}(3)-\mathrm{C}(53)-\mathrm{H}(53 \mathrm{~A})$ & 109.5 \\
\hline $\mathrm{Si}(3)-\mathrm{C}(53)-\mathrm{H}(53 \mathrm{~B})$ & 109.5 \\
\hline $\mathrm{Si}(3)-\mathrm{C}(53)-\mathrm{H}(53 \mathrm{C})$ & 109.5 \\
\hline $\mathrm{H}(53 \mathrm{~A})-\mathrm{C}(53)-\mathrm{H}(53 \mathrm{~B})$ & 109.5 \\
\hline $\mathrm{H}(53 \mathrm{~A})-\mathrm{C}(53)-\mathrm{H}(53 \mathrm{C})$ & 109.5 \\
\hline $\mathrm{H}(53 \mathrm{~B})-\mathrm{C}(53)-\mathrm{H}(53 \mathrm{C})$ & 109.5 \\
\hline $\mathrm{C}(69)-\mathrm{C}(70)-\mathrm{H}(70 \mathrm{~A})$ & 109.5 \\
\hline $\mathrm{C}(69)-\mathrm{C}(70)-\mathrm{H}(70 \mathrm{~B})$ & 109.5 \\
\hline
\end{tabular}




\begin{tabular}{|c|c|}
\hline $\mathrm{C}(69)-\mathrm{C}(70)-\mathrm{H}(70 \mathrm{C})$ & 109.5 \\
\hline $\mathrm{H}(70 \mathrm{~A})-\mathrm{C}(70)-\mathrm{H}(70 \mathrm{~B})$ & 109.5 \\
\hline $\mathrm{H}(70 \mathrm{~A})-\mathrm{C}(70)-\mathrm{H}(70 \mathrm{C})$ & 109.5 \\
\hline H(70B)-C(70)-H(70C) & 109.5 \\
\hline$C(28)-C(27)-C(24)$ & 173(3) \\
\hline $\mathrm{Si}(1)-\mathrm{C}(14)-\mathrm{H}(14 \mathrm{~A})$ & 109.5 \\
\hline $\mathrm{Si}(1)-\mathrm{C}(14)-\mathrm{H}(14 \mathrm{~B})$ & 109.5 \\
\hline $\mathrm{Si}(1)-\mathrm{C}(14)-\mathrm{H}(14 \mathrm{C})$ & 109.5 \\
\hline $\mathrm{H}(14 \mathrm{~A})-\mathrm{C}(14)-\mathrm{H}(14 \mathrm{~B})$ & 109.5 \\
\hline $\mathrm{H}(14 \mathrm{~A})-\mathrm{C}(14)-\mathrm{H}(14 \mathrm{C})$ & 109.5 \\
\hline $\mathrm{H}(14 \mathrm{~B})-\mathrm{C}(14)-\mathrm{H}(14 \mathrm{C})$ & 109.5 \\
\hline $\mathrm{Si}(1)-\mathrm{C}(13)-\mathrm{H}(13 \mathrm{~A})$ & 109.5 \\
\hline $\mathrm{Si}(1)-\mathrm{C}(13)-\mathrm{H}(13 \mathrm{~B})$ & 109.5 \\
\hline $\mathrm{Si}(1)-\mathrm{C}(13)-\mathrm{H}(13 \mathrm{C})$ & 109.5 \\
\hline $\mathrm{H}(13 \mathrm{~A})-\mathrm{C}(13)-\mathrm{H}(13 \mathrm{~B})$ & 109.5 \\
\hline $\mathrm{H}(13 \mathrm{~A})-\mathrm{C}(13)-\mathrm{H}(13 \mathrm{C})$ & 109.5 \\
\hline $\mathrm{H}(13 \mathrm{~B})-\mathrm{C}(13)-\mathrm{H}(13 \mathrm{C})$ & 109.5 \\
\hline$C(27)-C(28)-C(29)$ & $174(3)$ \\
\hline $\mathrm{Si}(4)-\mathrm{C}(74)-\mathrm{H}(74 \mathrm{~A})$ & 109.5 \\
\hline $\mathrm{Si}(4)-\mathrm{C}(74)-\mathrm{H}(74 \mathrm{~B})$ & 109.5 \\
\hline $\mathrm{Si}(4)-\mathrm{C}(74)-\mathrm{H}(74 \mathrm{C})$ & 109.5 \\
\hline $\mathrm{H}(74 \mathrm{~A})-\mathrm{C}(74)-\mathrm{H}(74 \mathrm{~B})$ & 109.5 \\
\hline $\mathrm{H}(74 \mathrm{~A})-\mathrm{C}(74)-\mathrm{H}(74 \mathrm{C})$ & 109.5 \\
\hline $\mathrm{H}(74 \mathrm{~B})-\mathrm{C}(74)-\mathrm{H}(74 \mathrm{C})$ & 109.5 \\
\hline $\mathrm{O}(4)-\mathrm{N}(3)-\mathrm{C}(21)$ & $119(2)$ \\
\hline $\mathrm{O}(4)-\mathrm{N}(3)-\mathrm{O}(5)$ & 123(3) \\
\hline $\mathrm{O}(5)-\mathrm{N}(3)-\mathrm{C}(21)$ & 117(3) \\
\hline $\mathrm{O}(1)-\mathrm{N}(4)-\mathrm{C}(1)$ & $119(2)$ \\
\hline $\mathrm{O}(2)-\mathrm{N}(4)-\mathrm{C}(1)$ & $121(2)$ \\
\hline $\mathrm{O}(2)-\mathrm{N}(4)-\mathrm{O}(1)$ & $119(2)$ \\
\hline $\mathrm{O}(12)-\mathrm{C}(71)-\mathrm{Si}(4)$ & $102.0(12)$ \\
\hline $\mathrm{O}(12)-\mathrm{C}(71)-\mathrm{C}(69)$ & 111.3(14) \\
\hline $\mathrm{O}(12)-\mathrm{C}(71)-\mathrm{C}(72)$ & $113.5(18)$ \\
\hline$C(69)-C(71)-S i(4)$ & $112.6(14)$ \\
\hline$C(69)-C(71)-C(72)$ & $110.4(19)$ \\
\hline $\mathrm{C}(72)-\mathrm{C}(71)-\mathrm{Si}(4)$ & $106.8(15)$ \\
\hline $\mathrm{F}(7)-\mathrm{C}(72)-\mathrm{F}(8)$ & $103(2)$ \\
\hline $\mathrm{F}(7)-\mathrm{C}(72)-\mathrm{C}(71)$ & $107(2)$ \\
\hline
\end{tabular}




$\begin{array}{ll}\mathrm{F}(7)-\mathrm{C}(72)-\mathrm{H}(72) & 112.6 \\ \mathrm{~F}(8)-\mathrm{C}(72)-\mathrm{C}(71) & 109(2) \\ \mathrm{F}(8)-\mathrm{C}(72)-\mathrm{H}(72) & 112.6 \\ \mathrm{C}(71)-\mathrm{C}(72)-\mathrm{H}(72) & 112.6\end{array}$

Symmetry transformations used to generate equivalent atoms:

Table 4. Anisotropic displacement parameters $\left(\AA^{2} \mathrm{x} 10^{3}\right)$ for final-wensongwei-wsw-4-74-250k-191223 the anisotropic displacement factor exponent takes the form: $-2 \pi^{2}\left[h^{2} a^{* 2} U^{11}+\ldots+2 h k a^{*} b^{*} U^{12}\right]$.

\begin{tabular}{|c|c|c|c|c|c|c|}
\hline & $\mathrm{U}^{11}$ & $\mathrm{U}^{22}$ & $\mathrm{U}^{33}$ & $U^{23}$ & $\mathrm{U}^{13}$ & $\mathrm{U}^{12}$ \\
\hline $\mathrm{Si}(1)$ & $86(4)$ & $80(4)$ & $96(4)$ & $27(3)$ & $28(3)$ & $31(3)$ \\
\hline $\mathrm{Si}(4)$ & $80(4)$ & $85(4)$ & $85(3)$ & $32(3)$ & $17(3)$ & $35(3)$ \\
\hline $\mathrm{Si}(3)$ & $87(4)$ & $89(4)$ & $108(4)$ & $33(3)$ & $33(3)$ & $37(3)$ \\
\hline $\mathrm{Si}(2)$ & $98(4)$ & $96(5)$ & $107(4)$ & $11(4)$ & $21(4)$ & $46(4)$ \\
\hline $\mathrm{F}(6)$ & $150(13)$ & 178(16) & 98(9) & $16(10)$ & $33(9)$ & $69(12)$ \\
\hline $\mathrm{O}(3)$ & $95(11)$ & $68(10)$ & $145(13)$ & $28(9)$ & $44(9)$ & $21(8)$ \\
\hline $\mathrm{C}(47)$ & $90(14)$ & $69(14)$ & $90(13)$ & $24(11)$ & $20(10)$ & $32(12)$ \\
\hline $\mathrm{O}(6)$ & $85(11)$ & $125(14)$ & $142(14)$ & $17(12)$ & $25(9)$ & $37(10)$ \\
\hline $\mathrm{O}(8)$ & 138(16) & $84(13)$ & $210(20)$ & $58(13)$ & $69(14)$ & $49(11)$ \\
\hline $\mathrm{F}(2)$ & $185(14)$ & 102(10) & $123(10)$ & $52(8)$ & $21(9)$ & $58(10)$ \\
\hline $\mathrm{N}(1)$ & 118(16) & $57(12)$ & $147(18)$ & $35(12)$ & $34(14)$ & $25(12)$ \\
\hline $\mathrm{O}(11)$ & $123(15)$ & $81(12)$ & $169(17)$ & $25(12)$ & $23(13)$ & $16(11)$ \\
\hline $\mathrm{N}(2)$ & 104(16) & $57(13)$ & $180(20)$ & $40(14)$ & $54(15)$ & $27(12)$ \\
\hline $\mathrm{O}(9)$ & $118(12)$ & $80(11)$ & $141(14)$ & $36(10)$ & $34(12)$ & $31(10)$ \\
\hline $\mathrm{C}(41)$ & $82(13)$ & $81(14)$ & $95(13)$ & $33(11)$ & $38(11)$ & $13(11)$ \\
\hline $\mathrm{C}(46)$ & $127(18)$ & $86(16)$ & $108(16)$ & $35(13)$ & $-1(14)$ & $46(14)$ \\
\hline $\mathrm{C}(45)$ & $113(16)$ & $53(12)$ & $108(15)$ & $31(11)$ & $2(12)$ & $15(12)$ \\
\hline $\mathrm{C}(44)$ & $94(14)$ & $72(13)$ & $83(12)$ & $17(10)$ & $31(11)$ & $26(11)$ \\
\hline $\mathrm{C}(43)$ & $103(17)$ & $109(18)$ & $121(17)$ & $45(14)$ & $2(14)$ & $42(14)$ \\
\hline $\mathrm{C}(42)$ & $83(14)$ & $87(16)$ & $118(16)$ & $30(13)$ & $30(12)$ & $8(12)$ \\
\hline $\mathrm{C}(48)$ & $91(14)$ & $76(14)$ & $85(12)$ & $24(11)$ & $33(10)$ & $56(12)$ \\
\hline $\mathrm{C}(49)$ & $85(14)$ & $76(14)$ & $101(14)$ & $29(11)$ & $39(11)$ & $24(11)$ \\
\hline $\mathrm{C}(68)$ & $84(11)$ & $75(12)$ & $102(11)$ & $17(10)$ & $26(9)$ & $28(9)$ \\
\hline $\mathrm{F}(1)$ & 190(16) & $162(15)$ & $133(11)$ & $53(11)$ & $90(11)$ & $74(12)$ \\
\hline $\mathrm{O}(12)$ & $79(9)$ & $58(9)$ & $126(11)$ & $15(8)$ & $28(8)$ & $17(7)$ \\
\hline $\mathrm{C}(79)$ & 116(18) & $140(20)$ & $98(16)$ & $31(15)$ & $35(13)$ & $73(16)$ \\
\hline $\mathrm{C}(80)$ & 114(16) & $81(14)$ & $96(14)$ & $34(12)$ & $30(12)$ & $52(12)$ \\
\hline
\end{tabular}




\begin{tabular}{|c|c|c|c|c|c|c|}
\hline$C(75)$ & $55(11)$ & $100(14)$ & $99(13)$ & $34(12)$ & $36(9)$ & $43(10)$ \\
\hline$C(76)$ & $76(13)$ & $99(17)$ & $96(15)$ & $14(13)$ & $7(11)$ & $24(12)$ \\
\hline $\mathrm{C}(77)$ & $79(14)$ & $120(19)$ & $106(16)$ & $-4(14)$ & $-1(12)$ & $33(13)$ \\
\hline $\mathrm{C}(78)$ & $94(16)$ & $180(20)$ & $81(15)$ & 19(16) & $17(12)$ & $65(17)$ \\
\hline $\mathrm{C}(11)$ & $116(16)$ & $90(15)$ & $104(14)$ & $54(12)$ & $31(12)$ & $23(13)$ \\
\hline $\mathrm{F}(3)$ & $162(14)$ & $176(16)$ & $110(10)$ & $14(10)$ & $54(10)$ & $73(12)$ \\
\hline $\mathrm{C}(69)$ & $87(14)$ & $73(14)$ & $105(14)$ & $38(11)$ & $17(11)$ & $23(11)$ \\
\hline$C(4)$ & 73(8) & 59(9) & $87(9)$ & $19(7)$ & 28(7) & $13(8)$ \\
\hline$C(3)$ & 77(9) & 62(9) & $95(9)$ & $20(8)$ & 20(8) & $27(7)$ \\
\hline $\mathrm{C}(2)$ & $81(9)$ & $67(9)$ & $88(9)$ & $25(8)$ & $8(8)$ & $21(8)$ \\
\hline $\mathrm{C}(1)$ & 76(9) & 60(9) & $86(9)$ & $26(7)$ & 13(7) & $16(8)$ \\
\hline$C(6)$ & $83(9)$ & $61(8)$ & $97(9)$ & $27(8)$ & $16(8)$ & $27(7)$ \\
\hline$C(5)$ & $80(9)$ & $60(9)$ & $93(9)$ & $20(8)$ & $18(8)$ & $17(7)$ \\
\hline $\mathrm{F}(5)$ & $118(12)$ & $186(16)$ & $104(10)$ & $9(10)$ & $-9(8)$ & $52(11)$ \\
\hline$C(21)$ & 121(16) & $68(14)$ & $110(15)$ & $20(12)$ & $31(13)$ & $54(13)$ \\
\hline $\mathrm{C}(22)$ & $140(20)$ & 101(18) & $125(18)$ & $56(15)$ & $50(16)$ & $41(17)$ \\
\hline$C(23)$ & 112(17) & $113(18)$ & $110(16)$ & $50(14)$ & $14(13)$ & $54(15)$ \\
\hline$C(24)$ & $78(13)$ & $75(13)$ & $97(13)$ & $18(11)$ & $29(11)$ & $27(11)$ \\
\hline$C(25)$ & $106(16)$ & $89(16)$ & $99(14)$ & $31(12)$ & $15(13)$ & $34(13)$ \\
\hline$C(26)$ & $117(17)$ & $96(16)$ & $82(13)$ & $28(12)$ & $18(12)$ & $30(14)$ \\
\hline $\mathrm{C}(73)$ & $76(14)$ & $140(20)$ & $113(17)$ & $40(15)$ & $42(13)$ & $47(14)$ \\
\hline $\mathrm{C}(31)$ & $75(13)$ & $115(17)$ & $101(15)$ & $9(12)$ & $42(11)$ & $15(13)$ \\
\hline $\mathrm{C}(52)$ & 107(19) & $120(20)$ & $99(17)$ & $31(15)$ & $31(15)$ & $34(16)$ \\
\hline $\mathrm{C}(67)$ & $81(10)$ & $72(10)$ & $101(10)$ & $24(8)$ & $26(8)$ & $26(8)$ \\
\hline $\mathrm{C}(29)$ & $87(15)$ & $97(16)$ & $89(14)$ & $10(12)$ & $16(12)$ & 19(13) \\
\hline $\mathrm{C}(30)$ & $77(15)$ & $91(17)$ & $139(19)$ & $37(14)$ & $17(13)$ & $22(13)$ \\
\hline $\mathrm{C}(54)$ & $80(15)$ & $150(20)$ & $140(20)$ & $52(18)$ & $46(14)$ & $36(15)$ \\
\hline $\mathrm{C}(7)$ & $92(16)$ & $108(18)$ & $103(15)$ & $43(14)$ & $30(12)$ & $37(14)$ \\
\hline$C(35)$ & $92(14)$ & $99(16)$ & $109(15)$ & $28(13)$ & $15(12)$ & $47(13)$ \\
\hline $\mathrm{C}(40)$ & $105(16)$ & $105(17)$ & $92(15)$ & $10(13)$ & $18(13)$ & $52(14)$ \\
\hline $\mathrm{C}(39)$ & 114(18) & $130(20)$ & $119(18)$ & $19(16)$ & $17(14)$ & $56(16)$ \\
\hline $\mathrm{C}(38)$ & $140(20)$ & $120(20)$ & $122(18)$ & $51(16)$ & $45(15)$ & $81(17)$ \\
\hline $\mathrm{C}(37)$ & 123(19) & 111(19) & $160(20)$ & $62(17)$ & $48(17)$ & $70(16)$ \\
\hline $\mathrm{C}(36)$ & $98(16)$ & 117(19) & $132(19)$ & $30(16)$ & $13(15)$ & $46(15)$ \\
\hline $\mathrm{F}(4)$ & $218(18)$ & $155(15)$ & $122(11)$ & $61(11)$ & $43(11)$ & $76(14)$ \\
\hline$C(15)$ & $110(15)$ & $80(14)$ & $91(13)$ & $37(11)$ & $22(12)$ & $54(12)$ \\
\hline $\mathrm{C}(20)$ & 101(17) & $127(19)$ & $103(16)$ & $24(15)$ & $23(13)$ & $43(15)$ \\
\hline $\mathrm{C}(19)$ & $140(20)$ & $160(20)$ & $140(20)$ & $10(18)$ & $19(18)$ & $85(19)$ \\
\hline
\end{tabular}




\begin{tabular}{|c|c|c|c|c|c|c|}
\hline$C(18)$ & $200(30)$ & $170(30)$ & 110(19) & $12(18)$ & $35(19)$ & $120(20)$ \\
\hline $\mathrm{C}(17)$ & $190(30)$ & $140(20)$ & 112(19) & $34(17)$ & $52(18)$ & $110(20)$ \\
\hline$C(16)$ & $150(20)$ & 101(17) & $93(15)$ & $31(13)$ & 41(14) & $69(15)$ \\
\hline $\mathrm{O}(7)$ & $99(14)$ & $106(15)$ & $220(20)$ & $12(15)$ & $37(15)$ & $14(12)$ \\
\hline $\mathrm{O}(10)$ & 141(16) & $122(16)$ & $200(20)$ & $112(15)$ & $48(14)$ & $35(12)$ \\
\hline$C(66)$ & $98(9)$ & $69(9)$ & $96(9)$ & $34(8)$ & $12(8)$ & $34(8)$ \\
\hline$C(65)$ & $94(10)$ & $67(9)$ & $99(9)$ & $27(8)$ & $22(8)$ & $16(8)$ \\
\hline $\mathrm{C}(64)$ & $79(8)$ & $55(8)$ & $92(8)$ & $30(7)$ & $29(7)$ & $19(7)$ \\
\hline$C(63)$ & $84(9)$ & $69(9)$ & 93(9) & $25(8)$ & $23(8)$ & $21(8)$ \\
\hline$C(62)$ & $81(9)$ & $62(9)$ & $102(10)$ & $16(8)$ & $25(8)$ & $27(7)$ \\
\hline$C(61)$ & $92(9)$ & $66(9)$ & $100(10)$ & $21(8)$ & $25(8)$ & $20(8)$ \\
\hline$C(32)$ & $125(19)$ & $130(20)$ & $89(16)$ & $20(15)$ & $35(14)$ & $53(16)$ \\
\hline $\mathrm{F}(7)$ & $136(11)$ & 171(15) & 131(11) & $3(11)$ & 21(9) & $45(11)$ \\
\hline$C(12)$ & $180(20)$ & $72(15)$ & $120(18)$ & $46(14)$ & $55(18)$ & $21(16)$ \\
\hline $\mathrm{C}(9)$ & $81(14)$ & $90(16)$ & $117(15)$ & $41(13)$ & $40(12)$ & $19(12)$ \\
\hline$C(33)$ & $120(20)$ & $130(20)$ & $130(20)$ & $20(17)$ & $29(16)$ & $57(18)$ \\
\hline $\mathrm{C}(55)$ & $112(15)$ & 101(15) & 93(14) & $42(12)$ & $51(12)$ & $60(13)$ \\
\hline$C(56)$ & 122(19) & 113(19) & 111(17) & $14(15)$ & $3(15)$ & $43(15)$ \\
\hline$C(57)$ & $140(20)$ & $140(20)$ & $130(20)$ & $15(17)$ & $-1(18)$ & $68(19)$ \\
\hline$C(58)$ & $160(20)$ & $190(30)$ & 104(18) & 33(19) & $15(17)$ & $90(20)$ \\
\hline$C(59)$ & $130(20)$ & $210(30)$ & $130(20)$ & $60(20)$ & $30(16)$ & $100(20)$ \\
\hline$C(60)$ & $98(16)$ & $150(20)$ & $112(16)$ & $69(16)$ & $35(13)$ & $58(15)$ \\
\hline$C(51)$ & $103(15)$ & $93(15)$ & $85(13)$ & $20(12)$ & $29(11)$ & $-2(13)$ \\
\hline$C(34)$ & $120(20)$ & $150(30)$ & $150(20)$ & $-24(19)$ & $3(17)$ & $67(19)$ \\
\hline$C(8)$ & $88(16)$ & $120(20)$ & $108(16)$ & $28(15)$ & $28(13)$ & $53(15)$ \\
\hline$C(10)$ & $87(16)$ & $47(13)$ & $190(30)$ & $24(14)$ & $33(16)$ & $9(11)$ \\
\hline$C(50)$ & $70(14)$ & $98(18)$ & $160(20)$ & $47(16)$ & $30(13)$ & $14(13)$ \\
\hline$C(53)$ & $140(20)$ & $110(20)$ & $160(20)$ & $29(17)$ & $57(18)$ & 81(18) \\
\hline$C(70)$ & 107(18) & $79(16)$ & $180(20)$ & $32(15)$ & $66(16)$ & $54(14)$ \\
\hline$C(27)$ & $84(16)$ & $88(17)$ & $100(15)$ & $7(13)$ & 21(12) & $31(13)$ \\
\hline$C(14)$ & $65(13)$ & $140(20)$ & 125(18) & $23(16)$ & $22(12)$ & 18(14) \\
\hline$C(13)$ & $150(20)$ & $120(20)$ & 107(17) & $35(16)$ & $35(16)$ & $55(18)$ \\
\hline $\mathrm{C}(28)$ & $93(17)$ & $130(20)$ & $82(14)$ & $8(15)$ & $8(13)$ & 41(16) \\
\hline$C(74)$ & $96(16)$ & $102(17)$ & 101(15) & $29(13)$ & $18(12)$ & $34(13)$ \\
\hline $\mathrm{F}(8)$ & 121(10) & $144(12)$ & $92(8)$ & $22(8)$ & $2(7)$ & $45(9)$ \\
\hline $\mathrm{O}(1)$ & $96(13)$ & $83(11)$ & 171(17) & $9(11)$ & $7(12)$ & $-2(10)$ \\
\hline $\mathrm{O}(4)$ & $160(20)$ & 130(19) & 154(19) & $12(15)$ & $53(16)$ & $-25(15)$ \\
\hline $\mathrm{N}(3)$ & $135(19)$ & $62(14)$ & $150(19)$ & $40(14)$ & $63(15)$ & 19(13) \\
\hline
\end{tabular}




$\begin{array}{lcccccr}\mathrm{N}(4) & 76(13) & 75(13) & 138(16) & 25(12) & 19(12) & 10(11) \\ \mathrm{O}(5) & 180(20) & 106(15) & 220(20) & 83(16) & 63(17) & 51(14) \\ \mathrm{O}(2) & 125(14) & 77(12) & 210(20) & 85(14) & -15(13) & -15(10) \\ \mathrm{C}(71) & 84(12) & 53(11) & 85(12) & 25(9) & 12(10) & 23(10) \\ \mathrm{C}(72) & 119(14) & 134(16) & 105(14) & -8(13) & 1(13) & 49(14)\end{array}$

Table 5. Hydrogen coordinates ( x 10 $)$ and isotropic displacement parameters $\left(\AA^{2} \times 10^{3}\right)$ for final-wensongwei-wsw-4-74-250k-191223.

\begin{tabular}{|c|c|c|c|c|}
\hline & $\mathrm{x}$ & $\mathrm{y}$ & $\mathrm{z}$ & $\mathrm{U}(\mathrm{eq})$ \\
\hline $\mathrm{H}(3)$ & -2284 & 3797 & 929 & 153 \\
\hline $\mathrm{H}(6 \mathrm{~A})$ & 6541 & 8198 & 3728 & 177 \\
\hline $\mathrm{H}(9 \mathrm{~A})$ & 6879 & 11918 & 6403 & 168 \\
\hline $\mathrm{H}(46)$ & 2315 & 4428 & 6733 & 126 \\
\hline $\mathrm{H}(45)$ & 4049 & 6218 & 6755 & 115 \\
\hline $\mathrm{H}(43)$ & 896 & 6705 & 5267 & 131 \\
\hline $\mathrm{H}(42)$ & -838 & 4914 & 5246 & 120 \\
\hline $\mathrm{H}(49)$ & 5387 & 9955 & 5422 & 103 \\
\hline $\mathrm{H}(12 \mathrm{~A})$ & 6098 & -3181 & 9179 & 133 \\
\hline $\mathrm{H}(79)$ & 7585 & -1594 & 11976 & 129 \\
\hline $\mathrm{H}(80)$ & 6367 & -1899 & 10761 & 108 \\
\hline $\mathrm{H}(76)$ & 8413 & 1362 & 10706 & 112 \\
\hline $\mathrm{H}(77)$ & 9631 & 1667 & 11921 & 127 \\
\hline $\mathrm{H}(78)$ & 9217 & 189 & 12556 & 138 \\
\hline $\mathrm{H}(69)$ & 8644 & -1537 & 9782 & 105 \\
\hline $\mathrm{H}(3 \mathrm{~A})$ & 3813 & 8665 & 1801 & 92 \\
\hline $\mathrm{H}(2)$ & 5630 & 10468 & 1981 & 96 \\
\hline $\mathrm{H}(6)$ & 2386 & 11455 & 922 & 95 \\
\hline $\mathrm{H}(5)$ & 569 & 9653 & 743 & 94 \\
\hline $\mathrm{H}(22)$ & 259 & 1433 & 4720 & 141 \\
\hline $\mathrm{H}(23)$ & 2148 & 3165 & 4740 & 127 \\
\hline $\mathrm{H}(25)$ & -721 & 3746 & 3161 & 116 \\
\hline $\mathrm{H}(26)$ & -2611 & 2014 & 3141 & 119 \\
\hline $\mathrm{H}(73 \mathrm{~A})$ & 3686 & -1836 & 9725 & 153 \\
\hline $\mathrm{H}(73 \mathrm{~B})$ & 3466 & -1109 & 9136 & 153 \\
\hline $\mathrm{H}(73 \mathrm{C})$ & 3746 & -616 & 9977 & 153 \\
\hline
\end{tabular}




\begin{tabular}{|c|c|c|c|c|}
\hline $\mathrm{H}(52)$ & 4852 & 9837 & 7261 & 131 \\
\hline $\mathrm{H}(29)$ & 4756 & 6963 & 4619 & 115 \\
\hline $\mathrm{H}(30 \mathrm{~A})$ & 4262 & 8277 & 3918 & 155 \\
\hline $\mathrm{H}(30 \mathrm{~B})$ & 2949 & 7723 & 4360 & 155 \\
\hline $\mathrm{H}(30 \mathrm{C})$ & 2716 & 7312 & 3510 & 155 \\
\hline $\mathrm{H}(54 \mathrm{~A})$ & 404 & 9495 & 6258 & 176 \\
\hline $\mathrm{H}(54 \mathrm{~B})$ & 1667 & 9635 & 6946 & 176 \\
\hline $\mathrm{H}(54 \mathrm{C})$ & 1461 & 8763 & 6240 & 176 \\
\hline $\mathrm{H}(40)$ & 7736 & 7320 & 5269 & 117 \\
\hline $\mathrm{H}(39)$ & 8022 & 7360 & 6529 & 140 \\
\hline $\mathrm{H}(38)$ & 7018 & 5721 & 6983 & 138 \\
\hline $\mathrm{H}(37)$ & 5728 & 4042 & 6177 & 142 \\
\hline $\mathrm{H}(36)$ & 5442 & 4002 & 4917 & 136 \\
\hline $\mathrm{H}(20)$ & -1534 & 3471 & -769 & 131 \\
\hline $\mathrm{H}(19)$ & -2391 & 3456 & -1997 & 167 \\
\hline $\mathrm{H}(18)$ & -893 & 4779 & -2604 & 176 \\
\hline $\mathrm{H}(17)$ & 1462 & 6116 & -1983 & 159 \\
\hline $\mathrm{H}(16)$ & 2320 & 6131 & -755 & 126 \\
\hline $\mathrm{H}(66)$ & 11636 & 3344 & 7947 & 102 \\
\hline $\mathrm{H}(65)$ & 9934 & 1645 & 8124 & 106 \\
\hline $\mathrm{H}(63)$ & 13416 & 1311 & 9496 & 99 \\
\hline $\mathrm{H}(62)$ & 15118 & 3010 & 9319 & 97 \\
\hline $\mathrm{H}(32)$ & 3876 & 5704 & 2748 & 134 \\
\hline $\mathrm{H}(12)$ & 977 & 5968 & 1865 & 149 \\
\hline $\mathrm{H}(9)$ & -1359 & 5582 & 120 & 113 \\
\hline $\mathrm{H}(33 \mathrm{~A})$ & 8519 & 6092 & 3243 & 186 \\
\hline $\mathrm{H}(33 \mathrm{~B})$ & 9093 & 5679 & 3943 & 186 \\
\hline $\mathrm{H}(33 \mathrm{C})$ & 9049 & 6889 & 4010 & 186 \\
\hline $\mathrm{H}(56)$ & 535 & 8957 & 4846 & 140 \\
\hline $\mathrm{H}(57)$ & 59 & 8717 & 3572 & 161 \\
\hline $\mathrm{H}(58)$ & 1823 & 9878 & 2968 & 171 \\
\hline $\mathrm{H}(59)$ & 4065 & 11281 & 3640 & 171 \\
\hline $\mathrm{H}(60)$ & 4542 & 11521 & 4914 & 133 \\
\hline $\mathrm{H}(34 \mathrm{~A})$ & 4277 & 4003 & 3385 & 209 \\
\hline $\mathrm{H}(34 \mathrm{~B})$ & 5718 & 3642 & 3594 & 209 \\
\hline $\mathrm{H}(34 \mathrm{C})$ & 5568 & 4171 & 2888 & 209 \\
\hline $\mathrm{H}(10 \mathrm{~A})$ & -3430 & 4977 & 791 & 168 \\
\hline $\mathrm{H}(10 \mathrm{~B})$ & -3065 & 6218 & 684 & 168 \\
\hline
\end{tabular}




\begin{tabular}{lrrrr}
$\mathrm{H}(10 \mathrm{C})$ & -2470 & 5959 & 1443 & 168 \\
$\mathrm{H}(50 \mathrm{~A})$ & 7428 & 9725 & 6621 & 163 \\
$\mathrm{H}(50 \mathrm{~B})$ & 7973 & 10631 & 6126 & 163 \\
$\mathrm{H}(50 \mathrm{C})$ & 7459 & 9362 & 5789 & 163 \\
$\mathrm{H}(53 \mathrm{~A})$ & 1717 & 11972 & 6190 & 184 \\
$\mathrm{H}(53 \mathrm{~B})$ & 3519 & 12571 & 6213 & 184 \\
$\mathrm{H}(53 \mathrm{C})$ & 2913 & 12137 & 6910 & 184 \\
$\mathrm{H}(70 \mathrm{~A})$ & 8936 & -2542 & 8390 & 166 \\
$\mathrm{H}(70 \mathrm{~B})$ & 8171 & -3256 & 8958 & 166 \\
$\mathrm{H}(70 \mathrm{C})$ & 9942 & -2476 & 9149 & 166 \\
$\mathrm{H}(14 \mathrm{~A})$ & 3140 & 6570 & 445 & 170 \\
$\mathrm{H}(14 \mathrm{~B})$ & 3979 & 5717 & 569 & 170 \\
$\mathrm{H}(14 \mathrm{C})$ & 3261 & 6173 & 1205 & 170 \\
$\mathrm{H}(13 \mathrm{~A})$ & 1184 & 3173 & 860 & 183 \\
$\mathrm{H}(13 \mathrm{~B})$ & 2504 & 3450 & 379 & 183 \\
$\mathrm{H}(13 \mathrm{C})$ & 745 & 2837 & 1 & 183 \\
$\mathrm{H}(74 \mathrm{~A})$ & 6589 & 1348 & 9634 & 148 \\
$\mathrm{H}(74 \mathrm{~B})$ & 6148 & 701 & 8821 & 148 \\
$\mathrm{H}(74 \mathrm{C})$ & 7857 & 1035 & 9258 & 148 \\
$\mathrm{H}(72)$ & 7097 & -941 & 8094 & 148 \\
& & & & \\
\hline
\end{tabular}


10 NMR spectra for new compounds

${ }^{1} \mathrm{H}$ NMR of $2 \mathrm{c}\left(\mathrm{CDCl}_{3}, 400 \mathrm{MHz}, 25^{\circ} \mathrm{C}\right)$

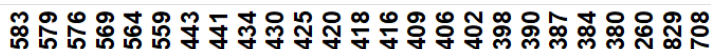

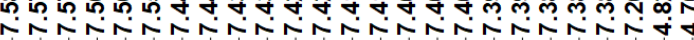

๕

○ं

$\mathrm{FH}_{2} \mathrm{C}_{\mathrm{SiMe}_{2} \mathrm{Ph}}^{\mathrm{O}}$

2c
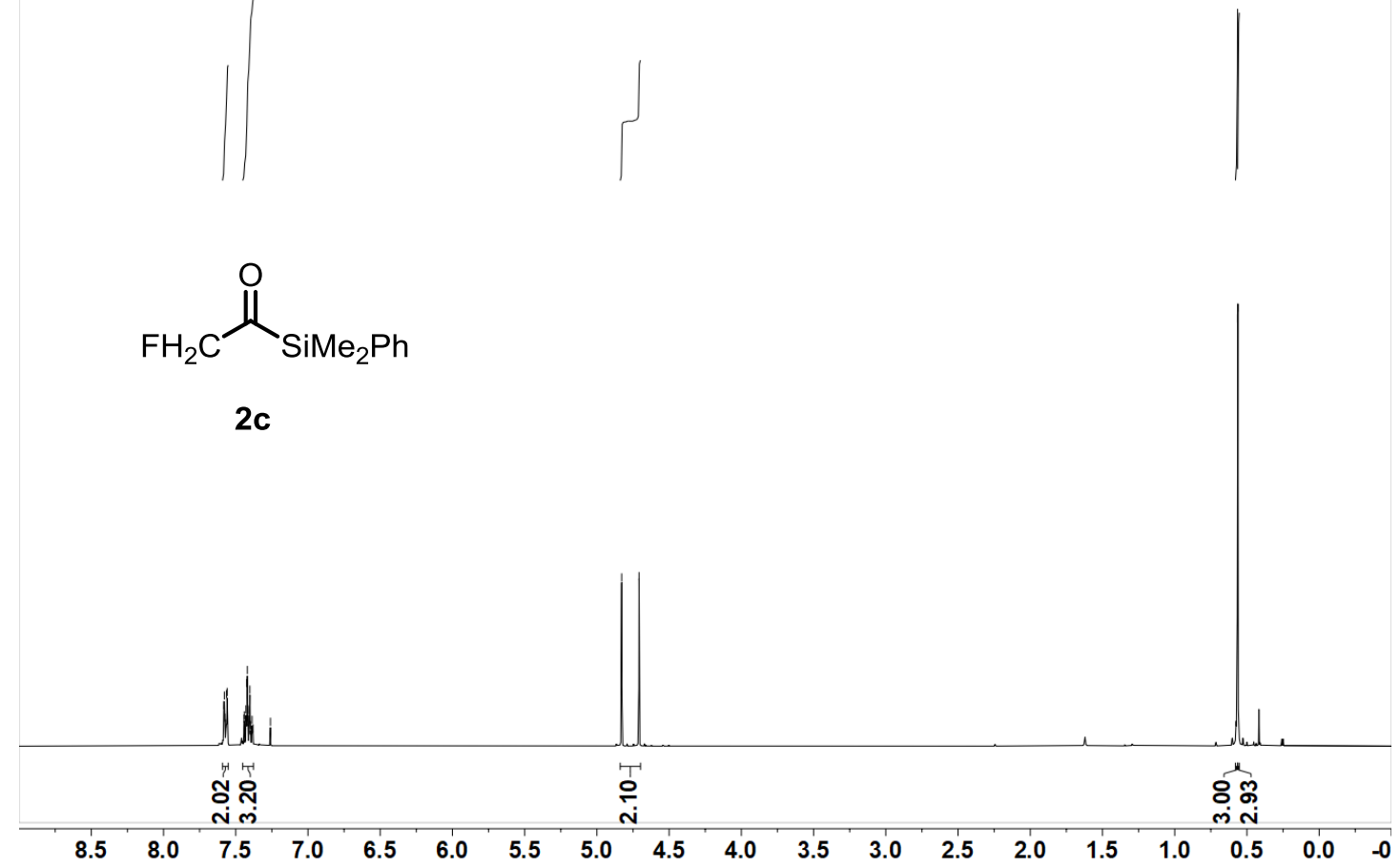

${ }^{13} \mathrm{C}$ NMR of $2 \mathrm{c}\left(\mathrm{CDCl}_{3}, 101 \mathrm{MHz}, 25{ }^{\circ} \mathrm{C}\right)$

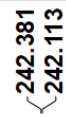

ฟึำ

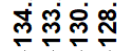

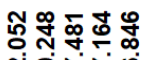

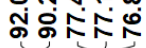

$\stackrel{\circ}{\circ \infty}+\underset{+}{+}$

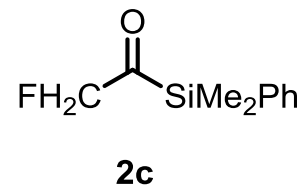

2c

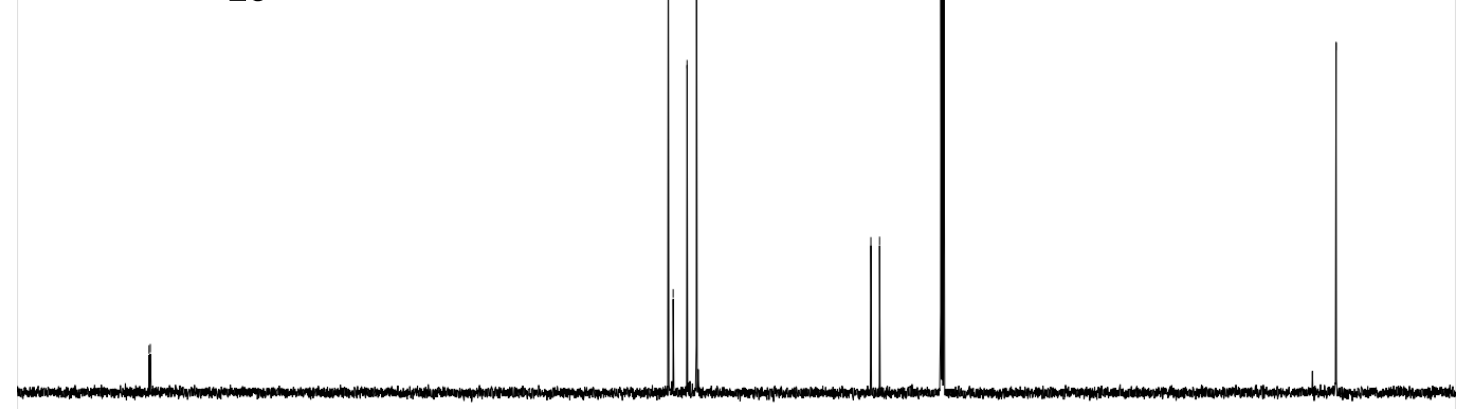

$26025024023022021020019018017016015014013012011010090 \quad 8070 \quad 60 \begin{array}{lllllllllll}40 & 40 & 30 & 20 & 10 & 0 & -10 & -20\end{array}$ 
${ }^{19} \mathrm{~F}$ NMR of $2 \mathrm{c}\left(\mathrm{CDCl}_{3}, 376 \mathrm{MHz}, 25^{\circ} \mathrm{C}\right)$

잉영융

สิสิิ สิ

$\mathrm{FH}_{2} \mathrm{C}_{2 \mathrm{C}}^{\mathrm{O}} \mathrm{SiMe}_{2} \mathrm{Ph}$

\begin{tabular}{lllllllllllllllllllllllllllll}
\hline 100 & 80 & 60 & 40 & 20 & 0 & -20 & -40 & -60 & -80 & -100 & -120 & -140 & -160 & -180 & -200 & -220 & -240 & -260 & -280 & -300
\end{tabular}

${ }^{1} \mathrm{H}$ NMR of $3 \mathrm{a}\left(\mathrm{CDCl}_{3}, 400 \mathrm{MHz}, 25^{\circ} \mathrm{C}\right)$

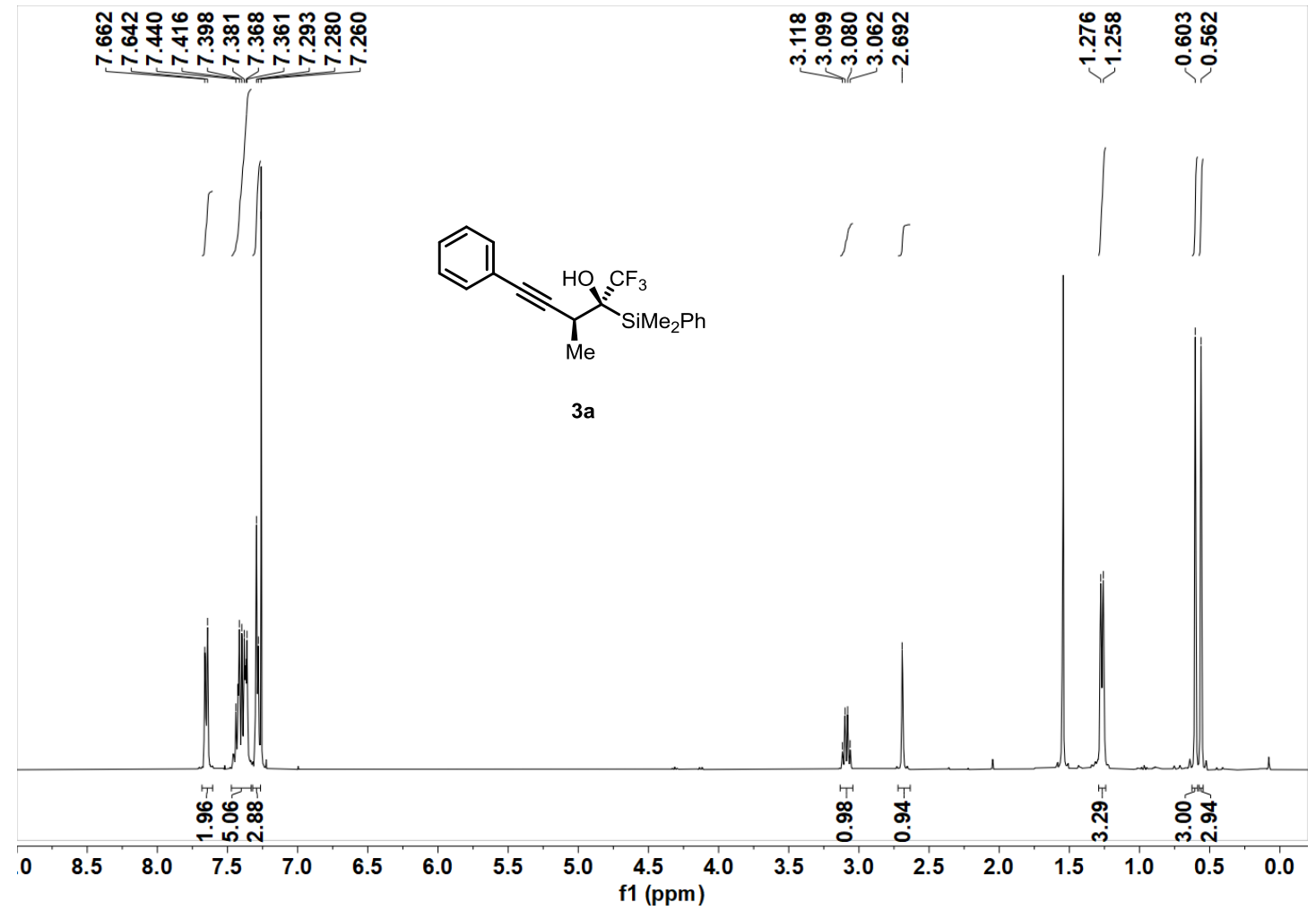


${ }^{13} \mathrm{C}$ NMR of 3a $\left(\mathrm{CDCl}_{3}, 101 \mathrm{MHz}, 25^{\circ} \mathrm{C}\right)$

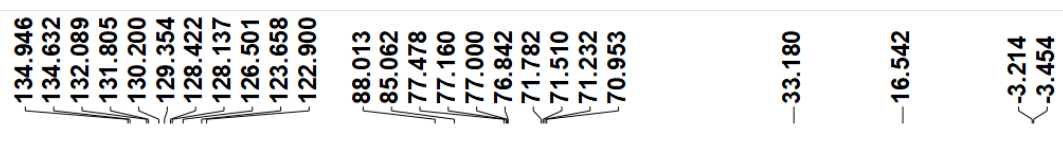

(1)

3a

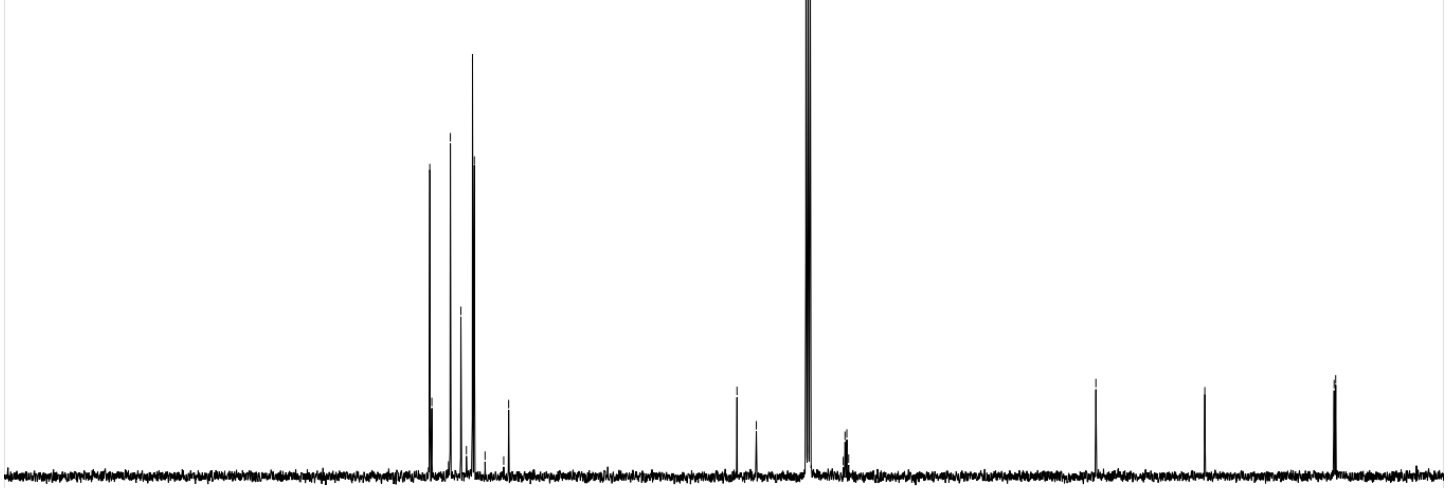

$\begin{array}{llllllllllllllllllllllll}10 & 190 & 180 & 170 & 160 & 150 & 140 & 130 & 120 & 110 & 100 & 90 & 80 & 70 & 60 & 50 & 40 & 30 & 20 & 10 & 0 & -10 & -2\end{array}$

${ }^{19} \mathrm{~F}$ NMR of $3 \mathrm{a}\left(\mathrm{CDCl}_{3}, 376 \mathrm{MHz}, 25^{\circ} \mathrm{C}\right)$

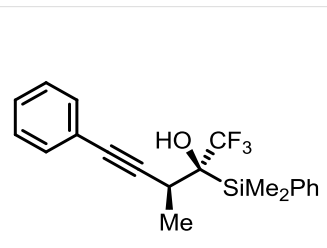

影

3a

$\begin{array}{lllllllllllllllllllllllllllllllllll}100 & 80 & 60 & 40 & 20 & 0 & -20 & -40 & -60 & -80 & -100 & -120 & -140 & -160 & -180 & -200 & -220 & -240 & -260 & -280 & -300\end{array}$ 
${ }^{1} \mathrm{H}$ NMR of $3 \mathrm{~b}\left(\mathrm{CDCl}_{3}, 400 \mathrm{MHz}, 25^{\circ} \mathrm{C}\right)$

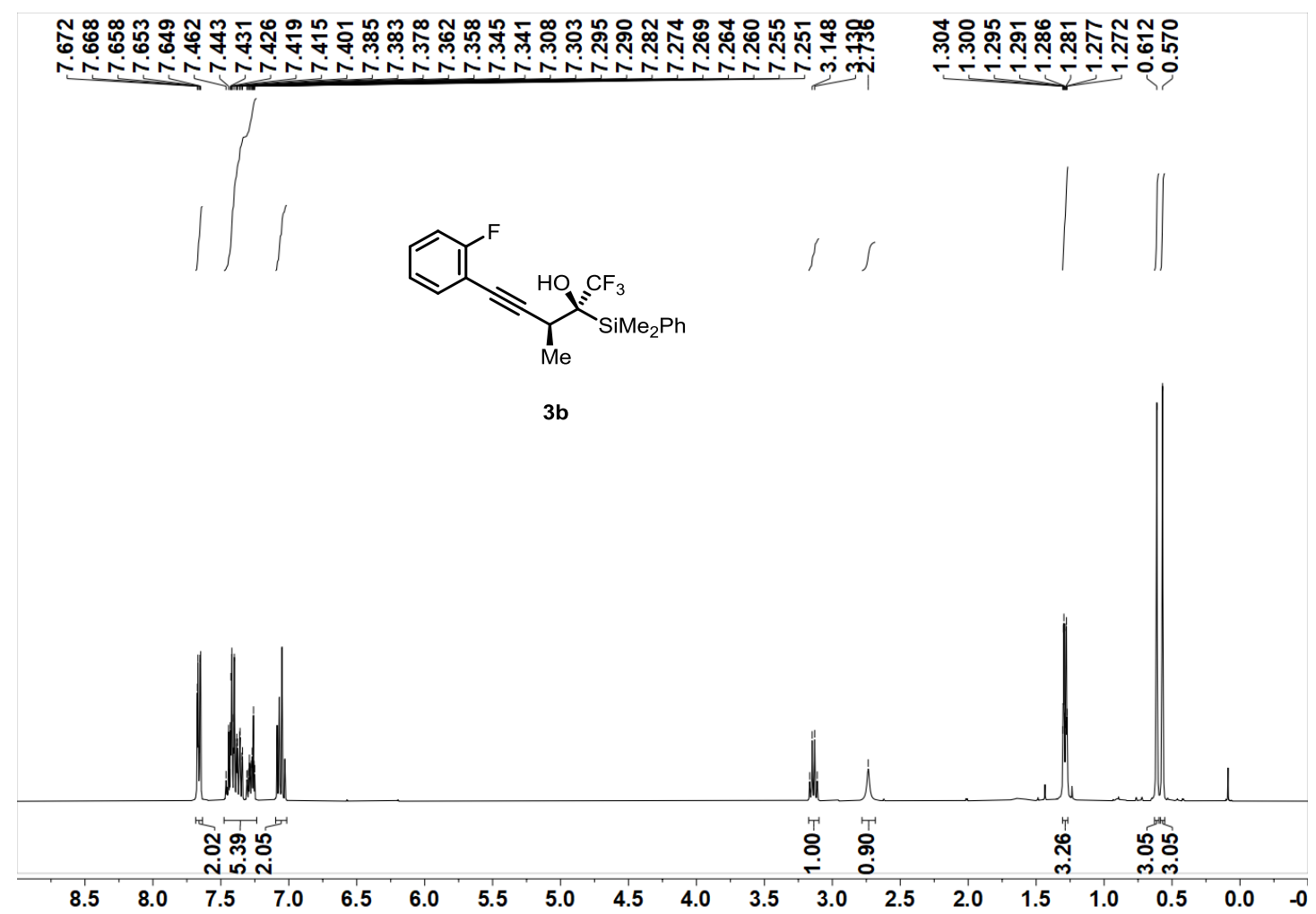

${ }^{13} \mathrm{C}$ NMR of $3 \mathrm{~b}\left(\mathrm{CDCl}_{3}, 101 \mathrm{MHz}, 25{ }^{\circ} \mathrm{C}\right)$

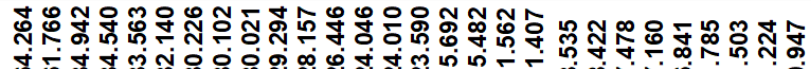

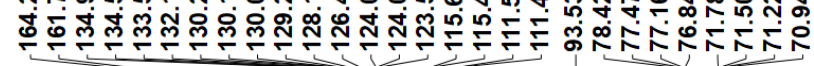

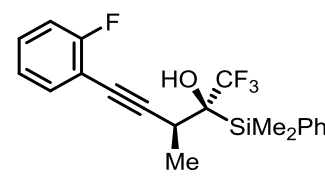

3b

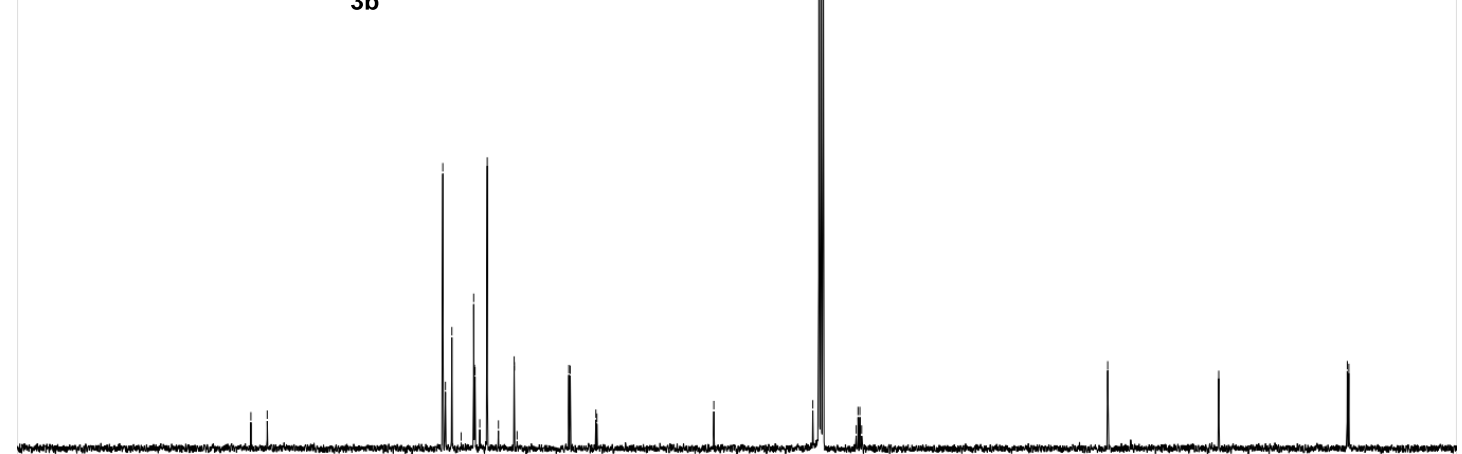

$\begin{array}{lllllllllllllllllllllllll}10 & 190 & 180 & 170 & 160 & 150 & 140 & 130 & 120 & 110 & 100 & 90 & 80 & 70 & 60 & 50 & 40 & 30 & 20 & 10 & 0 & -10 & -2\end{array}$ 
${ }^{19} \mathrm{~F}$ NMR of $3 \mathrm{~b}\left(\mathrm{CDCl}_{3}, 376 \mathrm{MHz}, 25^{\circ} \mathrm{C}\right)$

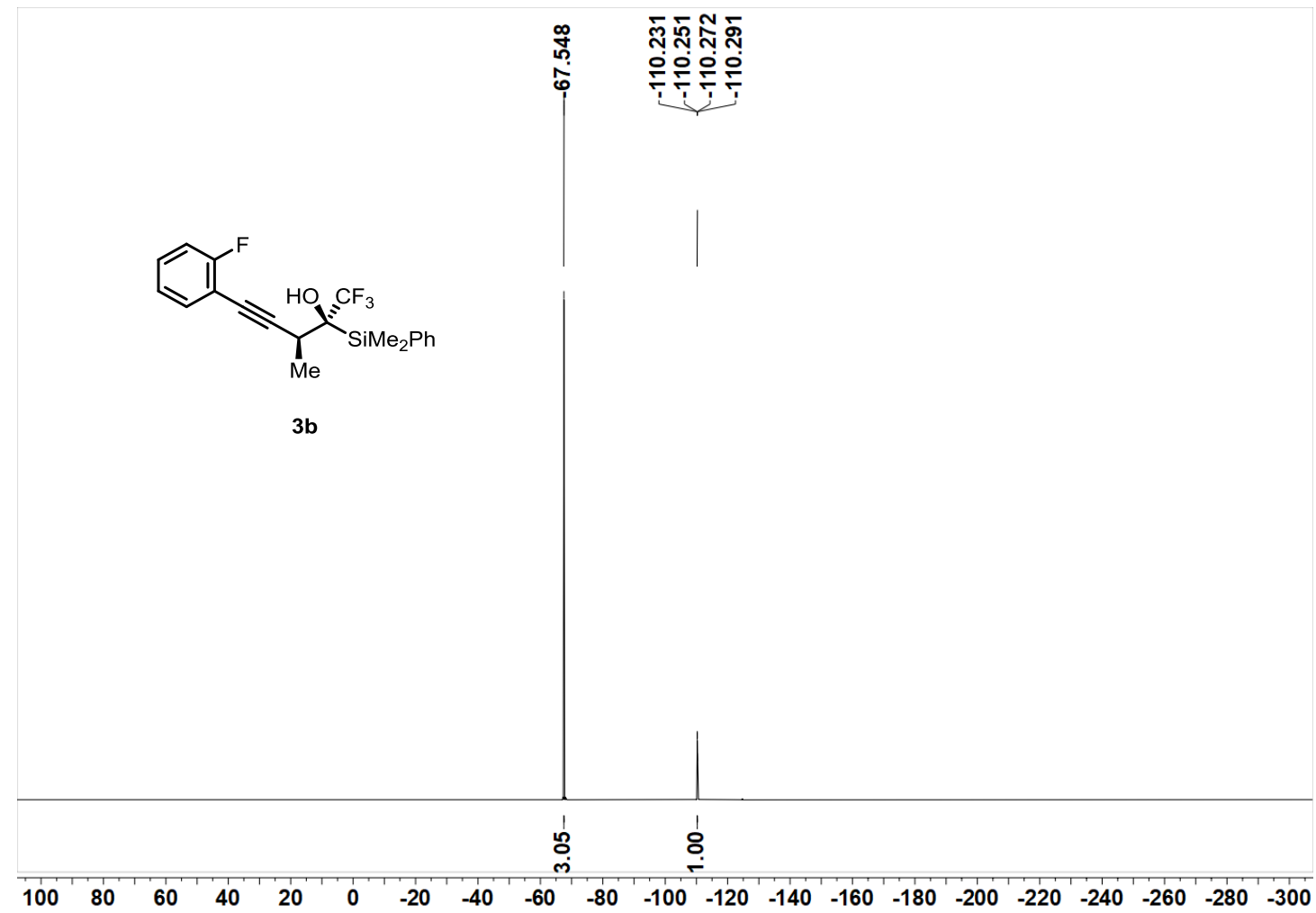

${ }^{1} \mathrm{H}$ NMR of $3 \mathrm{c}\left(\mathrm{CDCl}_{3}, 400 \mathrm{MHz}, 25^{\circ} \mathrm{C}\right)$

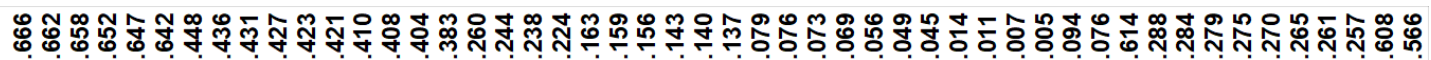
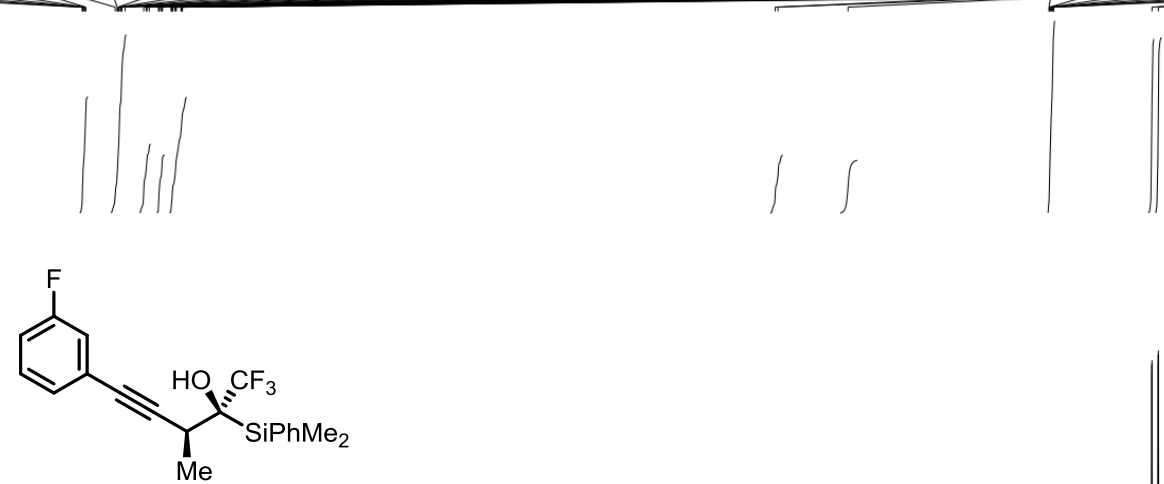

$3 c$
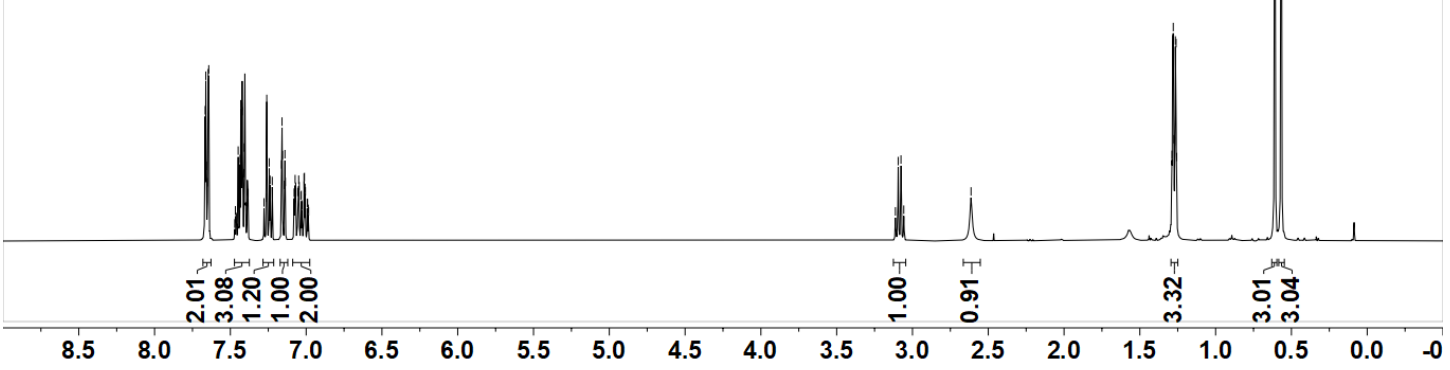
${ }^{13} \mathrm{C}$ NMR of $3 \mathrm{c}\left(\mathrm{CDCl}_{3}, 101 \mathrm{MHz}, 25^{\circ} \mathrm{C}\right)$

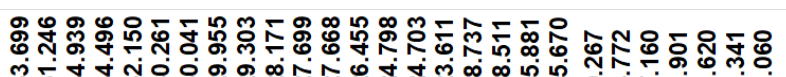

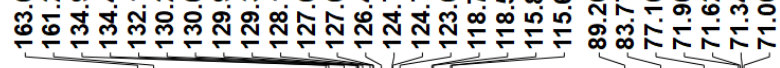

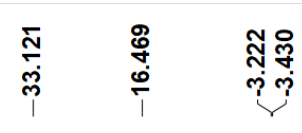

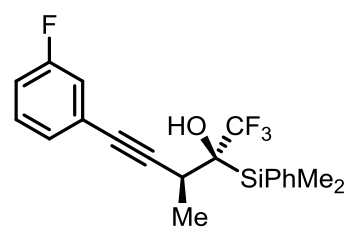

$3 c$

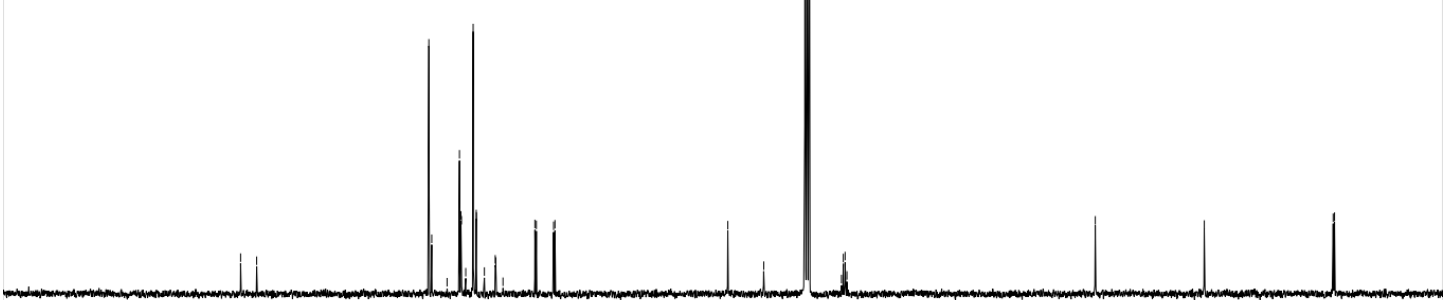

$\begin{array}{llllllllllllllllllllllll}10 & 190 & 180 & 170 & 160 & 150 & 140 & 130 & 120 & 110 & 100 & 90 & 80 & 70 & 60 & 50 & 40 & 30 & 20 & 10 & 0 & -10 & -2\end{array}$

${ }^{19} \mathrm{~F}$ NMR of $3 \mathrm{c}\left(\mathrm{CDCl}_{3}, 376 \mathrm{MHz}, 25^{\circ} \mathrm{C}\right)$

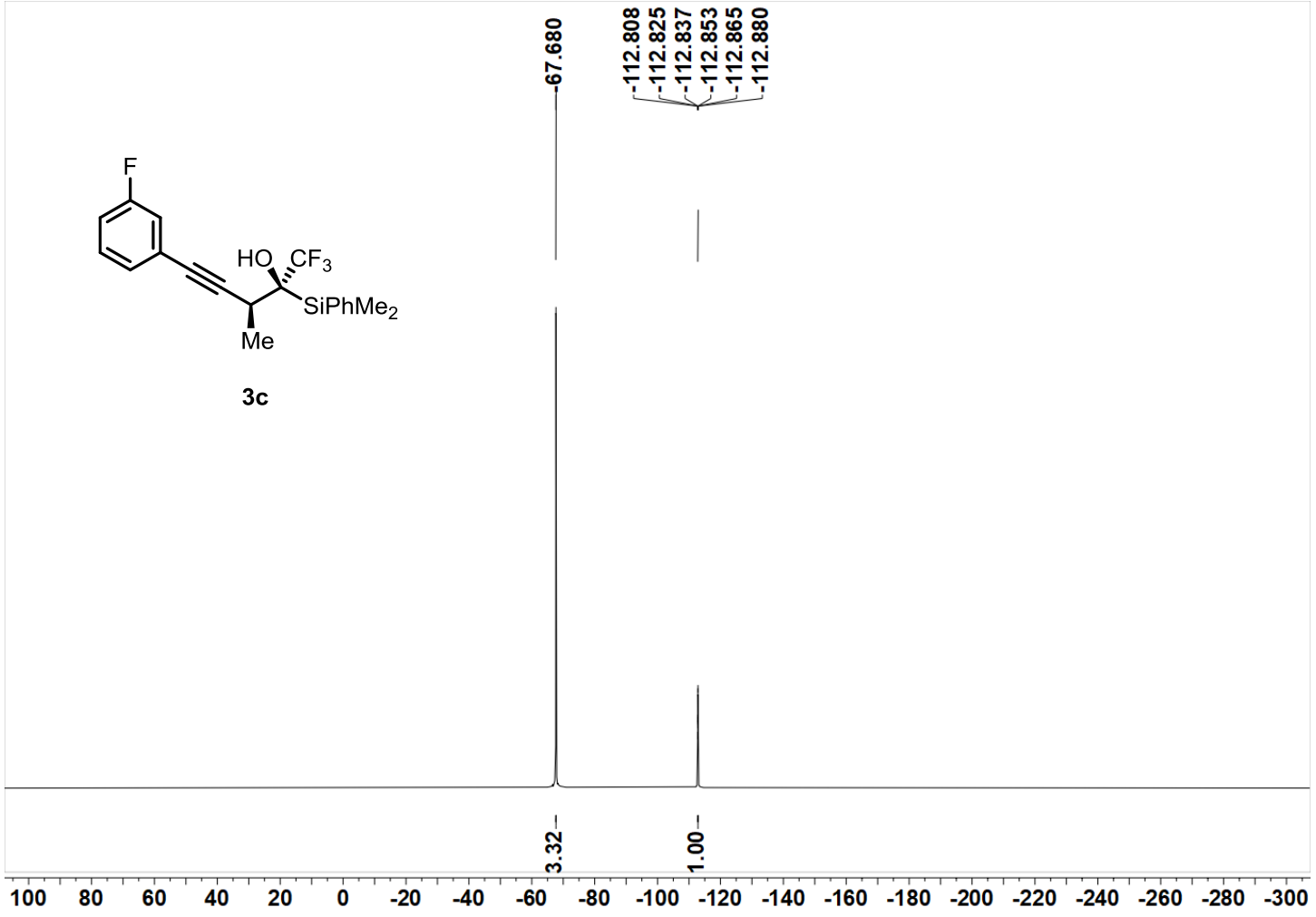


${ }^{1} \mathrm{H}$ NMR of $3 \mathrm{~d}\left(\mathrm{CDCl}_{3}, 400 \mathrm{MHz}, 25^{\circ} \mathrm{C}\right)$

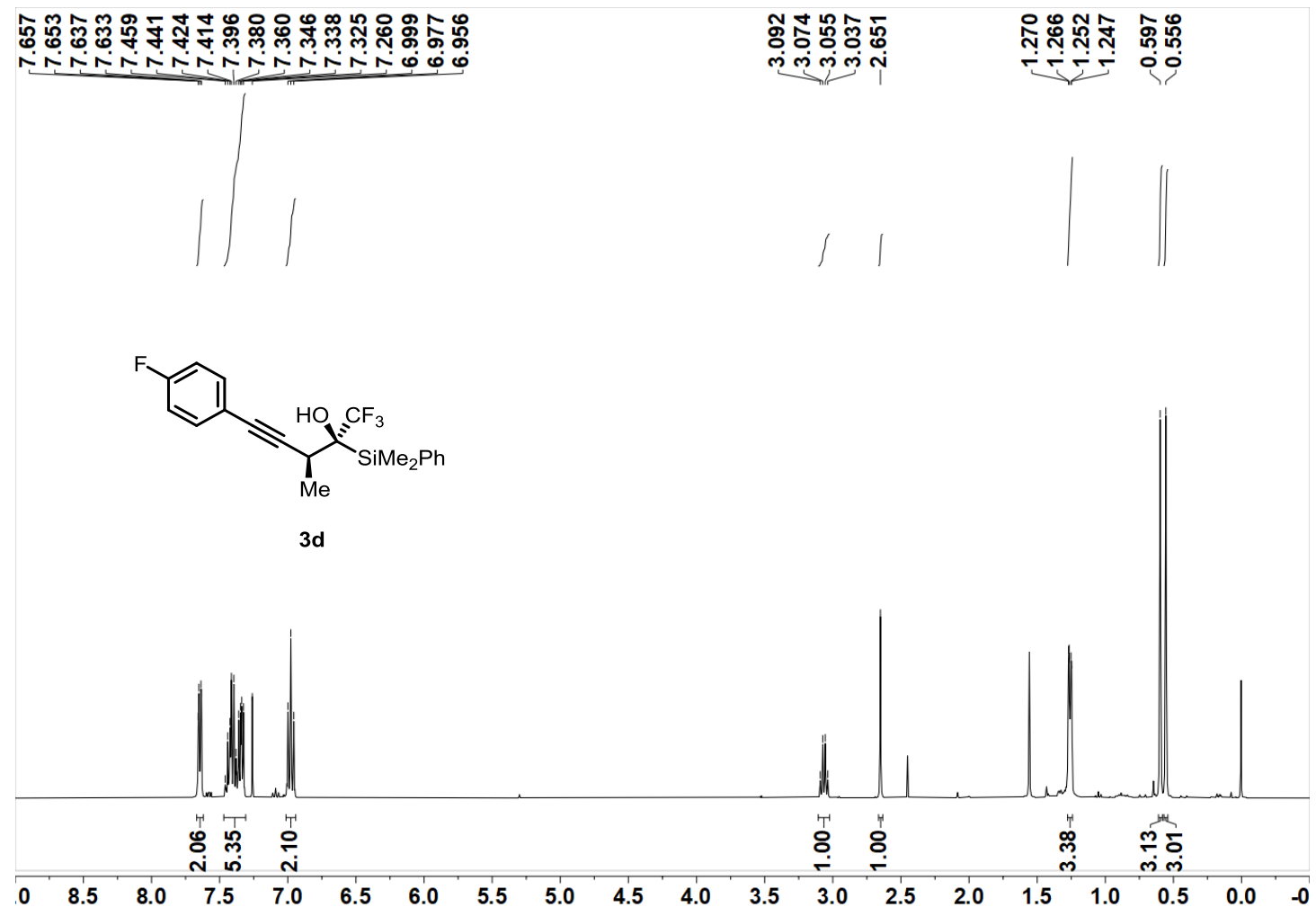

${ }^{13} \mathrm{C}$ NMR of 3d $\left(\mathrm{CDCl}_{3}, 101 \mathrm{MHz}, 25{ }^{\circ} \mathrm{C}\right)$

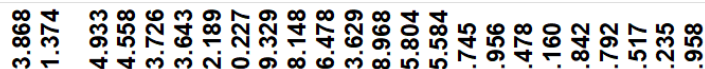

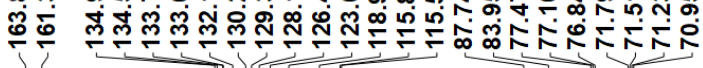

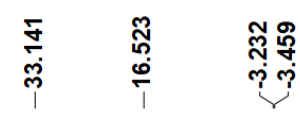

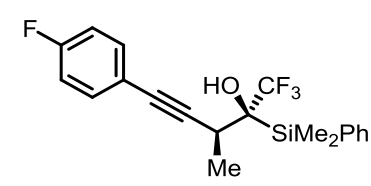

3d

$\begin{array}{llllllllllllllllllllllllllllllll}10 & 190 & 180 & 170 & 160 & 150 & 140 & 130 & 120 & 110 & 100 & 90 & 80 & 70 & 60 & 50 & 40 & 30 & 20 & 10 & 0 & -10 & -2\end{array}$ 
${ }^{19} \mathrm{~F}$ NMR of $3 \mathrm{~d}\left(\mathrm{CDCl}_{3}, 376 \mathrm{MHz}, 25^{\circ} \mathrm{C}\right)$

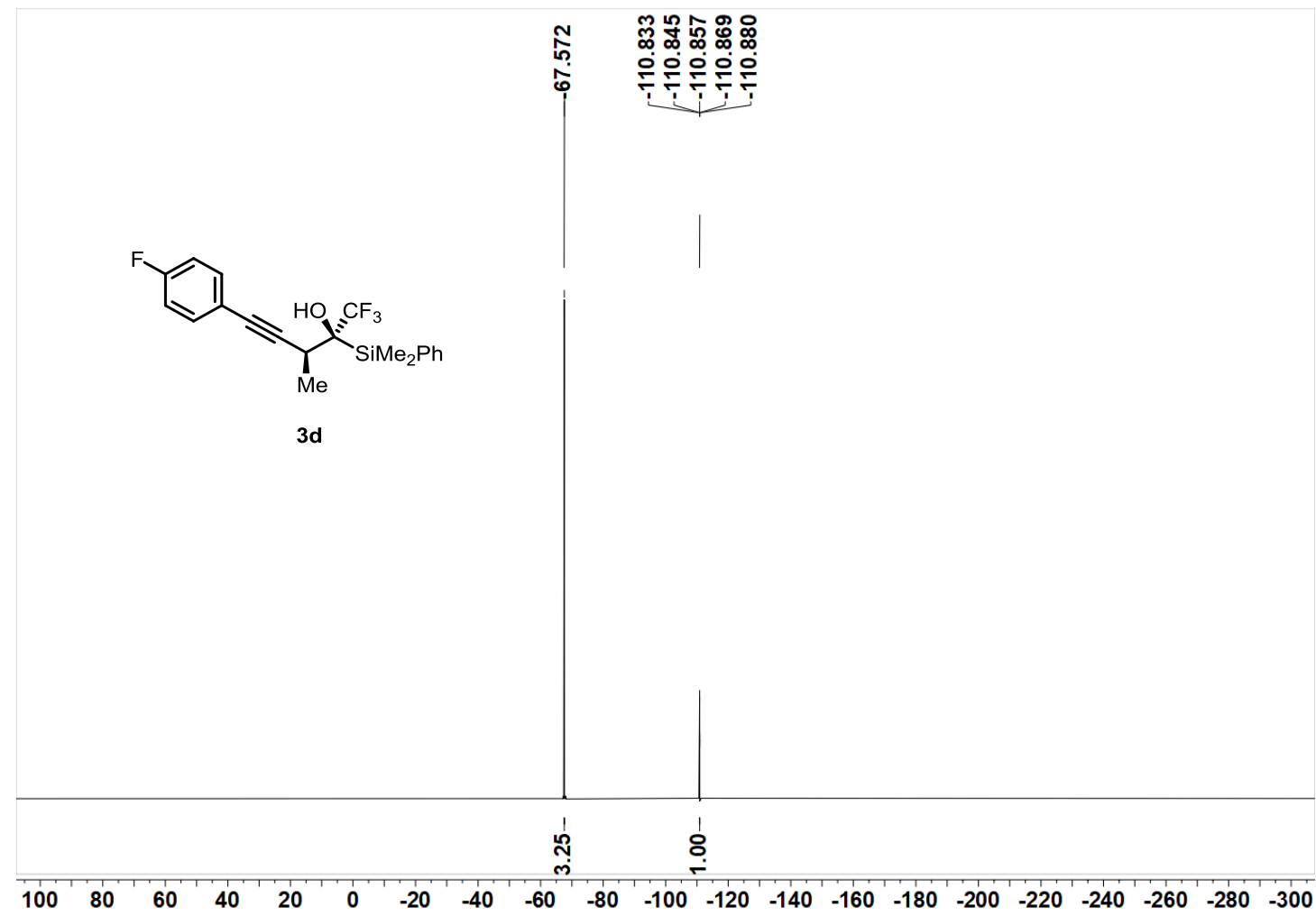

${ }^{1} \mathrm{H}$ NMR of $3 \mathrm{e}\left(\mathrm{CDCl}_{3}, 400 \mathrm{MHz}, 25^{\circ} \mathrm{C}\right)$

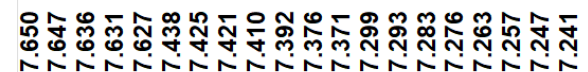

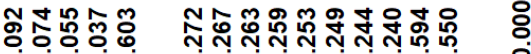

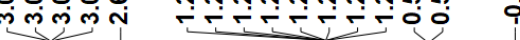
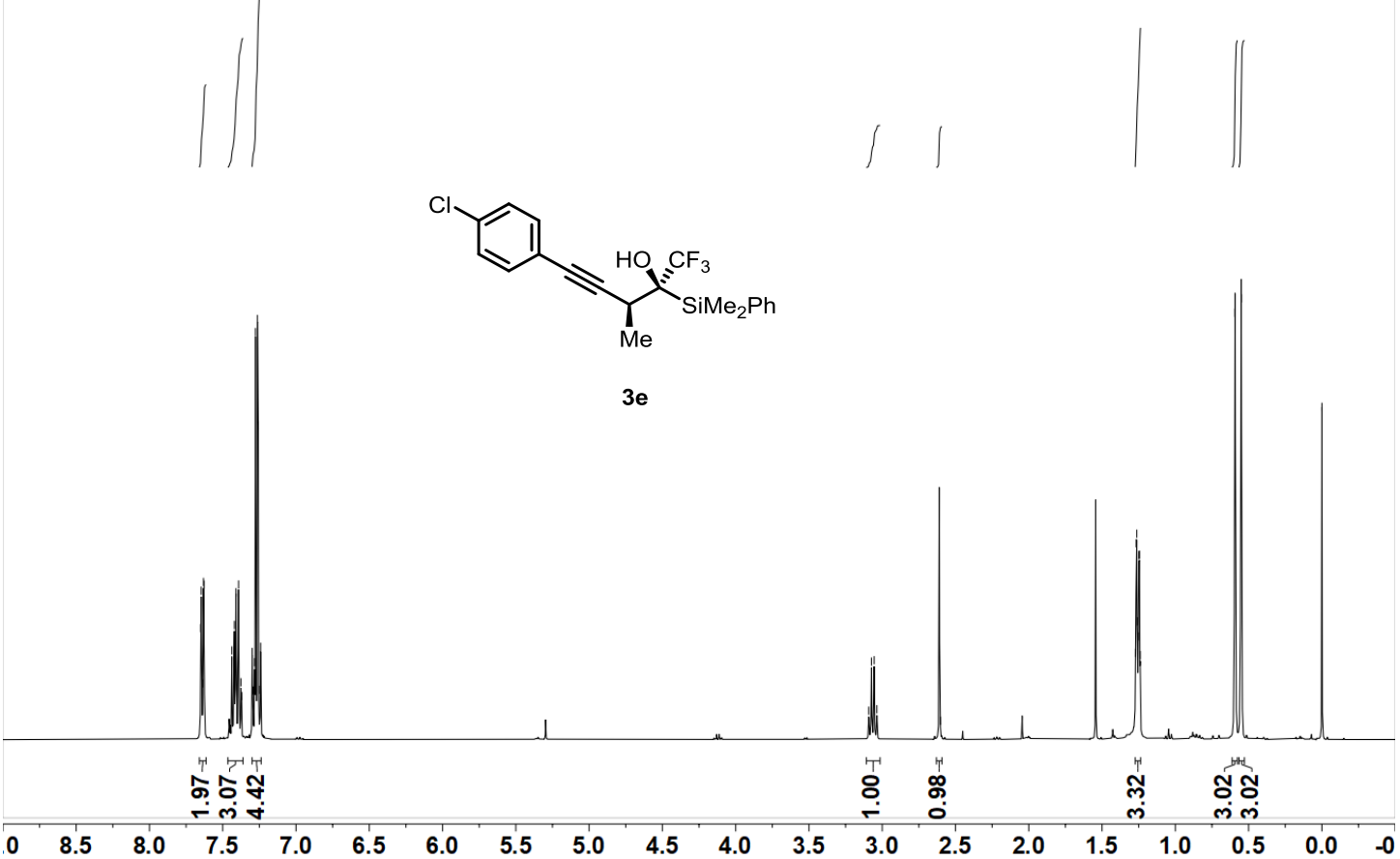
${ }^{13} \mathrm{C}$ NMR of $3 \mathrm{e}\left(\mathrm{CDCl}_{3}, 101 \mathrm{MHz}, 25{ }^{\circ} \mathrm{C}\right)$

䒛

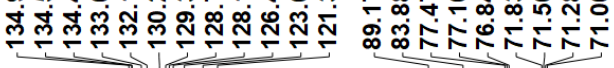

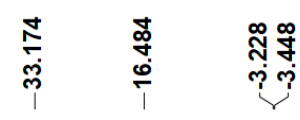

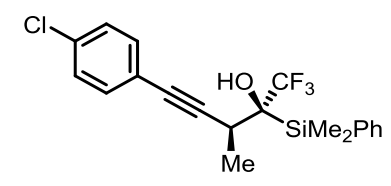

3 e

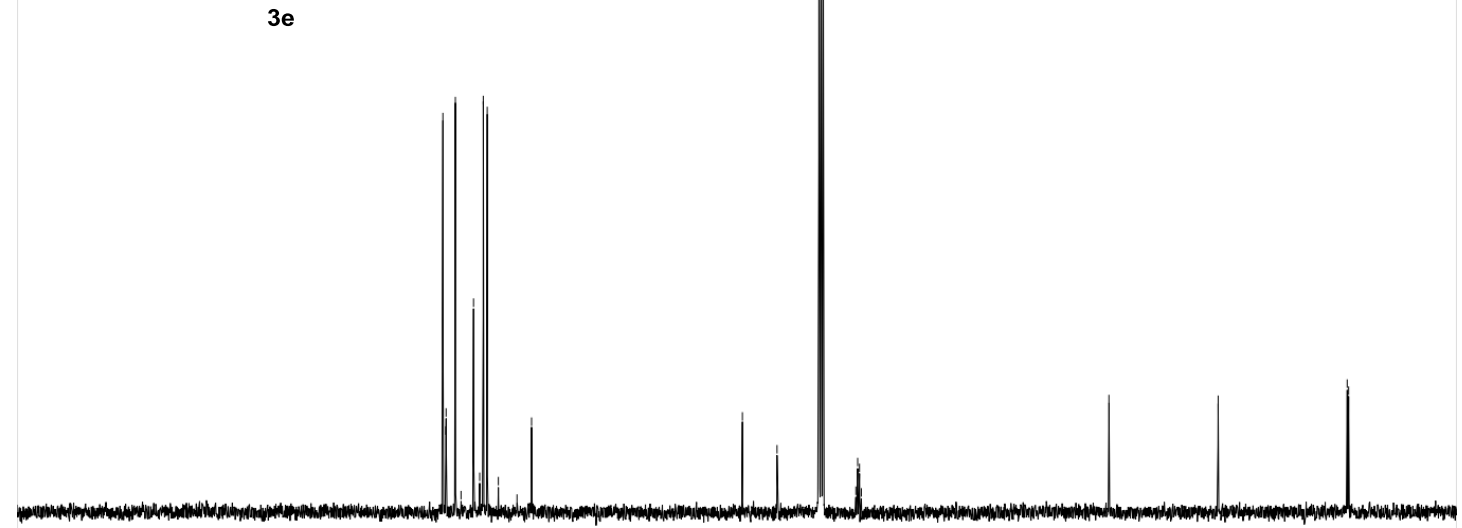

$\begin{array}{llllllllllllllllllllllll}190 & 180 & 170 & 160 & 150 & 140 & 130 & 120 & 110 & 100 & 90 & 80 & 70 & 60 & 50 & 40 & 30 & 20 & 10 & 0 & -10 & -2\end{array}$

${ }^{19} \mathrm{~F}$ NMR of $3 \mathrm{e}\left(\mathrm{CDCl}_{3}, 376 \mathrm{MHz}, 25^{\circ} \mathrm{C}\right)$

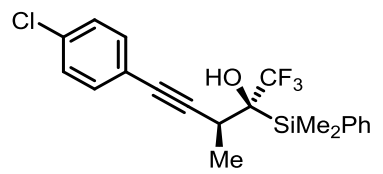

3e

$\begin{array}{llllllllllllllllllllllllllllllllll}100 & 80 & 60 & 40 & 20 & 0 & -20 & -40 & -60 & -80 & -100 & -120 & -140 & -160 & -180 & -200 & -220 & -240 & -260 & -280 & -300\end{array}$ 
${ }^{1} \mathrm{H}$ NMR of $3 f\left(\mathrm{CDCl}_{3}, 400 \mathrm{MHz}, 25^{\circ} \mathrm{C}\right)$

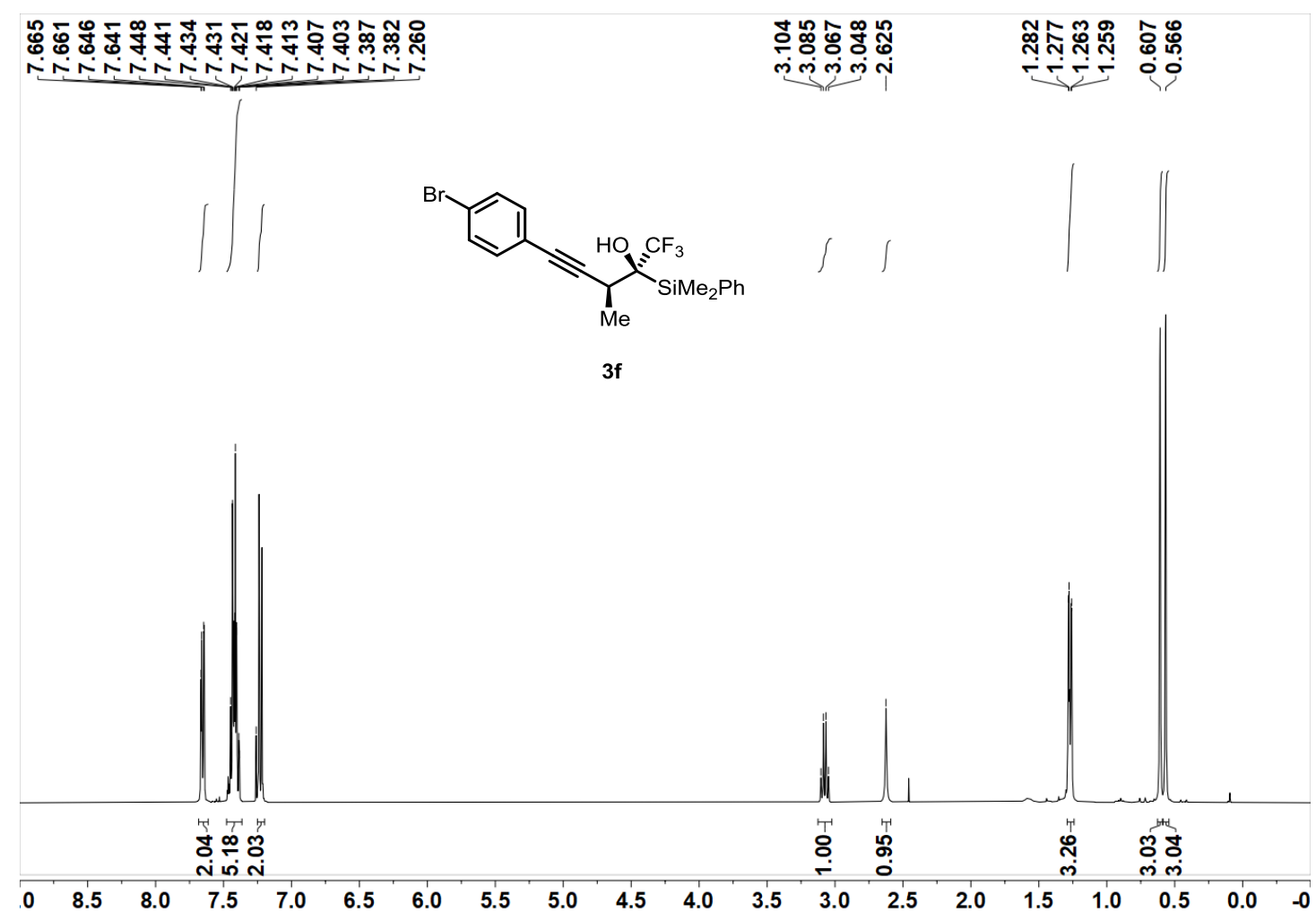

${ }^{13} \mathrm{C}$ NMR of $3 \mathrm{f}\left(\mathrm{CDCl}_{3}, 101 \mathrm{MHz}, 25^{\circ} \mathrm{C}\right)$

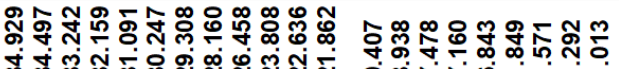

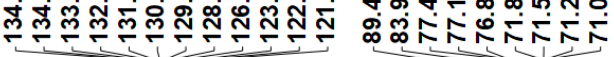

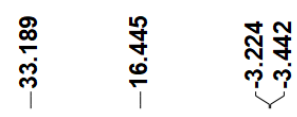

(1)

$3 f$

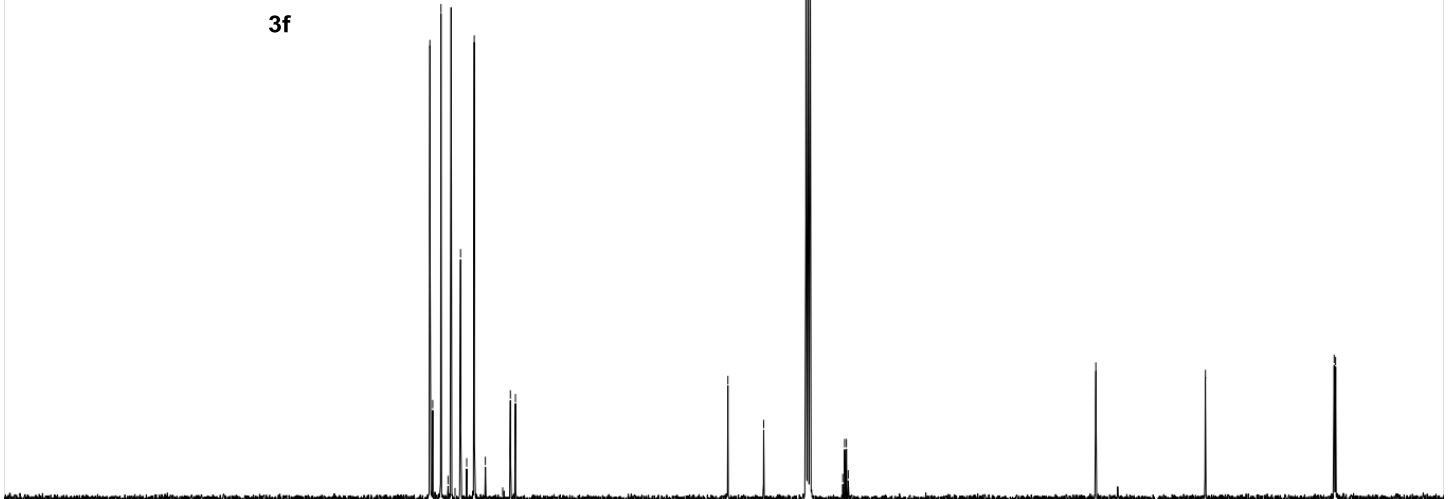

$\begin{array}{lllllllllllllllllllllll}190 & 180 & 170 & 160 & 150 & 140 & 130 & 120 & 110 & 100 & 90 & 80 & 70 & 60 & 50 & 40 & 30 & 20 & 10 & 0 & -10 & -2\end{array}$ 
${ }^{19} \mathrm{~F}$ NMR of $3 f\left(\mathrm{CDCl}_{3}, 376 \mathrm{MHz}, 25^{\circ} \mathrm{C}\right)$

ণั่์<smiles></smiles>

3f

$\begin{array}{lllllllllllllllllllllllllllll}100 & 80 & 60 & 40 & 20 & 0 & -20 & -40 & -60 & -80 & -100 & -120 & -140 & -160 & -180 & -200 & -220 & -240 & -260 & -280 & -300\end{array}$

${ }^{1} \mathrm{H}$ NMR of $3 \mathrm{~g}\left(\mathrm{CDCl}_{3}, 600 \mathrm{MHz}, 25^{\circ} \mathrm{C}\right)$

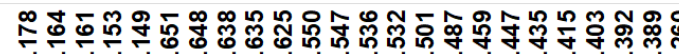

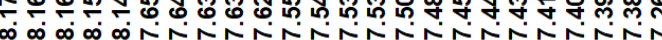

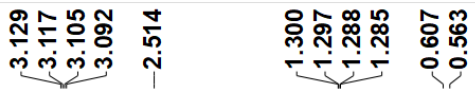
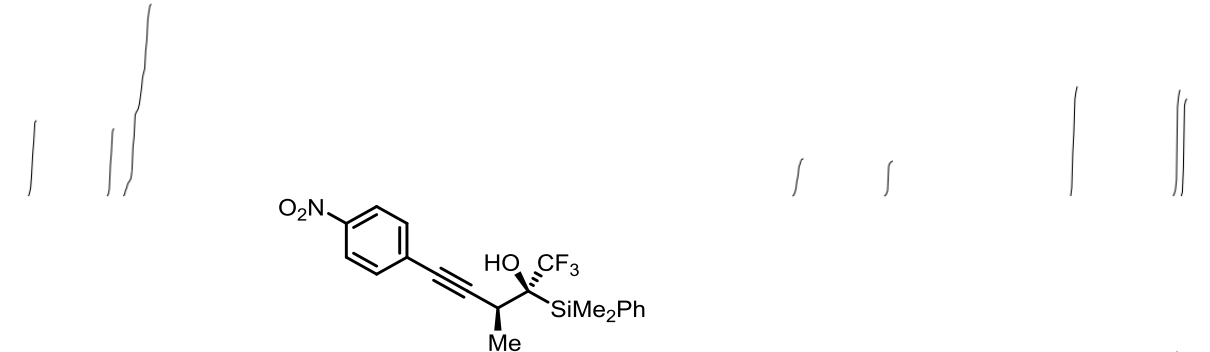

$3 g$

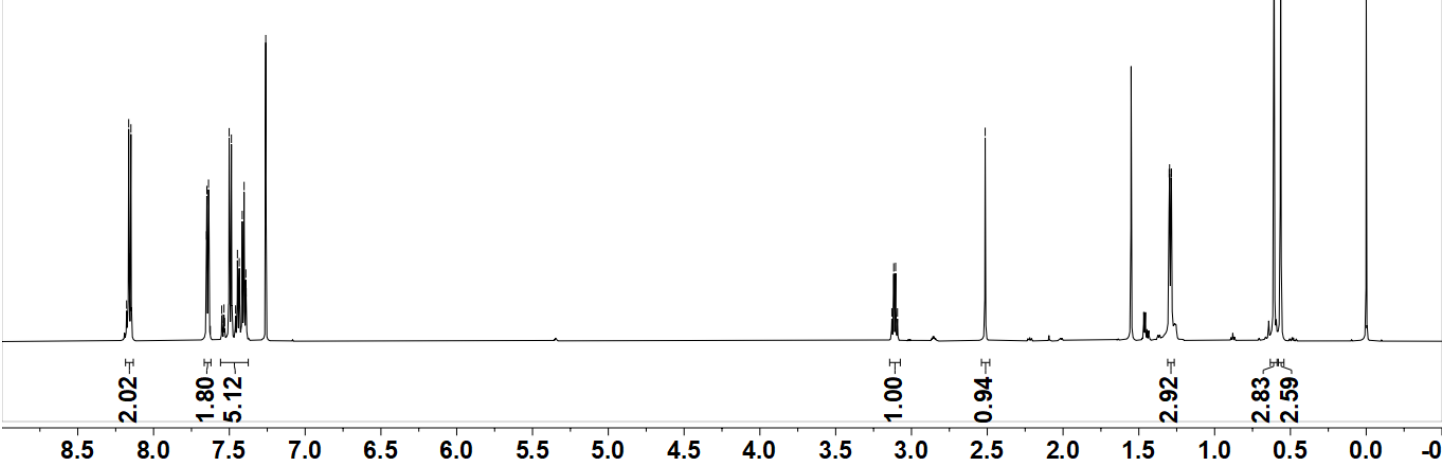


${ }^{13} \mathrm{C}$ NMR of $3 \mathrm{~g}\left(\mathrm{CDCl}_{3}, 151 \mathrm{MHz}, 25^{\circ} \mathrm{C}\right)$

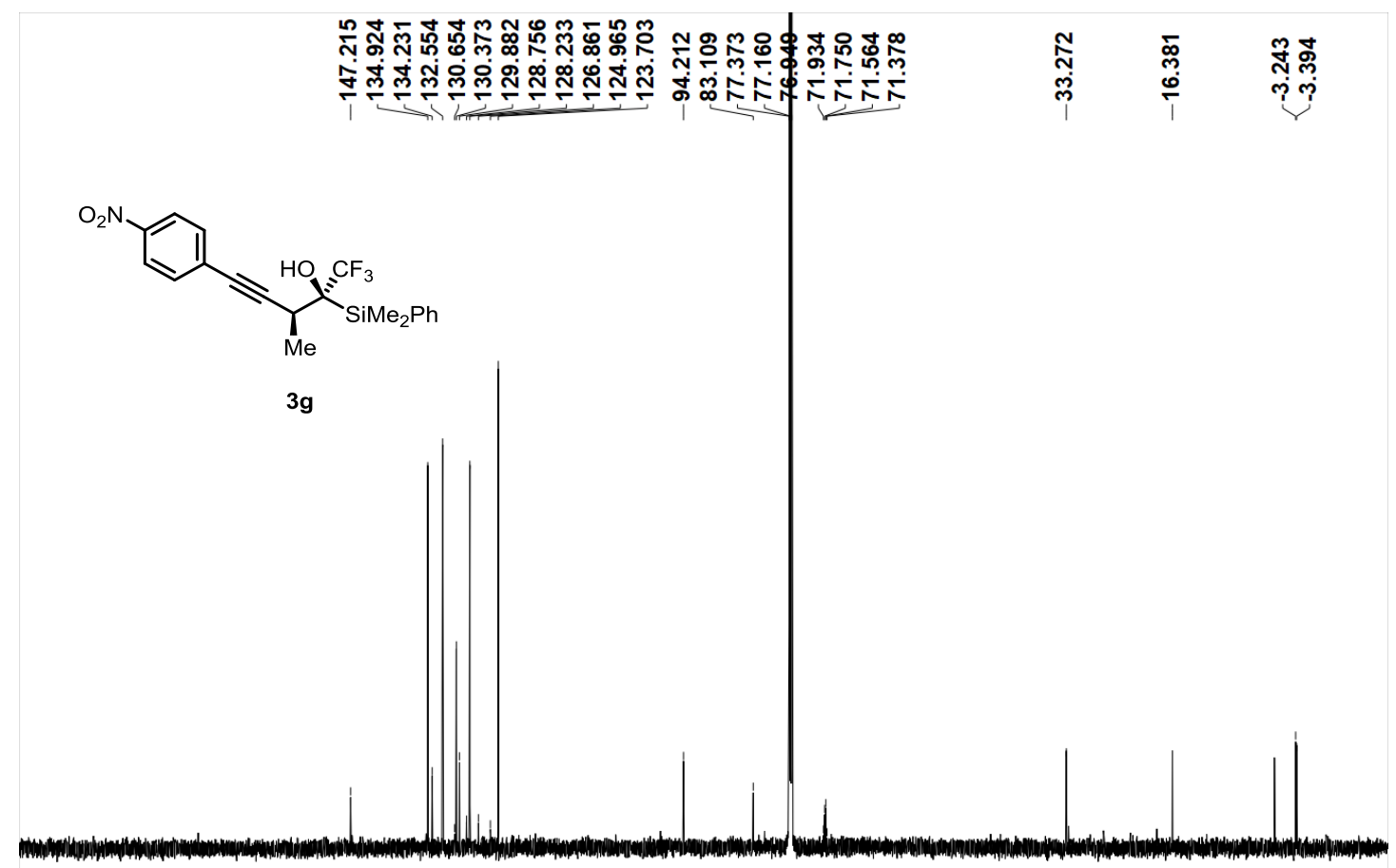

\begin{tabular}{lllllllllllllllllllllllll}
\hline 10 & 190 & 180 & 170 & 160 & 150 & 140 & 130 & 120 & 110 & 100 & 90 & 80 & 70 & 60 & 50 & 40 & 30 & 20 & 10 & 0 & -10
\end{tabular}

${ }^{19} \mathrm{~F}$ NMR of $3 \mathrm{~g}\left(\mathrm{CDCl}_{3}, 565 \mathrm{MHz}, 25^{\circ} \mathrm{C}\right)$

$$
\text { ঠั̊. }
$$

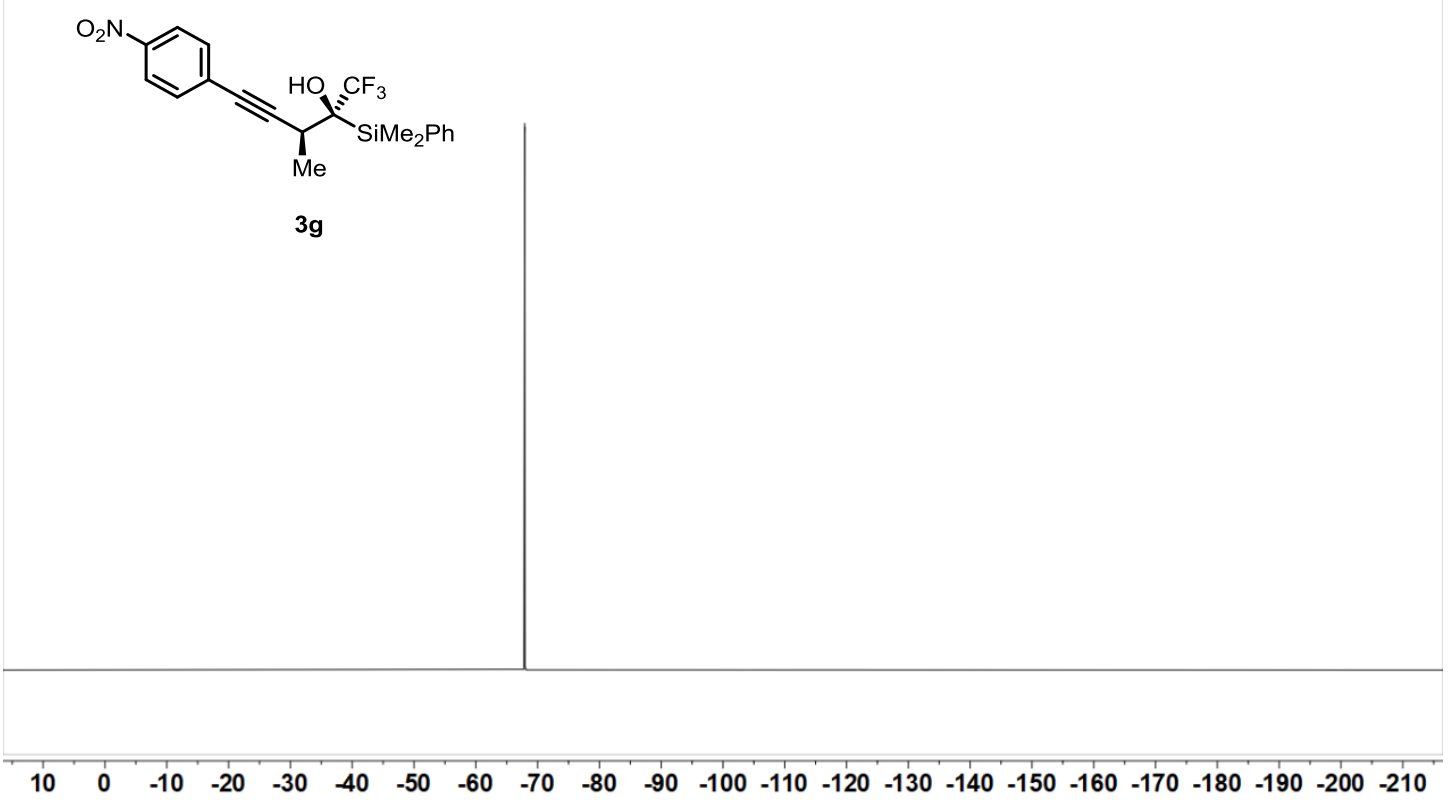


${ }^{1} \mathrm{H}$ NMR of $3 \mathrm{~h}\left(\mathrm{CDCl}_{3}, 400 \mathrm{MHz}, 25^{\circ} \mathrm{C}\right)$

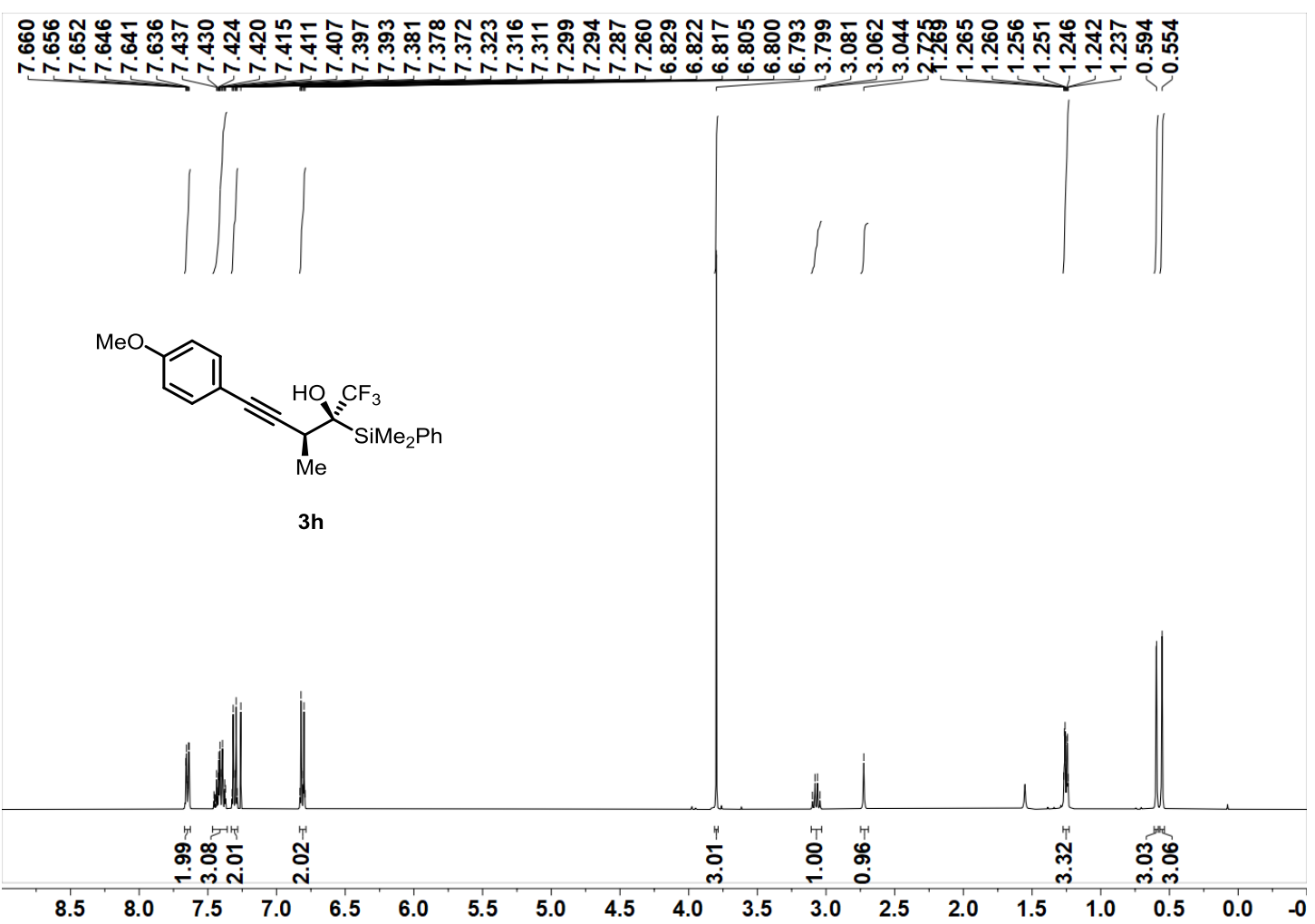

${ }^{13} \mathrm{C}$ NMR of $3 \mathrm{~h}\left(\mathrm{CDCl}_{3}, 101 \mathrm{MHz}, 25^{\circ} \mathrm{C}\right)$

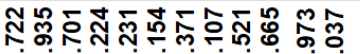

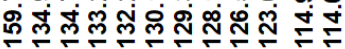

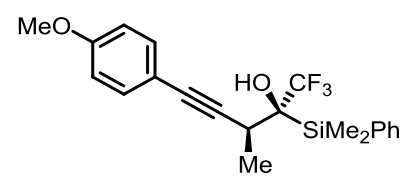

3h

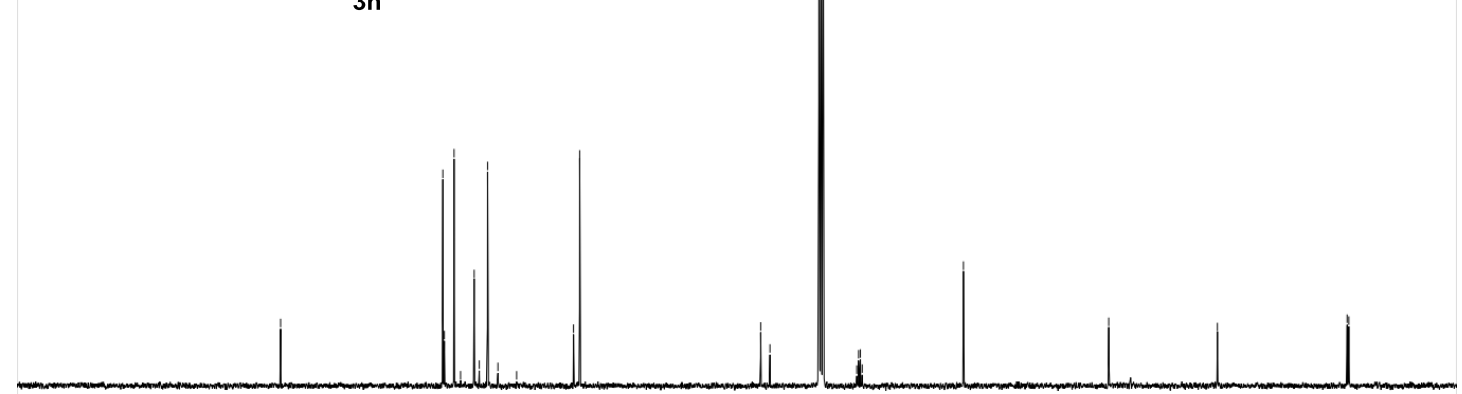

$\begin{array}{llllllllllllllllllllllllllll}190 & 180 & 170 & 160 & 150 & 140 & 130 & 120 & 110 & 100 & 90 & 80 & 70 & 60 & 50 & 40 & 30 & 20 & 10 & 0 & -10 & -2\end{array}$ 
${ }^{19} \mathrm{~F}$ NMR of $3 \mathrm{~h}\left(\mathrm{CDCl}_{3}, 376 \mathrm{MHz}, 25^{\circ} \mathrm{C}\right)$

\section{오ํ}

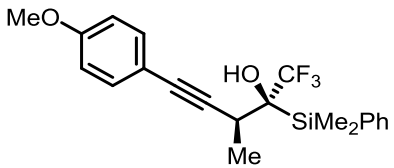

$3 h$

$\begin{array}{lllllllllllllllllllllllllllllllllll}100 & 80 & 60 & 40 & 20 & 0 & -20 & -40 & -60 & -80 & -100 & -120 & -140 & -160 & -180 & -200 & -220 & -240 & -260 & -280 & -300\end{array}$

${ }^{1} \mathrm{H}$ NMR of $3 \mathrm{i}\left(\mathrm{CDCl}_{3}, 400 \mathrm{MHz}, 25^{\circ} \mathrm{C}\right)$

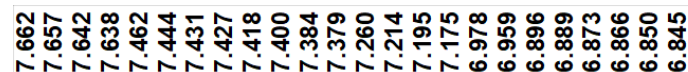

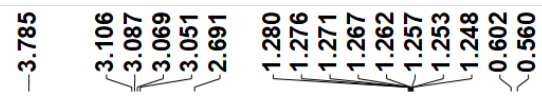
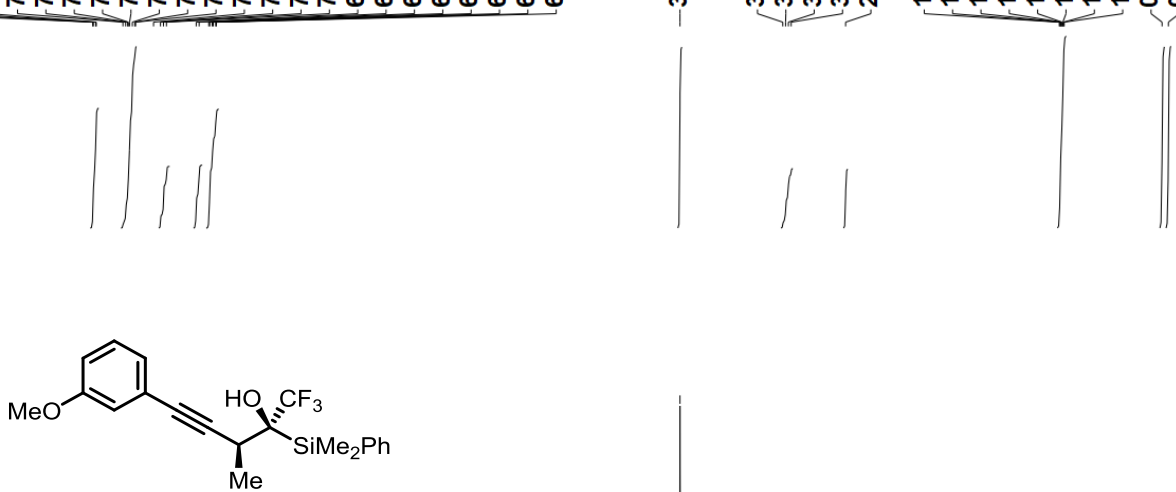

3i

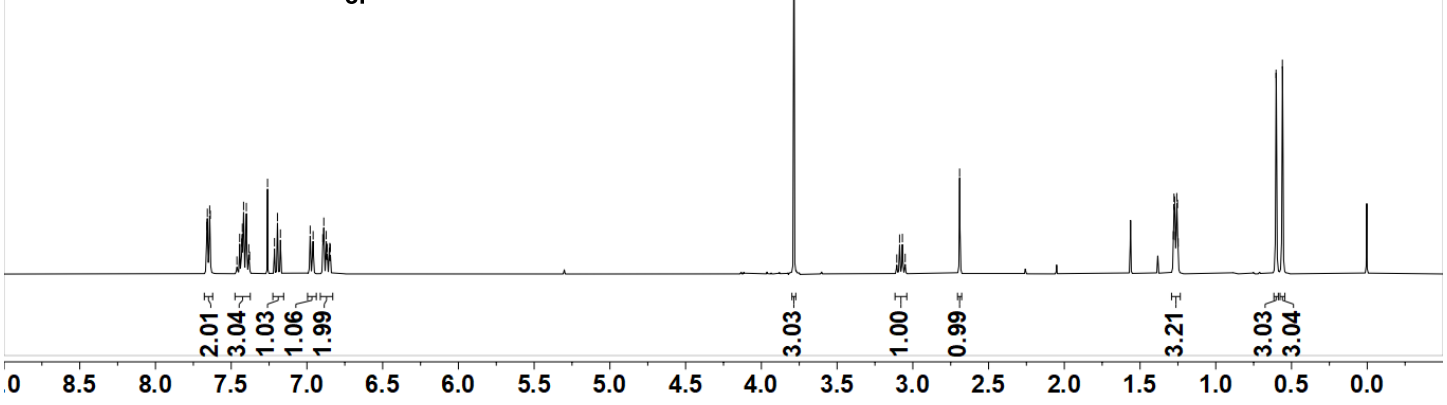


${ }^{13} \mathrm{C}$ NMR of $3 \mathrm{i}\left(\mathrm{CDCl}_{3}, 151 \mathrm{MHz}, 25^{\circ} \mathrm{C}\right)$

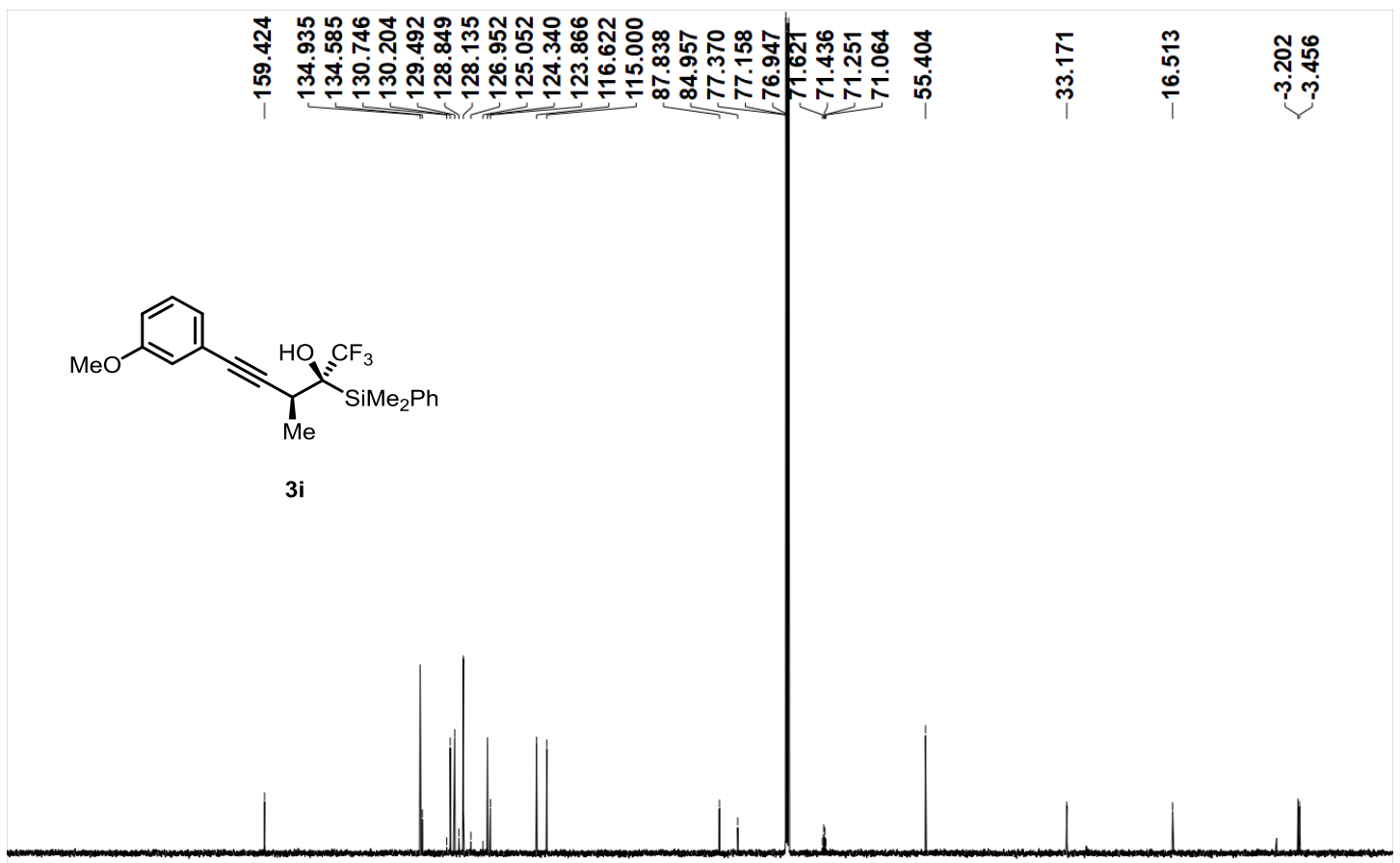

\begin{tabular}{lllllllllllllllllllllllll}
\hline 0 & 190 & 180 & 170 & 160 & 150 & 140 & 130 & 120 & 110 & 100 & 90 & 80 & 70 & 60 & 50 & 40 & 30 & 20 & 10 & 0 & -10
\end{tabular}

${ }^{19}$ F NMR of 3i $\left(\mathrm{CDCl}_{3}, 376 \mathrm{MHz}, 25{ }^{\circ} \mathrm{C}\right)$

กิ๊

$\underbrace{\mathrm{CO}}_{\mathrm{Me}} \mathrm{SF}_{\mathrm{SiMe}_{2} \mathrm{Ph}}$

$3 \mathbf{i}$

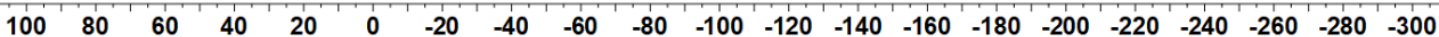


${ }^{1} \mathrm{H}$ NMR of $3 \mathrm{j}\left(\mathrm{CDCl}_{3}, 400 \mathrm{MHz}, 25^{\circ} \mathrm{C}\right)$

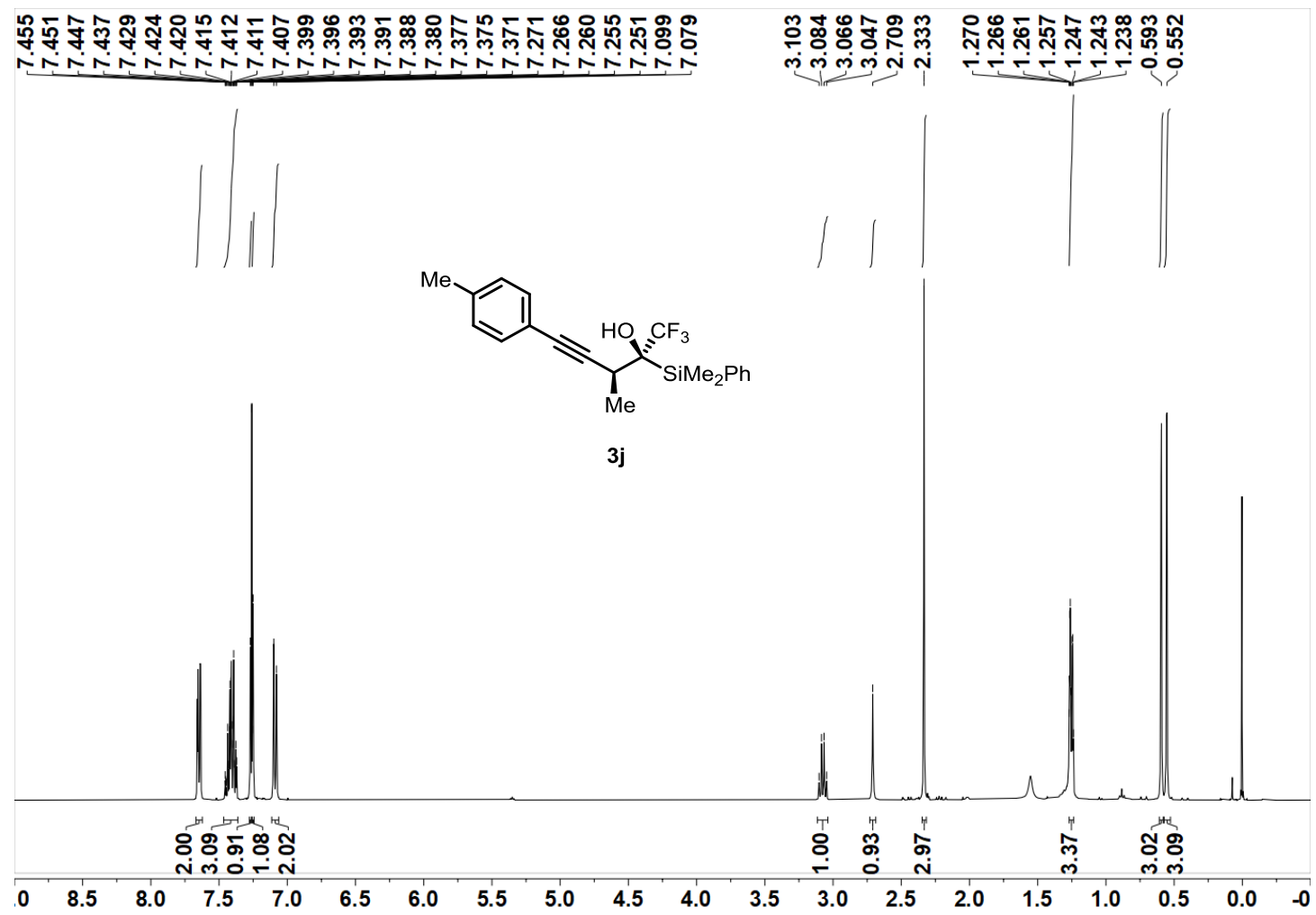

${ }^{13} \mathrm{C}$ NMR of $3 \mathrm{j}\left(\mathrm{CDCl}_{3}, 101 \mathrm{MHz}, 25^{\circ} \mathrm{C}\right)$

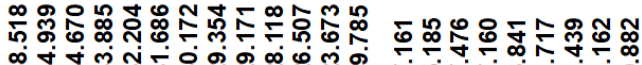

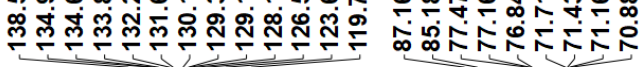

产

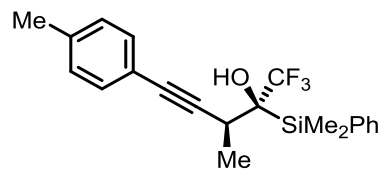

3j

$\begin{array}{lllllllllllllllllllllll}190 & 180 & 170 & 160 & 150 & 140 & 130 & 120 & 110 & 100 & 90 & 80 & 70 & 60 & 50 & 40 & 30 & 20 & 10 & 0 & -10 & -2\end{array}$ 
${ }^{19} \mathrm{~F}$ NMR of 3j $\left(\mathrm{CDCl}_{3}, 376 \mathrm{MHz}, 25^{\circ} \mathrm{C}\right)$

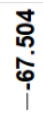

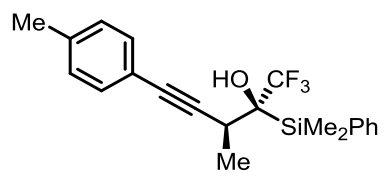

3j

$\begin{array}{lllllllllllllllllllll}100 & 80 & 60 & 40 & 20 & 0 & -20 & -40 & -60 & -80 & -100 & -120 & -140 & -160 & -180 & -200 & -220 & -240 & -260 & -280 & -300\end{array}$

${ }^{1} \mathrm{H}$ NMR of 3k (CDCl $\left.3,400 \mathrm{MHz}, 25^{\circ} \mathrm{C}\right)$

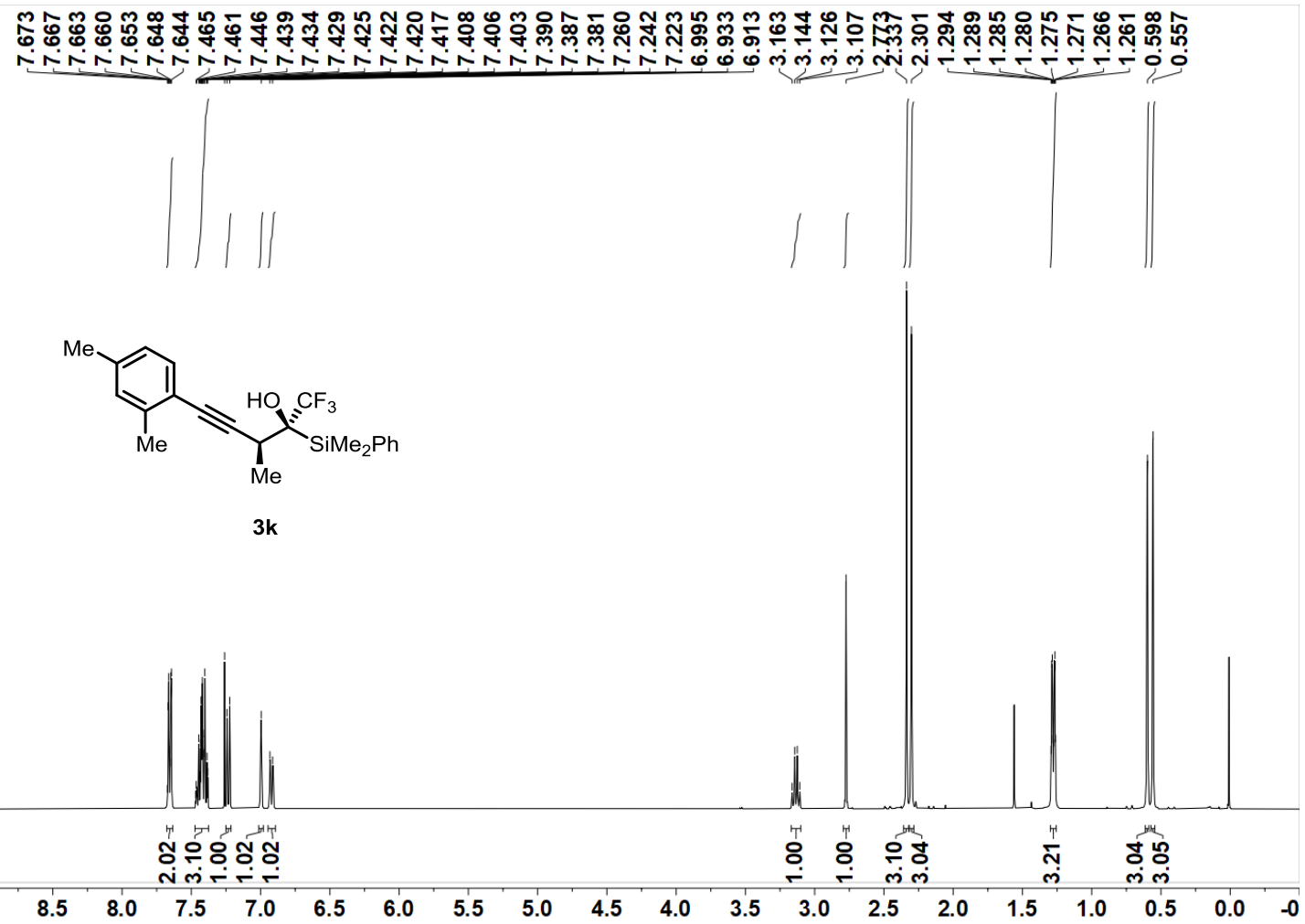


${ }^{13} \mathrm{C}$ NMR of 3k $\left(\mathrm{CDCl}_{3}, 151 \mathrm{MHz}, 25{ }^{\circ} \mathrm{C}\right)$

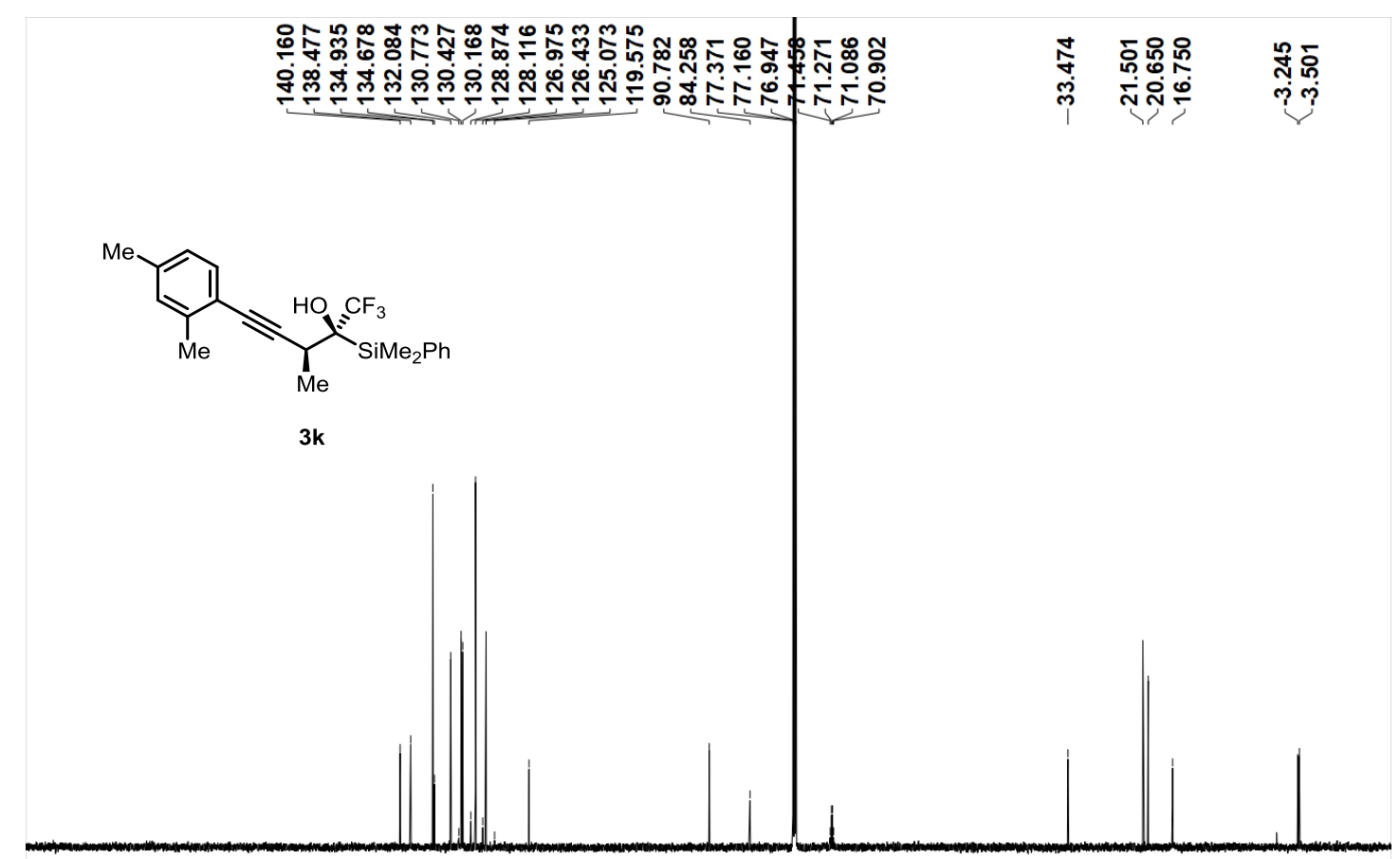

$\begin{array}{lllllllllllllllllllllllll}10 & 190 & 180 & 170 & 160 & 150 & 140 & 130 & 120 & 110 & 100 & 90 & 80 & 70 & 60 & 50 & 40 & 30 & 20 & 10 & 0 & -10\end{array}$

${ }^{19} \mathrm{~F}$ NMR of 3k $\left(\mathrm{CDCl}_{3}, 376 \mathrm{MHz}, 25^{\circ} \mathrm{C}\right)$

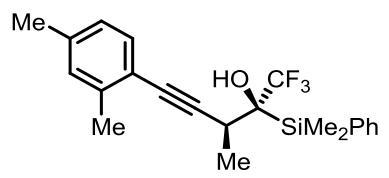

$3 \mathbf{k}$

$\begin{array}{llllllllllllllllllllllllllllllllll}100 & 80 & 60 & 40 & 20 & 0 & -20 & -40 & -60 & -80 & -100 & -120 & -140 & -160 & -180 & -200 & -220 & -240 & -260 & -280 & -300\end{array}$ 
${ }^{1} \mathrm{H}$ NMR of $31\left(\mathrm{CDCl}_{3}, 400 \mathrm{MHz}, 25^{\circ} \mathrm{C}\right)$

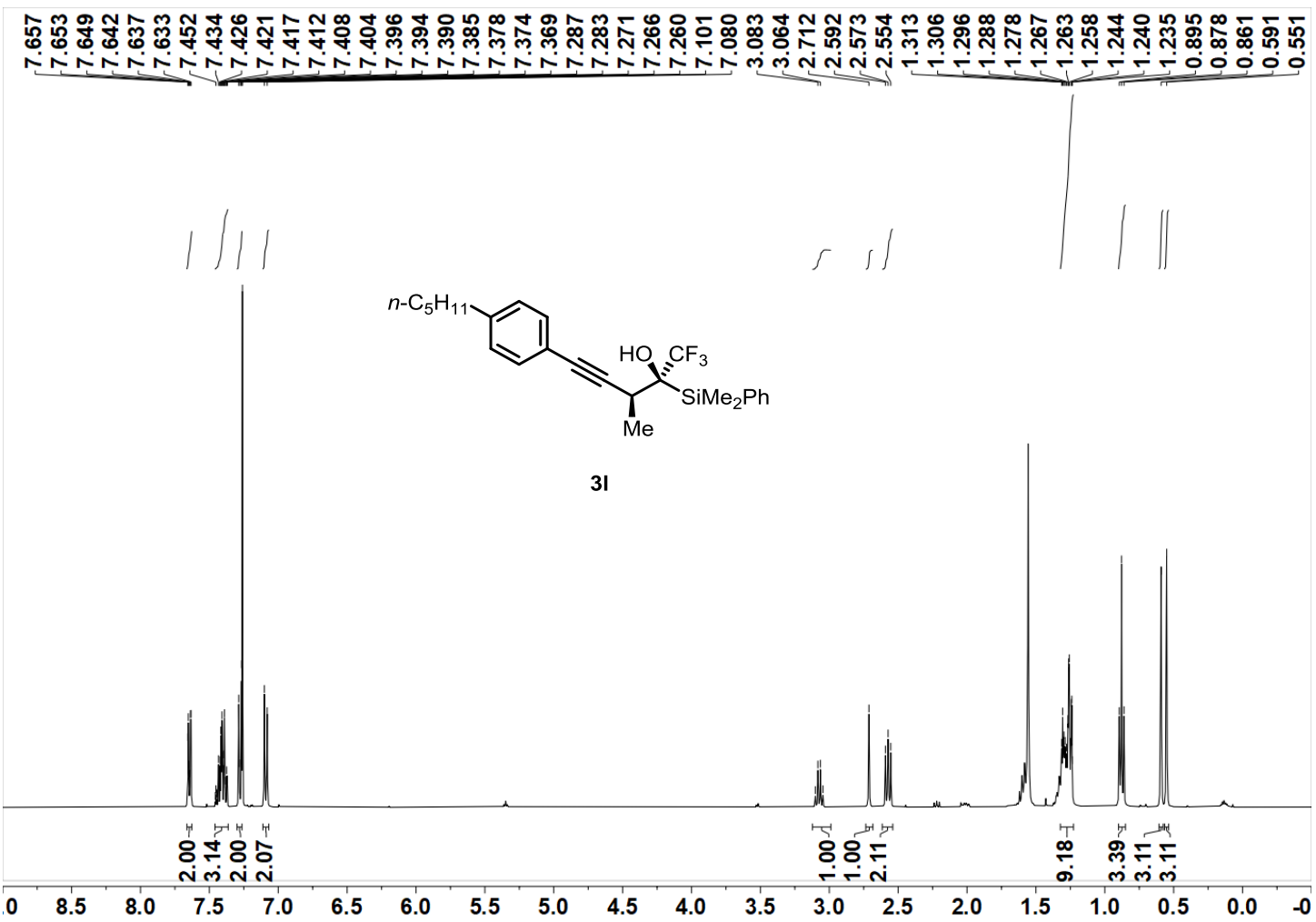

${ }^{13} \mathrm{C}$ NMR of $31\left(\mathrm{CDCl}_{3}, 151 \mathrm{MHz}, 25{ }^{\circ} \mathrm{C}\right)$

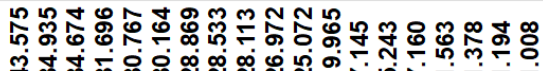

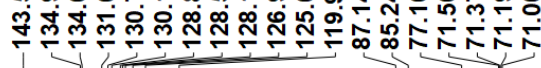

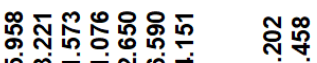

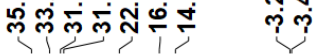

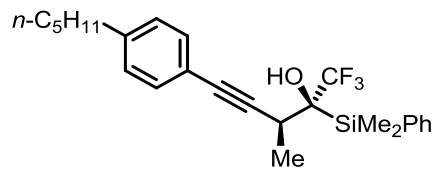

3I

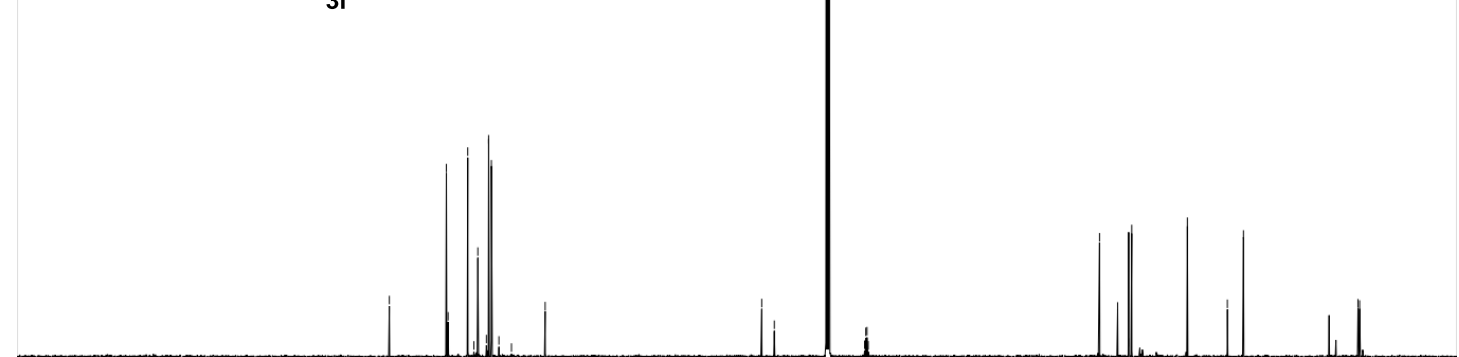

\begin{tabular}{llllllllllllllllllllllll}
\hline 10 & 190 & 180 & 170 & 160 & 150 & 140 & 130 & 120 & 110 & 100 & 90 & 80 & 70 & 60 & 50 & 40 & 30 & 20 & 10 & 0 & -10
\end{tabular} 
${ }^{19} \mathrm{~F}$ NMR of $31\left(\mathrm{CDCl}_{3}, 376 \mathrm{MHz}, 25^{\circ} \mathrm{C}\right)$

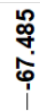

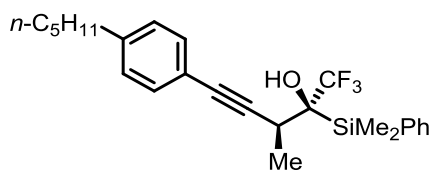

31

\begin{tabular}{llllllllllllllllllllllllllllllll}
\hline 100 & 80 & 60 & 40 & 20 & 0 & -20 & -40 & -60 & -80 & -100 & -120 & -140 & -160 & -180 & -200 & -220 & -240 & -260 & -280 & -300
\end{tabular}

${ }^{1} \mathrm{H}$ NMR of $3 \mathrm{~m}\left(\mathrm{CDCl}_{3}, 400 \mathrm{MHz}, 25^{\circ} \mathrm{C}\right)$

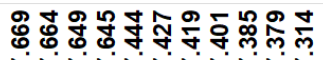

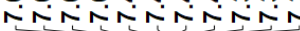

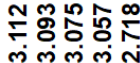

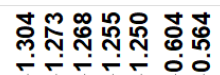

mलm

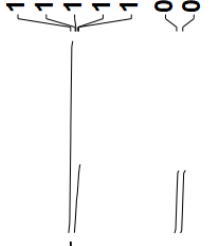

$t$-Bu

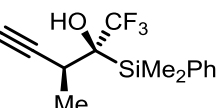

$3 m$

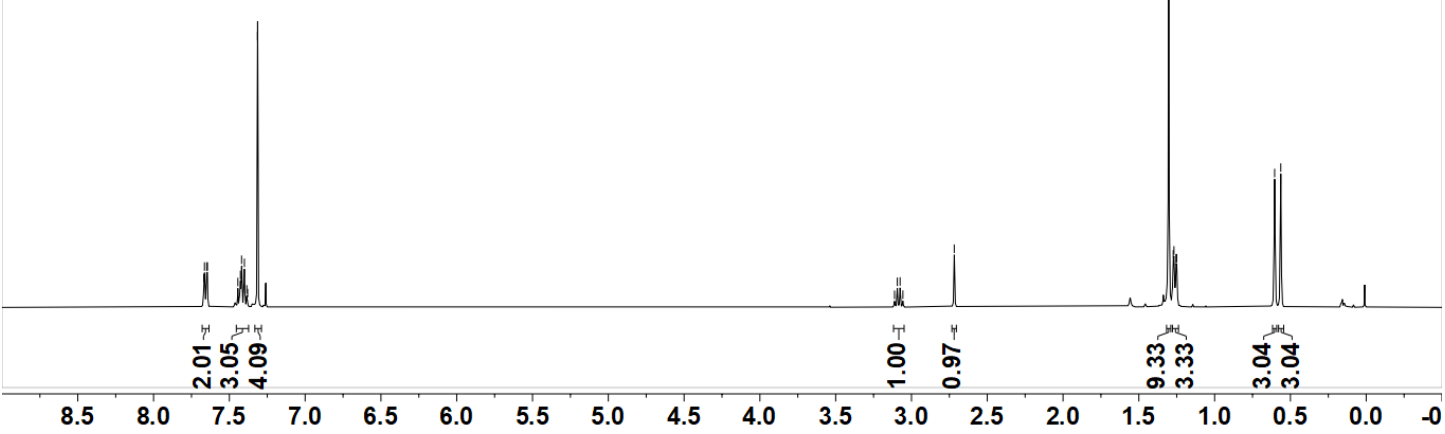


${ }^{13} \mathrm{C}$ NMR of $3 \mathrm{~m}\left(\mathrm{CDCl}_{3}, 151 \mathrm{MHz}, 25^{\circ} \mathrm{C}\right)$

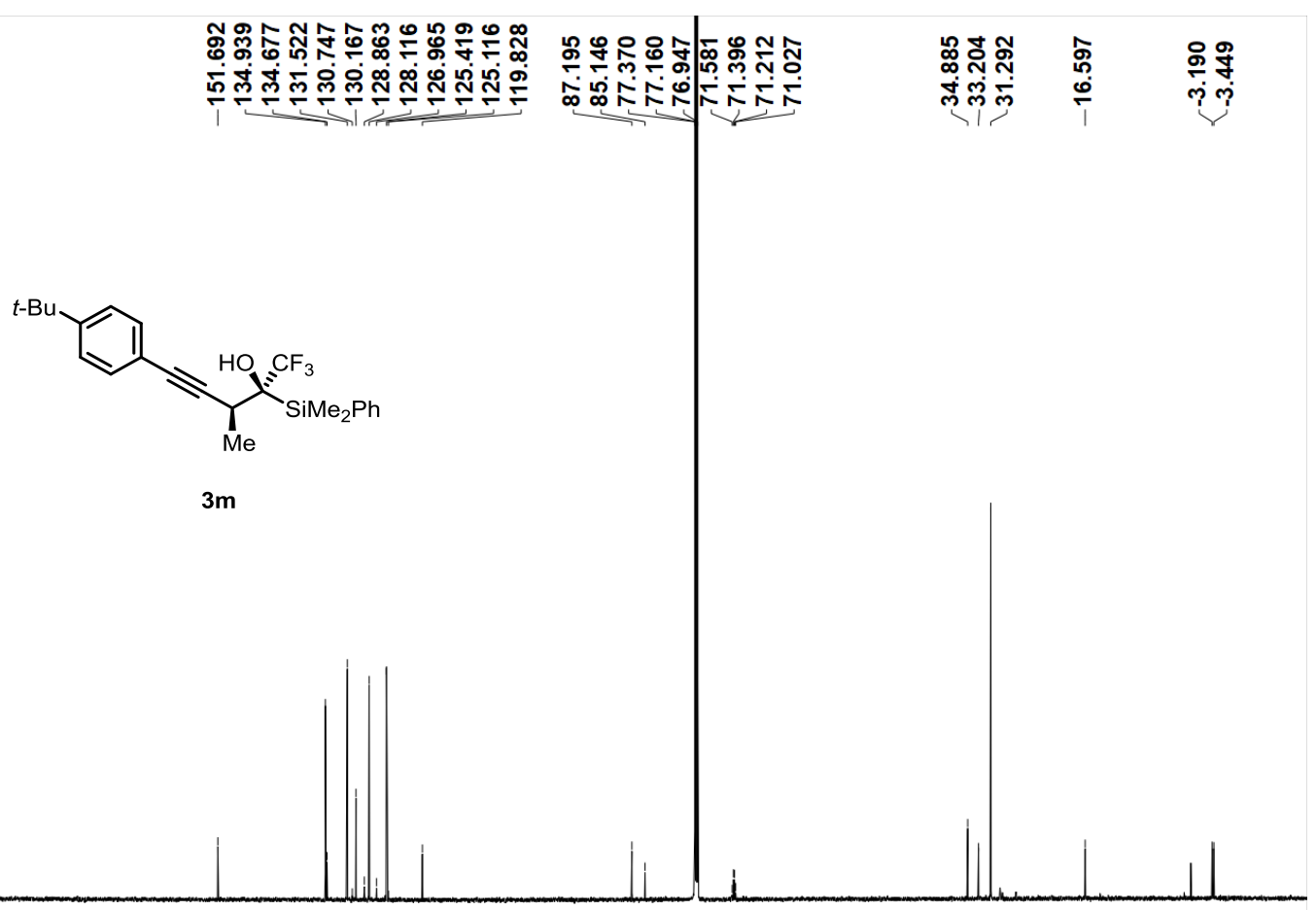

\begin{tabular}{llllllllllllllllllllllll}
\hline 10 & 190 & 180 & 170 & 160 & 150 & 140 & 130 & 120 & 110 & 100 & 90 & 80 & 70 & 60 & 50 & 40 & 30 & 20 & 10 & 0 & -10
\end{tabular}

${ }^{19} \mathrm{~F}$ NMR of $3 \mathrm{~m}\left(\mathrm{CDCl}_{3}, 376 \mathrm{MHz}, 25^{\circ} \mathrm{C}\right)$

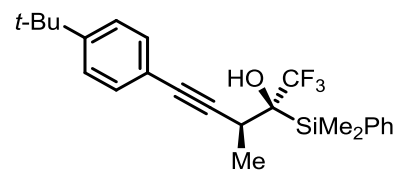

$3 m$ 
${ }^{1} \mathrm{H}$ NMR of 3n $\left(\mathrm{CDCl}_{3}, 400 \mathrm{MHz}, 25^{\circ} \mathrm{C}\right)$

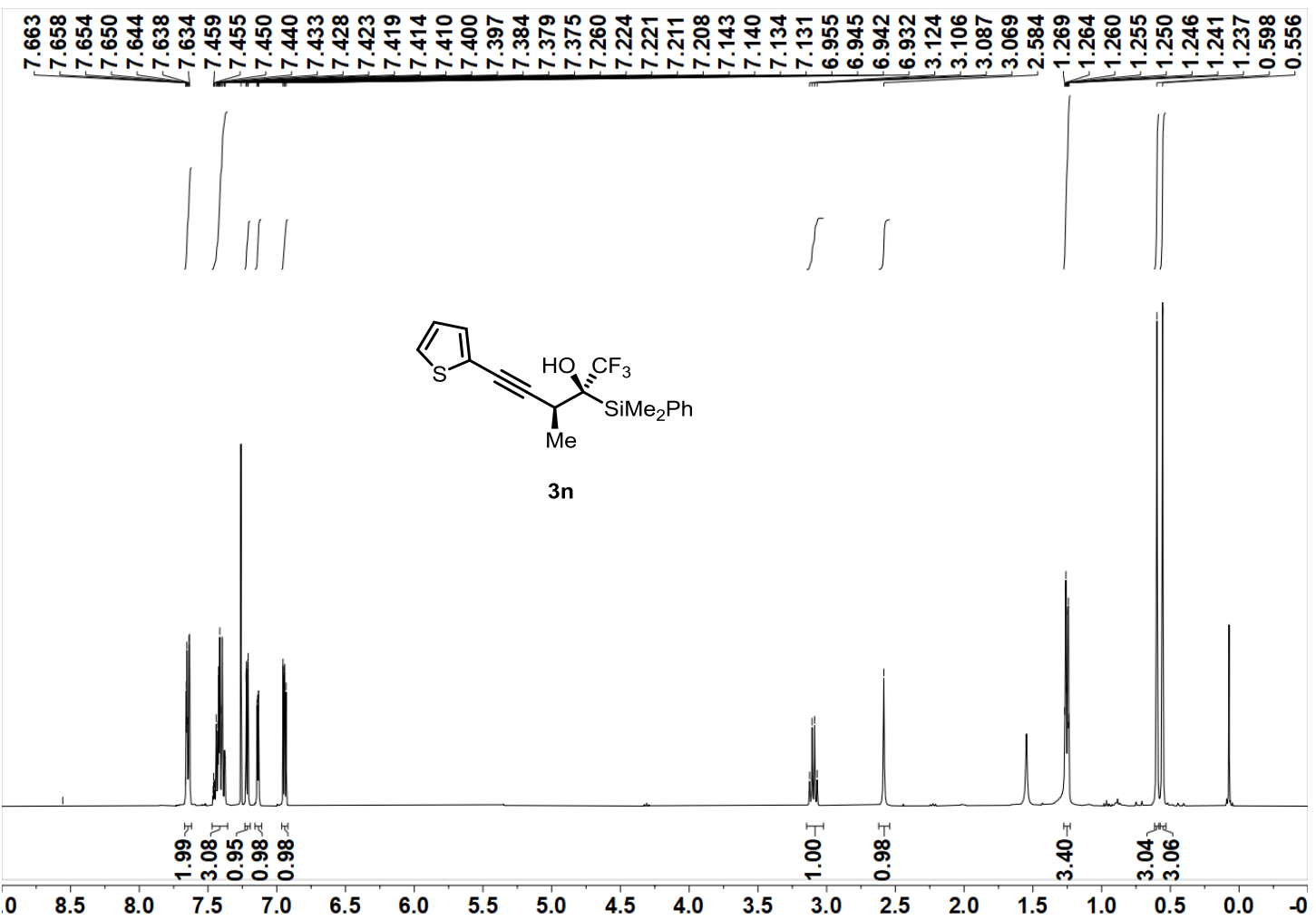

${ }^{13} \mathrm{C}$ NMR of 3n $\left(\mathrm{CDCl}_{3}, 101 \mathrm{MHz}, 25^{\circ} \mathrm{C}\right)$

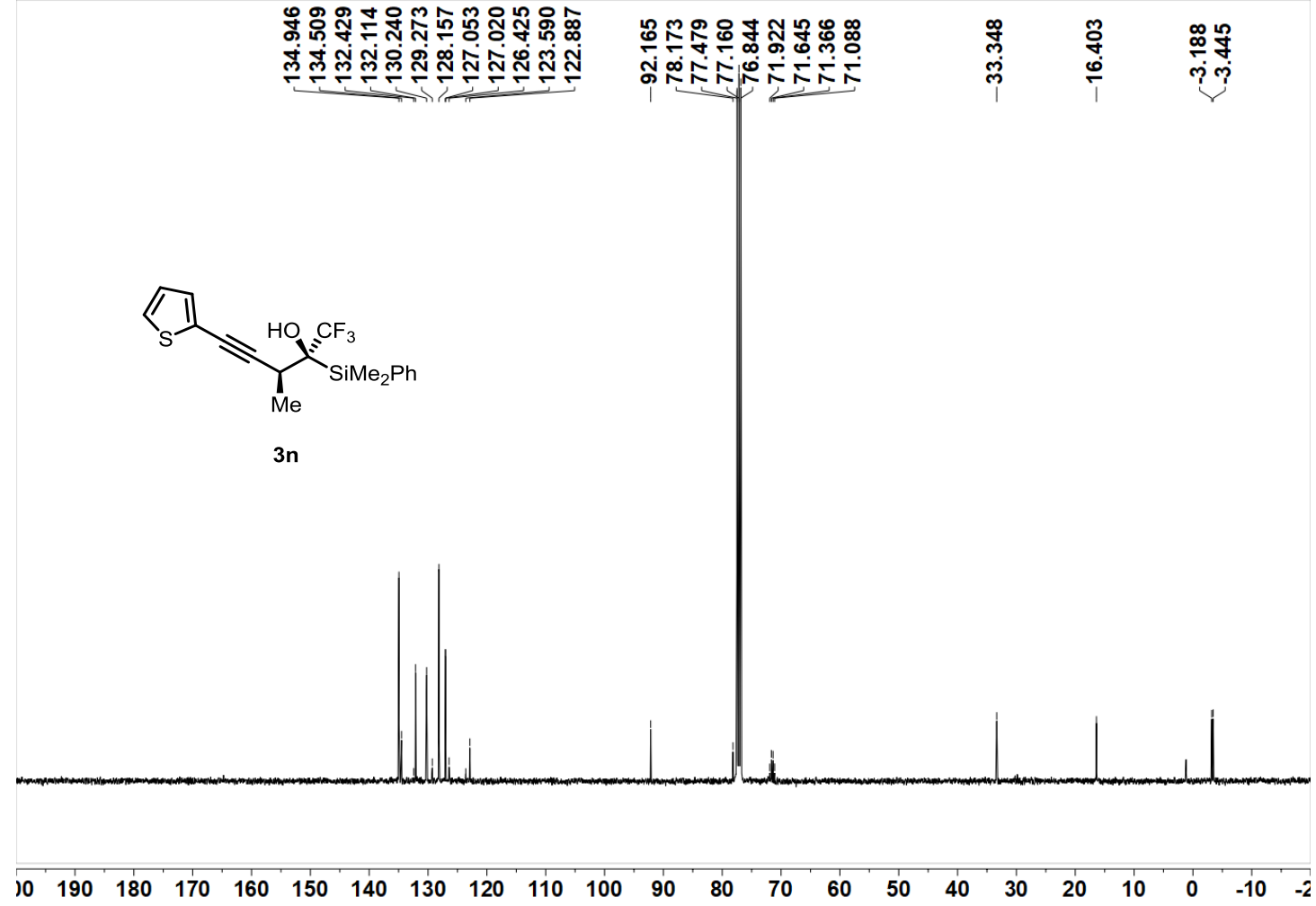


${ }^{19} \mathrm{~F}$ NMR of 3n $\left(\mathrm{CDCl}_{3}, 376 \mathrm{MHz}, 25^{\circ} \mathrm{C}\right)$

\section{$\underset{\substack{\infty \\ 0}}{\stackrel{0}{0}}$}

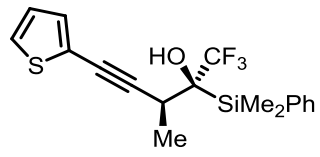

$3 n$

${ }^{1} \mathrm{H}$ NMR of $30\left(\mathrm{CDCl}_{3}, 400 \mathrm{MHz}, 25^{\circ} \mathrm{C}\right)$

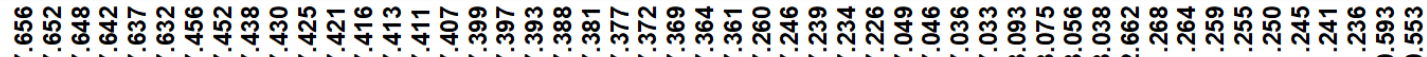

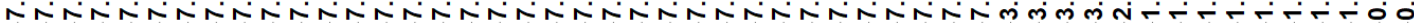
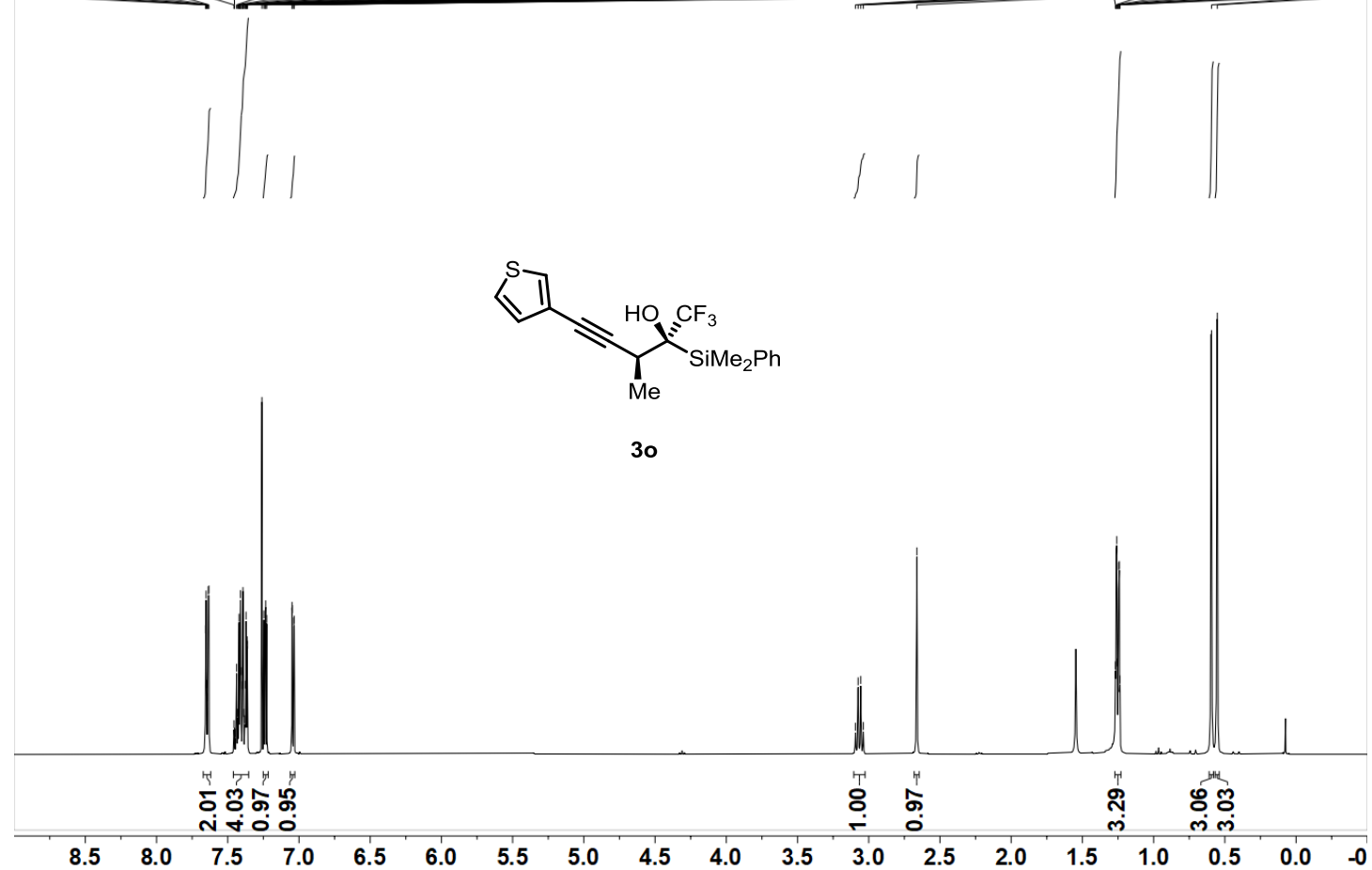
${ }^{13} \mathrm{C}$ NMR of $30\left(\mathrm{CDCl}_{3}, 101 \mathrm{MHz}, 25^{\circ} \mathrm{C}\right)$

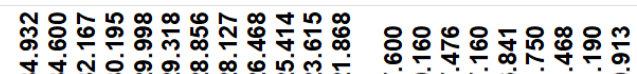

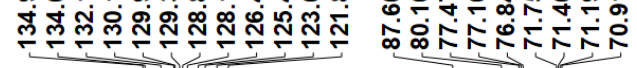

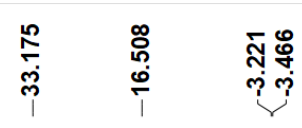

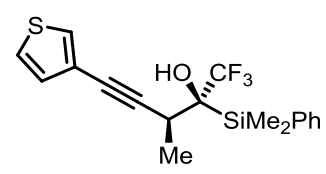

30

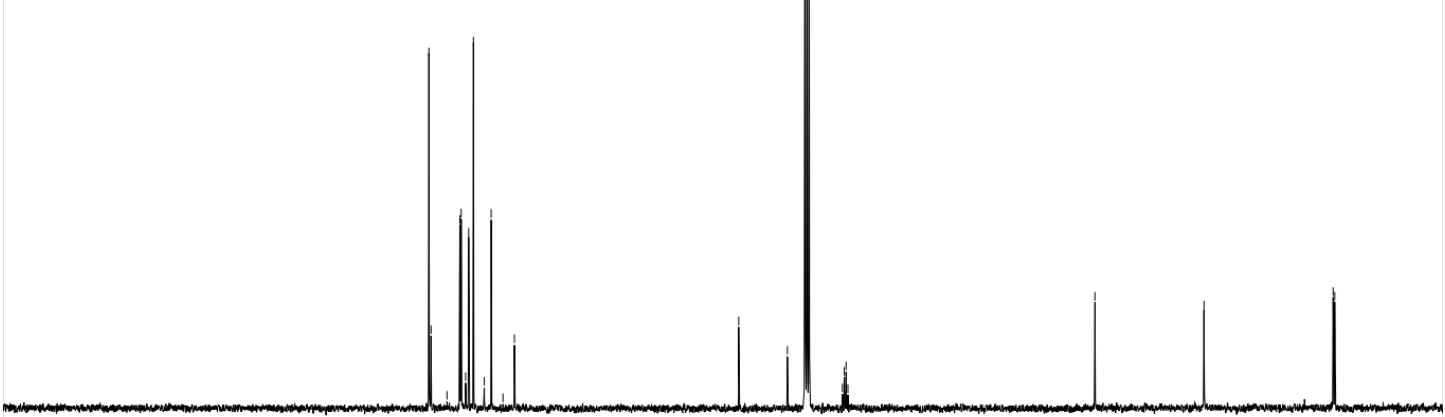

$\begin{array}{llllllllllllllllllllllll}10 & 190 & 180 & 170 & 160 & 150 & 140 & 130 & 120 & 110 & 100 & 90 & 80 & 70 & 60 & 50 & 40 & 30 & 20 & 10 & 0 & -10 & -2\end{array}$

${ }^{19} \mathrm{~F}$ NMR of $30\left(\mathrm{CDCl}_{3}, 376 \mathrm{MHz}, 25^{\circ} \mathrm{C}\right)$

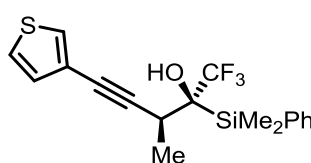

30 
${ }^{1} \mathrm{H}$ NMR of 3p $\left(\mathrm{CDCl}_{3}, 400 \mathrm{MHz}, 25^{\circ} \mathrm{C}\right)$

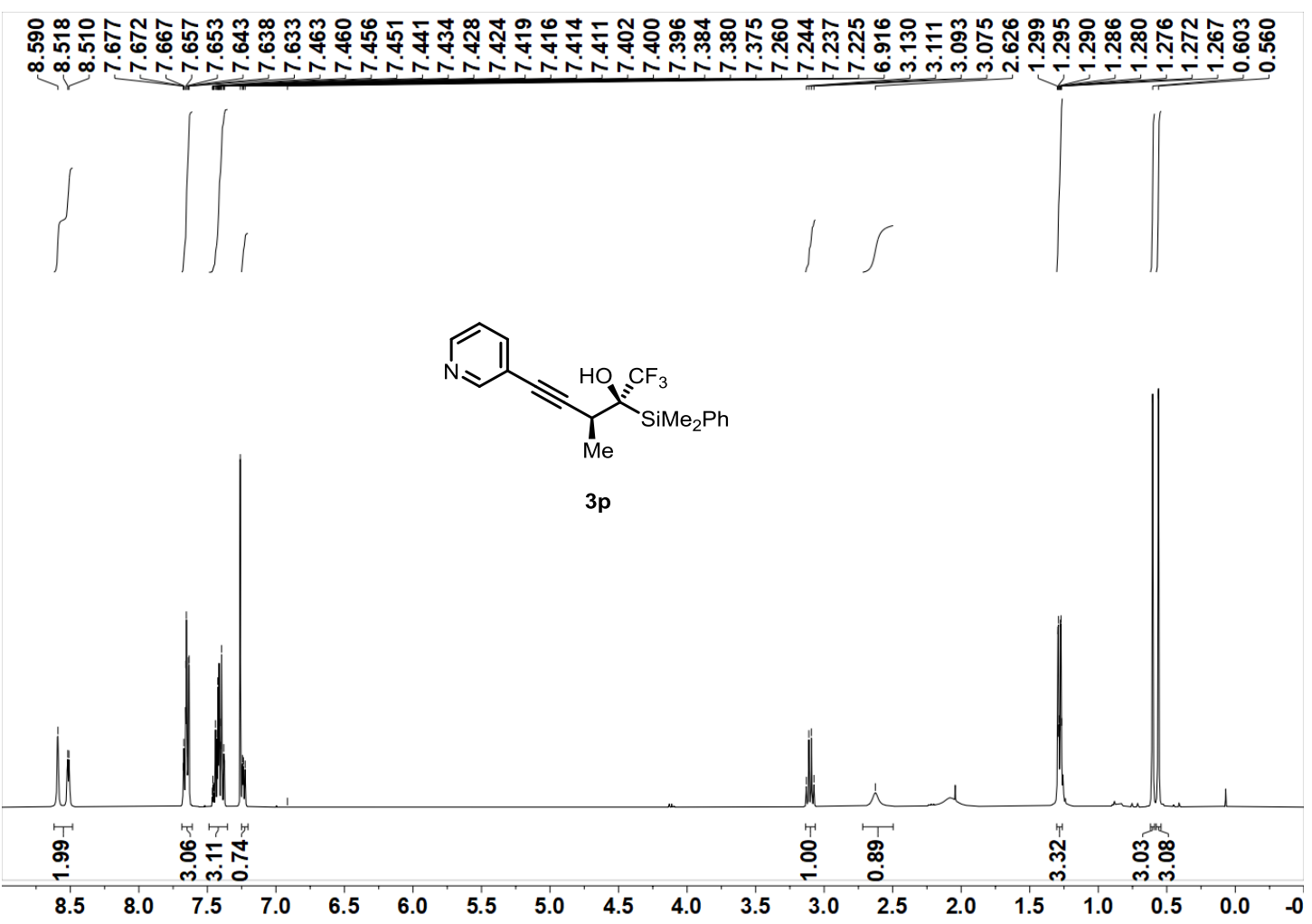

${ }^{13} \mathrm{C}$ NMR of $3 p\left(\mathrm{CDCl}_{3}, 101 \mathrm{MHz}, 25^{\circ} \mathrm{C}\right)$

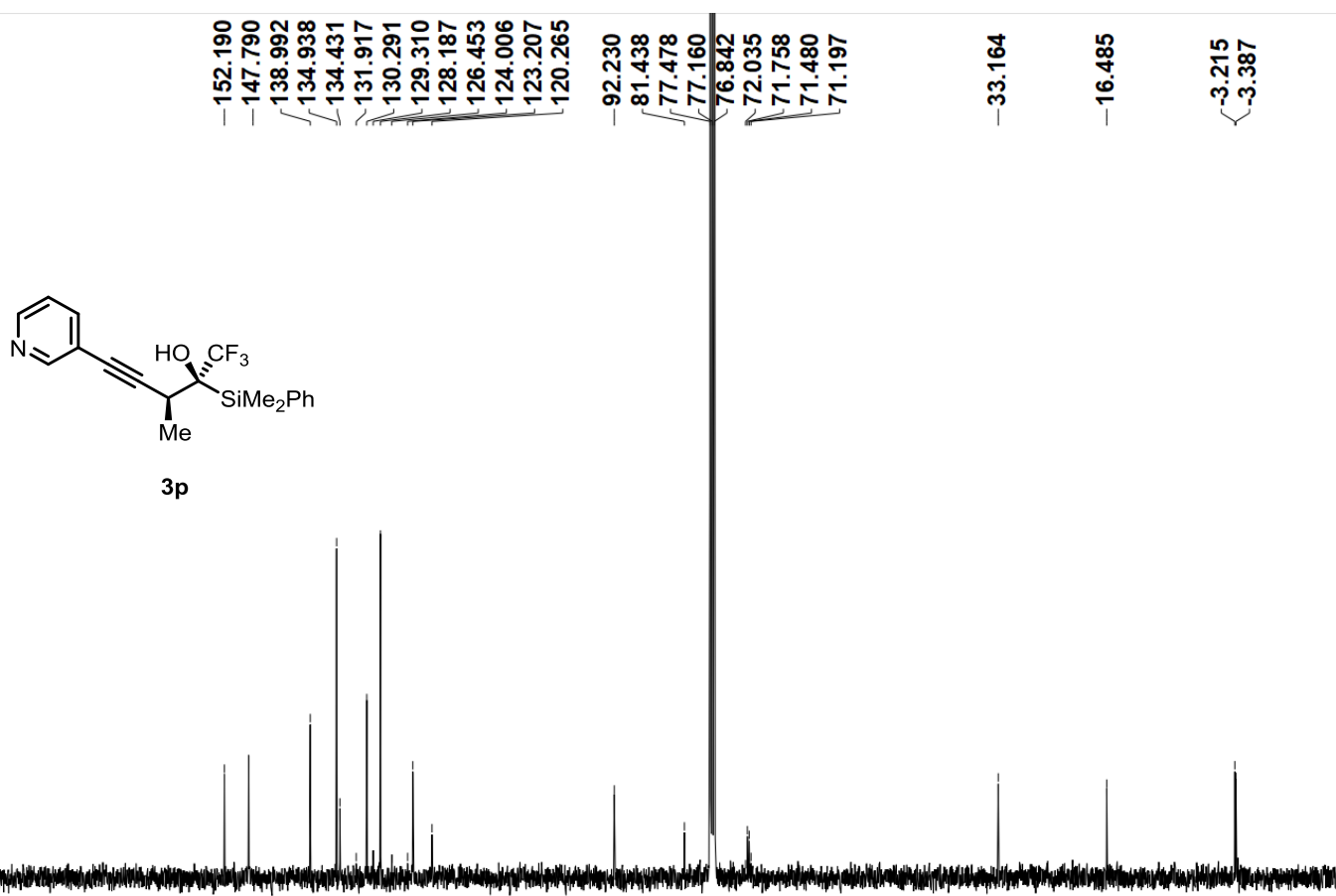

$\begin{array}{lllllllllllllllllllllll}190 & 180 & 170 & 160 & 150 & 140 & 130 & 120 & 110 & 100 & 90 & 80 & 70 & 60 & 50 & 40 & 30 & 20 & 10 & 0 & -10\end{array}$ 
${ }^{19} \mathrm{~F}$ NMR of 3p $\left(\mathrm{CDCl}_{3}, 376 \mathrm{MHz}, 25^{\circ} \mathrm{C}\right)$

ํㅗำ

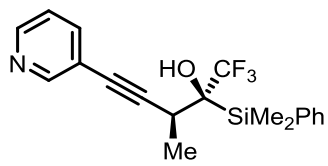

$3 p$

$\begin{array}{lllllllllllllllllllllllll}100 & 80 & 60 & 40 & 20 & 0 & -20 & -40 & -60 & -80 & -100 & -120 & -140 & -160 & -180 & -200 & -220 & -240 & -260 & -280 & -300\end{array}$

${ }^{1} \mathrm{H}$ NMR of $3 q\left(\mathrm{CDCl}_{3}, 400 \mathrm{MHz}, 25^{\circ} \mathrm{C}\right)$

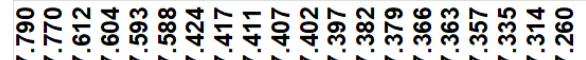

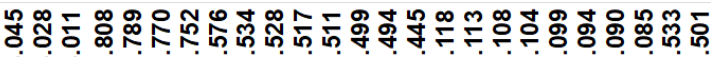

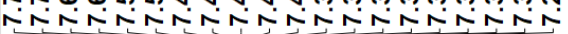
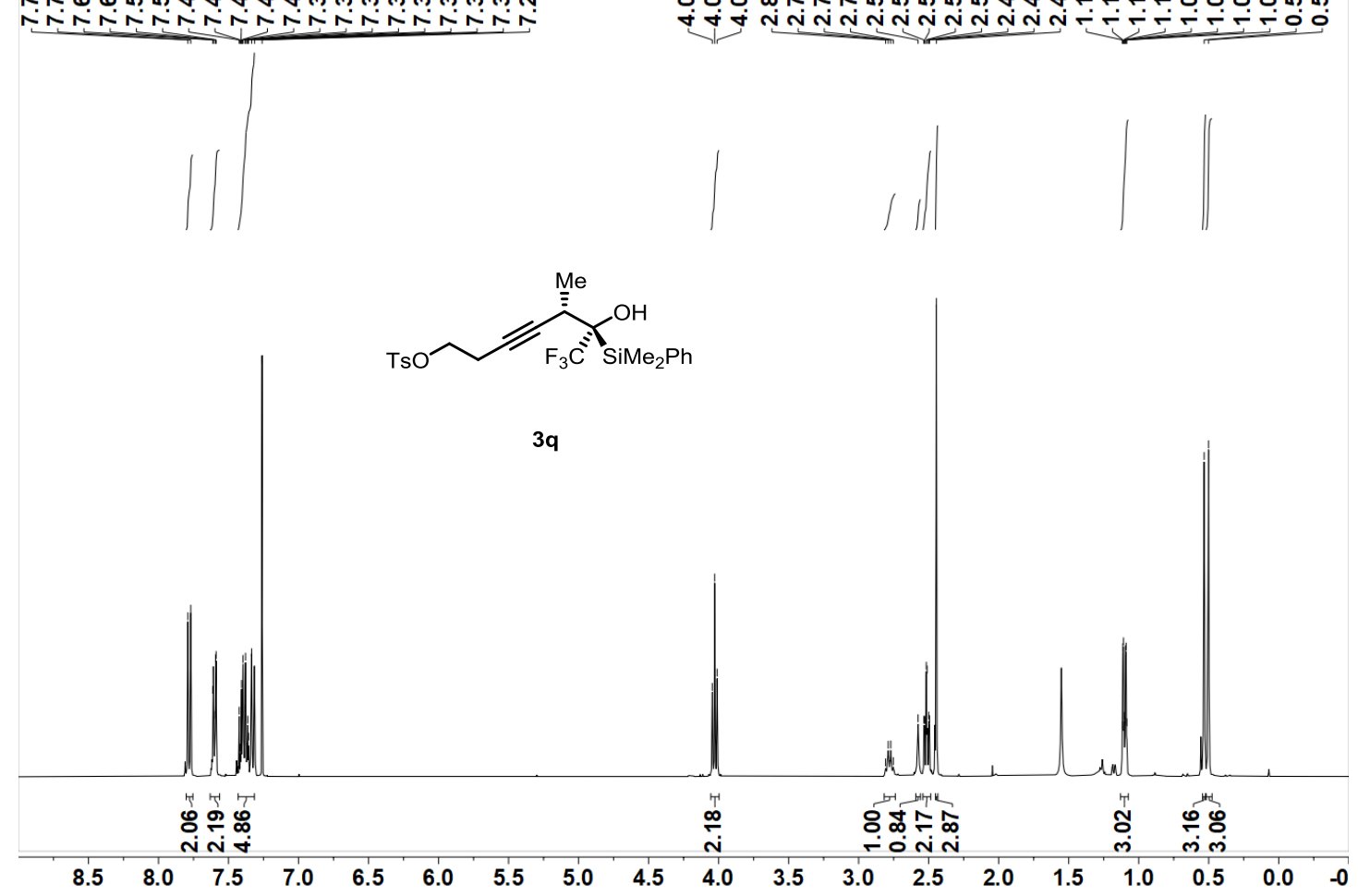
${ }^{13} \mathrm{C}$ NMR of 3q $\left(\mathrm{CDCl}_{3}, 151 \mathrm{MHz}, 25{ }^{\circ} \mathrm{C}\right)$

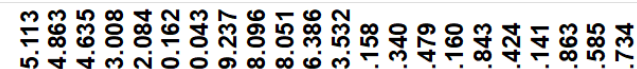

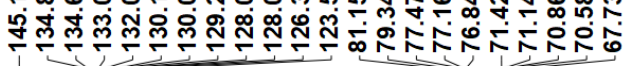

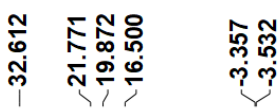

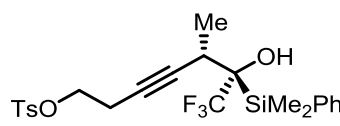

3q

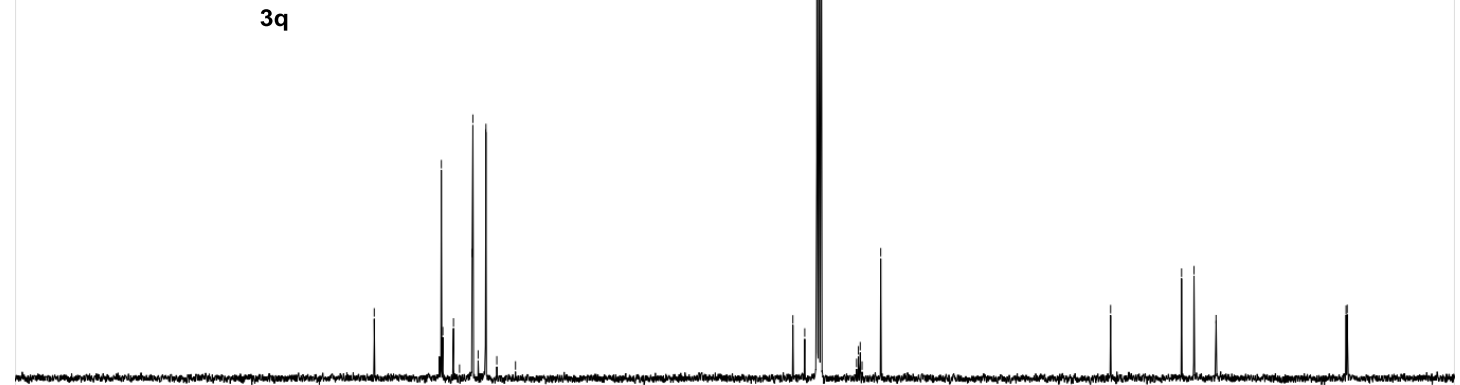

$\begin{array}{lllllllllllllllllllllllllllll}10 & 190 & 180 & 170 & 160 & 150 & 140 & 130 & 120 & 110 & 100 & 90 & 80 & 70 & 60 & 50 & 40 & 30 & 20 & 10 & 0 & -10 & -2\end{array}$

${ }^{19} \mathrm{~F}$ NMR of $3 \mathrm{q}\left(\mathrm{CDCl}_{3}, 376 \mathrm{MHz}, 25^{\circ} \mathrm{C}\right)$

ֻัฒุ

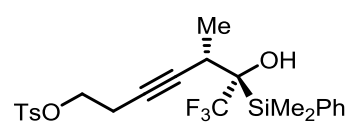

$3 q$

$\begin{array}{llllllllllllllllllllllllllllllllll}100 & 80 & 60 & 40 & 20 & 0 & -20 & -40 & -60 & -80 & -100 & -120 & -140 & -160 & -180 & -200 & -220 & -240 & -260 & -280 & -300\end{array}$ 
${ }^{1} \mathrm{H}$ NMR of $3 \mathrm{ad}\left(\mathrm{CDCl}_{3}, 400 \mathrm{MHz}, 25^{\circ} \mathrm{C}\right)$

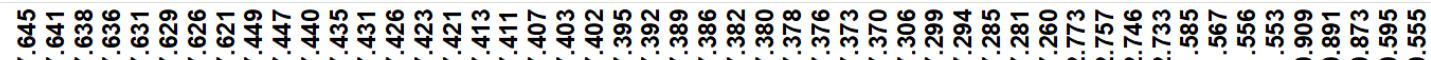
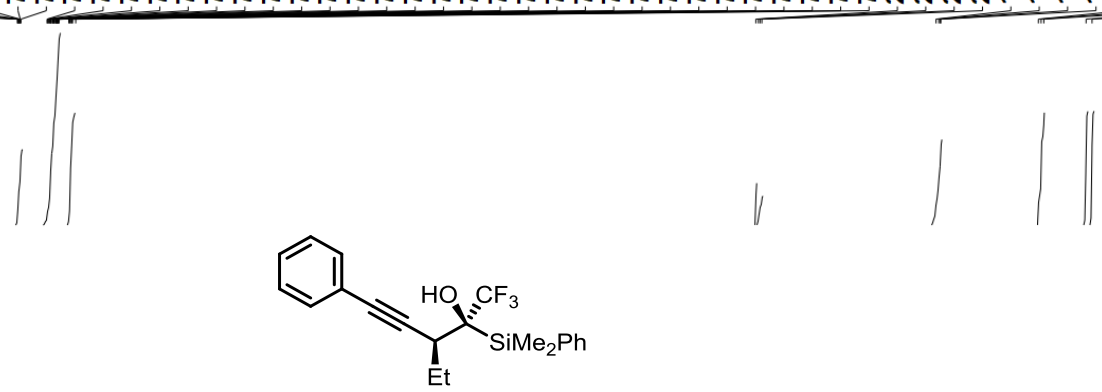

3ad

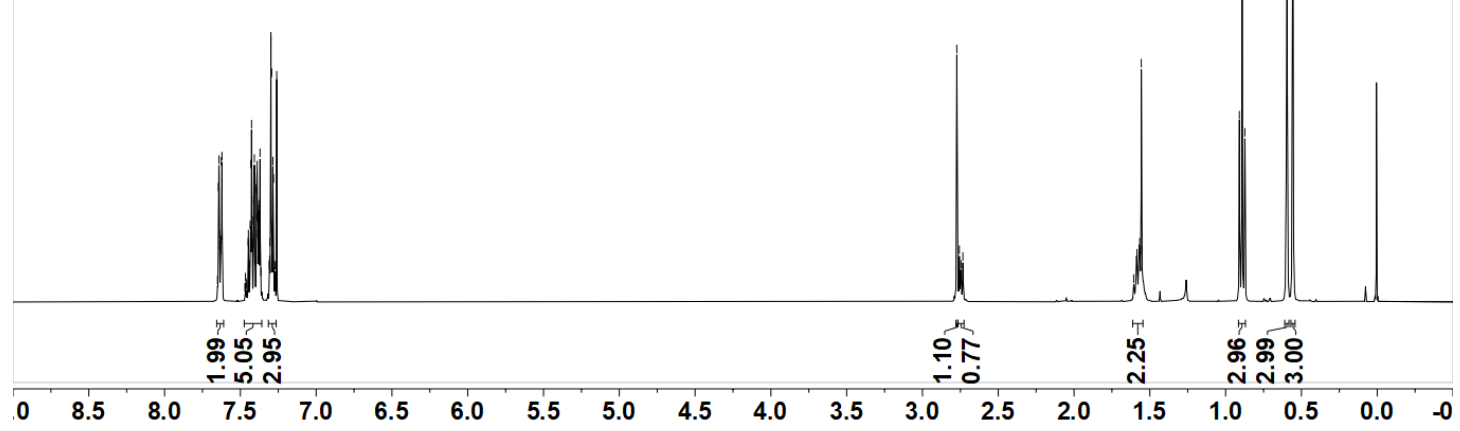

${ }^{13} \mathrm{C}$ NMR of $3 \mathrm{ad}\left(\mathrm{CDCl}_{3}, 151 \mathrm{MHz}, 25^{\circ} \mathrm{C}\right)$

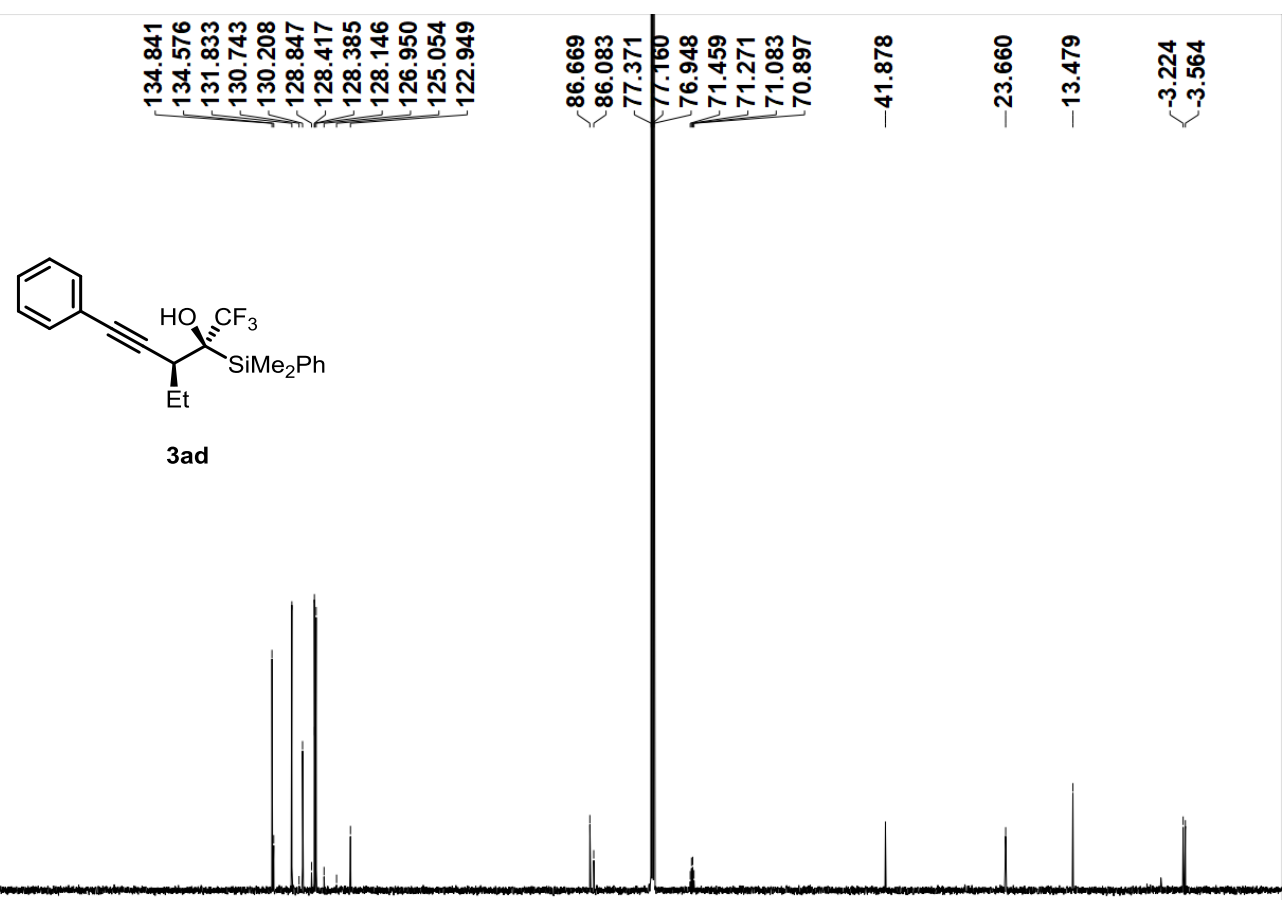

$\begin{array}{llllllllllllllllllllllll}10 & 190 & 180 & 170 & 160 & 150 & 140 & 130 & 120 & 110 & 100 & 90 & 80 & 70 & 60 & 50 & 40 & 30 & 20 & 10 & 0 & -10\end{array}$ 
${ }^{19} \mathrm{~F}$ NMR of $3 \mathrm{ad}\left(\mathrm{CDCl}_{3}, 376 \mathrm{MHz}, 25^{\circ} \mathrm{C}\right)$

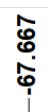

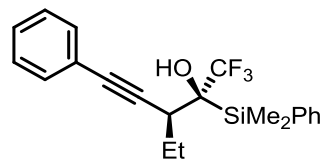

3ad

\begin{tabular}{lllllllllllllllllllllllllllll}
\hline 100 & 80 & 60 & 40 & 20 & 0 & -20 & -40 & -60 & -80 & -100 & -120 & -140 & -160 & -180 & -200 & -220 & -240 & -260 & -280 & -300
\end{tabular}

${ }^{1} \mathrm{H}$ NMR of $3 \mathrm{r}\left(\mathrm{CDCl}_{3}, 400 \mathrm{MHz}, 25^{\circ} \mathrm{C}\right)$

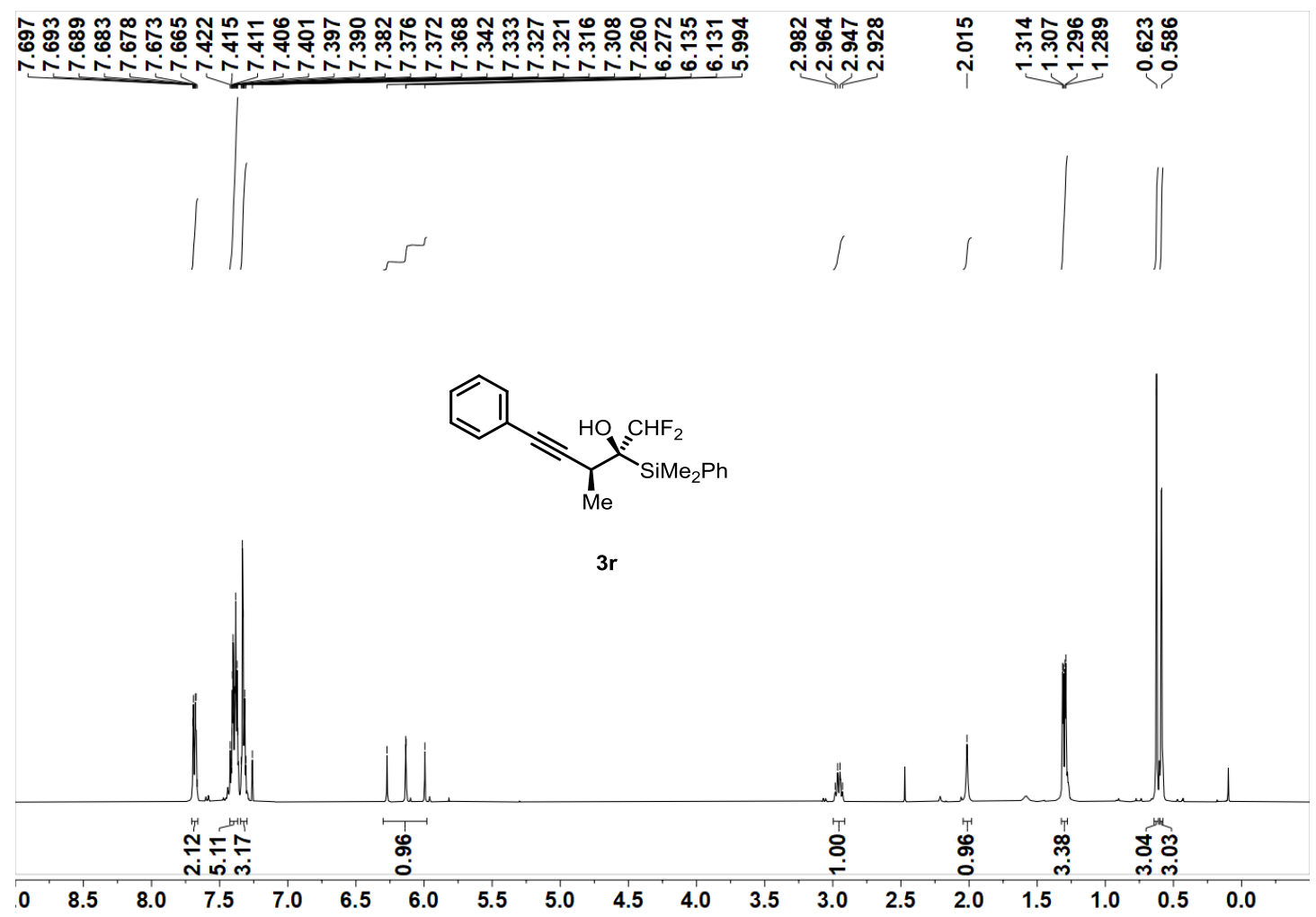


${ }^{13} \mathrm{C}$ NMR of $3 \mathrm{r}\left(\mathrm{CDCl}_{3}, 151 \mathrm{MHz}, 25^{\circ} \mathrm{C}\right)$

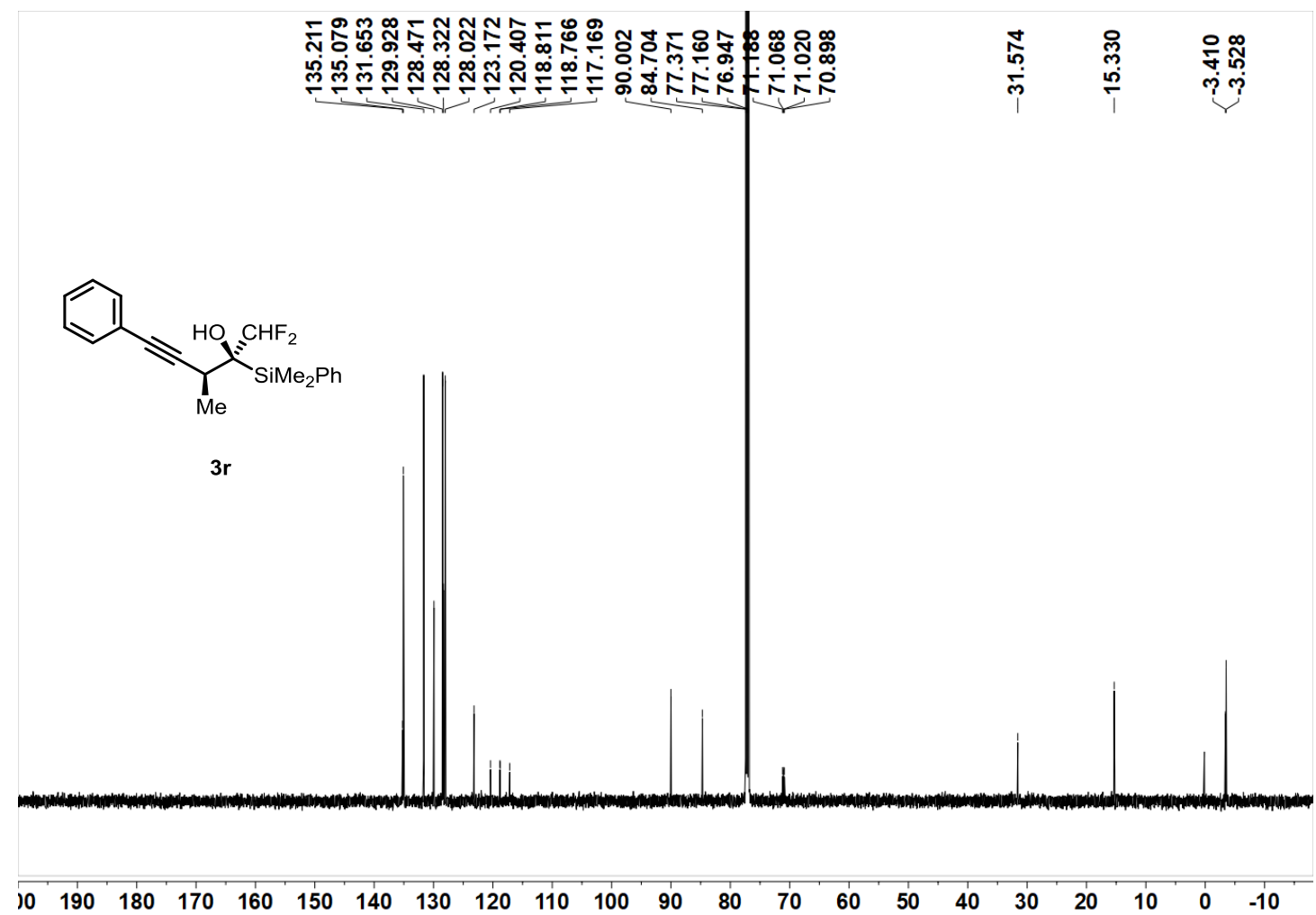

${ }^{19} \mathrm{~F}$ NMR of $3 \mathrm{r}\left(\mathrm{CDCl}_{3}, 376 \mathrm{MHz}, 25^{\circ} \mathrm{C}\right)$

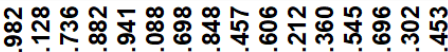

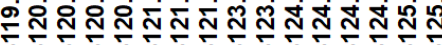

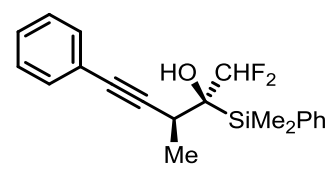

$3 \mathbf{r}$

$\begin{array}{lllllllllllllllllllllllllllll}100 & 80 & 60 & 40 & 20 & 0 & -20 & -40 & -60 & -80 & -100 & -120 & -140 & -160 & -180 & -200 & -220 & -240 & -260 & -280 & -300\end{array}$ 
${ }^{1} \mathrm{H}$ NMR of 3s $\left(\mathrm{CDCl}_{3}, 400 \mathrm{MHz}, 25^{\circ} \mathrm{C}\right)$

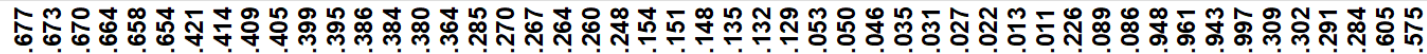

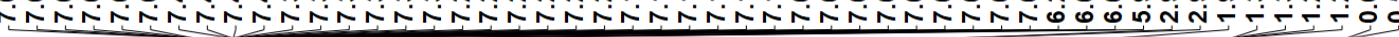
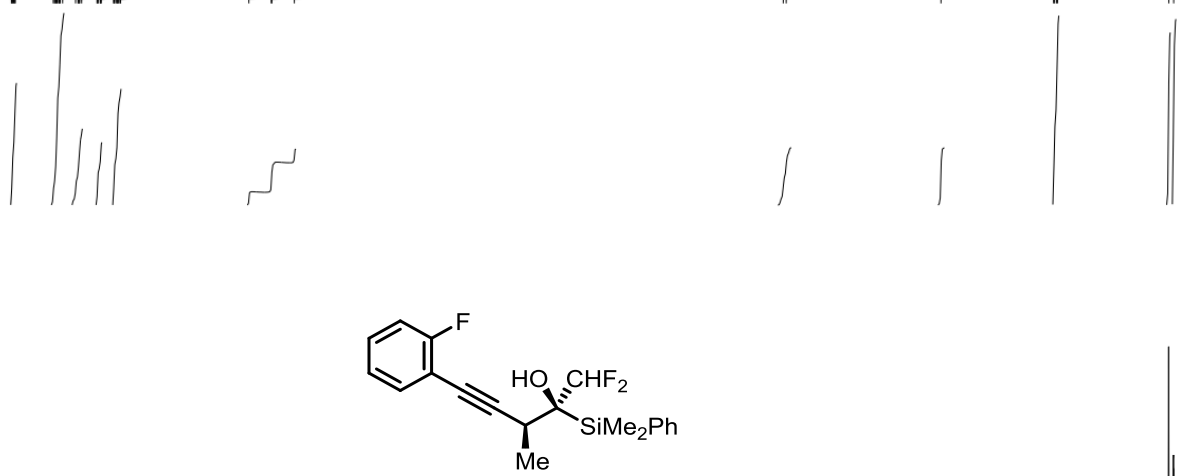

3s

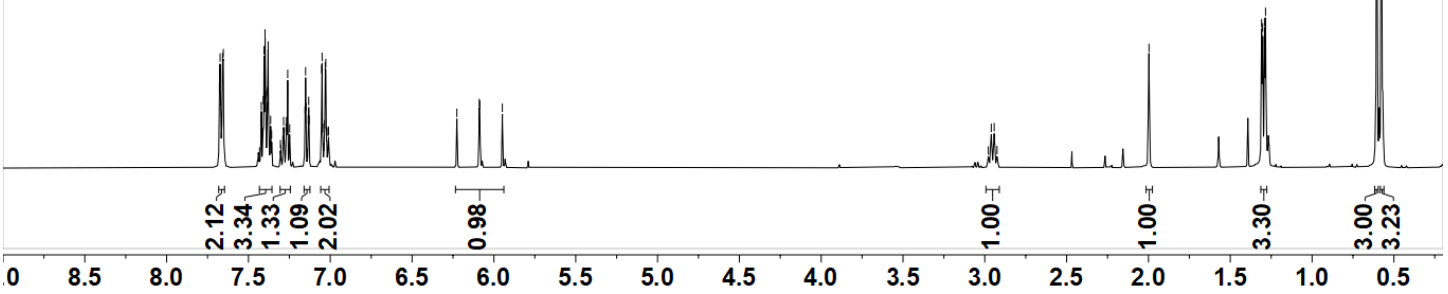

${ }^{13} \mathrm{C}$ NMR of 3s $\left(\mathrm{CDCl}_{3}, 151 \mathrm{MHz}, 25^{\circ} \mathrm{C}\right)$

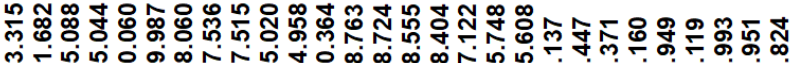

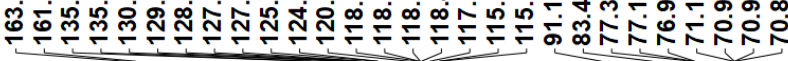

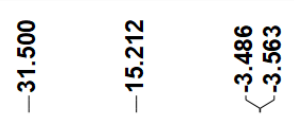

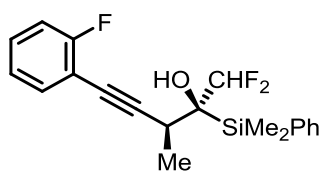

3s

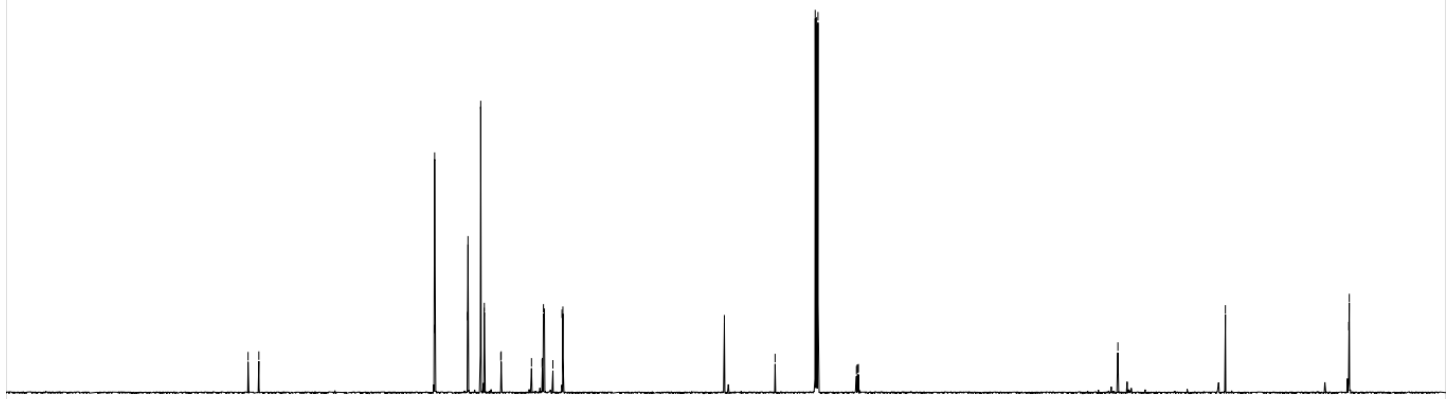

$\begin{array}{lllllllllllllllllllllll}10 & 190 & 180 & 170 & 160 & 150 & 140 & 130 & 120 & 110 & 100 & 90 & 80 & 70 & 60 & 50 & 40 & 30 & 20 & 10 & 0 & -10\end{array}$ 
${ }^{19} \mathrm{~F}$ NMR of $3 \mathrm{~s}\left(\mathrm{CDCl}_{3}, 376 \mathrm{MHz}, 25^{\circ} \mathrm{C}\right)$

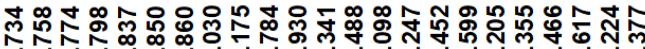

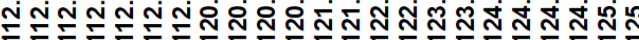

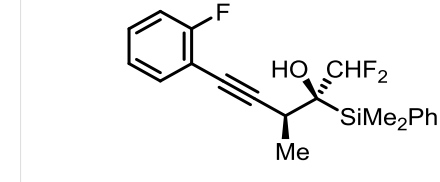

3s
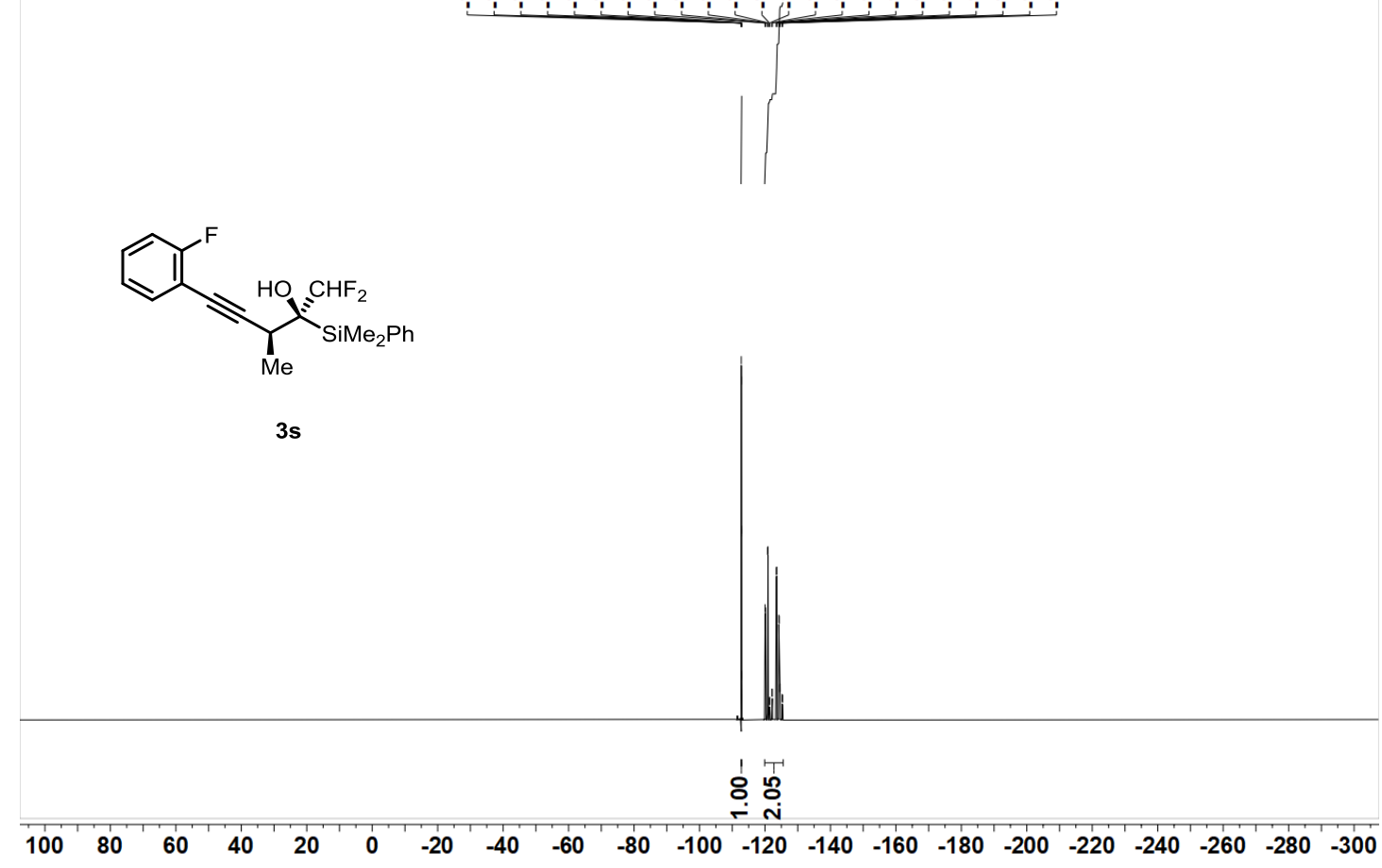

${ }^{1} \mathrm{H}$ NMR of $3 \mathrm{t}\left(\mathrm{CDCl}_{3}, 400 \mathrm{MHz}, 25^{\circ} \mathrm{C}\right)$

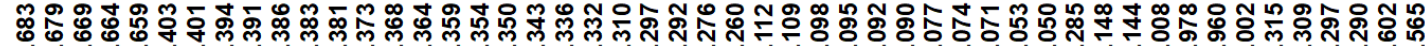
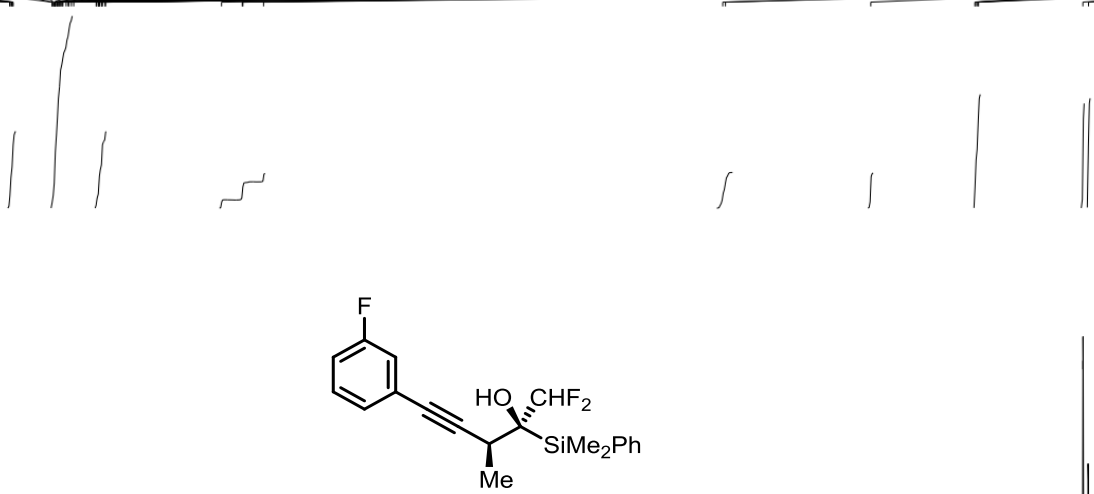

3t

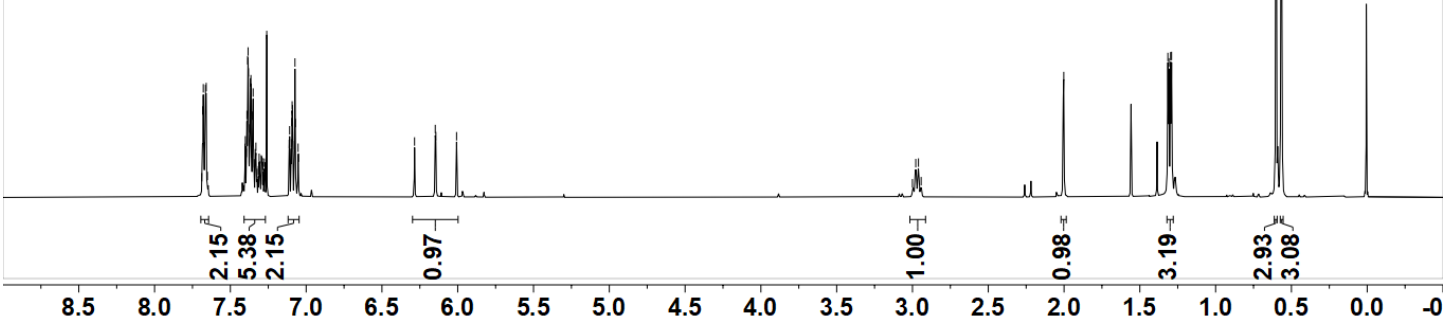


${ }^{13} \mathrm{C}$ NMR of $3 \mathrm{t}\left(\mathrm{CDCl}_{3}, 151 \mathrm{MHz}, 25{ }^{\circ} \mathrm{C}\right)$

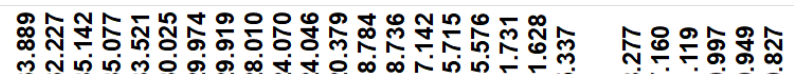

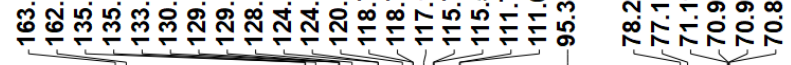

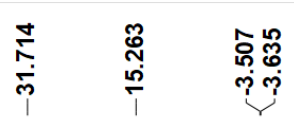

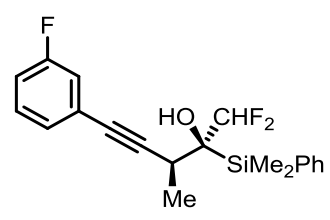

3t

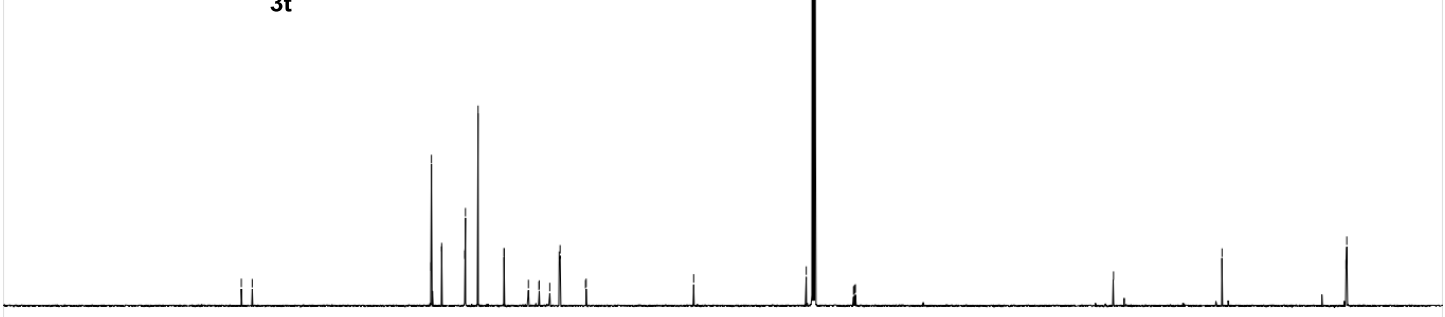

$\begin{array}{llllllllllllllllllllllll}190 & 180 & 170 & 160 & 150 & 140 & 130 & 120 & 110 & 100 & 90 & 80 & 70 & 60 & 50 & 40 & 30 & 20 & 10 & 0 & -10\end{array}$

${ }^{19} \mathrm{~F}$ NMR of $3 \mathrm{t}\left(\mathrm{CDCl}_{3}, 376 \mathrm{MHz}, 25{ }^{\circ} \mathrm{C}\right)$

胥

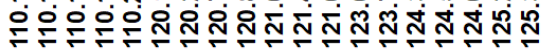

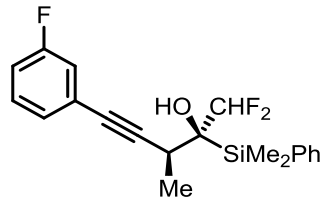

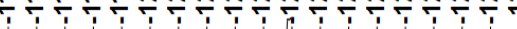

3t

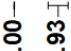

\begin{tabular}{lllllllllllllllllllllllllllll}
\hline 100 & 80 & 60 & 40 & 20 & 0 & -20 & -40 & -60 & -80 & -100 & -120 & -140 & -160 & -180 & -200 & -220 & -240 & -260 & -280 & -300
\end{tabular} 
${ }^{1} \mathrm{H}$ NMR of $3 \mathrm{u}\left(\mathrm{CDCl}_{3}, 400 \mathrm{MHz}, 25^{\circ} \mathrm{C}\right)$

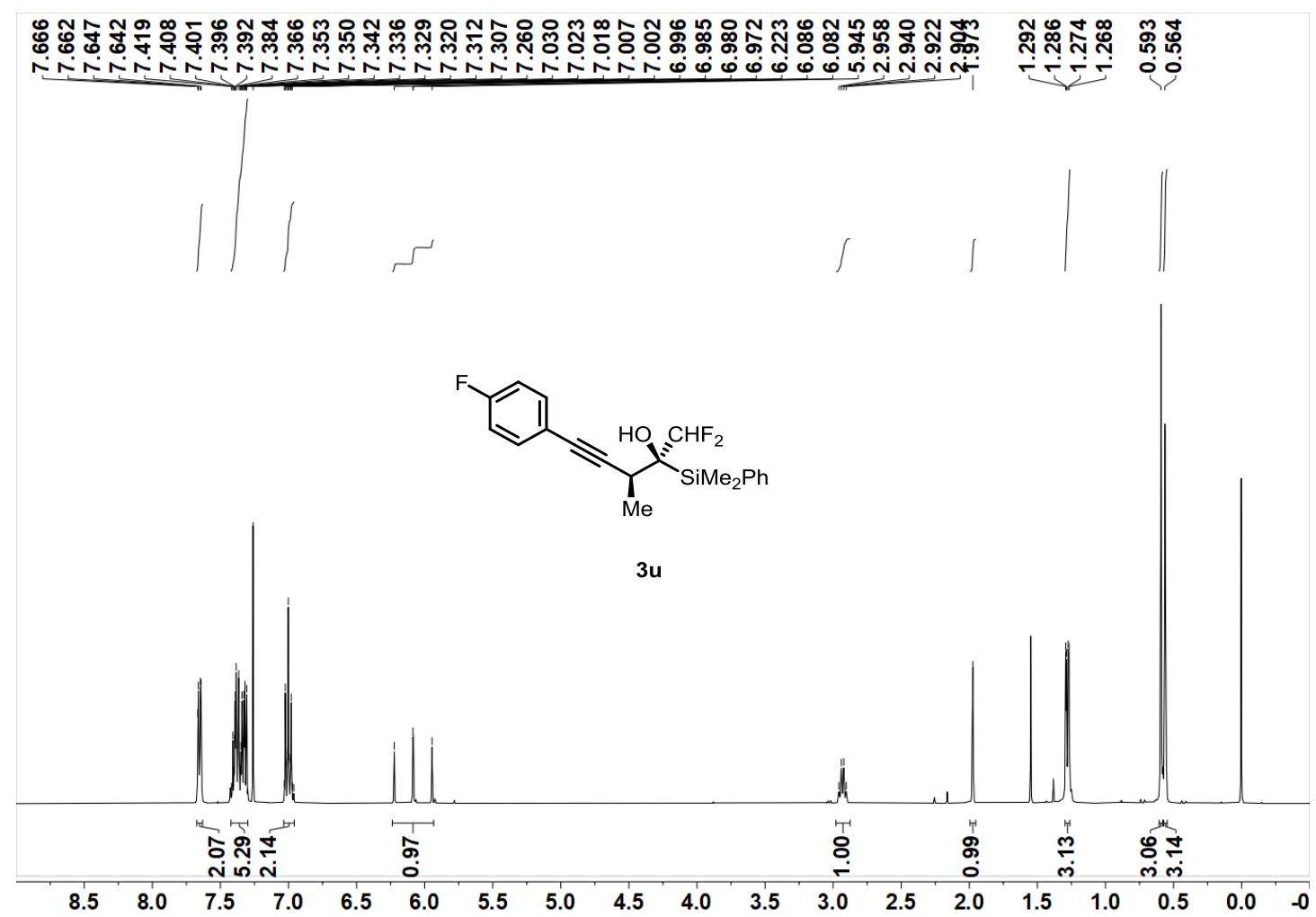

${ }^{13} \mathrm{C}$ NMR of $3 \mathrm{u}\left(\mathrm{CDCl}_{3}, 151 \mathrm{MHz}, 25^{\circ} \mathrm{C}\right)$

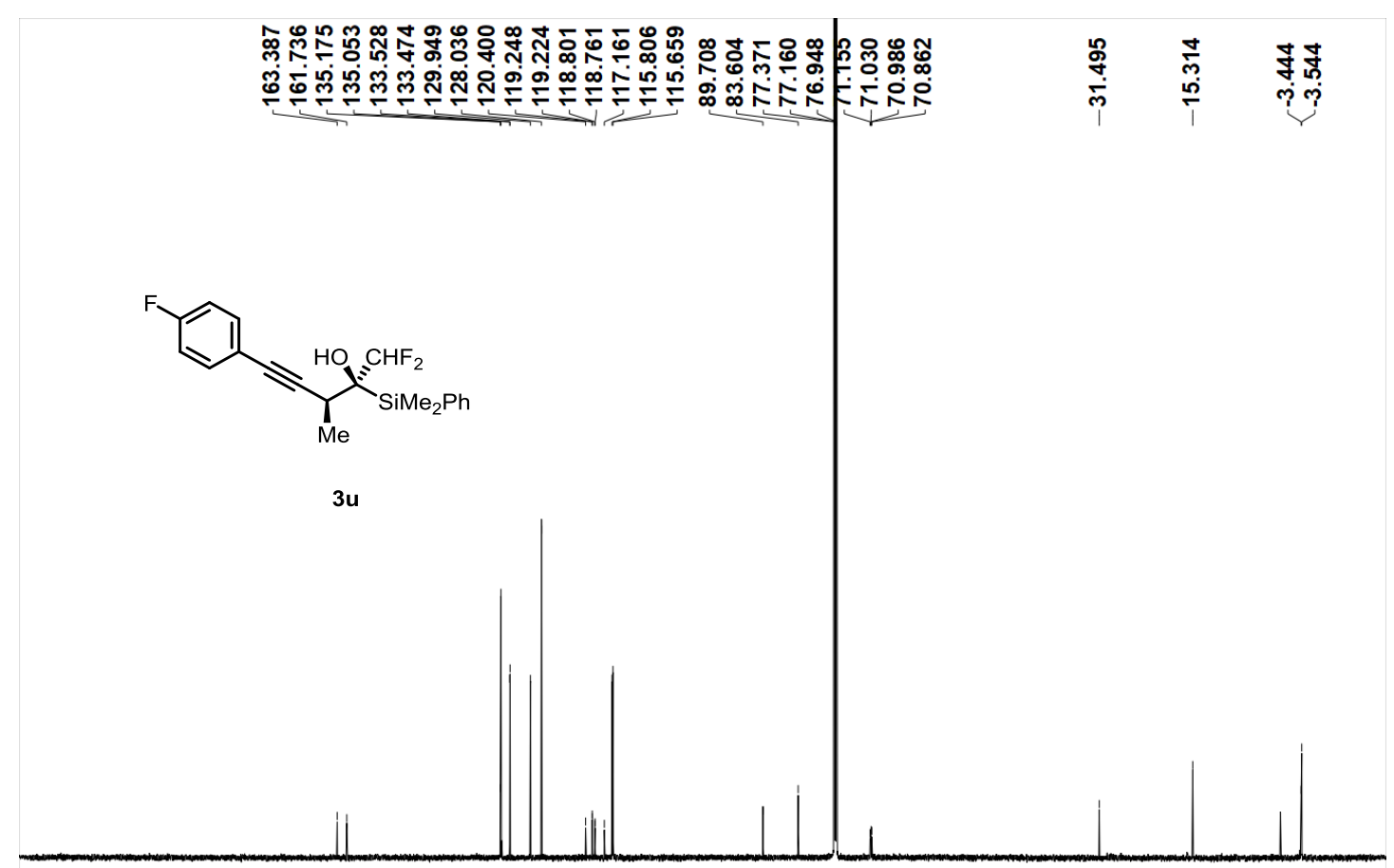

$\begin{array}{lllllllllllllllllllllllll}210 & 200 & 190 & 180 & 170 & 160 & 150 & 140 & 130 & 120 & 110 & 100 & 90 & 80 & 70 & 60 & 50 & 40 & 30 & 20 & 10 & 0 & -10\end{array}$ 
${ }^{19} \mathrm{~F}$ NMR of $3 \mathrm{u}\left(\mathrm{CDCl}_{3}, 376 \mathrm{MHz}, 25^{\circ} \mathrm{C}\right)$

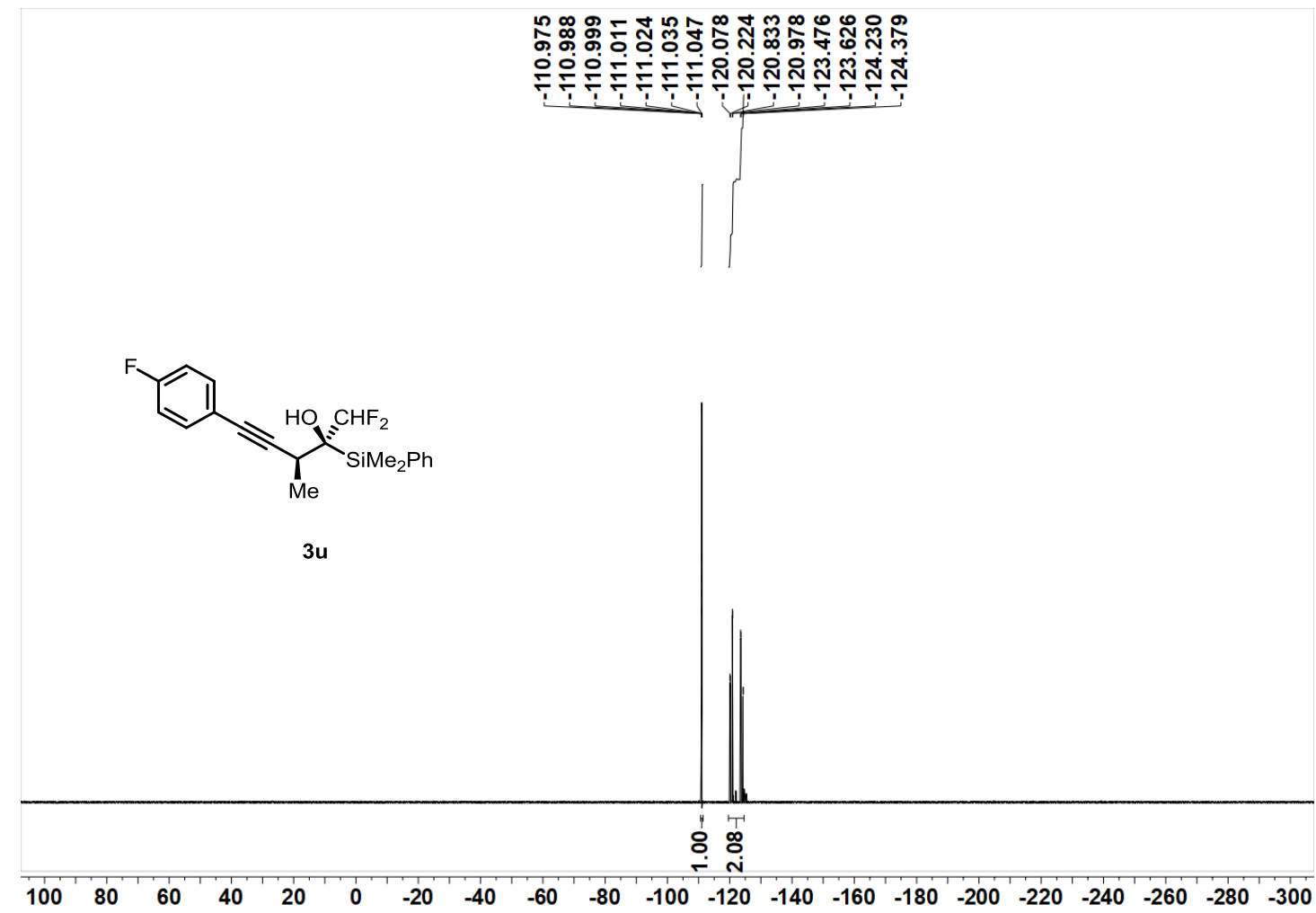

${ }^{1} \mathrm{H}$ NMR of 3v $\left(\mathrm{CDCl}_{3}, 400 \mathrm{MHz}, 25^{\circ} \mathrm{C}\right)$

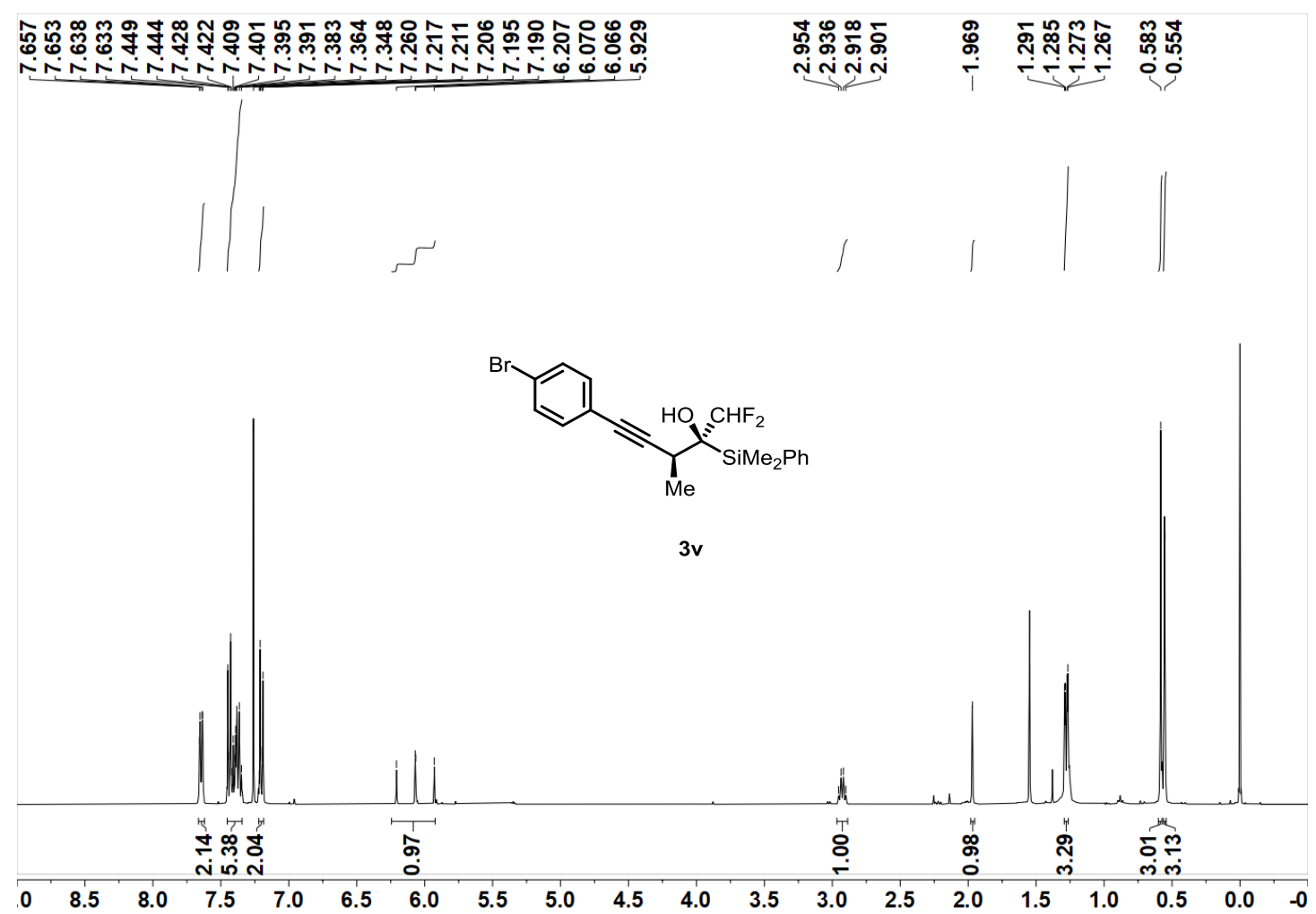


${ }^{13} \mathrm{C}$ NMR of 3v $\left(\mathrm{CDCl}_{3}, 151 \mathrm{MHz}, 25^{\circ} \mathrm{C}\right)$

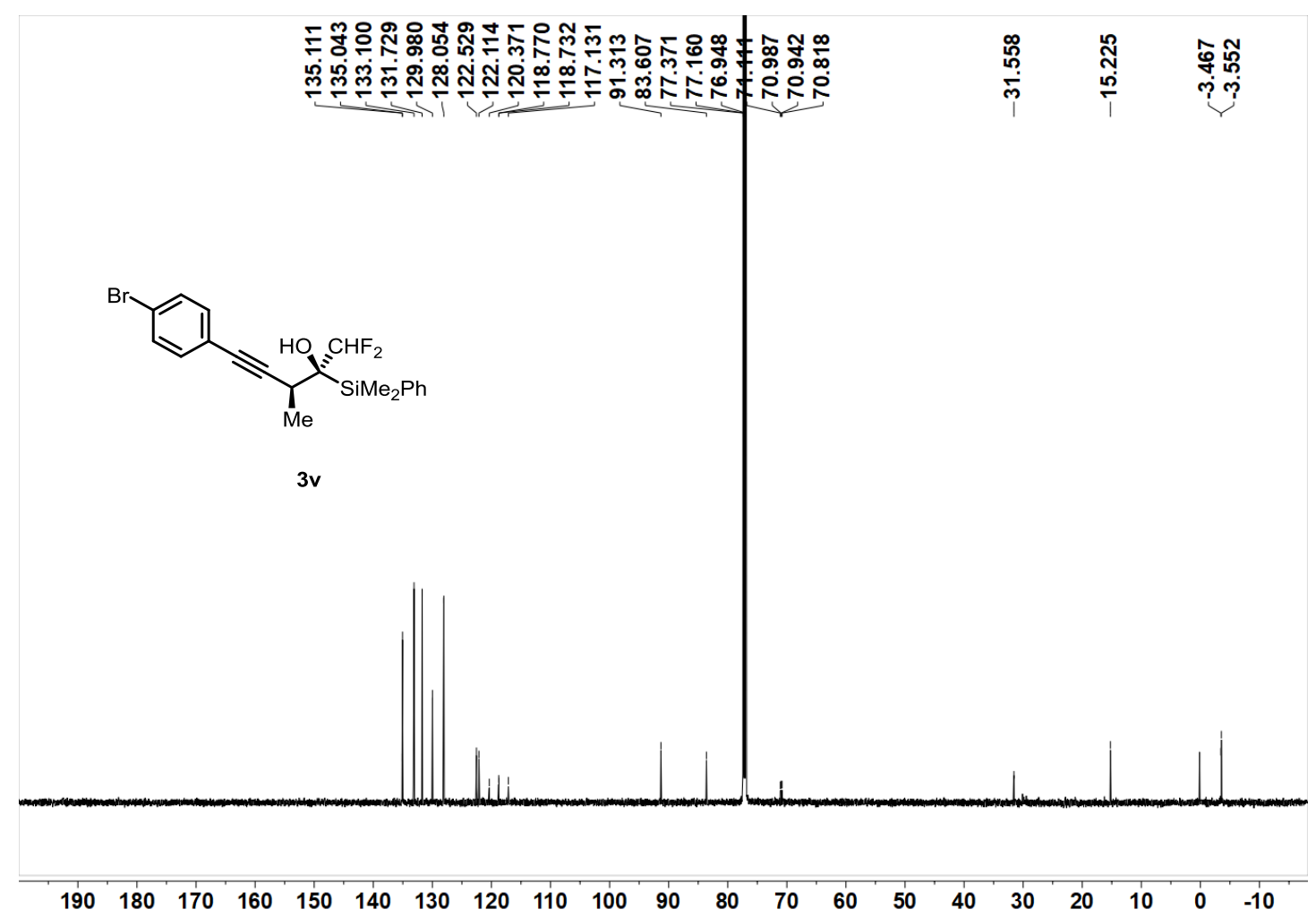

${ }^{19} \mathrm{~F}$ NMR of 3v $\left(\mathrm{CDCl}_{3}, 376 \mathrm{MHz}, 25^{\circ} \mathrm{C}\right)$

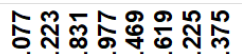

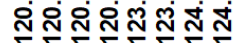

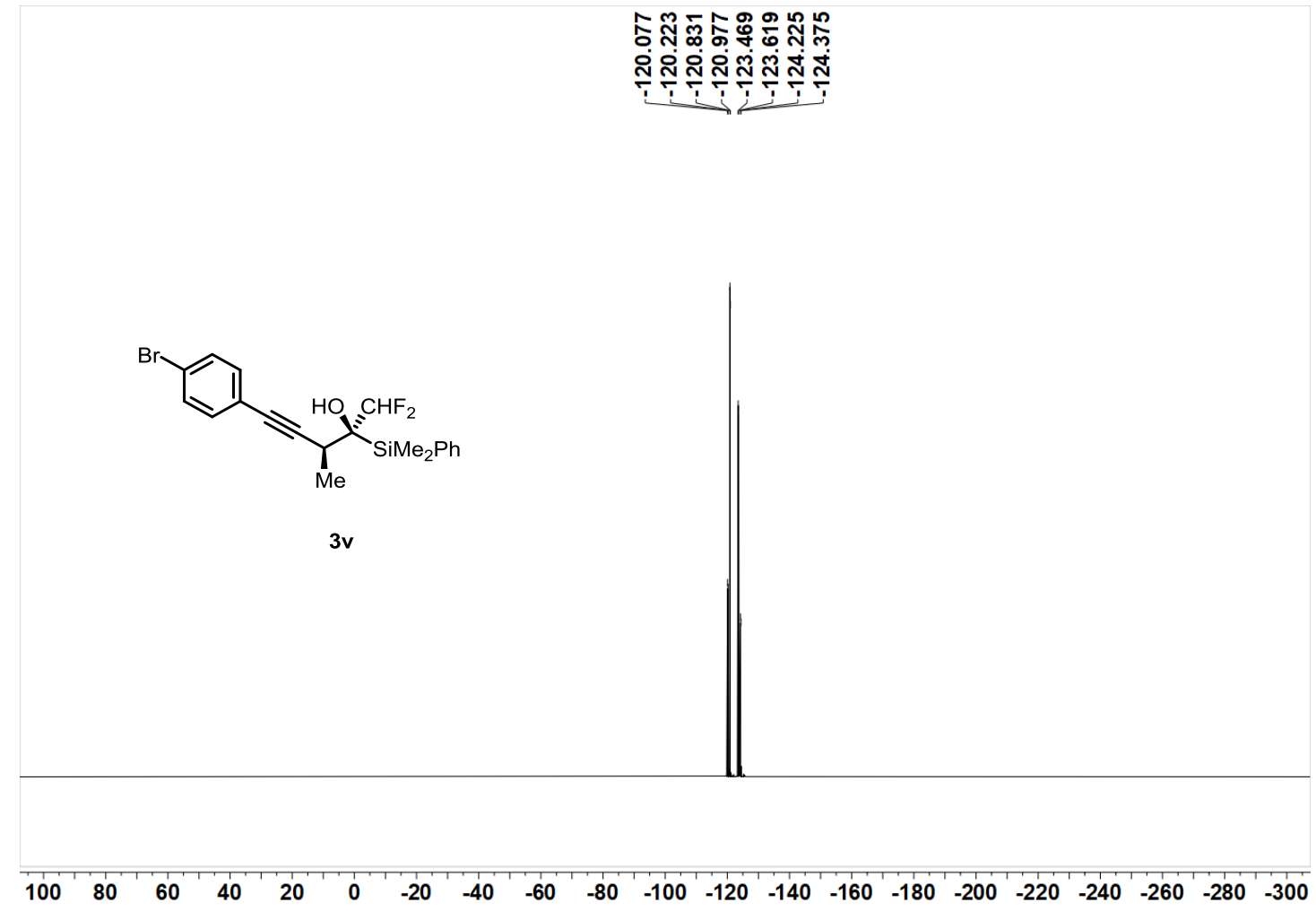


${ }^{1} \mathrm{H}$ NMR of $3 \mathrm{~W}\left(\mathrm{CDCl}_{3}, 600 \mathrm{MHz}, 25{ }^{\circ} \mathrm{C}\right)$

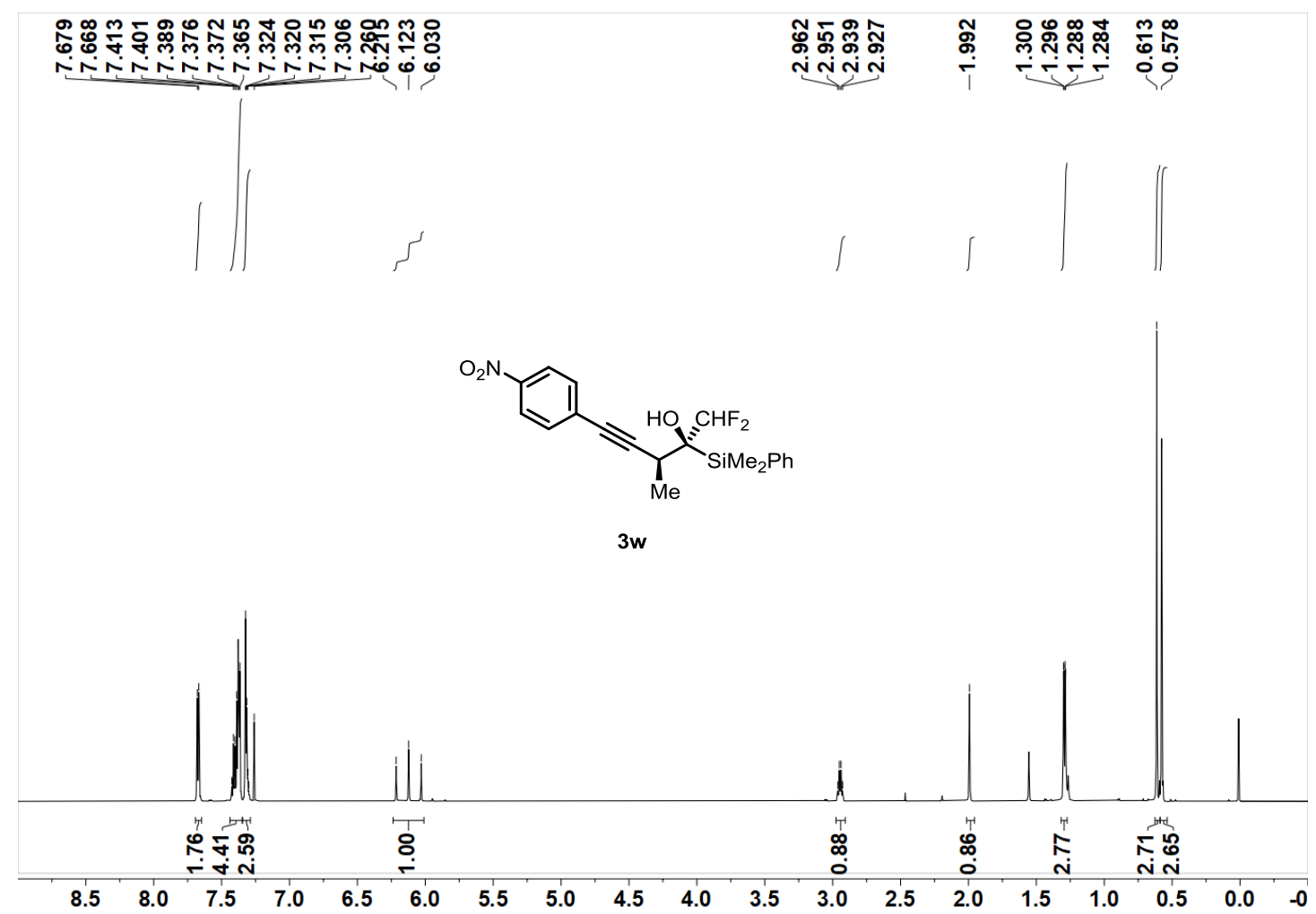

${ }^{13} \mathrm{C}$ NMR of $3 \mathrm{w}\left(\mathrm{CDCl}_{3}, 151 \mathrm{MHz}, 25^{\circ} \mathrm{C}\right)$

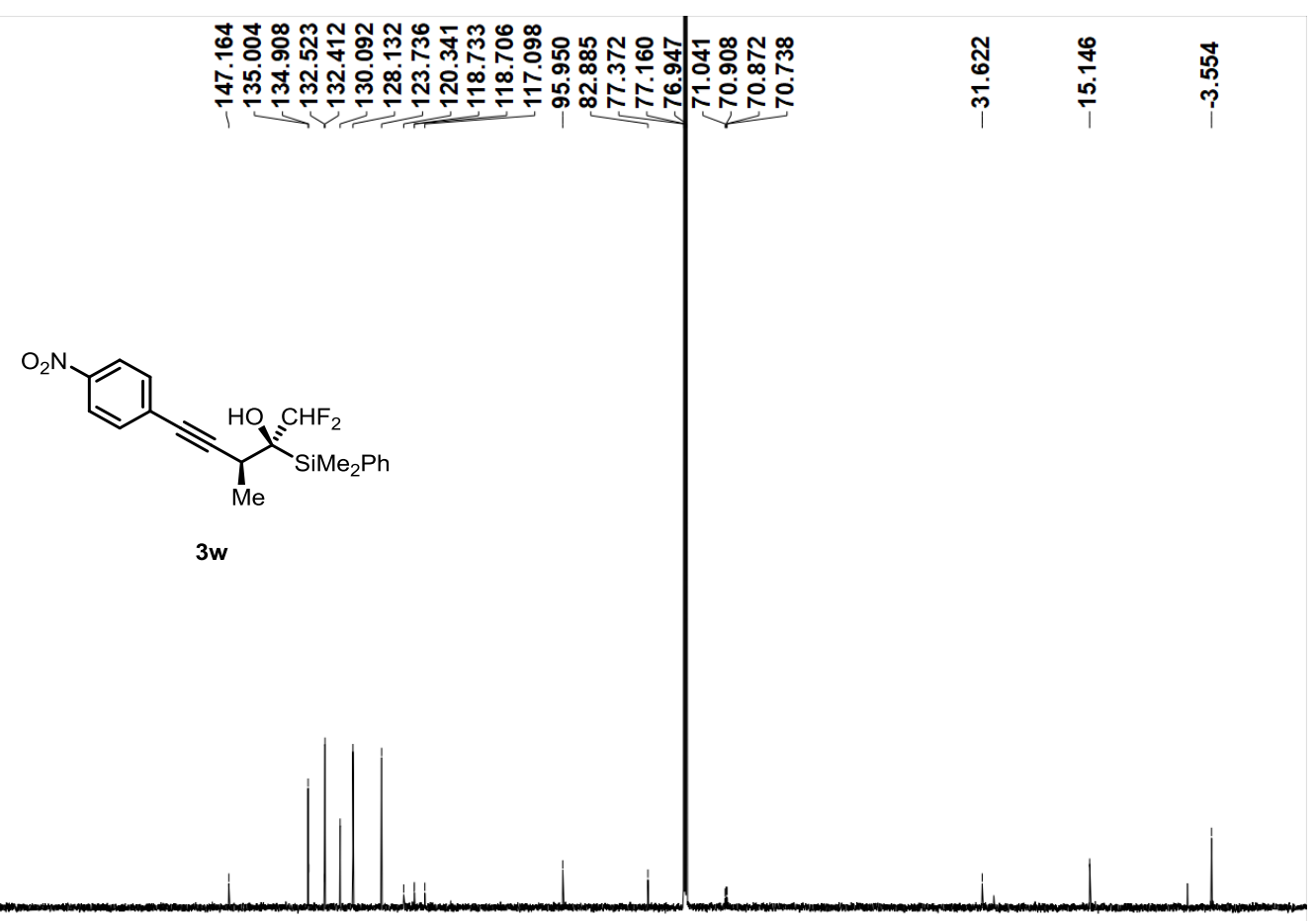

\begin{tabular}{lllllllllllllllllllllll}
\hline 0 & 190 & 180 & 170 & 160 & 150 & 140 & 130 & 120 & 110 & 100 & 90 & 80 & 70 & 60 & 50 & 40 & 30 & 20 & 10 & 0 & -10
\end{tabular} 
${ }^{19} \mathrm{~F}$ NMR of 3w $\left(\mathrm{CDCl}_{3}, 565 \mathrm{MHz}, 25{ }^{\circ} \mathrm{C}\right)$

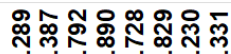

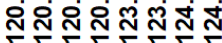

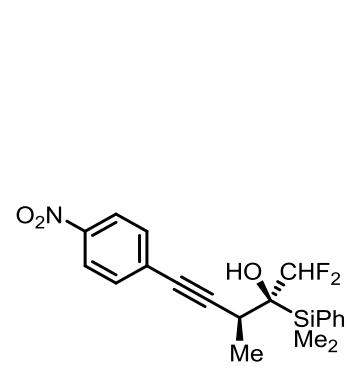

$3 w$
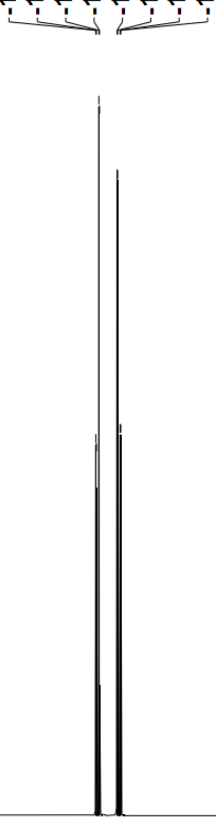

$\begin{array}{lllllllllllllllllllllllllll}10 & 0 & -10 & -20 & -30 & -40 & -50 & -60 & -70 & -80 & -90 & -100 & -110 & -120 & -130 & -140 & -150 & -160 & -170 & -180 & -190 & -200 & -210\end{array}$

${ }^{1} \mathrm{H}$ NMR of 3x $\left(\mathrm{CDCl}_{3}, 400 \mathrm{MHz}, 25^{\circ} \mathrm{C}\right)$

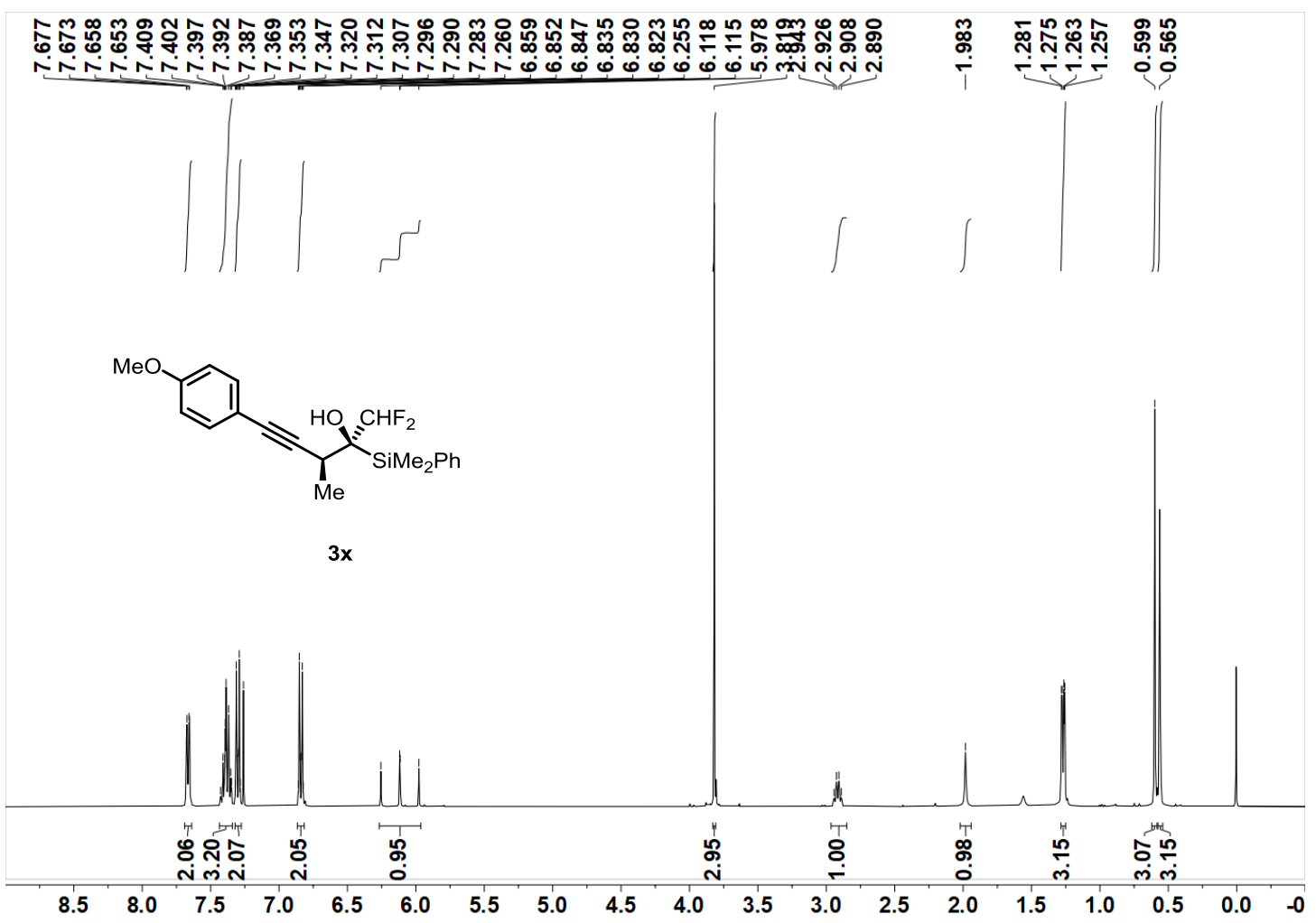


${ }^{13} \mathrm{C}$ NMR of 3x $\left(\mathrm{CDCl}_{3}, 151 \mathrm{MHz}, 25{ }^{\circ} \mathrm{C}\right)$

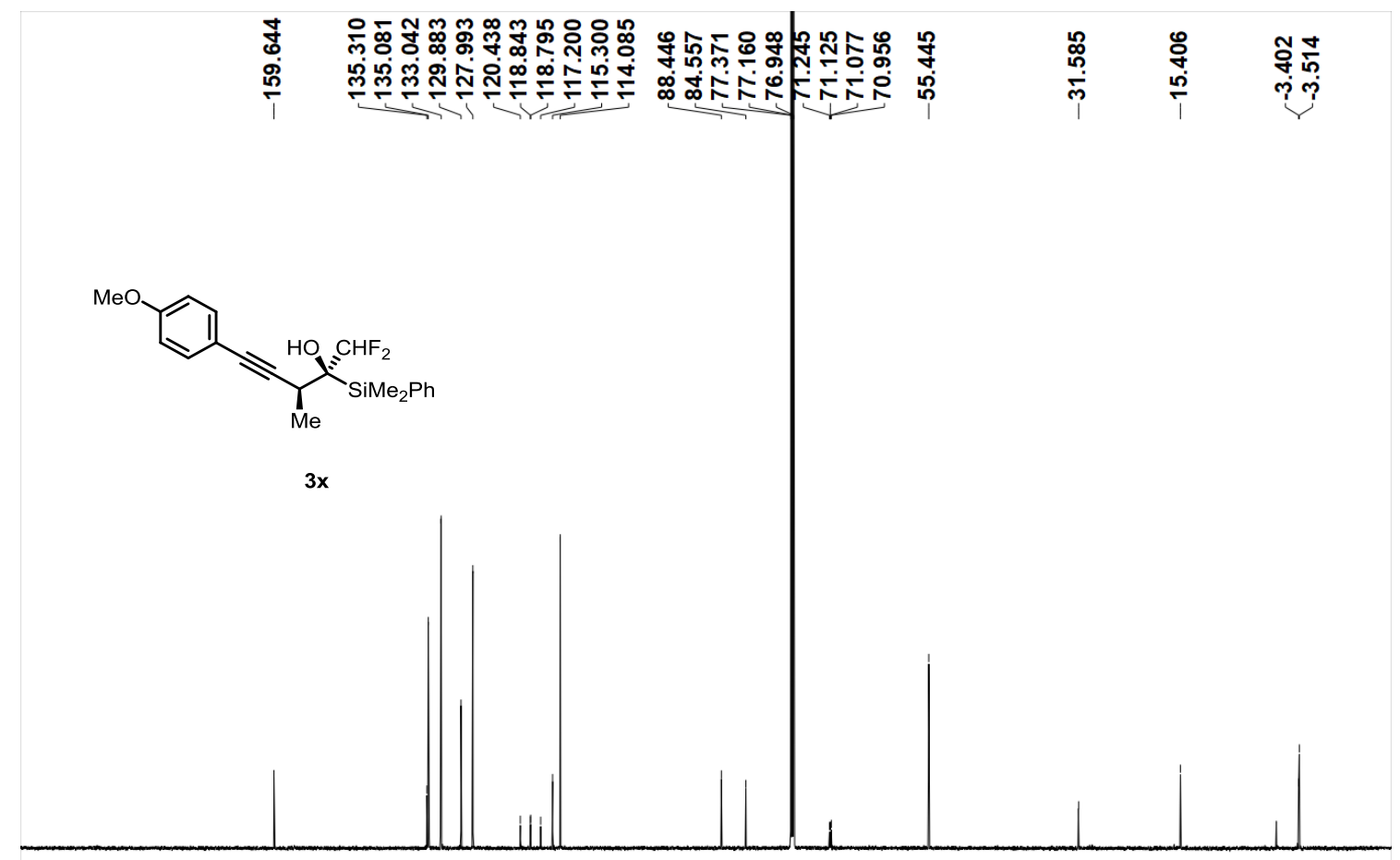

$\begin{array}{lllllllllllllllllllllllllllll}190 & 180 & 170 & 160 & 150 & 140 & 130 & 120 & 110 & 100 & 90 & 80 & 70 & 60 & 50 & 40 & 30 & 20 & 10 & 0 & -10\end{array}$

${ }^{19} \mathrm{~F}$ NMR of 3x $\left(\mathrm{CDCl}_{3}, 376 \mathrm{MHz}, 25^{\circ} \mathrm{C}\right)$

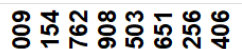

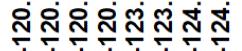

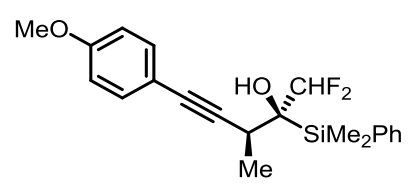

$3 x$

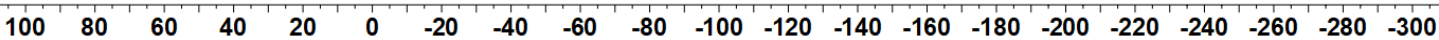


${ }^{1} \mathrm{H}$ NMR of $3 \mathrm{y}\left(\mathrm{CDCl}_{3}, 400 \mathrm{MHz}, 25^{\circ} \mathrm{C}\right)$

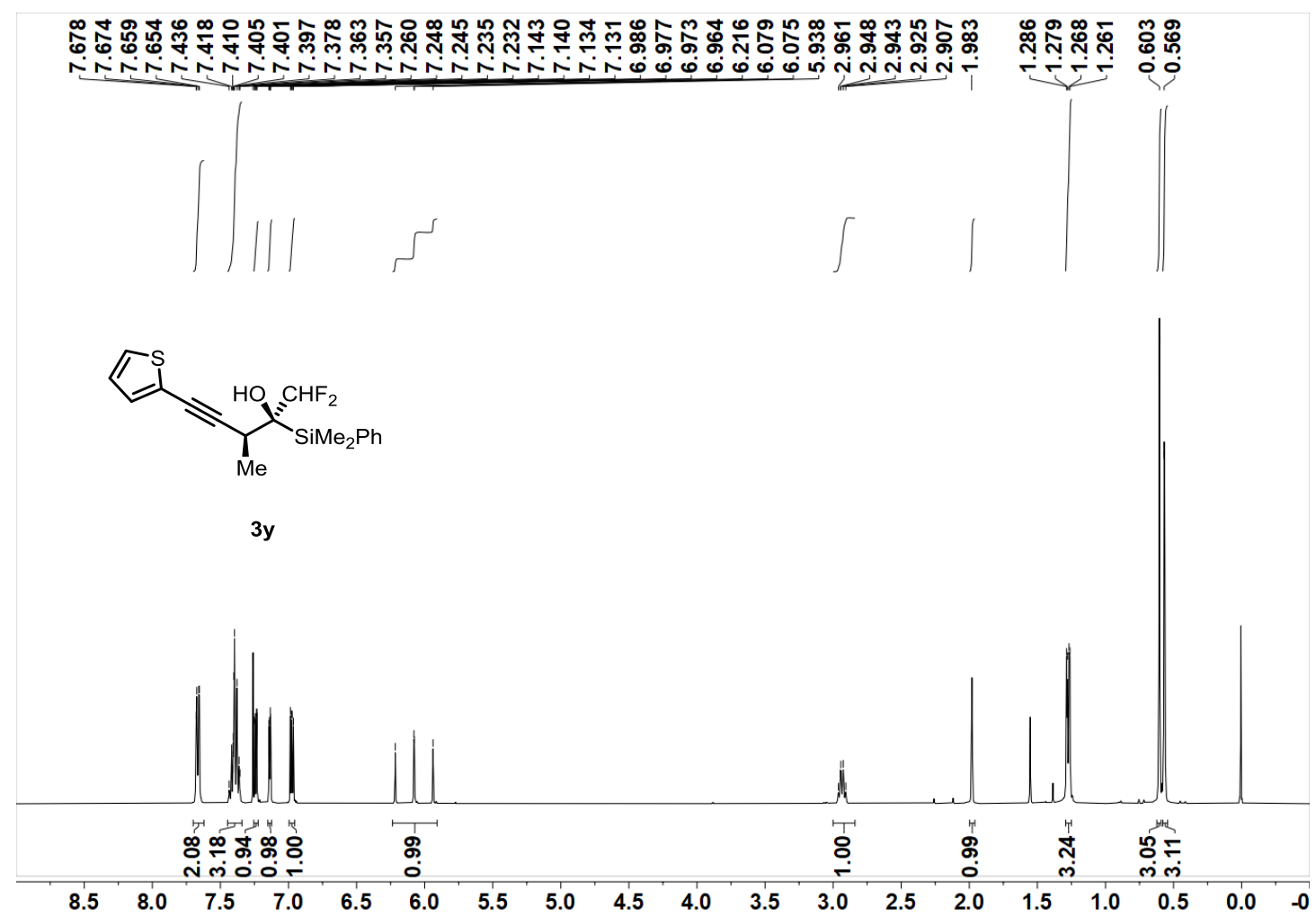

${ }^{13} \mathrm{C}$ NMR of $3 \mathrm{y}\left(\mathrm{CDCl}_{3}, 151 \mathrm{MHz}, 25^{\circ} \mathrm{C}\right)$
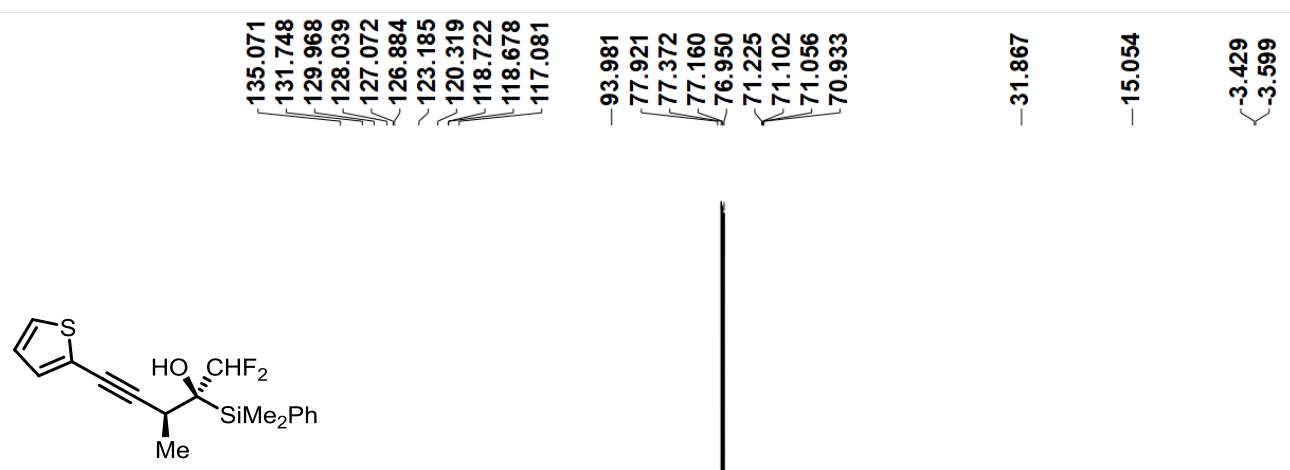

3y

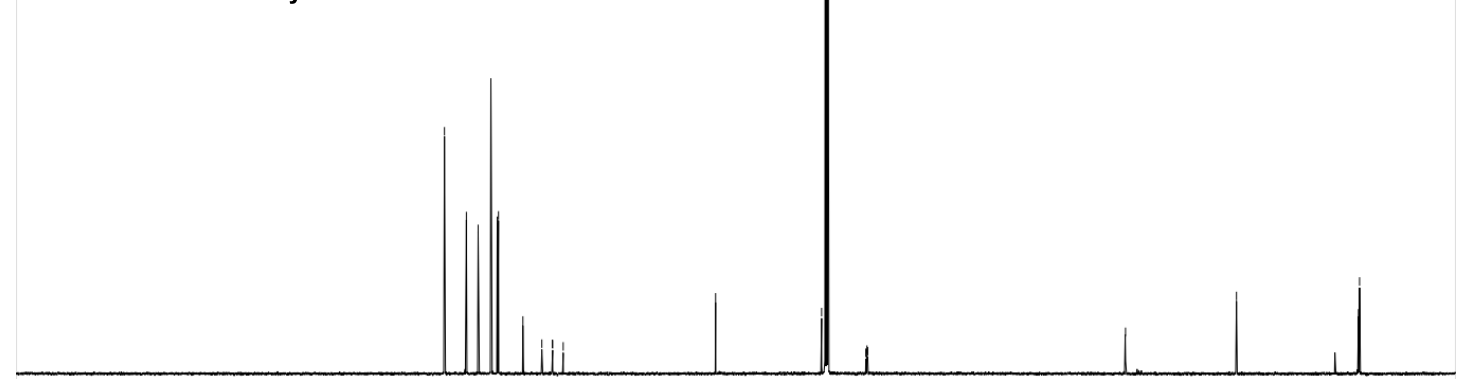

\begin{tabular}{lllllllllllllllllllllll}
\hline 0 & 190 & 180 & 170 & 160 & 150 & 140 & 130 & 120 & 110 & 100 & 90 & 80 & 70 & 60 & 50 & 40 & 30 & 20 & 10 & 0 & -10
\end{tabular} 
${ }^{19} \mathrm{~F}$ NMR of $3 \mathrm{y}\left(\mathrm{CDCl}_{3}, 376 \mathrm{MHz}, 25^{\circ} \mathrm{C}\right)$

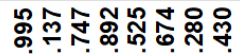

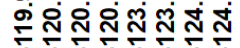

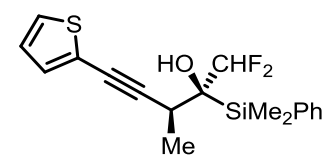

3y

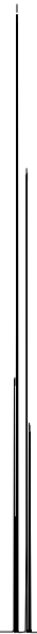

$\begin{array}{llllllllllllllllllllllllll}100 & 80 & 60 & 40 & 20 & 0 & -20 & -40 & -60 & -80 & -100 & -120 & -140 & -160 & -180 & -200 & -220 & -240 & -260 & -280 & -300\end{array}$

${ }^{1} \mathrm{H}$ NMR of $3 \mathrm{z}\left(\mathrm{CDCl}_{3}, 400 \mathrm{MHz}, 25^{\circ} \mathrm{C}\right)$

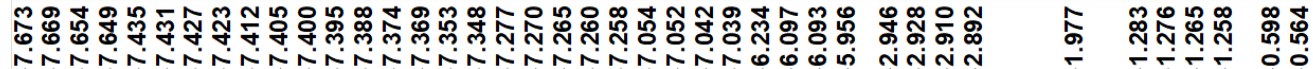

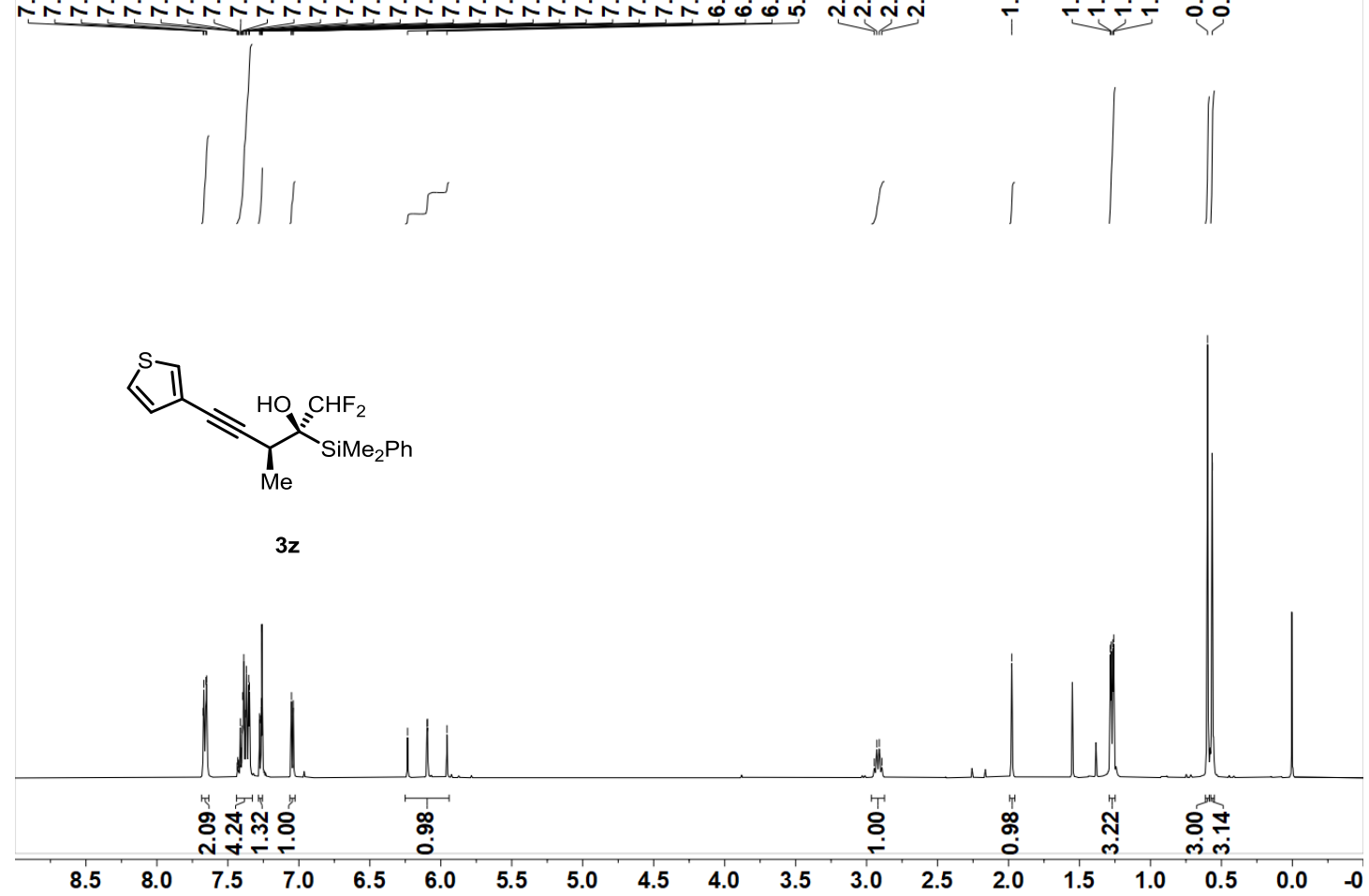


${ }^{13} \mathrm{C}$ NMR of $3 \mathrm{z}\left(\mathrm{CDCl}_{3}, 151 \mathrm{MHz}, 25{ }^{\circ} \mathrm{C}\right)$

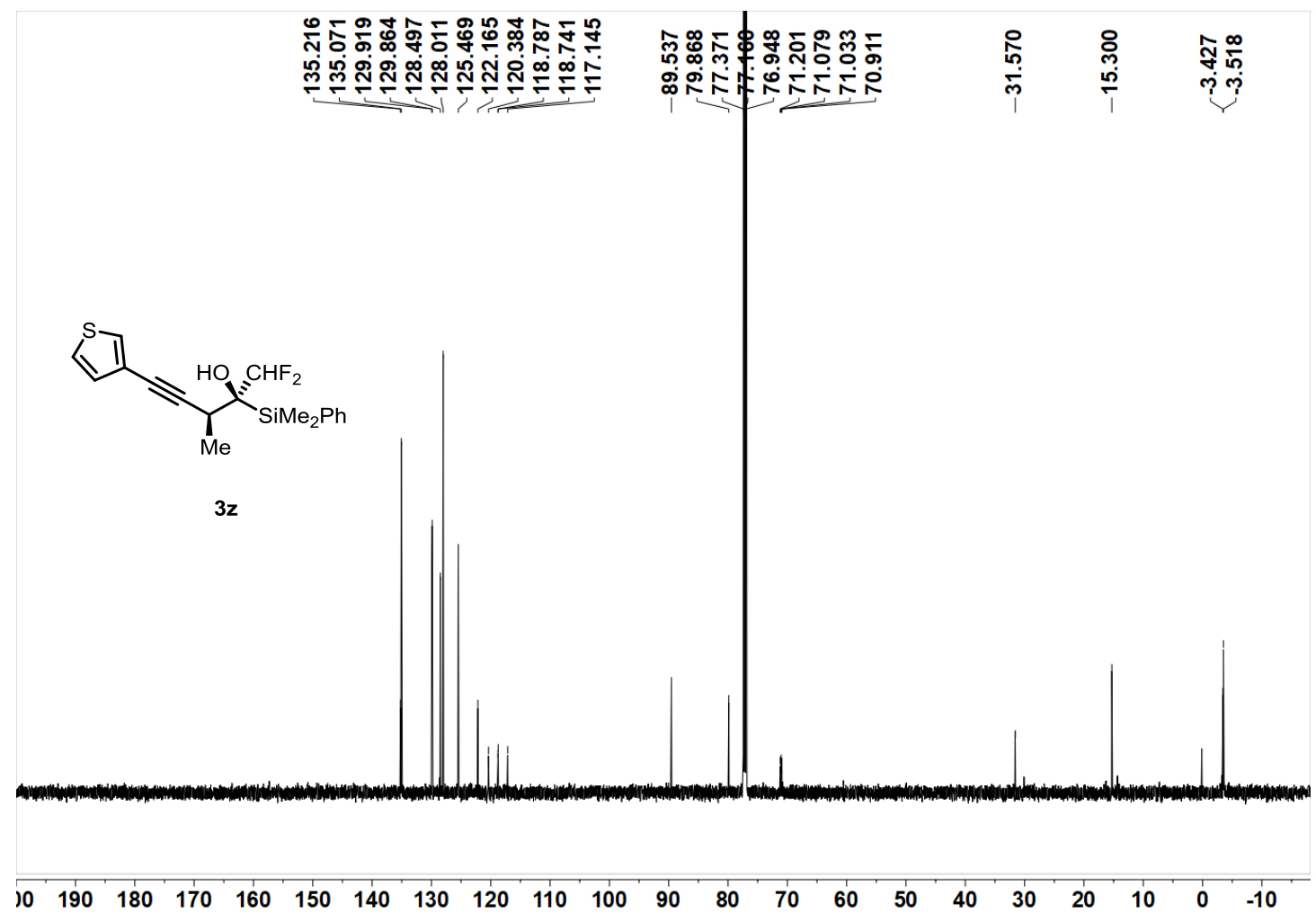

${ }^{19}$ F NMR of $3 z\left(\mathrm{CDCl}_{3}, 376 \mathrm{MHz}, 25^{\circ} \mathrm{C}\right)$

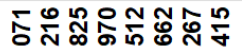

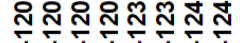

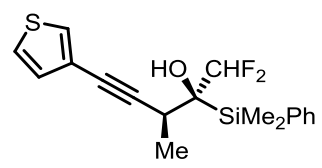

$3 z$

$\begin{array}{lllllllllllllllllllllllllllllllll}100 & 80 & 60 & 40 & 20 & 0 & -20 & -40 & -60 & -80 & -100 & -120 & -140 & -160 & -180 & -200 & -220 & -240 & -260 & -280 & -300\end{array}$ 
${ }^{1} \mathrm{H}$ NMR of $3 \mathrm{aa}\left(\mathrm{CDCl}_{3}, 400 \mathrm{MHz}, 25^{\circ} \mathrm{C}\right)$

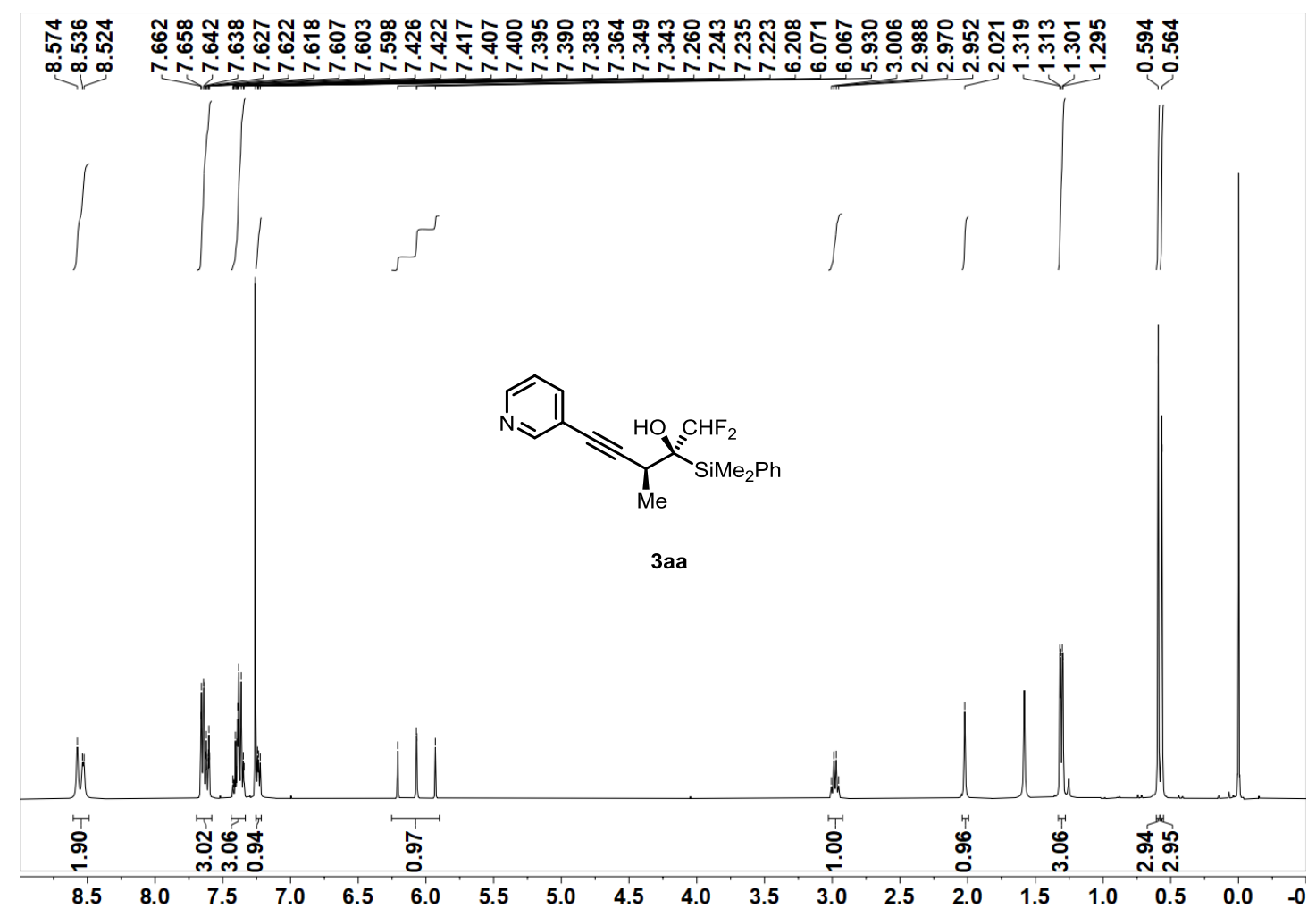

${ }^{13} \mathrm{C}$ NMR of $3 \mathrm{aa}\left(\mathrm{CDCl}_{3}, 151 \mathrm{MHz}, 25^{\circ} \mathrm{C}\right)$

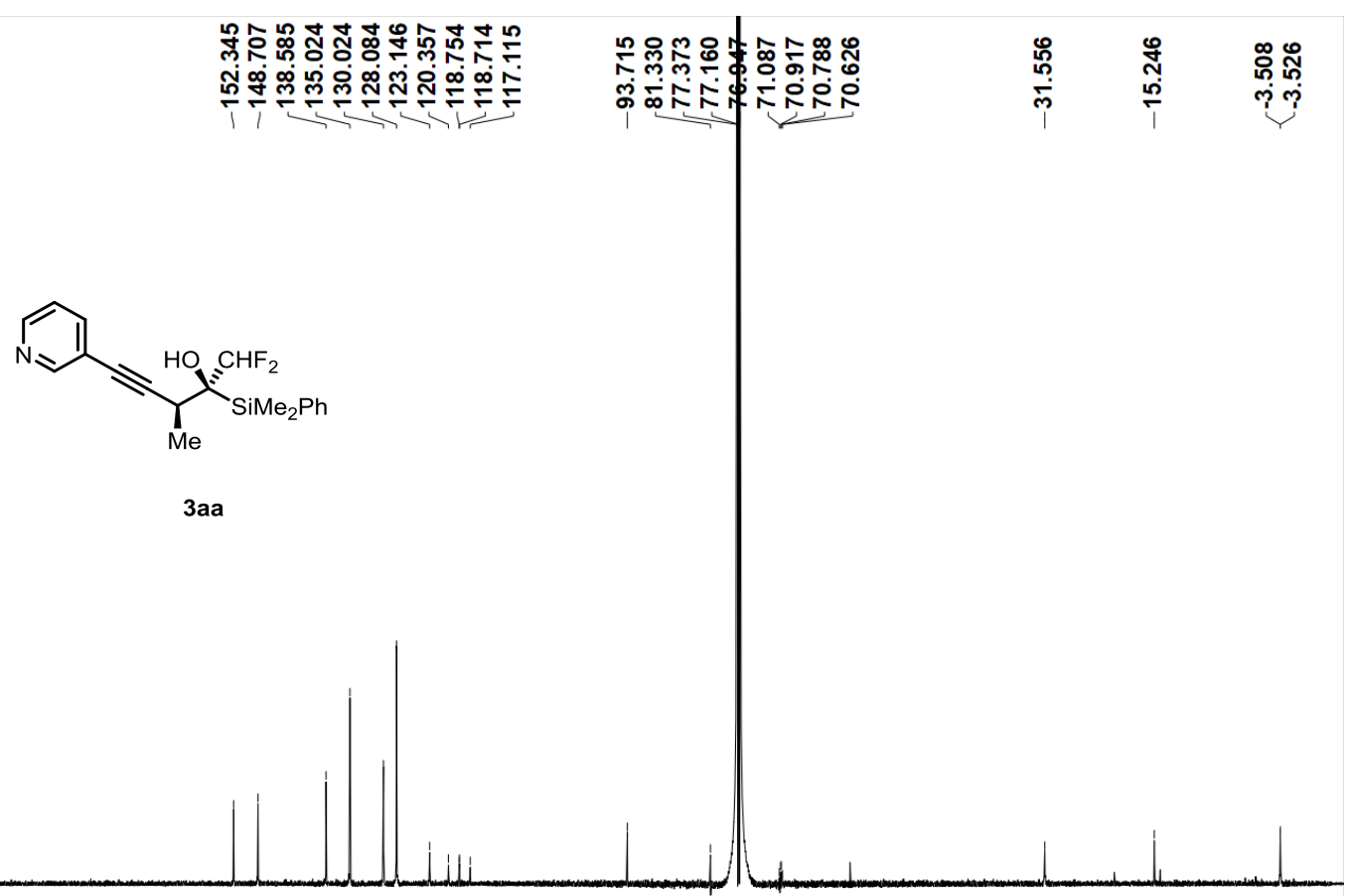

\begin{tabular}{llllllllllllllllllllllll}
\hline 10 & 190 & 180 & 170 & 160 & 150 & 140 & 130 & 120 & 110 & 100 & 90 & 80 & 70 & 60 & 50 & 40 & 30 & 20 & 10 & 0 & -10
\end{tabular} 
${ }^{19} \mathrm{~F}$ NMR of 3aa $\left(\mathrm{CDCl}_{3}, 376 \mathrm{MHz}, 25{ }^{\circ} \mathrm{C}\right)$

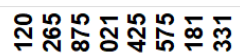

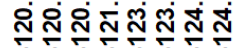

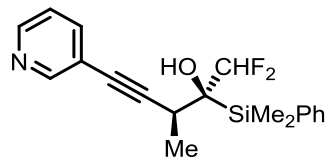

3aa

$\begin{array}{llllllllllllllllllllllllllllllllll}100 & 80 & 60 & 40 & 20 & 0 & -20 & -40 & -60 & -80 & -100 & -120 & -140 & -160 & -180 & -200 & -220 & -240 & -260 & -280 & -300\end{array}$

${ }^{1} \mathrm{H}$ NMR of $3 \mathrm{ab}\left(\mathrm{CDCl}_{3}, 400 \mathrm{MHz}, 25^{\circ} \mathrm{C}\right)$

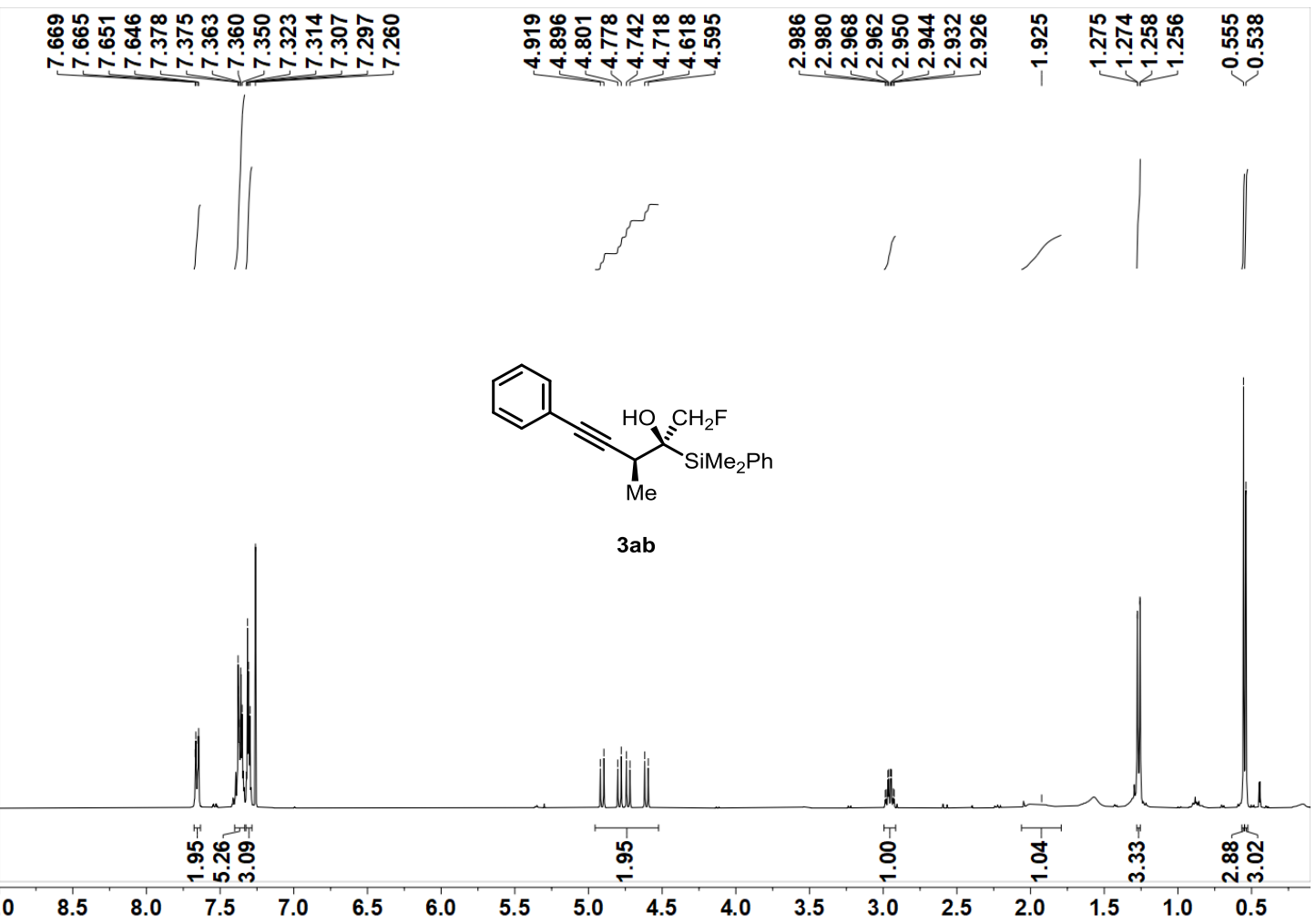


${ }^{13} \mathrm{C}$ NMR of $3 \mathrm{ab}\left(\mathrm{CDCl}_{3}, 101 \mathrm{MHz}, 25{ }^{\circ} \mathrm{C}\right)$

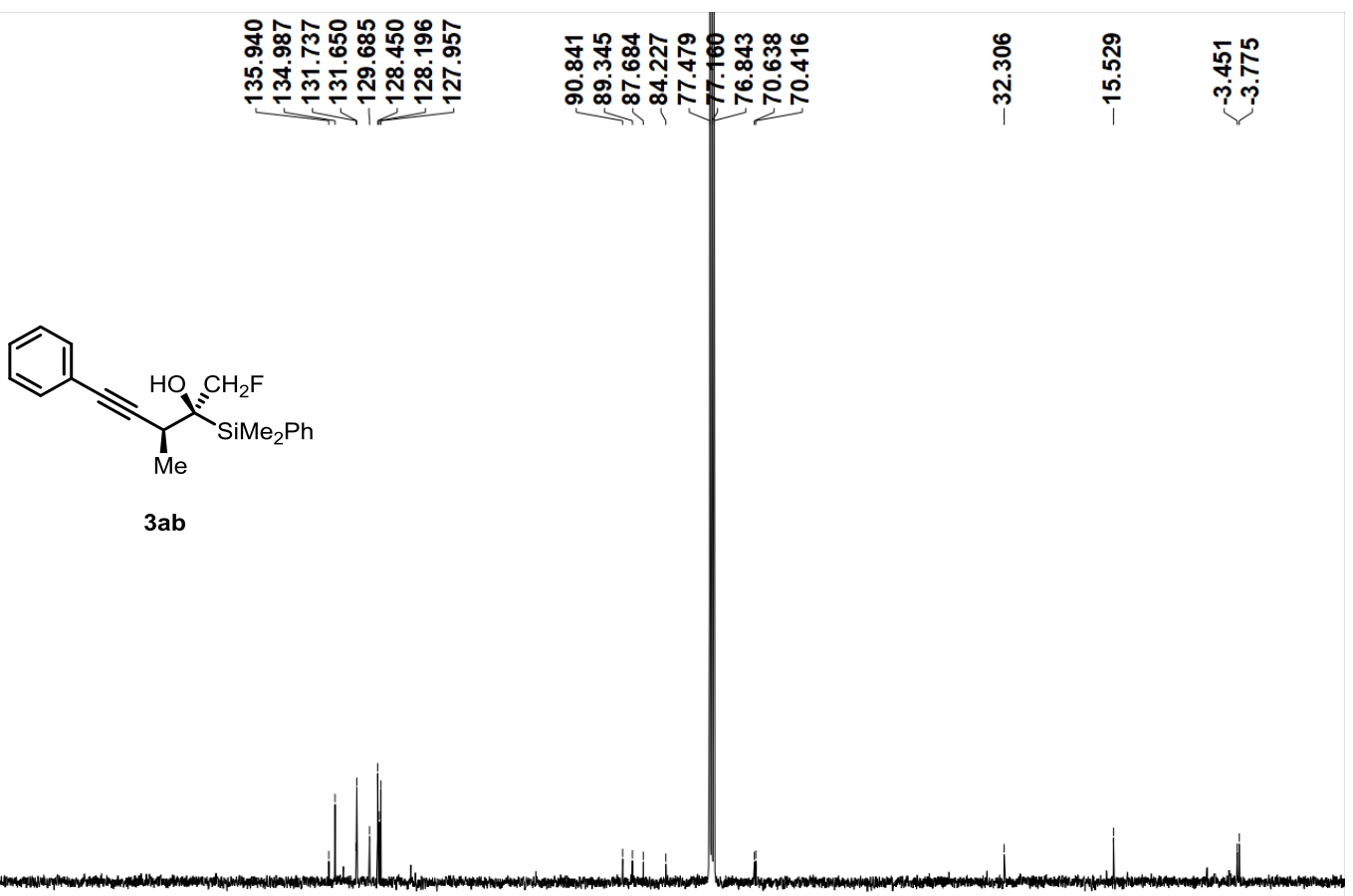

$\begin{array}{llllllllllllllllllllllll}10 & 190 & 180 & 170 & 160 & 150 & 140 & 130 & 120 & 110 & 100 & 90 & 80 & 70 & 60 & 50 & 40 & 30 & 20 & 10 & 0 & -10 & -2\end{array}$

${ }^{19} \mathrm{~F}$ NMR of $3 \mathrm{ab}\left(\mathrm{CDCl}_{3}, 376 \mathrm{MHz}, 25^{\circ} \mathrm{C}\right)$

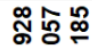

สู่สูกิู

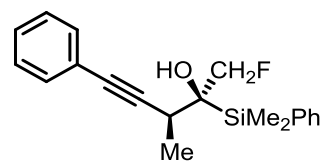

3ab

$\begin{array}{llllllllllllllllllllllllllllllllll}100 & 80 & 60 & 40 & 20 & 0 & -20 & -40 & -60 & -80 & -100 & -120 & -140 & -160 & -180 & -200 & -220 & -240 & -260 & -280 & -300\end{array}$ 
${ }^{1} \mathrm{H}$ NMR of $3 \mathrm{ac}\left(\mathrm{CDCl}_{3}, 600 \mathrm{MHz}, 25^{\circ} \mathrm{C}\right)$

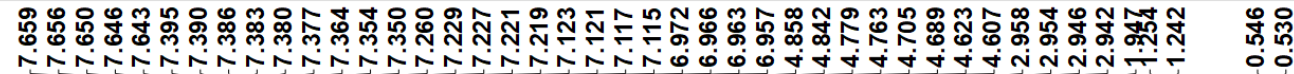
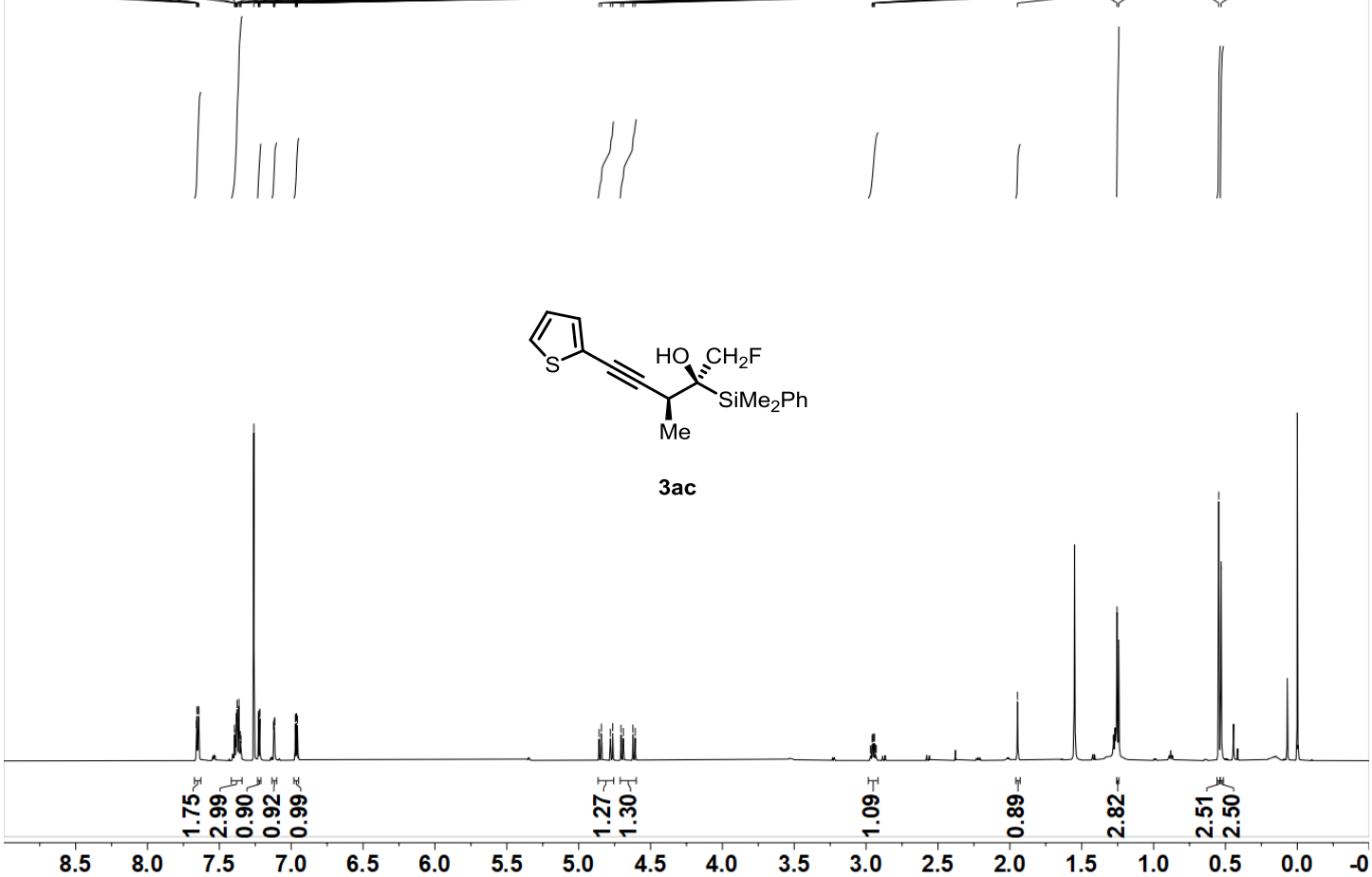

${ }^{13} \mathrm{C}$ NMR of $3 \mathrm{ac}\left(\mathrm{CDCl}_{3}, 151 \mathrm{MHz}, 25^{\circ} \mathrm{C}\right)$

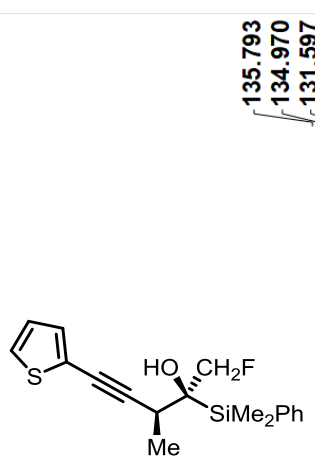

3ac 
${ }^{19} \mathrm{~F}$ NMR of $3 \mathrm{ac}\left(\mathrm{CDCl}_{3}, 376 \mathrm{MHz}, 25^{\circ} \mathrm{C}\right)$

\section{규유ำ}

สุสู่สิ

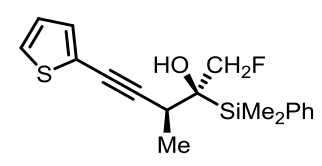

3ac

$\begin{array}{llllllllllllllllllllllllllllll}100 & 80 & 60 & 40 & 20 & 0 & -20 & -40 & -60 & -80 & -100 & -120 & -140 & -160 & -180 & -200 & -220 & -240 & -260 & -280 & -300\end{array}$

${ }^{1} \mathrm{H}$ NMR of $5 \mathrm{a}\left(\mathrm{CDCl}_{3}, 600 \mathrm{MHz}, 25^{\circ} \mathrm{C}\right)$

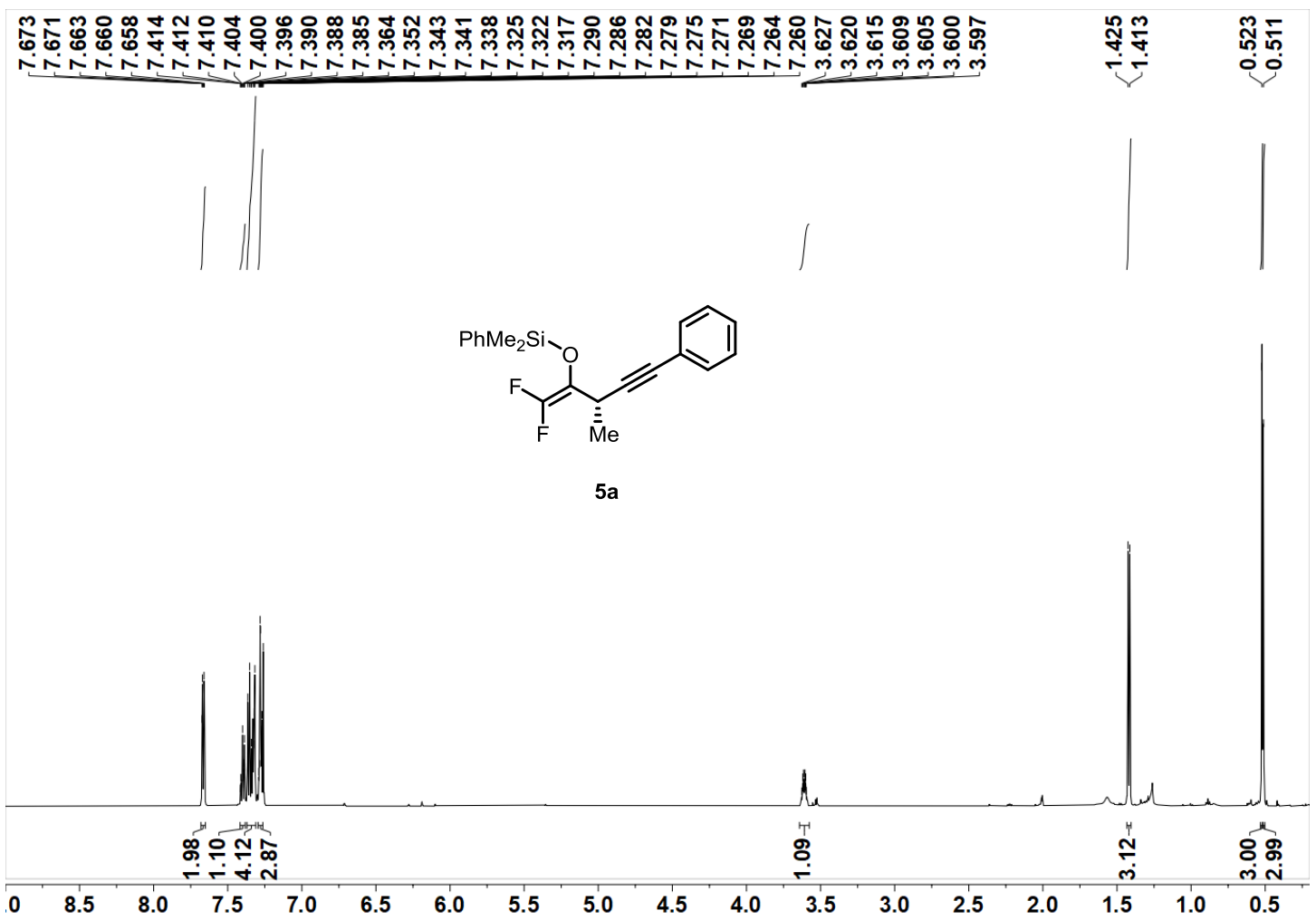


${ }^{13} \mathrm{C}$ NMR of 5a $\left(\mathrm{CDCl}_{3}, 151 \mathrm{MHz}, 25^{\circ} \mathrm{C}\right)$

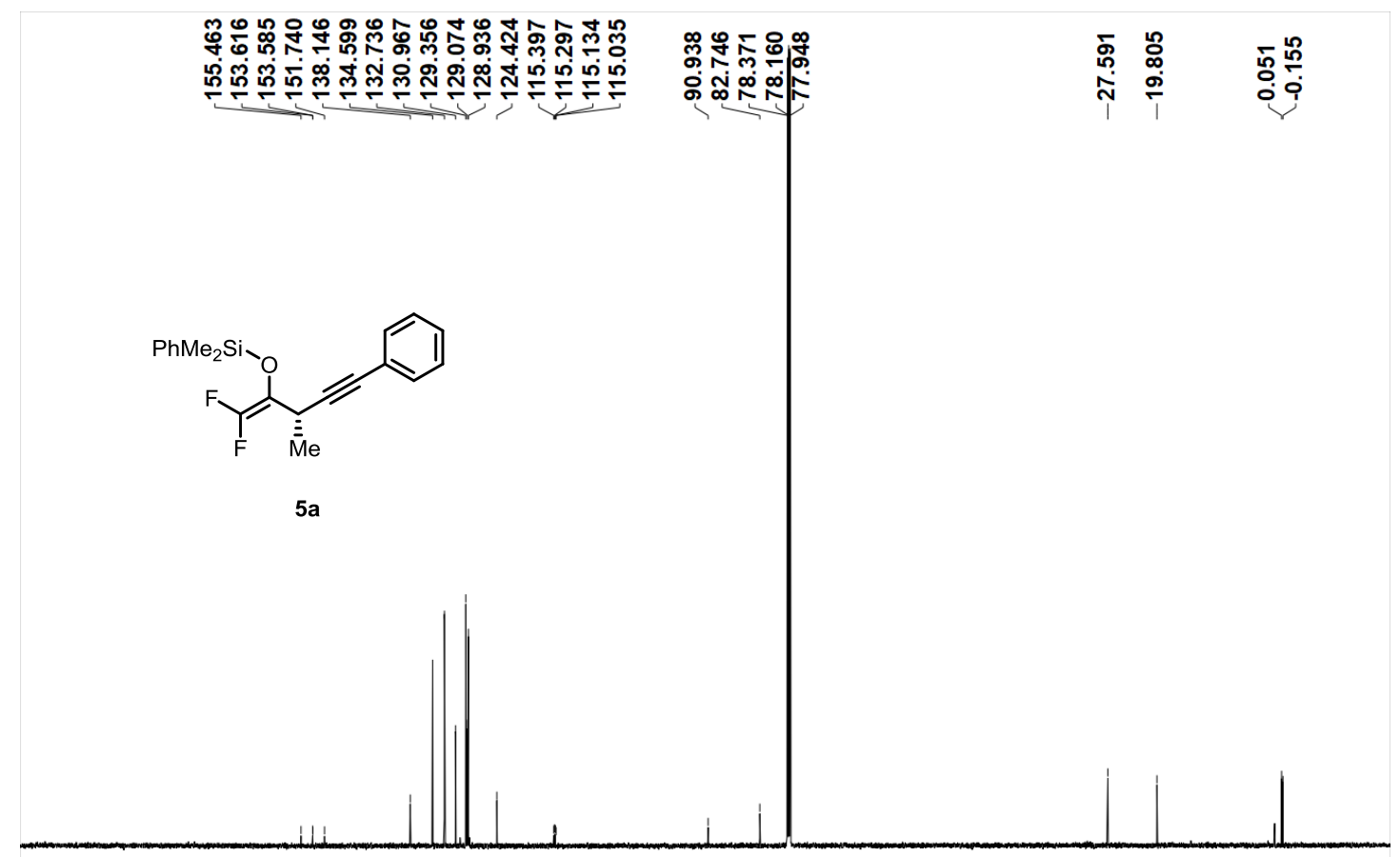

\begin{tabular}{lllllllllllllllllllllllll}
\hline 0 & 190 & 180 & 170 & 160 & 150 & 140 & 130 & 120 & 110 & 100 & 90 & 80 & 70 & 60 & 50 & 40 & 30 & 20 & 10 & 0 & -10
\end{tabular}

${ }^{19} \mathrm{~F}$ NMR of $5 \mathrm{a}\left(\mathrm{CDCl}_{3}, 376 \mathrm{MHz}, 25{ }^{\circ} \mathrm{C}\right)$
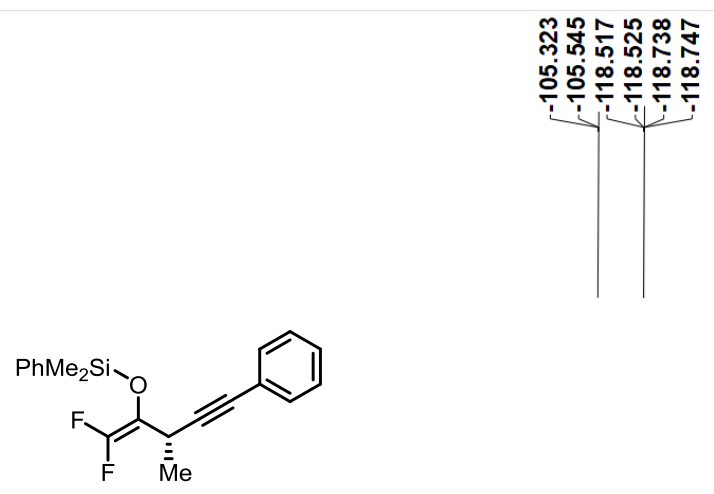

$5 a$

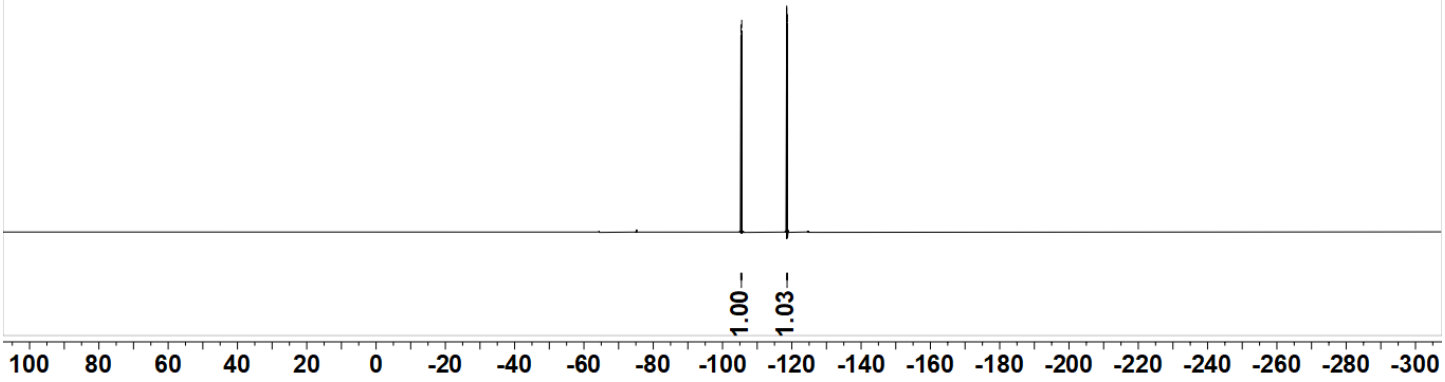


${ }^{1} \mathrm{H}$ NMR of $5 \mathrm{~b}\left(\mathrm{CDCl}_{3}, 400 \mathrm{MHz}, 25^{\circ} \mathrm{C}\right)$

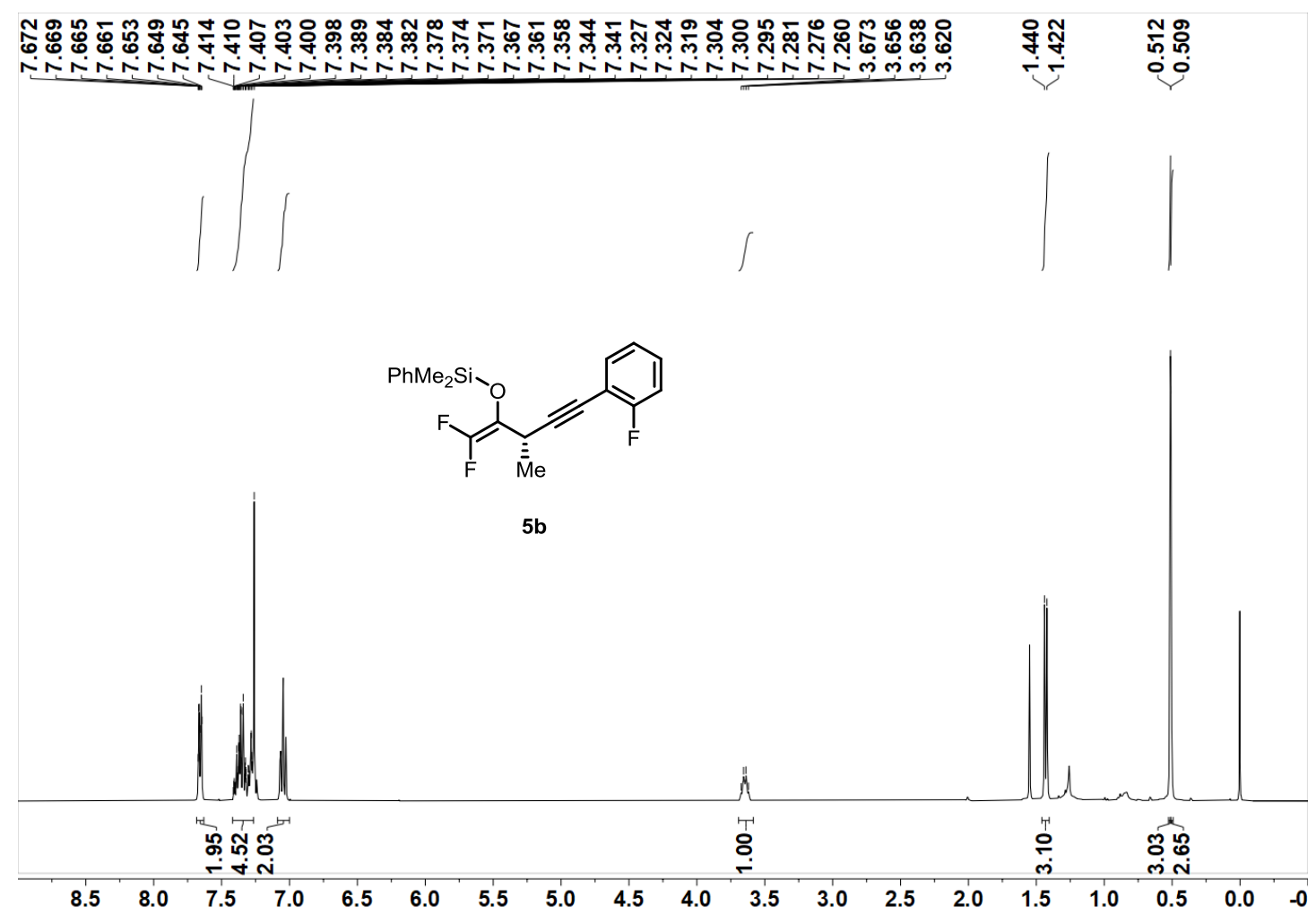

${ }^{13} \mathrm{C}$ NMR of $5 \mathrm{~b}\left(\mathrm{CDCl}_{3}, 151 \mathrm{MHz}, 25{ }^{\circ} \mathrm{C}\right)$

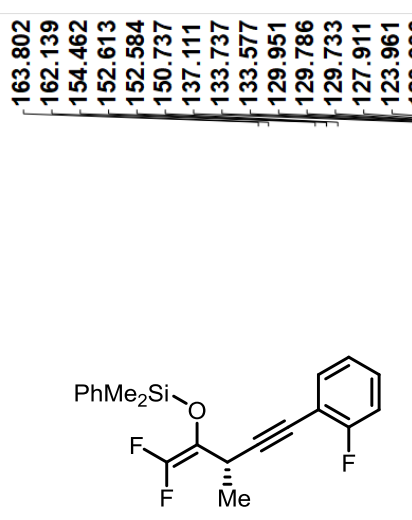

$5 b$

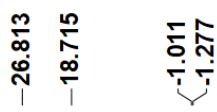

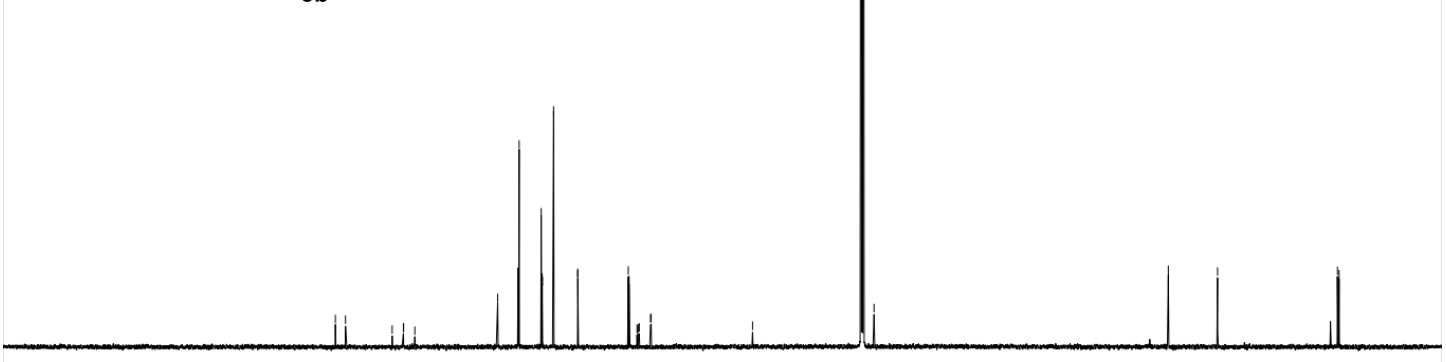

$\begin{array}{lllllllllllllllllllllllll}210 & 200 & 190 & 180 & 170 & 160 & 150 & 140 & 130 & 120 & 110 & 100 & 90 & 80 & 70 & 60 & 50 & 40 & 30 & 20 & 10 & 0 & -10\end{array}$ 
${ }^{19} \mathrm{~F}$ NMR of $5 \mathrm{~b}\left(\mathrm{CDCl}_{3}, 376 \mathrm{MHz}, 25^{\circ} \mathrm{C}\right)$

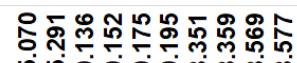

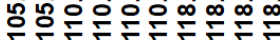

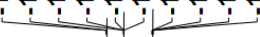<smiles>COOC(C#Cc1ccccc1F)[C@@H](C)OC</smiles>

5b

ชุำ

$\begin{array}{llllllllllllllllllllllllllll}100 & 80 & 60 & 40 & 20 & 0 & -20 & -40 & -60 & -80 & -100 & -120 & -140 & -160 & -180 & -200 & -220 & -240 & -260 & -280 & -300\end{array}$

${ }^{1} \mathrm{H}$ NMR of $5 \mathrm{c}\left(\mathrm{CDCl}_{3}, 400 \mathrm{MHz}, 25^{\circ} \mathrm{C}\right)$

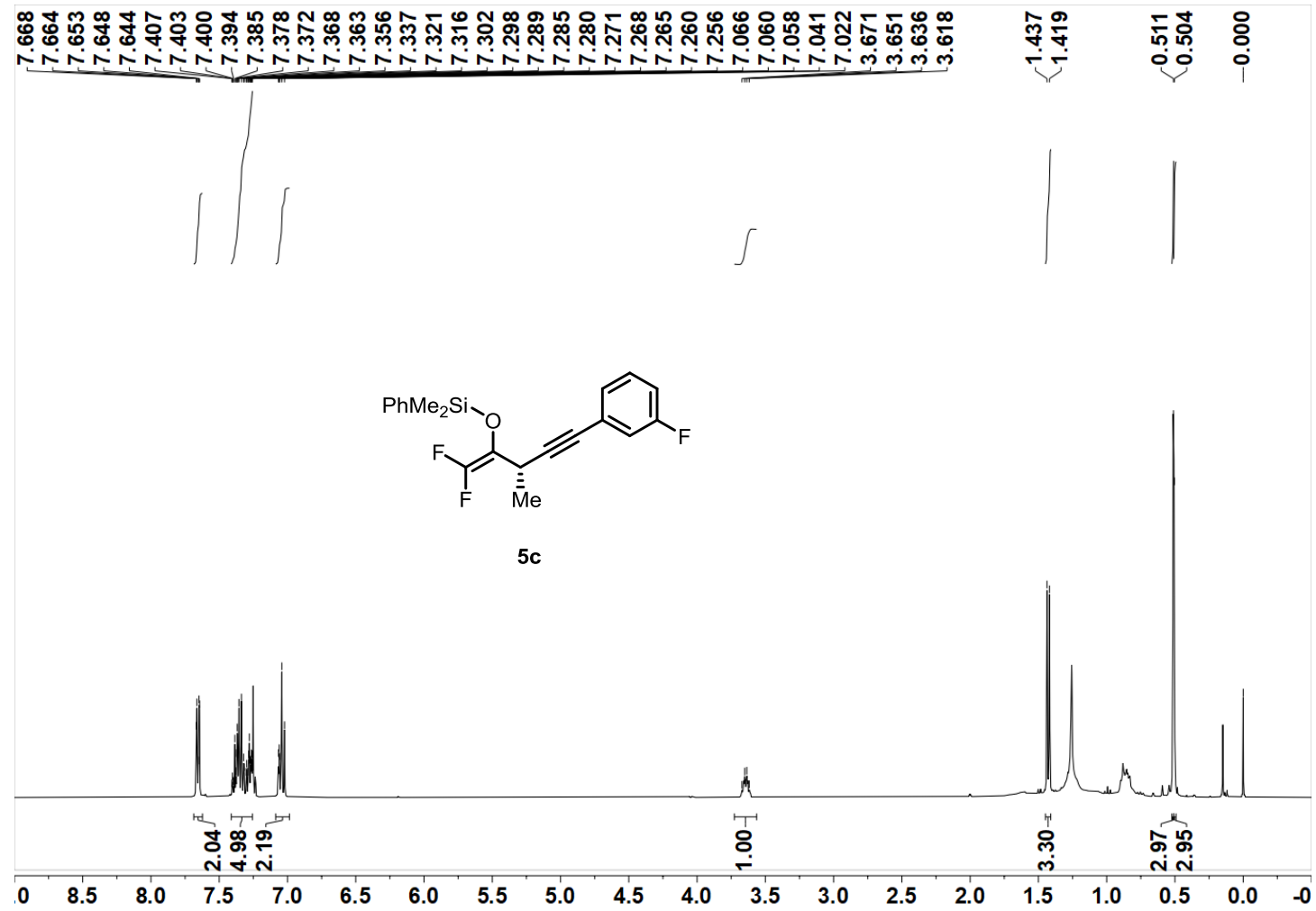


${ }^{13} \mathrm{C}$ NMR of $5 \mathrm{c}\left(\mathrm{CDCl}_{3}, 151 \mathrm{MHz}, 25^{\circ} \mathrm{C}\right)$

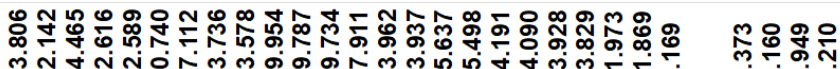

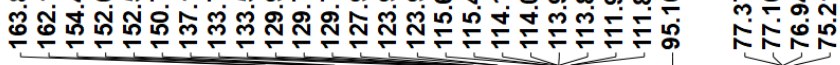

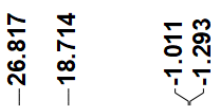

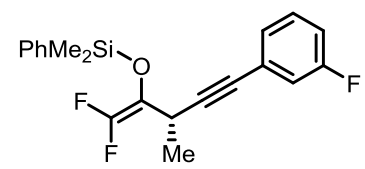

$5 c$

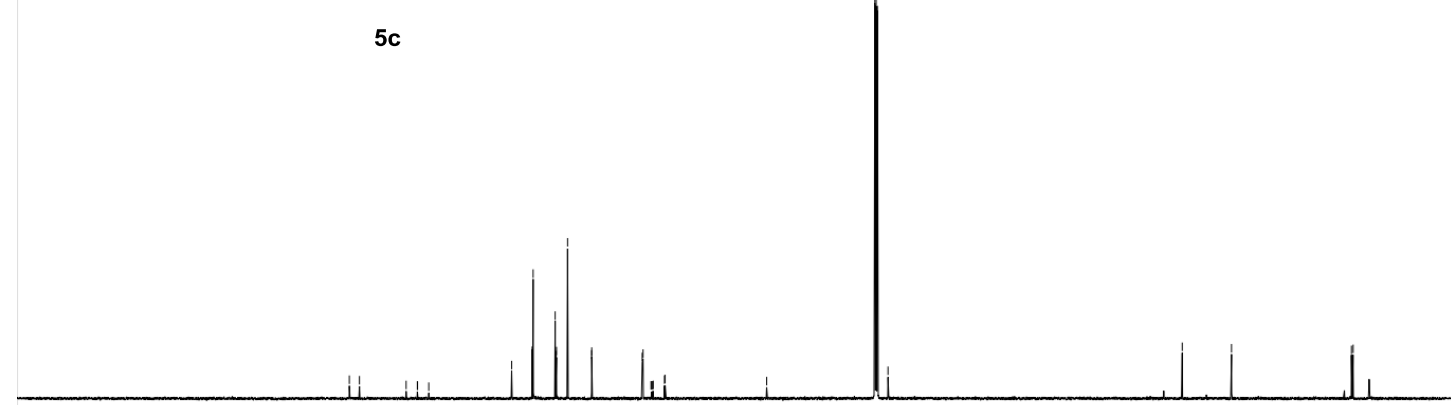

$\begin{array}{llllllllllllllllllllllll}210 & 200 & 190 & 180 & 170 & 160 & 150 & 140 & 130 & 120 & 110 & 100 & 90 & 80 & 70 & 60 & 50 & 40 & 30 & 20 & 10 & 0 & -10\end{array}$

${ }^{19} \mathrm{~F}$ NMR of $5 \mathrm{c}\left(\mathrm{CDCl}_{3}, 376 \mathrm{MHz}, 25^{\circ} \mathrm{C}\right)$
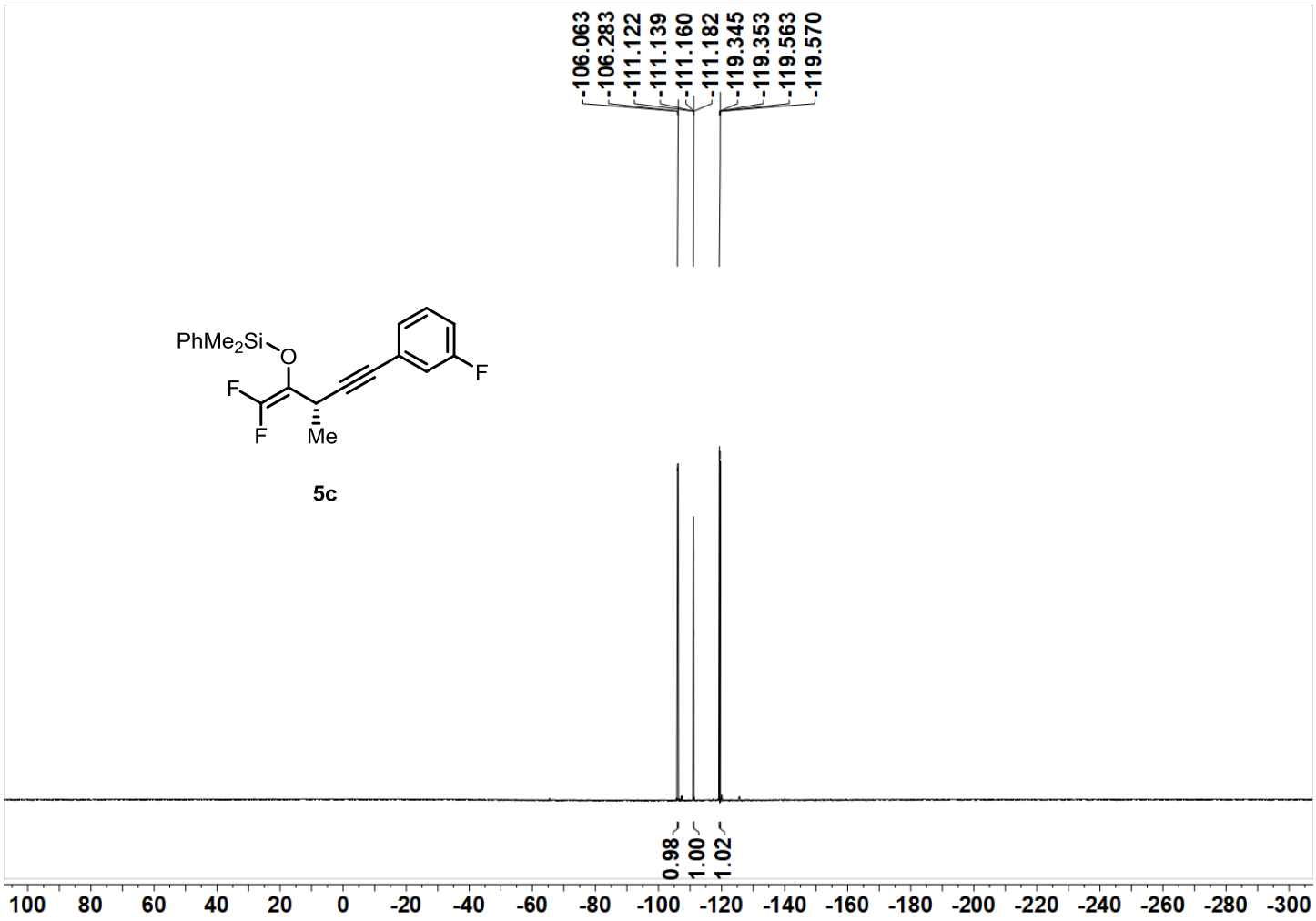
${ }^{1} \mathrm{H}$ NMR of $5 \mathrm{~d}\left(\mathrm{CDCl}_{3}, 600 \mathrm{MHz}, 25{ }^{\circ} \mathrm{C}\right)$

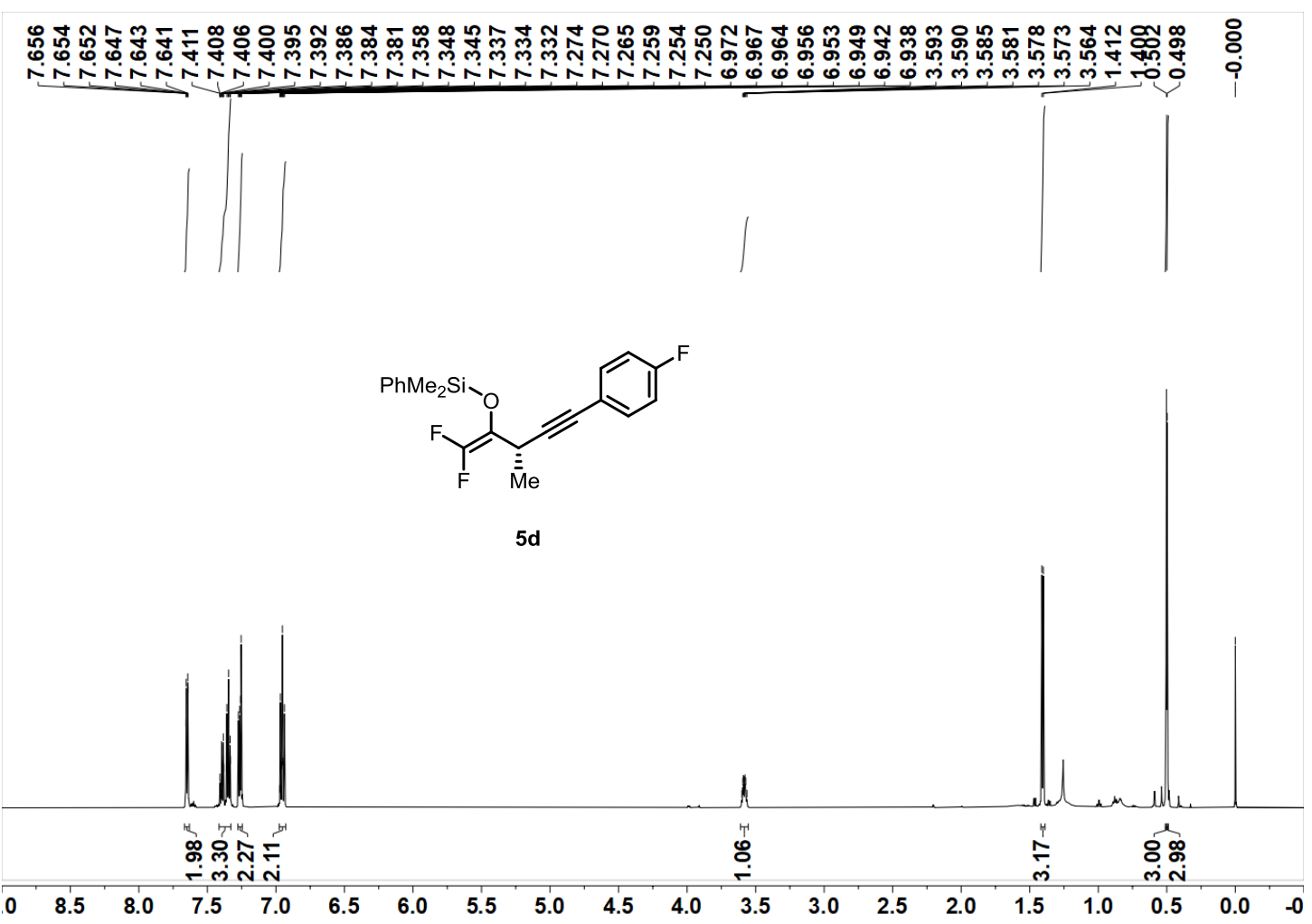

${ }^{13} \mathrm{C}$ NMR of $5 \mathrm{~d}\left(\mathrm{CDCl}_{3}, 151 \mathrm{MHz}, 25^{\circ} \mathrm{C}\right)$

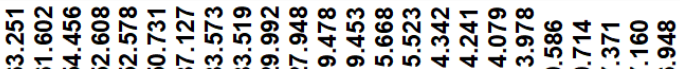

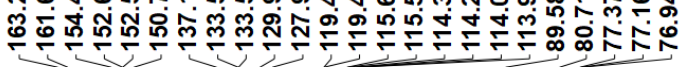

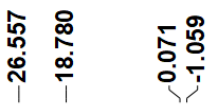

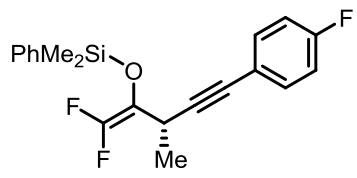

5d

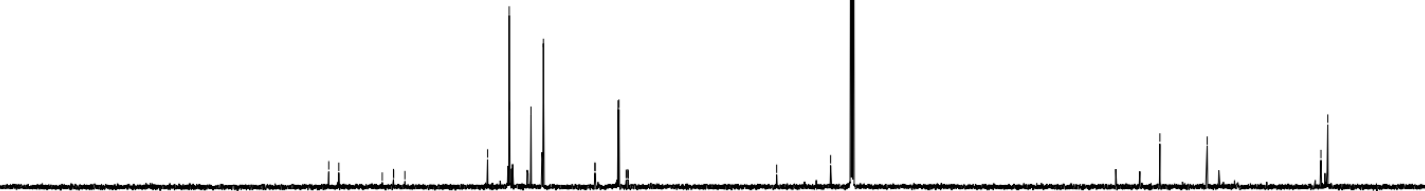

$\begin{array}{lllllllllllllllllllllllll}210 & 200 & 190 & 180 & 170 & 160 & 150 & 140 & 130 & 120 & 110 & 100 & 90 & 80 & 70 & 60 & 50 & 40 & 30 & 20 & 10 & 0 & -10\end{array}$ 
${ }^{19} \mathrm{~F}$ NMR of $5 \mathrm{~d}\left(\mathrm{CDCl}_{3}, 565 \mathrm{MHz}, 25^{\circ} \mathrm{C}\right)$
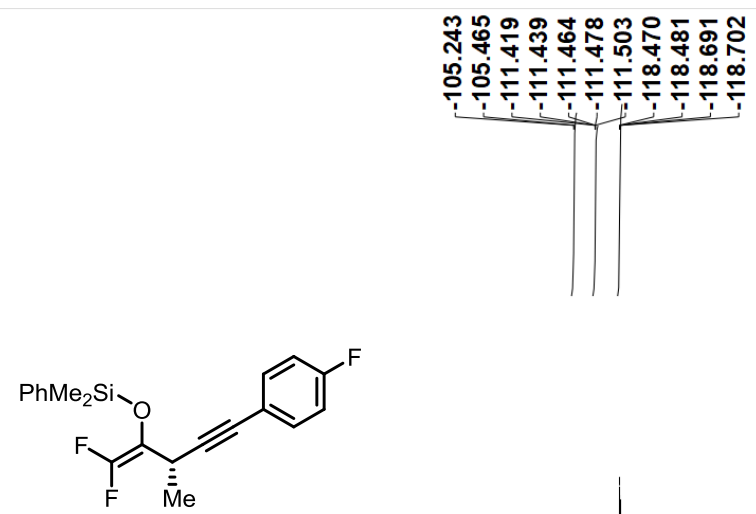

5d

\%o

$\begin{array}{lllllllllllllllllllllllllllll}100 & 80 & 60 & 40 & 20 & 0 & -20 & -40 & -60 & -80 & -100 & -120 & -140 & -160 & -180 & -200 & -220 & -240 & -260 & -280 & -300\end{array}$

${ }^{1} \mathrm{H}$ NMR of $5 \mathrm{e}\left(\mathrm{CDCl}_{3}, 400 \mathrm{MHz}, 25^{\circ} \mathrm{C}\right)$

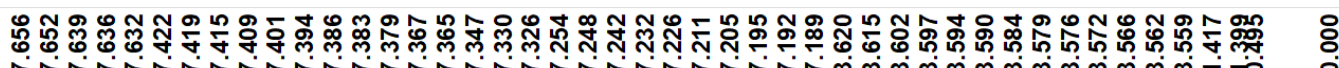

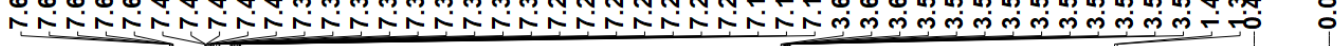
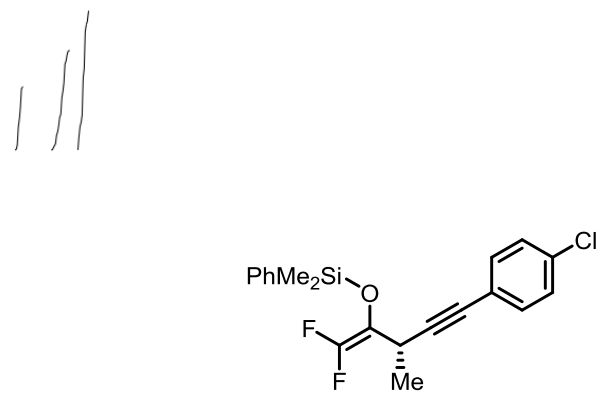

$5 e$

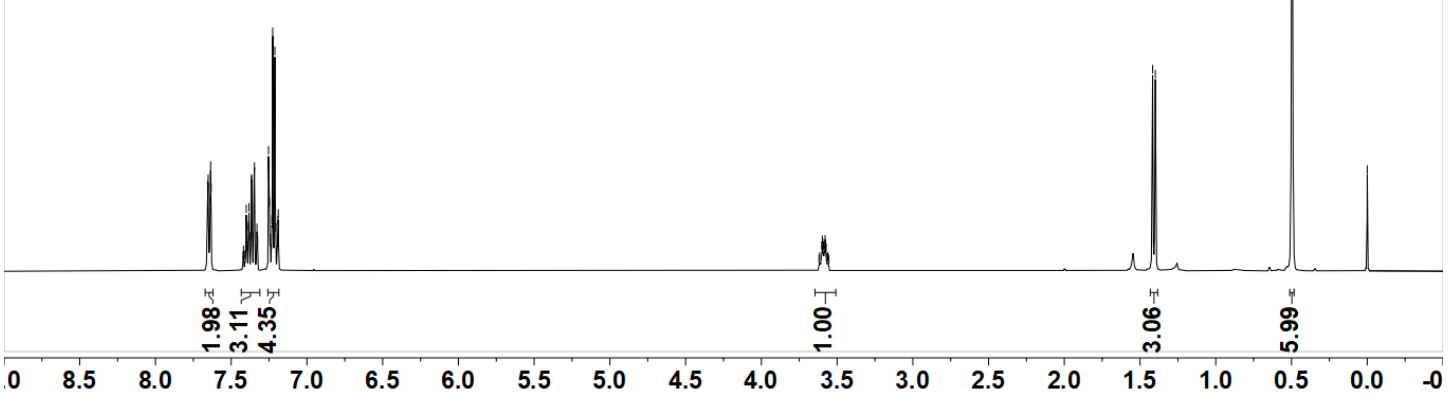


${ }^{13} \mathrm{C}$ NMR of $5 \mathrm{e}\left(\mathrm{CDCl}_{3}, 151 \mathrm{MHz}, 25^{\circ} \mathrm{C}\right)$

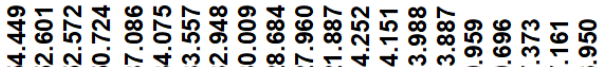

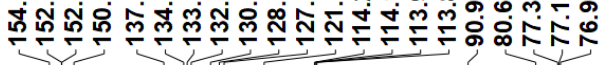

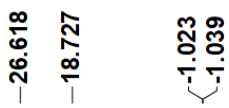

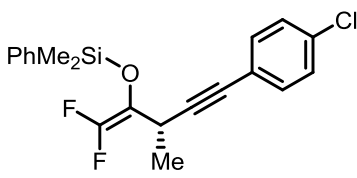

$5 e$

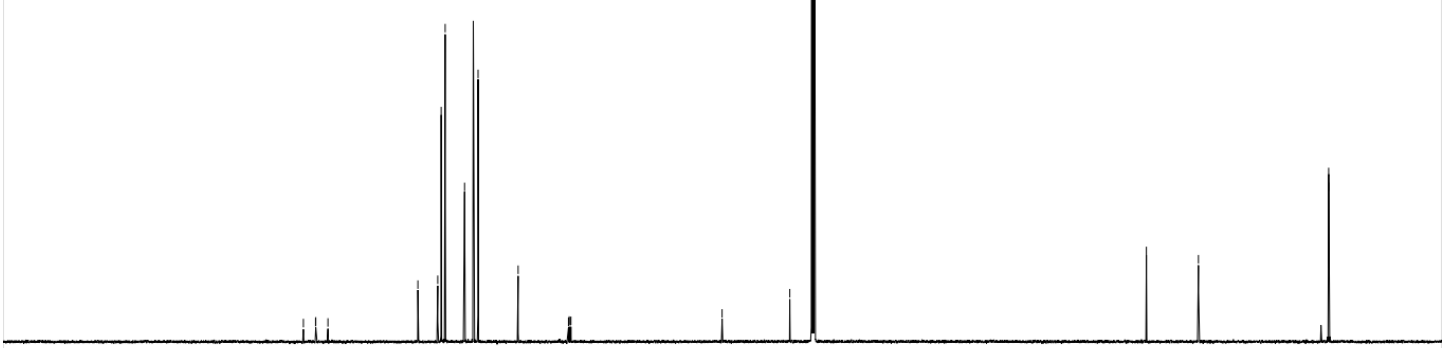

$\begin{array}{lllllllllllllllllllllll}10 & 190 & 180 & 170 & 160 & 150 & 140 & 130 & 120 & 110 & 100 & 90 & 80 & 70 & 60 & 50 & 40 & 30 & 20 & 10 & 0 & -10\end{array}$

${ }^{19} \mathrm{~F}$ NMR of $5 \mathrm{e}\left(\mathrm{CDCl}_{3}, 376 \mathrm{MHz}, 25^{\circ} \mathrm{C}\right)$
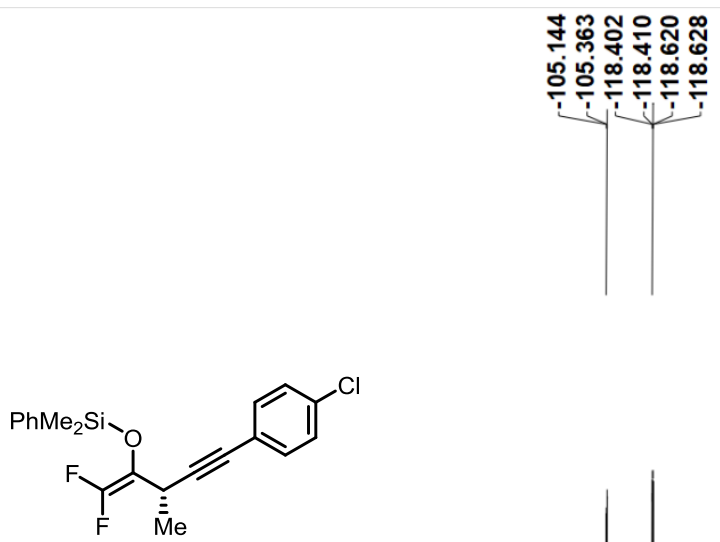

5 e

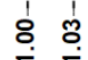

$\begin{array}{llllllllllllllllllllllllllll}100 & 80 & 60 & 40 & 20 & 0 & -20 & -40 & -60 & -80 & -100 & -120 & -140 & -160 & -180 & -200 & -220 & -240 & -260 & -280 & -300\end{array}$ 
${ }^{1} \mathrm{H}$ NMR of $5 \mathrm{f}\left(\mathrm{CDCl}_{3}, 600 \mathrm{MHz}, 25^{\circ} \mathrm{C}\right)$

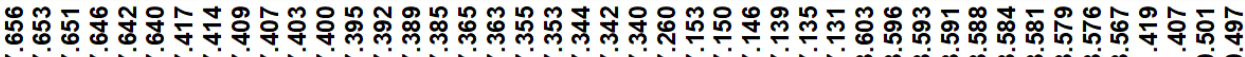

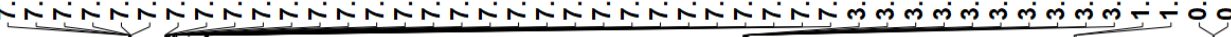
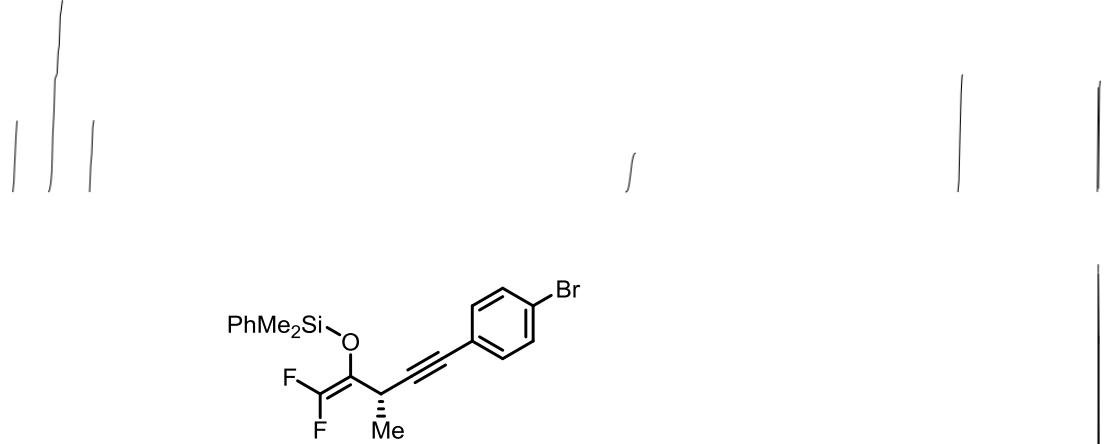

$5 f$

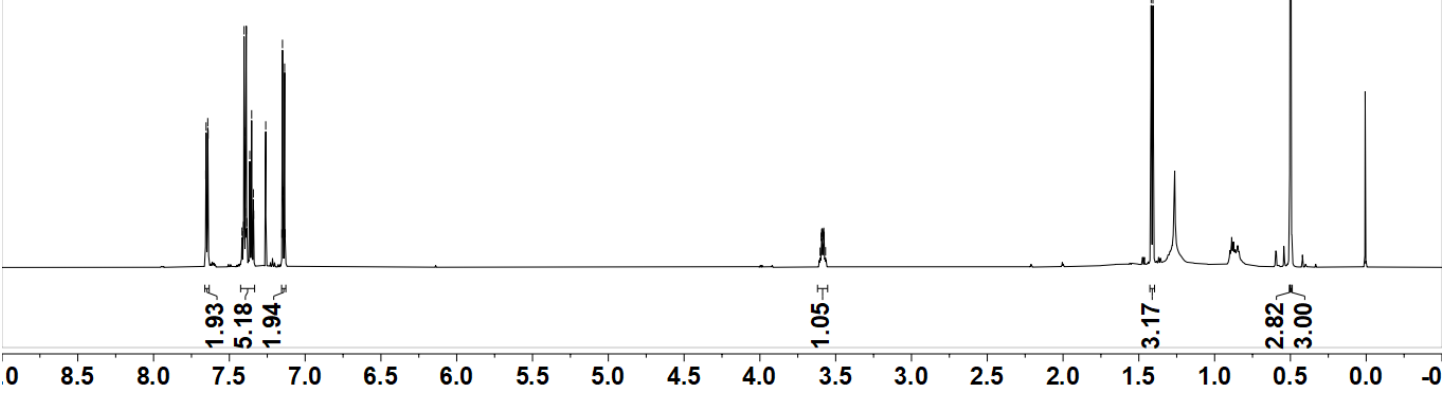

${ }^{13} \mathrm{C}$ NMR of $5 \mathrm{f}\left(\mathrm{CDCl}_{3}, 151 \mathrm{MHz}, 25^{\circ} \mathrm{C}\right)$

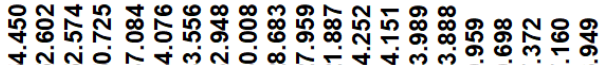

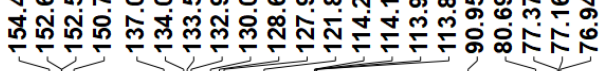

市<smiles>C[C@H](O[SiH2])/C(O[AlH2])=C(/F)C#Cc1ccc(Br)cc1</smiles>

$5 \mathbf{f}$

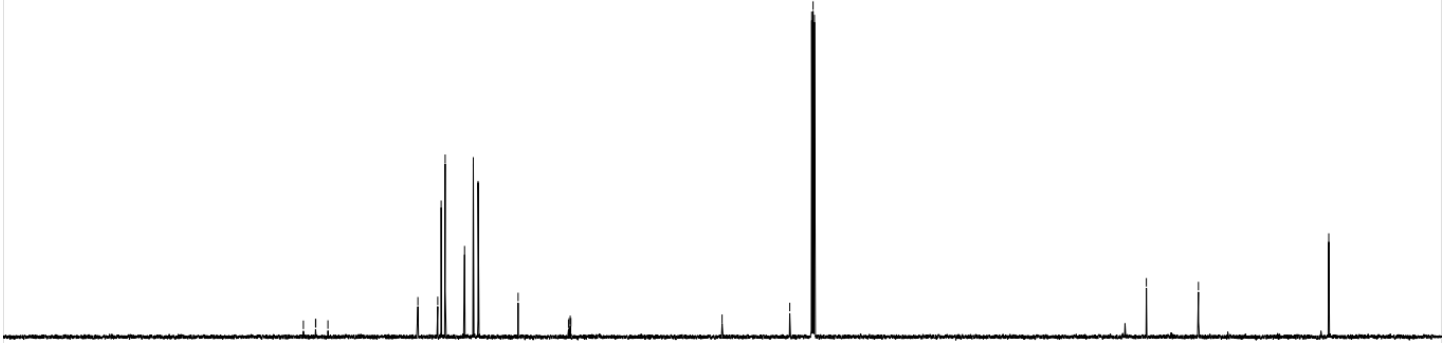

$\begin{array}{lllllllllllllllllllllll}10 & 190 & 180 & 170 & 160 & 150 & 140 & 130 & 120 & 110 & 100 & 90 & 80 & 70 & 60 & 50 & 40 & 30 & 20 & 10 & 0 & -10\end{array}$ 
${ }^{19} \mathrm{~F}$ NMR of $5 \mathrm{f}\left(\mathrm{CDCl}_{3}, 376 \mathrm{MHz}, 25^{\circ} \mathrm{C}\right)$

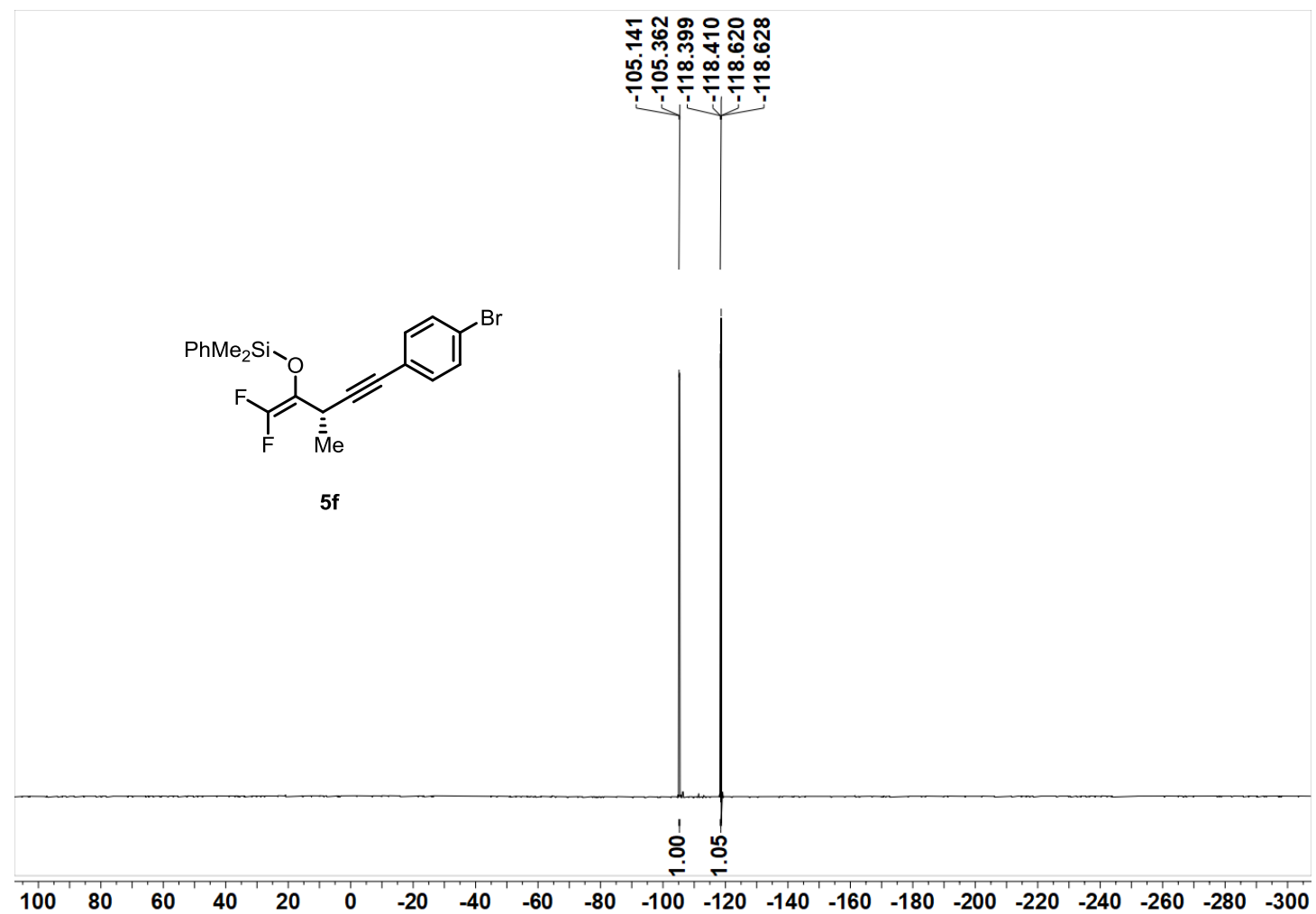

${ }^{1} \mathrm{H}$ NMR of $5 \mathrm{~g}\left(\mathrm{CDCl}_{3}, 600 \mathrm{MHz}, 25^{\circ} \mathrm{C}\right)$

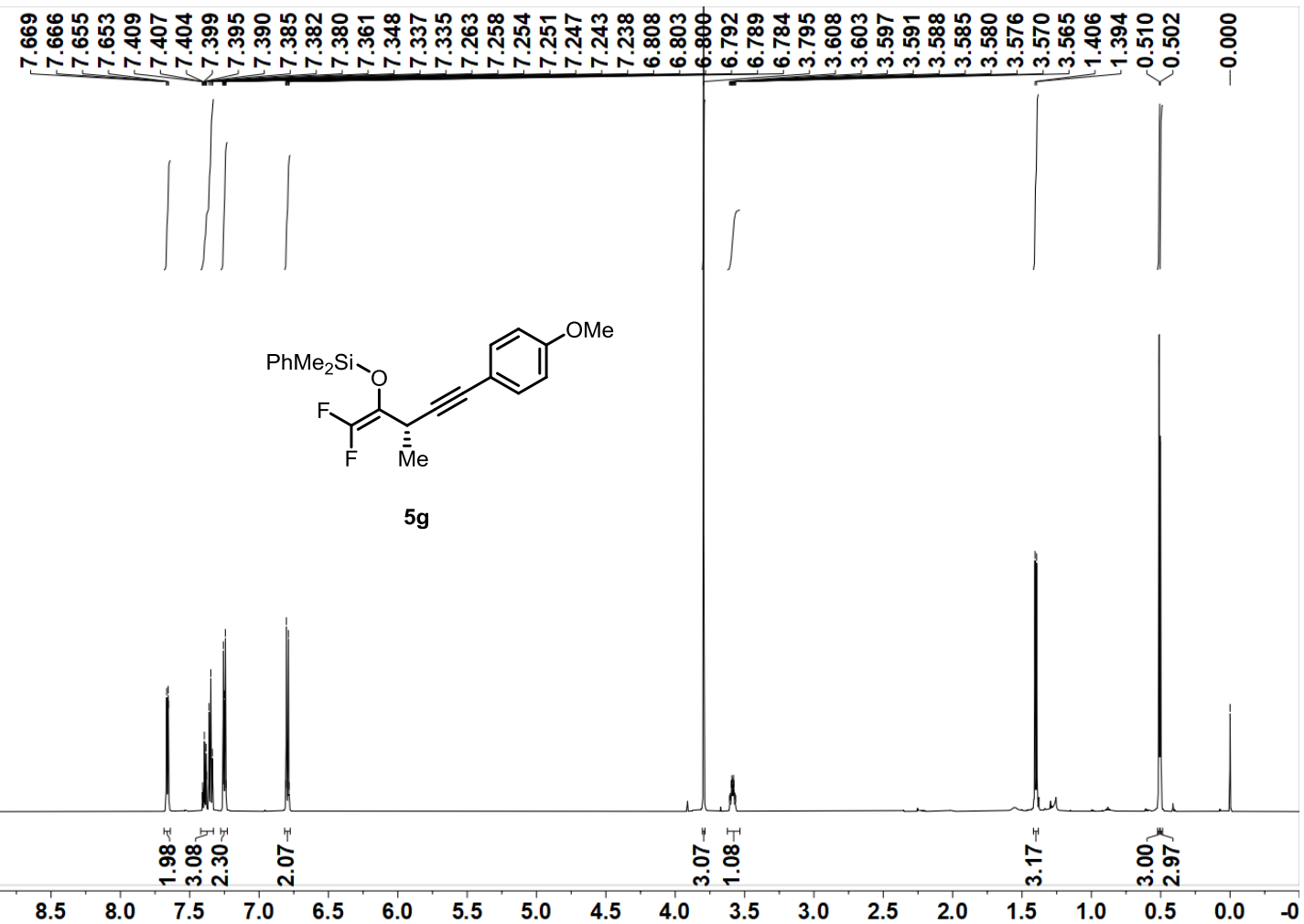


${ }^{13} \mathrm{C}$ NMR of $5 \mathrm{~g}\left(\mathrm{CDCl}_{3}, 151 \mathrm{MHz}, 25^{\circ} \mathrm{C}\right)$

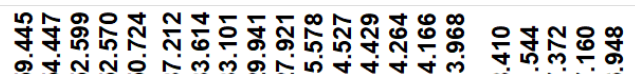

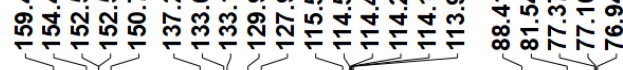

๙్లై

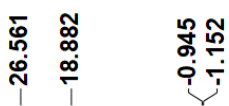

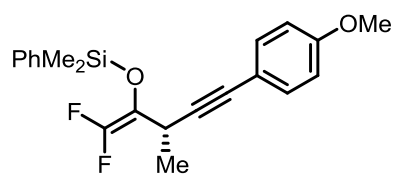

$5 \mathrm{~g}$

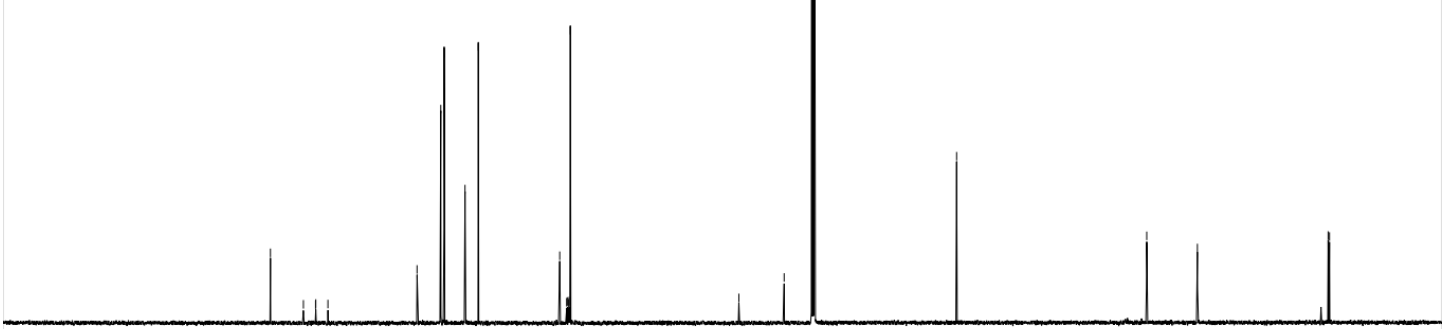

$\begin{array}{llllllllllllllllllllll}190 & 180 & 170 & 160 & 150 & 140 & 130 & 120 & 110 & 100 & 90 & 80 & 70 & 60 & 50 & 40 & 30 & 20 & 10 & 0 & -10\end{array}$

${ }^{19} \mathrm{~F}$ NMR of $5 \mathrm{~g}\left(\mathrm{CDCl}_{3}, 376 \mathrm{MHz}, 25^{\circ} \mathrm{C}\right)$
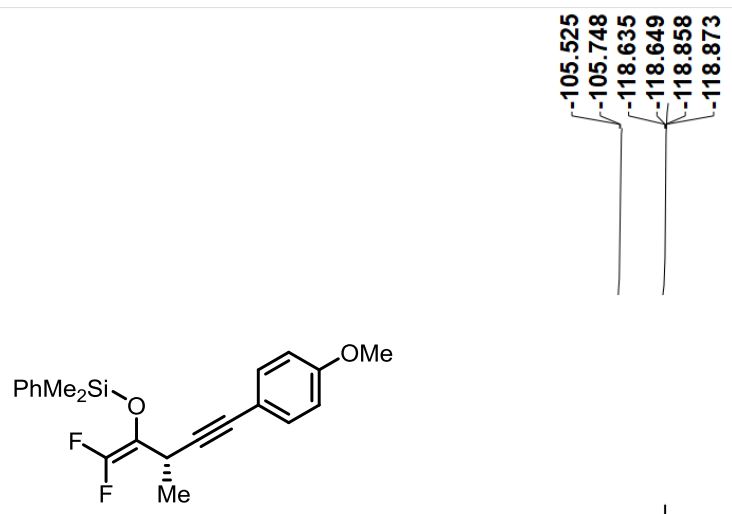

59

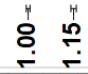

$\begin{array}{llllllllllllllllllllllllll}100 & 80 & 60 & 40 & 20 & 0 & -20 & -40 & -60 & -80 & -100 & -120 & -140 & -160 & -180 & -200 & -220 & -240 & -260 & -280 & -300\end{array}$ 
${ }^{1} \mathrm{H}$ NMR of $5 \mathrm{~h}\left(\mathrm{CDCl}_{3}, 400 \mathrm{MHz}, 25^{\circ} \mathrm{C}\right)$

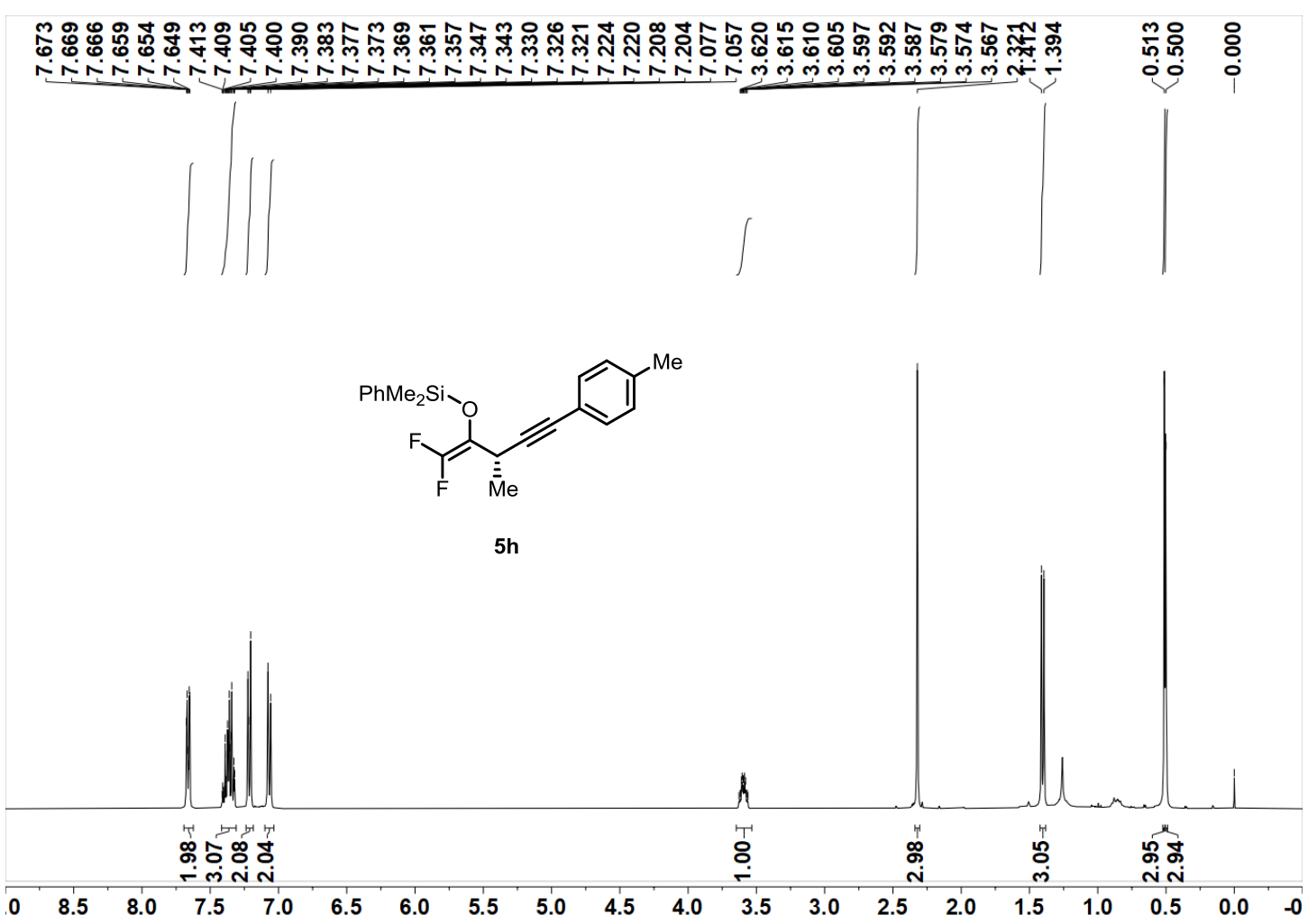

${ }^{13} \mathrm{C}$ NMR of $5 \mathrm{~h}\left(\mathrm{CDCl}_{3}, 151 \mathrm{MHz}, 25^{\circ} \mathrm{C}\right)$

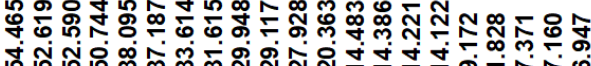

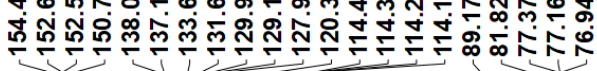

兽品范

ஸิ

i্s

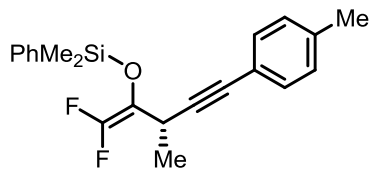

$5 \mathrm{~h}$

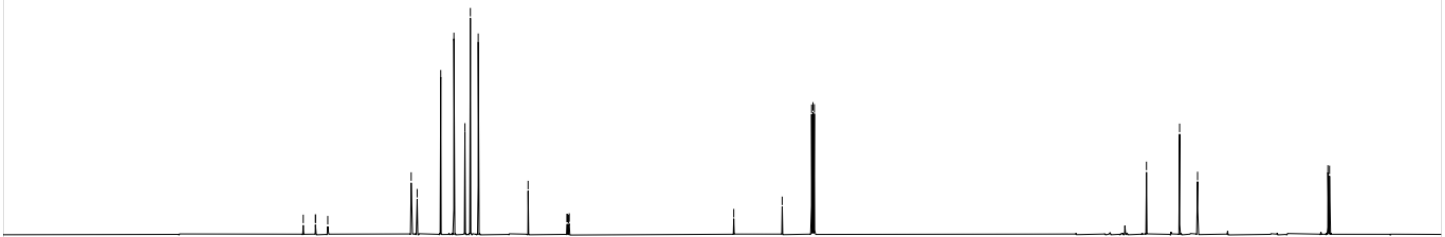

\begin{tabular}{lllllllllllllllllllllll}
\hline 0 & 190 & 180 & 170 & 160 & 150 & 140 & 130 & 120 & 110 & 100 & 90 & 80 & 70 & 60 & 50 & 40 & 30 & 20 & 10 & 0 & -10
\end{tabular} 
${ }^{19} \mathrm{~F}$ NMR of $5 \mathrm{~h}\left(\mathrm{CDCl}_{3}, 376 \mathrm{MHz}, 25^{\circ} \mathrm{C}\right)$
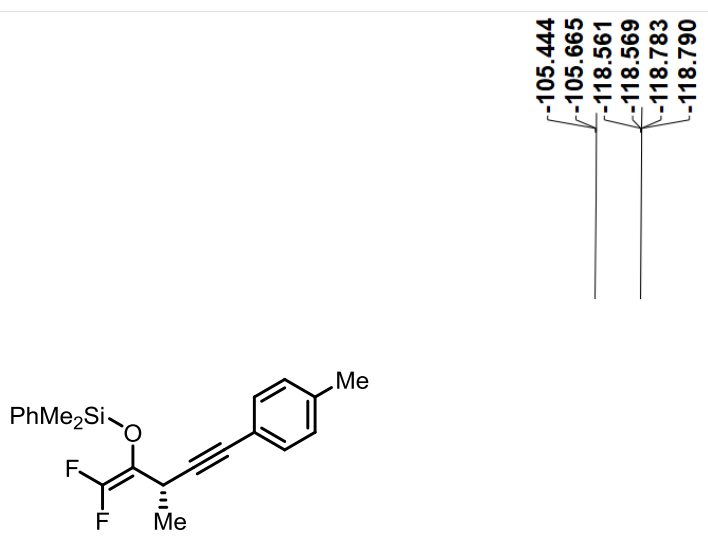

$5 h$

\section{\&े \&}

$\begin{array}{llllllllllllllllllllllll}100 & 80 & 60 & 40 & 20 & 0 & -20 & -40 & -60 & -80 & -100 & -120 & -140 & -160 & -180 & -200 & -220 & -240 & -260 & -280 & -300\end{array}$

${ }^{1} \mathrm{H}$ NMR of $3 \mathrm{ah}\left(\mathrm{CDCl}_{3}, 400 \mathrm{MHz}, 25^{\circ} \mathrm{C}\right)$

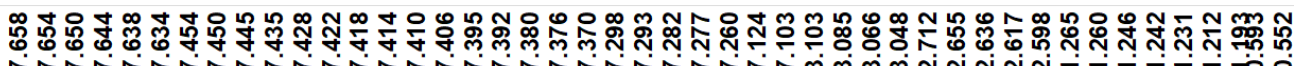

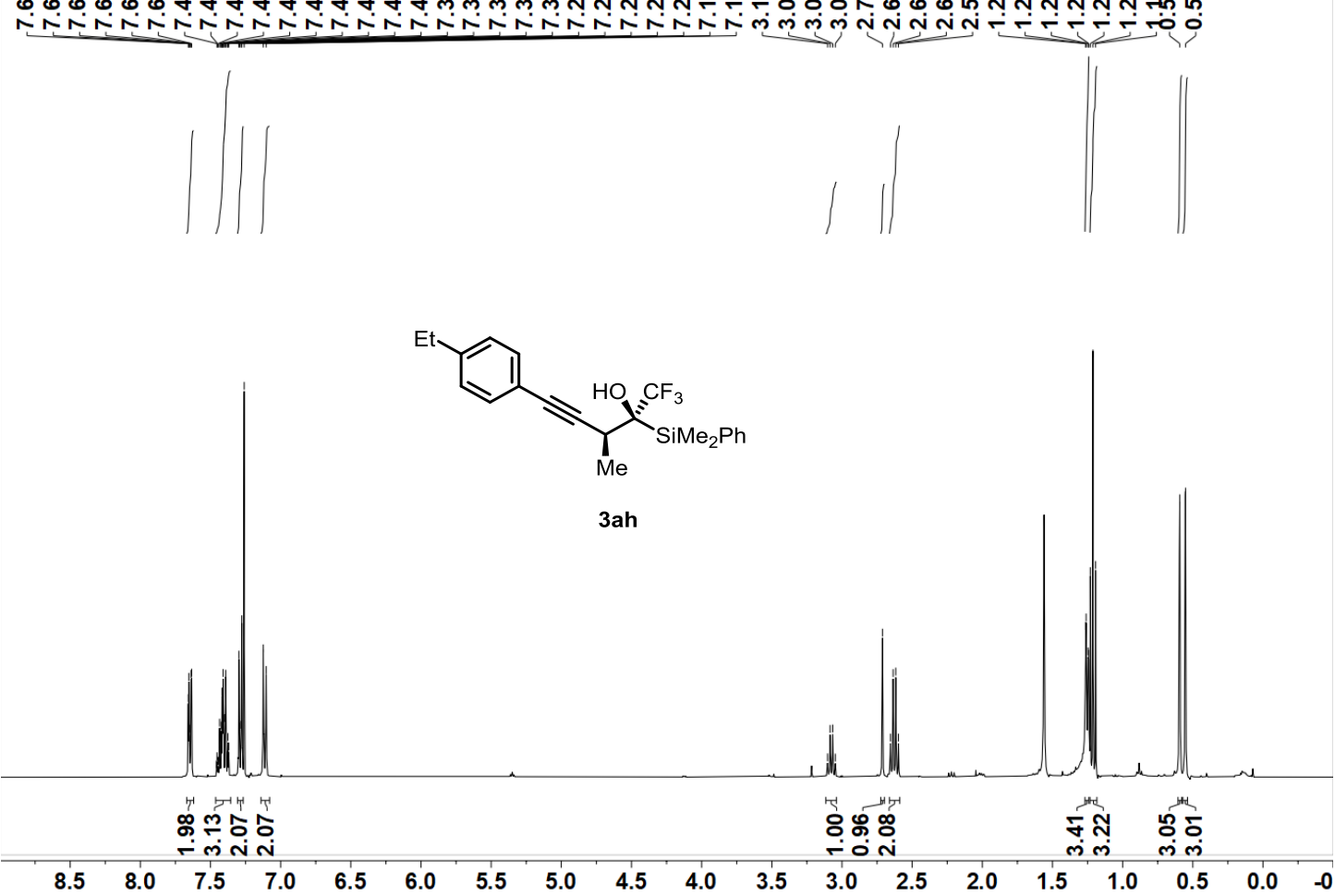


${ }^{13} \mathrm{C}$ NMR of $3 \mathrm{ah}\left(\mathrm{CDCl}_{3}, 101 \mathrm{MHz}, 25{ }^{\circ} \mathrm{C}\right)$

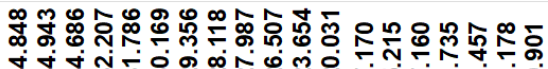

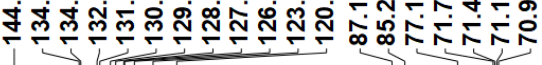

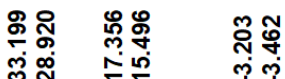

Et<smiles>C#CC(C(O)O)C(O)(F)c1ccccc1</smiles>

3ah

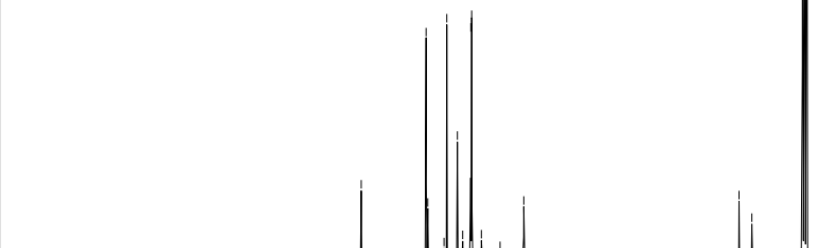

$\begin{array}{lllllllllllllllllllllllllll}10 & 190 & 180 & 170 & 160 & 150 & 140 & 130 & 120 & 110 & 100 & 90 & 80 & 70 & 60 & 50 & 40 & 30 & 20 & 10 & 0 & -10\end{array}$

${ }^{19} \mathrm{~F}$ NMR of $3 \mathrm{ah}\left(\mathrm{CDCl}_{3}, 376 \mathrm{MHz}, 25^{\circ} \mathrm{C}\right)$

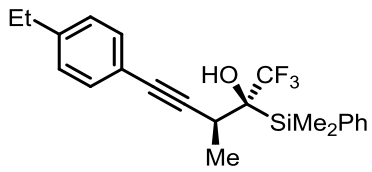

$3 a h$ 
${ }^{1} \mathrm{H}$ NMR of $5 \mathrm{i}\left(\mathrm{CDCl}_{3}, 600 \mathrm{MHz}, 25^{\circ} \mathrm{C}\right)$

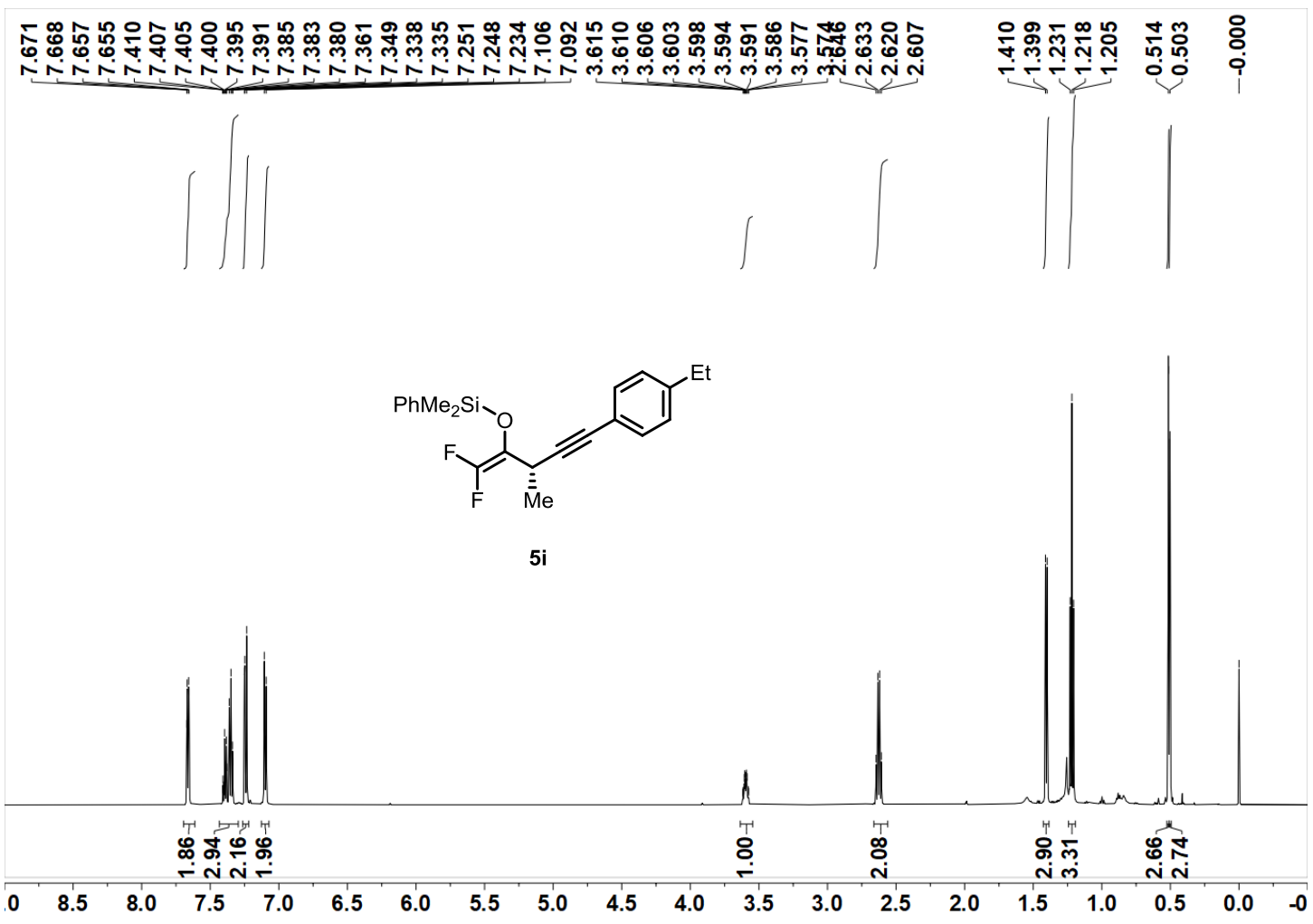

${ }^{13} \mathrm{C}$ NMR of $5 \mathrm{i}\left(\mathrm{CDCl}_{3}, 151 \mathrm{MHz}, 25{ }^{\circ} \mathrm{C}\right)$

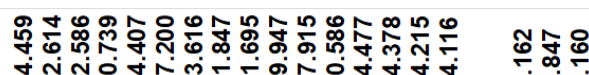

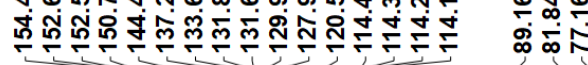

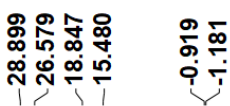

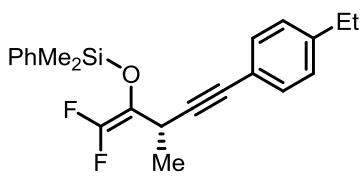

$5 \mathbf{i}$

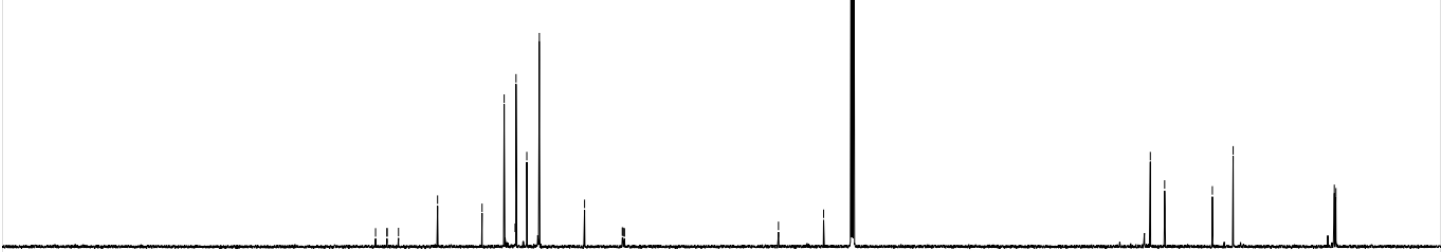

$\begin{array}{lllllllllllllllllllllllllll}210 & 200 & 190 & 180 & 170 & 160 & 150 & 140 & 130 & 120 & 110 & 100 & 90 & 80 & 70 & 60 & 50 & 40 & 30 & 20 & 10 & 0 & -10\end{array}$ 
${ }^{19} \mathrm{~F}$ NMR of $5 \mathrm{i}\left(\mathrm{CDCl}_{3}, 565 \mathrm{MHz}, 25^{\circ} \mathrm{C}\right)$

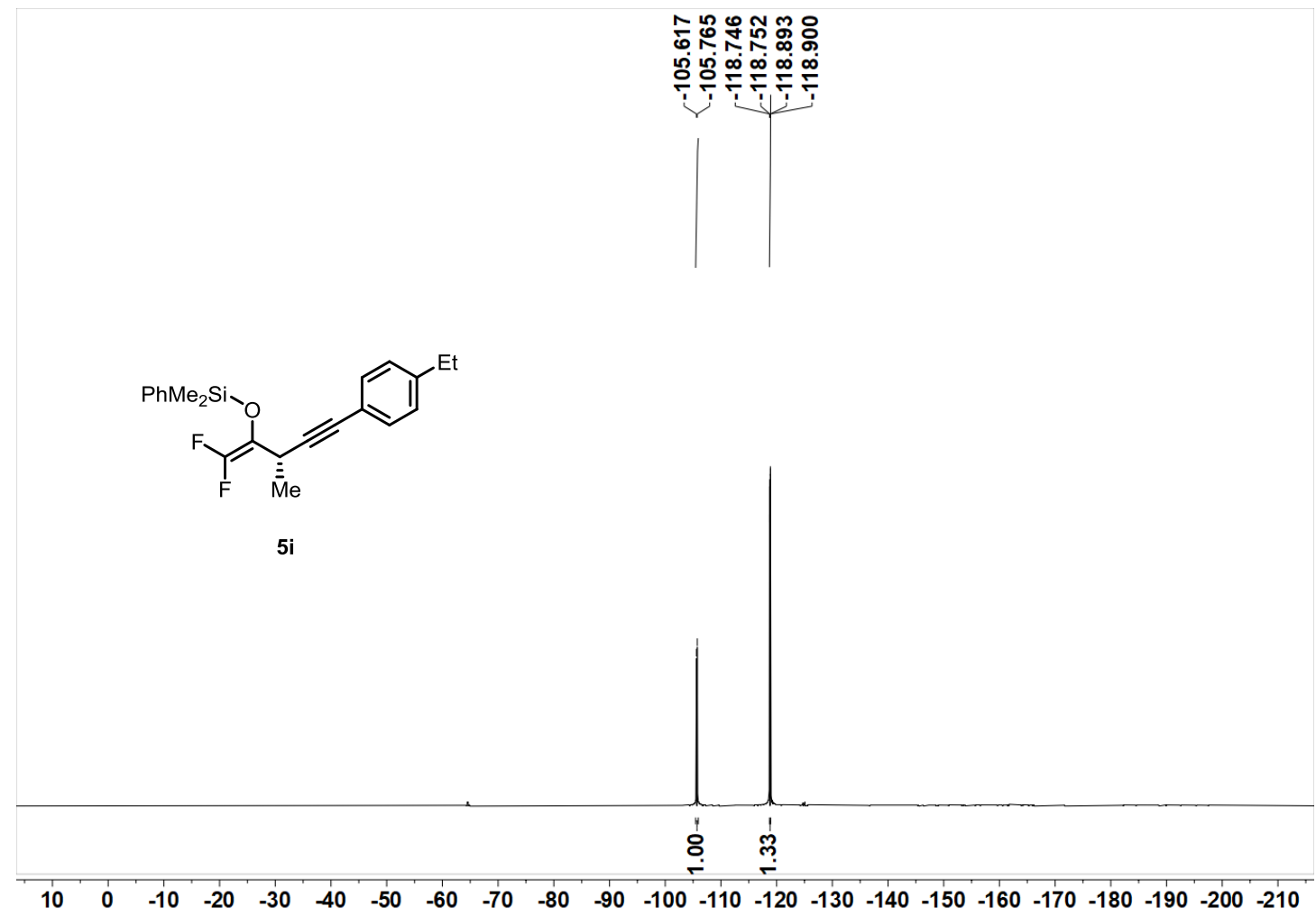

${ }^{1} \mathrm{H}$ NMR of $5 \mathrm{j}\left(\mathrm{CDCl}_{3}, 600 \mathrm{MHz}, 25^{\circ} \mathrm{C}\right)$

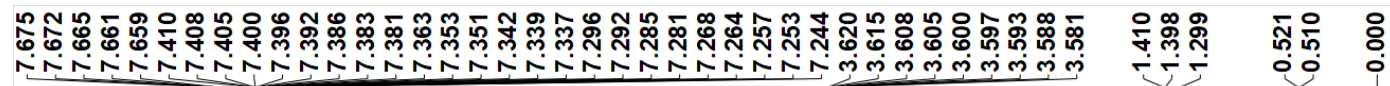

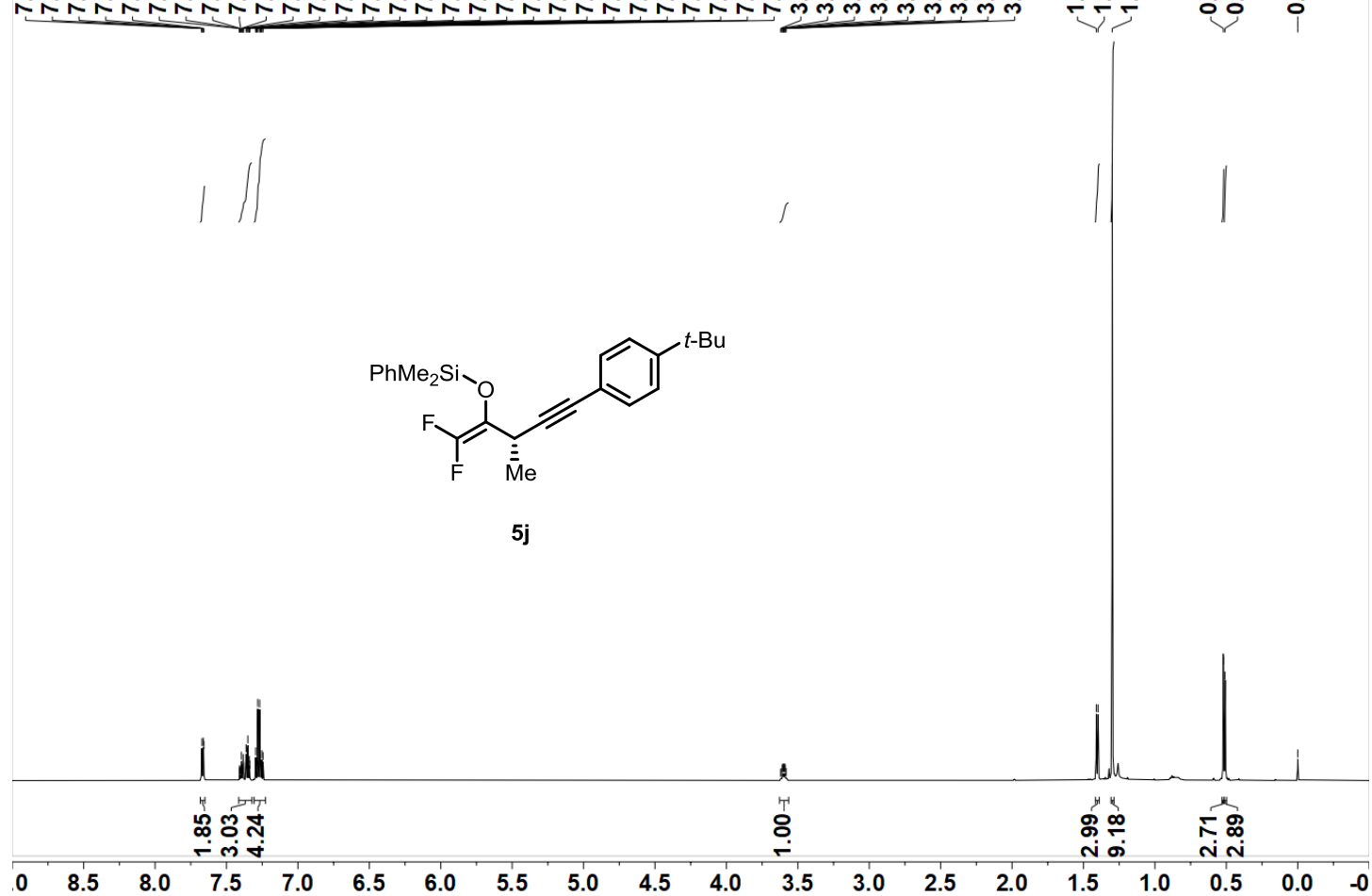


${ }^{13} \mathrm{C}$ NMR of $5 \mathrm{j}\left(\mathrm{CDCl}_{3}, 151 \mathrm{MHz}, 25{ }^{\circ} \mathrm{C}\right)$

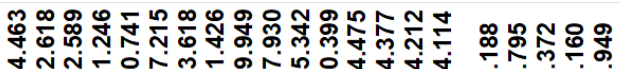

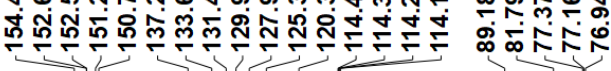

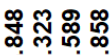

峁的边

递<smiles>C[C@H](C#Cc1ccc(C(C)(C)C)cc1)C(O[SiH3])=C(F)F</smiles>

5j

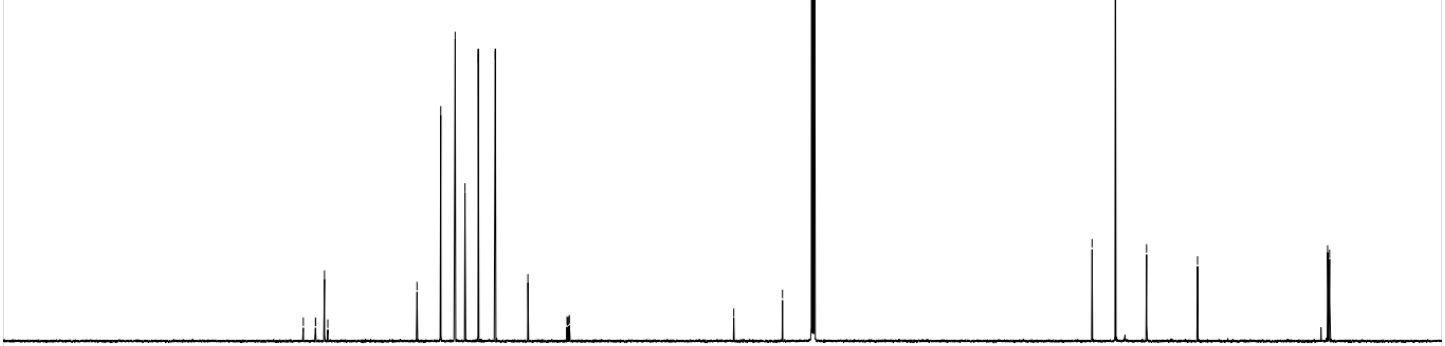

$\begin{array}{lllllllllllllllllllllllllllll}190 & 180 & 170 & 160 & 150 & 140 & 130 & 120 & 110 & 100 & 90 & 80 & 70 & 60 & 50 & 40 & 30 & 20 & 10 & 0 & -10\end{array}$

${ }^{19} \mathrm{~F}$ NMR of $5 \mathrm{j}\left(\mathrm{CDCl}_{3}, 376 \mathrm{MHz}, 25^{\circ} \mathrm{C}\right)$
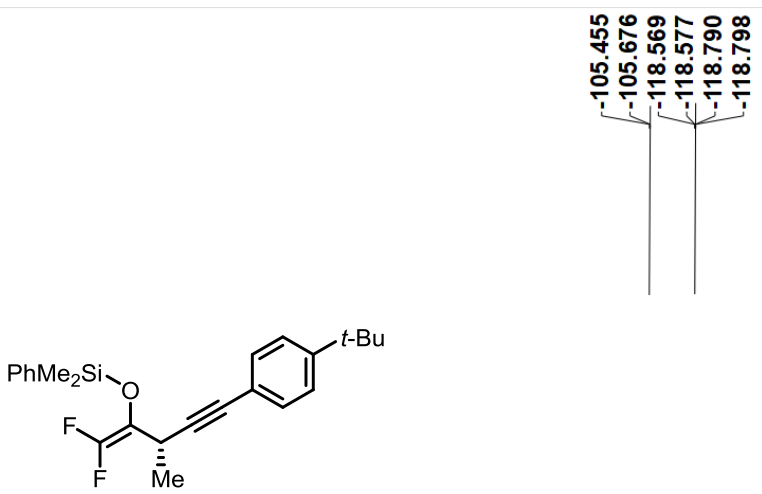

5j

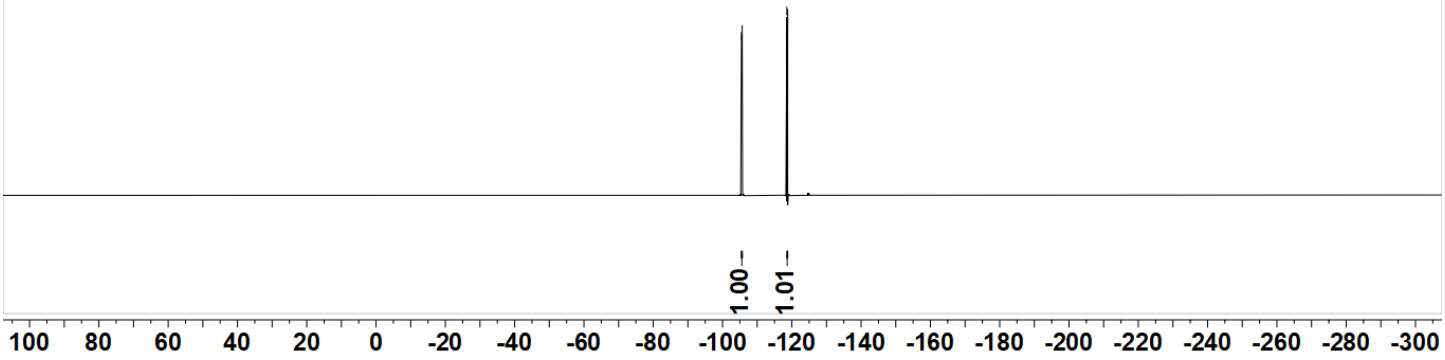


${ }^{1} \mathrm{H}$ NMR of 5k $\left(\mathrm{CDCl}_{3}, 600 \mathrm{MHz}, 25^{\circ} \mathrm{C}\right)$

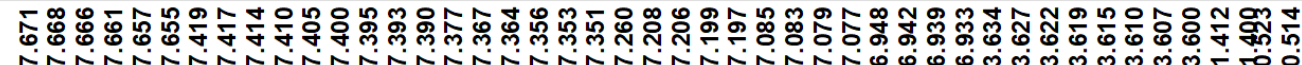

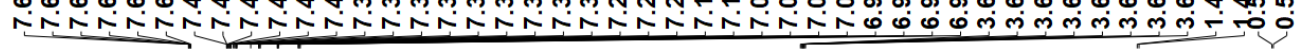
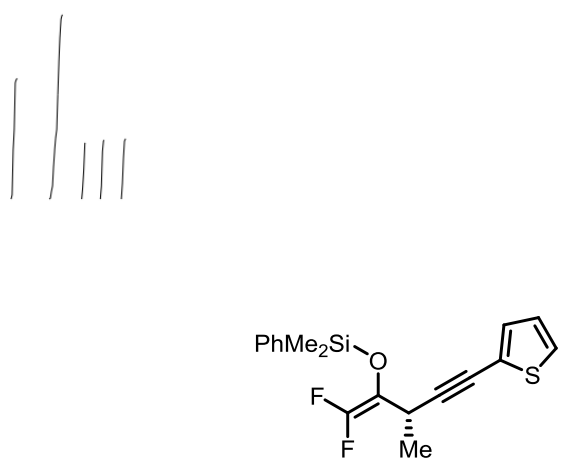

$5 k$

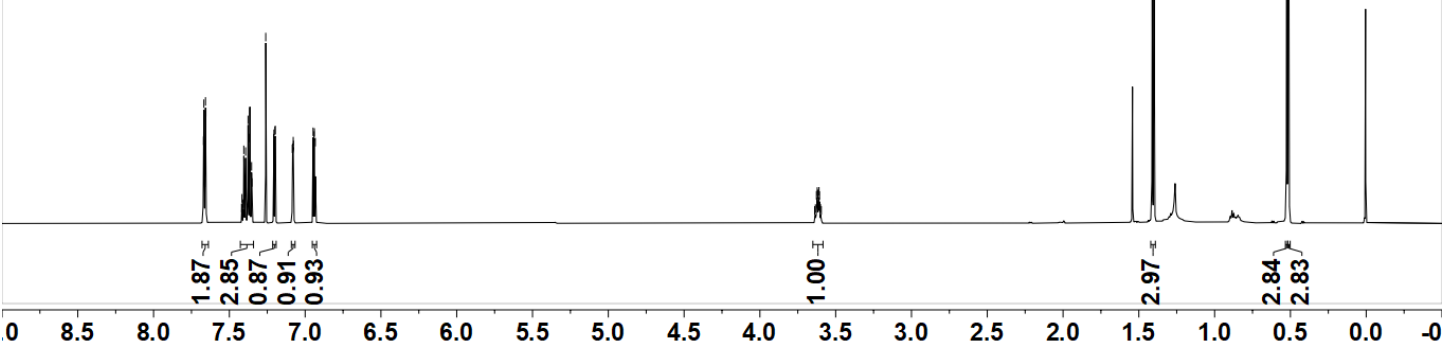

${ }^{13} \mathrm{C}$ NMR of 5k $\left(\mathrm{CDCl}_{3}, 151 \mathrm{MHz}, 25^{\circ} \mathrm{C}\right)$

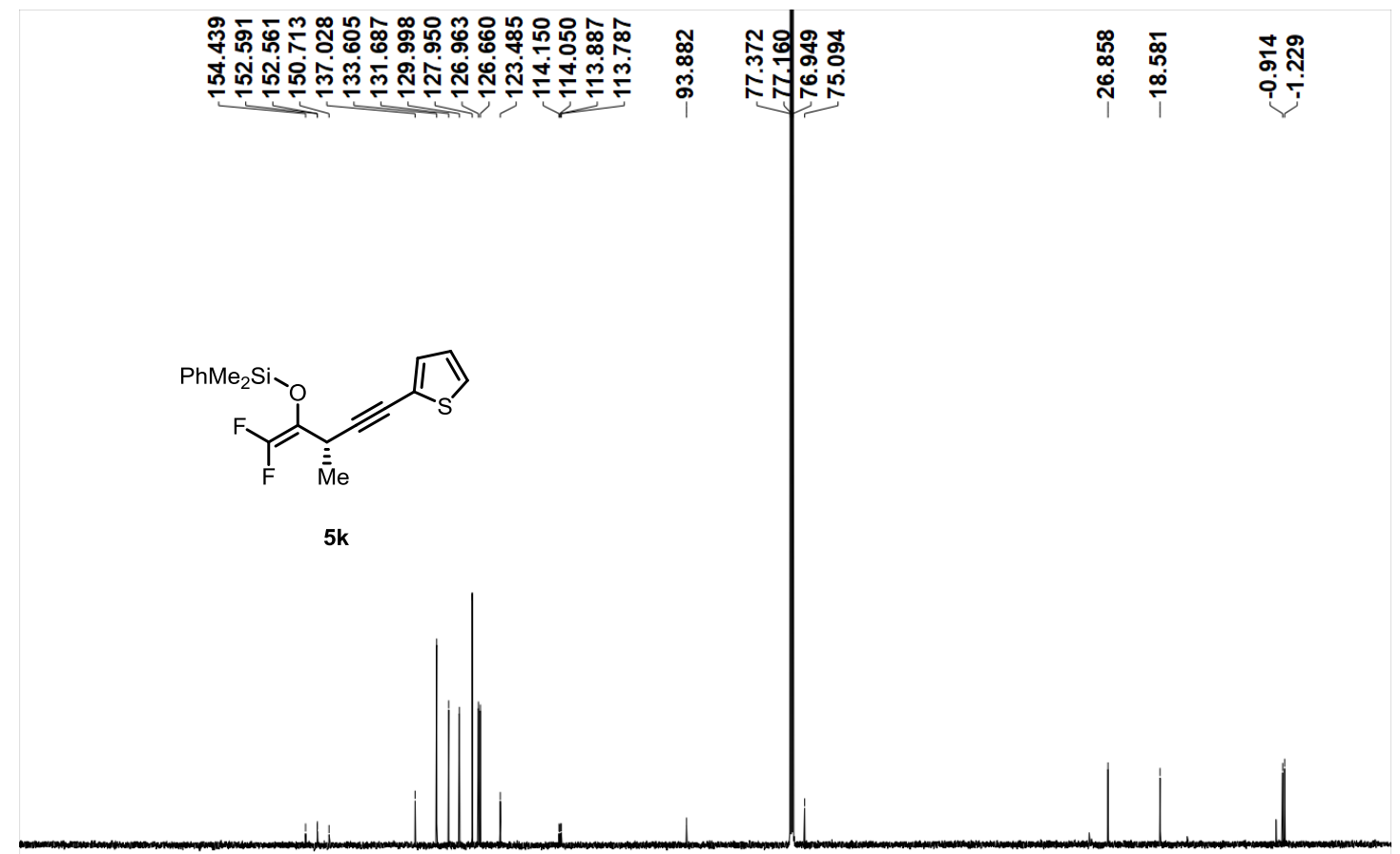

\begin{tabular}{lllllllllllllllllllllll}
\hline 0 & 190 & 180 & 170 & 160 & 150 & 140 & 130 & 120 & 110 & 100 & 90 & 80 & 70 & 60 & 50 & 40 & 30 & 20 & 10 & 0 & -10
\end{tabular} 
${ }^{19} \mathrm{~F}$ NMR of $5 \mathrm{k}\left(\mathrm{CDCl}_{3}, 376 \mathrm{MHz}, 25^{\circ} \mathrm{C}\right)$

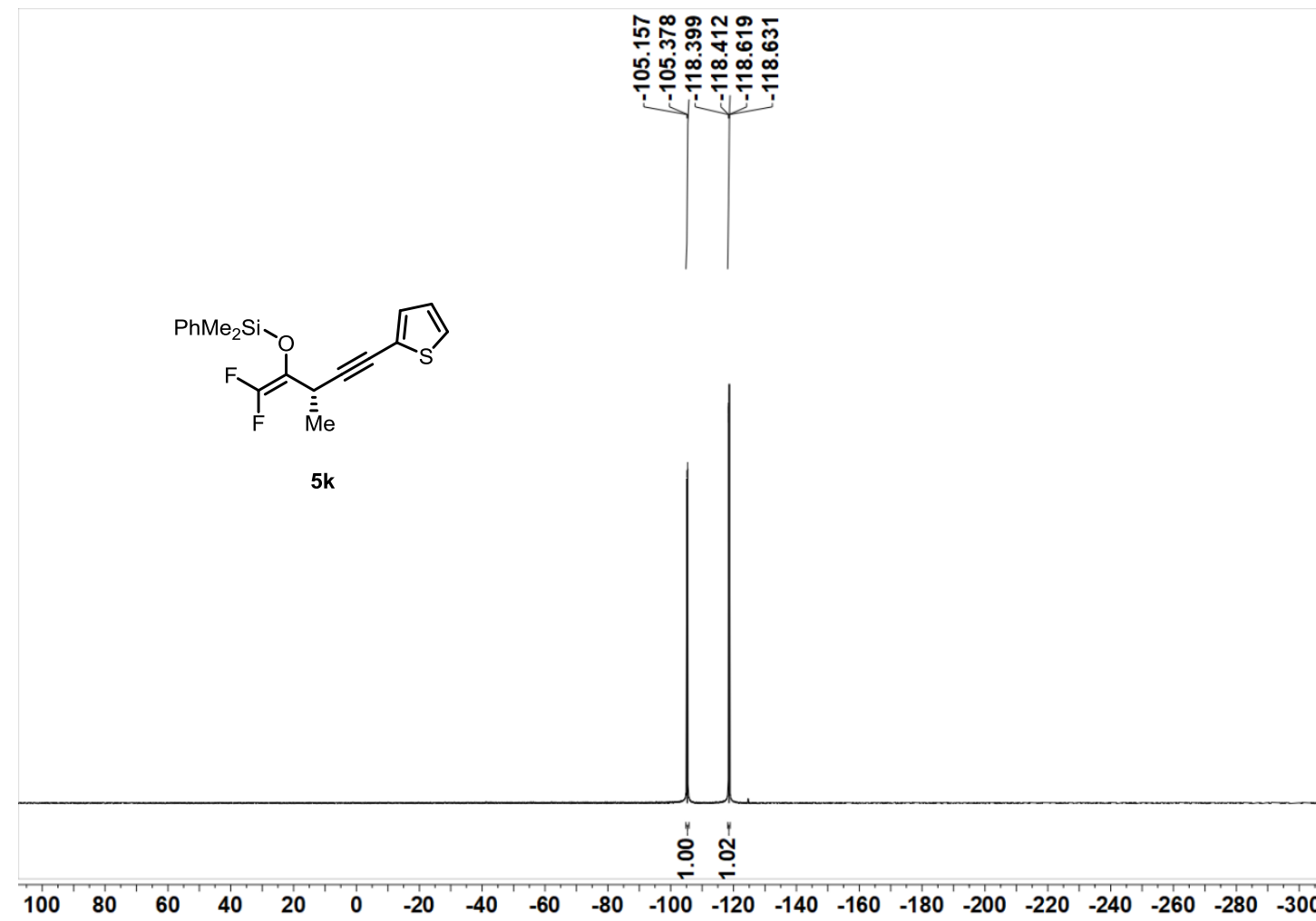

${ }^{1} \mathrm{H}$ NMR of $5 \mathrm{I}\left(\mathrm{CDCl}_{3}, 400 \mathrm{MHz}, 25{ }^{\circ} \mathrm{C}\right)$

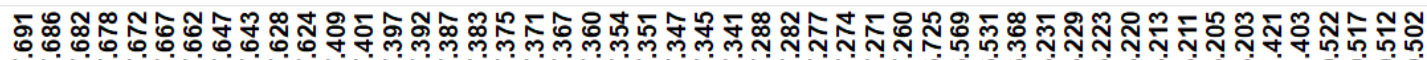

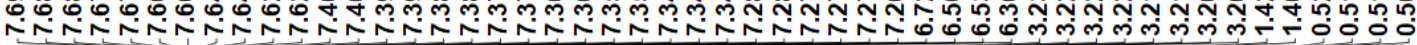
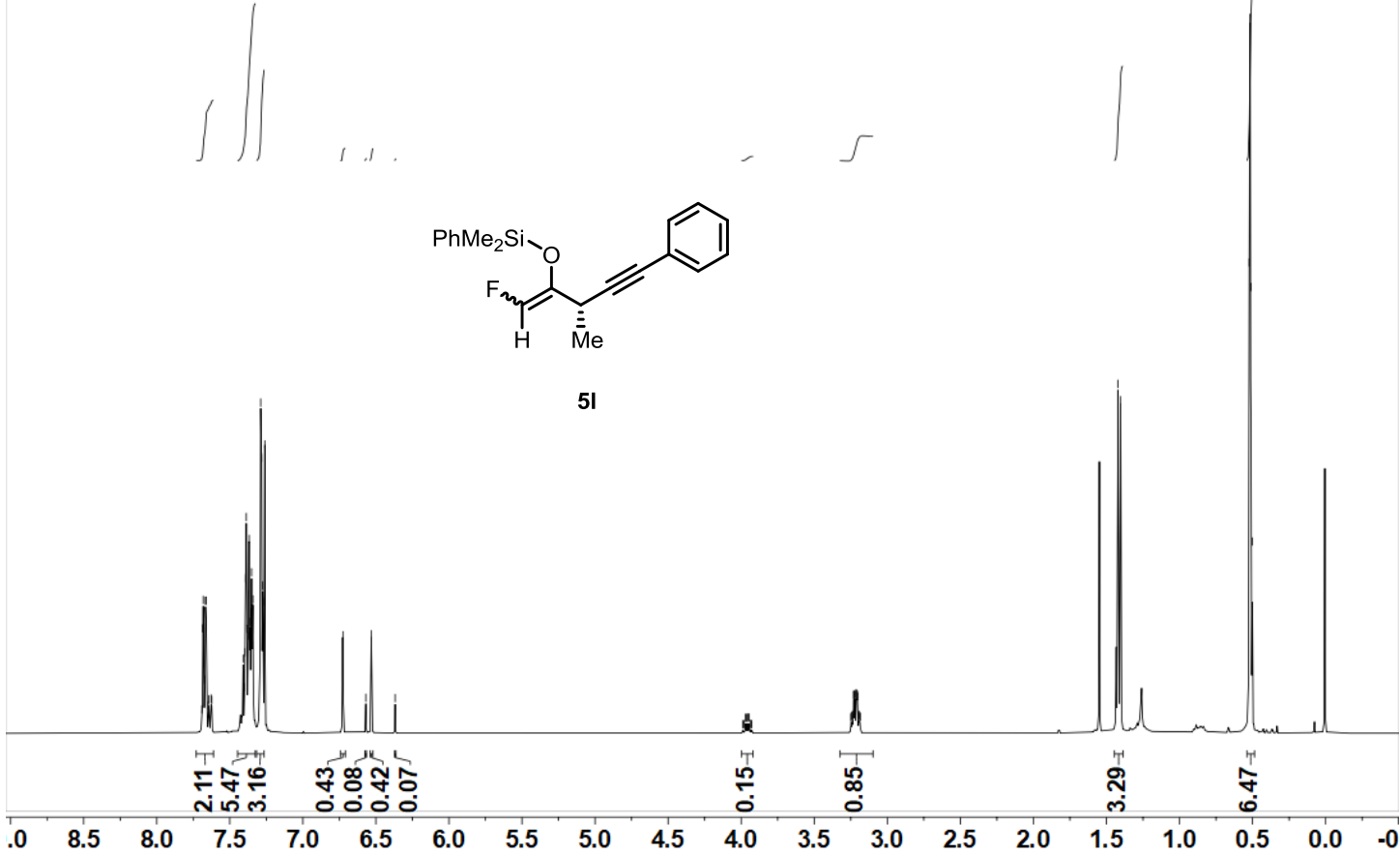
${ }^{13} \mathrm{C}$ NMR of $51\left(\mathrm{CDCl}_{3}, 151 \mathrm{MHz}, 25^{\circ} \mathrm{C}\right)$

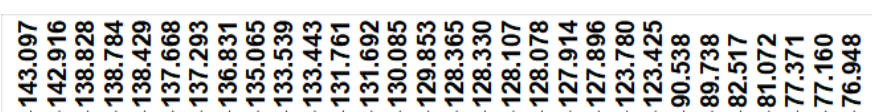

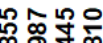

๓ุ่

ลิ่

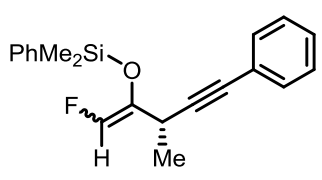

51

प
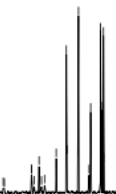

\begin{tabular}{llllllllllllllllllllllllllll}
\hline 0 & 190 & 180 & 170 & 160 & 150 & 140 & 130 & 120 & 110 & 100 & 90 & 80 & 70 & 60 & 50 & 40 & 30 & 20 & 10 & 0 & -10
\end{tabular}

${ }^{19} \mathrm{~F}$ NMR of $5 \mathrm{l}\left(\mathrm{CDCl}_{3}, 376 \mathrm{MHz}, 25^{\circ} \mathrm{C}\right)$

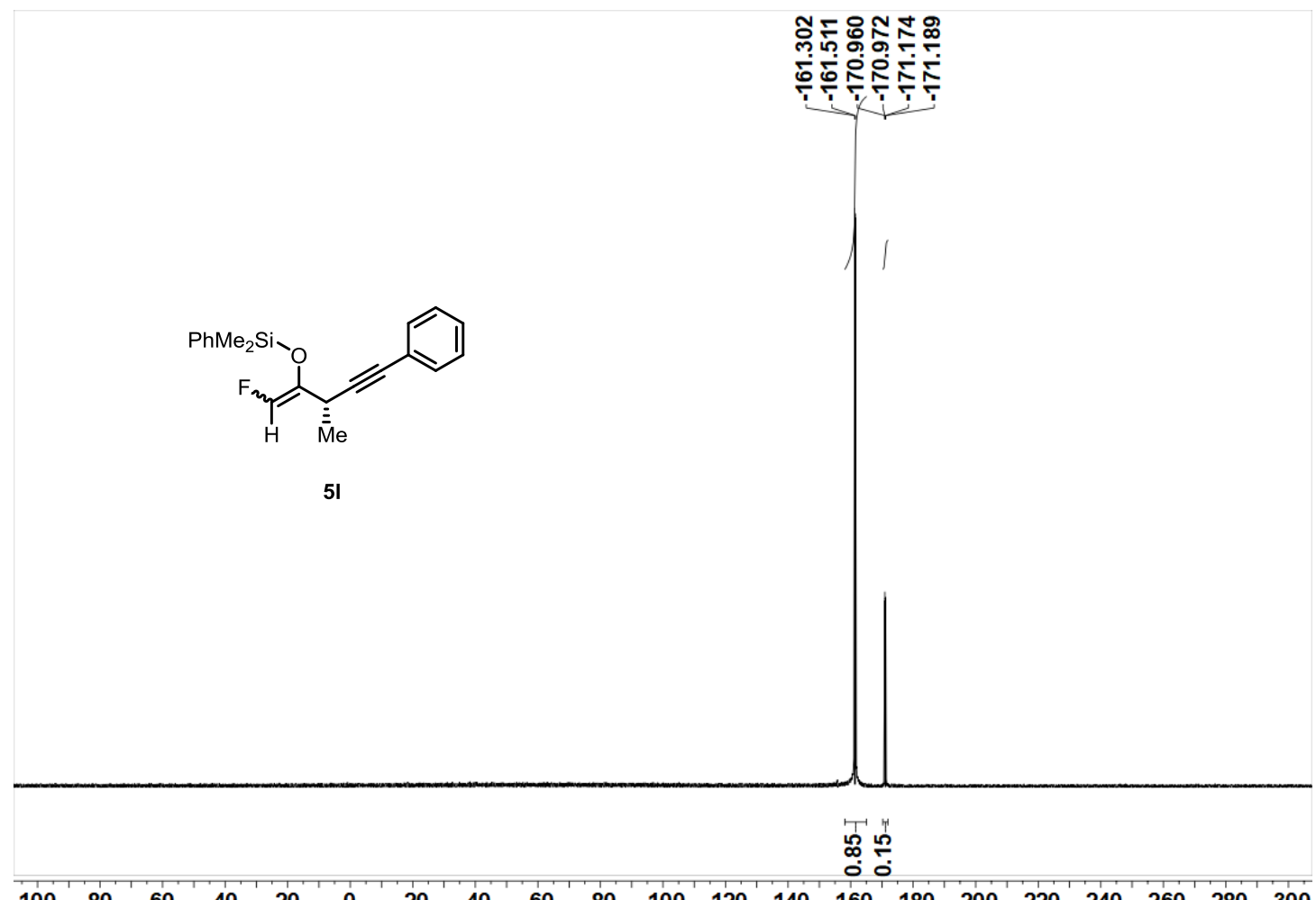

$\begin{array}{llllllllllllllllllllllllllll}100 & 80 & 60 & 40 & 20 & 0 & -20 & -40 & -60 & -80 & -100 & -120 & -140 & -160 & -180 & -200 & -220 & -240 & -260 & -280 & -300\end{array}$ 
${ }^{1} \mathrm{H}$ NMR of $6\left(\mathrm{CDCl}_{3}, 400 \mathrm{MHz}, 25^{\circ} \mathrm{C}\right)$

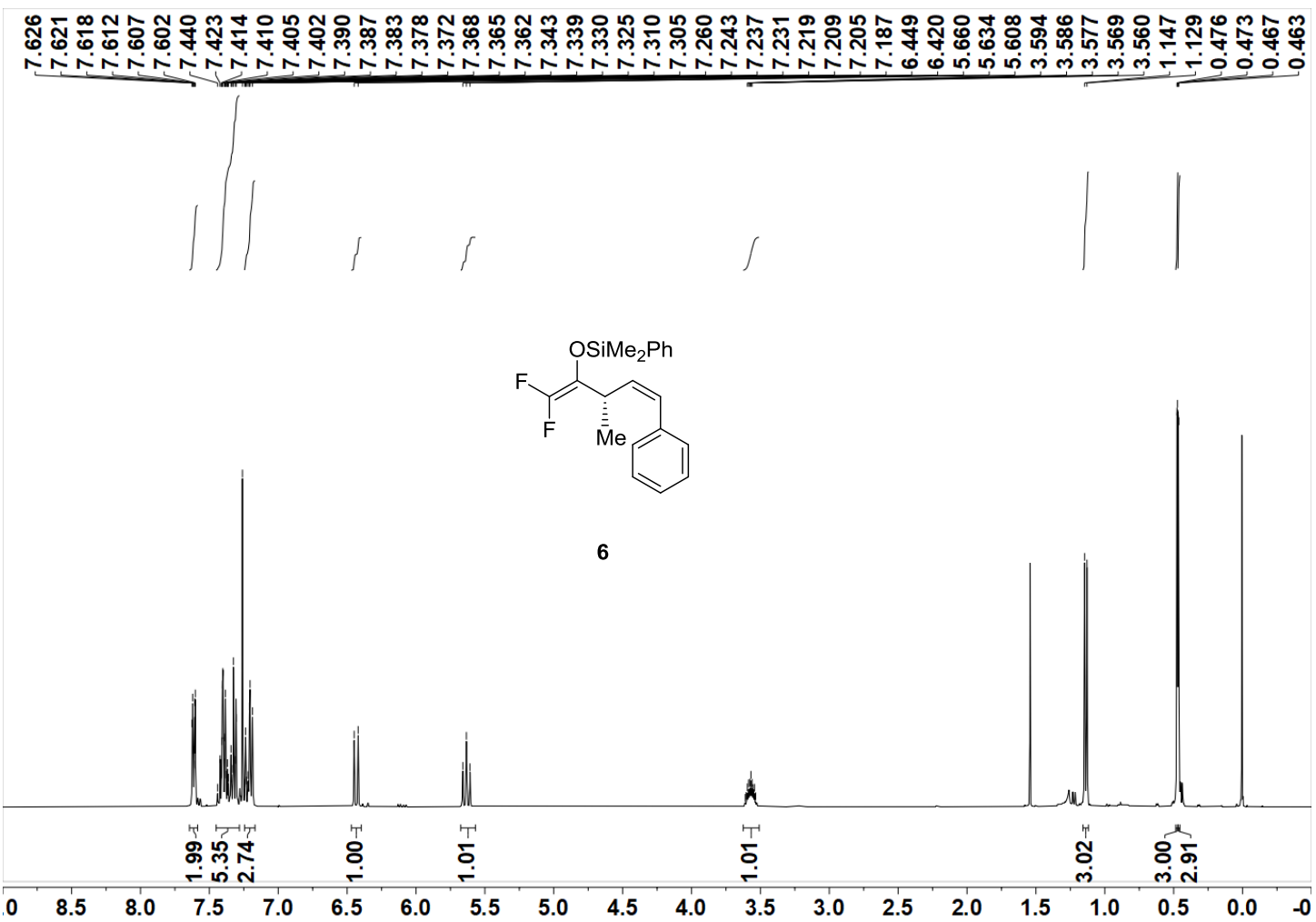

${ }^{13} \mathrm{C}$ NMR of $6\left(\mathrm{CDCl}_{3}, 151 \mathrm{MHz}, 25^{\circ} \mathrm{C}\right)$

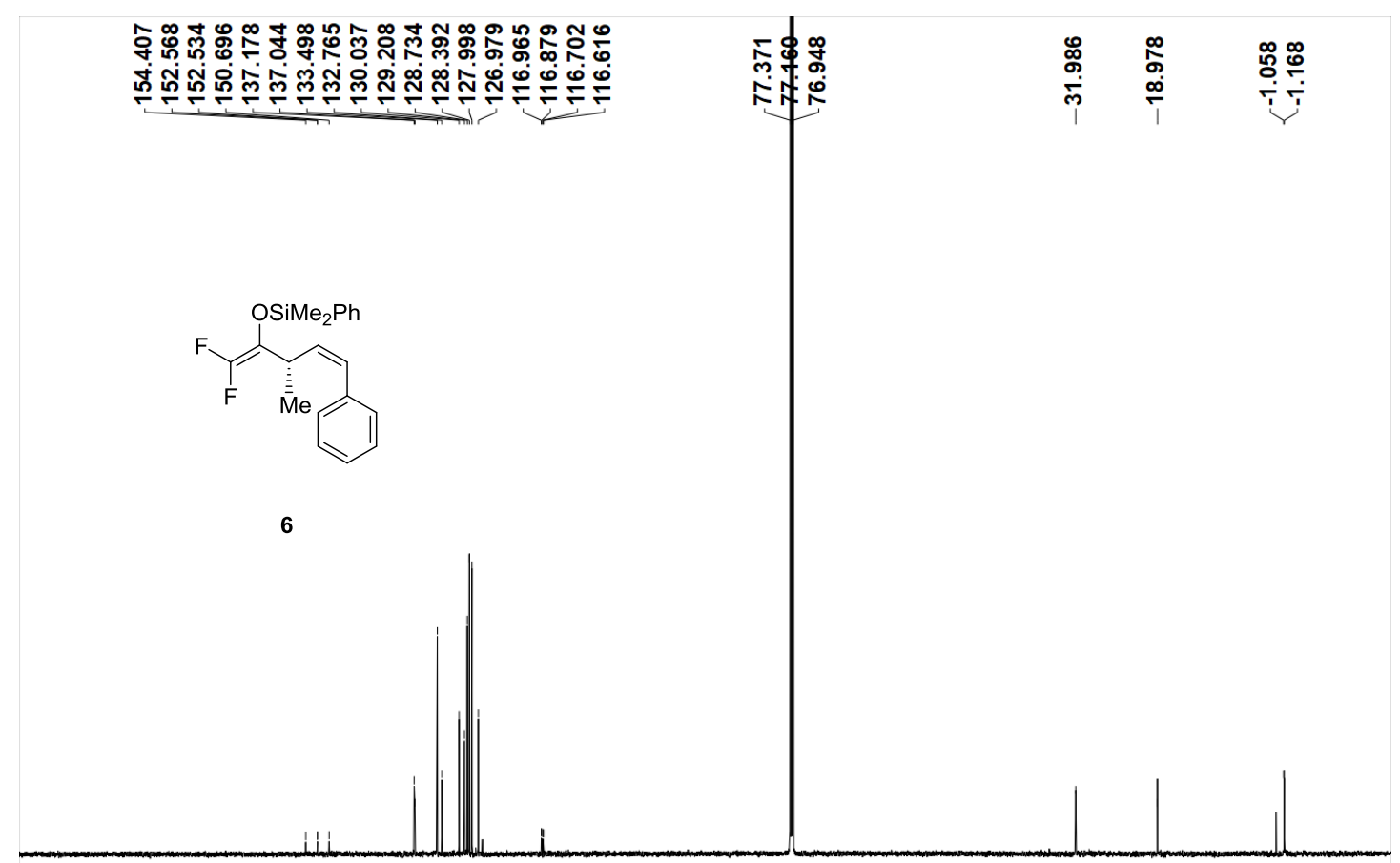

\begin{tabular}{lllllllllllllllllllllll}
\hline 0 & 190 & 180 & 170 & 160 & 150 & 140 & 130 & 120 & 110 & 100 & 90 & 80 & 70 & 60 & 50 & 40 & 30 & 20 & 10 & 0 & -10
\end{tabular} 
${ }^{19} \mathrm{~F}$ NMR of $6\left(\mathrm{CDCl}_{3}, 376 \mathrm{MHz}, 25^{\circ} \mathrm{C}\right)$

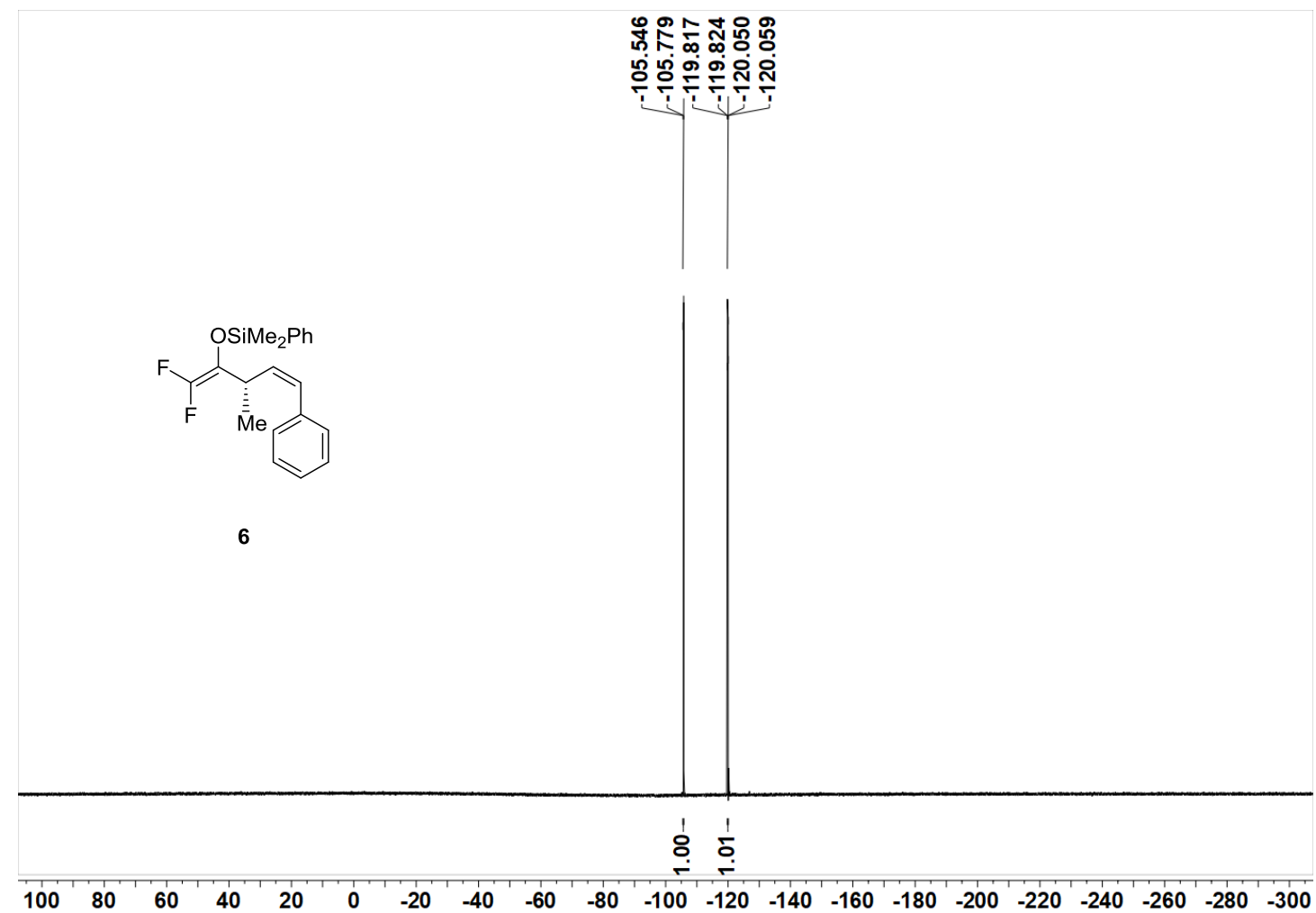

${ }^{1} \mathrm{H}$ NMR of $7\left(\mathrm{CDCl}_{3}, 400 \mathrm{MHz}, 25^{\circ} \mathrm{C}\right)$

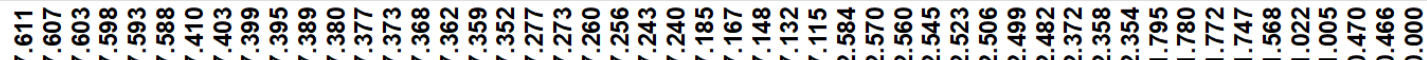

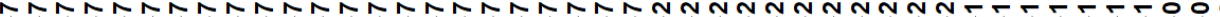
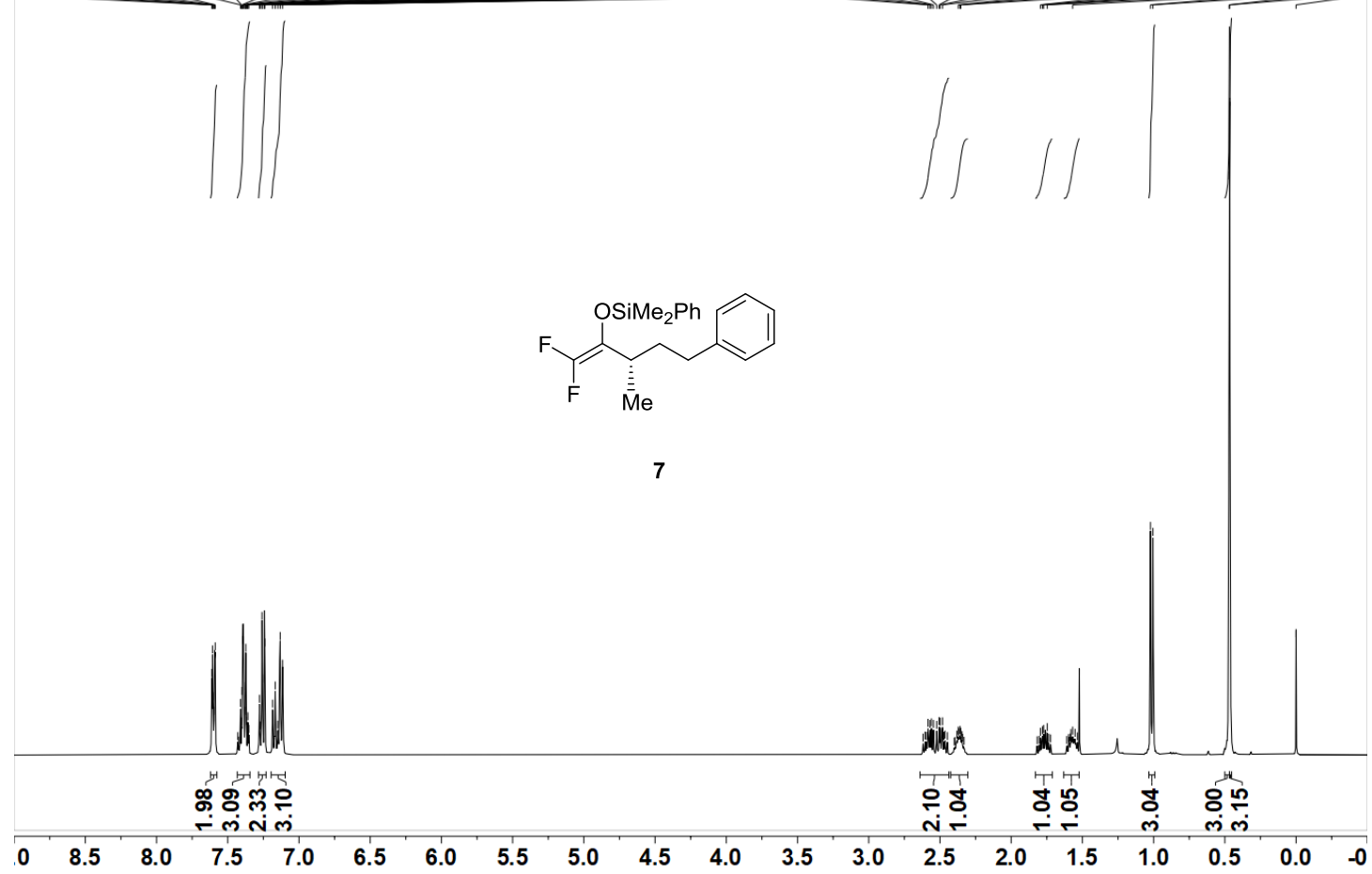
${ }^{13} \mathrm{C}$ NMR of $7\left(\mathrm{CDCl}_{3}, 151 \mathrm{MHz}, 25{ }^{\circ} \mathrm{C}\right)$

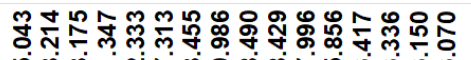

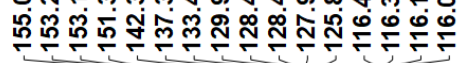

중응

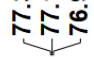

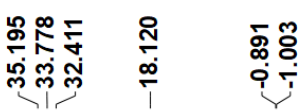

竞e

7

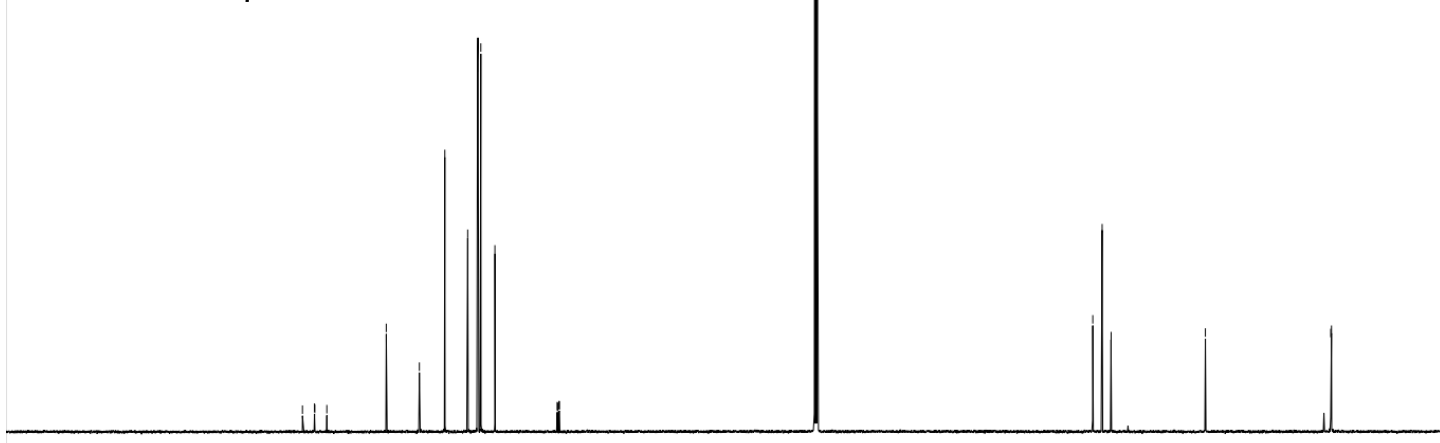

$\begin{array}{lllllllllllllllllllllllllll}190 & 180 & 170 & 160 & 150 & 140 & 130 & 120 & 110 & 100 & 90 & 80 & 70 & 60 & 50 & 40 & 30 & 20 & 10 & 0 & -10\end{array}$

${ }^{19}$ F NMR of $7\left(\mathrm{CDCl}_{3}, 376 \mathrm{MHz}, 25^{\circ} \mathrm{C}\right)$

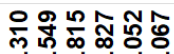

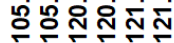
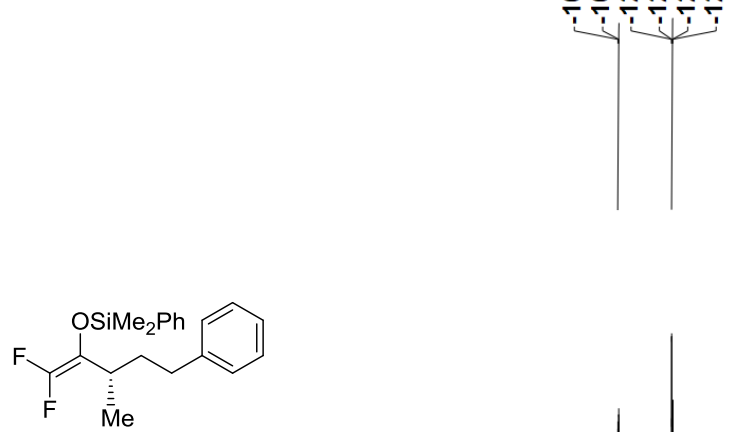

7

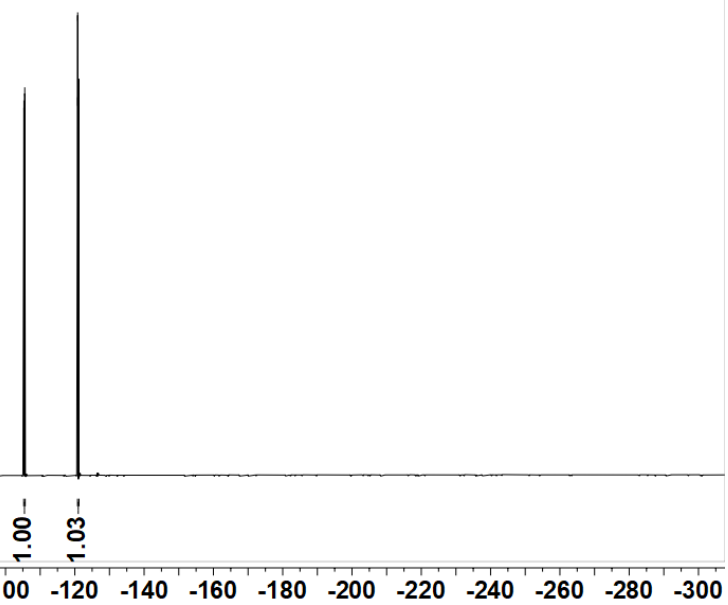


${ }^{1} \mathrm{H}$ NMR of $8\left(\mathrm{CDCl}_{3}, 400 \mathrm{MHz}, 25^{\circ} \mathrm{C}\right)$

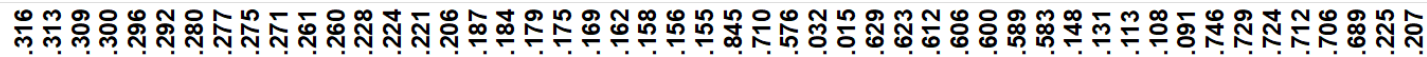

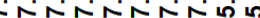
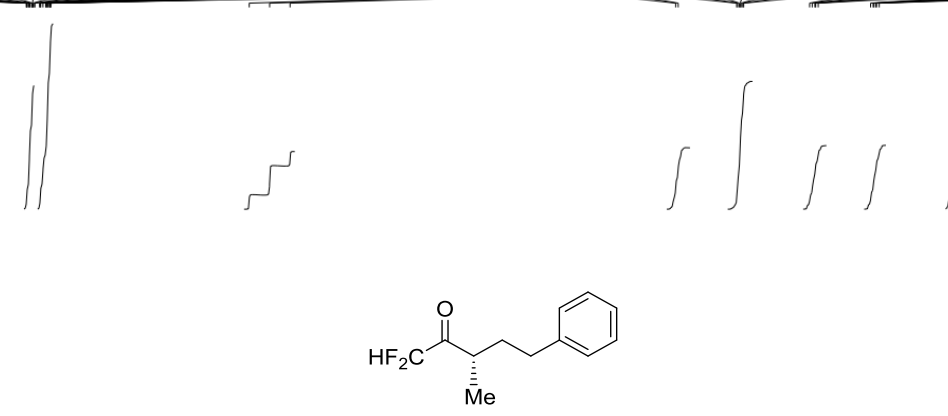

8

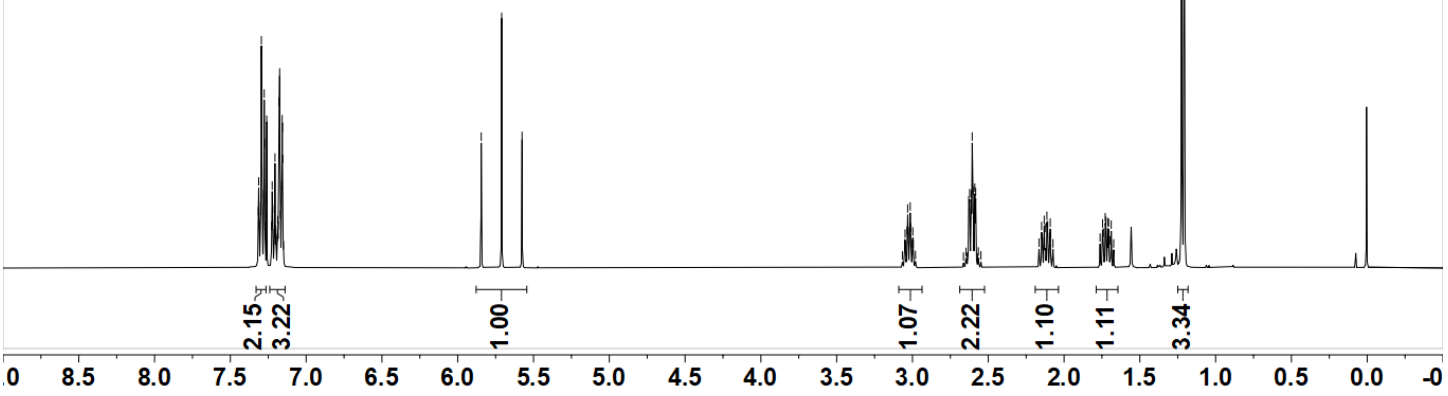

${ }^{13} \mathrm{C}$ NMR of $8\left(\mathrm{CDCl}_{3}, 151 \mathrm{MHz}, 25^{\circ} \mathrm{C}\right)$

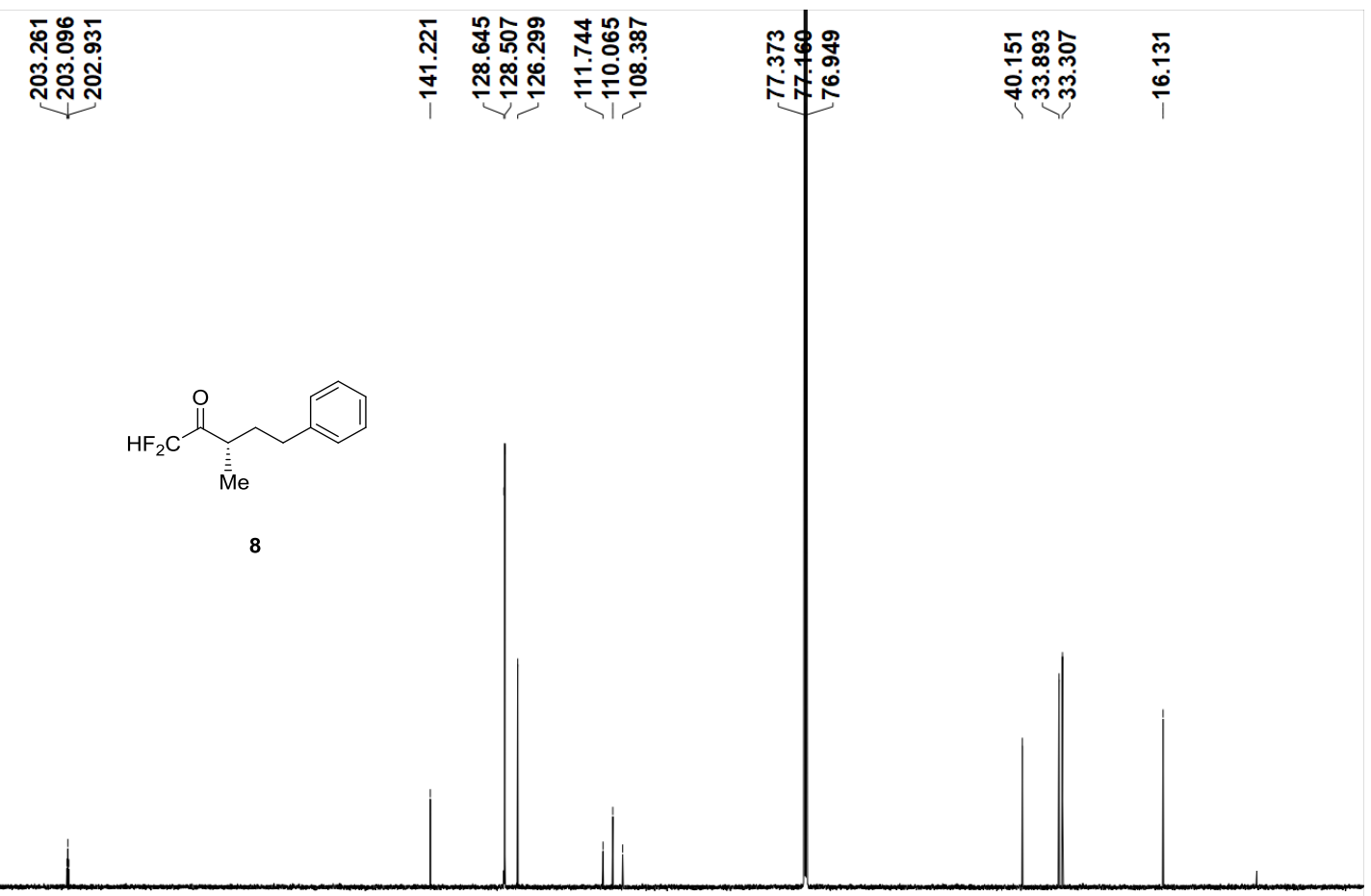

$\begin{array}{llllllllllllllllllllllll}210 & 200 & 190 & 180 & 170 & 160 & 150 & 140 & 130 & 120 & 110 & 100 & 90 & 80 & 70 & 60 & 50 & 40 & 30 & 20 & 10 & 0 & -10 & 10\end{array}$ 
${ }^{19} \mathrm{~F}$ NMR of $8\left(\mathrm{CDCl}_{3}, 376 \mathrm{MHz}, 25^{\circ} \mathrm{C}\right)$

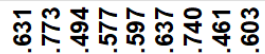

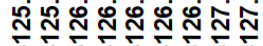

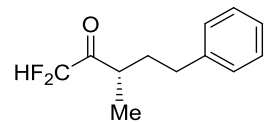

8

$\begin{array}{lllllllllllllllllllllllllllll}100 & 80 & 60 & 40 & 20 & 0 & -20 & -40 & -60 & -80 & -100 & -120 & -140 & -160 & -180 & -200 & -220 & -240 & -260 & -280 & -300\end{array}$

${ }^{1} \mathrm{H}$ NMR of $9\left(\mathrm{CDCl}_{3}, 600 \mathrm{MHz}, 25^{\circ} \mathrm{C}\right)$

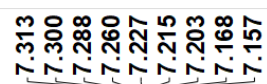

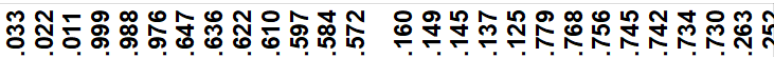

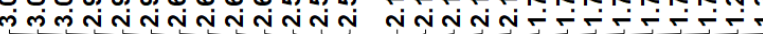
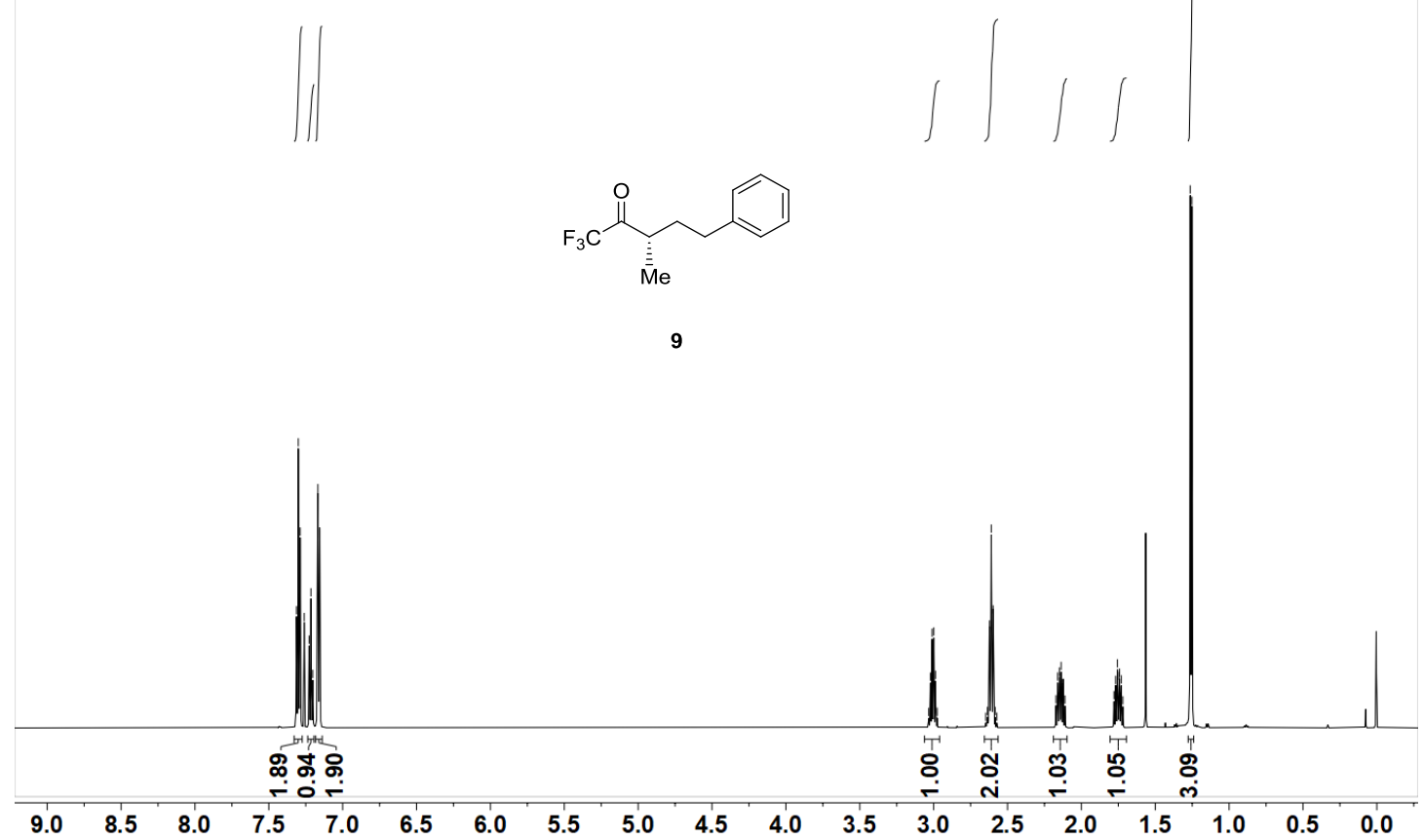
${ }^{13} \mathrm{C} \mathrm{NMR}$ of $9\left(\mathrm{CDCl}_{3}, 151 \mathrm{MHz}, 25{ }^{\circ} \mathrm{C}\right)$

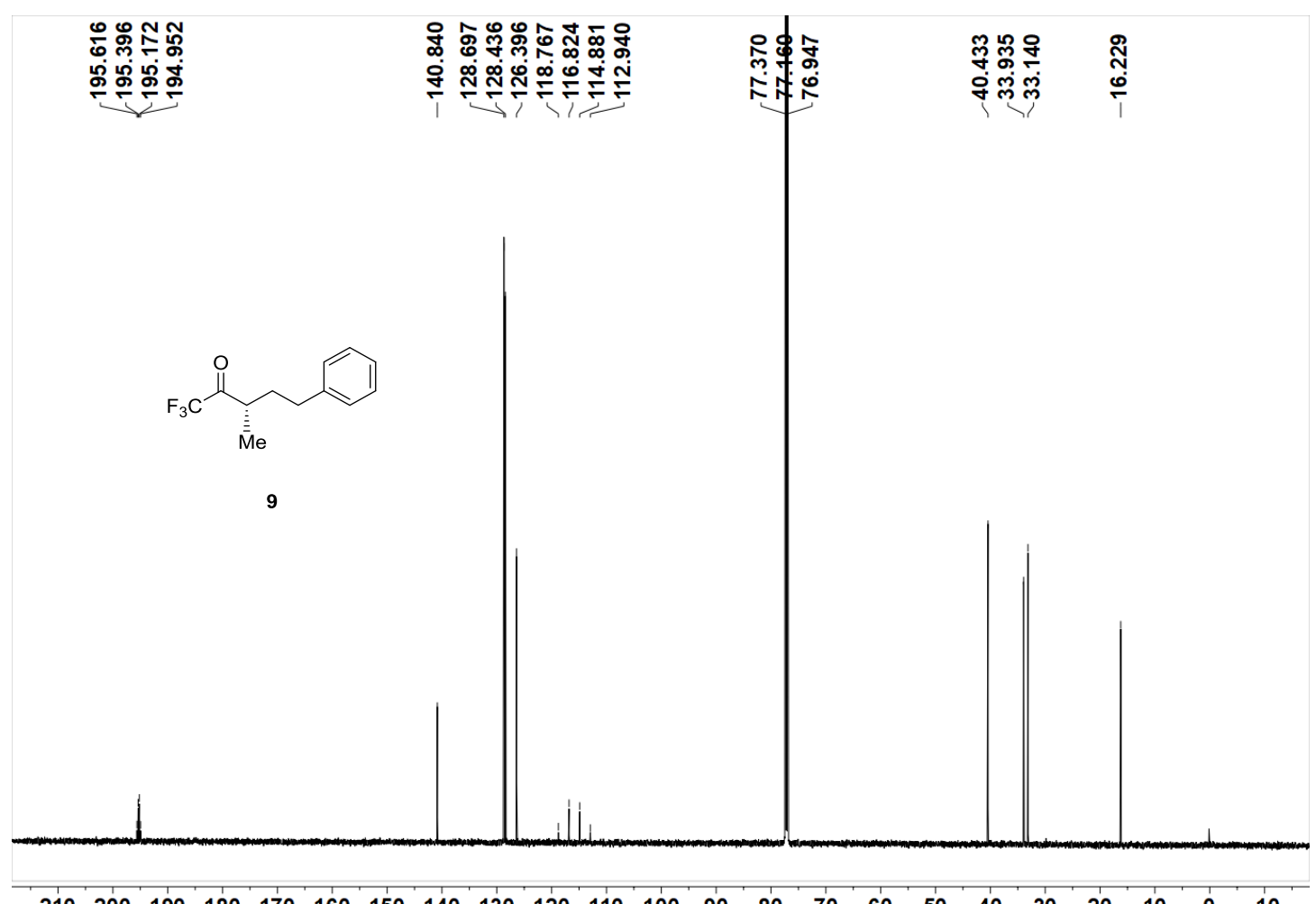

$\begin{array}{lllllllllllllllllllllllll}210 & 200 & 190 & 180 & 170 & 160 & 150 & 140 & 130 & 120 & 110 & 100 & 90 & 80 & 70 & 60 & 50 & 40 & 30 & 20 & 10 & 0 & -10\end{array}$

${ }^{19} \mathrm{~F}$ NMR of $9\left(\mathrm{CDCl}_{3}, 376 \mathrm{MHz}, 25^{\circ} \mathrm{C}\right)$

$\stackrel{\text { fo }}{\stackrel{1}{0}}$

î

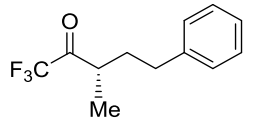

$\begin{array}{lllllllllllllllllllllllllllllll}100 & 80 & 60 & 40 & 20 & 0 & -20 & -40 & -60 & -80 & -100 & -120 & -140 & -160 & -180 & -200 & -220 & -240 & -260 & -280 & -300\end{array}$ 
${ }^{1} \mathrm{H}$ NMR of $10\left(\mathrm{CDCl}_{3}, 400 \mathrm{MHz}, 25^{\circ} \mathrm{C}\right)$

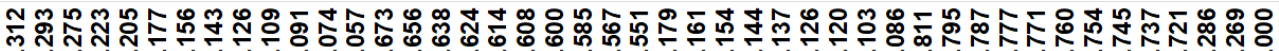

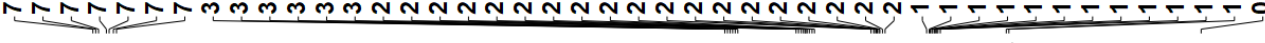
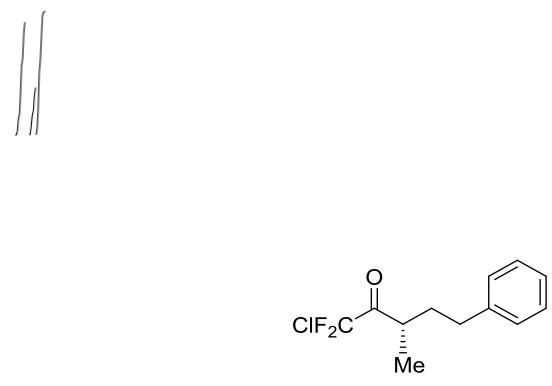

10

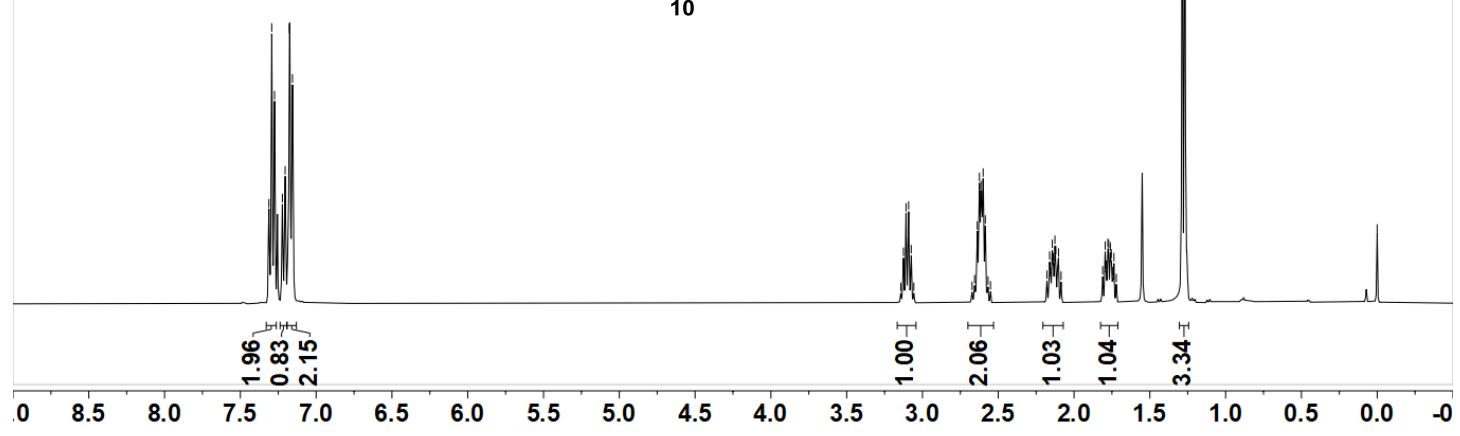

${ }^{13} \mathrm{C}$ NMR of $10\left(\mathrm{CDCl}_{3}, 151 \mathrm{MHz}, 25{ }^{\circ} \mathrm{C}\right)$

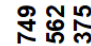

官哭兽

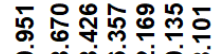

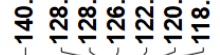

事事高

禺通墕

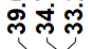

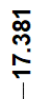

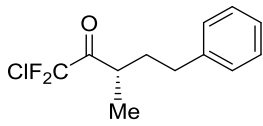

10

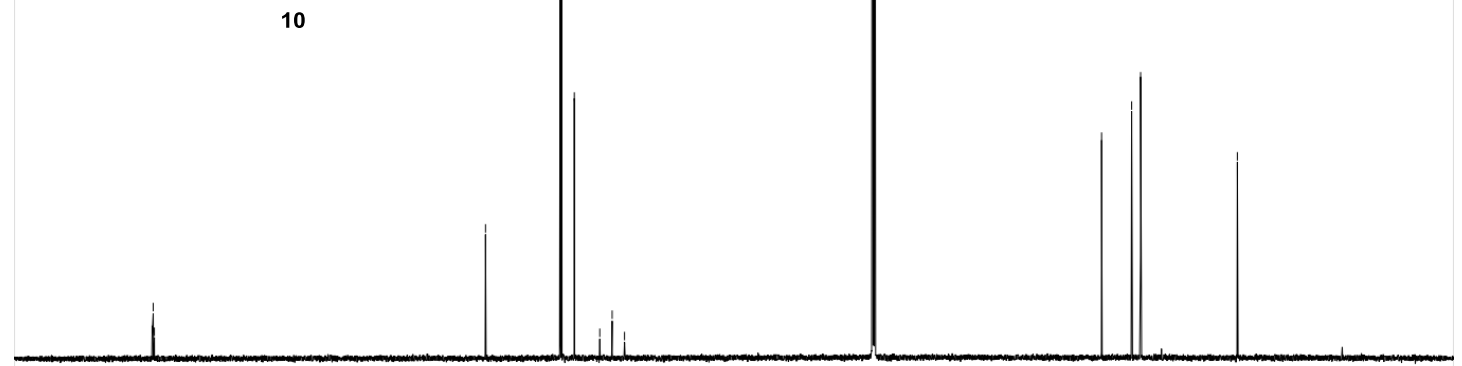

$\begin{array}{llllllllllllllllllllllll}210 & 200 & 190 & 180 & 170 & 160 & 150 & 140 & 130 & 120 & 110 & 100 & 90 & 80 & 70 & 60 & 50 & 40 & 30 & 20 & 10 & 0 & -10\end{array}$ 
${ }^{19}$ F NMR of $10\left(\mathrm{CDCl}_{3}, 376 \mathrm{MHz}, 25^{\circ} \mathrm{C}\right)$

ํํำำ

फ़

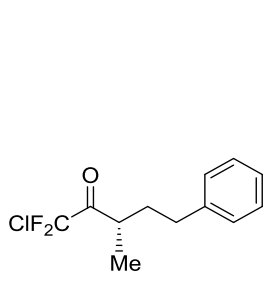

10

$\checkmark$

\section{بَّ}


${ }^{13} \mathrm{C}$ NMR of $11\left(\mathrm{CDCl}_{3}, 151 \mathrm{MHz}, 25{ }^{\circ} \mathrm{C}\right)$

竞遍去

实安客

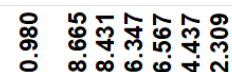

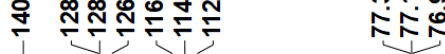

赵产:

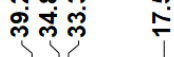

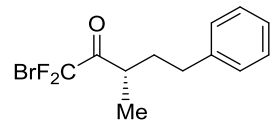

11

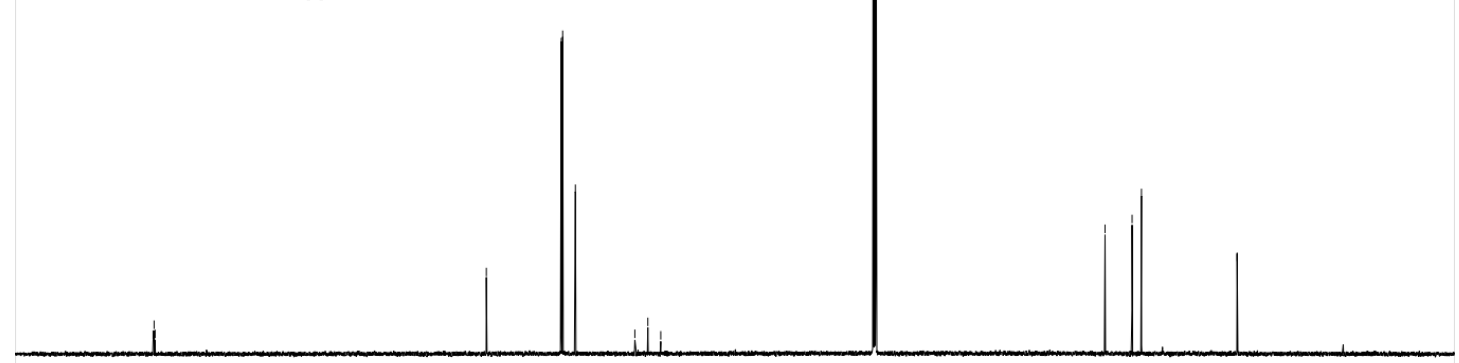

$\begin{array}{llllllllllllllllllllllllll}210 & 200 & 190 & 180 & 170 & 160 & 150 & 140 & 130 & 120 & 110 & 100 & 90 & 80 & 70 & 60 & 50 & 40 & 30 & 20 & 10 & 0 & -10\end{array}$

${ }^{19} \mathrm{~F}$ NMR of $11\left(\mathrm{CDCl}_{3}, 376 \mathrm{MHz}, 25^{\circ} \mathrm{C}\right)$

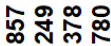

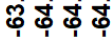

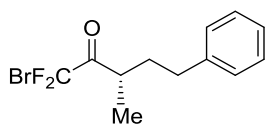

$\begin{array}{lllllllllllllllllllllllllllll}100 & 80 & 60 & 40 & 20 & 0 & -20 & -40 & -60 & -80 & -100 & -120 & -140 & -160 & -180 & -200 & -220 & -240 & -260 & -280 & -300\end{array}$ 
${ }^{1} \mathrm{H}$ NMR of $12\left(\mathrm{CDCl}_{3}, 400 \mathrm{MHz}, 25^{\circ} \mathrm{C}\right)$

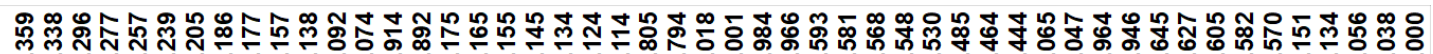

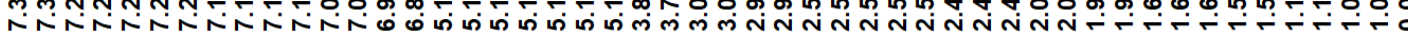
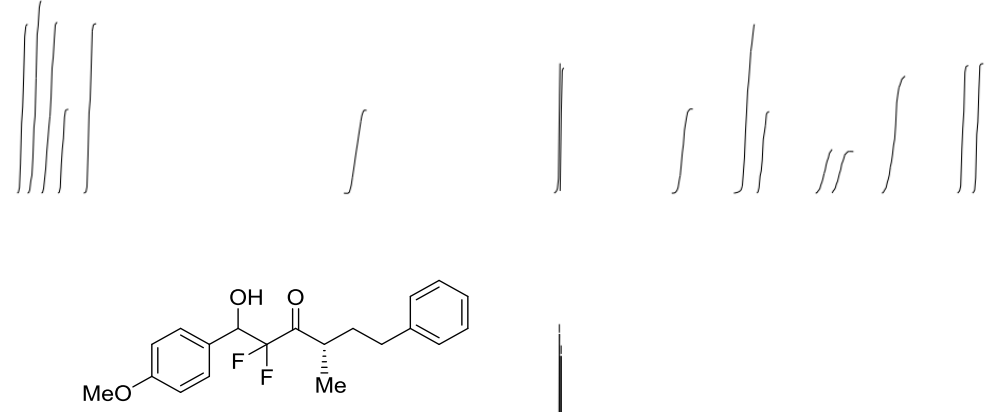

12

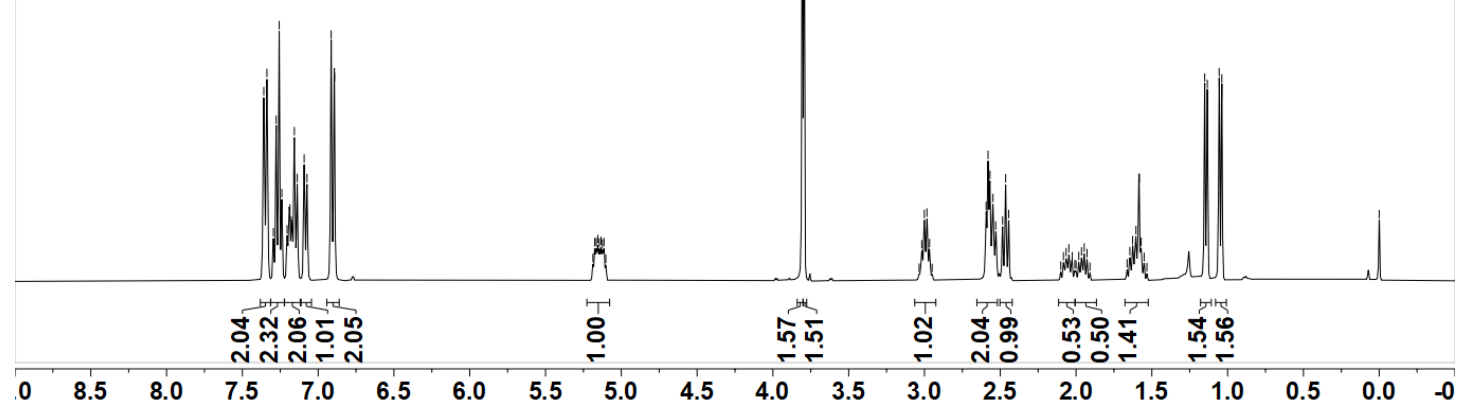

${ }^{13} \mathrm{C}$ NMR of $12\left(\mathrm{CDCl}_{3}, 151 \mathrm{MHz}, 25^{\circ} \mathrm{C}\right)$

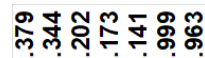

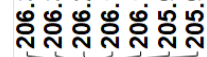

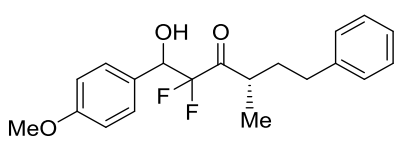

12 


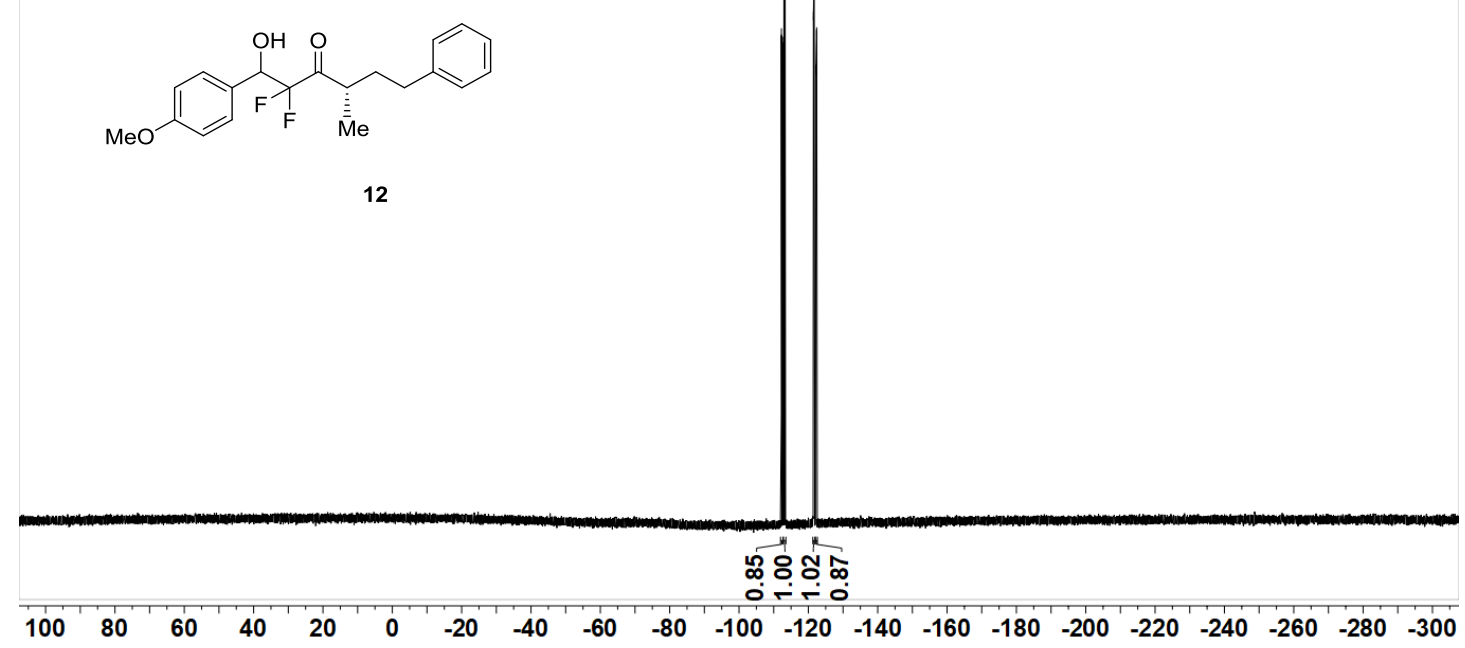

\section{References}

(1) (a) Kang, B.; Kim, D. H.; Do, Y.; Chang S. Conjugated Enynes as a New Type of Substrates for Olefin Metathesis. Org. Lett. 2003, 5, 3041-3043. (b) Yang, Y.; Perry, I. B.; Lu, G.; Buchwald, S. L. CopperCatalyzed Asymmetric Addition of Olefin-Derived Nucleophiles to Ketones. Science. 2016, 353, 144-150. (c) Liao, Y.; Yin, X.-M.; Wang, X.-H.; Yu, W.-Z.; Fang, D.-M.; Hu, L.-R.; Wang, M.; Liao, J. Enantioselective Synthesis of Multisubstituted Allenes by Cooperative $\mathrm{Cu} / \mathrm{Pd}$ - Catalyzed 1,4 Arylboration of 1,3-Enynes. Angew. Chem. Int. Ed. 2020, 59, 1176-1180.

(2) (a) Chung, W. J.; Welch, J. T. A General Method for Synthesis of Trifluoroacetyltrialkyl(aryl)silanes and the Sakurai Reaction of Fluorinated Acylsilanes with Allyl Silanes. J. Fluorine Chem. 2004, 125, 543-548. (b) Chung, W. J.; Ngo, S. C.; Higashiya, S.; Welch, J. T. Lewis Acid Promoted Aldol Reaction of Fluorinated Silyl Enol Ethers from New Fluoroacetylsilane Derivatives. Tetrahedron Lett. 2004, 45, 5403-5406. (c) Chen, X.; Gong, X. X.; Li, Z. Y.; Zhou, G.; Zhang, W. L.; Liu, S. S.; Shen, X. Direct Transfer of Tri- and Di-Fluoroethanol Units Enabled by Radical Activation of Organosilicon Reagents. Nat. Commun. 2020, 11, 2756. 